Andrews University

Digital Commons @ Andrews University

\title{
"Witness" And "Bearing Witness" In The Legal Settings Of The Pentateuch And The Gospel Of John: An Intertextual Study
}

Franklin A. Marti

Andrews University, marti@andrews.edu

Follow this and additional works at: https://digitalcommons.andrews.edu/dissertations

Part of the Biblical Studies Commons

\section{Recommended Citation}

Marti, Franklin A., "'Witness" And "Bearing Witness" In The Legal Settings Of The Pentateuch And The Gospel Of John: An Intertextual Study" (2017). Dissertations. 1639.

https://digitalcommons.andrews.edu/dissertations/1639

https://dx.doi.org/10.32597/dissertations/1639

This Dissertation is brought to you for free and open access by the Graduate Research at Digital Commons @ Andrews University. It has been accepted for inclusion in Dissertations by an authorized administrator of Digital Commons@ Andrews University. For more information, please contact repository@andrews.edu. 



\begin{abstract}
"WITNESS" AND "BEARING WITNESS" IN THE LEGAL SETTINGS OF THE PENTATEUCH AND THE GOSPEL OF JOHN: AN INTERTEXTUAL STUDY
\end{abstract}

by

Franklin A. Marti

Adviser: Jiří Moskala 


\section{ABSTRACT OF GRADUATE STUDENT RESEARCH}

Dissertation

Andrews University

Seventh-day Adventist Theological Seminary

\section{Title: "WITNESS" AND "BEARING WITNESS" IN THE LEGAL SETTINGS OF THE PENTATEUCH AND THE GOSPEL OF JOHN: AN INTERTEXTUAL STUDY}

Name of researcher: Franklin A. Marti

Name and degrees of faculty adviser: Jiří Moskala, Th.D., Ph.D.

Date completed: May 2017

This dissertation studies the words "witness" and "to bear witness" in the Pentateuch and in the Gospel of John, and at the same time presents an intertextual connection between these books.

The study begins with an introduction in which I present the background and statement of the problem, the purpose of the study, the delimitations and the methodology.

Following the introduction chapter 1 deals with the review of the literature from ANE documents to ancient Jewish interpretation. I conclude that even though the Code of Hammurabi and the Hittite treaties are documents with different purposes, they reflect a similar feature: gods are called to be witnesses and judges between the Great King and 
his vassals. These gods are summoned to bring blessings or inflict curses, depending on the obedience or disobedience of the vassal.

In relation to ancient Jewish literature, the members of the Qumran community believe that they are the faithful remnant of Israel with whom God has established his covenant and those who are living under his blessings while all Jews living outside the community are living under curses (Deut 28). Philo, on his part, is well acquainted with the topic of more than one witness for a just judgment (Deut 17:6; 19:15). Josephus debates the reliability of women's testimonies in court, and the Talmud establishes the punishment that has to be inflicted on false witnesses.

Chapter 2 shows modern scholars' arguments about the witness motif in the Old Testament from Hermann Gunkel to Paul J. N. Lawrence, and in the Gospel of John from Théo Preiss to Andrew T. Lincoln. This chapter verifies that most scholars agree to the relation of the witness motif in the Old Testament with treaties of second millennium BC, and that the witness motif in the Gospel of John is connected to the Old Testament through judicial language.

Chapter 3 examines exegetically the Pentateuchal passages in which the word עִ and its cognates appear, and tests their connection with the Code of Hammurabi, and ANE treaties.

Chapter 4 is an analysis of the words "witness" and "bearing witness" in the Gospel of John, and identifies that many of the stories of this Gospel are built on the judicial language of the Pentateuch in order to show testimonies about Jesus, either in favor of him or against him. The Gospel of John uses this motif to demonstrate that Jesus 
is righteous and true, and the Son of God. Likewise, Jesus's judgment is similar to him (righteous and true). In this manner, his identity and origin are settled.

Chapter 5 surveys the many passages of the Gospel of John that are infused with Pentateuchal language in order to demonstrate that the Evangelist wants to show, from the beginning of his Gospel, that Jesus is the Messiah, the Son of God who fulfills the promises of the Pentateuch. The conclusion is a summary of the main points of this investigation in which I also offer its main implications for biblical studies and further research. 
Andrews University

Seventh-day Adventist Theological Seminary

\title{
"WITNESS" AND "BEARING WITNESS" IN THE LEGAL SETTINGS OF THE PENTATEUCH AND THE GOSPEL OF JOHN: AN INTERTEXTUAL STUDY
}

\author{
A Dissertation \\ Presented in Partial Fulfillment \\ of the Requirements for the Degree \\ Doctor of Theology
}

by

Franklin A. Marti

May 2017 
Copyright by Franklin A. Marti 2017 (C) All Rights Reserved 


\title{
"WITNESS" AND "BEARING WITNESS" IN THE LEGAL SETTINGS OF THE PENTATEUCH AND THE GOSPEL OF JOHN: AN INTERTEXTUAL STUDY
}

\author{
A dissertation \\ presented in partial fulfillment \\ of the requirements for the degree \\ Doctor of Theology
}

by

Franklin A. Marti

APPROVAL BY THE COMMITTEE:

Faculty Adviser

Jiř́i Moskala

Professor of Hebrew and Old Testament

Exegesis

Richard M. Davidson

J. N. Andrews Professor of Old Testament Interpretation

Tom Shepherd

Professor of New Testament
Director, Ph.D./Th.D. Program

Tom Shepherd

Dean SDA Theological Seminary Jiří Moskala

Date approved 
To the memory of my mother Juana Bautista Santana (1927-2014) who inspired me to study though she never went to school

To my beloved wife Marina who gave me time to finish this dissertation without regret

To Frankel, my playful boy who always asks me for more fun

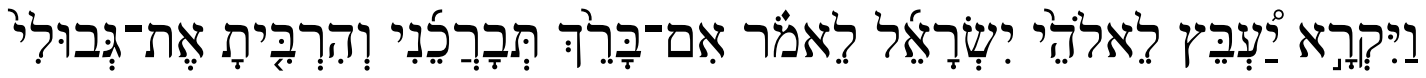

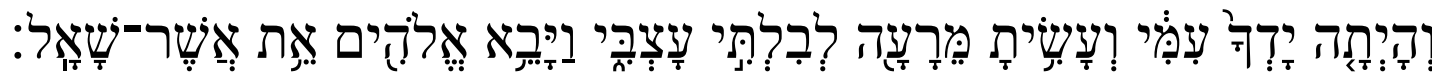

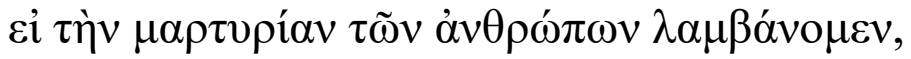

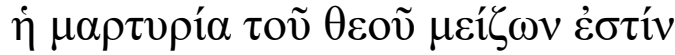

I prefer to fall into the hands of God while I am filthy, impure, and unclean than into the hands of men, being clean, pure, and holy

(My paraphrase of 2 Sam 24:14) 


\section{TABLE OF CONTENTS}

LIST OF TABLES

viii

LIST OF ABBREVIATIONS

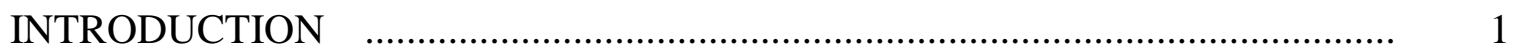

Background of the Problem ……............................................................. 1

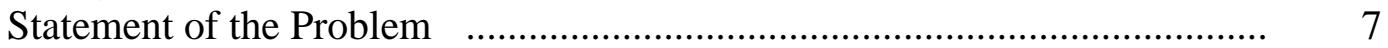

Purpose of the Study

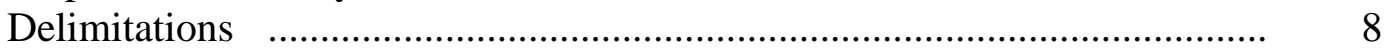

Methodology $\quad$........................................................................................ 8

Definition of Terms ................................................................................ 10

Chapter

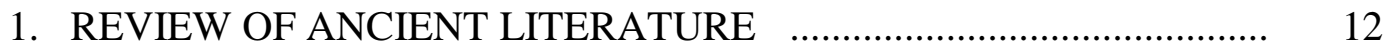

"Witness" and "Bearing Witness" in ANE Literature .................... 12

The Code of Hammurabi (18th Century BC) …………..... 12

Mesopotamian Legal Documents (15th Century BC) $\quad$ …..... 15

Treaty Between Niqmepa of Alalakh and $\mathrm{Ir}^{\mathrm{d}}{ }^{\mathrm{d}} \mathrm{im}$ of Tunip (15th Century BC) ……………………………..... 16

Hittite Treaties …….................................................... 18

Suppiluliumas and Kurtiwaza (14th Century

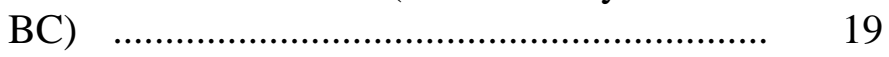

Suppiluliumas and Aziras (14th Century BC) $\quad$......... 20

Mursilis and Duppi-Tessub (Mid-14th Century BC) ……............................................ 21

Ramses Meri-Amon of Egypt and Hattusilis of Hatti (1280 BC) ……………………….... 22

Akkadian Treaty from Assyria ………………………....... 24

Ashurnirari V of Assyria and Mati'ilu of Arpad $(755-745$ BC)

The Vassal-Treaties of Esarhaddon (7th Century BC) ……........................................... 26

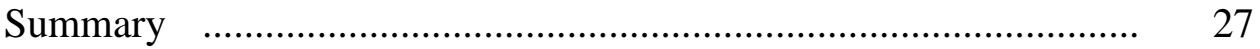

"Witness" and "Bearing Witness" in Ancient Jewish

Interpretation of the Pentateuch ………………………........ $\quad 30$ 
Qumran (c. 2nd Century BC-c. 1st Century AD) $\quad$ …............ 30

Philo of Alexandria (c. 20 BC-c. AD 50) …....................... 39

Flavius Josephus (c. 37-c. 100) …........................................ 40

Talmud (AD 200-500) .................................................... 42

Summary $\quad$................................................................ 42

2. REVIEW OF THE LITERATURE IN MODERN RESEARCH $\quad$.......... 45

In the Old Testament .................................................................. 45

Hermann Gunkel (1909-1913) ....................................... 45

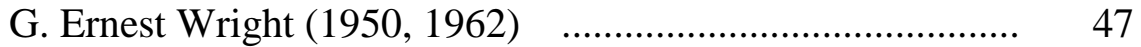

George E. Mendenhall (1954) …...................................... 48

Herbert Huffmon (1959) $\quad$.............................................. $\quad 52$

James Muilenburg (1959) $\quad$................................................ 54

Meredith G. Kline (1960) ….......................................... 56

Dennis J. McCarthy (1963) …............................................ 61

Ray F. Chester (1966) ...................................................... 62

James Limburg (1969) ................................................ 63

Klaus Baltzer (1971) ..................................................... 64

Kenneth Anderson Kitchen (1978) $\quad$................................... 65

Michael de Roche (1983) ................................................. 69

Dwight R. Daniels (1987) ................................................ 72

Richard M. Davidson (2007) ........................................... 75

Paul J. N. Lawrence (2011) ............................................ 75

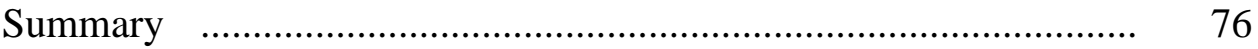

In the Gospel of John ................................................................ 81

Théo Preiss (1952) ........................................................... 82

James Montgomery Boice (1970) …............................... 85

Johannes Beutler (1972) ….............................................. 86

Anthony E. Harvey (1976) ….......................................... 86

Allison A. Trites (1977) .................................................. 89

Robert Gordon Maccini (1996) ......................................... 90

Andrew T. Lincoln (2000) ........................................... 92

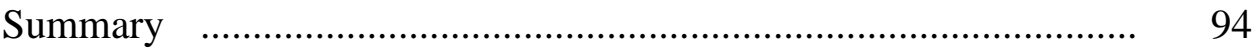

3. "WITNESS" AND "BEARING WITNESS" IN THE

PENTATEUCH $\quad$..................................................................... 97

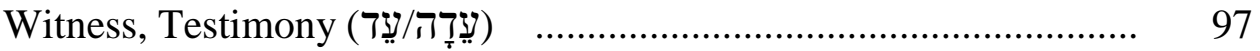

Abraham and Abimelech (Gen 21:30) ............................ 97

Jacob and Laban (Gen 31:26-55 [Heb. ch. 32:1]) .............. 108

The Ninth Commandment (Exod 20:16 and Deut 5:20) $\quad \ldots . . . \quad 115$

A Torn Animal (Exod 22:13 [Heb. v. 12]) ........................ 117

A False Witness (Exod 23:1, 2) ........................................ 118

A Witness Who Does Not Want to Testify (Lev 5:1) ......... 119

Lack of Witness (Num 5:11-31) ....................................... 121 
More than One Witness (Num 35:30; Deut 17:2-7;

$$
\text { 19:15) }
$$

The Law on This Side of the Jordan (Deut 4:44, 45)

"If a False Witness Rises" (Deut 19:16-21)

The Song of Moses (Deut 31:19-21; 32)

The Book of the Law (Deut 31:24-26)

Summary

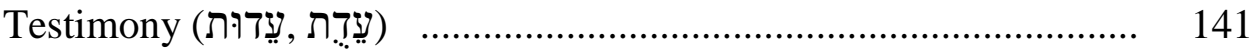

"To Bear Witness"” or "To Testify" (עוּד) .................................... 145

Joseph and His Brothers in Egypt (Gen 43:3) .................. 145

God and Israel at Mount Sinai (Exod 19:21-23) $\quad$................. 146

Warning to an Owner of an Ox (Exod 21:29) $\quad$..................... 147

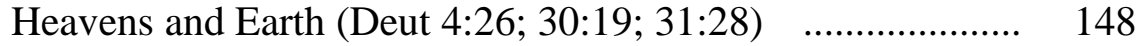

Moses's Testimony (Deut 8:18, 19; 32:46) ...................... 150

Summary

4. ANALYSIS OF THE THEME OF WITNESS IN THE GOSPEL OF JOHN

Witnesses

People's Testimonies $\quad$.................................................. 163

John the Baptist ................................................... 163

The Samaritan Woman $\quad$........................................ 173

The People Who Saw Lazarus Raised From the Dead

Jesus's Disciples ............................................... 176

The Evangelist .................................................... 177

Summary

Objects' Testimonies ...................................................... 180

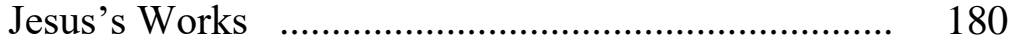

The Scriptures ................................................ 184

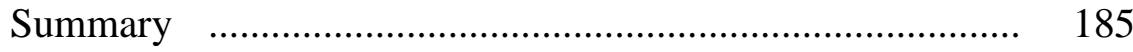

Deity's Testimonies ...................................................... 186

The Father and the Son ….................................. 187

Jesus .............................................................. 191

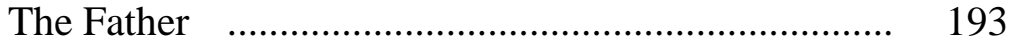

The Holy Spirit ................................................... 193

Summary

Other Testimonies ......................................................... 199

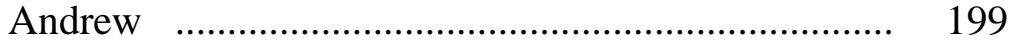

Philip ............................................................ 200

Nathanael ....................................................... 201

Nicodemus $\quad$................................................... 202

The Samaritans ................................................... 203

The Multitude on the Mountain ............................ 203 


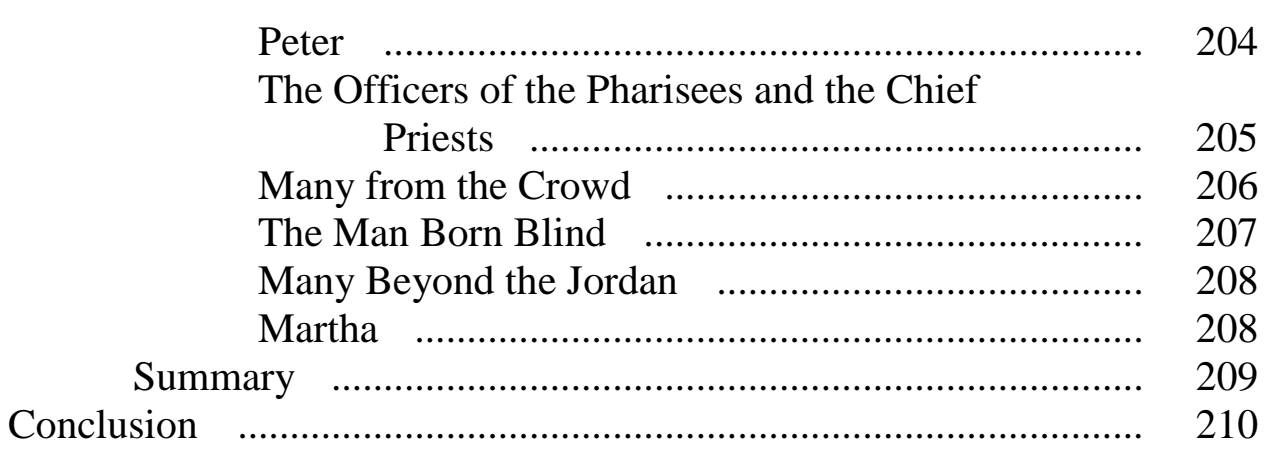

\section{INTERTEXTUAL ANALYSIS: PENTATEUCH AND GOSPEL} OF JOHN

Legal Structure of the Gospel of John _........................................... 214

The Pentateuch in the Gospel of John ……………........................ 220

Creation (John 1:1 and Gen 1:1; John 20:22 and

Gen 2:7)

223

Sanctuary (John 1:4; Exod 25:8) ……................................ 224

Moses and Jesus (John 1:17, 18; Exod 33:17-20 …............. 225

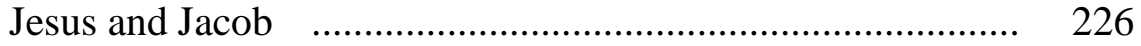

Heaven Open (John 1:51; Gen 28:12-22) $\quad$ ……….... 226

Jacob's Well (John 4) ……………...................... 227

Abraham and Jesus (John 8:31-59; Gen 15:5; 21:12, 13;

22:18)

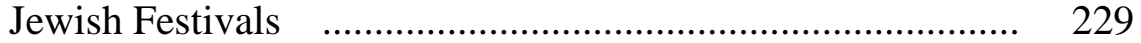

Jesus's “I-Am” Saying (John 8:58; Exod 3:14) ………....... 231

Judgment and Truth _........................................................ 231

The Bronze Serpent ................................................. 232

Manna ................................................................. 232

The Father and the Son Judge and Save

Together

235

The Father and the Son Testify and Judge

Together _................................................... 236

Righteous Judgment ............................................. 237

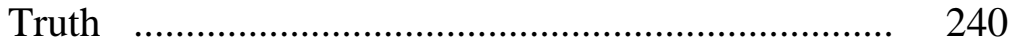

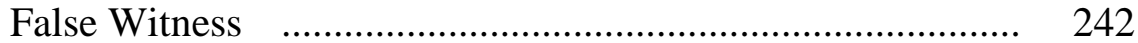

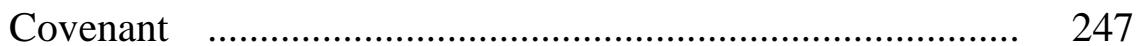

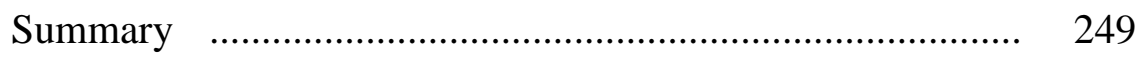

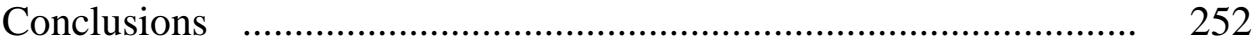

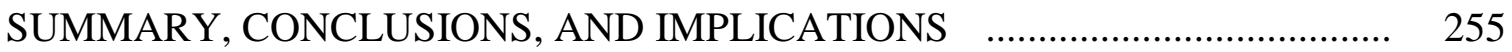

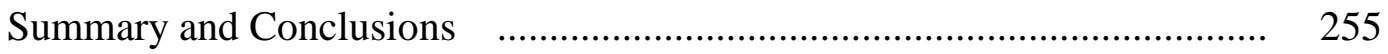

Implications for Biblical Studies and Further Research $\quad$.............................. 278

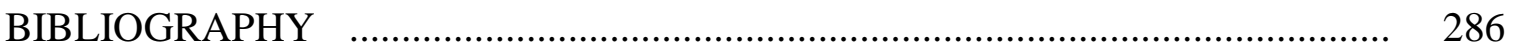




\section{LIST OF TABLES}

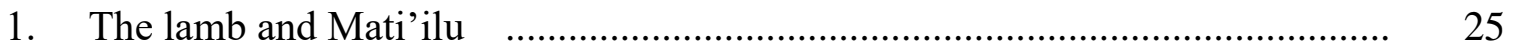

2. "Witness" within the structure of the Code of Hammurabi and treaties in different Periods

3. Modern scholarship on the use of "witness" within the context of the Old Testament covenant lawsuit genre

4. Modern scholarship on the use of "witness" in the Gospel of John

5. Parallelism of covenant in Gen 21:22-32 and 26:26-33

6. Pentateuchal passages with " . . . ברין"

7. “Commandments," "testimonies," "statutes," "judgments"

8. Deut $8: 1,6,11$

9. Subject-object-punishment of the Pentateuchal

10. Subject-object-reward of the Pentateuchal כרּר formula

11. Song of Moses and the Book of the law

12. Context of Deut 4:26 and 30:19

13. Last testimony of Moses in connection to the fifth commandment

14. Verb עופ in the Pentateuch

15. "Witness" and "bearing witness" in relation to judgment in the Pentateuch

16. The Baptist's testimony in John 1:15, 27

17. Testimonies in favor of Jesus 
18. The Pentateuch in the Gospel of John

19. Accusations against Jesus 


\section{LIST OF ABBREVIATIONS}

\begin{tabular}{ll} 
Bible Versions & \\
BFC & French Bible, 1997 \\
CJB & Complete Jewish Bible, 1998 \\
DRB & French Version Darby, 1885 \\
ESV & English Standard Version, 2011 \\
JPS & JPS Holy Scriptures, 1917 \\
KJV & King James Version, 1769 \\
LSG & French Louis Segond; 1910 \\
NAB & New American Bible, 1991 \\
NAS & New American Standard Bible, 1995 \\
NAU & New American Standard Bible (NASB), (NAS [1977] and NAU [1995]) \\
NEB & New English Bible \\
NIV & New International Version, 1984 \\
NJB & New Jerusalem Bible, 1985 \\
NKJ & New King James Version, 1982 \\
NRS & New Revised Standard Version Bible, 1989 \\
RSV & Revised Standard Version of the Bible, 1971 \\
TNK & JPS TANAKH, 1985 \\
ZUR & Zürcher Bibel, 2008 \\
\hline
\end{tabular}


General

ANE ancient Near East

HB Hebrew Bible

Heb. Hebrew

MT Masoretic Text

$\mathrm{p}(\mathrm{p}) . \quad$ page(s)

Secondary Sources

AAA Annals of Archaeology and Anthropology

$\mathrm{AB} \quad$ Anchor Bible

ABD Anchor Bible Dictionary. Edited by D. N. Freedman. 6 vols. New York, 1992

ABRL Anchor Bible Reference Library

ACCS Ancient Christian Commentary on Scripture

AGSJU Arbeiten zur Geschichte des späteren Judentums und des Urchristentums

AnBib Analecta biblica

AOAT Alter Orient und Altes Testament

AOS American Oriental Series

AThR Anglican Theological Review

BA Biblical Archaeologist

BASOR Bulletin of the American Schools of Oriental Research

BBR Bulletin for Biblical Research

BDB Brown, F., S. R. Driver, and C. A. Briggs, A Hebrew and English Lexicon of the Old Testament. Oxford, 1907 


\begin{tabular}{|c|c|}
\hline$B D T$ & Baker's Dictionary of Theology \\
\hline BETL & Bibliotheca ephemeridum theologicarum lovaniensium \\
\hline$B i b$ & Biblica \\
\hline BIS & Biblical Interpretation Series \\
\hline$B O$ & Bibliotheca orientalis \\
\hline$B R$ & Biblical Research \\
\hline BSac & Bibliotheca sacra \\
\hline$B T B$ & Biblical Theology Bulletin \\
\hline$B T D B$ & $\begin{array}{l}\text { Baker Theological Dictionary of the Bible. Edited by Walter A. Elwell. } \\
\text { Grand Rapids, } 1996\end{array}$ \\
\hline BTNTS & Biblical Theology of the New Testament Series \\
\hline$B Z$ & Biblische Zeitschrift \\
\hline BZAW & Beihefte zur Zeitschrift für die alttestamentliche Wissenschaft \\
\hline BZNW & Beihefte zur Zeitschrift für die neutestamentliche Wissenschaft \\
\hline$C B Q$ & Catholic Biblical Quarterly \\
\hline CNT & Commentaire du Nouveau Testament \\
\hline Cont & Continuum \\
\hline$C Q R$ & Church Quarterly Review \\
\hline CRINT & Compendia rerum iudaicarum ad Novum Testamentum \\
\hline$C V$ & Communio viatorum \\
\hline$D J G$ & $\begin{array}{l}\text { Dictionary of Jesus and the Gospels. Edited by J. B. Green and S. } \\
\text { Mcknight. Downers Grove, } 1992\end{array}$ \\
\hline EBC & The Expositor's Bible Commentary \\
\hline
\end{tabular}


EDSS Encyclopedia of the Dead Sea Scrolls. Edited by Lawrence H. Schiffman and James C. VanderKam. Oxford, 2000

EgT Eglise et Théologie

ER The Encyclopedia of Religion. Edited by M. Eliade. 16 vols. New York, 1987

EstBib Estudios bíblicos

ETL Ephemerides theologicae Iovanienses

EvQ Evangelical Quarterly

ExpTim Expository Times

FAT Forschungen zum Alten Testament

FBBS $\quad$ Facet Books, Biblical Series

HALOT Koehler, L., W. Baumgartner, and J. J. Stamm, The Hebrew and Aramaic

Lexicon of the Old Testament. Translated and edited under the supervision of M. E. J. Richardson. 4 vols. Leiden 1994-1999

HeyJ Heythrop Journal

HTR Harvard Theological Review

HTS Harvard Theological Studies

HUCA Hebrew Union College Annual

IA Iranica Antiqua

IB Interpreter's Bible

IBC Interpretation: A Bible Commentary for Teaching and Preaching

IBS Irish Biblical Studies

IBT Interpreting Biblical Texts 
IDB Interpreter's Dictionary of the Bible. Edited by G. A. Buttrick. 4 vols.

Nashville, 1962

IDBSuP Interpreter's Dictionary of the Bible: Supplementary Volume. Edited by

K. Crim. Nashville, 1976

Int Interpretation

Iraq Iraq

ISBE International Standard Bible Encyclopedia. Edited by G. W. Bromiley. 4

vols. Grand Rapids, 1979-1988

JAOS Journal of the American Oriental Society

JAOSSup Supplements to the Journal of the American Oriental Society

JATS Journal of the Adventist Theological Society

JBL Journal of Biblical Literature

$J B Q \quad$ Jewish Bible Quarterly

JCS Journal of Cuneiform Studies

JECB Journal of Education \& Christian Belief

JETS Journal of the Evangelical Theological Society

JIPh Journal of Indian Philosophy

JJS Journal of Jewish Studies

JNES Journal of Near Eastern Studies

JNSL Journal of Northwest Semitic Languages

JPSTC The JPS Torah Commentary

JQR Jewish Quarterly Review

JSHJ Journal for the Story of the Historical Jesus 
JSNT Journal for the Study of the New Testament

JSNTSup Journal for the Study of the New Testament: Supplement Series

JSOT Journal for the Study of the Old Testament

JSOTSup Journal for the Study of the Old Testament: Supplement Series

JSPSup Journal for the Study of the Pseudepigrapha: Supplement Series

JTS Journal of Theological Studies

JTSA Journal of Theology for Southern Africa

K\&D Keil, C. F., and F. Delitzsch, Biblical Commentary on the Old Testament.

Translated by J. Martin et al. 25 vols. Edinburgh, 1857-1878. Reprint, 10

vols., Grand Rapids, MI, 1983

KEK Kritisch-exegetischer Kommentar über das Neue Testament

(Meyer-Kommentar)

LTJ Lutheran Theological Journal

MAJTh Mid-America Journal of Theology

MBP Mellen Biblical Press Series

MCNT Meyer's Commentary on the New Testament

NAC New American Commentary

NIB New Interpreter's Bible

NICNT New International Commentary on the New Testament

NICOT New International Commentary on the Old Testament

NIDNTT New International Dictionary of New Testament Theology. Edited by C.

Brown. 4 vols. Grand Rapids, 1975-1985 
NIDNTTE New International Dictionary of New Testament Theology and Exegesis.

Edited by Moisés Silva. 5 vols. Grand Rapids, 2014

NIDOTTE New International Dictionary of Old Testament Theology \& Exegesis.

Edited by W. A. VanGemeren. 5 vols. Grand Rapids, 1997

NIVAC NIV Application Commentary

NovTSup Novum Testamentum Supplements

NPOT New Perspectives on the Old Testament

NSBT New Studies in Biblical Theology

NTD Das Neue Testament Deutsch

Or Orientalia

OTL Old Testament Library

OTS Old Testament Studies

OtSt Oudtestamentische Studiën

PCNT Paideia Commentaries on the New Testament

Proc Proceedings

RelSRev Religious Studies Review

$\operatorname{Res} Q \quad$ Restoration Quarterly

RevExp Review and Expositor

RTR Reformed Theological Review

SBJT Southern Baptist Journal of Theology

SBL Society of Biblical Literature

SBLDS Society of Biblical Literature Dissertation Series

SBT Studies in Biblical Theology 
Scr Scripture

SDSSRL Studies in the Dead Sea Scrolls and Related Literature

SEA Svensk exegetisk årsbok

Semeia Semeia

SJT Scottish Journal of Theology

SNTSMS Society for New Testament Studies Monograph Series

SPCK Society for Promoting Christian Knowledge

SJOT Scandinavian Journal of the Old Testament

ST Studia theologica

STDJ Studies of the Texts of the Desert of Judah

SubBi Subsidia biblica

TBD Tydale Bible Dictionary

TD Theology Digest

TDNT Theological Dictionary of the New Testament. Edited by G. Kittel and G.

Friedrich. Translated by G. W. Bromiley. 10 vols. Grand Rapids, 19641976

TDOT Theological Dictionary of the Old Testament. Edited by G. J. Botterweck, H. Ringgren, and Heinz-Josef Fabry. Translated by J. T. Willis, G. W. Bromiley, and D. E. Green. 15 vols. Grand Rapids, 1974-2015

TLNT Theological Lexicon of the New Testament. C. Spicq. Translated and edited by J. D. Ernest. 3 vols. Peabody, MA, 1994

TNTC Tyndale New Testament Commentaries

TOTC Tyndale Old Testament Commentaries 
TWOT Theological Wordbook of the Old Testament. Edited by R. L. Harris, G. L.

Archer Jr. 2 vols. Chicago, 1980

VT Vetus Testamentum

VTSup Vetus Testamentum Supplements

WBC Word Biblical Commentary

WPC Westminster Pelican Commentary

WTJ Westminster Theological Journal

WUNT Wissenchaftliche Untersuchungen zum Neuen Testament

ZAW Zeitschrift für die alttestamentliche Wissenschaft

ZIBBC Zondervan Illustrated Bible Background Commentary: Old Testament:

2 vols. Edited by John H. Walton. Grand Rapids, 2009

ZNW Zeitschrift für die neutestamentliche Wissenschaft und die Kunde der

älteren Kirche

Dead Sea Scrolls (DSS)

1QM War Scroll

1QS Community Rule

4Q158 Pentateuch Paraphrase

4Q266 Damascus Document ${ }^{a}$

CD Damascus Document

Josephus

Ag. Ap. Against Apion 
Ant. Jewish Antiquities

Philo

Aet. $\quad$ De aeternitate mundi

Flacc. In Flaccum

Her. Quis rerum divinarum heres sit

Leg. Legum allegoriae

Mut. $\quad$ De mutatione nominum

Pep. $\quad$ De praemiis et poenis and De exsecrationibus

Plant. De plantatione

Pot. Quod deterius potiori insidiari soleat

Sacr. De sacrificiis Abelis et Caini

Spec. De specialibus legibus 


\section{INTRODUCTION}

\section{Background of the Problem}

According to Kirsten Nielsen, Hermann Gunkel was the first scholar who discovered the genre of Gerichtsrede or "covenant lawsuit." Since this observation scholars have widely studied this genre especially in the books of the prophets, but without consensus among them. Thus Grant R. Osborne wrote, "Scholars debate whether the form originated from Hittite suzerainty treaties, the covenant or heavenly 'lawsuit' (rîb), current legal customs or the covenant renewal liturgy of Israel. ${ }^{22}$ Furthermore he adds, "Most likely we can never decide this type of detail with any precision." 3 Some scholars have even argued that the covenant lawsuit as a genre should be abandoned because it is not present in the Scripture. ${ }^{4}$

Those who believe that the covenant lawsuit is present in the Scripture have associated this genre with some Hebrew words; among them the verb עוּד, "to bear

\footnotetext{
${ }^{1}$ See Kirsten Nielsen, Yahweh as Prosecutor and Judge: An Investigation of the Prophetic Lawsuit (Rîb-pattern) (Sheffield, England: Department of Biblical Studies, University of Sheffield, 1978), 5,6 .

${ }^{2}$ Grant R. Osborne, The Hermeneutical Spiral: A Comprehensive Introduction to Biblical Interpretation, rev. and exp. ed. (Downers Grove, IL: InterVarsity, 2006), 269.

${ }^{3}$ Ibid.

${ }^{4}$ Among those who disagree are Michael de Roche, "Yahweh rîb against Israel: A Reassessment of the So-Called 'Prophetic Lawsuit' in the Preexilic Prophets," JBL 102 (1983): 563-74; and Dwight R. Daniels, "Is There a 'Prophetic Lawsuit' Genre?," ZAW 99 (1987): 339-60. These two journals have been so influential that after their publications some scholars have preferred not to evaluate this issue. As an example of this, see John M. Bracke, "ריב” NIDOTTE 3:1105; and Osborne, Hermeneutical Spiral, 269.
} 


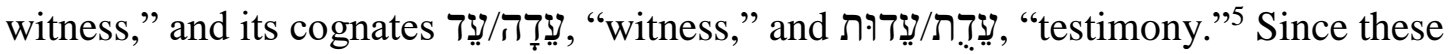

words have been related to the covenant lawsuit, and the conflicting arguments of this genre have been based especially on the Old Testament Prophets, many scholars, who agree with it, have recognized that the language of the Gospel of John is based on the legal language of Isaiah. As a result, they have bypassed the similarities that the Gospel of John has with the Pentateuch based on the use of the word "witness" and its cognate verb. Therefore, the proper study of this term could help to answer the dilemma of the main source of the Gospel of John when its author uses the "witness" motif.

For example, an introductory examination shows the following: For the concept of witness, the Pentateuch uses the term 30 times, six times in Genesis, three in

\footnotetext{
${ }^{5}$ Among scholars who support the covenant lawsuit motif are: Hans Schmidt, Die großen Propheten (Göttingen: Vandenhoed and Ruprecht, 1915), 1xiii; Herbert B. Huffmon, "The Covenant Lawsuit in the Prophets," JBL 78 (1959): 285-95; George E. Mendenhall, "Covenant Forms in Israelite Tradition," BA 17 (1954): 50-76; B. Gemser, "The Rib- or Controversy-Pattern in Hebrew Mentality," in Wisdom in Israel and in the Ancient Near East, VTSup 3, ed. Martin Noth and D. Winton Thomas (Leiden: Brill, 1955), 128-33; Julien Harvey, 'Le 'Rîb Pattern,' requisitoire prophétique contre Israël, après la rupture de l'alliance," Bib 43 (1962): 172-96; G. Ernest Wright, "The Lawsuit of God: A Form-Critical Study of Deuteronomy 32," in Israel's Prophetic Heritage: Essays in Honor of James Muilenburg, ed. Bernhard W. Anderson and Walter Harrelson (NY: Harper \& Row, 1962), 26-67; James Limburg, "The Root ריב and the Prophetic Lawsuit Speeches,” JBL 88 (1969): 291-304; Hans Jochen Boecker, Redeformen des Rechtslebens im Alten Testament, WMANT 14, 2nd ed. (Neukerchen-Vluyn: Neukirchener, 1970), 86-87; G. W. Ramsey, "Speech-Forms in Hebrew Law and Prophetic Oracles," JBL 96 (1977): 45-58; Charles Mabee, "Jacob and Laban: The Structure of Judicial Proceedings (Genesis XXXI 25-42)," VT 30 (1980): 192-207; Claus Westermann, Basic Forms of Prophetic Speech, trans. Hugh C. White (Louisville: Westminster, 1991), 199; H. Ringgren, "ריב" TDOT 13:475-78.

Other Hebrew word associated with the covenant lawsuit genre is ריב" which in its context is

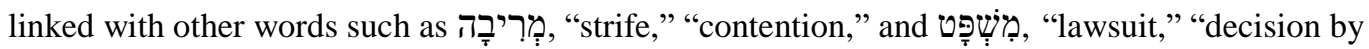

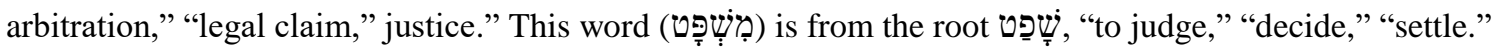

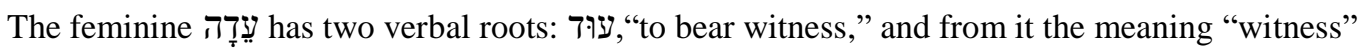
and "testimony," and "עד "עוב "appoint," used as a niphal means "assemble," "meet." From that root, the noun עָרדה is translated "congregation" or "assembly." With this particular meaning is used 149 times in the Old Testament; of those, 109 in the Pentateuch. This particular term is translated as $\sigma v v \alpha \gamma \omega \gamma \eta$ by the LXX. Nevertheless, sometimes scholars are not sure, even within the context, how to translate this word, either as

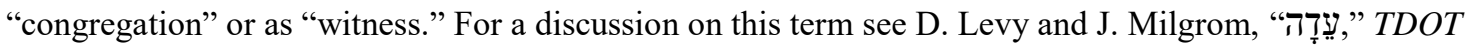
10:468-80.
} 
Exodus, one in Leviticus, three in Numbers, and 17 in Deuteronomy. ${ }^{6}$ This term refers to "someone who confirms before a court that something is right or wrong" and "is able by his evidence to bring a legal dispute to a conclusion." ${ }^{7}$

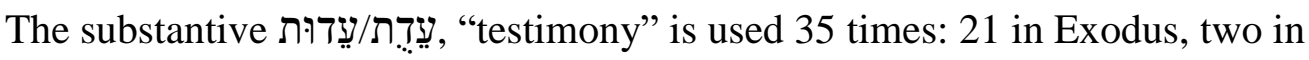
Leviticus, and 12 in Numbers. Its nuance is used in relationship to the "ark of the testimony," the "two tablets of the testimony," and the "tabernacle of testimony.",

The verb עוּד occurs 10 times: two in Genesis; three in Exodus, and five in Deuteronomy. ${ }^{9}$ Of these occurrences, only one time is in the hophal (Exod 21:29), and the rest in the hiphil. In the hophal, the verb is associated with a person who has previous knowledge about a warning against him for something wrong that has happened in the past. If this person does not heed the warning, then that person shall be put to death. In the hiphil, it is a charge, summoning somebody to bring proof of what he has said. It is also a solemn call to a third party to be involved in a legal process.

Additionally a witness might be a human being, a divine being, or inanimate objects. As in the case of Jacob and Laban when they met at Gilead and made a covenant,

${ }^{6}$ Gen 21:30; 31:44, 48, 50, 52 (two times); Exod 20:16; 22:13 (Heb. v. 12); 23:1; Lev 5:1; Num 5:13; 35:30 (two times); Deut 4:45; 5:20; 6:17, 20; 17:6 (three times), 7; 19:15 (three times), 16,18 (two times); 31:19, 21, 26.

${ }^{7}$ Ludwig Köhler and Walter Baumgartner, "עַד]," HALOT 1:788. See also C. van Leeuwen, “"ēd," TLOT 2:840, 841; Ronald B. Allen, Numbers, EBC (Grand Rapids, MI: Zondervan, 1990), 2:1005; H. Simian-Yofre, "עוּד, TDOT 10:501.

${ }^{8}$ Exod 16:34; 25:16, 21, 22; 26:33, 34; 27:21; 30:6 (two times), 26, 36; 31:7, 18; 32:15; 34:29; $38: 21 ; 39: 35 ; 40: 3,5,20,21$; Lev 16:13; 24:3; Num 1:50, 53 (two times); 4:5; 7:89; 9:15; 10:11; 17:4, 7, 8, 10 (Heb. vv. 19, 22, 23, 25); 18:2.

\footnotetext{
${ }^{9}$ Gen 43:3 (two times); Exod 19:21, 23; 21:29; Deut 4:26; 8:19; 30:19; 31:28; 32:46.
} 
Laban proposed two different witnesses which gave the pact abiding validity. ${ }^{10}$

According to Num 35:30; Deut 17:6, and 19:15, one witness alone cannot bring a legal accusation against somebody. ${ }^{11}$ Also, a false testimony is prohibited (Exod 20:16; 23:1; Deut 5:20), given with a warning to inflict upon the false witness the same penalty that he intended to impose upon the accused (Deut 19:16-21). Furthermore, a curse could be pronounced publicly against a witness who withholds a testimony (Lev 5:1). Thus, R. B. Allen argues that "this provision was made to avoid the possibility of an innocent party being accused and sentenced to death on insufficient evidence." 12

This concept of witness appears as a practice in ANE literature, such as the Code of Hammurabi, and the Egyptian and Hittite Treaties. ${ }^{13}$ Similarly, it is used in a context of a judicial environment in the Qumran community. ${ }^{14}$ And on their part, Philo, Josephus,

${ }^{10}$ Victor P. Hamilton, The Book of Genesis: Chapters 18-50, NICOT (Grand Rapids, MI: Eerdmans, 1995), 313. See Gen 31:42, 44, 48, 50; Exod 22:12; Deut 31:19, 21, 26.

11 This law did not take effect when a jealous husband accused his wife of unfaithfulness (Num 5:11-31), for which his lone testimony was enough to take her to trial but not to apply the death penalty because "there was not witness against her, nor was she caught" (Num 5:13).

${ }^{12}$ Allen, Numbers, 2: 1005.

13 The first 13 laws of the Code of Hammurabi are based on a trial where the people in conflict had to provide witnesses (šì $\bar{u} t u m)$ in order to make their case (dīnum). They were warned not to bring "false testimony (š̄bütum) in a case" because this might result in death of an innocent person. An analysis of these laws shows that the Code is concerned with the report brought by the witness of the two parties rather than with what the people in dispute were saying. The Code does not say whether the witnesses, who were on the side of the guilty party, were punished along with that party. However, the way these laws are written reveals that the judges did not involve the witnesses with what the parties in dispute said. The judges were more interested in listening to what the witnesses knew, declaring their testimony "in the presence of god." See James B. Prichard, ed., Ancient Near Eastern Texts Relating to the Old Testament (Princeton, NJ: Princeton University Press, 1950), 163-80.

\footnotetext{
14 The settlement of a trial is used in two important DSS: the Damascus Document (CD), and the Rule of the Community (1QS).
} 
and the Jewish Talmud render that concept with a legal overtone as well, emphasizing in this way the judicial context within Jewish thought. ${ }^{15}$

For the Hebrew verb עוּ, the LXX generally uses the word $\mu \alpha \rho \tau v \rho \varepsilon ́ \omega$, "to witness, to testify, to bear witness;", and its cognate verbs $\delta 1 \alpha \mu \alpha \rho \tau v \rho \varepsilon ́ \omega$, "to testify," "to

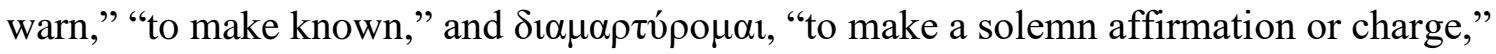
"protest," "to declare solemnly and earnestly." For the substantive עֵّד, the LXX uses

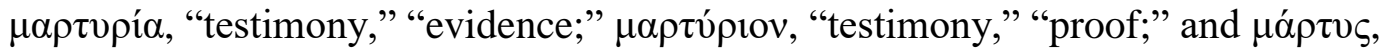
"witness."

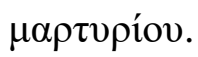

In the New Testament, $\mu \alpha \rho \tau v \rho i ́ \alpha$ occurs 37 times, and only seven of those occurrences are outside the Johannine writings: four are related to the court motif in the trial of Jesus before his crucifixion (Mark 14:55, 56, 59; Luke 22:71); one with reference to the character of a person who wants to be a bishop (1 Tim 3:7), one gives verification to a quotation from Epimenides, a Greek poet (Titus 1:12, 13), and one in which God sends Paul to preach the gospel (Acts 22:18). In the Gospel of John $\mu \alpha \rho \tau v \rho i ́ \alpha$ is used 14 times, and the verb $\mu \alpha \rho \tau v \rho \varepsilon ́ \omega 33$ times. ${ }^{18}$ In the Synoptics the noun occurs four times:

\footnotetext{
${ }^{15}$ Philo, Aet. 1:25; ibid., Sacr. 1:91; ibid., Pep. 1:79; ibid., Leg. 3:208; ibid., Her. 1:4; ibid., Mut. 1:258; ibid., Pots. 1:124; ibid., Plant. 1:173; ibid., Spec. 4:53-55; Josephus, Ant. 4.219; 16.161; ibid., Ag. Ap. 1.160; B. T. Pesahim 118a; Yebamoth 25a; 31b.

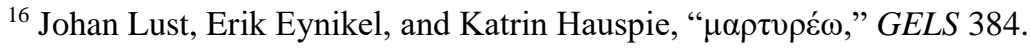

${ }^{17}$ Ibid.

${ }^{18}$ For the noun $\mu \alpha \rho \tau$ tupía, see John 1:7, 19; 3:11, 32, 33; 5:31, 32, 34, 36; 8:13, 14, 17; 19:35; 21:24. For the verb $\mu \alpha \rho \tau$ ḉ์ times), 33, 36, 37, 39; 7:7; 8:13, 14, 18 (two times); 10:25; 12:17; 13:21; 15:26, 27; 18:23, 37; 19:35; 21:24. The Phrase "Gospel of John" in this dissertation has nothing to do with matter of authorship but with general convention based on the received text.
} 
three in Mark $(14: 55,56,59)$, and one in Luke $(22: 71)$; and the verb is used two times: once in Matthew (23:31) and once in Luke (4:22). ${ }^{19}$

The prominent use of the word $\mu \alpha \rho \tau$ pí $\alpha$ and its cognates, in the Gospel of John, calls for attention. Why is the Evangelist so interested in this word? What is the value of his repetitive use of the verb $\mu \alpha \rho \tau \nu \rho \varepsilon ́ \omega$ ? Has this concept of witness in the Gospel of John some judicial link with the Pentateuch?

Théo Preiss wrote in 1951 the book La Vie en Christ, of which several essays were selected and translated three years later to make an English volume with the title Life in Christ. ${ }^{20}$ In this book he examined part of the Gospel of John, and explained how Gnostics, Neoplatonist mystics, and liberal critics had studied it as a metaphysical Gospel. ${ }^{21}$ After a debate against the arguments of those groups, he wrote that the judicial character of the Gospel of John had been strangely neglected by exegetes because of its mystical reputation. ${ }^{22}$

After Preiss' suggestion, several New Testament scholars have studied the Gospel of John, looking for a judicial motif. Johannes Beutler researched the concept of $\mu \alpha \rho \tau v \rho i ́ \alpha$ based on linguistic procedure, ${ }^{23}$ Anthony Ernest Harvey connected that concept

\footnotetext{
${ }^{19}$ See Andrew T. Lincoln, Truth on Trial: The Lawsuit Motif in the Fourth Gospel (Peabody, MA: Hendrickson, 2000), 12.

${ }^{20}$ Théo Preiss, La Vie en Christ (Neuchâtel, Switzerland: Delachaux et Niestlé, 1951); ibid., Life in Christ (IL: Alec R. Allenson, 1954).

${ }^{21}$ Ibid., 9.

22 Ibid., 11.

23 Johannes Beutler, Martyria: Traditionsgeschichtliche Untersechungen zum Zeugnisthema bei Johannes (Frankfurt: Josef Knecht, 1972).
} 
with the Synoptic Gospels; ${ }^{24}$ Andrew T. Lincoln based his analysis of John on Isa 40-55, which, he says, "provides the resources for the Fourth Gospel's narrative." ${ }^{25}$ But for the nature of those studies, those scholars did not connect the concept of witness in the Gospel of John with the Pentateuch. ${ }^{26}$

\section{Statement of the Problem}

Scholars have bypassed or taken for granted the intertextual connection of the concept of witness between the Pentateuch and the Gospel of John. Instead they have focused on the Prophets, especially the book of Isaiah. An exhaustive research of this concept in the Pentateuch and in the Gospel of John may help to link them both and establish the Gospel of John's main source for its legal arguments.

\footnotetext{
${ }^{24}$ See Anthony Ernest Harvey, Jesus on Trial: A Study in the Fourth Gospel (London: SPCK, 1976).
}

${ }^{25}$ Lincoln, Truth on Trial, 38. For the judicial concept in the Fourth Gospel see also Josef Blank, Krisis: Untersuchungen zur Johanneischen Christologie und Eschatologie (Freiburg im Breisgau: Lambertus-Verlag, 1964); Severino Pancaro, The Law in the Fourth Gospel: The Torah and the Gospel, Moses and Jesus, Judaism and Christianity According to John, NovTSup 42 (Leiden: Brill, 1975); Raymond F. Collins, John and His Witness (Collegeville, MN: Liturgical, 1991).

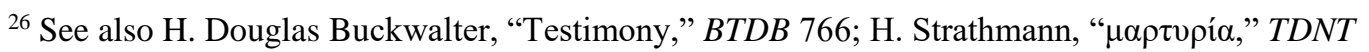
4:500; Allison A. Trites, The New Testament Concept of Witness (Cambridge: Cambridge University Press, 1977), 78-124; and Lincoln, Truth on Trial, 42-56. Other scholars have addressed the question of the source of the Old Testament quotations in the Gospel of John such as Edwin D. Freed, Old Testament Quotations in the Gospel of John (Netherlands: Brill, 1965), 1-130; Maarten J. J. Menken, Old Testament Quotations in the Fourth Gospel: Studies in Textual Form (Kampen, Netherlands: Kok Pharos, 1996), 11212. Nevertheless, the concern of this dissertation is in the legal vocabulary that appears in the Pentateuch and in the Gospel of John, paying special attention to the word "witness" and its cognates, which could help in the establishment of the proper meaning of this subject, and the possible connection of these two literatures.

Herbert Wolf, An Introduction to the Old Testament: Pentateuch (Chicago, IL: Moody, 1991), 1820, shows the clear unity of the Pentateuch; and John H. Sailhamer, The Pentateuch as Narrative: A Biblical-Theological Commentary, LBI (Grand Rapids, MI: Zondervan, 1992), 1, 2, makes a good point in the introduction of his book, saying that the Pentateuch was originally a single book as it is mentioned throughout the Bible, i.e. 2 Chr 25:4; 35:12; Ezra 6:18; Neh 13:1; Mark 12:26. Every time, these passages call the Pentateuch "the book of Moses." Taking this consideration into account, I will use the name "Pentateuch" as a single unit or book, throughout this dissertation. 
Taking into consideration these problems, this dissertation will address the following questions: Does the witness terminology point toward an intertextual relation between the Pentateuch and the Gospel of John? If so, in what way are they connected?

\section{Purpose of the Study}

The purpose of this study is to analyze the "witness" motif and its cognates, theological background, proper meaning, and connection between the Pentateuch and the Gospel of John.

\section{Delimitations}

In this dissertation I pay special attention to the word "witness" and its cognates in the Pentateuch and in the Gospel of John. However, I do not deal with questions of historical background related to sources and authorship of the Pentateuch and of the Gospel of John; nor I address the Writings, the Prophets, the Synoptic Gospels, Paul's Epistles and general Epistles.

\section{Methodology}

This study is a research of the Pentateuch and the Gospel of John based on a grammatical-historical exegesis of the passages in which the word "witness" and its cognates appear. This grammatical-historical methodology, which has been the traditional definition of exegesis, in this dissertation is based on the final canonical form of the biblical text in their respective original languages (Hebrew and Greek). ${ }^{27}$ Along

\footnotetext{
${ }^{27}$ For more on the topic of exegesis and the grammatical-historical methodology discussion see Gordon D. Fee and Douglas Stuart, How to Read the Bible for All Its Worth: A Guide to Understanding the Bible, 2nd ed. (Grand Rapids, MI: Zondervan, 1993), 19-25; Stanley E. Porter and Kent D. Clarke, "What is Exegesis?: An Analysis of Various Definitions," in A Handbook to the Exegesis of the New Testament,
} 
with it, the approach of intertextuality is used, grounded on the understanding that a biblical text belongs to a network of texts and as such can be interpreted based on citations, key words, motifs, and allusions of previous writers. This intertextual approach is going to be textual oriented rather than reader oriented. ${ }^{28}$

ed. Stanley E. Porter (Boston, MA: Brill, 2002), 7-9; Darrell L. Bock, "Opening Questions: Definition and Philosophy of Exegesis," in Interpreting the New Testament Text: Introduction to the Art and Science of Exegesis, eds. Darrell L. Bock and Buist M. Fanning (Wheaton, IL: Crossway, 2006), 23-32; John H. Hayes and Carl R. Holladay, Biblical Exegesis: A Beginner's Handbook, 3rd ed. (Louisville, KY: WJK, 2007), 1-21; W. Randolph Tate, Handbook for Biblical Interpretation: An Essential Guide to Methods, Terms, and Concepts, 2nd ed. (Grand Rapids, MI: Baker Academic, 2012), 152-153, 183-184.

The final canonical form refers to the Leningrad Hebrew text, received in the Biblia Hebraica Sttugartensia, and the Greek text in Nestle-Aland 28th edition. See also Bruce K. Waltke and Charles Yu, An Old Testament Theology: An Exegetical, Canonical, and Thematic Approach (Grand Rapids, MI: Zondervan, 2007), 10, 72; Brevard S. Childs, Biblical Theology in Crisis (Philadelphia, PA: Westminster, 1970), 147; Rolf P. Knierim, The Task of Old Testament Theology: Substance, Method, and Cases (Grand Rapids, MI: Eerdmans, 1995), 4; John H. Sailhamer, Introduction to Old Testament Theology: A Canonical Approach (Grand Rapids, MI: Zondervan, 1995); Max Turner, "New Testament Commentary and Systematic Theology: Strangers or Friends," in Between Two Horizons: Spanning New Testament Studies and Systematic Theology, ed. J. B. Green and M. Turner (Grand Rapids, MI: Eerdmans, 2000), 54-55; Frank Thielmann, Theology of the New Testament: A Canonical and Synthetic Approach (Grand Rapids, MI: Zondervan, 2005), 36-37; Gerald A. Klingbeil, "The Text and the Canon of Scripture," in Understanding Scripture: An Adventist Approach, ed. George W. Reid (Hagerstown, MD: Review and Herald Publishing Association, 2006), 91-110; Osborne, The Hermeneutical Spiral, 359-61.

${ }^{28}$ See Waltke and Yu, An Old Testament Theology, 125-42; Michael Fishbane, Biblical Interpretation in Ancient Israel (Oxford: Clarendon, 1985); ibid., "Types of Biblical Intertextuality," in Congress Volume, VTSup 80, ed. A Lemaire and M. Saebo, (Boston, MA: Brill, 2000), 39-44; Spike Draisma, ed., Intertextuality in Biblical Writings: Essays in Honour of Bas van Iersel (Kampen, Netherlands: J. H. Kok, 1989); Danna Nolan Fewell, ed., Reading Between Texts: Intertextuality and the Hebrew Bible (Louisville, KY: Westminster John Knox, 1992); George Wesley Buchanan, Introduction to Intertextuality, MBP 26 (Lewiston, NY: Edwin Mellen, 1994); Craig A. Evans and Shemaryahu Talmon, eds., The Quest for Context and Meaning: Studies in Biblical Intertextuality in Honor of James A. Sanders (Leiden, Netherlands: Brill, 1997); Timothy K. Beal, "Intertextuality," in Handbook of Postmodern Biblical Interpretation, ed. A. K. M. Adam (St. Louis, MI: Chalice, 2000), 128-30; Steve Moyise, "Intertextuality," in The Old Testament in the New Testament: Essays in Honour of J. L. North, JSNTSup 189, ed. Steve Moyise (Sheffield, England: Sheffield Academic, 2000), 14-41; Kirsten Nielsen, "Intertextuality and Hebrew Bible," in Congress Volume, VTSup 80, eds. A Lemaire and M. Saebo, (Boston, MA: Brill, 2000), 17-31; John Barton, "Intertextuality and the 'Final Form' of the Text," in Congress Volume, VTSup 80, eds. A Lemaire and M. Saebo, (Boston, MA: Brill, 2000), 33-37; Richard N. Soulen and R. Kendall Soulen, Handbook of Biblical Criticism: Now Includes Precritical and Postcritical Interpretation, 3rd rev. and exp. ed. Louisville, KY: WJK, 2001), 87-88; S. D. Giere, A New Glimpse of Day One: Intertextuality, History of Interpretation, and Genesis 1.1-5 (Berlin: Walter de Gruyter, 2009), 3; Martin Pröbstle, "Truth and Terror: A Text-Oriented Analysis of Daniel 8:9-14" (Ph.D. diss., Andrews University, 2006), 565-80; David Ryan Klingler, "Validity in the Identification and Interpretation of a Literary Allusion in the Hebrew Bible" (Ph.D. diss., Dallas Theological Seminary, 2010); Henk Leene, Newness in Old Testament Prophecy: An Intertextual Study, OTS 64, ed. B. Becking (Boston, MA: Brill, 2014), 4-9. 
Also, in this process, I use inductive and deductive methodologies which have been defined as a search for evidencial (inductive) and presuppositional (deductive) interpretations of the biblical text. ${ }^{29}$ The inductive and deductive methodologies are going to be used for interpreting the biblical text and survey what scholars say about the witness motif.

After the introduction, chapter one is a survey of the "witness" language in the literature of ANE cultures. Inductive and deductively, chapter two reviews modern scholarship in order to evaluate their study of the "witness" motif in the Old Testament, and how they have been influenced to bypass the connection between the Pentateuch and the Gospel of John in their legal language. Chapters three and four will be devoted to an exegetical analysis of the "witness" language in the Pentateuch and in the Gospel of John respectively. Chapter four is an intertextual exploration of the links that the Gospel of John has with the Pentateuch in their rendering of "witness" and "bearing witness," and their possible agreements and disagreements in the way they use these words. And chapter five is an intertextual analysis of the many passages in which the author of the Gospel of John has used the Pentateuch in any form.

\section{Definition of Terms}

Covenant Lawsuit: A legal case placed by God against his people because they have broken his covenant.

${ }^{29}$ David R. Bauer and Robert A. Traina, Inductive Bible Study: A Comprehensive Guide to the Practice of Hermeneutics (Grand Rapids, MI: Baker Academic, 2001)1, 2, 17; James D. Hernando, Dictionary of Hermeneutics: A Concise Guide to Terms, Names, Methods, and Expressions (Springfield, MI: GPH, 2005), 18, 25. 
False Witness: $\quad$ A person who brings lies to court against an innocent party. In a just verdict, this person would be punished with the same punishment that the innocent party would be punished if found guilty.

Lawsuit: A case brought to a rudimentary or an official court in which two parties generally place their claims before a third party.

Witness: A person who can speak about a legal case because either he has seen the event or known about any sensitive information useful to help the judges make a decision. In biblical times it was required that people involved in litigations bring to court at least two witnesses in order to make a final decision in a case. 


\section{CHAPTER 1}

\section{REVIEW OF ANCIENT LITERATURE}

This is a two-section chronological review of extrabiblical literature which deals with the language of "witness" in ANE literature and ancient Jewish interpretation from late 18th century $\mathrm{BC}$ to $\mathrm{AD} 500$. The first section is an analysis of nine treaties in ancient cities such as Hattusa, Egypt, Babylon, Assyria and Syria, which are important for their covenantal value. And the second one examines Jewish literature from the time of the DSS to the development of the Talmud, in order to know what they say about "witness" and "bearing witness" in their writings. This section could help to clarify Jewish mentlity concerning this matter.

\section{"Witness" and "Bearing Witness" in ANE Literature}

\section{The Code of Hammurabi (18th Century BC)}

The Code of Hammurabi was the law of the land of Babylon and her vassal cities; promulgated at some time during the 43 years of Hammurabi's rule. ${ }^{1}$ This Code of Hammurabi has been divided in three parts: The Prologue, the Law, and the Epilogue.

\footnotetext{
1 “The Code of Hammurabi," translated by Theophile J. Meek (ANET, 163-80). According to Meek, Hammurabi was the sixth of eleven kings in the Old Babylonian Dynasty who ruled for 43 years, from 1728 to 1686 BC. Cf. Robert Francis Harper, The Code of Hammurabi, King of Babylon (London: University of Chicago Press, 1904); Thorkild Jacobsen, "Primitive Democracy in Ancient Mesopotamia," JNES 2 (1943): 159-72; William W. Hallo and K. Lawson Younger, eds., Early Mesopotamian Royal Titles, AOS 43 (New Haven: AOS, 1957); Martin Noth, The Laws in the Pentateuch and other Studies, trans. D. R. Ap-Thomas (Edinburgh: Oliver \& Boyd, 1966), 14, 122, 123. The date of Hammurabi's
} 
In the prologue, Hammurabi expands his discourse giving the reasons of his kingship and the promulgation of the law: The gods have been favorable to Babylon, and exalted Hammurabi as king to promote justice throughout the land; and as he goes on conquering cities, he honors his gods in gratitude, restoring and building shrines and temples. $^{2}$

The second part is a composition of 282 laws in which the first 13 are based on a trial where the people in conflict have to provide witnesses in order to make their case. ${ }^{3}$ They are warned not to bring "false testimony in a case" because the result would be a cause of punishment with death. ${ }^{4}$

kingship has a variety of opinions, but for this dissertation the code itself is more relevant than this. See more about the Code of Hammurabi in John P. Peters, "Excavation in Persia," HTR 8 (1915): 82-93; Godfrey R. Driver and John C. Miles, The Babylonian Laws, 2 vols. (Oxford: Clarendon, 1952-1955); Kenneth A. Kitchen, Ancient Orient and Old Testament (Chicago, IL: InterVarsity, 1966), 44, 134, 135, 148; Mordecai Zer-Kavod, "The Code of Hammurabi and the Laws of the Torah," JBQ 26 (1998): 107-10; Mark W. Chavalas and Lawson Younger, eds., Mesopotamia and the Bible:Comparative Explorations (Grand Rapids, MI: Baker, 2002); John Sassoon, Ancient Laws and Modern Problems: The Balance Between Justice and a Legal System (Bristol: Intellect, 2004); M. E. J. Richardson, Hammurabi's Laws: Text, Translation, and Glossary (London: T\&T Clark, 2004); Tamera Bryant, The Life and Times of Hammurabi (Hockessin, DE: Mitchell Lane, 2005); Louis L. Orlin, Life and Thought in the Ancient Near East (Ann Arbor, MI: University of Michigan Press, 2007); Marc van de Mieroop, A History of the Ancient Near East, ca. 3000-323 B.C. (Malden, MA: Blackwell, 2007); ibid., "Hammurabi's Self-Presentation," Or 80 (2011): 305-38; Raymond Westbrook, F. Rachel Magdalene, and Bruce Wells, Law from the Tigris to the Tiber: The Writings of Raymond Westbrook (Winona Lake, IN: Eisenbrauns, 2009); Shalom E. Holtz, "Inventing God's Law: How the Covenant Code of the Bible Used and Revised the Laws of Hammurabi," $C B Q 72$ (2010): 820-22; David S. Farkas, "In Search of the Biblical Hammurabi," JBQ 39 (2011): 159-64.

2 "The Code of Hammurabi," (ANET 164, 165).

${ }^{3}$ Ibid., 166. As an example, Law 1 says: "If a seignior accused a(nother) seignior and brought a charge of murder against him, but has not proved it, his accuser shall be put to death." Cf. Num 35:30; Deut 17:6; 19:15. Parentheses or brackets in quoted material are original to the author.

${ }^{4}$ Laws 3, 4. Cf. Exod 20:16; 23:1; Deut 5:20; 19:16-19. Law 9 is an example of punishment for being a false witness: "When a seignior, (some of) whose property was lost, has found his lost property in the possession of a(nother) seignior, if the seignior in whose possession the lost (property) was found has declared, 'A seller sold (it) to me; I made the purchase in the presence of witnesses,' and the owner of the lost (property) in turn has declared, 'I will produce witnesses attesting to my lost (property)'; the purchaser having then produced the seller who made the sale to him and the witnesses in whose presence he made the purchase, and the owner of the lost (property) having also produced the witnesses attesting to his lost (property), the judges shall consider their evidence, and the witnesses in whose presence the purchase was made, along with the witnesses attesting to the lost (property), shall declare what they know in the presence 
The Epilogue has several sections: (1) Hammurabi declares his actions, bringing peace throughout the land $;^{5}$ (2) Any oppressed man could have delight in this law; ${ }^{6}$ also Hammurabi's successor is called to follow this Code $;^{7}$ and (3) Depending on the obedience of the law, the gods are called to be judges who give blessings or inflict curses to his successor, his people, and his land. ${ }^{8}$

Though in its translation, the Code has been divided in three parts, its content indicates more than that: (1) A preamble, translated as a prologue; (2) Stipulations: The actual laws; (3) Historical prologue; ${ }^{9}$ (4) Deposit of the law before Hammurabi’s statue, thus providing everyone with the opportunity to read it; ${ }^{10}$ and (5) Calling to the gods to

of god, and since the seller was the thief, he shall be put to death, while the owner of the lost (property) shall take his lost (property), with the purchaser obtaining from the estate of the seller the money that he paid out." See "The Code of Hammurabi," (ANET 166).

5 Ibid.

6 Ibid.

${ }^{7}$ Ibid.

${ }^{8}$ Ibid. In this part, Hammurabi himself does not punish any disobedient person. But this punishment is applied by the gods to Hammurabi's successors who do not pay attention to the code. Reverse xxvi have 10 lines dedicated to two blessings: "If that man heeded my words which I wrote on my stela, and did not rescind my law, has not distorted my words, did not alter my statutes, may Shamash make that man reign as long as I, the king of justice; may he shepherd his people in justice!" On the other hand, 280 lines in reverses xxvi to xxviii are dedicated to 38 curses. The same pattern is used in Deut 28, with 12 blessings and 56 curses.

${ }^{9}$ Ibid.

${ }^{10}$ Ibid. Part of the epilogue in reverse xxiv, lines 68-reverse xxv, lines 102: "I wrote my precious words on my stela, and in the presence of the statue of me, the king of justice, I set (it) up in order to administer the law of the land, to prescribe the ordinances of the land, to give justice to the oppressed. I am the king who is preeminent among kings; my words are choice; my ability has no equal. By the order of Shamash, the great judge of heaven and earth, may my justice prevail in the land, may my statues have no one to rescind them." This part could be challenged by some; nevertheless a deposit of the law in a temple or palace, properly speaking, has similarities to Hittite treaties. For example, the parity treaty between Ramses Meri-Amon of Egypt and Hattusilis of Hatti is engraved on the walls of the Ramesseum temple (see below, pp. 21-23). 
bring blessings or curses. ${ }^{11}$

This law code shows the importance of involving the people as witnesses and judges in order to bring justice and peace to the land through a righteous judgment. Therefore, the gods are summoned by Hammurabi to watch everybody that the law can be accomplished in its fullness.

\section{Mesopotamian Legal Documents (15th Century BC)}

A Nuzi Akkadian tablet shows six legal documents, one of which reports a lawsuit among three brothers: Shukriya and Kula-hupi against Tarmiya. ${ }^{12}$ The latter argues that his father Huya, who was sick in bed, had given him a female slave called Sululi-Ishtar as his wife because his brothers had wives already. ${ }^{13}$ After the presentation of his case the judges demanded "the witnesses of Tarmiya [and Tarmiya] had his witnesses appear [before the judges] . . ., the son of Hurshaya . .., the son of Ikkiya . .., the son of Itrusha, (and) . . the son of Hamanna." ${ }^{14}$ Immediately after they were examined, the judges required that Shukriya and Kula-hupi took "the oath of the gods against the witnesses of Tarmiya" but they refused to take it. Thus the judges assigned "the female slave, Sululi-Ishtar, to Tarmiya."15

11 "The Code of Hammurabi," (ANET 166). Part of the epilogue in reverses xxvi-xxviii. Though I have divided the Code of Hammurabi in such a way that could correspond to a Hittite treaty's structure I am aware that Hammurabi had a different intention than those kings who imposed their will upon their vassals.

\footnotetext{
12 The other five are: Two sale adoptions, a real adoption and two Hebrew slave documents. See “Mesopotamian Legal Documents," translated by Theophile J. Meek (ANET, 219, 220).

${ }^{13}$ Pritchard, ed., The Ancient Near East: An Anthology of Texts and Pictures (Princeton, NJ: Princeton University Press, 1958), 169.

${ }^{14}$ Ibid.

${ }^{15}$ Ibid., 169, 170.
} 
This is a secular lawsuit among people in equal social standing, in which judges intervened but made a decision only after the plaintiffs were not willing to take the oath of the gods. This document does not say what the oath of the gods was; nevertheless, it is clear that the people were convinced that an oath was a serious matter, and when they knew they were in the wrong they prefered not to take it. This lawsuit, which belongs to an epoch as early as the mid-second millennium BC, shows traces of earlier lawsuits in which the parties took an oath before their gods and invoked blessings and curses upon those who broke the covenant. This document does not have blessings and curses; nevertheless, the refusal of Shukriya and Kula-hupi to take the oath means that its content puts a burdensome fear upon those who were about to take the oath while they were guilty. Also, this lawsuit shows the antiquity of the custom of presenting witnesses in a court in order to evaluate a case.

\section{Treaty between Niqmepa of Alalakh and Ir- ${ }^{\mathrm{d}}$ im of Tunip (15th Century BC)}

This treaty is called an "(agreement) sanctioned by an oath to the gods" in which Niqmepa binds Ir- ${ }^{\mathrm{d}} \mathrm{im}$ to his will. ${ }^{16}$ Even though this agreement, at first sight, looks like a parity treaty, an "[agreement] between them," because in the heading it is sealed by Ir${ }^{\mathrm{im}}$, king of Tunip, ${ }^{, 17}$ and in the conclusion by Niqmepa, king of Alalakh, ${ }^{18}$ this is not the case. A close reading shows that Niqmepa has more power than Ir- ${ }^{\mathrm{d}} \mathrm{im}$. This observation $531)$.

16 "Treaty Between Niqmepa of Alalakh and Ir- ${ }^{\mathrm{d} I m}$ of Tunip," translated by E. Reiner (ANET,
17 Ibid.
18 Ibid., 532. 
is stated more clearly when Niqmepa asks Ir- ${ }^{\mathrm{d}} \mathrm{im}$ to extradite to him anyone who is plotting against him but he does not say what he would do if he knows of anyone plotting against Ir- $^{-}$im.

[If in your land] there is [a plot against me, and] they plot [to . .., and you hear of it], you will search for them, [if] they say, [“...] we [are citizens of] Mukishhe," you must not kill those men [but you have to extradite them]. If someone from my land [plots against me], if you hear of it, you must [ . . .] and you must not conceal it from me, and if he lives in your land, you must extradite him. ${ }^{19}$

The same applies to "any booty coming from" Niqmepa's land which had been sold in Ir- ${ }^{\mathrm{d}}$ im's land. Ir- ${ }^{\mathrm{d}} \mathrm{im}$ is warned to seize the booty "together with the one who sells it, and hand it over to me. ${ }^{, 20}$ Also if families enter Ir- ${ }^{\mathrm{d}} \mathrm{im}$ 's land looking for subsistence, Ir- ${ }^{\mathrm{d}} \mathrm{im}$ is sworn to "take them into custody in your land, and feed them, (but) whenever they want to [ret]urn to my land, you must gather them and return them to [my land], and you must not detain one single family in your land." 21

From that part, the text is broken, thus it is difficult to know what Niqmepa would

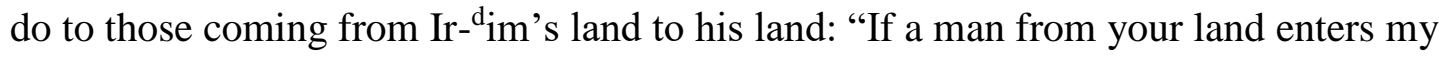
land to find subsistence, and says: 'In my city [there is nothing] to [eat]' [ . . ] if he is a criminal, [ . . ]." 22 The way this part finishes it appears that Niqmepa would look for any means not to feed those coming from Ir- ${ }^{\mathrm{d} i m}$ 's land. After that, the text reveals another difficulty. The twelfth part says: "[If] (any) Hurrian (subject of) our lord becomes an

\footnotetext{
${ }^{19}$ Ibid., 531. Where the text is broken the translator has supplied editorial brackets which are based on parallel passages.

${ }^{20}$ Ibid.

${ }^{21}$ Ibid., 532.

${ }^{22}$ Ibid.
} 
enemy of the king of the Hurrians, I will not break the oath made with the king of the Hurrians, my lord, (unless) he releases me from these stipulations of the oath." 23

Does it mean that Niqmepa is a vassal himself to the king of the Hurrians to whom he calls "my lord," but at the same time he has other vassals under him, [i.e. Ir${ }^{\mathrm{d}} \mathrm{im}$ ? Or are these words said by $\operatorname{Ir}^{\mathrm{d}}{ }^{\mathrm{im}}$ to Niqmepa?] The text is not clear in this section though I am inclined to believe the former argumentation. The treaty/oath ends with a curse, calling the gods to kill "whosoever transgresses these agreements" and "make disappear his name and (his) descendants from the lands, [. . .], they will make him forsake his throne and scepter."24

The composition of this treaty/oath is thus, a heading: Ir- ${ }^{\mathrm{d}}$ im's seal; a preamble which contains the testimony of an oath to the gods between the two kings and the agreements or stipulations; a conclusion: Niqmepa's seal; and a curse that "the great gods" are called to execute against "whosoever transgresses these agreements." 25 This last part confirms the intervention of the gods not only as witnesses, but also as judges in order to preserve the fulfillment of the treaty. Thus, the gods who have been summoned to observe the agreement are in better position to execute a fair decision.

\section{Hittite Treaties}

There are four second-millennium BC treaties that shed light on the importance of witnesses in ANE culture. These are the treaties between Suppiluliumas and Kurtiwaza,

$$
\begin{aligned}
& { }^{23} \text { Ibid. } \\
& { }^{24} \text { Ibid. } \\
& { }^{25} \text { Ibid. }
\end{aligned}
$$


Suppiluliumas and Aziras, Mursilis and Duppi-Tessub, and Ramses Meri-Amon of Egypt and Hattusilis of Hatti. ${ }^{26}$ This evaluation can give clarification to the role of witnesses involved in the process of the treaties of this time and help to interpret the topic of witness in the Pentateuch.

\section{Suppiluliumas and Kurtiwaza (14th Century BC)}

Suppiluliumas, king of Mitanni, and Kurtiwaza, prince of Hurri made a treaty in two parts: (1) A list of "the gods of the contracting parties ... called to listen and to serve as witnesses, ${ }^{27}$ and (2) A summon to them to execute their curses and blessings. Any other part of this treaty is missing. The gods are called to be there in order to curse or bless Kurtiwaza and the sons of Hurri, depending on Kurtiwaza's fulfillment of the words of the treaty, ${ }^{28}$

If you, Kurtiwaza, the prince, and (you) the sons of Hurri country do not fulfill the words of this treaty, may the gods, the lords of the oath, blot you out, (you) Kurtiwaza and (you) the Hurri men together with your country, your wives, and all that you have....

If (on the other hand) you, Kurtiwaza, the prince, and (you), the Hurrians, fulfill this treaty and (this) oath, may these gods protect you, Kurtiwaza, together with your wife, the daughter of the Hatti land, her children and her children's children,

\footnotetext{
${ }^{26}$ To expand more on the history behind the Hittite treaties, see A. H. Sayce, The Hittites: The Story of a Forgotten Empire (London: The Religious Tract Society, 1892), 28-53; L. Messerschmidt, The Hittites, trans. J. Hutchison (London: David Nutt, 1903), 9-20; A. E. Cowley, The Hittites (London: Oxford University Press, 1920); John Garstang, The Hittite Empire: Being a Survey of the History, Geography and Monuments of Hittite Asia Minor and Syria (NY: Richard R. Smith, 1930), 1-11, 105-19; F. F. Bruce, The Hittites and the Old Testament (London: Tyndale, 1947), 5-28; Oliver R. Gurney, The Hittites (Baltimore: Penguin, 1961), 36-39, 58-79; C. W. Ceram, The Secret of the Hittites, trans. Richard Winston and Clara Winston (NY: Schocken Books, 1973), 46-68; J. G. Macqueen, The Hittites and Their Contemporaries in Asia Minor, rev. and enl. ed. (London: Thames and Hudson, 1975), 36-52; Trevor Bryce, Life and Society in the Hittite World (Oxford, England: Oxford University Press, 2002); ibid., The Kingdom of the Hittites, new ed. (Oxford, England: Oxford University Press, 2005); Billie Jean Collins, The Hittite and Their World, SBL 7 (Atlanta, GA: SBL, 2007); Joshua Berman, "History Twice Told: Deuteronomy 1-3 and the Hittite Treaty Prologue Tradition," JBL 132 (2013): 229-50.

27 "God List, Blessings and Curses of the Treaty Between Suppiluliumas and Kurtiwaza," translated by Albrecht Goetze (ANET, 205, 206).

${ }^{28}$ Ibid., 206.
} 
and also (you), the Hurrians, together with your wives, your children, and your children's children and together with your country. May the Mitanni country return to the place which it occupied before, may it thrive and expand. May you, Kurtiwaza, your sons and your sons' sons (descended) from the daughter of the Great King of the Hatti land, and (you), the Hurrians, exercise kingship forever. May the throne of your father persist, may the Mittani country persist. ${ }^{29}$

Notice that nothing is mentioned about what would happen to Suppiluliumas if he did not abide under this agreement, which states that Suppiluliumas, as the king, was imposing this treaty with its curses and blessings upon the prince Kurtiwaza and his people.

\section{Suppiluliumas and Aziras (14th Century BC)}

The Hittite Suppiluliumas made a treaty with Aziras of Amurru after the latter surrendered before the former. ${ }^{30}$ Aziras was ordered to protect Suppiluliumas and his land plus "300 she[kels of refined gold] first class (and) pure" as tribute per year. ${ }^{31}$ This treaty is not like a usual one with each part clearly identified.

Nevertheless, it has a preamble, a historical background or introduction, military clauses in which Suppiluliumas made an oath to protect Amurru if this supported Suppiluliumas in his military campaigns (blessings), and a warning no to transgress the oath. ${ }^{32}$ This warning says as follows, “[If . . .] before you, Aziras, somebody speaks [evil words concerning] the Sun, be it a [notable] or be it an (ordinary) subject of yours, (if)

\footnotetext{
${ }^{29}$ Ibid.

30 "Treaty of Suppiluliumas and Aziras of Amurru," translated by Albrecht Goetze (ANET, 529, $530)$.

${ }^{31}$ Ibid., 529; cf. Jeffrey J. Niehaus, Ancient Near Eastern Themes in Biblical Theology (Grand Rapids, MI: Kregel, 2008), 149.

32 "Treaty of Suppiluliumas and Aziras of Amurru," 529.
} 
you, [Azir]as, will not seize [him] and will not hand him over to the king of the Hatti land, thereby you will transgress the oath." ${ }^{33}$

At the end of the treaty, a gap leads the translator to say that it is "too mutilated for translation;" however, he recognizes that the treaty "closes with a list of gods called to serve as witnesses at the conclusion of the treaty." ${ }^{\prime 34}$

\section{Mursilis and Duppi-Tessub (Mid-14th Century BC)}

The treaty between Mursilis of Hatti and Duppi-Tessub of Amurru is a suzeraintyvassal treaty with the following parts: (1) Preamble: Mursilis declares himself as the Great King of Hatti and son of Suppiluliumas; (2) Historical introduction: Mursilis reminds Duppi-Tessub that his father and grandfather were obedient to Suppiluliumas, thus he has to do the same; (3) Agreement related to the future relations of the two countries: if Duppi-Tessub remains loyal as his ancestors did, Mursilis will support Duppi-Tessub. Also Duppi-Tessub is demanded to continue paying as his ancestors a contribution of 300 shekels of gold; (4) Military clauses: Mursilis says to Duppi-Tessub, "My friends are your friends and my enemies are your enemies;" (5) How to deal with foreigners, and other issues: Duppi-Tessub is bound to return to the Hatti land every fugitive, to declare the name of anybody who has spoken against Mursilis, to execute a doable order, and not to take anything from a country which is put to flight by the king of the Hatti land; (6) Invocation of gods: the gods of both countries are invoked to function as witnesses of this treaty; in this section also, the mountains, the rivers, the springs, the

\footnotetext{
${ }^{33}$ Ibid., 530.

34 Ibid.
} 
great Sea, heaven and earth, the winds and the clouds are included; ${ }^{35}$ and (7) Curses and blessings: if Duppi-Tessub is disloyal, the gods who have witnessed the treaty will destroy him and everything he has; otherwise, they will protect him and everything he possesses. ${ }^{36}$

\section{Ramses Meri-Amon of Egypt and Hattusilis of Hatti (1280 BC)}

In $1280 \mathrm{BC}$ the Great Prince of Hatti made a parity treaty with the Egyptian

Pharaoh Ramses Meri-Amon in order to conclude their mutual hostility. ${ }^{37}$ This treaty was written in Akkadian, which was the diplomatic language of the day, and then translated into Egyptian. ${ }^{38}$ The future relationship of the treaty, from the Hittite point of view is as follows,

Rea-mashesha mai Amana, the great king, the king of the land of Egypt, has entered into a treaty (written) upon a silver tablet with Hattusilis, the great king, the king of the Hatti land, [his] brother, [from] this [da] $\mathrm{y}^{39}$ on to establish good peace (and) good brotherhood be[tween us] forever. He is brother [to me] and I am brother to him and at peace with him forever. And as for us, our brotherhood and our peace is being brought about and it will be better than the brotherhood and the peace which existed formerly for the land of Egypt with the Hatti land. ${ }^{40}$

\footnotetext{
${ }^{35}$ In Deut 4:26; 30:19; 31:28; 32:1, God and Moses call heaven and earth as witnesses.

36 "Treaty between Mursilis and Duppi-Tessub of Amurru," translated by Albrecht Goetze (ANET,
} 203-05).

${ }^{37}$ This treaty has two versions: (1) the Egyptian: "Treaty Between the Hittites and Egypt," translated by John A. Wilson (ANET, 199-201); and (2) the Hittite: "Treaty Between Hattusilis and Ramses II," translated by Albrecht Goetze (ANET, 201-03).

38 "Treaty Between Hittites and Egypt," 199.

39 The Egyptian version sets the date: "Year 21, $1^{\text {st }}$ month of the second season, day 21." According to Wilson's reckoning this would be around the end of November, $1280 \mathrm{BC}$.

40 "Treaty between Hattusilis and Ramses II," 202. The Egyptian version, ibid., 199, says, "Behold, Hattusilis, the Great Prince of Hatti, has set himself in a regulation with User-maat-Re Setep-en$\mathrm{Re}$, the great ruler of Egypt, beginning from this day, to cause that good peace and brotherhood occur between us forever, while he is in brotherhood with me and he is at peace with me, and I am in brotherhood with him and I am at peace with him forever." 
Albrecht Goetze divided the Hittite version in nine parts: (1) Title, (2) preamble, (3) Relations up to the conclusion of the treaty, (4) Present treaty, (5) Future relations of the two countries, (6) Mutual renunciation of aggression, (7) Defensive alliance, (8) Succession to the throne, and (9) Extradition of fugitives. ${ }^{41}$

However, the Egyptian version has been divided in sixteen parts: (1) Time in which the treaty is set, ${ }^{42}$ (2) Preamble, (3) Former relations, (4) Present treaty, (5) Mutual renunciation of invasion, (6) Reaffirmation of former treaties, (7) Defensive alliance for Egypt, (8) Defensive alliance for Hatti, (9) Contingency of death, (10) Extradition of refugees to Egypt, (11) Extradition of refugees to Hatti, (12) Divine witnesses to the treaty, (13) Curses and blessings, (14) Extradition of Egyptians from Hatti, (15) Extradition of Hittites from Egypt, and (16) Description of the tablet. ${ }^{43}$

It is noticeable that the Egyptian version is longer and well preserved. The explanation of this would be that while the Hittite version is preserved in a tablet, "the Egyptian version is carved upon the walls of the Temple of Amon at Karnak and of the Ramesseum;"44 also, the Egyptian version is "edited to give greater prominence to the role of Egypt granting peace;" 45 thus, it might be altered. In the Egyptian version the calling upon divine witnesses is an invocation of the male and female gods of Hatti and the male and female gods of Egypt:

\footnotetext{
41 “Treaty between Hattusilis and Ramses II," 201-03.

${ }^{42}$ This part has not this subtitle, this is my suggestion.

43 "Treaty between the Hittites and Egypt," 199-201.

${ }^{44}$ Ibid., 199.

${ }^{45}$ Ibid.
} 
As for these words of the regulation [which] the Great Prince of Hatti [made] with Ramses [Meri-Amon], the great ruler [of Egypt], in writing upon this tablet of silver - as for these words, a thousand gods of the male gods and of the female gods of them of the land of Hatti, together with a thousand gods of them of the male gods and of the female gods of them of the land of Egypt, are with me as witnesses [hearing] these words. ${ }^{46}$

Concerning the Hittite version, the translator specifies that "some fragmentary lines ... with the end of the treaty" in which "the list of gods who were invoked as witnesses is missing." ${ }^{47}$ This treaty does not recollect human witnesses for its establishment, but rather divine beings which are above human enterprise. ${ }^{48}$

Akkadian Treaty from Assyria

\section{Ashurnirari V of Assyria and Mati'ilu of Arpad (755-745 BC)}

Only a part from this Suzerain treaty has been recovered; and this one starts with the curses that are blended with the stipulations in which Mati'ilu has to show his loyalty

${ }^{46}$ Ibid., 200, 201.

${ }^{47}$ Ibid., 203.

${ }^{48}$ This is also a connection to the Pentateuch in which the Lord God is invoked as witness in several parity treaties. Cf. Oliver R. Gurney, "Hittite Prayers of Mursili II," AAA 27 (1940): 3-163; ibid., Some Aspects of Hittite Religion (Oxford, England: Oxford University Press, 1977); Manfred R. Lehmann, "Abraham's Purchase of Machpelah and Hittite Law," BASOR 129 (1953): 15-17; Hans G. Güterbok, Authority and Law in the Hittite Kingdom, JAOSSup 17 (New Haven: American Oriental Society, 1954); John Albert Wilson, E. A. Speiser, and H. G. Guterbock, Authority and Law in the Ancient Orient, JAOSSup 17 (Baltimore: American Oriental Society, 1954); Abraham Malamat, "Doctrines of Causality in Hittite and Biblical Historiography: A Parallel," VT 5 (1955): 1-12; García de la Fuente, "Los Contratos en el AT Comparados con los de Egipto, Asiria y Babilonia," EstBib 14 (1955): 223-54; J. M. Munn-Rankin, "Diplomacy in Western Asia in the Early Second Millennium," Iraq 18 (1956): 68-110; John A.

Thompson, "Covenant Patterns in the Ancient Near East and Their Significance for Biblical Studies," RTR 18 (1959): 64-75; Philip J. Calderone, Dynastic Oracle and Suzerainty Treaty (Manila, Philippines: Loyola House of Studies, 1966); F. Charles Fensham, "Clauses of Protection in Hittite Vassal-Treaties and the Old Testament," VT 13 (1963): 133-43; Viktor Korosec, "The Warfare of the Hittites-From the Legal Point of View," Iraq 25 (1963): 159-66. 
to Ashurnirari V. ${ }^{49}$ In this part, Ashurnirari V tells Mati'ilu to keep the "treaty made under oath by gods;" otherwise, a curse will fall upon him, his sons and daughters, his officials, his people and his land. ${ }^{50}$ As table 1 shows, that oath is made cutting a lamb into pieces which is used as an illustration of what would happen to Mati'ilu if he breaks the treaty:

Table 1. The lamb and Mati'ilu

\begin{tabular}{|l|l|}
\hline \multicolumn{1}{|c|}{ The lamb } & \multicolumn{1}{c|}{ Mati'ilu } \\
\hline \hline It will not return to its fold. & He will not return to his land. \\
\hline It will not behold its fold again. & $\begin{array}{l}\text { He will not behold his sons and } \\
\text { daughters, his officials and his people. }\end{array}$ \\
\hline Its head is cut off. & $\begin{array}{l}\text { His head and the heads of his sons and } \\
\text { daughters, his officials and his people } \\
\text { will be cut off. }\end{array}$ \\
\hline Its shoulder is cut off. & $\begin{array}{l}\text { His shoulder and the shoulder of his sons } \\
\text { and daughters, his officials and his people } \\
\text { will be cut off. }\end{array}$ \\
\hline
\end{tabular}

The text says, "This spring lamb has been brought from its fold not for sacrifice, not for a banquet, not for a purchase, not for (divination concerning) a sick man, not to be

\footnotetext{
49 “Treaty between Ashurnirari V of Assyria and Mati'ilu of Arpad," translated by E. Reiner (ANET, 532-33). Thompson, The Ancient Near East Treaty and the Old Testament (London: Tyndale, 1963), 13, calls upon the difference between Hittite and Assyrian vassal treaties, saying that while in the Hittite treaty the vassal was given "some semblance of choice," the Assyrian treaty "was a unilateral invention of the suzerain ... without any consulting with the vassal." For this reason he concludes that the Hittite treaties and the covenant between God and Israel are parallel.

${ }^{50}$ Ibid., 532. Ringgren, "עוּד," TDOT 10: 496, calls this treaty a "dependency contract" in which the higher ranking partner forced an individual to fulfill "specific responsibility or obligation (depending on the perspective of the liege lord or vassal, respectively) ceremoniously accepted on the basis of an oath."

${ }^{51}$ Ibid., 532, 533. About the shedding of blood in covenant ritual see David L. Petersen, “Covenant Ritual: A Traditio-Historical Perspective,” BR 22 (1977): 7-18.
} 
slaughtered for [...]: it has been brought to sanction the treaty between Ashurnirari and Mati'ilu. ${ }^{, 52}$ The treaty ends with the naming of the gods and goddesses of both nations who are called by Ashurnirari V not only to adjure the treaty but also to be the means of the curses against Mati'ilu, his sons and daughters, his officials, his people and his land.

\section{The Vassal-Treaties of Esarhaddon (7th Century BC)}

The main parts of the treaty between Esarhaddon, king of Assyria, son of Sennacherib and Ramataya, city-ruler of Urakazabanu and all his people, are: (1) Heading in which Esarhaddon declares who he is and the reason of the treaty (on behalf of Ashurbanipal, crown prince designate of Assyria, and Shamashshumukin, crown prince designate of Babylonia); (2) The gods called as witnesses to the treaty; (3) The terms of the treaty which are given under oath and starts with "If you do (not);" (4) The curses by the gods if Urakazabanu violates the terms of the treaty (this part has no blessings); and (5) The date of the treaty. ${ }^{53}$

52 "Treaty between Ashurnirari V of Assyria and Mati'ilu of Arpad," 532. Something similar took place in Gen 15:7-21 in which God asked Abram to bring "a three-year-old female goat, a three-year-old heifer, a three-year-old ram, a turtledove, and a young pigeon" (v. 9); and after this, Abram "cut them in two, down the middle, and placed each piece opposite the other; but he did not cut the bird in two" (v. 10). That day God renewed his covenant with Abram to give his descendants from the Nile River to the Euphrates which was populated by ten pagan communities (vv. 18-21). However, the Assyrian treaty was negative to the vassal Mati'ilu who was put under fear by his Suzerain. This was not the case with Abram who received promises from God. Though Abram's descendants would serve in another land for about 400 years, they would come out from there "with great possessions" (vv. 13, 14). Abram would die in peace in a good old age and his descendants would possess their enemies' lands (vv. 15, 18-21).

53 "Treaty of Esarhaddon with Baal of Tyre," translated by E. Reiner (ANET, 534-41). See more on Esarhaddon in Godfrey R. Driver and John C. Miles, The Assyrian Laws (Oxford: Clarendon, 1935); Donald John Wiseman, "The Vassal-Treaties of Esarhaddon," Iraq 20 (1958): 1-99; R. Frankena, "The Vassal Treaties of Esarhaddon and the Dating of Deuteronomy," OtSt 14 (1965): 122-54; Israel Eph 'al, "Esarhaddon, Egypt, and Shubria: Politics and Propaganda," JCS 57 (2005): 99-111; Nadav Na'aman, Ancient Israel and Its Neighbors: Interaction and Counteraction: Collected Essays, vol. 1 (Winona Lake, IN: Eisenbrauns, 2005); Maltthijs J. Jong, Isaiah Among the Ancient Near Eastern Prophets: A Comparative Study of the Earliest Stages of the Isaiah Tradition and the Neo-Assyrian Prophecies, VTSup (Leiden: Brill, 2007); Stephanie Dalley, Esther's Revenge at Susa: From Sennacherib to Ahasueru 


\section{Summary}

The Code of Hammurabi antedates suzerain-vassal treaties, thus it has to be evaluated on its own ground. The reader has to take into account that this was a code of laws given to people in a way that Hammurabi decided as a representation of the gods. As such, these laws were set in a covenantal form in which the people were bound to it without a choice; nevertheless, this law code was given to establish law and justice through court procedures in order to acquit innocent people and to punish guilty ones; thus, Hammurabi legislated about court process between people in which he did not take part. In this case, the Code of Hammurabi was a legislation to be performed in court. Also, every part of a suzerain treaty could be found in the Code of Hammurabi; however, the purpose of both were different: In a suzerain treaty a Great King imposed his will to obligate people to serve him, while in the Code of Hammurabi laws were given in order to perform justice among people through judgment.

On the other hand, the treaty of Niqmepa (the Great King) and Ir- ${ }^{\mathrm{d}}$ im (the vassal) shows a lack of justice on the part of Niqmepa toward Ir- ${ }^{\mathrm{d} i m}$. Throughout the treaty, Niqmepa does not take any responsibility upon him if the treaty fails. It seems that the

(Oxford, England: Oxford University Press, 2007); Aarnoud van der Deijl, Protest or Propaganda: War in the Old Testament Book of Kings and Contemporaneous Ancient Near Eastern Texts (Leiden: Brill, 2008); Markus Zehnder, "Building on Stone? Deuteronomy and Esarhaddon's Loyalty Oaths. (Par 1): Some Preliminary Observations," BBR 19 (2009): 341-74; Ibid., "Building on Stone? Deuteronomy and Esarhaddon's Loyalty Oaths. (Part 2): Some Additional Observations," BBR 19 (2009): 511-35; David T. Lamb, "The Non-Eternal Dynastic Promises of Jehu of Israel and Esarhaddon of Assyria," VT 60 (2010): 337-44; Erle Leichty, The Royal Inscriptions of Neo-Assyrian Period (Winona Lake, IN: Eisenbraus, 2011); Berman, "CTH 133 and the Hittite Provenance of Deuteronomy 13," JBL 130 (2011): 25-44; Bernard M. Levinson, "Esarhaddon's Succession Treaty as Source for the Canon Formula in Deuteronomy 13:1," JAOS 130 (2011): 337-47; Jacob Lauinger, "Esarhaddon's Succession Treaty at Tell Tayinat: Text and Commentary," JCS 64 (2012): 87-123; Sajjad Alibaigi, Abdol-Malek Shanbehzadeh, and Hossain Alibaigi, "The Discovery of a Neo-Assyrian Rock-Relief at Mishkhas, Ilam Province (Iran)," IA 47 (2012): $29-40$. 
whole burden is imposed upon Ir- ${ }^{\mathrm{d}} \mathrm{im}$. Though at its end, the treaty concludes with a curse against "whosoever transgresses these agreements," it could be possible to determine that "whosoever" only includes Ir- ${ }^{\mathrm{d}} \mathrm{im}$ and his people. Also, as this treaty has broken parts, it is impossible to determine its original structure in relation to a Hittite vassal treaty which regularly contains more parts than this treaty as I show below in Table 2. Furthermore, paragraphs 13 to 75 are not present in the tablet, bringing the disadvantage of a better conclusion regarding this treaty and its relation to the Pentateuch. Nevertheless, in each of them, gods are called as witnesses to the treaty.

Table 2. "Witness" within the structure of the Code of Hammurabi and treaties in different periods

\begin{tabular}{|c||c|c|c|}
\hline $\begin{array}{c}\text { Code of } \\
\text { Hammurabi }\end{array}$ & $\begin{array}{c}\text { Hittite Treaties } \\
\text { (Suzerain-Vassal) }\end{array}$ & $\begin{array}{c}\text { Hittite Treaties } \\
\text { (Parity) }\end{array}$ & $\begin{array}{c}\text { Akkadian Treaty } \\
\text { from Assyria }\end{array}$ \\
\hline \hline $\begin{array}{c}\text { Prologue } \\
\text { (Preamble) }\end{array}$ & Preamble & Title of the Kings & \\
\hline Stipulations/Laws & Agreement/Military & Terms of the \\
Clauses & Relationship & Stipulations \\
\hline Historical Prologue & Historical & $\begin{array}{c}\text { Historical } \\
\text { Background } \\
\text { of both Kings }\end{array}$ & Historical Prologue \\
\hline Deposit of the Law & $\begin{array}{c}\text { Deposit of the } \\
\text { Treaty }\end{array}$ & $\begin{array}{c}\text { Deposit of the } \\
\text { Treaty }\end{array}$ & \\
\hline $\begin{array}{c}\text { List of gods and } \\
\text { Witnesses }\end{array}$ & $\begin{array}{c}\text { List of gods and } \\
\text { Witnesses }\end{array}$ & $\begin{array}{c}\text { List of gods and } \\
\text { Witnesses }\end{array}$ & $\begin{array}{c}\text { List of gods and } \\
\text { Witnesses }\end{array}$ \\
\hline Blessings and & Blessings and & Blessings and \\
Curses & Curses & Curses & Curses \\
\hline
\end{tabular}

In the Suzerain treaty between Suppiluliumas and Kurtiwaza the list of gods, called to be witnesses, is vast. They are the same who bring curses and blessings upon Kurtiwaza and his people. Therefore, the gods are witnesses and judges at the same time. 
Following this line of thought, the treaty between Ramses Meri-Amon and Hattusilis is a parity treaty in which the gods function as witnesses and judges of both parties. In the Suzerain treaty between Suppiluliumas and Aziras, the former binds himself through oath to protect Aziras, if this latter always supports Suppiluliumas.

One more feature is that despite the mutilation of the tablet on which the treaty between Suppiluliumas and Aziras appears, its translator, Albrecht Goetze, agrees that a list of gods was present to serve as witnesses of the treaty. Also, the treaty between Mursilis and Duppi-Tessub follows the formulation of the previous, adding the sun and the nearby mountains to the list of gods.

A new ingredient that had not been seen in the Hittite treaties was added in Akkadian treaties from Assyria: an oath is made cutting a lamb into pieces in the treaty between Ashurnirari V and Mati'ilu. This part recalls Gen 15 in which God makes a covenant with Abram asking him to bring several animals "to cut them in two, down in the middle" (vv. 9, 10).

The vassal treaty of Esarhaddon is more concerned about the wellbeing and succession of Esarhaddon's sons, Ashurbanipal and Shamachshumukin, than about the security of Ramataya and his country. This is based on the fact that this treaty has only curses. It could be true that blessings would come upon Ramataya if he is faithful to the treaty; however, the treaty's structure suggests that Esarhaddon was not thinking in blessings but in curses. This change in emphasis (only curses are mentioned) may be due to the difference in objectives and in the time Hittite and Assyrian treaties were made.

The ANE treaties had a regular convention. Though it could change, depending on the need of the people involved, its form was widely known in its environment. While 
treaties expose certain differences from Hatti to Syria and Assyria, these differences confirm the influence that the Hittite treaties exercised internationally throughout the time even after the Hittite empire disappeared.

Suzerain/Vassal treaties show that the calling of gods as witnesses and judges was prominent. This equation of being witness and judge at the same time, gives the advantage of performing a just decision, at least from the Suzerain's point of view. This review shows also that a language of judgment is embedded in Hittite treaties. This is the reason gods were not only called to be witnesses of the parties involved but also judges to punish the disobedient party. Thus, witnesses were capable of defending the one who abided by the treaty and punish the party who did not follow the agreement.

\section{"Witness" and "Bearing Witness" in Ancient Jewish Interpretation of the Pentateuch}

In order to know Jewish mentality in the practice of requiring "witness" and "bearing witness" in legal setting, the most relevant extra biblical documents at hand in relation to this topic are examined: The documents of the Qumran community, Philo, Josephus and the Talmud. These four sources could help to connect, if any, this legal language with the Pentateuch and the Gospel of John. This connection could be strengthened because most of these extra biblical literatures pay attention primarily to the Pentateuch.

Qumran (c. 2nd Century BC-c. 1st Century AD)

The settlement of a secular trial is described in the CD and in the 1QS. The CD establishes that anyone who entered to be part of the community and brought an 
accusation against his fellow had to do it before witnesses (עִִדים) or before the elders. ${ }^{54}$ The same document says that when somebody sinned and his fellow saw this wrongdoing and they were alone, if this was a capital matter, the fellow had to denounce the sinner "in his presence, with reproach, to the Inspector." 55

Nevertheless, when one witness denounced the sinner, the Inspector could only write about the matter and wait until the sinner fell in the same sin in the presence of someone else who, as a witness, denounced the sinner to the Inspector. ${ }^{56}$ In this way, the practice to accept the testimony of two or more witnesses was accomplished in order to complete the process of a judgment. ${ }^{57}$ Also the document says, "A witness is not to be accepted by the judges to condemn to death on his word, if he has not completed his days to pass among those who are recruited, and is fearful of God. . . No-one who has consciously transgressed anything of a precept is to be believed as a witness against his fellow." 58

The 1QS teaches that the community had a council composed of 12 men and three priests called witnesses (עִָדים), who had "to implement truth, justice, judgment, compassionate love and unassuming behavior of each person to his fellow." ${ }^{59}$ In addition,

\footnotetext{
${ }^{54} \mathrm{CD}$ IX, 3, 4.

${ }^{55}$ CD IX, 16-18.

${ }^{56}$ CD IX, 18, 19.

${ }^{57}$ CD IX, 20-23.

${ }^{58}$ CD IX, 23-X, 1-3.

59 1QS VIII, 1-6.
} 
this document establishes that “. . . no-one should raise a matter against his fellow in front of the Many unless it is with reproof in the presence of witnesses (עיָדים)."10

In other writings, such as the paraphrase of the Pentateuch, the members of the community taught the ninth commandment, saying "[you shall not give] false evidence against your fellow man;" ${ }^{61}$ in the book of Jubilees God is described sending "witnesses (עִָדים) [to testify against them (the people of Israel)];"62 and in the apocryphal Psalms the term "witness" is used in the context of the people who judge the congregation of the Lord, but at the end "YHWH will sit in judgement with" 63 his people "to judge in truth and without injustice." ${ }^{64}$ In this context, 1QS, in its first column, establishes some of the main regulations in which all who entered the community had to make a covenant with both the community and the Lord: Primarily, the beginner had to enter in a covenant with God. This covenant was called "the covenant of mercy," 65 and it was based on the promise of being faithful to the Lord, keeping all his commandments, showing love to "the sons of light and to hate the sons of darkness," 66 because this was the way to walk perfectly before the Lord, and to stay as a member of the community. ${ }^{67}$

\footnotetext{
${ }^{60} 1 \mathrm{QS}$ VI, 1.

61 QQ158 7-8, 1, 2.

62 4Q216 II, 12.

${ }^{63} 4 \mathrm{Q} 381$ 76-77, 11, 12.

${ }^{64}$ 4Q381 76-77, 12.

651 QS I, 8.

66 QQS I, 9, 10. 17.

${ }^{67}$ 1QS I, 8.
} 
This text is dominated by the phrase עָּבר means "to cross over into the covenant" or "to enter into the covenant" which is an allusion of Deut 29:12 (Heb. v. 11) where curses and blessings are pronounced upon Israel. This repetition emphasizes the commitment in which the member of the community was involved and called "to do" or "to act" according to what the Lord commanded. Therefore the member had to stay in the community without turning back; no matter what the adversities might be.

In order to generate a confession from him, the priests proclaimed God's mercy, and the Levites declared Israel's infidelity. Thus, as the beginner was part of Israel, he confessed his sins and transgressions, recognizing at the same time that only God was righteous.

The community in Qumran divided in four the adversities mentioned above: terror, dread, affliction and agony. ${ }^{69}$ This last word is the translation of the noun from the root נסה that means "to test." But Geza Vermes translated it as "sorrow" and García Martínez, as "trials."70 Vermes probably considered this noun as a synonym

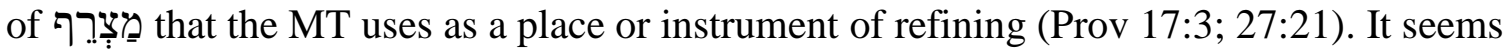
that these four words were rendered to illustrate the negative crescendo in the challenges that the members of the community could face: fear, dread, grief, and agony.

${ }^{68} 1 \mathrm{QS}$ I, 16, 18, 20, 24.

${ }^{69} 1 \mathrm{QS} \mathrm{I}, 17$.

70 1QS VIII, 4; Geza Vermes, The Complete Dead Sea Scrolls in English, 4th ed. (London, England: Penguin Books, 2004), 99; Florentino García Martínez, The Dead Sea Scrolls Translated: The Qumran Texts in English, 2nd ed. (Grand Rapids, MI: Eerdmans, 1996), 3. 
Thus, "fear" was the beginning of any torment, "dread" and "grief" the midpoint of any test, and "agony" could be the last level of it, and put at risk the fidelity of those who were persecuted for Belial. Therefore, "agony" was the fine line that defined who was going to stay in the community or quit from it, breaking the covenant and, as a result, taking part with Belial.

While the priests reported the righteousness of God, the Levites enumerated three

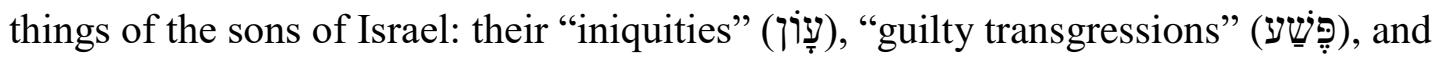
"sins" (חָטָטאת). In this way, the totality of sins was confessed by the community with three parallel verbs that are the root of the three previous nouns: נעוינו "we have

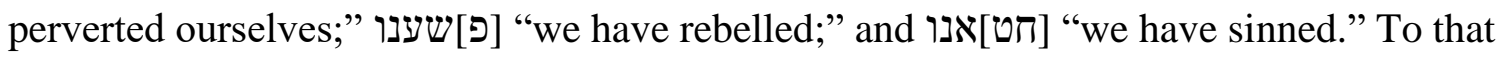
confession the community added a fourth one: הרשענו "we have acted impiously" because of "our walking."

In 1QM, Belial was the angel of enmity, created by God, having dominion upon the destroying angels and opposing the Prince of light. ${ }^{71} \mathrm{He}$ was also the leader of the "sons of darkness" who battled against "the sons of light." ${ }^{\text {" } 2}$ Therefore he was a figure who battled against God and his people, using "spirits" to trap the sons of light with a "malicious plan."”3

${ }^{71}$ 1QM III, 10-13.

${ }^{72}$ 1QM I, 1.

${ }^{73}$ 1QM XIII, 1, 2, 4. 
Thus he was "accursed" and "damned" together with "all the spirits of his lot" because of "his malicious plan" and "for his wicked rule."" With his "empire," he was trying to separate the "remnant" of God from his covenant. ${ }^{75}$

Also, an important phrase in 1QM is "the survivors of your covenant" which is in apposition to "remnant"76 and means that the remnant people considered themselves under a covenant with God, and, as a result, those who had obeyed God's requirements. God had created them for him and "made" them "fall into the lot of light"77 which meant God had chosen them to be his. He had established a covenant with their fathers, and the time to ratify it "with their offspring for times eternal" had arrived. ${ }^{78}$

Accordingly, James VanderKam suggested that the people of the community in Qumran believed that "God made a new covenant ... with a surviving remnant of his people." ${ }^{79}$ Thus, they were the people chosen by God, and not the Jewish people who lived in Judea. Only those who lived in the community were "the true Israel" $" 80$ that God had called for "a deeper understanding of what was required and a greater incentive to obey." $" 11$

${ }^{74} 1 \mathrm{QM}$ XIII, 4. Also in CD, Belial is equivalent to the prince of all unclean spirits.

${ }^{75} 1 \mathrm{QM}$ XIV, 9.

${ }^{76}$ 1QM XIII, 8.

77 1QM XIII, 9.

${ }^{78} 1 \mathrm{QM}$ XIII, $7,8$.

79 James C. VanderKam, The Dead Sea Scrolls Today (Grand Rapids, MI: Eerdmans, 1994), 111.

${ }^{80}$ Ibid.

${ }^{81}$ Ibid. 
In that context the $\mathrm{CD}$ teaches that those who were unfaithful to the covenant were delivered up to the sword, but those who adhered to the commandments of God were preserved, so God confirmed his covenant with them. ${ }^{82}$ With the seed of that remnant God was going to fill the surface of the earth. ${ }^{83}$

In 1QM, God is depicted gathering "an assembly of nations for destruction with no remnant," while, at the same time, he elects a "people" for redemption. "A4 "All the wicked nations shall be destroyed" 85 along with "their heroes;" nevertheless, "the remnant of your people ... will remain standing," 86 because they are "the redeemed ones." 87 The remnant "blesses" God because he has protected its members with "favors" in order to stand still "during the empire of Belial," who is trying to separate them from the covenant of the Lord. ${ }^{88}$

Vermes emphasized that the "covenant ideology" led the men in the Qumran community not only to consider "themselves to be the "remnant of their time, but the 'remnant' of all time, the final 'remnant.' "89 This belief marked their life to be devoted students of the Scriptures, and "to observe its precepts with absolute faithfulness.",90

\footnotetext{
${ }^{82}$ CD III, $10-13$.

${ }^{83}$ CD II, 11.

${ }^{84} 1 \mathrm{QM}$ XIV, 5.

${ }^{85} 1 \mathrm{QM}$ XIV, 7.

${ }^{86} 1 \mathrm{QM}$ XIV, 8.

${ }^{87} 1 \mathrm{QM}$ XIV, 10.

${ }^{88} 1 \mathrm{QM}$ XIV $, 8,9$.

${ }^{89}$ Vermes, The Complete Dead Sea Scrolls, 68, 69.

${ }^{90} \mathrm{Ibid}, 69$.
} 
The liturgical texts of the Rule of the Blessings repeat that those who kept the covenant received blessings from the Lord, while the others were left "with not [sic] survivor." ${ }^{\text {91 }}$ And in a fragment titled the Curses of Melkiresha ', a curse is pronounced upon those who had "turned away from following" God, "plotting against" his covenant, saying, "[May you be cursed] with no [sic] remnant, and damned without escape."

In 4Q266 the community establishes that its members were "the people of Thy redemption and the flock of Thy pasture" 93 because they kept "all the precepts found in the Law of Moses." ${ }^{.94}$ Evidently the identity of the community would be to keep the covenant of God; therefore anybody who lived in a different way was rejected, taken as a rebel, and "dismissed from the Congregation." "95

The CD summons the people "who know righteousness, and understand the dealings of God" $"$ in order to explain that God "hid his face from Israel and from his sanctuary" because "they sinned in forsaking him." ${ }^{\text {" }}$ Because of that, God "remembered the covenant of the fathers" and "preserved a remnant for Israel and did not bring them to total destruction.." ${ }^{98}$ This passage talks about an event in which the community possibly had been persecuted by its enemies and reduced to a lesser quantity. Accordingly, Philip

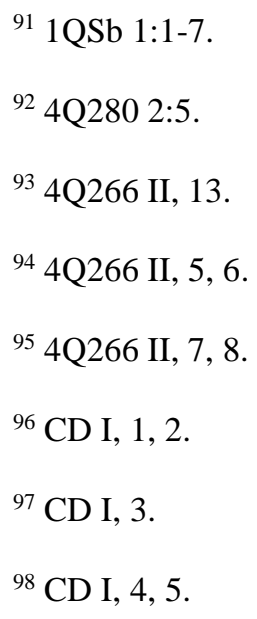


R. Davies said that the CD is "a series of condemnations of apostates;",99 which means that at least two opposed communities had been fighting against each other: One that adhered to the Teacher of Righteousness and the other formed of those who once were part of the covenant, but later departed from it. ${ }^{100}$

This kind of notion of covenant was a covenantal membership in which only those who decided to live according to the covenant could be members of the community. In this line of thought, the $1 \mathrm{QS}$ adds that all who wanted to be part of the community had to decide with a personal commitment to be faithful to the covenant and reject all that was evil. ${ }^{101}$ Even though the Law of Moses establishes the renewal of the covenant every seven years by the "year of release" (Deut 31:10-13), this community was so dedicated to follow the covenant that it had a renewal every year.

Accordingly VanderKam added, "The people who lived in and around Qumran believed firmly that they were part of that remnant, raised by God to be a plant of righteousness and truth." 102 And this objective could only be achieved by living in a covenantal relationship with God. For them, the covenant was so important that "they enacted a ceremony of covenant renewal annually, at the festival of Weeks." ${ }^{\prime 103}$

The major contention of the people of the community in relation to the covenant was that they did not sacrifice in the temple. How could they be the remnant of Israel and

\footnotetext{
${ }^{99}$ Philip R. Davies, The Damascus Document (Sheffield, England: JSOT, 1982), 173.

${ }^{100}$ CD XIX, 33-XX, 1.

${ }^{101} 1 \mathrm{QS}$ I, 4-8.

${ }^{102}$ VanderKam, Dead Sea Scrolls, 111.

${ }^{103}$ Ibid.
} 
in agreement with the law when they did not offer sacrifices in the temple? They were clear in the obligation of the sacrifice in the temple; but according to them the priests who were in charge of the temple were corrupt, therefore to offer sacrifices would be contrary to the law.

Millar Burrows suggested that the only alternative was "to worship by their own rites until the temple" could be purified. ${ }^{104}$ In this context the community established a distinction among those who defiled the temple, and were going to arise for wars destroying themselves, and those who kept the covenant, and were going to be saved and set free by God. ${ }^{105}$ It is evident that to be cursed or blessed would depend on the relation of the individual to the Covenant.

\section{Philo of Alexandria (c. 20 BC - c. AD 50)}

In his writings, Philo used $\mu \alpha \rho \tau v \rho i ́ \alpha$ as a testimony or evidence to confirm what somebody had said or what it had been written in any ancient book or in the Hebrew Scripture. Thus a testimony was what had been said "in the Timaeus,"106 what God had said, ${ }^{107}$ what Moses said, ${ }^{108}$ and what Sarah said when she laughed on behalf of the promise of having a son. ${ }^{109} \mathrm{He}$ also employed the word $\mu \alpha \rho \tau$ pí $\alpha$ as a "testimony" in a

\footnotetext{
${ }^{104}$ Millar Burrows, More Light on the Dead Sea Scrolls (NY: Viking, 1958), 365.

$1054 \mathrm{Q} 183$ 1-3.

106 Philo, Aet. I, 25.

${ }^{107}$ Ibid., Sacr. I, 91; ibid., Pep. I, 79; ibid., Leg. III, 208.

${ }^{108}$ Ibid., Her. I, 4; ibid., Mut. I, 258.

${ }^{109}$ Ibid., Pot. I, 124.
} 
secular trial, ${ }^{110}$ and in the context of his interpretation of Deut 17:6 and 19:15 concerning the advantage to have several witnesses rather than one. ${ }^{111}$ However, he did not use $\mu \alpha \rho \tau$ cí $\alpha$ in relation to God and human beings, in a religious sphere or in a covenant context.

Flavius Josephus (c. AD 37-100)

Josephus spoke about secular trials and the Pentateuchal law which requires witnesses for a just judgment; so, he said: "Let not a single witness be credited, but three, or two at the least, and those such whose testimony is confirmed by their good lives."112 And in a comment about anyone who brought false witness to the court, he suggested to apply Deut 19:16-21, saying: "But if it is believed someone has borne false witness, let him, when he is convicted, suffer all the very same punishments which the man, against whom he bore witness, was to have suffered."113

He objected to women and servants taking part in a trial, establishing that women were not to be admitted "on account of the levity and boldness of their sex;" and servants "on account of the ignobility of their soul; since it was probable that they might not speak truth, either out of hope of gain, or fear of punishment."114 Nevertheless, he asked any

\footnotetext{
${ }^{110}$ Ibid., Plant. I, 173.

${ }^{111}$ Ibid., Spec. IV, 53-55.

112 Josephus, Ant. IV, 219.

${ }^{113}$ Ibid.; cf. Exod 20:16; 23:1; Deut 5:20; 19:16-19.

${ }^{114}$ Josephus, Ant. IV, 219. Several rabbinic writings take part on the discussion about women's testimony, such as m. Sotah. 1:4-5 and 6:4 where a woman is brought before the elders to say whether she is clean or unclean, defiled or not defiled. In m. Sanh. 3:4 and m. Šebu. 4:1 women are not allowed to give testimony; but m. B. Qam. 1:3; m. Šebu 5:1; 7:8; m. Ketub.1:6, 7; 2:5, 6; 9:4; m. Yebam. 15:1, 2; 16:7; Sifre Deut. 190 favor that women give testimony in court.
} 
widow to go before the elders when the brother of her deceased husband did not want to marry her:

But if the brother will not marry her, let the woman come before the elders, and protest $(\mu \alpha \rho \tau v \rho o \mu \alpha)$ openly that this brother will not admit her for his wife, but will injure the memory of his deceased brother, while she is willing to continue in the family, and to bear him children; and when the elders have inquired of him for what reason it is that he is averse to this marriage, whether he gives a bad or a good reason, the matter must come to this issue. ${ }^{115}$

He also used the cognate word $\mu \alpha \rho \tau v ́ \rho t o v$ which is an accusative, neuter singular

that has the sense of a proof, as attestation of what he has said or written:

When, therefore, they were thus afflicted, and found no end of their barbarous treatment they met with the Greeks, they sent ambassadors to Caesar on those accounts; who gave them the same privileges as they had before, and sent letters to the same purpose to the governors of the provinces, copies of which I subjoin here, as testimonials ( $\mu \alpha \rho \tau u ́ p ı v$ ) of the ancient favourable disposition the Roman emperors had toward us. ${ }^{116}$

This same idea is in his book Against Apion in which he referred to what people of other nations said about Israel and the temple in Jerusalem. He took those testimonies as proof of what he had been saying concerning the antiquity of Israel: "So that the records of the Chaldeans and Tyrians agree with our writings about this temple; and the testimonies ( $\mu \alpha \rho \tau v \rho i ́ \alpha)$ here produced are an indisputable and undeniable attestation to the antiquity of our nation; and I suppose that what I have already said may be sufficient to such as are not very contentious."

\footnotetext{
${ }^{115}$ Ibid., Ant. IV, 255.

116 Ibid., Ant. XVI, 161.

${ }^{117}$ Ibid., Ag. Ap. I:160.
} 
Talmud (AD 200-500)

In an interpretation of Exod 23:1, which requires the death penalty for a false witness, the Talmud is consistent showing the word witness in a context of a trial. Accordingly, the Talmud stipulates that a false witness deserved to be cast to the dogs. ${ }^{118}$ And in an accusation of adultery the witnesses "could come and tender their evidence" by mouth or by writing before the judges; but according to the regulation the first requirement should be an oral testimony, by mouth, and not a document which could be altered. ${ }^{119}$ Also, if anyone accused another of committing pederasty, this witness and any other witness might be combined to procure the execution of the accused. ${ }^{120}$ This last case raises the question of any biblical support for the accuser to be combined with another witness to present an accusation of a wrongdoing which was seen by one person. Despite the possible answers, the Talmud supports that Jewish law only accepted a testimony which was supported by at least two witnesses.

\section{Summary}

In the community of Qumran, the language of "witness" and "bearing witness" occurs in the context of the belief that the people of the community were the remnant of God, and under a covenant with him. As these people relied on this teaching, they advanced a system in which everybody was either under blessings or curses depending on his relation to God. This conclusion was based on the belief that for the Qumran

\footnotetext{
118 m. Pesah. 607.

119 m. Yebam. 198. The "evidence" means the date of the betrothal, and the inclusion of it in a letter.

${ }^{120}$ Ibid., 154.
} 
community, Deut 28, a chapter which speaks about blessings and curses, was

accomplished in its days because the religious leaders in Judea were living in apostasy. Therefore, the people of the community were the "true Israel;" but the others, who were taking part with those leaders in Judea, would be punished along with the Gentiles.

In order to keep the purity of its members, everyone who witnessed a wrongdoing, was required to denounce the sinner in the presence of an Inspector. Related to that point of view, the members of the community believed to have the truth; therefore, those who wanted to be saved had to accept the community's truth because God was preparing a people to be ready for the coming of the Messiah who would bring judgment upon the wicked, accomplish his promise with Abraham, Isaac and Jacob, and restore the Kingdom of David. For the community, "Israel" was no longer the people living in Judea, but the people who kept the covenant, living in Qumran. Thus, this concept of remnant came to challenge a fundamental Jewish presupposition of Israel as the people of God.

On the other hand, Philo rendered the language of "witness" in two ways: (1) In secular trials, in the context of Deut 17:6 and 19:15 in which the people of Israel were required to bring more than one witness for a righteous judgment; and (2) As evidence or testimony to confirm what somebody had said or written in any ancient book or in the Hebrew Bible. In like manner, Josephus spoke about "witness" and "bearing witness;" however, he added also two more things: That Deut 19:16-21 should be applied to those who brought false witnesses to the court; and that women and servants should not be allowed to testify in court. Taking into account that Josephus wrote about the same time that the Gospel of John was written, the matter of accepting or not accepting women as witnesses in Israel highlights the importance of this discussion. The Talmud applies Exod 
23:1 as a warning to false witnesses who deserve to be put to death. This document also teaches that a testimony before the judges can be oral or written.

These ancient literary sources surveyed in this chapter have been studied by modern scholars to establish or reject the suppose covenant lawsuit language together with the witness motif in the OT. The next chapter reviews this scholarly opinion on the covenant lawsuit language as well as the witness motif. 


\section{CHAPTER 2}

\section{REVIEW OF THE LITERATURE IN MODERN RESEARCH}

This chapter is an analysis of modern studies of the words "witness" and "bearing witness" in the Pentateuch and in the Gospel of John from the beginning of the twentieth century to the present. The arrangement of the literature tries to build a bridge throughout the different sections to clarify any agreement or disagreement among them.

Most of Scholars who have studied the words "witness" and "bearing witness" have done it in the context of the covenant lawsuit genre in the Old Testament Prophets, and a few in the Pentateuch. ${ }^{1}$ Because of that, a review of these words without taking into account the study of the covenant lawsuit in the Prophets is unavoidable. The intention is not to stay in it, but rather to survey the topic where the debate began. This review is not exhaustive but will include chief tendencies in the study of witness and bearing witness.

\section{In the Old Testament}

Hermann Gunkel (1909-1913)

At the beginning of the twentieth century, Hermann Gunkel studied several prophetic speeches in which, according to him, the prophets threaten, reproach, and

\footnotetext{
${ }^{1}$ Hermann Gunkel started the covenant lawsuit's inquiry in preexilic prophets and in Psalms. Since then, scholars have been hovering over the same material, scarcely examining other Old Testament books. Thus, when one examines this topic, it is difficult to ignore the beginning of this quest.
} 
expose "Israel's offence."2 He maintained that such speeches are an imitation of "the style of a speech before a court" ${ }^{3}$ which is composed of the heavens and the earth (Isa 1:2; Jer 2:12; Ps 50:4), and the mountains (Mic 6:1, 2). God calls them to hear his judgment against the people of Israel for breaking his covenant. Also, God asks the nations to "bring out their witnesses" and hear the truth of his judgment (Isa 43:9). God is not only a judge but also a witness who testifies against his people (Ps 50:6, 7). While analyzing Ps 50, Gunkel maintained that "as a whole the divine speech, according to its basic shape, is to be named Gerichtsrede, that is, an accusation or censure-speech in which Yahweh goes to court with his people and censures their errors."

\footnotetext{
${ }^{2}$ Hermann Gunkel, "Propheten Israels seit Amos," in Religion in Geschichte und Gegenwart, 2nd ed. (Tübingen: Mohr, 1909-1913), 4: 1553. These speeches are found in Isa 1:2-20; 3:13-15; 41; 42; 43:9ff; Jer 2:4-9, 10-13; Mic 6:1-16; Hos 2:4-23; Pss 50:7-13; 82.

${ }^{3}$ Ibid. According to Niehaus, Ancient Near Eastern Themes, 28, 29, with these parallels Gunkel, along with other scholars, wanted to dismiss "the doctrine of special revelation and the historicity of the Old Testament."

${ }^{4}$ Gunkel, Die Psalmen (Göttingen: Vandenhoeck and Ruprecht, 1926), 215. See also Schmidt, Die Großen Propheten, LXIII. While accepting Gunkel's conclusion of a Gerichtsrede other scholars have studied this genre in the prophets looking for categories in the speeches; such as Hugo Gressmann, "Die literarische Analyse Deuterojesajas," ZAW 34 (1914): 254-97; Ludwig Köhler, Deuterojesaja stilkritisch untersucht, BZAW 37 (Giessen: Alfred Töpelmann, 1923), 110-11.

In the Psalms, cf. Hermann Gunkel and Joachim Begrich, An Introduction to the Psalms: The Genres of the Religious Lyric of Israel, trans. James D. Nogalski (Macon, GA: Mercer University Press, 1998). In this book, Begrich concluded that the term Gerichtsrede has a broad designation including speeches with pre-trial setting and speeches during the court process. He found at least six categories: (1) Appeal by the accused; (2) Appeal by the accuser; (3) Speech of the accuser before the court; (4) Speech of the accused before the court; (5) Speech of the judge; and (6) Portrayal of a judicial procedure.

Wright, "The Lawsuit of God," 46, 47, disagreed with Gunkel who said that heaven and earth "are summoned in the Biblical form to act as judges" and stated that a Suzerain had "authority over all powers on earth," implying that he "is presiding over the highest tribunal in the universe" in such a way that he calls heaven and earth as witnesses or jury. Therefore, they act as special "agents of the Suzerain for the execution of the natural curses stipulated in the treaty for its violation."
} 


\section{G. Ernest Wright $(1950,1962)$}

In his study of Deut 32, G. E. Wright sustained that this chapter is a covenant lawsuit "based on the covenant-renewal form" that "is as follows: (1) recital of the Suzerain's benevolent acts (the Credo), preceded by a preamble that identifies the Suzerain; (2) the stipulations of the covenant; (3) vows, witnesses, and solemn declaration; (4) blessings and curses."

Based on this form he outlined the "major elements" of the covenant lawsuit as: (1) Call to the witnesses to give ear to the proceedings; (2) Introductory statement of the case at issue by the Divine Judge and Prosecutor or by his earthly official; (3) Recital of the benevolent acts of the Suzerain; (4) The indictment; and (5) The sentence. ${ }^{7}$

He was aware that "both the covenant renewal and the covenant lawsuit ... rest upon the suzerainty treaty form." ${ }^{8}$ In his study, he challenged Huffmon's structure in

${ }^{5}$ Wright, "The Lawsuit of God," 52, 65. He was one of the first scholars to argue that Deut 32 is a covenant lawsuit or rîb. On p. 40 he said that "Dt. 32 is a 'broken' rîb, that is, a specific cultic form adapted and expanded by other themes to serve a more generalized purpose in confession and praise."

Matthew Thiessen, "The Form and Function of the Song of Moses (Deuteronomy 32:1-43)," JBL 123 (2004): 401 n. 2, stated that many scholars have taken for granted Wright's conclusion. Cf. Thompson, Deuteronomy: An Introduction and Commentary, TOTC 5 (Leicester: InterVarsity, 1974), 296-97; A. D. H. Mayes, Deuteronomy, NCB (Greenwood, SC: Attic, 1979), 380-81; Patrick D. Miller, Deuteronomy (Int; Louisville: John Knox, 1990), 226; Ian Cairns, Word and Presence: A Commentary on the Book of Deuteronomy, ITC (Grand Rapids, MI: Eerdmans, 1992), 278-90; Christopher J. H. Wright, Deuteronomy, NIBC 4 (Peabody, MA: Hendrickson, 1996), 297-98; and Marjorie O'Rourke Boyle, "The Covenant Lawsuit of the Prophet Amos III 1 - IV 13," VT 21 (1971): 341.

Thus, Thiessen, "Form and Function," 401, departed from Wright's argument, and maintained that Deut 32 "fits the category of a hymn." James R. Boston, "The Wisdom Influence upon the Song of Moses," JBL 87 (1968): 198-202 in Thiessen, "Form and Function," 401, argued that Deut 32 "belongs to the sphere of wisdom literature." William Foxwell Albright, "Some Remarks on the Song of Moses in Deuteronomy XXXII," VT 9 (1959): 346, simply concluded that Deut 32 is a poem composed "when Yahwism was fighting for its life against both external and internal foes - in brief, to the period when Samuel rallied Israel against its hereditary enemy as well as against the paganism rampant in its midst."

\footnotetext{
${ }^{6}$ Wright, "The Lawsuit of God," 51, 52.

${ }^{7}$ Ibid., 52.

${ }^{8}$ Ibid., 53.
} 
relation to Deut 32. While Huffmon, in II A, saw heaven and earth appointed as judges, Wright concluded that they were seen as witnesses to the indictment. ${ }^{9}$ For this he gave four biblical examples where this formula appears in which Yahweh calls the "mountains," the "foundation of the earth," and "heaven and earth" to act as witnesses, hearing "the case of Yahweh against his people." ${ }^{10}$ Further, he mentioned Deut 4:26;

30:19 and 31:28 in which "Moses is warning Israel of the consequences of disobedience to the covenant, and in each case, in legal style, the call is given to heaven and earth to serve as witnesses of the broken covenant."11

\section{George E. Mendenhall (1954)}

In his explanations about "the relationship between Israel and Yahweh" and "the beginning point of Israelite religion," George E. Mendenhall suggested, "There is a type of covenant preserved in ancient oriental sources which may be of use in arriving at some tentative conclusions concerning all of the problems mentioned above. This is the suzerainty treaty by which a great king bound his vassals to faithfulness and obedience to himself." 12 Even though the material to study the Suzerain treaty from the Hittite Empire,

${ }^{9}$ Ibid., 43, 44. Though Wright started his journey with this topic in 1950 — nine years earlier than Herbert Huffmon - he challenged Huffmon's interpretation. Cf. Huffmon, "The Covenant Lawsuit," 286.

${ }^{10}$ Isa 1:2 (heaven and earth); Mic 6:2 (mountains and the foundations of the earth); Jer 2:4-13 (heavens); and Ps 50:4 (heavens and earth).

${ }^{11}$ Wright, "The Lawsuit of God," 44.

12 Mendenhall, "Covenant Forms," 51, 52. Cf. Gleason Archer, A Survey of Old Testament Introduction, rev. and exp. ed. (Chicago, IL: Moody, 1994), 274; Dennis J. McCarthy, "Covenant in the Old Testament: The Present State of Inquiry," CBQ 27 (1965): 220, 221; Michael Horton, Introducing Covenant Theology (Grand Rapids, MI: Baker Book House, 2006), 23-34; Ernest C. Lucas, "Covenant, Treaty, and Prophecy" Themelios 8 (1982): 19-23.

For the role that honor and shame played in the vassal-Suzerain relationship in a covenant setting, see Saul M. Olyan, "Honor, Shame, and Covenant Relations in Ancient Israel and its Environment," JBL 115 (1996): 201-18. 
from 1450-1200 BC is plenty, Mendenhall recognized also the "references to international (i.e. inter-city-state) covenants ... in old Sumerian texts of the third millennium B.C." 13 This means that the covenant form of the Suzerain treaty was not bound to a specific city but rather it was recognized internationally. ${ }^{14}$ Thus, he stated three facts:

1. It seems certain that the Hittites themselves did not originate the covenant form. ... Rather, there is abundant indication that they themselves borrowed the form from the East, i.e. ultimately Mesopotamian sources, and consequently it must have been common property of any number of peoples and states in the second millennium B.C. It is by its very nature an international form.

2. Many of these covenants were made with peoples of Syria itself. Among others we have covenants with Aziru, his son, and his grandson referred to or preserved for us in the Hittite archives. The same form was used for concluding a treaty with Egypt. In view of the fact that Israelite traditions now vindicated indicate close relationships between the pre-Mosaic peoples who became Israel and northern Mesopotamia, abundant opportunity to become familiar with the treaty form must be admitted for ancient Israel.

3. Other completely independent parallels between the Hittite and biblical materials have already been pointed out. ${ }^{15}$

The Suzerain treaty was unilateral in which the vassal took an oath of obedience.

The king was not under any obligation, even though he promised to help and support the vassal in case of any claim or attacks of other foreign states. The king did not bind himself to this treaty because this would be a violation to his "self-determination and sovereignty." $" 16$

\footnotetext{
${ }^{13}$ Mendenhall, "Covenant Forms," 52, 53.

${ }^{14}$ Ibid.

${ }^{15}$ Ibid., 54. Contrary to this, Gene M. Tucker, "Covenant Forms and Contract Forms," VT 15 (1965): 495, suggested that the parallelism between Hittite treaty and biblical covenant "is not likely to be answered conclusively, primarily because the OT preserves only narratives about covenants and covenant ceremonies, not covenant texts themselves" (Emphasis is in the original).

${ }^{16}$ Mendenhall, "Covenant Forms,” 56.
} 
The most important part of this treaty was "the vassal's obligation to trust in the benevolence of the sovereign."17 Mendenhall, under V. Korosec's influence, recognized that Hittite treaties' structure "nearly always . . . [had] six elements," as follows: "(1) Preamble: Begins with a formula, 'thus (saith) NN, the great king of the Hatti land, son of NN . . the valiant." "The king identified himself "giving his titles and attributes, as well as his genealogy." (2) The historical prologue: the previous relation between the suzerain and his vassal was described. The king emphasized his benevolent attitude on behalf of his vassal with the "I-Thou" form of address. The king had been so benevolent that his vassal was "obligated to perpetual gratitude toward the great king." (3) The stipulations: Obligations imposed upon and accepted by the vassal. (4) Provision to deposit the treaty in the temple and periodic public reading. Both the vassal king and his state were bound by the treaty, thus "periodic public reading served ... to familiarize the" people "with the obligations to the great king; and ... to increase the respect for the vassal king by describing the close and warm relationship with the mighty and majestic Emperor which he enjoyed." (5) The list of gods as witnesses from both pantheons was included. "The mountains, rivers, springs, sea, heaven and earth, the winds and the clouds" could also be

\footnotetext{
${ }^{17}$ Ibid. Mendenhall shared Viktor Korosec's finding that "the covenants are not all of a single type, but are rather to be classified as suzerainty treaties or as parity treaties" (ibid., 55). Cf. McCarthy, "Three Covenants in Genesis," CBQ 26 (1964): 179-89; and ibid., "Covenant in the Old Testament," 228, where he concluded that "the two types of treaties are identical."

${ }^{18}$ Mendenhall, “Covenant Forms,” 58. Ray F. Chester, "Covenant Types,” ResQ 9 (1966): 286, was aware of these variations; which means that scholars are no concerned about them. He stated, "Usually six elements are found although at times an element or two may be missing. There is some variation in the order of the elements." Nielsen, Yahweh as Prosecutor, 25, said that "the fascinating aspect of the prophetic lawsuit is that it sometimes leaves out one, and on occasion two of these elements." Then, he asked, "What does the prophet aim to achieve by his leaving something out?"
} 
mentioned. (6) The curses and blessings formula which the king uttered as the agent of the gods against or in favor of his vassal. ${ }^{19}$

Also Mendenhall indicated that this structure could have variations. So, he mentioned three more elements: (7) "the formal oath by which the vassal pledged his obedience ..., (8) some solemn ceremony which accompanied the oath," and (9) a "procedure against a rebellious vassal." ${ }^{20}$ Nevertheless, he made clear that these last three elements were uncertain. Notwithstanding, about the whole structure he said, "This particular structure of covenants is not attested for any other subsequent period. Though it is to be expected that survival of the form outlasted the Hittite Empire, it is perfectly clear that the home of this form is in the second millennium B.C. and cannot be proven (outside Israel) to have survived elsewhere."21

Accordingly, he observed that only two biblical traditions "fall into the form described above:" The Decalogue and Josh 24. Nevertheless, he argued that in the text of the Decalogue "the last three elements of the Hittite form are lacking," such as "the provision for deposit in the sanctuary and periodic public reading; . . . no list of witnesses, nor the curses and blessings. ${ }^{22}$

Taking into account the covenant lawsuit structure and wording, Mendenhall was right when he said that the list of witnesses is lacking in the Decalogue. However, the

\footnotetext{
${ }^{19}$ Mendenhall, "Covenant Forms," 58-60. Cf. Chester, "Covenant Types," 286; Klaus Baltzer, The Covenant Formulary in Old Testament, Jewish and Early Christian Writings, trans. D. Green (Philadelphia: Fortress, 1971), 10.

${ }^{20}$ Mendenhall, "Covenant Forms," 60, 61.

${ }^{21}$ Ibid., 61.

${ }^{22}$ Ibid., 62, 65; cf. Baltzer, The Covenant Formulary, 19-27.
} 
ninth commandment with its prohibition of being a false witness in a legal process, looks for a fair judgment, and places this language in agreement with the Code of Hammurabi.

\section{Herbert Huffmon (1959)}

Following Mendenhall, Herbert Huffmon studied some lawsuit oracles trying to clarify their Sitz im Leben. ${ }^{23}$ He outlined in two ways the description of the Gattung given by Hermann Gunkel and Joachin Begrich. The first one is as follows:

I. A description of the scene of judgment

II. The speech of the plaintiff

A. Heaven and earth are appointed judges

B. Summons to the defendant (or judges)

C. Address in the second person to the defendant

1. Accusation in question form to the defendant

2. Refutation of the defendant's possible arguments

3. Specific indictment. ${ }^{24}$

The second one is an alternate form:

I. A description of the scene of judgment

II. The speech by the judge

A. Address to the defendant

1. Reproach (based on the accusation)

2. Statement (usually in the third person) that the accused has no defense

B. Pronouncement of guilt

C. Sentence (in second or third person). ${ }^{25}$

While in the first form, "in the speech of the plaintiff, Yahweh is the plaintiff,

Israel is the defendant, and heaven and earth ... are the judges;" in the second, "the speech of the judge, the judge is ... Yahweh and the defendants are the foreign gods (Ps

\footnotetext{
${ }^{23}$ Huffmon, "The Covenant Lawsuit," 285. He studied passages especially from Psalms and the prophets such as Ps 50; 82; Isa 1:2, 3; 3:13-15; 41:21-29; 44:6 ff; Jer 2:4-13; Mic 6:1-8; from the Pentateuch he took Deut 32. Cf. Boyle, "The Covenant Lawsuit of the Prophet Amos," 340.

${ }^{24}$ Huffmon, "The Covenant Lawsuit," 285.

${ }^{25}$ Ibid., 286.
} 
82; Isa 41:21-29; 44:6ff)." ${ }^{26}$ Accordingly, he explained that the most striking part "is the appeal to the natural elements" 27 such as "heavens, earth, mountains, hills, and foundations of the earth to hear the controversy." ${ }^{28}$ He mentioned several scholars who had given diverse interpretations about the summons of heaven and earth: Gunkel and Bentzen said that heaven and earth are summoned as judges; S. R. Driver stated that they are "worthy auditors of a solemn song;" R. B. Y. Scott argued that they "are not elements of the natural world, but are called upon as population areas;" and G. E. Wright suggested that they are part of the divine assembly, which was called by Cross the council of Yahweh. $^{29}$

Nevertheless, Huffmon disagreed with that conclusion and cited the lack of direct evidence "with interpreting heaven and earth, the mountains and the hills, and the foundations of the earth as members of the divine assembly." 30 Thus, he clarified that "in Mesopotamia, the divine assembly was a council of the gods, a pantheon."31

\footnotetext{
${ }^{26}$ Ibid.

${ }^{27}$ Ibid.

${ }^{28}$ Ibid., 288.
}

${ }^{29}$ Ibid., 290. Wright, "The Lawsuit of God," 45, pointed out that, as in Hittite treaties all the gods of each party are called to serve as witnesses, the formula "heaven and earth" is used as its equivalent. Thus, when this treaty form is adopted by Israel, "this element of the treaty for obvious reasons had to be set aside or reinterpreted."

${ }^{30}$ Huffmon, "The Covenant Lawsuit," 291. Cf. Boyle, "The Covenant Lawsuit of the Prophet Amos," 338-62, who said that the statement of Amos 3:7 in which the prophet states "that Yahweh does not act against Israel without first revealing his purpose $(s \hat{o} d)$ to his servants the prophets, it presents the embryonic notion of the council of Yahweh ( $s \hat{o} d)$ which is developed in later prophetic rîbs." On p. 346 Boyle says that it appears that the council of Yahweh in Amos is made up of prophets rather than divine beings. See also David E. Bokovoy, "שמעו בבית והעידו יעקב: Invoking the Council as Witnesses in Amos 3:13," JBL 127 (2008): 37-51.

${ }^{31}$ Huffmon, "The Covenant Lawsuit," 291. 
Consequently, heaven and earth, along with the mountains, rivers, sea, winds,

clouds and also the gods of both countries were shown as witnesses of the covenant in the Hittite international treaties. Parallel to this clarification he pointed to Deut 4:26; 30:19

and 31:28, in which that kind of appeal appears. He wrote in this manner:

The three passages ([Deut] 4:26; 30:19; 31:28) are all in connection with covenant ceremonies. In 4:26 the heavens and the earth are called upon to witness Moses' affirmation that if the Israelites violate the covenant Yahweh will invoke the curses of the covenant (4:23-28). In 30:19 the heavens and the earth are clearly mentioned as witnesses to the covenant (30:15-20). And in 31:28 they serve as witnesses to Moses' speech about the covenant (31:24-29). ${ }^{32}$

Yet, Huffmon did not eliminate the opinion that heaven and earth could be called as a third party to judge between God and Israel, even though God "is ultimately the judge." ${ }^{33}$ In the end he concluded, "There are two fairly distinct types of 'lawsuits,' having a different Near Eastern background and a different content:" the one "connected with the divine council" and "the other ... the indictment of Israel for breach of covenant." 34

\section{James Muilenburg (1959)}

James Muilenburg reviewed the structure of Exod 19:3-6; Jos 24 and 1 Sam 12, which, according to him, belong to the so called Elohist literature. ${ }^{35}$ He maintained that

\footnotetext{
32 Ibid., 292.

33 Ibid., 293.

34 Ibid., 295.

35 Though the biblical data establishes that Moses is the author of the Pentateuch, some scholars deny it following the Documentary Hypothesis from which the Elohist literature is part. Accordingly, the Elohist (E) literature was written in northern Israel, shortly after the collapse of the united monarchy around 850/750 BC. Tremper Longman and Raymond B. Dillard, An Introduction to the Old Testament, 2nd ed. (Grand Rapids: Zondervan, 2006), 41, say, "In strict sense, the Torah is anonymous. Nowhere do these five books explicitly claim that Moses is their exclusive author." Despite this, the biblical data (in the OT and in
} 
Exod 19-24 and the book of Deuteronomy correspond each other in their general

structure. Thus, going from this observation, about Exod 19:3-6, he explained,

The literary type is the message or proclamation, and belongs to the fixed forms of ancient Near Eastern utterance. Its provenance is probably to be seen in the royal message, whether in the manner of the suzerainty treaties . . . or in the epilogues to the great legal corpuses of the Near East. It is the language of direct address, of proclamation and urgent call to hearing, of stress upon the first and second persons, the $I$ and the Thou, and above all of the covenant contingency with its protasis and apodosis, which lies at the heart of the message. ${ }^{36}$

For him, the structure of Exod 19:3-6 is: (1) Oracular opening (v. 3b) which, he recognized, is similar to "the Mari royal texts and the Hittite treaties;"37 (2) The proclamation of the mighty acts (v. 4) where Israel is witness of them. Again, he says that "this motif of the witness has its ancient Near Eastern parallels;" (3) The covenant condition (vv. 5, 6), with two parts, comes from the salvation/prophetic oracles and the royal speech respectively. ${ }^{38}$

Muilenburg maintained that Exod 19:3-6 along with Jos 24 and 1 Sam 12 are passages "placed in a cultic situation 'before Yahweh,' and it is apparent that the

the NT) mentions Moses as the author of certain parts of the Torah, without specifying its shape and scope (Exod 17:14; 24:4; 34:27; Num 33:2; Deut 31:22; 32; Josh 1:7, 8; 2 Chron 25:4; Ezra 6:18; Neh 13:1; Matt 19:7; 22:24; Mark 7:10; 12:26; John 1:17; 5:46; 7:23).

See more about the Documentary Hypothesis in Julius Wellhausen, Prolegomena to the History of Israel, trans. J. S. Blace and A. Menzies (Atlanta, GA: Scholars, 1994); Paul R. House, Old Testament Theology (Downers Grove, IL: InterVarsity, 1998); Childs, Biblical Theology of the Old and New Testaments: Theological Reflection on the Christian Bible (Minneapolis, MN: Fortress, 1993); Rolf Rendtorff, The Covenant Formula: An Exegetical and Theological Investigation (Edinburgh: T\&T Clark, 1998); Ben C. Ollenburger, Old Testament Theology: Flowering and Future. Sources for Biblical and Theological Study 1 (Winona Lake, IL: Eisenbrauns, 2004); Antony F. Campbell and Mark A. O’Brien. Rethinking the Pentateuch: Prolegomena to the Theology of Ancient Israel (Louisville, KY: Westminster John Knox, 2005); Umberto Cassuto, The Documentary Hypothesis and the Composition of the Pentateuch (Jerusalem: Shalem, 2006).

36 James Muilenburg, "The Form and Structure of the Covenantal Formulations," VT 9 (1959): 352. (Emphasis is in the original).

\footnotetext{
${ }^{37}$ Ibid., 354.

${ }^{38}$ Ibid., 354, 355.
} 
sanctuary is the locus of all three." ${ }^{39}$ Thus, related to Exod 19:3-6 he concluded that "it is significant that the covenant formulation appears at the conclusion of the codes of law (Exod xxiii:22; Deut xxviii; Lev xxvi) in the manner of the Hittite treaties noted above and the Code of Hammurabi." 40 And for all three he agreed that they belong to "an ancient literary form," with "terminology and structure that "may be derived from royal compacts or treaties, and that the covenant mediator and intercessor plays a definite role in all of them." ${ }^{41}$

\section{Meredith G. Kline (1960)}

Meredith G. Kline linked the pattern of suzerainty treaties with the two tables of the covenant found in the Pentateuch. He said that the phrase "I am the Lord thy God" in Exod 20:2a corresponds "to the preamble of the suzerainty treaties, which identified the suzerain and that in terms calculated to inspire awe and fear." 42 The historical prologue is found in Exod 20:2b: "Which have brought thee out of the land of Egypt, out of the house of bondage." ${ }^{43}$ Consequently, Kline said, "This element in the covenant document was

${ }^{39}$ Ibid., 364. Cf. Boyle "The Covenant Lawsuit of the Prophet Amos," 349-352; Klaus Baltzer, The Covenant Formulary in Old Testament, Jewish and Early Christian Writings, trans. D. Green (Philadelphia, PA: Fortress, 1971), 19-27, also concluded that Jos 24 is patterned after the Hittite treaty formulary.

${ }^{40}$ Muilenburg, "The Form and Structure of the Covenantal Formulations," 356.

${ }^{41}$ Ibid., 365.

${ }^{42}$ Meredith G. Kline, “The Two Tables of the Covenant,” WTJ 22 (1960), 134. On this same page, as an example, he referred to the treaty of Mursilis with his vassal Duppi-Tessub of Amurru: "These are the words of the Sun Mursilis, the great king, the king of the Hatti land, the valiant, the favorite of the Stormgod, the son of Suppiluliumas, etc." Also on p. 138, he talked about the preamble and the historical prologue in the Decalogue, and suggested that they "must not be minimized nor ignored because of their brevity for this (the two tables of the Covenant) is a covenant in miniature."

43 Ibid., 134. Kline also added that in the historical prologue, the suzerainty treaty "continue in an 'I-thou' style ... surveying the great kings, previous relations with, and especially his benefactions to, the vassal king." Here, "Mursilis reminds Duppi-Tessub of the vassal status of his father and grandfather, of 
clearly designed to inspire confidence and gratitude in the vassal and thereby to dispose him to attend to the covenant obligations, which constitute the third element in both Exodus 20 and the international treaties." ${ }^{\prime 4}$ This part contains the stipulations in which "Yahweh commands his servant: 'Thou Shalt have no other gods before me' (Exod. 20:3; cf. 4,5$).{ }^{.45}$

The parallelism already noted, however, is sufficient to demonstrate that the revelation committed to the two tables was rather a suzerainty treaty or covenant than a legal code. The customary exclusive use of "decalogue" to designate this revelation, biblical terminology though it is (cf. "the ten words", Exod. 34:28; Deut. $4: 13 ; 10: 4)$, has unfortunately served to obscure the whole truth of the matter. That this designation is intended as only pars pro toto is confirmed by the fact that "covenant" (... Deut. 4:13) and "the words of the covenant" (Exod. 34:28; Deut. 28:69; 29:8; etc.) are alternate biblical terminology. So too is "testimony" (. . Exod. 25:16, 21; 40:20; cf. II Kg. 17:15), which characterizes the stipulations as oath-bound obligations or as a covenant order of life. Consequently, the two tables are called "the tables of the covenant" (Deut. 9:9, 11,15 ) and "the tables of the testimony" (Exod. 31:18; 32:15; 34:29); the ark, as the "depository" of the tables, "the ark of the covenant" or "of the testimony"; and the tabernacle, where the ark was located, "the tabernacle of the testimony." 46

He also maintained that the "formal literary approximation to the invocation of the oath witnesses" is in Deut 4:26; 30:19 and 31:28 where heaven and earth, the mountains and rivers are invoked to be witnesses of the covenant ${ }^{47}$ For the invocation of the gods, he stated,

their loyalty and enjoyment of Mursilis' just oversight, and climactically there is narrated how Mursilis, true to his promise to Duppi-Tessub's father, secured the dynastic succession for Duppi-Tessub, sick and ailing though he was."

${ }^{44}$ Ibid.

${ }^{45}$ Ibid., 135. On pp. 134, 135, he links the first commandment with Mursilis' advise to DuppiTessub: "Thus, Mursilis insists: 'But you, Duppi-Tessub, remain loyal toward the king of the Hatti land, the Hatti land, my sons (and) my grandsons forever. ... Do not turn your eyes to anyone else!' "

\footnotetext{
${ }^{46}$ Ibid., 136, 137.

${ }^{47}$ Ibid., 135 n. 6.
} 
Obviously in the case of God's covenant with Israel there could be no thought of a realistic invocation of a third party as divine witness. Indeed, it is implicit in the third word of the decalogue that all Israel's oaths must be sworn by the name of Yahweh (Exod. 20:7). The immediate contextual application of this commandment is that the Israelite must remain true to the oath he was about to take at Sinai in accordance with the standard procedure in ceremonies of covenant ratification (cf. Exod. 24). ${ }^{48}$

Kline maintained that in vassal treaties, one feature was the "deposit of the treaty before the gods" expressing "their role as witnesses and avengers of the oath." ${ }^{49}$ This happened similarly with the Decalogue that was deposited in the tabernacle of the testimony (Exod 25:16, 21; 40:20; Deut 10:2), making clear that God was witness and judge at the same time.${ }^{50}$ However, Kline clarified that the purpose of the deposit of the treaty before the gods, in international treaties, and before God, in the tabernacle, were different:

Both copies of the covenant were laid before Yahweh as God of the oath. But what was the purpose of Yahweh's own copy in his capacity as covenant suzerain? In the case of the international treaties, the suzerain would naturally want to possess, preserve, and protect a sealed legal witness to the treaty. It would remind him of the vassal's aide for the purpose of enforcement and punishment; for he would be the actual avenger of the oath, the instrument of the oath deities according to the religious theory which was the legal fiction lending sacred sanction to the treaty. It would also remind him of his suzerain's role as protector of the vassal and of the various specific promises of assistance often contained in the treaties. He had not, however, like the vassal taken a covenant oath and human lords being what they are he would have considerably less interest in the benefits he might bestow than in the amount of annual tribute he was entitled to exact from the vassal.

\footnotetext{
${ }^{48}$ Ibid., 135.

${ }^{49}$ Ibid., 139.
}

${ }^{50}$ Cf. Ibid., 140. On pp. 139, 140, he argued that the two tables of the Decalogue "were duplicate copies of the covenant. And the correctness of this interpretation is decisively confirmed by the fact that it was normal procedure in establishing suzerainty covenant to prepare duplicate copies of the treaty text." And "because Yahweh was at once Israel's covenant suzerain God of Israel and Israel's oath, there was but one sanctuary for the deposit of both treaty duplicates." 
Such mutatis mutandis was the purpose of Yahweh's own stone table of covenant witness. However, even from the formal point of view there is here a remarkable shift in emphasis arising from the fact that God's suzerainty covenant with Israel is an administration of salvation. ${ }^{51}$

This is emphasized in the form of curses and blessings in which God promises mercy "not merely to the third and the fourth generation of them that love him but, contrary to the balance observed in this respect in the curse and blessing formulae of the international treaties, "to the thousand generations." ",52

Kline argued that the section related to the "deposit of one copy of the treaty document in a sanctuary of the vassal and another in a sanctuary of the suzerain," 53 are "similar instructions ... given Moses at Sinai concerning the two tables. They were to be deposited in the ark, which in turn was to be placed in the tabernacle (Exod. 25:16, 21;

40:20; Deut. 10:2)." ${ }^{54}$ Additionally, he established,

As for the further custom of periodic reading of treaty documents, the contents of the two tables were ... declared in the hearing of all Israel and the Book of the Covenant was read to the people as part of the ratification ceremony (Exod. 24:7). But the practice of periodic proclamation was first formulated some forty years later in the Book of Deuteronomy when God was renewing the covenant unto the second generation. ${ }^{55}$

${ }^{51}$ Ibid., 142, 143.

52 Ibid., 143. 136. He also adds on p. 136 that "the curses and blessings are present in Exodus 20, though not as a separate section. They are rather interspersed among the stipulations (cf. verses 5, 6, 11, and 12)." However, Mendenhall, "Covenant Forms," 66, affirms that "there is no curse and blessing formula in the Decalogue."

${ }^{53}$ Kline, "The Tables of the Covenant," 139.

${ }^{54}$ Ibid., 140.

55 Ibid. 
Kline developed this statement in his next article, challenging current scholarship based on the structure of the book of Deuteronomy. ${ }^{56}$ For him the structure of

\section{Deuteronomy is:}

“1. Preamble (1:1-5). 2. Historical prologue (1:6-4:49). 3. Stipulations (5-26). 4. Curses

and Blessings or Covenant Ratification (27-30). 5. Succession Arrangements or Covenant

Continuity, in which are included the invocation of witnesses and directions for the

disposition and public reading of the treaty (31-34). ${ }^{.57}$

${ }^{56}$ Ibid., "Dynastic Covenant," WTJ 23 (1960):1-15. In this aspect he emphasized on p. 1 as follows: "Over twenty years ago Gerhard von Rad signalized the need for discovering the nature and meaning of the over-all form of Deuteronomy. Attention had been paid to the individual Gattung, whether parenesis, legal precept, or curse and blessing formula. But what was the structural coherence of the several parts within the whole? In current discussions this question is of crucial significance because the problem of the unity of Deuteronomy is judged to be not stylistic but structural.

Higher criticism has sought to distinguish an original core of Deuteronomy from the alleged accretions. Wellhausen and others have limited this core to chapters 12-26 but due to the stylistic homogeneity most would now expand this to chapters 5-26 and 28." See also Wright, Deuteronomy, IB 2 (TN: Abingdon, 1953), 314-18.

${ }^{57}$ Kline, Deuteronomy, WBC, ed. C. F. Pfeiffer and E. F. Harrison (Chicago, IL: Moody, 1962), 155-204, 459-90, later developed this structure as follows:

"I. Preamble: Covenant mediator. 1:1-5.

II. Historical prologue: Covenant history. 1:6-4:49.

III. Stipulations: Covenant life. 5:1-26:19.

A. The Great Commandment. 5:1-11:32.

B. Ancillary commandments. 12:1-26:19.

IV. Sanctions: Covenant ratification. 27:1-30:20.

A. Ratification ceremony in Canaan. 27.

B. Proclamation of the sanctions. 28:1-68.

(1) Blessings. 28:1-14.

(2) Curses. 28:15-68.

C. Summons to the covenant oath. 29.

D. Ultimate restoration. 30:1-10.

E. Radical decision. 30:11-20.

V. Dynastic disposition: Covenant continuity. 31:1-34:12.

A. Final arrangements. 31:1-29.

B. The song of Witness. 31:30-32:47.

C. Moses' testament. 32:48-33:29.

D. Dynastic succession. 34." 


\section{Dennis J. McCarthy (1963)}

Dennis J. McCarthy analyzed ancient Hittite, Syrian and Assyrian treaties, as early as to $2500 \mathrm{BC}$ down to $700 \mathrm{BC}$, in order to compare them among themselves and, afterward, to consider them with some Old Testament passages, especially from the Pentateuch and Joshua. He mentioned that these books contain the same form of ancient treaties. ${ }^{58} \mathrm{He}$ recognized that "formal treaties . . . in Akkadian Mesopotamia before the coming of the Hittites" have been used. ${ }^{59}$ Thus, he said that "the whole style shows that the treaty was alive and well defined in a very old West Semitic environment.",60

McCarthy established that in many instances biblical texts have details that "have nothing to do with covenant." ${ }^{\prime 61}$ However, in his study of Gen 21:22-24; 26:26-33 and 31:49-54 he accepted that both suzerainty and parity treaties were based on the same

${ }^{58}$ McCarthy, Treaty and Covenant: A Study in Form in the Ancient Oriental Documents and in the Old Testament (Rome: Pontifical Biblical Institute, 1981).

${ }^{59}$ Ibid., 33; cf. Chester, "Covenant Types," 285, established the evidence of international treaties or covenants in Sumerian sources dated from the mid 3000 BC. Though fragmentary they prove a long tradition which regulates the affairs between suzerains and vassals in ANE culture.

${ }^{60}$ McCarthy, Treaty and Covenant, 35. Related to this point, on pp. 285-86, McCarthy expressed his doubt about two points: (1) the setting of Exod 19:3b-8, and (2) the time and identification of the biblical Hittites. For this last point he said, "There was a Canaanite population whom the Bible calls Hittites, but exactly who they were and whence they came is an unresolved question."

${ }^{61}$ Ibid., 6. A question that McCarthy asked on p. 5 is this: "Do they [the Biblical texts] by their structure ... reflect the structure of the treaties?" The answer to this question is the key point to his thesis throughout his book. And the first thing he did was to disagree with Mendenhall's study. Cf. Ibid., "Three Covenants in Genesis," 179-82. Though McCarthy recognized that the covenant between Abraham and Abimelech (Gen 21:22-24) may be called a parity treaty, he stated on p. 184 that the former "is clearly superior and yet takes an oath." The same thing happens between Laban and Jacob (Gen 31:49-54), in which the latter takes an oath, although he is the superior because he makes the sacrifice.

Cf. Tucker, "Covenant Forms and Contract Forms," 488-89, who compared covenant with taking an oath, and showed also several passages in which Yahweh takes an oath with the covenant between him and Israel: Deut 4:31: "(for the LORD your God is a merciful God), He will not forsake you nor destroy

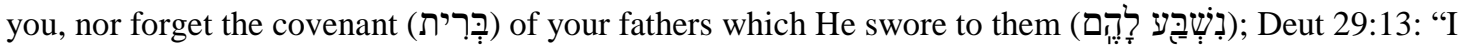

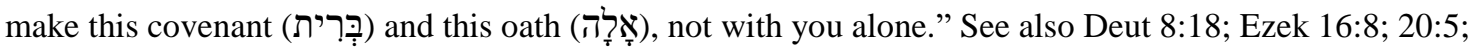
Ps 89:4,5; 105:8-11; Jer 11:1-5; 2 Sam 3:9; 2 Chr 15:12-15; Ezra 10:3-5; Neh 10:30. 
structure: introduction of the speaker, the historical prologue, the stipulations, the

document, the gods as witnesses and curse and blessing. ${ }^{62}$ He recognized also that though these treaties could have the same arrangement or many variations, two elements constantly appear: the gods called to be witnesses, and the curse and blessing. ${ }^{63}$

\section{Ray F. Chester (1966)}

In an analysis of the Mosaic, Abrahamic, Noahic, Joshua, and Davidic covenants, Ray F. Chester exposed the similarities and differences in them. ${ }^{64}$ Accordingly he said that "the covenant of Joshua 24 follows" the outline of the Mosaic covenant; and though they have "some striking differences," they fit into the Hittite treaty. ${ }^{65}$ However the Abrahamic, Noahic, Davidic covenants are different because in them "only God is bound whereas under the Mosaic type only Israel is bound." 66 Thus, he examined the Mosaic covenant and put it in the Hittite-treaty framework:

1. The Preamble. "I am the Lord your God. ...

2. The historical prologue. "who brought you out of the land of Egypt." This is the benevolent act of the suzerain on behalf of the covenant people.

3. The stipulations. The Ten Commandments or the Decalogue. There is a close parallel to the Hittite treaties in that they frequently began with a prohibition on entering relationships with other sovereigns. ...

${ }^{62}$ McCarthy, Treaty and Covenant, 1, 2. 50, 51, 67, 68.

${ }^{63}$ Ibid., 39, 40, 48; cf. Tucker, "Covenant Forms and Contract Forms,” 494, 495.

${ }^{64}$ Chester, "Covenant Types," 285-89.

65 Ibid., 287. Those differences include that "the introductory formula which identifies the author of the covenant and the historical prologue goes backward beyond the Exodus to include the patriarchal period and also includes the immediate past events such as the defeat of Jericho" and the nations which were in Canaan. The other difference is that "the only stipulation included here is a reference to the putting away of other gods."

${ }^{66}$ Ibid., 288. This is a point that he introduced on p. 287 saying "that the covenant grows out of the gracious act of God. Israel was to keep the law because of God's prior act on her behalf. The Mosaic Covenant, fitting into the Hittite suzerainty treaty type, is one where only man is bound." 
4. The deposit and public reading. The text of the Decalogue does not include this item but in the later narratives of the Pentateuch we read of provision for the deposit of the covenant in the Ark or the Covenant and for the periodic reading. 5. The list of witnesses. Of necessity the witness of pagan deities in the Hittite treaties is excluded. ...

6. The blessing and cursing. These appear in various places. The prophetic tradition of pre-exilic times is tied to this aspect of covenant. Both the blessings and cursings were predominantly natural phenomena such as fertility and famine, health and disease, victory and defeat. ${ }^{67}$

Chester argued that as in Hittite treaties "the stipulations were binding only on the vassal" as in the Mosaic covenant. ${ }^{68}$ In a covenant where two equal parties were bound with an oath, he called it "parity covenant." ${ }^{99}$ Therefore, in this type of covenant, a Godhuman treaty is not the case. He added that "there is never a case where man initiates a covenant with God or stipulates the conditions by which he shows his loyalty to God." 70 Based on the parallels of the Hittite treaties, he affirmed, "For the sovereign to bind himself in any way to the vassal was regarded as an infringement on his sovereignty and self-determination." 71

James Limburg (1969)

James Limburg paid attention to the Gerichtsrede of several "prophetic texts in which Yahweh and people are represented as participants in a legal process."72 $\mathrm{He}$

${ }^{67}$ Ibid., 286, 287.

${ }^{68}$ Ibid., 285.

${ }^{69}$ Ibid., 289.

70 Ibid.

${ }^{71}$ Ibid., 285, 286; cf. McCarthy, "Three Covenants," 180; Archer, A Survey of Old Testament Introduction, 274.

72 Limburg, "The Root ריב and the Prophetic Lawsuit Speeches," 291. On p. 296 he said that in the majority of these texts "the subject of the verb is an aggrieved party making an accusation against an aggrieving party." See also Limburg's doctoral dissertation, "The Lawsuit of God in the Eighth-Century 
maintained that the root ריב occurs in "three separate 'spheres of life:' "(1) The court at the gate, (2) The sphere of the cult, and (3) International relationships. ${ }^{73}$ This latter, he affirmed, "has not been noticed in the literature."74 At the end of his research he contended that it is difficult to decide which one of the three is the precedence of the legal forms of speech. Nevertheless, he took a decision saying that the word ריב is "very much at home in the sphere of international relationships, particularly in connection with international treaties."75

\section{Klaus Baltzer (1971)}

K. Baltzer, in his survey of the opinion of several scholars regarding the meaning of question of the structure and employment of the formulary of" the biblical ${ }^{77}{ }^{77}$ and

Prophets," Th.D. diss., Union Theological Seminary, 1969), 1-52; in which he surveyed 60 years of biblical research, from Gunkel to Eberhard von Waldow, with the "questions of the 'whence' and the 'why' of" the "juridical forms of speech" in the eighth-century prophets. He did not question the validity of the covenant lawsuit but the origin of it.

${ }^{73}$ Limburg, "The Root ריב and the Prophetic Lawsuit Speeches," 297. He mentioned also on pp. 10-35, 45, 46, the main advocates for each position: (1) H. J. Boecker: The court at the gate; (2) Ernst Würthwein: The sphere of the cult; and (3) J. Harvey: International relationships. Cf. Nielsen, Yahweh as Prosecutor and Judge, 22.

${ }^{74}$ Limburg, "The Root ריב and the Prophetic Lawsuit Speeches," 297.

${ }^{75}$ Ibid., 303, 304.

${ }^{76}$ Baltzer, The Covenant Formulary, 1-18. He specially mentioned: J. Wellhausen, Kraetzschma, J. Pedersen, L. Köhler, J. Begrich, S. Mowinckel, M. Noth, A. Alt, G. von Rad and O. Eißfeldt. Cf. McCarthy, "Covenant in the Old Testament," 225, 226.

${ }^{77}$ Baltzer, The Covenant Formulary, 7, 8. 
concluded: "Our study has shown that the covenant formulary in Israel exhibits a close association with the international treaties of the ancient Near East."78

In his findings, Baltzer said that in "an ancient legal tradition . . . when a treaty is concluded, witnesses are necessary." For this function, lists of gods are mentioned including "mountains, rivers, springs, the great sea, heaven and earth, winds and clouds."79

Furthermore, he concluded that the gods are not merely witnesses; but also "they act as guarantors that the stipulations of the treaty will be carried out, as 'lords of the oaths. $"{ }^{80}$ In order to guarantee the treaty, the list of gods and the list of blessings and curses are together because specific gods are called to bring about "the protection of the gods, prosperity of the land, eternal reign; . . . abundant harvests, joy of heart, and peace of mind forever;" or on the contrary the horror of specific plagues that would come if the vassal breaks the treaty. ${ }^{81}$

\section{Kenneth Anderson Kitchen (1978)}

In 1978 Kenneth A. Kitchen published the fifth printing of his book Ancient Orient and Old Testament in which he agreed with Mendenhall on the "striking parallels in form between the covenant in Exodus $20 \mathrm{ff}$. (...) and the international covenant treaties of the fourteenth/thirteenth centuries BC recovered mainly from the Hittite

\footnotetext{
${ }^{78}$ Ibid., 53.

${ }^{79}$ Ibid., 14.

${ }^{80}$ Ibid., 14, 15.

${ }^{81}$ Ibid., 15.
} 
archives at Boghazköy." 82 He maintained that the set of treaties from the late second millennium and of the first millennium BC are significantly different. Therefore, the Sinai covenant form corresponds "to that of the treaties of the second millennium but not to those of the first millennium BC." 83

For this, Kitchen made a comparison between the forms of these two set of treaties with the form of the Sinai covenant. The comparison is as follows: Covenant of the Late Second Millennium BC:

1. Preamble or title, identifying the author of the covenant.

2. Historical prologue or retrospect, mentioning previous relations between the two parties involved; past benefactions by the suzerain are a basis for the vassal's gratitude and future obedience.

3. Stipulations, basic and detailed; the obligations laid upon the vassal by the sovereign.

4. (a). Deposition of a copy of the covenant in the vassal's sanctuary and

(b). Periodic public reading of the covenant terms to the people.

5. Witnesses, a long list of gods invoked to witness the covenant.

6. (a). Curses, invoked upon the vassal if he breaks the covenant, and

(b). Blessings, invoked upon the vassal if he keeps the covenant. ${ }^{84}$

Elements of the Sinai Covenant:

${ }^{82}$ Kitchen, Ancient Orient and Old Testament, 91. Cf. Waltke and Yu, An Old Testament Theology, 409-11, 414, 431, 433; Erhard Gerstenberger, "Covenant and Commandment," JBL 84 (1965): 38-51, had already challenged this interpretation. He divided Exod 20:2-17 in two sections: vv. 2-6 are cultcentered exhortations for a wider audience and vv. 7-17 are related to a social order. He also denied the relation between treaties, covenant and commandments. While the first two are protection of an agreement between two parties, the latter refers to an order given without agreement that men take for granted. Thus instead of looking the original setting of Exod 20:7-17 in vassal-suzerain treaties it is better to look at it in the welfare of society. Other passages with this characteristic are Exod 22:17-23:9; Lev 18; 19; Deut 22:1$12 ; 23: 1,16-26 ; 24: 8-22 ; 25: 13-15$. Another reason he gave for this division was that while in Exod 20:2-6 the first person ("I") is clearly established, in vv. 7-17 "the first person of Yahweh is clearly secondary." Then, he concluded saying that "treaty stipulation and commandment have little in common." For the sake of disagreement it is worth noting to say that Exod 19-24 has been recognized as a literary unit by most of scholars. An example of this is Rendtorff, "Covenant' as a Structuring Concept in Genesis and Exodus," JBL 108 (1989): 388.

\footnotetext{
${ }^{83}$ Kitchen, Ancient Orient and Old Testament, 91. See ibid., 99.

${ }^{84}$ Ibid., 92, 93.
} 
1. Preamble: A. Exodus 20:1. B. Deuteronomy 1:1-5. (C. Dt. 29:1 ?). D. Joshua 24:2.

2. Historical prologue: A. Exodus 20:2. B. Deuteronomy 1:6-3:29 (C. Dt. 29:2-8).

D. Joshua 24:2-13.

3. Stipulations: A. Exodus 20:3-17, 22-26 (basic); Exodus 21-23, 25-31 (detailed), plus Leviticus 1-25 ?? B. Deuteronomy 4, 5-11 (basic); 12-26 (detailed). (C. Dt. 29:9-31:8). D. Joshua 24:14-15 (plus 16-25, the people's response, etc.).

4. (a). Deposition of Text: A. Exodus 25:16; Exodus 34:1, 28, 29; $c f$.

Deuteronomy 10:1-5 (retrospect). B. Deuteronomy 31:9, 24-26. D. Cf. Joshua 24:26 (written in the book of the law).

(b). Public reading: B. Deuteronomy 31:10-13.

5. Witnesses: The gods of paganism were excluded, so the god-lists of the Ancient Oriental covenants are not found in the biblical ones. Instead, memorial-stones could be a witness (A. Ex. 24:4; cf. D. Jos. 24:27), or Moses' song (B. Dt. 31:1630; Dt. 32:1-47), or the law-book itself (B. Dt. 31:26), or even the people as participants (D. Jos. 24:22).

6. Curses and Blessings occur not in this order but reversed in the Old Testament, following the witness. A. Perhaps, $c f$. Leviticus 26:3-13 (blessings), 14-20 (curses; with more for repeated disobedience, 21-33). B. Deuteronomy 28:1-14 (blessings), 15-68 (curses). D. Implicit in Joshua 24:19-20. ${ }^{85}$

On the part of the form of the first millennium treaties, his analysis brought to light that they are much less extensive with: "(1) Preamble or title (where the beginning of the text exists). (2) Then Stipulations and Curses, succeeded or proceeded by the divine Witnesses" with parts (3) and (4) interchangeable. ${ }^{86}$ In this comparison, he concluded that "the Sinai covenant and its renewals must be classed with the late-second millennium covenants; it is entirely different in arrangement from the first-millennium covenants and shares with them only the indispensable terminology (title, stipulations, witness and curses) and some terminology." 97

To those who argued that the form of the treaties were fixed in the first

${ }^{85}$ Ibid., 96, 97. Letters A, B, (C), and D refer to Kitchen's organization of the Sinai Covenant as follows: A: Exod 20-31; B: Deut 1-32:47; (C: Deut 29-30); and D: Jos 24.

${ }^{86}$ Ibid., 94.

${ }^{87}$ Ibid., 98, 99. 
millennium, Kitchen asked why the writers of the covenant treaties of the first millennium used the form of the second millennium when it was no more in use and at the same time failed to use the first millennium form which was in practice. The answer to this question could be that the second-millennium treaty's structure came to influence the arrangement of the first millennium, though it was not used regularly anymore. ${ }^{88}$

He made a call to those who cherished certain "theories of Hebrew religious evolution or of literary criticism" to put them aside because "facts must take precedence, and theories be adjusted to fit them or else (...) be discarded." 89 Taking into account this suggestion, he went through a long research along with Paul J. N. Lawrence, analyzing 106 documents which include rules, laws, treaties and covenants from 2500 to $46 \mathrm{BC}$, showing their variations, consistencies and development throughout the years. ${ }^{90}$

\footnotetext{
${ }^{88}$ Ibid., 100.

${ }^{89}$ Ibid., 101, 102.
}

${ }^{90}$ K. A. Kitchen and Paul J. N. Lawrence, Treaty, Law and Covenant in the Ancient Near East (Wiebaden: Harrassowitz Verlag, 2012), 1:XXIII-XXV, based each document on the following structure: (1) Title/Preamble; (2) Historical or other Prologue; (3) Stipulations or Laws; (4) Deposit of the Document and Periodic Reading of Document to adherents of Parties; (5) Witnesses; (6) Blessings and Curses; (7) Oath(s); (8) Solemn Ceremony; (9) Epilogue; (10) Additional Items; (11) Sanctions; and (12) Historical Report and/or Archaeological Flashback.

They evaluated the covenants of God and Israel as it is written in Exodus-Leviticus, and in Deuteronomy on pp. 696-768: For Exodus-Leviticus covenant, their findings are: (1) Title (Exod 20:1); (2) Historical Prologue (Exod 20:2); (3) Stipulations (Exod 20:3-17, 23-26), plus Additional Item (Frame text; Exod 20:18-21), and a full series of stipulations (Exod 21-23); (8) Solemn Ceremony (Exod 24:1-14), which includes (4) Reading of Document, and (5) Witnesses (Exod 24:4b-7); (10) Additional Item (Frame Text; Exod 24:15-18); (3) Stipulations with Title (Exod 25:1-8); (4) Deposit of Text (Exod 25:10, 16, 17 , 21); (3) Stipulations (Exod 34:8-27; 35:1-19); (3) Stipulations including Title and Sectional Colophons (Lev 11-15; 18-20; 24:15; 25:1-26:2); (6) Blessings and curses (Lev 26:3-46); (10) Main Terminal Colophon (Lev 26:46); (3) Stipulations (Lev 27); and (10) Final Colophon (Lev 27:34). The structure of Kitchen and Lawrence is hard to follow sometimes because of a series of parts given within another part and divided by letters. Thus the former structure is my simplification of it.

On the part of the covenant in Deuteronomy, on pp. 775-898, they concluded as follows: (1) Title with (12) Historical Report and/or Archaeological Flashback (1:1-5); (2) Historical Prologue with Historical Report and/or Archaeological Flashback and Witnesses (1:6-3:29); (3) Stipulations with Frame Text, Sub-Title, Historical Report and/or Archaeological Flashback (chaps. 4-26); (5) Witnesses plus Solemn Ceremony with Sub-Title (27:1-26; 30:19); (6) Blessings and Curses (28:1-68); (9) Recapitulation/ 
Michael de Roche (1983)

Based on Simon Roberts' book, Order and Dispute, ${ }^{91}$ de Roche argued that "the terms 'prophetic lawsuit' and 'covenant lawsuit' should be abandoned"92 because the word " 'lawsuit' is a modern technical term that has no real Hebrew equivalent." ${ }^{93} \mathrm{He}$ added that in order to have a lawsuit a third party has to be involved in the quarrel, and that party must be someone who, after hearing all the arguments, "hands down a verdict that is binding on all parties."94 The key point of de Roche's contention is to make clear whether a quarrel is being resolved in a bilateral or trilateral way. Further, he agreed with Roberts' argument that "there are three main ways by which disputes can be solved, the second actually being a special case of the first." 95

Epilogue including Oath (29:1-31:8); (4) Deposit/Reading (31:9-13; 24-26); (5) Witnesses including Sub Title (31:14-30); (4) Deposit, Song in Preamble (31:24-29); (5) Witness (Song; 32:1-43); (10) Additional Items: Colophon (32:44-47); Frame Text (32:48-34); and Frame Text, extraneous matter (32:33-34).

${ }^{91}$ Simon Roberts, Order and Dispute: An Introduction to Legal Anthropology (Middlesex, England: Penguin, 1979).

92 de Roche, "Yahweh rîb Against Israel," 574.

93 Ibid., 564. In this matter, Roberts, Order and Dispute, 17, argues, "It has to be recognized as a central problem of the social sciences that in any inquiry the observer is prone to fit the material under investigation, consciously or unconsciously, into a conceptual and institutional framework of his own, distorting the material as he does so. The hazard is obvious where the subject matter he is trying to understand and describe is located in an alien culture; and the risks are perhaps greatest where the arrangements under observation bear a superficial resemblance to those in our own society about which we may have established clear and dogmatic ideas."

94 de Roche, "Yahweh rîb Against Israel," 565. Roberts, Order and Dispute, 26, said, "In stateless societies, there may well be no one recognized as competent to hand down a decision to disputants from a third-party standpoint, let alone enforce that decision once it has been made. Thus, third parties are typically limited to acting as go-betweens, transmitting messages from one disputant to another, or as mediators, actively coaxing the parties towards a settlement, but still without the power to resolve the matter by decision."

Roberts, Order and Dispute, 17-29, made clear that "stateless societies" is a term that defines a society wherein there are neither official enforcement agencies nor courts presided by specialists nor a centralized government. Contrary to this argument, cf. Mabee, "Jacob and Laban," 203-4, who demonstrated that a covenant lawsuit could be held within a two-party dispute.

95 de Roche, "Yahweh rîb Against Israel," 565. Roberts, Order and Dispute, 69, said, “The 
In the first example the two parties try to solve their contention by themselves through any means. Whatever decision they reach is of a "bilateral nature" no matter how many people may be involved. ${ }^{96}$ The second example happens when the two parties in quarrel "agree to ask a third party to act as mediator," but in this case "there is no guarantee that they will accept his advice." 97 This second example is taken as a variation of the first one.

In the third example a third party, "who is pre-acknowledged by all as an umpire," has the power to execute a lawsuit. ${ }^{98}$ Even though the first two could be legal, "only this third category can properly be called judicial, and it is within this category that the modern lawsuit belongs." 99

In order to make his point, de Roche applied these three categories to several "passages that employ the root $r y b$ " to decide the category they belong to. ${ }^{100}$ As a result he contended that "the word $r \hat{\imath} b$ does not in itself indicate a judicial process. It is a more general term indicating only that one party has a grievance against another. It does not

disputants may feel their way towards a settlement through bilateral negotiation; they may try to resolve the matter with the help of a neutral mediator; or they may submit the quarrel to an umpire for decision."

96 de Roche, "Yahweh rîb Against Israel," 565.

97 Ibid.

${ }^{98}$ Ibid. On p. 569 de Roche says that this third party is "a binding arbiter."

${ }^{99}$ Ibid., 565. Roberts, Order and Dispute, 19, states that "the courts are specialized in the sense that their sole function is to administer the law in the context of disputes which are brought before them."

100 de Roche, "Yahweh rîb Against Israel," 567. These passages are Gen 13:7-9; 26:17-22; 31; and Judg 6:28-32 which, according to him, belong to the first method; and Judg 11 which belongs to the third method. Even though, de Roche accepts that Judg 11 belongs to the third category, he adds, "In this instance it is correct to speak of a judicial process, although it is a special theological adaptation. Yet the $r i ̂ b$ clearly occurs before Jephthah invokes the divine Judge to decide the case. Initially he tries to solve the $r \hat{i} b$ by international diplomacy. Thus the word $r \hat{i} b$ does not in itself indicate a judicial process" (ibid., 568). To this third category also belongs Deut 25:1-3; Prov 25:7b-10; 2 Sam 15:1-6, but he contends that in these passages "it is clear that a $r \hat{\imath} b$ is something that occurs prior to any judicial procedure" (ibid., 569). 
indicate the process by which the grievance is resolved." 101 And, in order to have a lawsuit the dispute shall be resolved by a third party. ${ }^{102}$ Therefore, a ריב and a lawsuit are different: "a $r \hat{\imath} b$ is a contention, while a lawsuit is a particular way of solving a contention." $" 103$

After that explanation he examined some prophetic oracles that had been taken as lawsuits (Jer 2:5-9; Hos 2:4-25; 4:1-3; 12:3). And he concluded that every oracle "corresponds to the first method" in which God, the harmed party, "seeks restitution for his grievance by his own means, according to his own concept of justice." 104 Thus, this is a ריב or contention but not a lawsuit because it has not been taken to a third party. As example of a lawsuit he explains Isa 5:1-7; 41:21-27 and 43:8-13 in which a third party takes part of the litigation.

In Isa 5:1-7 "the plaintiff is the planter, the defendant is the vineyard, and Judah is the judge."105 So, "Israel plays the role of both defendant and judge," passing judgment

${ }^{101}$ Ibid., 568. The two different transliterations $r y b$, rîb belong to de Roche.

102 Ibid., 570. Roberts, Order and Dispute, 49, failed to see that in those "stateless societies," as he called them, though there was not a "third party" to mediate in a quarrel, there were traditional conventions that functioned as taking the place of that "third party." He mentioned, for example the Nuer tribe. When any tribesman was wronged by another, both could expect members of his lineage to rally to support each party. He went further saying that there were "principles . . . sometimes found which indicate to the members which co-member they should support in the event of a quarrel."

Also Robert talked about some conventional rules that regulated "both the severity of the permitted aggression and the manner in which it is carried out." If the aggression was permitted then it had been regulated by a third party. This one could be one person or the tribe itself or any other source (ibid., 57). He gave other example of the Minj-Wahgi peoples of the Western Highlands of New Guinea where "disputes which come to involve two groups of kinsmen may be handled through an institution known as tagba boz" (ibid., 58). More examples are on ibid., 59-69.

$$
\begin{aligned}
& { }^{103} \text { de Roche, "Yahweh rîb Against Israel," } 569 . \\
& { }^{104} \text { Ibid., } 570 . \\
& { }^{105} \text { Ibid., } 572 .
\end{aligned}
$$


inadvertently on herself. ${ }^{106}$ Likewise, Isa 41:21-27 and 43:8-13 narrate a lawsuit where "Yahweh is . . the plaintiff, the idols are the defendants, and Israel . . . the judge." ${ }^{107}$ In this part he said, "Significantly, none of the examples that employ motifs derived from the courtroom contain the root $r y b . " 108$ He concluded his essay arguing that these lawsuit passages, instead of being identical with the ANE suzerainty treaties, drew their parallels either "in the secular courts" or "by reference to the nature of the covenant."109 Therefore, the quarrel between Yahweh and Israel remains on a personal, bilateral level, which is certainly more in keeping with the prophets' use of the marriage metaphor, and their practice of referring to Yahweh as Israel's God, and Israel as Yahweh's people. For this reason the terms "prophetic lawsuit" and "covenant lawsuit" should be abandoned. ${ }^{110}$

\section{Dwight R. Daniels (1987)}

Dwight R. Daniels picked up the argument against the prophetic lawsuit genre where de Roche left it. Whereas de Roche said that the ריב oracle is a special group Daniels contended that this is not the case. ${ }^{111}$ A key point in Daniels' understanding of the word $r \hat{\imath} b$ is this: "The root refers to activity, irrespective of location, which disrupts or restores the proper order of things or relationships among people, groups, or nations, i.e.

\footnotetext{
106 Ibid., 571.

${ }^{107}$ Ibid.

108 Ibid., 572.

109 Ibid.
}

${ }^{110}$ Ibid., 574. G. E. Wright, "The Lawsuit of God," 47, said clearly that in a heavenly lawsuit God, as "the Suzerain is himself the real Judge, Plaintiff, and Jury; he is the one who has been violated, and since there is no power above him he wields power himself, both accusing and sentencing. The heavenly assembly is in this case only witness and counsel . . nothing more."

${ }^{111}$ Daniels, “Is There a 'Prophetic Lawsuit' Genre?,” 340. 
which disrupts/restores משפט; where this proper positive order prevails, ריב disrupts it; where it is lacking, ריב may serve to restore it."112

Thus, in order to disqualify the accuracy of the pיב pattern, Daniels focused his arguments on three main points: (1) the main characteristics of a genre, ${ }^{113}$ (2) the meaning of the German word Gerichtsrede and the English "lawsuit,""114 and (3) a survey of common passages, used by scholar related to the covenant lawsuit. ${ }^{115}$

First, he said that a genre: (1) is an abstraction that finds expression in particular texts; (2) displays a common set of structural elements, in such a way that it is easily distinguished from other genres. This structure is categorized in two ways: the surface structure and the deeper structure; and (3) as a set has a fixed order, but with possible variations which do not disrupt the nature of the genre.

Second, in the evaluation of the meaning of the German word Gerichtsrede, he concluded that it has nothing to do with the English word "lawsuit." While "Gerichtsrede refers to any speech in a court of law" a "lawsuit ... has a concrete legal process in view."116 This lack of relation between these two terms has led scholars to disagree on

${ }^{112}$ Ibid., 353. To support this statement he mentioned Deut 25:1; Isa 1:17; and 51:17-23.

${ }^{113}$ Ibid., 341-342. In this point Gemser, "The Rîb-or Controversy-pattern," 128, believed "that the rîb-pattern is often, if not mostly, used metaphorically, although not as a purely literary style motif, but rather as a form of thinking and feeling, a category, a frame of mind."

\footnotetext{
${ }^{114}$ Daniels, "Is There a 'Prophetic Lawsuit' Genre?," 342.

${ }^{115}$ Ibid., 343-60.

${ }^{116}$ Ibid., 342. Limburg, "The Lawsuit of God," 3 n. 5, was aware of the ambiguity of the word Gerichtsrede, thus he argued in his dissertation that this "is not a technical term of current German jurisprudence." He also said that Gerichtsrede is "a court speech; could refer to either pleadings by lawyers or an address by the court" (ibid., 49). This has led to confusion in such a way that scholars have used "this term to indicate no only 'indictments' or 'accusations,' but also defense-speeches, appeals for trial, etc."
} 
both the definition of what a "prophetic lawsuit" is and which texts belong to it. ${ }^{117}$

This disagreement led Daniels to the third point, where he analyzed Isa $1: 2,3,18$ 20; Jer 2:4-13; Mic 6:1-8 and Hos 4:1-3, which scholars interpreted as being related to the covenant lawsuit genre. ${ }^{118}$ His conclusions, regarding these passages, were: Jer 2:4-13 and Hos 4:1-3 are prophecies of disaster, ${ }^{119}$ Isa 1:18-20, along with vv. 10-17, and Mic 6:1-8 are priestly torah with imagery from the cultic sphere of sin and atonement: ${ }^{120}$ and Isa 1:2, 3 shows a late development in the invocation of heaven and earth as witnesses to the covenant, because those natural elements were not used in Israel as part of covenantal formulation before 701 BC, when Hezekiah defeated Sennacherib.

Based on the inaccuracy of these passages and the ambiguity of the two first points, Daniel concluded as he started, "not only should the term 'prophetic lawsuit' be abandoned but also the underlying conception that these texts belong to a single genre." 121

${ }^{117}$ Daniels, “Is There a 'Prophetic Lawsuit' Genre?,” 343-60.

${ }^{118}$ Ibid., 343.

${ }^{119}$ Ibid., 344, 346. Also Daniels considered that Jer 2:12-13, where the word ריב appears, are not original. They are employed "to function as a redactional link between v. 4-11 and v. 14-19" in order to expand vv. 10,11. Even though Daniels tried to clarify that "the term 'redactional' must not be confused with 'inauthentic" " he was not able to avoid the phrase "is not original" (ibid., $345 \mathrm{n}$.14). This means that Jeremiah in "the gathering and arrangement of" his "prophecies" was a redactor. Thus, he moved certain passages from their original position to another in order to expand a prophecy.

${ }^{120}$ Ibid., 349, 350, 352, 353.

${ }^{121}$ Ibid., 360. 
Richard M. Davidson (2007)

Recently, Richard M. Davidson surveyed more than 320 passages of the Hebrew canon and concluded that they are "references to a divine covenant lawsuit." 122 Apart from that, he also offered a brief remark about the Gospel of John, the Pauline epistles and the book of Revelation, and in each of them he agreed that the divine lawsuit between God and the people is in place. ${ }^{123}$ Even though, he did not affirm openly that the whole Bible is a lawsuit, he did not hesitate to say "that the divine covenant lawsuit is pervasive in Scripture, both as a discrete sub-genre and as a prominent motif throughout the various parts of both OT and NT."124 It is noteworthy that this article was written practically as a response to de Roche's and Daniels' positions against a covenant lawsuit in the Old Testament.

Paul J. N. Lawrence (2011)

Paul J. N. Lawrence compared thirty-four Hittite treaties with the covenant in Exodus/Leviticus and Deuteronomy in order to demonstrate the late second-millennium$\mathrm{BC}$ origin of the Pentateuch, and at a same time to make a case for its mosaic authorship. ${ }^{125}$

\footnotetext{
122 Richard M. Davidson, “The Divine Covenant Lawsuit Motif in Canonical Perspective," JATS 21 (2010): 83 .

${ }^{123}$ Ibid., 81. Cf. F. L. Fisher, "Witness, Testimony," $B D T$, 555, who speaks about the need of a thorough study of witnessing in the whole Bible.

${ }^{124}$ Davidson, “The Divine Covenant Lawsuit Motif," 83.

${ }^{125}$ Paul J. Lawrence, The Book of Moses Revisited (Eugene, OR: Wipf \& Stock, 2011), 47-64.
} 
He stated that for two centuries (1380-1180 BC) "the conventions for the content and layout of treaties remained remarkably uniform" throughout the Near East region until the fall of the Hittite Empire. ${ }^{126}$

Lawrence, knowing that some scholars have been opposed to this comparison, ${ }^{127}$ clung to P. C. Craigie's statement that argued that "the use of the treaty form in the Hebrew tradition must necessarily have involved adaptation . . . of a political document for a specifically religious purpose." ${ }^{128}$ Lawrence maintained that while the treaties of the Pentateuch and of the Hittites are made with people, this feature is absent in first millennium treaties. He commented on the Succession Treaty of Esarhaddon (672 BC), arguing that this is not a treaty made with people, but rather a recognition of a succession arrangements. $^{129}$

\section{Summary}

The topic of "witness" has been studied largely in relation to the covenant lawsuit genre in ANE documents and in the Prophets, but scarcely in the Pentateuch, in which the subject of significant research has focused especially on Exod 19-24 and the book of Deuteronomy.

\section{${ }^{126}$ Ibid., 52, 53.}

${ }^{127}$ Ibid., 53 n. 16. He mentioned specifically to A. D. H. Mayes.

${ }^{128}$ Peter C. Craigie, The Book of Deuteronomy, NICOT (Grand Rapids, MI: Eerdmans, 1976), 27 in Lawrence, The Books of Moses, 54.

${ }^{129}$ Ibid., 53. Contrary to this position Moshe Weinfeld, Deuteronomy and the Deuteronomy School (Oxford, Oxford University Press, 1972), 60, tried to establish that the Treaty of Esarhaddon is a suzerain-vassal treaty. With this position, he wanted to persuade scholars that the book of Deuteronomy was written around the eight century BC. If the formulation of the Hittite treaties were in use as early as $672 \mathrm{BC}$ by other nations then it is not fair to conclude that Deuteronomy was written in the second millennium that resembles the Hittite form. 
On the other hand, the covenant lawsuit has been studied from the time that Hermann Gunkel suggested that some speeches in Psalms and in the Prophets were given in a court style in which God accuses Israel of breaking the covenant.

After that observation, George Mendenhall proposed that such covenant lawsuit language has been influenced by Hittite treaties in which a great king summoned his vassals to be obedient in order to avoid a punishment.

With this approach, he concluded that the Decalogue and the book of Joshua have connection with the Hittite treaties. Nevertheless, he recognized the lack of three important elements in the Decalogue in order to match the Hittite treaties, namely, the provision for deposit in the sanctuary, the public reading, and a list of witnesses.

In this aspect, however, Mendenhall failed to verify that at the time Moses received the Ten Commandments the sanctuary had not yet been built. This happened later, and then Moses placed the Ten Commandments into the Ark of the Covenant under God's commandment. ${ }^{130}$

Other scholars, such as Herbert Huffmon, James Muilenburg, James Limburg, Kirsten Nielsen and George W. Ramsey, assuming Mendenhall's conclusions, paid more attention to the Sitz im Lebem of the ריב pattern: Huffmon maintained that the Sitz im Lebem was probably the divine council or the indictment of Israel for breach of covenant, and Muilenburg concluded that it was the sanctuary.

130 See Exod 40:20; Deut 10:4, 5; cf. Exod 24:12; 31:18; 32:15, 16; 34:28; Deut 4:13. According to the biblical text, Moses, along with the people of Israel, stood at the foot of Mount Sinai when God gave the Ten Commandments (Exod 19:21-20:17). This means that God gave the Ten Commandments orally to the people of Israel; and then after Moses ascended to Mount Sinai several times (Exod 20:21, 22; 24:3, 9 , 12-18), God instructed Moses, among other things, to build the sanctuary (Exod 25-31). Finally, God gave Moses the "two tablets of the Testimony" (Exod 31:18), which were placed in the ark when the sanctuary was built at a later time (Exod 40:20). 
Limburg had difficulties to decide on three suggestions: the court at the gate, the sphere of the cult and the international relationship; while Nielsen declared that it was the covenant-relationship with God which the prophet forced upon the people.

Ramsey had a similar view, though on different grounds, saying that the covenant lawsuit oracles had their origin in the secular legal process of Israel with a cultic ceremony of covenant renewal in which the people had the opportunity to return, under penitence, to Yahweh, thus the speech was intended to restore a broken relationship rather than to inflict a punishment.

On their part, G. Ernest Wright, Ray F. Chester, Meredith G. Kline, Klaus Baltzer and Kenneth Kitchen based their investigations on the comparison between the Hebrew covenant lawsuit and ANE treaties.

Accordingly, Wright concluded that Deut 32 is based upon the suzerainty treaty form; and Ray F. Chester affirmed that the Mosaic, Abrahamic, Noahic, Joshua and Davidic covenants fit into the Hittite treaty. Kline suggested, on his part, that the two tables of the Decalogue of Exod 20 are linked to the suzerainty treaty pattern. And after a review of scholars' opinions of his time, Baltzer traced the trajectory of the Hittite treaty style throughout Jewish literature to early Christian texts and established that a basic schema was preserved though changes in details are present. Further, Kitchen, with a long collection of treaties, concluded that the Sinai covenant agrees in form with second millennium $\mathrm{BC}$ treaties but not with those of first millennium $\mathrm{BC}$, pointing out, with this research, to the antiquity of the biblical covenant.

However, R. E. Clements, Dennis J. McCarthy, and more recently Michael de Roche and Dwight R. Daniels, have been against the conclusions set forth above. 
Clements rejected the proposed similarities between the Old Testament Covenant and the ANE treaty documents. About the same time of Clements, McCarthy put in doubt that the people of Israel had used the covenant lawsuit genre, and sustained that those passages which speak about covenant are intended to emphasize God's theophany. Moreover, he suggested that those passages, which may be linked to the Hittite treaties, are not original to the biblical text but are late-comer to the text. As it is noticed, McCarthy's research was based on the Documentary Hypothesis, thus his approach caused him to arrive at conclusions contrary to what the canonical text may support.

Though the covenant lawsuit genre has been highly debated from the days of Gunkel, the disagreement upon the subject has increased especially from the 80's with the influential articles of de Roche and Daniels. They both rejected the covenant lawsuit as a genre in the Hebrew Bible. On that ground, de Roche manifested that a true lawsuit involves three parties, but the quarrel between Yahweh and Israel is bilateral, in which a third party is absent, thus it cannot be called a covenant lawsuit proper. And Daniels, based on de Roche's conclusions, said that the term "prophetic lawsuit" must be abandoned for three reasons: first, the pattern does not embrace the main characteristics of a genre which is distinguished from other genres; second, the German word Gerichtsrede has nothing to do with the English word "lawsuit" which brings ambiguities and false claims upon the text; and third, those texts which have been traditionally taken as belonging to the covenant lawsuit genre are better called prophecies of disaster and priestly torah with imagery from the cultic sphere of sin and atonement.

After the articles of de Roche and Daniels, the balance on the topic has been inclined toward a complete rejection of the covenant lawsuit genre. Nevertheless, 
scholars such as Richard M. Davidson, Kenneth Kitchen and Paul J. N. Lawrence have made their case supporting the covenant lawsuit genre. While Kitchen and Lawrence have recognized the influence of the Hittite treaties on the Pentateuch, Davidson stretched the line even further indicating their influence throughout both Testaments.

Table 3 shows that in the review of the literature most scholars agree on the relation of the suzerain-vassal treaties in the ANE and the covenant lawsuit or ריב pattern in the Old Testament. They are certain that the suzerain-vassal treaty structure is not rigid, that it could vary depending on the situation and the relation involved between the parties; and despite of the lack of rigidness in its structure, the suzerain-vassal treaties have two constant elements: the gods called to be witnesses and the section of curses and blessings.

Table 3. Modern scholarship on the use of "witness" within the context of the Old Testament covenant lawsuit genre

\begin{tabular}{||l||l|}
\hline \multicolumn{1}{|c|}{ Scholars } & \multicolumn{1}{c|}{ Propositions } \\
\hline \hline Hermann Gunkel & $\begin{array}{l}\text { In Psalms and the Prophets, God is not only a judge but also a } \\
\text { witness against his people. }\end{array}$ \\
\hline G. Ernest Wright & $\begin{array}{l}\text { In Deut 32, God calls heaven and earth as witnesses to the } \\
\text { indictment, hearing the case of Yahweh against his people }\end{array}$ \\
\hline $\begin{array}{l}\text { George E. } \\
\text { Mendenhall }\end{array}$ & $\begin{array}{l}\text { Though it lacks the list of witnesses the Decalogue in Exod 20 } \\
\text { falls into the form of a Hittite treaty }\end{array}$ \\
\hline Herbert Huffmon & $\begin{array}{l}\text { In Mesopotamia, heaven and earth, the mountains, rivers, sea, } \\
\text { winds, and clouds are shown as witnesses of the covenant } \\
\text { between two countries. Parallel references to this conclusion are } \\
\text { found in Deut 4:26; 30:19, and 31:28. In these passages heaven } \\
\text { and earth could be called also as judges between God and Israel }\end{array}$ \\
\hline James Muilenburg & $\begin{array}{l}\text { In Exod 19:3-6 Israel is witness to the mighty acts of God, which } \\
\text { parallels witness in ANE treaties }\end{array}$ \\
\hline Meredith G. Kline & $\begin{array}{l}\text { The whole book of Deuteronomy exhibits a legal form which } \\
\text { parallels treaties of the second century BC in which the } \\
\text { invocation of witness is part of its structure (Deut 31-34) }\end{array}$ \\
\hline
\end{tabular}


Table 3-Continued

\begin{tabular}{|c|c|}
\hline Scholars & Propositions \\
\hline $\begin{array}{l}\text { Dennis J. } \\
\text { McCarthy }\end{array}$ & $\begin{array}{l}\text { Ancient treaties from } 2500 \text { to } 700 \mathrm{BC} \text { have two constant } \\
\text { elements: the gods called to be witnesses, and the curses and } \\
\text { blessings }\end{array}$ \\
\hline Ray F. Chester & $\begin{array}{l}\text { The Mosaic covenant is in agreement with the six traditional parts } \\
\text { of the Hittite-treaty framework }\end{array}$ \\
\hline James Limburg & $\begin{array}{l}\text { The legal forms of speech, in which the root ריב appears, are } \\
\text { connected with international treaties }\end{array}$ \\
\hline Klaus Baltzer & $\begin{array}{l}\text { Witnesses are necessary in the conclusion of a covenant, in order } \\
\text { to guarantee the stipulations of the treaties, and their blessings } \\
\text { and curses }\end{array}$ \\
\hline $\begin{array}{l}\text { Kenneth Anderson } \\
\text { Kitchen }\end{array}$ & $\begin{array}{l}\text { Covenants of the late second millennium BC use a long list of } \\
\text { gods as witnesses; in the Sinai Covenant, the gods of paganism } \\
\text { were excluded and substituted by memorial stones (Exod } 24: 4 \text { ), } \\
\text { Moses's song (Dt. 31:16-30; Dt. 32:1-47), or the law book (Deut } \\
31: 26 \text { ) }\end{array}$ \\
\hline Michael de Roche & $\begin{array}{l}\text { True lawsuit involves three parties. What happens between } \\
\text { Yahweh and Israel is bilateral }\end{array}$ \\
\hline Dwight R. Daniels & $\begin{array}{l}\text { Texts taken as covenant lawsuits are more correctly called } \\
\text { prophecies of disaster and priestly torah. Invocation of natural } \\
\text { elements as witnesses in Israel is not used before } 701 \mathrm{BC} \text {. }\end{array}$ \\
\hline Richard Davidson & $\begin{array}{l}\text { Covenant lawsuit is pervasive in Scripture. In covenant lawsuit } \\
\text { structure of Israel, the witnesses (natural elements) are often } \\
\text { placed at the beginning of the list }\end{array}$ \\
\hline $\begin{array}{l}\text { Paul J. N. } \\
\text { Lawrence }\end{array}$ & $\begin{array}{l}\text { The conventions for the content and layout of treaties remain } \\
\text { uniform throughout the Near East region until the fall of the } \\
\text { Hittite Empire, though the Hebrew lawsuit involves adaptation. } \\
\text { Pentateuchal covenants resemble the format of late Second } \\
\text { Millennium Hittite treaties in having witness section, clauses for } \\
\text { the deposit and reading of the terms of the covenant, but they are } \\
\text { different in the sequence of curses and blessings }\end{array}$ \\
\hline
\end{tabular}

\section{In the Gospel of John}

The use of "witness" in the Gospel of John has been a familiar topic in scholarship circles from long ago. ${ }^{131}$ This section is a survey of the main studies that have

${ }^{131}$ Cf. Pancaro, The Law in the Fourth Gospel, 193-231; Paul Ricoeur, Essays on Biblical Interpretation (Philadelphia, PA: Fortress, 1980), 136-42; L. de la Potterie, "The Truth in Saint John," in 
been done in this area. For the evaluation of scholars' awareness of the connection

between the Gospel of John and the Pentateuch I give some suggestions for this step, in

order to be faithful to the title of this dissertation.

\section{Théo Preiss (1952)}

Théo Preiss opened the door to study the Gospel of John with a new approach.

Aware of what was happening in his days, he called attention to an aspect that according

to him had been ignored. ${ }^{132}$ In his own word, he said,

The Interpretation of John, 2nd ed., ed. John Ashton (Edinburgh: T\&T Clark, 1997), 67-82; Victor C. Pfitzner, "The Coronation of the King: The Passion Narrative and Passion Theology in the Gospel of John," LTJ 10 (1976): 1-12; Martin Asiedu-Prepah, Johannine Sabbath Conflicts as Juridical Controversy, WUNT 132 (Tübingen: Mohr Siebeck, 2001). David Rensberger, "The Politics of John: The Trial of Jesus in the Fourth Gospel," JBL (1984): 395-411, maintains the form-critical approach that C. H. Dodd applied to the Fourth Gospel, and the claims by R. E. Brown, J. L. Martyn, W. A. Meeks, and others that in the Fourth Gospel a social milieu has been maintained in a tradition. Nevertheless, in order to inquire about the trial motif, on pp. 399, 401, Rensberger takes a different approach speaking about Jesus's trial in the Fourth Gospel from a political perspective. On pp. 410, 411 he gives a high value to the figure of Pilate who acts as a link between the Jews and Jesus: "The Fourth Gospel thus confronts the issue of Israel's freedom in the late first-century Roman Empire with an alternative to both Zealotry and collaboration, by calling for adherence to the king who is not of this world, whose servants do not fight, but remain in the world bearing witness to the truth before the rulers of both synagogue and Empire."

132 Théo Preiss, Life in Christ, 9, 10. He gave a summary of several views that had been given so far based on the Gospel of John: i.e.: Spiritual character of the Gospel of John (Clement of Alexandria); gnostic and neoplatonic speculations; orthodox theology: the key of the interpretation of John is in the Prologue with the phrase "the logos became flesh" (from Heracleon to Rudolf Steiner); metaphysical Gospel or Philonism of John (liberal criticism); Hermetic mysticism and gnosis (Bousset); Mandean gnosis (Bauer and Bultmann); mystical Jewish writings (Odeberg); literary view (Burney, Billerbeck Büchsel and Schlatter); influence "of the Hellenization of Pauline mysticism into a species of mysticism of the divine" (Schweitzer). Examples of this are also: the so called Johannine community (Raymond E. Brown, The Gospel and Epistles of John: A Concise Commentary [Collegeville, MN: Liturgical, 1988]); the religious environment (ibid., "The Qumran Scrolls and the Johannine Gospel and Epistles," in The Scrolls and the New Testament, ed. Krister Stendahl [NY: Harper, 1957], 183-207; Michael J. Taylor, ed., A Companion to John: Readings in Johannine Theology (John's Gospel and Epistles) [NY: Alba House, 1977]; E. Earle Ellis, The World of St. John: The Gospel and the Epistles [Grand Rapids, MI: Eerdmans, 1984], 17-32; Peder Borgen, Philo, John, and Paul: New Perspectives on Judaism and Early Christianity [Atlanta, GA: Scholars, 1987]; Jan Abraham du Rand, Johannine Perspectives: Introduction to the Johannine Writings [NY: Orion, 1991], 43-58; Westermann, The Gospel of John in the Light of the Old Testament, trans. Siegfried S. Schatzmann [Peabody, MA: Hendrickson, 1998]; Aage Pilgaard, "The Qumran Scrolls and John's Gospel," in New Readings in John: Literary and Theological Perspectives: Essays from the Scandinavian Conference on the Fourth Gospel in Arhus 1997, ed. J. Nissen and S. Pedersen, JSNTSup 182 [Sheffield, England: Sheffield Academic, 1999], 126-42; C. K. Barrett, "John and Judaism," in Anti- 
Yet there is one aspect of Johannine thought which, while not being divorced from the whole, seems to me to afford a more coherent system of ideas. The reason for that is doubtless its less 'mystical' character. This aspect has been strangely neglected by exegetes and still more so, if that is possible, by those who have tried to give a bird's eye view of Johannine thought: I mean the juridical aspect. It is an elementary, evident fact and so simple that I feel inclined to apologize for making of it the object of a study, that juridical terms and arguments are notably frequent in the Gospel and Epistles - the Christ who is sent, witness, judge, judgment, accuse, convince, Paraclete. Even terms of a rather mystical character, like light and truth, reveal if considered from this standpoint a very marked juridical emphasis: truth is contrasted less with error than with falsehood, and less with falsehood in general than with false witness: and Jesus is the light which judges, and sheds light, as we say, in this dark and sinister world. ${ }^{133}$

Judaism and the Fourth Gospel, ed. R. Bieringer, D. Pollefeyt, and F. Vandecasteele-Vanneville [Louisville: Westminster, 2001], 231-46; Jamie Clark-Soles, Scripture Cannot Be Broken: The Social Function of the Use of Scripture in the Fourth Gospel [Leiden: Brill, 2003]).

Others who have surveyed the probability of the influence of mysticism or Gnosticism or both, are: Christoph Ernst Luthardt, St. John's Gospel Described and Explained According to its Peculiar Character, 3 vols. (Edinburgh: T\&T Clark, 1876-1878); Henry Latimer Jackson, The Problem of the Fourth Gospel (Cambridge, England: Cambridge University Press, 1918), 83; Rudolph Bultmann, "Die Bedeutung der neuerscholssenen mandäischen un manichäischen Quellen für das Verständnis des Johannesevangeliums," ZNW 24 (1925): 102-04; ibid, Theology of the New Testament (NY: Charles Scribner's, 1955), 2:39-61; ibid., The Gospel of John: A Commentary, ed. R. W. N. Hoare and J. K. Riches, trans. G. R. Beasley-Murray ( Oxford: Basil Blackwell,1971); Howard, The Fourth Gospel in Recent Criticism and Interpretation (London: Epworth, 1931), 197-214; André Feuillet, Johannine Studies (Staten Island, NY: Alba House, 1965), 169-80; Ernest Käsemann, The Testament of Jesus: A Study of the Gospel of John in Light of Chapter 17 (Philadelphia, PA: Fortress, 1968); William J. Fulco, Maranatha: Reflections on the Mystical Theology of John the Evangelist (NY: Paulist, 1973); Larry W. Hurtado, "New Testament Christology: Retrospect and Prospect," Semeia 30 (1984): 15-27; Helmut Koester, "The Historyof-Religions School, Gnosis, and Gospel of John,” ST 40 (1986): 115-36; Siegfried Schulz, Das Evangelium nach Johannes, 5th ed., NTD 4 (Göttingen: Vandenhoeck \& Ruprecht, 1987), 10-12; Martin Hengel, The Johannine Question (Philadelphia, PA: Trinity, 1989), 8-10; Jürgen Becker, Das Evangelium nach Johannes, 3rd ed., KNT 4 (Würzbur: Echter, 1979), 1:53-55; Alister E. McGrath, The Making of Modern German Christology: 1750-1990, 2d ed. (Grand Rapids, MI: Zondervan, 1994); Alastair H. B. Logan, "John and the Gnostics: The Significance of John for the Debate about the Origin of the Johannine Literature," in The Johannine Writings, ed. Stanley E. Porter and Craig A. Evans (Sheffield, England: Sheffield Academic, 1995), 109-37; Ellis, Christ and the Future in New Testament History, NovTSup 97 (Leiden: Brill, 2000), 76.

As Preiss, some other scholars have challenged Gnosticism in relation to the Gospel of John. For example, Howard, Christianity According to St. John, 35, blamed Justin Martyr for the Greek philosophical speculation on the Gospel of John; Paul Sevier Minear, John, The Martyr's Gospel (NY: Pilgrim, 1984), x, criticized the way some Christians (otherworldly pietists, esoteric mystics, introspective Gnostics) had read the Gospel of John because of the vague and sentimental vocabulary used in it. Cf. also Edwin M.

Yamauchi, Gnostic Ethics and Mandaean Origins, HTS 24 (Cambridge: Harvard University Press, 1970); Udo Schnelle, Antidocetic Christology in the Gospel of John: An Investigation of the Place of the Fourth Gospel in the Johannine School (Minneapolis, MN: Fortress, 1992). Other examples of scholars who have viewed John as a spiritual Gospel are Wyatt Aiken Smart, The Spiritual Gospel (NY: AbingdonCokesbury, 1946); and Allen Dwight Callahan, A Love Supreme: A History of Johannine Tradition (MN: Fortress, 2005).

${ }^{133}$ Preiss, Life in Christ, 11. A survey shows that scholars of Preiss' days studied the word 
Further, he criticized those scholars who had been studying the Gospel of John making it dependent on Paul's writings. So, he suggested that this approach is no more solid "than a ghost" because John is writing in a time, at the end of the first century, when the church had a different situation that had nothing to do with that of Paul. ${ }^{134}$ Thus far, he made a short analysis of the substantive "witness" and the verb "to witness." $135 \mathrm{He}$ emphatically warned scholars who from the beginning decided between the juridical and the religious use of "witness" and its cognate verbs suggesting that these terms are "at one and the same time religious and juridical." 136

"witness," without paying proper attention to its judicial motif: Edwin A. Abbott, Johannine Vocabulary: A Comparison of the Words of the Fourth Gospel with Those of the Three (London: A. \& C. Black, 1905), 58; Alfred Ernest Garvie, The Beloved Disciple: Studies of the Fourth Gospel (London: Hodder \& Stoughton, 1922), 78-99; Joseph Estlin Carpenter, The Johannine Writing: A Study of the Apocalypse and the Fourth Gospel (Boston, MA: Houghton Mifflin, 1927), 259, 260; Robert Harvey Strachan, The Fourth Gospel, its Significance and Environment (London: SCM, 1941), 173-76; Wilbert F. Howard, Christianity According to St. John (London: Duckworth, 1943); Charles R. Erdman, The Gospel of John: An Exposition (Philadelphia, PA: Westminster, 1944); Frederick Louis Godet, Commentary on the Gospel of John, trans. Timothy Dwight from the 3rd French ed. with Pref., Introductory Suggestion, and Additional Notes (Grand Rapids, MI: Zondervan, 1955), 91-95.

Other scholars have taken into account "witness" or "trial" in John without major repercussions: John Dominic Crossan, The Gospel of Eternal Life: Reflections on the Theology of St. John (Milwaukee, WI: Bruce, 1967), 54, 74, 91; Franz Mussner. The Historical Jesus in the Gospel of St. John (NY: Herder \& Herder, 1967), 35-39; W. Robert Cook, The Theology of John (Chicago, IL: Moody, 1979), 69-75; Gary M. Burge, The Anointed Community: The Holy Spirit in the Johannine Tradition (Grand Rapids, MI:

Eerdmans, 1987), 36-38; A. R. C. Leaney, "The Johannine Paraclete and the Qumran Scrolls," in John and the Dead Sea Scrolls, ed. James H. Charlesworth (NY: Crossroad, 1990), 38; Elizabeth Harris, Prologue and Gospel: The Theology of the Fourth Evangelist (Sheffield, England: Sheffield Academic, 1994), 26-62; Lloyd D. Newell, “John's Testimony and Teachings on Truth," in The Testimony of John the Beloved: the $27^{\text {th }}$ Annual Sidney B. Sperry Symposium, ed. Sidney B. Sperry (Salt Lake City, UT: Deseret Books, 1998), 186-200; R. Alan Culpepper, "An Introduction to the Johannine Writings," in The Johannine Literature, ed. Barnabas Lindars, Ruth B. Edwards and John M. Court (Sheffield, England: Sheffield Academic, 2000), 13; Andreas J. Köstenberger, A Theology of John's Gospel and Letters: The Word, the Christ, the Son of God, BTNTS (Grand Rapids, MI: Zondervan, 2009), 436-56; Urban C. Von Wahlde, The Gospel and Letters of John (Grand Rapids, MI: Eerdmans, 2010), 432, 433; and Ellis, The World of St. John, 64-73.

\footnotetext{
${ }^{134}$ Preiss, Life in Christ, 12.

135 Ibid., 14, 15.

136 Ibid., 15.
} 


\section{James Montgomery Boice (1970)}

J. M. Boice noticed that the word "witness" in the Gospel of John had "almost nothing to do with the development of the word martys in the second century to denote one who had died for Jesus Christ." ${ }^{137}$ He said that John uses these words with two Old Testament backgrounds in mind: (1) the religious witness of the book of Isaiah and (2) the written law of God as testimony. ${ }^{138}$ Nevertheless, he claimed that one has to move beyond these concepts because in John "witness is clearly an event, not a relationship, a deed rather than a thing."139

Therefore, he suggested that "witness" or "testimony" and its cognate verb are used to speak of John's “understanding of the distinctive character of the Christian revelation" through the Scriptures, the prophets, Christ, and the Holy Spirit. ${ }^{140}$ And although the word "revelation" does not appear in John, it is associated with the witness of Jesus Christ. Consequently, Boice called the Gospel of John "the gospel of revelation," 141 in which, Jesus reveals "the Father in the fullness of grace and truth,"

\footnotetext{
${ }^{137}$ James Montgomery Boice, Witness and Revelation in the Gospel of John (Grand Rapids, MI: Zondervan, 1970), 9; see also p. 16. Cf. Boice and Philip Graham Ryken, Jesus on Trial (Wheaton: Crossway, 2002). Paul Ricoeur, Essays on Biblical Interpretation (Philadelphia, PA: Fortress, 1980), 129, recognized the difference between the witness and the accused. The life of the accused is in danger; nevertheless, the witness, willing to defend his conviction until the end, is ready to suffer and die for it. Thus, going from witness to martyr, demands a different reasoning that does not derive "from a purelyjuridical reflection." In this case, Ricoeur pointed out that the whole ministry of Jesus is a trial; but the notion of witness in the Gospel of John has both meaning (ibid., 138-40).

${ }^{138}$ Boice, Witness and Revelation, 16.

${ }^{139}$ Ibid., 19, 25.

${ }^{140}$ Ibid., 14, 15.

${ }^{141}$ Ibid., 32. Boice said that some words for "revelation" in the Gospel of John are pavepó $\omega$, "to reveal," "to make known," "to show" $(1: 31 ; 2: 11 ; 7: 4 ; 21: 1,14) ; \gamma v \omega \rho i ́ \zeta \omega$, "to make known," "to reveal" $(15: 15 ; 17: 26)$; $\delta \varepsilon i ́ \kappa v v \mu 1$, “to show” $(2: 18 ; 5: 20 ; 10: 32 ; 14: 8 ; 20: 20)$. This thesis permeates Boice’s book (ibid., 33).
} 
something that was not achieved in the Old Testament. ${ }^{142}$

\section{Johannes Beutler (1972)}

Johannes Beutler denied the connection in the Gospel of John between the word "witness" and the Old Testament lawsuit. Instead he believed that John is unique and original in the creation of this formulation. ${ }^{143}$ Furthermore, he asserted that the Gospel of John has to be understood from the perspective of the history of Jewish people, such as Philo, Josephus, Qumran documents and Jewish apocalyptic literature, not from GrecoRoman antiquity. ${ }^{144}$

\section{Anthony E. Harvey (1976)}

Anthony E. Harvey showed the Gospel of John as a form of legal proceedings or a dispute between Jesus and the Jews "in such a way that the reader is persuaded of the justice of Jesus' cause."145 Accordingly, he said that many of Jesus's discourses against the Jews are presented in a circular way where each disputant shows his argument back and forth until his opponent has nothing more to say. ${ }^{146}$ "In this sense, then, it is possible to understand the Fourth Gospel as a presentation of the claims of Jesus in the form of an

142 Ibid., 34. For Boice the Old Testament Scriptures are partial and not dispensable since they point to Jesus (ibid., 35).

${ }^{143}$ Beutler, Martyria, 42.

${ }^{144}$ Ibid., "In Search of a New Synthesis," in What We Have Heard from the Beginning: The Past, Present, and Future of Johannine Studies, ed. Tom Thatcher (Waco, TX: Baylor University Press, 2007), 27, 29.

145 A. E. Harvey, Jesus on Trial, 14, 15.

${ }^{146}$ Ibid., 16. 
extended 'trial." " 147 Thus, as a literary device, John exposes in his Gospel the righteous case of Jesus "against his adversaries before an imaginary court" which is challenged to reach its own verdict. ${ }^{148}$ Precisely, based on that extended trial, A. E. Harvey structured his book: "The Case of Jesus Christ," "The Witnesses in the Case," "The Procedure," "The Charges," "The Defense," "The Verdict," and a postscript: "The Record of the Proceedings."

In the chapter "The Witnesses in the Case," A. E. Harvey shows three witnesses—-John the Baptist, Nathanael, and Peter—who claim that Jesus is the Son of God. ${ }^{149}$ He explains further that Jesus could not bring any of these witnesses in his defense because either they are not present or as his followers they would have been disqualified anyway. ${ }^{150}$ Even if Jesus could bring the Paraclete's witness his testimony would not be accepted (John 14:17). ${ }^{151}$ In the end, "it is still the reader or the hearer who has to make up his mind whether Jesus is the Messiah, the Son of God." ${ }^{152}$

A. E. Harvey stressed three points that make Jewish legal procedure in the Old Testament different from western trial procedure: (1) it was not necessary "to appear before a formally constituted court" for a trial; ${ }^{153}$ (2) witnesses could function also as

${ }^{147}$ Ibid., 17.

${ }^{148}$ Ibid.

${ }^{149}$ Ibid., 18-45.

${ }^{150}$ Ibid., 92. He also revealed that Jesus's witnesses commanded no respect in a Jewish court. Furthermore, those who were accusing Jesus are characterized as Pharisees, thus they were not willing to pay attention to anybody who was not a Pharisee (ibid., 93).

${ }^{151}$ Ibid., 121.

${ }^{152}$ Ibid.

${ }^{153}$ Ibid., 46; cf. Amos 5:15; Deut 17:8-13; 19:12; 21:18-21; 22:18, 19; 25:7-9; Ruth 4:1-12. A. E. 
judges; ${ }^{154}$ and (3) many cases had only one witness involved, and in order to supply the lack of a second witness the claimant was asked to support his claim with an oath; thus, God was called to be witness for this matter. ${ }^{155}$

In the relation to the Gospel of John with the covenant lawsuit, A. E. Harvey said, "We have identified a literary form which may well have influenced the fourth evangelist's presentation of some of the episodes in the life of Jesus and of the dialogues associated with them: that of the law-suit, or ribh."156 And, in order to defend the historicity of John's Gospel, he added, "The literary form of the ribh may well have influenced the composition of the Gospel. But it does not follow from this that the episodes it comprises are altogether unhistorical, either in outline or in detail." $" 157$ Connected with this idea, at the beginning of his book, he established,

This tendency to present an issue under the literary form of a trial or dispute (a ribh) must be borne in mind when we come to consider how far the disputes recorded in John's Gospel are intended to be understood as records of actual legal

Harvey's statement stands in opposition to de Roche's position. Of course, since de Roche wrote after A. E. Harvey, de Roche is the one who challenges Harvey's argument. A. E. Harvey continued pressing this point saying that "the boundary between informal controversy and litigation was often hard to draw" (ibid., $55)$.

${ }^{154}$ Ibid., 46, 47. A. E. Harvey also observed that Jewish courts were not concerned with facts but with the reputable life of the witnesses involved in the trial. Therefore, the more respectable witnesses would win the case. Ricoeur, Essays, 127, 128, was surprised at the little credit Aristotle gave to testimony: For witnesses "are in fact at first poets or illustrious men whose judgments are publicly recognized, speakers of oracles, and authors of proverbs."

155 A. E. Harvey, Jesus on Trial, 48. He gave the example of somebody who claimed that he was the inheritor of a piece of ground, but he could not produce any witnesses in his favor because they had perished in a war. Although this example did not alter Jewish procedure, it is not clear the reason to confuse the function of a claimant with a witness, since he could not be both at the same time. Cf. m. Ketub. 2.

156 A. E. Harvey, Jesus on Trial, 12. Martin Asiedu-Prepah, Johannine Sabbath Conflicts as Juridical Controversy, WUNT 132 (Tübingen: Mohr Siebeck, 2001), 2, 9, believed that in the Sabbathcontroversy perspective between Jesus and the religious leaders, there is not a $r \hat{\imath} b$-pattern in the Gospel of John, but rather a two-party judicial controversy. Because of that the notion of "the Johannine juridical metaphor as a forensic process is fraught with many difficulties and inconsistencies."

${ }^{157}$ A. E.Harvey, Jesus on Trial, 127. 
proceeding, or how far they are rather literary elaborations of issues which were known to be in dispute between Jesus and the Jews (that of healing on the Sabbath, for instance). ${ }^{158}$

A. E. Harvey believed that the judgment is still open on the proposition that Jesus is the Christ, the Son of God, and each reader is called to weigh every argument and make a decision. ${ }^{159}$

\section{Allison A. Trites (1977)}

Allison A. Trites surveyed the Greek word $\mu \alpha \rho^{\prime} \tau v \varsigma$ and its cognates in secular Greek literature, Jewish literature, and the Old and New Testaments. ${ }^{160}$ As this book is concerned with the witness terminology he wrote abundantly concerning the words $\mu \alpha \rho \tau v \rho i ́ \alpha$ and $\mu \alpha \rho \tau \nu \rho \varepsilon ́ \omega$ and recognized their legal connotation throughout the Bible. He included two special features in his book: (1) The connection between the Gospel of John and Isa 40-55, ${ }^{161}$ and (2) His avoidance of using the phrase "covenant lawsuit." Instead he was eager to use a variety of related terms. ${ }^{162}$

${ }^{158}$ Ibid., 16.

${ }^{159}$ Ibid., 131. For a review of Harvey's thesis cf. R. Alan Culpepper, review of A. E. Harvey, Jesus on Trial: A Study in the Fourth Gospel, RevExp 76 (1979): 114-16.

160 Trites, The New Testament Concept of Witness, 1-239.

${ }^{161}$ Ibid., 23, 35-47, 78-127.

162 These terms are: lawcourt scenes (p. 23), Old Testament lawsuit (p. 23), lawcourt language (pp. 33, 89), language of the lawsuit (p. 35), trial scene (pp. 35, 40), controversy speech (ibid.), imagery of the lawcourt or lawcourt imagery (pp. 35, 39, 44), legal terminology or legal words (pp. 35, 52), lawcourt speech (p. 35, 82), Hebrew lawcourt (pp. 35, 39), juridical speech (p. 37), lawcourt (p. 41), legal process (p. 43), legal case (ibid.), lawsuit or great controversy/cosmic lawsuit (pp. 43, 44, 45, 46, 79, 84, 86, 90), controversy theme or pattern/controversy language or Old Testament controversy (pp. 53, 54, 71, 82, 88, 89), courtroom procedure (p. 57), juridical metaphor (p. 78), and juridical debate (p. 79). Though anybody could say that Trites is creatively using synonyms, his avoidance of the term "covenant lawsuit" is remarkable. Of course, this term has been related to the Old Testament and Trites' book is about the New Testament concept of witness; however he knows that "the controversy language" is used in the DSS "when Yahweh is said to have a rîb with all flesh" (p. 54). 


\title{
Robert Gordon Maccini (1996)
}

Under the complement of the historical-critical and narrative-critical methods,

\section{Robert Gordon Maccini developed his thesis of women as witnesses in the Gospel of}

John. ${ }^{163}$ He believed that the Gospel of John uses formal rhetoric, not in the technical

sense as it is known today, but in a wider sense in order to promote persuasion. ${ }^{164}$

Maccini repeated Trites' statement that the Gospel of John "conforms to the principle that

everything must be confirmed by the testimony of two or three witnesses." 165 In this

\begin{abstract}
${ }^{163}$ Robert Gordon Maccini, Her Testimony is True: Women as Witnesses According to John (Sheffield, England: Sheffield Academic, 1996).

${ }^{164}$ Ibid., 24. George Alexander Kennedy, Classical Rhetoric \& Its Christian and Secular Tradition from Ancient to Modern Times, $2 \mathrm{~d}$ ed., rev. and enl. (Chapel Hill: University of North Carolina Press, 1999), 20- 22, explains that a technical rhetoric evolved from "the needs of democracy in Greece," from about the fifth century BC in which any male citizen wanted to speak by himself before a public with four or more organized parts (such as introduction, narration, witnesses, evidence, and probabilities), constructed to refute or recapitulate an argument in order "to win the audience's good will." On ibid., 23, Kennedy concludes that "most oratory deals with matters of probability, not certainty, and most evidence is in the realm of the probable, not the scientifically demonstrable." Then on p. 127, he adds that Christian preaching is "not persuasion, but proclamation." Related to that point, D. E. Aune, Early New Testament in its Literary Environment (Philadelphia, PA: Westminster, 1987), 66, 67, argues that the Gospel is "revelation, not persuasion." Though Kennedy and Aune disagree on whether the Gospel is proclamation or revelation, at least they agree that the Gospel is not persuasion.

See also, Kennedy, New Testament Interpretation through Rhetorical Criticism (Chapel Hill: University of North Carolina Press, 1984); Thomas H. Olbricht, Dennis L. Stamps, and Stanley E. Porter, Rhetorical Criticism and the Bible, JSNTSup (London: Sheffield Academic, 2002); J. David Hester Amador, Academic Constraints in Rhetorical Criticism of the New Testament: An Introduction to a Rhetoric of Power, JSNTSup (Sheffield, England: Sheffield Academic, 1999); A. N. Wilder, Early Christian Rhetoric (Cambridge, MA: Harvard University Press, 1971); J. R. Levison, "Did the Spirit Inspire Rhetoric?: An Exploration of George Kennedy's Definition of Early Christian Rhetoric," in Persuasive Artistry: Studies in New Testament Rhetoric in Honor of George A. Kennedy, ed. Duane F. Watson; JSOTSup 50 (Sheffield, England: JSOT, 1991), 25-40.

Maccini, Her Testimony, 24, 25, explains what Levison suggested in his article: "John may have used rhetorical styles and devices unconsciously and instinctively, especially under divine inspiration" and this "Spirit-inspired rhetoric" such as in Wisdom, Sirach and Susanna "equips a person to be intelligent in thought and, consequently, persuasive in speech." Also he says that John was not schooled in rhetoric but a person who lived surrounded by it. So John, like a lawyer, selects "the most compelling pieces of evidence for a summation to a jury" (ibid., 26).
\end{abstract}

165 Trites, The New Testament, 121 in Maccini, Her Testimony, 61. 
aspect, he also followed Harvey, saying that "from start to finish John seeks to persuade the reader that the messiah is Jesus." 166

The main problem is that, according to Harvey, "a woman's testimony was unacceptable in Jewish courts."167 Therefore, Maccini tried to respond to that argument saying that "the Pentateuch records no instances of women giving legal testimony, neither does it record any explicit prohibition of such."168 Thus, he concluded that “women's testimony was prohibited not de jure but de facto." ${ }^{\prime 69}$ He explained Deut 21:18-21 and 22:13-21 where the testimony of father and mother before the elders at the town gate was required. ${ }^{170}$ But in the Second Temple period this issue was debated in the rabbinic literature in which some rabbis supported women's testimony and others were against. ${ }^{171}$ In this case, Maccini clarified that women's testimony was overwhelmingly excluded; but it was not a monolithic opinion. ${ }^{172}$

Because of the different opinions on this matter, Maccini proposed that women's testimony was denied progressively from exemption to exclusion and with the desire of "releasing women from some legal obligations." ${ }^{173}$ After this, he stated,

166 Ibid., 242.

${ }^{167}$ A. E. Harvey, Jesus on Trial, 45 in Maccini, Her Testimony, 62.

${ }^{168}$ Ibid., 65.

${ }^{169}$ Ibid. (Emphasis are in the original). That would mean that women's testimony was not legally prohibited but instead prohibited by traditional practice.

${ }^{170}$ Ibid., 66.

${ }^{171}$ Examples of this are $m . \check{S} e b u .4: 1$ (against); Sifre Deut. 90 (favorable) in Maccini, Her Testimony, 67.

172 Ibid.

${ }^{173}$ Ibid., 83. 
Jewish women (1) were proscribed in most but not all instances from giving testimony in forensic contexts; (2) were competent to swear religious vows and oaths; (3) gave testimony in non-forensic contexts that was received sometimes positively, sometimes negatively, depending upon the circumstances; (4) were, under the influence of the Holy Spirit (or demonic spirits), widely recognized and accepted as prophets; (5) were viewed by some people as whimsical and deceitful by nature, and by others as stable and sincere. ${ }^{174}$

Maccini tried to solve this problem stating that, in the Gospel of John, women are presented "as individuals not as a class." 175 Therefore, characters, in the Gospel of John, are individuals testifying about Jesus's Messiahship. "If there is a pattern" in the Gospel of John it is that "there is no pattern, only individuals responding as such to Jesus." 176 The Gospel of John is not trying to present women in a positive way but rather to present those individuals who testify in favor of Jesus, "regardless of their gender."177

\section{Andrew T. Lincoln (2000)}

Andrew T. Lincoln, aware of each of the former studies about the trial motif in the Gospel of John, ${ }^{178}$ argued that these studies have been "done mostly in isolation from each other." ${ }^{179}$ Thus, he tried to integrate them all in his new study, in which he claimed that an area has been neglected by scholars; that is, "to produce a more wide-ranging exploration" employing "a variety of perspectives." 180 In order to employ this variety of

\footnotetext{
${ }^{174}$ Ibid., 97.

${ }^{175}$ Ibid., 243.

${ }^{176}$ Ibid., 244.

${ }^{177}$ Ibid., 244, 245.

${ }^{178}$ Lincoln, Truth on Trial, 4-6, 11.

${ }^{179}$ Ibid., 6.

${ }^{180}$ Ibid., 7. On this same page, Lincoln describes it in this way: "Although literary approaches to the Bible have moved beyond narrative and reader-response criticisms to poststructuralist, deconstructive,
} 
perspectives he mentioned some passages from the Pentateuch and from many other

books, but not as the main source of his study. ${ }^{181}$ Instead he arrived at Trites' conclusion, asserting that the trial motif of the Gospel of John is based on Isa 40-55. ${ }^{182}$ As a result, his main statement says:

But it is Isa 40-55 in particular that provides the resources for the Fourth Gospel's narrative. In it the lawsuit motif is especially dominant and colors much of the prophecy. It is widely agreed that Isa 42:18-25, 43:22-28, and 50:1-3 take the form of a lawsuit between Yahweh and Israel and, in an extension of the motif, Isa 41:1-5, 41:21-29, 43:8-13, 44:6-8, and 45:18-25 are in the form of a trial speech of Yahweh against the nations. In other places there are disputations (e.g., 40:12-31; 44:24-28; 45:9-13; 46:5-11; 48:1-15; 49:14-26; 55:8-13), and both within the trial passages and elsewhere in $40-55$, there are frequent references to judgment and witness. ${ }^{183}$

On these passages, Lincoln observed the basic elements of the ancient lawsuits such as "an introductory setting of the trial scene" with the calling of witnesses, accusation, the reminder of Yahweh's gracious deeds, a chance for a defense, and a verdict. He knew that "for various purposes, some of the elements might be omitted in any particular occurrence of the device." 184

and ideological criticisms, the resources of these earlier approaches, which I shall be primarily employing, for illumination of the text have not yet been exhausted."

${ }^{181}$ Ibid., 37, 51-54, 232, 233.

182 Ibid., 38-51, 107, 122, 123, 137, 138, 147, 148, 190, 196, 207, 214, 222, 256, 328, 447, 452. Cf. Alan S. Bandy, "Word and Witness: An Analysis of the Lawsuit Motif in Revelation Based on the Witness Terminology," 13-16; available from http//www.phc.edu/journalfiles/bandy; Internet; accessed 29 May 2013. At the time Bandy wrote this paper he was a Ph.D. candidate in New Testament Studies at Southeastern Baptist Theological Seminary. Though his major thesis was based on the lawsuit motif in the book of Revelation, he recognized that this motif runs throughout the NT, especially in the Johannine Literature.

${ }^{183}$ Lincoln, Truth on Trial, 38, 39. Boice, Witness and Revelation, 16, argued, "The themes which John develops and which he recasts on the basis of the new and determinative revelation which has come in Jesus Christ are already suggested in the pages of the Old Testament, especially in the religious witness of Isaiah.”

${ }^{184}$ Lincoln, Truth on Trial, 39. 
In order to establish the connection between the Gospel of John and Isa 40-55 he used "mainly narrative critical and reader-response approaches and exploring the interplay between this text and previous texts of Scripture." 185 He also noticed the frequency that certain words are used in the Gospel of John, such as witness or testimony (14 times), to judge (19 times), judgment (11 times), truth (25 times), true (25 times), ${ }^{186}$ and truly (seven times). ${ }^{187}$

\section{Summary}

From Théo Preiss to the present, scholars agree on the use of judicial language in the Gospel of John. ${ }^{188}$ This feature has been linked to Isa 40-55 and to the written law, but not to the Pentateuch as a whole, and especially to its legal setting. Thus, this is an opportunity to research the intertextual relation between the Pentateuch and the Gospel of

185 Ibid., 8. For the narrative critical approach, see Pheme Perkins, "Crisis in Jerusalem: Narrative Criticism in New Testament Studies," TS 50 (1989): 296-313; Mark Allan Powell, What is Narrative Criticism? (MN: Fortress, 1990); Cornelis P. Venema, "Theology and Narrative: A Critical Introduction," MAJTh 9 (1993): 149-53; Gail R. O’Day, “Toward a Narrative-Critical Study of John,” Int 49 (1995): 34146; James L. Resseguie, Narrative Criticism of the New Testament: An Introduction (Grand Rapids, MI: Baker, 2005); Karl Allen Kuhn, The Heart of Biblical Narrative: Rediscovering Biblical Appeal to the Emotions (MN: Fortress, 2009); Joan E. Taylor and Federico Adinolfi, "John the Baptist and Jesus the Baptist: A Narrative Critical Approach,” JSHJ 10 (2012): 247-84.

For Reader-Response Criticism, see Robert M. Fowler, "Who is 'the Reader' in Reader Response Criticism," Semeia 31 (1985): 5-23; Shawn Kelley, "Let the Reader Understand: A Response," Proc 13 (1993): 241-53; Edgar V. McKnight, Postmodern Use of the Bible: The Emergence of Reader-Oriented Criticism (Nashville: Abingdon, 1988); Michael Cahill, "Reader-Response Criticism and the Allegorizing Reader," TS 57 (1996): 89-96; John C. Poirier, "Some Detracting Considerations for Reader-Response Theory," CBQ 62 (2000): 250-63; Mark A. Pike, "The Bible and the Reader's Response," JECB 7 (2003): 37-57.

${ }^{186}$ Here there is a compilation of $\dot{\alpha} \lambda \eta \theta \eta \dot{\varsigma}$ (14 times) and $\dot{\alpha} \lambda \eta \theta$ vó́ (nine times).

${ }^{187}$ Lincoln, Truth on Trial, 12, 13. He compares those words in the Gospel of John with the Synoptics.

${ }^{188}$ As I have shown on p. 85, Beutler was not discussing the issue of whether the covenant lawsuit in the New Testament shall be accepted but rather John's connection with this genre. 
John. Table 4 is a summary of modern scholars about the legal language in the Gospel of John.

Table 4. Modern scholarship on the use of "witness" in the Gospel of John

\begin{tabular}{|l|l|}
\hline \multicolumn{1}{|c|}{ Scholars } & \multicolumn{1}{c|}{ Propositions } \\
\hline Théo Preiss & $\begin{array}{l}\text { Warned scholarship about the judicial language in the } \\
\text { Gospel of John }\end{array}$ \\
\hline James Montgomery Boice & $\begin{array}{l}\text { Linked the Gospel of John to the book of Isaiah and the } \\
\text { written law of God }\end{array}$ \\
\hline Johannes Beutler & $\begin{array}{l}\text { John is original in the creation of the "witness" } \\
\text { formulation }\end{array}$ \\
\hline Anthony Harvey & The ריב pattern has influenced the Gospel of John \\
\hline Allison A. Trites & The Gospel of John is connected to Isa 40-55 \\
\hline Robert Gordon Maccini & $\begin{array}{l}\text { The Gospel of John has no pattern, but individuals } \\
\text { (women) responding in favor of Jesus's Messiahship } \\
\text { The trial motif of the Gospel of John is based on Isa 40-55 }\end{array}$ \\
\hline Andrew T. Lincoln &
\end{tabular}

The legal language in the Gospel of John is based on a judgment which is achieved by the grace and truth of Jesus Christ (Boice); and as Harvey advocated, the Gospel of John is an extended trial in which the reader is called to participate and gives his verdict about the Messiahship of Jesus Christ. Maccini also recognized the principle of confirmation of a testimony given by at least two witnesses, so he took advantage of this regulation and proposed the importance of women as witnesses. And without going into the problems of regulations that were in vogue in New Testament times I concur with Maccini that in the Gospel of John, individuals are important not class or gender.

Trites, on his part, agreed that the Gospel of John has a judicial language but places as secondary the connection of this language with the Pentateuch's principles of judgment and trial. More recently, Lincoln has expanded Trites' connection of the Gospel of John with Isa 40-55. 
Though these New Testament scholars did not connect the "witness" language of the Gospel of John with the Pentateuch, at least they recognized the presence of a trial motif. Therefore, this acceptance could make the connection easier than to try to discover it in a vacuum.

Our survey makes clear that scholars build the connection between the Prophets and the Gospel of John in respect to the witness motif, and that the Pentateuchal winess language is overlooked. Considering the connection that scholars, especially Trites and Lincoln, have made between the Gospel of John and Isa 40-55, the following chapters are organized to demonstrate that the Pentateuch is additional and even stronger source in the Gospel of John. In order to establish that link, each passage of the Pentateuch, related to the witness language, is studied, and the result is analysed to provide the background to the Gospel of John on the basis of intertextual principles. 


\section{CHAPTER 3}

\section{“WITNESS” AND “BEARING WITNESS” IN THE PENTATEUCH}

In this chapter I examine, on an exegetical basis, the main elements of the word witness and its cognates in the Pentateuch. In order to avoid repetition (because sometimes these words interact within themselves in the same passage) I divide this chapter into the three categories of meanings that the word עִ and its cognates appear:

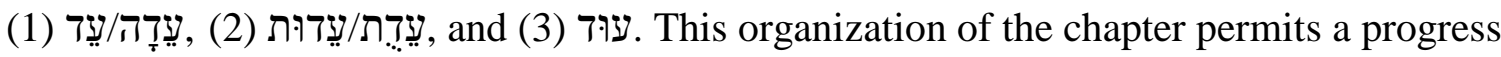
within the same category of meaning. This chapter lays the groundwork for analyzing the relationship between the witness terminology in the Pentateuch and John's Gospel.

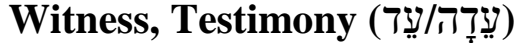

\section{Abraham and Abimelech (Gen 21:30)}

The word עִדָדה appears for the first time in the Hebrew Bible in Gen 21:30 when Abraham takes sheep and gives them to Abimelech, a Philistine king, as a "witness" or "evidence"1 that he had dug a well which Abimelech's servants had seized (Gen 21:25-

\footnotetext{
${ }^{1}$ John I. Durham, Exodus, WBC 3 (Nashville: Thomas Nelson, 1987), 296. Cf. Yofre, TDOT 10:506; McCarthy, “Three Covenants in Genesis," 185-87. ShaDal (S. D. Luzzatto), The Book of Genesis: A Commentary (Northvale, NJ: Jason Aronson, 1998), 199, translates it as "remembrance."
} 
32a) from Abraham's servant. Accordingly, they make a covenant in order to stop a dispute that is unknown by the latter but has angered Abraham. ${ }^{2}$

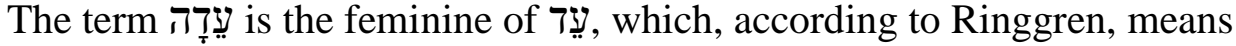
"attestation, female witness." ${ }^{3}$ In Gen 21:30 it could be taken as corresponding to "ewe

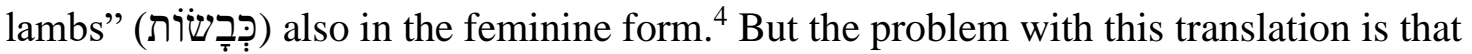
the syntax of the verse places the word עָדָדה more in agreement with Abimelech than with

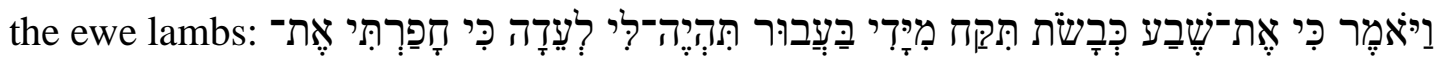

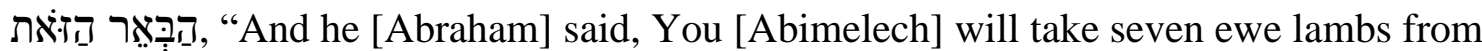
my hand in order that you [Abimelech] become to me for a witness that I have dug this well." Also, it is probable that עִדָדה could be translated better as "testimony" rather than “witness;" because Abimelech was not present when Abraham's servants dug the well (v. 26)..$^{5}$

${ }^{2}$ See Nahum M. Sarna, Genesis, JPSTC (Philadelphia, PA: JPS, 1989), 148; Gerhard von Rad, Genesis: A Commentary, OTL (Philadelphia: Westminster, 1972), 236-37; E. A. Speiser, Genesis, AB 1 (Garden City, NY: Doubleday, 1987), 160; and Hamilton, The Book of Genesis, 87-93.

${ }^{3}$ Ringgren, TDOT 10: 497.

${ }^{4}$ Cf. Kenneth A. Mathews, Genesis 11:27-50:26, NAC 1B: An Exegetical and Theological Exposition of Holy Scripture (Nashville, TN: Broadman \& Holman, 2005), 280, 281. Other documents about testimony and witness in the Hebrew Bible are: Z. W. Falk, "Forms of Testimony," VT 11 (1961): 88-91; Fisher, BDT 555-56; Charles M. Swezey, “Thou Shalt Not Bear False Witness Against Thy Neighbor," Int 34 (1980): 405-10; Walter Brueggemann, Theology of the Old Testament: Testimony, Dispute, Advocacy (Minneapolis, MN: Fortress, 1997); Minoru Hara, “Divine Witness," JIPh 37 (2009): 253-72; Giovanna Raengo Czander, "You Are My Witnesses: A Theological Approach to the Laws of Testimony" (Ph.D. diss. Fordham University, 2009); Bokovoy, "שמעו בבית והעידו יעקב: Invoking the Council as Witnesses," 37-51.

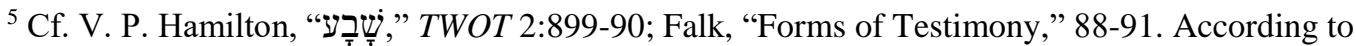
McCarthy, "Three Covenants in Genesis," 183, Abraham gave these lambs to Abimelech as a "gift" following the then current international diplomacy in order to cement a pact of friendship. 
While the MT connects Abimelech with the witness or testimony of Gen 21:30, the LXX links Abimelech with the ewe lambs. ${ }^{6}$ The difficulty to translate this verse is reflected in English versions, which assign עִבְדה to Abimelech or to the ewe lambs. ${ }^{7}$

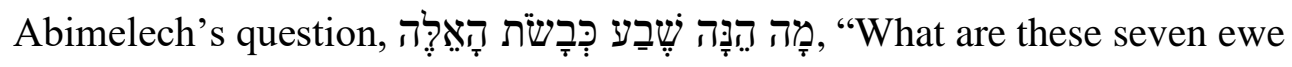

lambs?" (v. 29), implies his surprise by what he sees. ${ }^{8}$ McCarthy explains this event saying that "in simpler societies" like this one of Abraham and Abimelech, "it is the superior who binds people to him by gifts." ${ }^{\circ}$ Though Abimelech has come to submit Abraham under his pretentions (v. 23); nevertheless, as the story unfolds it looks like Abimelech is the weaker party, and as such, he has to submit to Abraham's

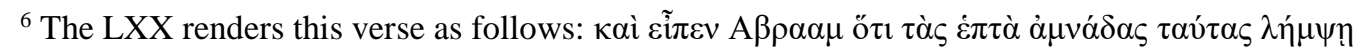

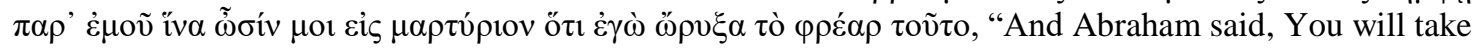
these seven lambs from me that they may be for a testimony that I dug this well."

${ }^{7}$ Abimelech as witness: "Abraham answered, The seven ewe lambs you shall accept from me that thus I may have your acknowledgment that the well was dug by me" (NAB); "He said, These seven ewe lambs you shall accept from my hand, in order that you may be a witness for me that I dug this well" (NRS); "He said, These seven ewe lambs you will take from my hand, that you may be a witness for me that I dug this well" (RSV).

Ewe lambs as witness: "He answered, You are to accept these seven female lambs from me as witness that I dug this well" (CJB); "He said, These seven ewe lambs you will take from my hand, that this may be a witness for me that I dug this well" (ESV); "And he said: Verily, these seven ewe-lambs shalt thou take of my hand, that it may be a witness unto me, that I have digged this well" (JPS); "And he said, For these seven ewe lambs shalt thou take of my hand, that they may be a witness unto me, that I have digged this well" (KJV); "And he said, You shall take these seven ewe lambs from my hand in order that it may be a witness to me, that I dug this well" (NAS); "He said, You shall take these seven ewe lambs from my hand so that it may be a witness to me, that I dug this well" (NAU); "He replied, Accept these seven lambs from my hand as a witness that I dug this well" (NIV); "He replied, You must accept these seven lambs from me as evidence that I have dug this well" (NJB); "And he said, You will take these seven ewe lambs from my hand, that they may be my witness that I have dug this well" (NKJ); "He replied, You are to accept these seven ewes from me as proof that I dug this well" (TNK).

${ }^{8}$ See this dissertation on pp. 24-26 about a vassal treaty of the mid-8th century where Ashurnirari $\mathrm{V}$ of Assyria cuts a lamb in order to illustrate what would happen if Mati'ilu of Arpad breaks the treaty. But this is not the case in the treaty between Abraham and Abimelech.

${ }^{9}$ McCarthy, "Three Covenants in Genesis," 183. 
requirement. ${ }^{10}$ Thus, it is not a surprise in this treaty that Abraham rebukes (הזֹכִח)

Abimelech and places before him an accusation (Gen 21:25). ${ }^{11}$

Another key word in this narrative is

used in two ways: (1) between human beings: Abraham and the Amorites (Gen 14:13);

Jacob and Laban (Gen 31:44); and (2) Between God and humans: with Noah (Gen 9:9-

17); with Abram (Gen 15:18); with Israel at Sinai (Gen 19:5); and the Ten

Commandments, referred as "tablets of the covenant" given to Israel (Deut 9:9, 11, 15),

and placed in the Ark of the Covenant (Num 10:33). With respect to Gen 21:27, 32, the

word רִִִּ is used in a relation of human beings, where a condition of peace is binding on

the two parties.

The word רִִִִּּ appears in the Flood narrative eight times in all in the second

sense (Gen 6-9). ${ }^{12}$ Here, the covenant is kept unilaterally by God, based on preserving

${ }^{10}$ The verb יכח in hiphil is used to make a judgment or a decision upon an accusation (Gen 31:37); wen Jacob assures that God has rebuked or given judgment against Laban (Gen 31:42); God will make decision in judgment (Isa 2:4); Job argue his case with God (Job 13:3). See also Job 19:5; 2 Kgs 19:4; Isa 11:3; Ezek 3:26.

${ }^{11}$ Josef Scharbert, “אָּזָ," TDOT 1:263.

${ }^{12}$ Gen 6:18; 9:9, 11, 12, 13, 15, 16, 17. Cf. Walter A. Elwell and Philip W. Comfort, "Covenant," $T B D$ 324. Other sources about "covenant" are: John L. McKenzie, "The Divine Sonship of Israel and the Covenant," CBQ 8 (1946): 320-31; Mendenhall, "Covenant," IDB 1:714-23; ibid., "Covenant Forms in Israelite Tradition," 50-76; ibid., "Puppy and Lettuce in Northwest-Semitic Covenant Making," BASOR 133 (1954): 26-30; ibid., Law and Covenant in Israel and the Ancient Near East (Pittsburgh, PA: Biblical Colloquium, 1955); Albright, "The Hebrew Expression for 'Making a Covenant' in the Pre-Israelite Documents," BASOR 121 (1951): 21-22; John Murray, The Covenant of Grace: A Biblico-Theological Study (London: Tyndale, 1956); Geo Widengren, "King and Covenant," JSS 2 (1957): 1-32; William L. Holladay, The Root Sûbh in the OT with Particular Reference to its Usages in Covenant Contexts (Leiden: Brill, 1958); L. A. Snijders, "Gen 15: The Covenant with Abram," OtSt 12 (1958): 261-79; Basil Minchin, Covenant and Sacrifice (London: Longmans, 1958); Kline, "Two Tablets of the Covenant," 133-46; ibid., "Dynastic Covenant," 1-15; Fensham, "The Possibility of the Presence of Casuistic Legal Material at the Making of the Covenant at Sinai," PEQ 93 (1961): 143-46; John P. Milton, God's Covenant of Blessing (Rock Island, IL: Augustana, 1961); Murray L. Newman, The People of the Covenant (Nashville, TN: Abingdon, 1962); Charles Francis Whitley, "Covenant and Commandment in Israel," JNES 22 (1963): 3748; Tucker, "Covenant Forms and Contract Forms," 487-503; John F. Priest, "The Covenant of Brothers," 
life on the earth. God gives a promise to Noah without asking him for obedience or willingness to participate. This is the reason God says four times, "My covenant" (Gen $6: 18 ; 9: 9,11,15)$. Though the covenant is between God and Noah, the initiative belongs to God. ${ }^{13}$ It also shows a divine judgment which starts with God who sees that the wickedness of man is increasing (Gen 6:1-5); so he is sorry and grieved (v. 6). Therefore, he proclaims the total destruction of what he has created (v. 7). ${ }^{14}$

JBL 84 (1965): 400-6; McCarthy, "Three Covenants in Genesis," 179-89; ibid., "Covenant in the Old Testament," 217-40; ibid., Old Testament Covenant: A Survey of Current Opinions (Oxford: Blackwell, 1972); ibid., Treaty and Covenant; L. Alonso-Schökel, "Sapiential and Covenant Themes in Gen 2-3," TD 13 (1965): 3-10; R. E. Clements, "Prophecy and Covenant," in SBT, ed. C. F. D. Moule (London: SCM, 1965), 27-34; Gerstenberger, "Covenant and Commandment," 38-51; W. Eischrodt, "Covenant and Law," Int 20 (1966): 302-21; Chester, “Covenant Types," 285-89; Delbert R. Hillers, Covenant: The History of a Biblical Idea (Baltimore, MD: Johns Hopkins University Press, 1969); ibid., "Covenant," in ER, ed. Mircea Eliade (NY: Macmillan, 1987), 4:133-37; C. L. Rogers, "The Covenant with Abraham and Its Historical Setting," BSac 127 (1970): 241-56; Petersen, "Covenant Ritual," 7-18; Robert Alan Hammer, "The New Covenant of Moses," Judaism 27 (1978): 345-50; Paul Kalluveettil, Declaration and Covenant, AnBib 88 (Rome: Biblical Institute, 1982); T. D. Alexander, "Gen 22 and the Covenant of Circumcision," JSOT 25 (1983): 17-22; William J. Dumbrell, Covenant and Creation: A Theology of Old Testament Covenants (Nashville, TN: Thomas Nelson, 1984); Alan F. Segal, "Covenant in Rabbinic Writings," SR 14 (1985): 5362; Arvid S. Kapelrud, “The Covenant as Agreement," SJOT 1 (1988): 30-38; Rendtorff, “ 'Covenant' as a Structuring Concept in Genesis and Exodus," 385-93; ibid., The Covenant Formula; Olyan, "Honor, Shame, and Covenant Relations," 201-18; Michael Horong, Introducing Covenant Theology, Grand Rapids, MI: Baker, 2006); Peter John Gentry, “The Covenant at Sinai,” SBJT 12 (2008): 38-63.

13 The inclusion in the participation of the covenant is expanded and displaced throughout the narrative, going from "you” singular to "you" plural and to "all flesh:" "[ֶ "[I will establish]

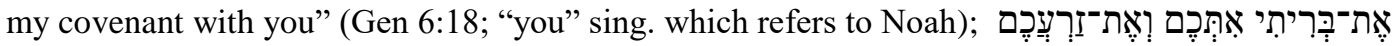
"אַחְרֵיכֶם : "I establish] my covenant with you, and with your descendants after you, and with every living creature that is with you” (Gen 9:9, 10; “you” pl. which refers to Noah and his sons); אֶֶת: "[I establish] my covenant with you" (Gen 9:11; “you” pl. which refers again to Noah and his sons);

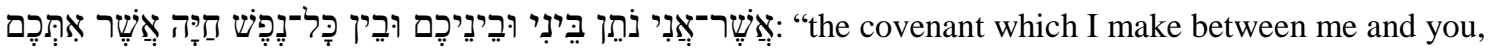

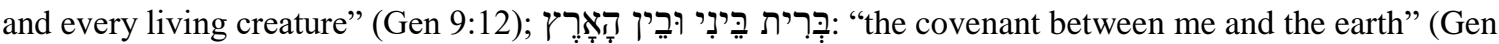

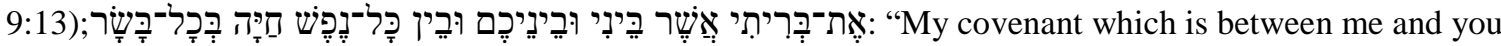

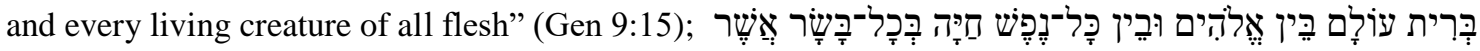
: עַל־הָארָץ : "the everlasting covenant between God and every living creature of all flesh that is on the earth"

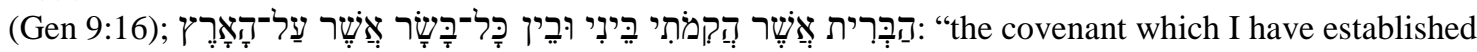
between me and all flesh that is on the earth" (Gen 9:17). Note that in Gen 9:13, 16 and 17 Noah is not included. This is what Hillers, "Covenant," 4:134, calls "Grant Covenant," which "is an unconditional divine gift" because "the deity alone undertakes obligations."

${ }^{14}$ J. P. Lewis, A Study of the Interpretation of Noah and the Flood in Jewish and Christian Literature (Leiden: Brill, 1968); D. J. A. Clines, "Noah's Flood: The Theology of the Flood Narrative," 
William J. Dumbrell discusses the translation of aִִִּּּ and says that "the notion conveyed by the English word is that of agreement, with the nuance of legal agreement whereby rights and privileges, commitments and obligations are set up between two parties, an agreement which may have involved extended or protracted negotiations."15 He also affirms that the etymological meaning of כִִִּ has no consensus thus he proposes that "the Middle Assyrian noun biritu, a word whose sense is 'bond' or 'fetter,' " is the "most commended ... and probably ought to be adopted."16

Weinfeld, in addition, translates רִִִִִּ as "imposition," "liability,” or "obligation;" 17 and also, as "synonymous with law and commandment." 18 Therefore, he disagrees that iִִּ is is an "agreement or settlement between two parties."19

On his part, Gordon J. McConville suggests that "the meaning of 'covenant' must be sought by means of a study of its usage." ${ }^{20}$ However, he is more interested in its nature which he concludes is "a mutual commitment, which paradoxically recognized both the initiative of God in the arrangement and insisted on the reality and necessity of human

Faith and Thought 100 (1972-1973): 128-42; S. E. Loewenstamm, Comparative Studies in Biblical and Ancient Literatures, AOAT 204 (Kevelaer: Butzon and Bercker, 1980), 93-121.

${ }^{15}$ Dumbrell, Covenant and Creation, 15.

${ }^{16}$ Ibid. Cf. Pritchard, Ancient Near Eastern Texts Relating to the Old Testament, 180; Weinfeld,

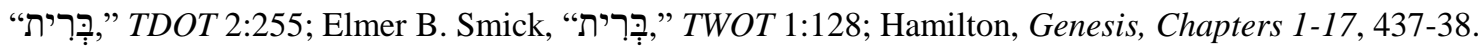
The Middle Assyrian period has been established from 15th to 10th centuries BC.

${ }^{17}$ Weinfeld, TDOT 2:255.

18 Ibid.

${ }^{19}$ Ibid. Favorable to this position is Hamilton, Genesis, Chapters 1-17, 438; against are John D. Davis, "Covenant," WDB 118; Smick, TWOT 1:128.

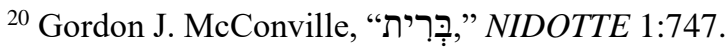


choice as well." ${ }^{21}$ McCarthy, on the other hand, is "convinced that covenant is an ancient concept in religious contexts" which "was an action and a state, not a word."22

Taking into account the implication of each of the previous positions, the context of Gen 21:27, 32 suggests that the word "covenant" is related to the verb כָָּ . Eugene Carpenter claims that כָָּּרת "has three basic meanings: (1) to cut (objects designated); (2) to eradicate, set aside, exclude, cut off (metaphorical), kill, fail, cease; and (3) to enter into, conclude a covenant," a matter, an agreement, or a treaty." ${ }^{23}$ This latter meaning is

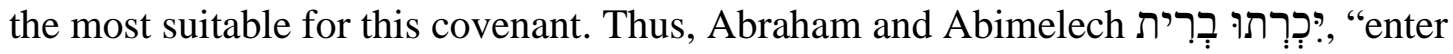
into a covenant," in order to stop the hostilities among their servants. ${ }^{24}$

Also, this covenant is accompanied by שבע, "an oath" to cause no harm between the two parties (Gen 21:31). ${ }^{25}$ According to Weinfeld, this שבע "included most probably

${ }^{21}$ Ibid., 752.

${ }^{22}$ McCarthy, Treaty and Covenant, 14. Cf. ibid., " $b^{e}$ rît in Old Testament History and Theology," Bib (1972): 101-21; Jon D. Levenson, "Covenant and Commandment," Tradition 21 (1983): 42-51; Kitchen, "The Fall and Rise of Covenant: Torah and Treaty," TynBul 40 (1989): 118-35; S. David, Sperling, "Rethinking Covenant in the Late Biblical Books," Bib 70 (1989): 50-73.

${ }^{23}$ Eugene Carpenter, "כרת," NIDOTTE 2:729.

${ }^{24}$ See Sarna, Genesis, 148; Von Rad, Genesis: A Commentary (Philadelphia, PA: Westminster, 1972), 236, 237; Hamilton, The Book of Genesis: Chapters 18-50, 87-93; and Speiser, Genesis, 1:160.

${ }^{25}$ See Weinfeld, TDOT 2:256. McCarthy, "Three Covenants in Genesis," 180 , suggested that "the mutual oath is typical of the treaty between equals though not of the vassal treaty." Also, on p. 181, he added that "to swear" taken by itself was enough to imply a covenant. There was no need to say "swear a covenant' even though the phrase is perfectly possible, and the verb appears parallel to 'cutting a covenant.' "'

Similarly the story between Isaac and Abimelech (Gen 26:26-33) has an oath (שבע) of no harm based on a covenant between two parties (v. 31). Also, in v. 28 the noun אָז "oath" or "curse" is used as part of the "covenant" between both parties. Though Scharbert, TDOT 1:263, says that "only the weaker who is forced into the treaty, take an oath in which they pronounce a curse on the partner who breaks the treaty," and it looks like Abimelech is the weaker (see vv. 26, 28, 29), in v. 31 the Hebrew

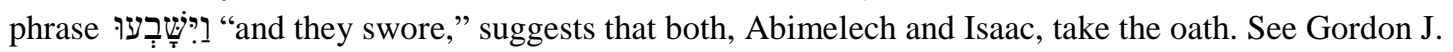


a conditional imprecation" of "binding validity." 26 And T. W. Cartledge adds that in oath statements the curse is conditional while the promise is not. ${ }^{27}$ The speaker's intent is certainly to live according to the oath, but "God's wrath has been invoked in the event of failure." ${ }^{28}$ Hamilton, on his part, states,

To swear in the Old Testament was to give one's sacred unbreakable word in testimony that the one swearing would faithfully perform some promised deed, or that he would faithfully refrain from some evil act. ... Occasionally one swore

Wenham, Genesis 16-50, WBC (Nashville, TN: Thomas Nelson, 1994), 193; Robert P. Gordon, "אלה," NIDOTTE 1:403, 404.

Jack B. Smith, "אָדָדה," TWOT 1:45, remarks that this word is used basically "in the sense of a solemn promise between human beings. . . For that reason it is also applied to solemn statements of testimony given in court (Lev 5:1; Prov. 29:24) and before God." Examples of this statement are: Gen 24:41; 26:28 (between human beings); Num 5:21-23; Jud 17:2; 1 Kgs 8:31; 1 Sam 14:24; Neh 5:21 (Heb. v. 30); Ezek 16:59; 17:13ff (before God).

More sources about oaths and curses are Sheldon H. Blank, "The Curse, the Blasphemy, the Spell and the Oath," HUCA 23 (1950/51): 73-95; Stanley Gevirtz, "West-Semitic Curses and the Problem of the Origins of Hebrew Law," VT 11 (1961): 137-58; F. Charles Fensham, "Maledictions and Benedictions in the Ancient Near Eastern Vassal-Treaties and the Old Testament," ZAW 74 (1962): 1-19; ibid., "Common Trends in Curses of the Near Eastern and Kudurru-Inscriptions Compared with Maledictions of Amos and Isaiah," ZAW 75 (1963): 155-75; Delbert R. Hillers, Treaty-Curses and the Old Testament Prophets, BibOr 16 (Rome: Pontifical Biblical Institute, 1964); Boyle, "The Covenant Lawsuit of the Prophet Amos," 347, 348; G. W. Coats, "The Curse in God's Blessing," in Die Botschaft un die Boten: FS für H. W. Wolff, ed. Joachim Jeremias and L. Perlitt (Neukirchen: Neukirchener Verlag, 1981), 31-41; Kalluveettil, Declaration and Covenant, 10; Meir Malul, "More on pachad vitschāq (Genesis 31:42, 53) and the Oath by the Thigh," VT 35 (1985):192-200; Markus Zehnder, "Building on Stone? (Part 1)," 341-74; ibid., "Building on Stone? (Part 2)," 511-35.

${ }^{26}$ Weinfeld, TDOT 2:256. Cf. also Smith, TWOT 1:45. Examples of this statement are: Gen 24:41; 26:28 (between human beings); Num 5:21-23.; Jud 17:2; 1 Kgs 8:31; 1 Sam 14:24; Neh 5:21 (Heb. v. 30); Ezek 16:59; 17:13, 16, 18, 19 (before God). Cf. Gordon, NIDOTTE 1:403, 404. Scharbert, TDOT 1:263, suggests that the oath is taken only by the weaker party; however, both parties "pronounce a curse on the partner who breaks the treaty." In Gen 21:22-32 and 26:26-31, both accounts reflect that Abimelech comes to ask Abraham and Isaac to take an oath; however, Abimelech is the weaker party. Also, Scharbert, TDOT $2: 265$, recognizes that "the meaning of 'alah overlaps with that of 'arar and qahal, but also with that of shebhu 'ah, 'oath.'" Thus, he affirms that "the curses designated as 'alah in the OT were already prayers to Yahweh that he would bring calamity on the evildoer and thus call him to account." Therefore, it is accepted that אָדָָה “is a very effective instrument in God's acts of punishment." See also Wenham, Genesis $16-50,193$.

27 T. W. Cartledge, "שבעע," NIDOTTE 4:32, states, "On the surface, oath statements seem conditional, but it is the curse — not the promise - that is conditional. There is no question on the speaker's intent to live up to his or her obligation: the 'if' is only reminder that God's wrath has been invoked in the event of failure."

28 Ibid. 
that he freely acknowledged a truth and would continue to acknowledge it in the future. ${ }^{29}$

Another important feature of Gen 21:22-32 is its covenant structure: (1) Historical prologue: ${ }^{30}$ Abimelech recognizes that God is with Abraham in everything he does (v. 22b); ${ }^{31}$ (2) Stipulations: Abimelech asks Abraham to swear that he would not harm him, his posterity, or his land (v. 23); (3) Oath: Abraham swears (שבע; v. 24). ${ }^{32}$ At this point an interruption in the treaty takes place: (4) Accusation: Abraham sets an accusation (יכח מiphil before Abimelech "because of a well of water which Abimelech's servants had seized" (v. 25); (5) Defense: Abimelech makes clear his unawareness of Abraham's

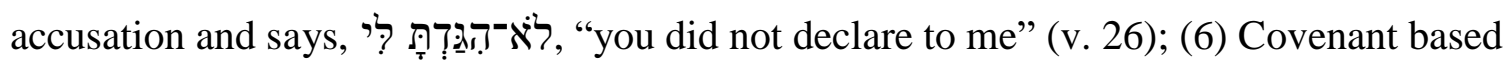
on sheep and oxen which Abraham gives to Abimelech (v. 27); (7) Witness: Abraham asks for a witness (vv. 28-30) that could be either Abimelech (MT) or the ewe lambs (LXX); (8) Second oath: At this time both of them swear (שבע) an oath (v. 31);33

${ }^{29}$ Hamilton, TWOT 2:900.

${ }^{30}$ Lucas, "Covenant," 20, says that "an historical prologue is typical of the second-millennium treaties but very rare in the first-millennium treaties." (Emphasis is in the original).

${ }^{31}$ Cf. Bracke, NIDOTTE 3:1105.

32 This part of the treaty is strange. Though Abimelech is afraid of Abraham because he recognized that God is with him, the former is asking the latter to do what a suzerain is supposed to ask to a vassal. Also it is interesting that even though this is a parity treaty, Abimelech's behavior suggests that Abraham is superior to him.

33 This would be a second oath depending how the translation of v. 24 fits better to the context, either in the present: "I swear" (NAB; NAS; NIV; NJB; NRS; TNK) or in the future: "I will swear" (ESV; KJV; NKJ; RSV; so also the LXX: ó other's stipulations and in the end they both take an oath. 
(9) Resumption of the covenant (v. 32a); and (10) Conclusion: Abimelech and Phichol rise and depart to their land (v. 32b). ${ }^{34}$

This could be called a parity treaty interrupted by an accusation and a defense, which is settled with the gift of seven ewe lambs from Abraham to Abimelech who is called to be a witness that Abraham has dug a well (v. 30). Thus Chisholm establishes that the noun עִ עִדָה "is used as a tangible reminder that an agreement has been made."35

The parity treaty between Abraham and Abimelech has similarities and differences with the parity treaty between Ramses Meri-Amon of Egypt and Hattusilis of Hatti made in 1280 BC. In every case they look for the end of hostilities between the parties. Also, the oath that Abraham and Abimelech swear could have similarities with the curses and blessings between Ramses and Hattusilis. However, in the treaty between Ramses and Hattusilis, gods are called as witnesses of the treaty while in the treaty between Abraham and Abimelech this practice does not appear. On the contrary, they are able to make a covenant based on the witness of Abimelech, a human being. ${ }^{36}$

Table 5 shows that this treaty of Abraham and Abimelech is also similar, but not in every detail, to the one between Isaac and Abimelech (Gen 26:26-33): Both treaties

${ }^{34}$ Lawrence, The Books of Moses Revisited, 40, has structured this covenant as follows, Oath I (Gen 21:23a); Divine witness (v. 23b); Stipulations (v. 23c); and Oath II (v. 24). He also stipulates on p. 42 that "the specific sequence of oath/witnesses + stipulations" found in this treaty "is identical to that found in the early Second Millennium treaties."

${ }^{35}$ Robert B. Chisholm, "עוד," NIDOTTE 3:339.

${ }^{36}$ I base this conclusion on the MT, which places Abimelech as witness. In this text no divine being is called to be witness. 
have an oath (שבע) of no harm based on a covenant between the two parties. ${ }^{37}$

Table 5. Parallelism of covenants in Gen 21:22-32 and 26:26-33

\begin{tabular}{|c|c|}
\hline $\begin{array}{l}\text { Covenant between Abraham and } \\
\text { Abimelech (Gen 21:22-32) }\end{array}$ & $\begin{array}{l}\text { Covenant between Isaac and Abimelech } \\
\text { (Gen 26:26-33) }\end{array}$ \\
\hline & $\begin{array}{l}\text { vv. 26, 27: Isaac's inquiry about the } \\
\text { presence of Abimelech and his friends }\end{array}$ \\
\hline 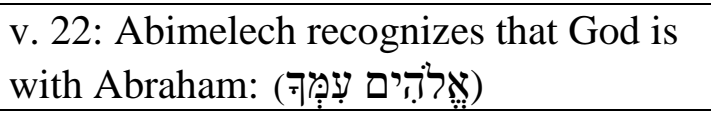 & 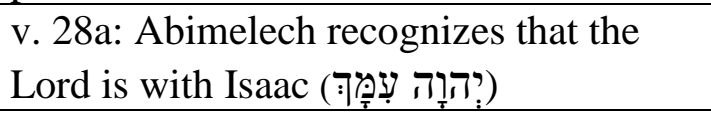 \\
\hline $\begin{array}{l}\text { v. 24, 24: Abimelech asks Abraham to } \\
\text { swear (שבע; niphal) }\end{array}$ & $\begin{array}{l}\text { v. 28b: Abimelech and Isaac swear an } \\
\text { oath" (אָָָזָ; noun, fem.) }\end{array}$ \\
\hline \multicolumn{2}{|l|}{$\begin{array}{l}\text { v. 25: Abraham complains (יכח) against } \\
\text { Abimelech }\end{array}$} \\
\hline \multicolumn{2}{|l|}{ v. 26: Abimelech's defense } \\
\hline v. 27: Covenant is made (פכָּרָת בְּרִית) & $\begin{array}{l}\text { vv. 28c, 29: Covenant of no harm is made } \\
\text { (כָָּרת כְּרְרית) }\end{array}$ \\
\hline \multicolumn{2}{|l|}{ vv. 28-30: Witness (עָדָה) } \\
\hline & v. 30: Communal meal \\
\hline 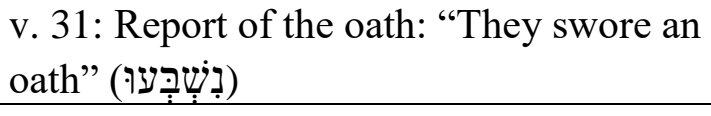 & 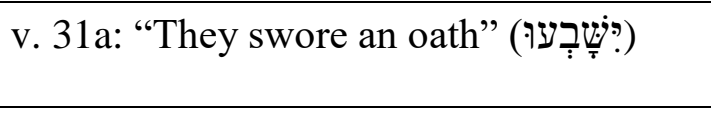 \\
\hline \multicolumn{2}{|l|}{ v. 32a: Report of the covenant (פָּרִית) } \\
\hline v. 32b: Abimelech and Phichol depart & v. 31b: Abimelech and his friends depart \\
\hline
\end{tabular}

The parallelism is notable but the difference is clear: While Abraham and Abimelech ratify their covenant by a witness, Isaac and Abimelech have a communal meal.

${ }^{37}$ Scharbert, TDOT 1:265, explains that in Gen 26:26-28, the two terms, "covenant" and "oath,"

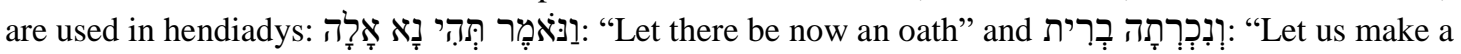
covenant." Also in Deut 29, "covenant" and "oath" are used as synonyms. Cf. Gordon, NIDOTTE 1:404. Weinfeld, TDOT 2:256, says, "Though originally these two terms express two different concepts, commitment on the one hand and oath on the other, in course of time they merged, and one could use either of them in order to express the idea of pact. Thus, e.g., instead of 'cutting a covenant' (karath berith), one could use 'cutting an oath' (karath 'alah)." Cf. Izak Cornelius, "Gen 26 and Mari: The Dispute over Water and the Socio-Economic Way of Life of the Patriarchs," JNSL 12 (1984): 53-61; G. G. Nicol, "Studies in the Interpretation of Gen 26:1-33" (Ph.D. diss., Oxford, 1987). 
Jacob and Laban (Gen 31:26-55 [Heb. ch. 32:1])

In Gen 31 the word עֵָד occurs 5 times, ${ }^{38}$ in which Laban persecutes Jacob because he has flown without giving any information about it (vv. 1-25). Several features are important around the word עִ עִד:

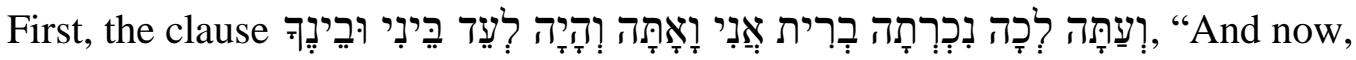
come, let us make a covenant you and I, and let it be for a witness between you and me" (v. 44), has posed some difficulties in its interpretation because the word apposition to עي ${ }^{39}$ Accordingly, different versions translate this verse as follows: "Let us make a covenant . . . and let it be a witness between you and me" (NKJV; NAS; NAU); "and let it be for a witness" (ASV; ERV; JPS; KJV, WEB); "and let it stand as a testimony" (CJB); "and it will be proof" (NET); "and let it serve as a witness" (NIV). The difficulty is also reflected in the French version DRB that translates as follows, " $E t$ elle sera en témoignage entre moi et toi." The personal pronoun elle is feminine in French and equivalent to "she" and even though it can also be an impersonal name, here it is in agreement with the word alliance, "covenant," which is also feminine.

The LSG is vague because it uses the demonstrative pronoun cela, "that," which does not resolve the problem. Also the German versions of Schlacter (SCH 1951), and Lutherbibel (LUO 1912) use der, "this," as demonstrative pronoun masculine and in

${ }^{38}$ Vv. 44, 48, 50, 52 (two times).

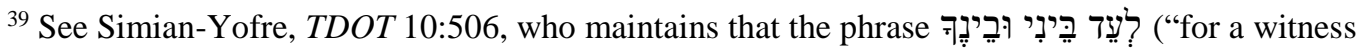
between you and me") is unclear and that "the agreement itself cannot be viewed as an 'éd. Genesis 11:27-50:26, 531, says "that the agreement itself could serve as a witness is not exceptional (cf. Deut 31:26).” 
agreement with Bund, "covenant," which is a masculine noun. The main difficulty with

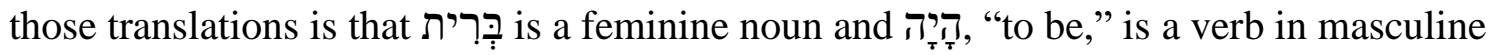
form. Furthermore, a waw (?!) copulative is attached to the verb דָיזָ, meaning that "the same situation is expressed in another way."40 Then, the question is, why is the verb Tָיזה in masculine form when בִִִּּרית. is a feminine substantive? The answer could be that Laban is asking to set up a "witness" that in his religious context he knows what or who would be. Therefore, they gather stones and make a "heap," and Laban says, "This heap (גָּ witness between you and me" (v. 45-48). ${ }^{41}$

The word לגֵ "heap," is a masculine noun that, probably, could be the answer to what the verb דָָיזה means on v. 44. The translators of the LXX recognized this issue, but they took a different choice placing $\theta \varepsilon$ ós, "God," as the masculine noun (which does not

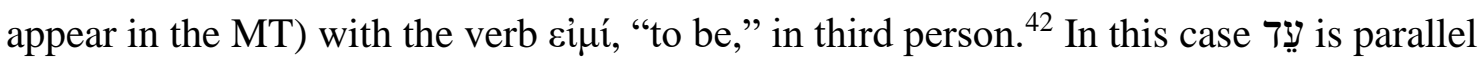

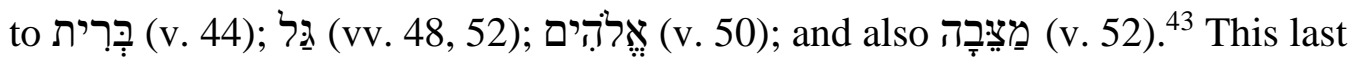

${ }^{40}$ Bruce K. Waltke and M. O’Connor, An Introduction to Biblical Hebrew Syntax (Winona Lake, IN: Eisenbrauns, 1990), 519, 520.

${ }^{41}$ Cf. Smick, TWOT 1:128 who recognizes that "it was common practice to set up a stela (stone) as a sign that a treaty had been established between two households or nations." On his part, Mathews, Genesis 11:27-50:26, NAC 1 A: An Exegetical and Theological Exposition of Holy Scripture (Nashville, TN: Broadman \& Holman, 1996), 532, suggests that the role of the heap is "a boundary marker."

${ }^{42}$ ShaDal (S. D. Luzzatto), The Book of Genesis, 300, believes that God is the real witness because he would see and judge whoever transgresses the covenant.

${ }^{43}$ Cf. Kitchen, Ancient Orient and Old Testament, 97: "The gods of paganism were excluded, so the god-lists of the Ancient Oriental covenants are not found in the biblical ones." Also René Lopez, "Israelite Covenant in the Light of Ancient Near Eastern Covenants (Part 2 of 2)," CTSJ 10 (2004): 98, says, "Unlike the ancient Near Eastern treaties that had long lists of gods, Israel's covenants did not." True, there is not a list of gods as they say; nevertheless, in this covenant God is called to be a witness between Laban and Jacob.

Smick, TWOT 1:128, suggests, "On both sides appeal is made to the deity as a witness showing that the covenant is unalterable." 
occurrence appears for the second time in feminine, where the process of settling a trial is identical to Gen $21 .{ }^{44}$

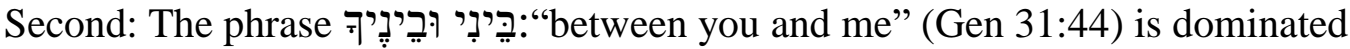
by the construct preposition בִיָ, which Schultz expresses that it has "the idea of divine judgment ..., when God is called upon to adjudicate between two disputing parties, vindicating one and condemning the other." 45 Table 6 tests this argument:

Table 6. Pentateuchal passages with " . . . "

\begin{tabular}{|c|c|c|c|}
\hline Passages & Divine Judgment & Secular Judgment & Decision \\
\hline 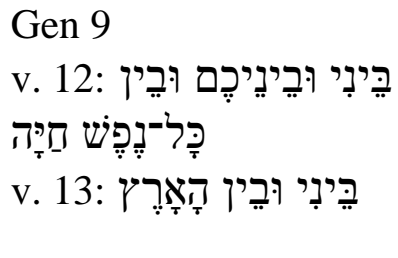 & $\begin{array}{l}\text { Destruction of all } \\
\text { the earth with the } \\
\text { Flood }\end{array}$ & & $\begin{array}{l}\text { A sign (אוֹת) of a } \\
\text { covenant (בְּרית): } \\
\text { God will not } \\
\text { destroy the earth } \\
\text { again } 46\end{array}$ \\
\hline
\end{tabular}

${ }^{44}$ The covenant between Jacob and Laban has some parallel features with the covenant between Isaac and Abimelech (Gen 26:26-31). The two narratives are not identical in every detail, but almost identical in scope and content: (1) Abimelech and some others come (הָרָ) to Isaac in peace (26:26), while Laban, with some others persecute (רָזָ) Jacob (31:23);.(2) Abimelech hates Isaac because of his prosperity (26:27); Laban is not favorable toward Jacob because of his prosperity (31:42; see also vv. 2, 2931, 42); (3) Abimelech sees that "the Lord is with" Isaac (26:28); Jacob tells Laban that the Lord is with him (31:42); (4) Abimelech, a pagan, calls Isaac to make a covenant (26:28) while Laban, a pagan, calls Jacob to make a covenant (31:44); (5) Abimelech and Isaac's covenant is based on a "no harm" treaty from Isaac to Abimelech and his country (26:29); Laban and Jacob's covenant was based on a "no affliction" and "no harm" treaty stipulating that Jacob should not take other wives besides Laban's daughters $(31: 50,52)$; (6) The pagans set the charge of the covenant in both cases $(26: 28,29 ; 31: 43-50)$; (7) There is a meal after the covenant in both events $(26: 30 ; 31: 46,54) ;(8)$ In both cases the two parties spend the night together

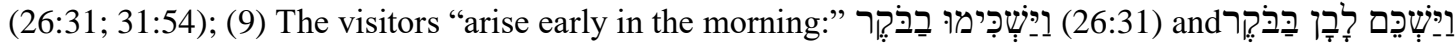
(31:55 [Heb. 32:1]); (10) The next day there is "an oath" between Abimelech and Isaac (26:31); the next day, Laban kisses his daughters and grandchildren and gives them a blessing that the narrator does not state (31:55 [Heb. 32:1]); and (11) Abimelech and his people depart (דָרָ) from Isaac "in peace" (26:31); Laban and his people depart (דָרָ) and returned to his place" (31:55 [Heb. 32:1]).

${ }^{45}$ Richard Schultz, "שפט," NIDOTTE 4:216.

${ }^{46}$ In the Flood narrative the Hebrew word דִִִּ aִ appears 8 times in all (Gen 6:18; 9:9, 11, 12, 13 , 15, 16, 17). For a discussion of the Heb. "Cִּרִ see McCarthy, Treaty and Covenant, 1-246; Elwell and Comfort, "Covenant," 324; Pritchard, Ancient Near Eastern Texts, 180; Weinfeld, TDOT 2:255; Smick, TWOT 1:128; Hamilton, Genesis, Chapters 1-17, 437, 438. For a position of the Flood account as a 
Table 6-Continued

\begin{tabular}{|c|c|c|c|}
\hline 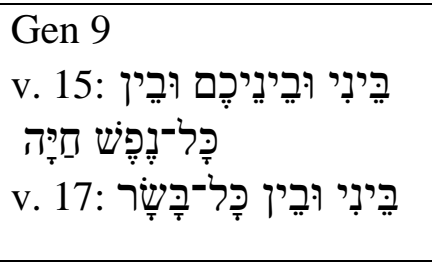 & $\begin{array}{l}\text { Destruction of all } \\
\text { the earth with the } \\
\text { Flood }\end{array}$ & & $\begin{array}{l}\text { A sign (אוֹת) of a } \\
\text { covenant (בְּרית): } \\
\text { God will not } \\
\text { destroy the earth } \\
\text { again }\end{array}$ \\
\hline 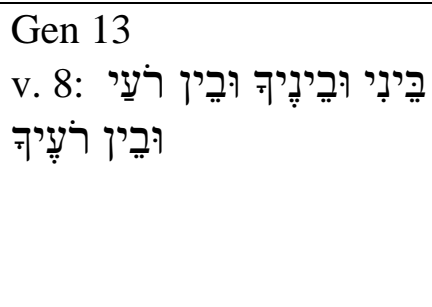 & & 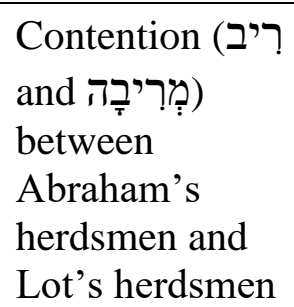 & $\begin{array}{l}\text { Separation of } \\
\text { Abraham and } \\
\text { Lot }^{47}\end{array}$ \\
\hline 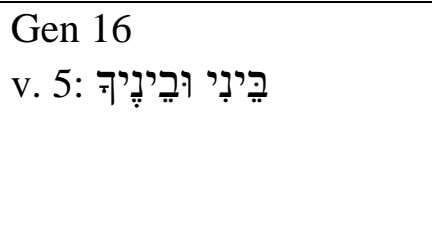 & $\begin{array}{l}\text { Sarai summons } \\
\text { God to judge } \\
\text { (نפָ) between } \\
\text { her and } \\
\text { Abraham }{ }^{48}\end{array}$ & & $\begin{array}{l}\text { Sarai is vindicated } \\
\text { Hagar submits to } \\
\text { Sarai } \\
\text { (vv. 6-15) }\end{array}$ \\
\hline 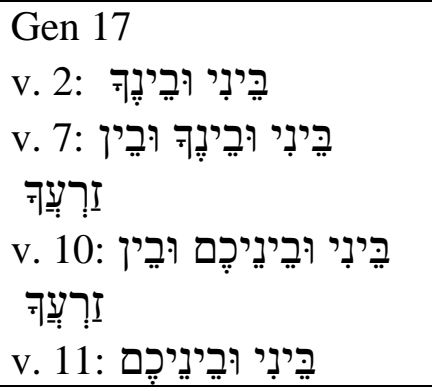 & $\begin{array}{l}\text { Whoever is not } \\
\text { circumcised } \\
\text { shall be cut off } \\
\text { (v. 14) }\end{array}$ & & $\begin{array}{l}\text { God makes an } \\
\text { everlasting } \\
\text { covenant with } \\
\text { Abraham }^{49}\end{array}$ \\
\hline 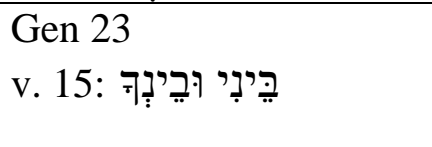 & & $\begin{array}{l}\text { A legal business } \\
\text { transaction } \\
(\mathrm{vv} .17,18)\end{array}$ & $\begin{array}{l}\text { Abraham buys the } \\
\text { field of Ephron in } \\
\text { Machpelah }\end{array}$ \\
\hline
\end{tabular}

narrative about judgment see Jiří Moskala, “Toward a Biblical Theology of God's Judgment: A Celebration of the Cross in Seven Phases of Divine Universal Judgment (An Overview of a Theocentric-Christocentric Approach)," JAST 15 (2004): 138; and ibid., "The Gospel According to God's Judgment," JAST 22 (2011): 35.

${ }^{47}$ Cf. Walter Vogels, "Lot in His Honor Restored: A Structural Analysis of Gen 13:2-18," EgT 10 (1979): 5-12; Larry R. Helyer, "The Separation of Abram and Lot: Its Significance in the Patriarchal Narratives," JSOT 26 (1983): 77-88.

${ }^{48}$ Wenham, Genesis 16-50, 8, calls this phrase a "curse."

${ }^{49} \mathrm{Cf}$. Smick, TWOT 1:129, who says that "the notion that a covenant between God and man did not exist in the formative stages of Israelite history as presented in Genesis and Exodus cannot be taken seriously any longer. Yahweh as a tribal deity in early Israel bound to his people by natural but not ethical ties, as a covenant relationship implies, is also a fading viewpoint." Also he suggests that God's covenant assures his beneficence "at a time when the deities were considered arbitrary originators of evil." 
Table 6-Continued

\begin{tabular}{|c|c|c|}
\hline 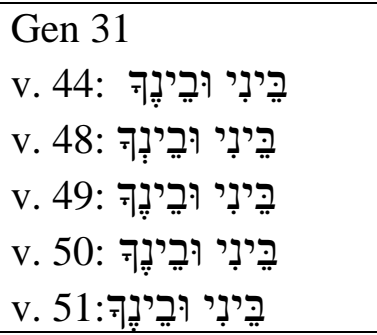 & $\begin{array}{l}\text { Laban summons } \\
\text { God to judge } \\
\text { between him and } \\
\text { Jacob (v. 53) }\end{array}$ & $\begin{array}{l}\text { Laban and Jacob } \\
\text { make a covenant } \\
\text { of no harm } \\
\text { between them }\end{array}$ \\
\hline 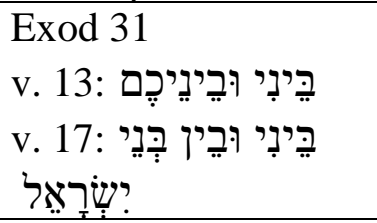 & $\begin{array}{l}\text { Whoever profanes } \\
\text { the Sabbath shall be } \\
\text { cut off (v. 14) }\end{array}$ & $\begin{array}{l}\text { The Sabbath is a } \\
\text { sign of God's } \\
\text { creation }\end{array}$ \\
\hline 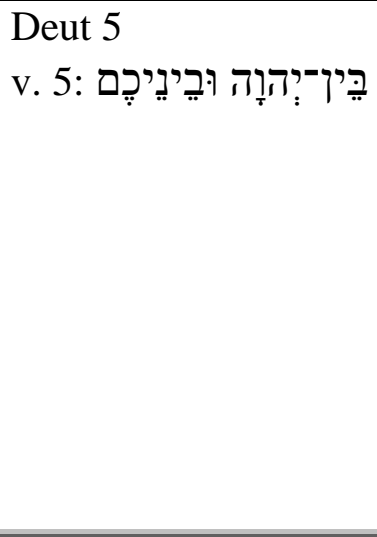 & $\begin{array}{l}\text { Moses calls the ten } \\
\text { commandments, } \\
\text { "the statutes and } \\
\text { judgments" and } \\
\text { reminds Israel his } \\
\text { intercession at } \\
\text { Mount Sinai } \\
\text { because they were } \\
\text { afraid of God's } \\
\text { theophany } \\
\text { (vv. 1-5) }\end{array}$ & $\begin{array}{l}\text { God makes a } \\
\text { covenant with } \\
\text { Israel }\end{array}$ \\
\hline
\end{tabular}

The table shows that whenever the preposition ". . . . בִין" appears in a text, two results are developed in the narrative: a (divine or secular) judgment, and a binding decision. Though the process of the judgment could be negative, the final decision is positive every time.

And third, in Gen 31:53 Laban uses the verb שָָָׁ, "judge," in qal imperfect, third

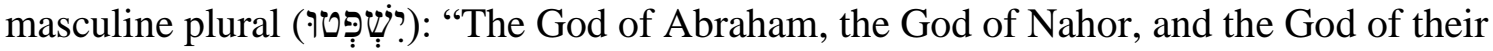

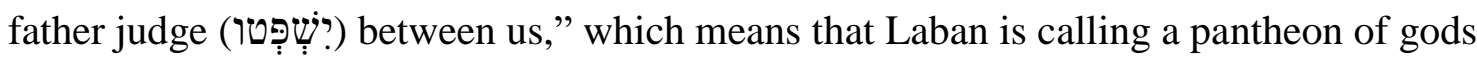


to judge between him and Jacob. ${ }^{50}$ Though the verb is jussive in meaning, the calling of gods is strengthened by the fact that in v. 42 Jacob uses a similar phraseology but with

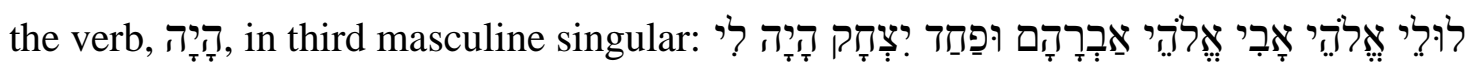

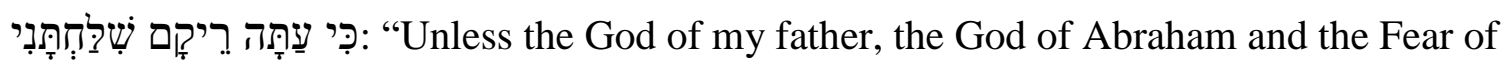
Isaac, had been with me, surely now you would have sent me away empty-handed." This makes clear that while for Jacob the "God of my father, the God of Abraham and the Fear of Isaac" is the same God, for Laban "the God of Abraham, the God of Nahor, and the God of their father" are different gods. ${ }^{51}$

This persecution ends with two actions: a judgment and a covenant. The general structure of the judgment is: (1) Laban's first accusation (vv. 26-30); (2) Jacob's first defense (vv. 31, 32); (3) Laban looks for evidence (vv. 33); (4) Rachel tampers with the evidence (v. 34a, 35); (5) Laban does not find the evidence (v. 34b, 35b); (6) Jacob's second defense calling for human judges, but he knows that God has intervened already for him (vv. 36-42); ${ }^{52}$ and (7) Laban drops his case (v. 43).

${ }^{50}$ Cf Kitchen and Lawrence, Treaty, Law and Covenant, 33, who agree on this point.

${ }^{51}$ If Laban would have believed that the God of Abraham is the same God of Nahor and their father, he would have used the verb שָָָָ ("judge") in third person, singular as Jacob did it in v. 42. No wonder why Laban was so interested in getting back the household idols that Rachel had stolen.

52 The irony of this passage is emphasized in v. 36 where Jacob questions Laban about his actions

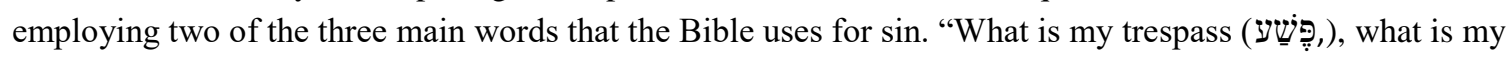

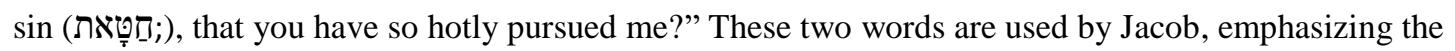
seriousness of Laban's haunting against him. That is why he has to confront Laban once for all in order to know what his goal is in this persecution. The way in which Jacob uses those two words for "sin" reveals that he is sure about Laban's intention against him. And the fact that Laban is not able to accuse him with property is the proof that God is at Jacob's side, and even though Laban has more power than Jacob, he has no other choice than to go away "empty-handed" as it was his plan against Jacob. 
At this point, Laban wants to make a covenant which is described as follows: (1)

Laban calls to make a covenant that could be a witness (vv. 44-46) ${ }^{53}$ (2) Sacrificial meal on a heap (v. 46c) $;^{54}$ (3) Stones as witnesses (vv. 48-49a) ${ }^{55}$ (4) Stipulations (v. 49b, 50); (5) God and the stones as witnesses (vv. 50d-52a); (7) More Stipulations (v. 52b); (8) List of gods as judges by Laban (v. 53a); (9) Jacob swears by God (v. 53b); (10) Sacrificial meal (v. 54); and (11) Laban departs (v. 55 [Heb. ch. 32:1]). ${ }^{56}$

This covenant takes the reader by surprise since up to this point nothing in the passage points toward this need. This surprise is parallel to the introduction of the issue of the household idols in the sequence of events. Thus, it is ironic that Laban's main object is to send Jacob "away empty-handed" (v. 42) to the land of his father; but it is Laban who returns with empty hands. Therefore, the household idols and the making of a covenant become distractors for Laban, which reveals how God is controlling the events:

${ }^{53}$ Cf. McCarthy, "Three Covenants in Genesis," 186, proposes that whether the "witness" of Gen 31:44 is in written form or by memory, the document is immaterial and "it can be cited as a witness in the sense that it can be referred to as a means to show whether and in what way one or the other party is out of line if dispute should arise."

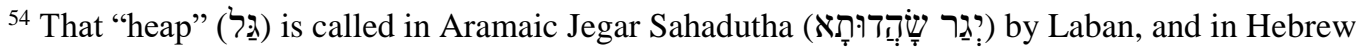

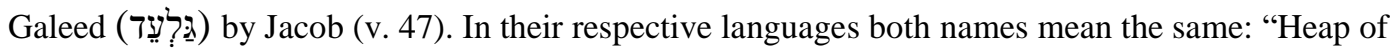
Witness" which is stated on the explanation that Laban gives, "This heap is a witness between you and me this day." And when the narrator says, "therefore" (עַעל־כַ), he is stating that the name which prevails for this place is "Galeed" (v. 48). But also the narrator says that it is called "Mizpah" as well, "because he (Laban) says, May the Lord watch between you and me when we are absent one from another" (v. 49). See also Chisholm, NIDOTTE 3:338, 339.

55 See Sarna, Genesis, 221; and Hamilton, The Book of Genesis: Chapters 1-17, 313.

${ }^{56}$ Based on the Documentary Hypothesis, McCarthy, "Three Covenant in Genesis," 179, believes that in this passage two accounts of covenant making are used: $\mathrm{J}$ (vv. 46, 51-53a) "with the mention of mașseebâ in 51 and 52 to be omitted as a harmonizing addition;" and E (vv. 44, 45, 49, 50, 53b, 54).

McCarthy also states that $\mathrm{E}$ is a marriage covenant and $\mathrm{J}$ "a covenant fixing a frontier" (ibid., 179, 180). He agrees that though these two "covenants appear in both $\mathrm{J}$ and $\mathrm{E}$ indicates [sic] that they belonged to a stage antedating both these traditions. Also, these covenants are marked by nomadic traits which were not those of the normative Israelite tradition after the conquest" (ibid., 180). 
The issue of the household idols serves to give Jacob an opportunity "to rebuke" Laban who has already been "rebuked" by the Lord; and the "covenant" gives Jacob the security that Laban would never come back to persecute him.

The Ninth Commandment (Exod 20:16 and Deut 5:20)

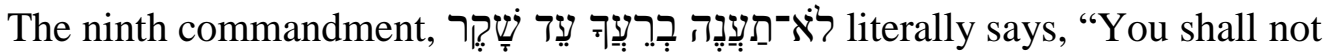
answer against your neighbor a testimony of lie" (Exod 20:16). In qal, the Hebrew

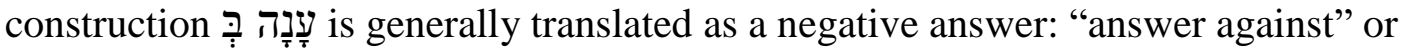
"testify against;" 57 though it is also possible to translate it in a positive form: "answer for" or "testify for" (Gen 30:33).

The same construction עָָָנָה כָָּ also appears in Deut 5:20, implying the same judicial purpose of the commandment. Thus, this commandment is given in a general form which is later described with more specific regulations.

Though the text does not give any hint to deny the possibility that the testimony could be given out of a trial, it is more probable that this commandment is more concerned with testimonies in court. This testimony against a neighbor is an answer to a question that has been asked previously. As a result, Simian-Yofre states that this is "a specific regulation designed to prevent witnesses from lying in court."58

\footnotetext{
${ }^{57}$ Naomi says that God עָכָנָה בִי "[has testified] against me” (Ruth 1:21); David says to the

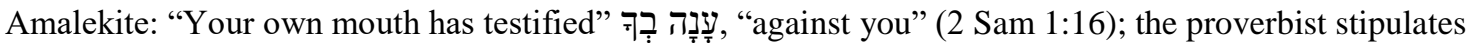

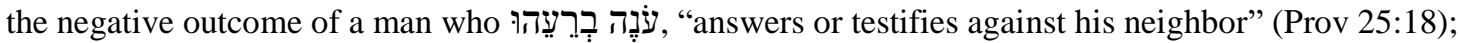

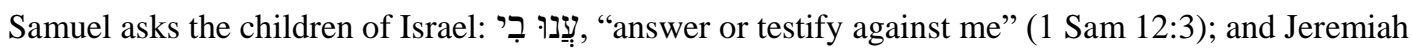

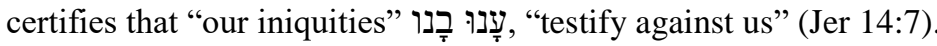

${ }^{58}$ Simian-Yofre, TDOT 10:500. Cf. Durham, John, 296; R. Alan Cole, Exodus: An Introduction \& Commentary, TOTC (Leicester, England: InterVarsity, 1973), 161; Peter C. Craigie, The Book of
} 


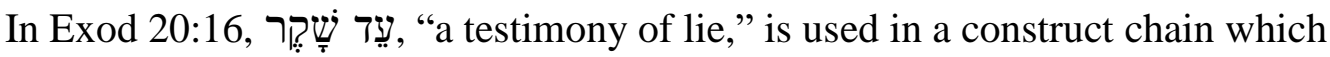
English versions prefer to translate as "false witness;" giving to שֶֶֶׁ the function of a qualifier. Durham points out that שֶֶׁ? means "lying, deceiving, false, fraudulent;" Hermann J. Austel adds that it is used for "activities which are false in the sense that they are groundless, without basis in fact or reality."

In the Old Testament, שֶׁ? is attributed by Pharaoh to Moses's word to the children of Israel (Exod 5:9); it is a false swearing about a lost article that has been found (Lev 6:3); it is a deceiving spirit in the mouth of false prophets (1 Kgs 22:22, 23; $2 \mathrm{Chr}$ 18:21, 22); Jehu hides a prophet's report (2 Kgs 9:12). This could mean that i⿱丷שֶׁ is the manipulation or hiding of a report that is replaced by a false account.

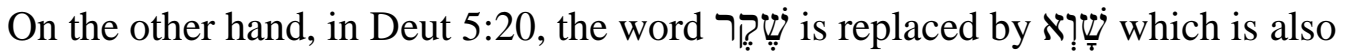

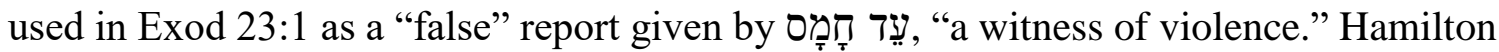

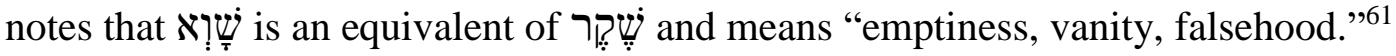
Durham suggests that this word means " 'nothingness, insubstantial thing,' even 'lie.' ",62

Deuteronomy, 162; Terence E. Fretheim, Exodus, IBC (Louisville, KY: John Knox, 1991), 236, 237; Jeffrey H. Tigay, Deuteronomy: דברים, JPSTC (Philadelphia, PA: The Jewish Publication Society, 1996), 71.

${ }^{59}$ Durham, Exodus, 296.

${ }^{60}$ Hermann J. Austel, "ששׁק," TWOT 2:956. See Ps 38:19 (Heb. v. 20): Those who hate without cause; Jer 23:32: "false dreams;" 27:10: "They prophecy a lie;" Zech 10:2: "The diviners see lie;" See also Prov 12:22; 20:17; 26:28; Isa 44: 20; 59:13; Mic 2:11; Job 13:4; Jer 8:10, 11; 10:14, 15; 37:14; 51:17; Hab 2:18.

${ }^{61}$ Hamilton, "שָׁׁוֹאיא," TWOT 2:908.

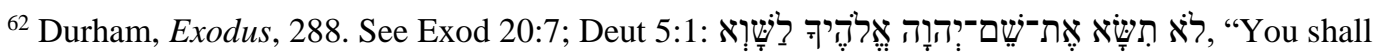

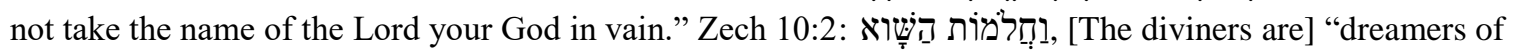
vanity." 
A Torn Animal (Exod 22:13 [Heb. v. 12])

In Exod 22:13 (Heb. v. 12), the word עִ appears in a secular context where a man delivers to his neighbor an animal to keep (Exod 22:10 [Heb. v. 9]), but the animal "is torn to pieces by a beast" (v. 13 [Heb. v. 12]), the neighbor is commanded to bring pieces of the torn animal as עִָד ,evidence," that he has not put his hands on the animal. This would be enough to liberate him to pay the torn animal. But this decision is given by the judges (v. 9 [Heb. v. 8]) who are placed to judge any kind of trespass. This judgment, though secular in nature, has a divine procedure in its development. So, what the judges decide is what God has commanded. Similarly, in the Code of Hammurabi, the laws 122 to 125 establish that whatever "a seignior" gives "for safekeeping" to another it has to be "in the presence of witnesses" and then "arrange the contracts" with the property committed for safekeeping. If the property is lost then the owner can claim it; but if the property is given "for safekeeping without witnesses and contracts ... that case is not subject to claim.. ${ }^{93}$ But on the whole, both legislations prescribe to make restitution to the owner if his property is stolen. However the legislation of Exod 22:13 (Heb. v. 12) addresses the issue of a stolen or torn animal, and the Code of Hammurabi is about "any sort of thing," including silver and gold. Thus, in the former, any piece of a torn animal is taken as sufficient evidence to clear the guilty, while in the latter the law contemplates from the beginning of the transaction the presence of human beings as witnesses to mediate between the parties.

\footnotetext{
63 “The Code of Hammurabi," (ANET 171).
} 
A False Witness (Exod 23:1,2)

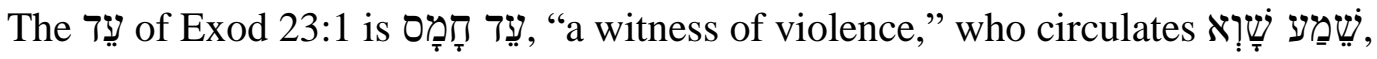
"a false report," and takes part in court with the wicked, either for his own cause or the

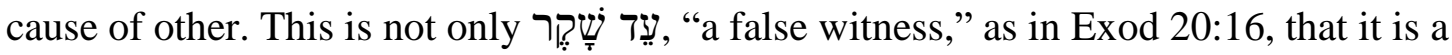
description of somebody who lies in court and wait for a judicial decision; but he also stands to defend the guilty, even spreading the earth with דָָָָ, "violence." Accordingly, the BDB says that this is a "witness that promotes violence and wrong." ${ }^{\circ}$ On his part, Ringgren tries to know who the עִד דָמָס is; which it could "be directed to all the members of the community who are involved in a legal matter" or the judges and/or the witnesses. ${ }^{65}$ The most important of Ringgren's quest is that he interprets the action of the "witness of murder" (עָָד חָָָס) "as the plaintiff who is thinking of attempted murder.,"66

The regulation of Exod 23:1 is heightened by the word ריב in v. 2: "You shall not follow the crowd to do evil; nor shall you testify in a dispute (ריב)..." This word has been translated mainly as "lawsuit" (ESV; NAB; NIV; NJB; NRS) or "dispute" (NAS; ריב

${ }^{64}$ BDB 329. Cf. M. E. Andrew, "Falsehood and Truth: An Amplified Sermon on Exodus 20:16," Int 17 (1963): 425-38.

${ }^{65}$ Ringgren, TDOT 10:501, 502.

${ }^{66}$ Ibid., 501. Also K\&D 1:144, say "that raising a false report furnishes the wicked man with a pretext for bringing the man, who is suspected of crime on account of this false report, before a court of law; in consequence of which the originator or propagator of the empty report becomes a witness of injustice and violence." 
means "quarrel" which "can involve two individuals (Ex. 21:18) or several persons" which "reached an amicable settlement." 67

Another feature of Exod 23:1 is that the ריב happens in court, while in Deut 25:1,

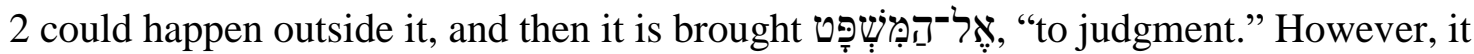
is clear that the רִיב in part of the which it is settled. Thus, the judgment, as a subsequent part of the dispute, applies justice for the righteous, and punishment for the wicked; but this punishment is applied according to the wickedness. ${ }^{68}$

Culver says that ריב has at least five meanings: (1) "To strive in the sense of physical combat" which is apparently the primary meaning (Exod 21:18; Deut 33:7); (2) "Combat, i.e. to quarrel, to chide" (Gen 26:20; 31:36; Exod 17:2); (3) "A legal-judicial significance and strangely, usually with God as acting subject" (Isa 13:13); (4) "Lie in wait or set an ambush" (1 Sam 15:5); and (5) “To complain” (Jer 2:29; 12:1; Job 33:13). ${ }^{69}$ The third classification applies for Exod 23:1 as a legal-judicial passage based on a human-human relationship; but with God's intervention who summons the people of Israel not to follow the crowd to do evil in a dispute.

\section{A Witness Who Does Not Want to Testify (Lev 5:1)}

The flip side of a witness in court is somebody who knows about "the utterance of an oath (אָדָהָ)" but prefers not to testify. Roy Gane explains that "a publicly proclaimed

\footnotetext{
${ }^{67}$ Ringgren, TDOT 13:474. Wenham, Genesis 1-15, 296 says that "ריב "may have the technical sense of legal dispute."

${ }^{68}$ Cf. Wright, Deuteronomy, UBCS (Grand Rapids, MI: Baker Book House, 2012), 264, 265.

${ }^{69}$ Robert D. Culver, “ריב,’TWOT 2:845-46.
} 
oath or (conditional) curse ('alah) of adjuration would serve notice that the call for witnesses was divinely enforced." 70

Gane agrees with T. Frymer-Kenski, and understands that this was "a general imprecation that demanded that anyone with knowledge step forward. Divine punishment would follow the person who knows something but keeps silent."71 Therefore, when in Israel somebody is a witness of any wrongdoing and hears an "oath" (אָרָה ) to testify, that person is under obligation to speak about it; otherwise, "he bears his guilt/iniquity (כָָָָאָ (ִַi).",

Accordingly, every citizen in Israel shall inform any wrongdoing in the community or he will be liable of a curse. ${ }^{72} \mathrm{~K} \& \mathrm{D}$ argue that this curse consists of "chastisements and judgments, by which God" punishes the sin. ${ }^{73}$

${ }^{70}$ Roy Gane, Leviticus, Numbers, NIVAC (Grand Rapids, MI: Zondervan, 2004), 124.

${ }^{71}$ T. Frymer-Kenski, "Israel," in A History of Ancient Near Eastern Law, HO 72, ed. R. Westbrook (Leiden: Brill, 2003), 2:994 in Gane, Genesis, Exodus, Leviticus, Numbers, Deuternonomy, ZIBBC, 1:295. This statement is in agreement with K\&D, 1:310, who say that " ָָרז does not mean a curse in general, but an oath, as an imprecation upon one's self (= the 'oath of cursing' in Num. [5] v. 21); and the sin referred to did not consist in the fact that a person heard a curse, imprecation, or blasphemy, and gave no evidence of it (for neither the expression 'and is a witness,' nor the words 'hath seen or known of it,' are in harmony with this), but in the fact that one who knew of another's crime, whether he had seen it, or had come to the certain knowledge of it in any other way, and was therefore qualified to appear in court as a witness for the conviction of the criminal, neglected to do so, and did not state what he had seen or learned, when he heard the solemn adjuration of the judge at the public investigation of the crime, by which all persons present, who knew anything of the matter, were urged to come forward as witnesses." Cf.

Tremper Longman and David E. Garland, eds., Genesis-Leviticus, EBC 1 (Grand Rapids, MI: Zondervan, 2008), 619.

${ }^{72}$ Cf. John Hartley, Leviticus, WBC 4 (Nashville, TN: Thomas Nelson, 1992), 68. Wenham, The Book of Leviticus, NICOT (Grand Rapids, MI: Eerdmans, 1979), 100, states that "this phrase commonly refers to sin and its punishment. Here it probably refers to the fulfilment of the curse, pronounced against witnesses who fail to come forward.... When the man starts to see the curse coming true, he feels guilty and then brings his offering."

${ }^{73} \mathrm{~K} \& \mathrm{D}, 2: 310$. 
The lack of witness in a trial is explained in Num 5:11-31 in which a man

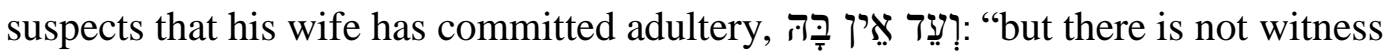
against her" (v. 13). Thus the man has no way to prove the supposed unfaithfulness of his wife. Nevertheless, under a spirit of jealousy (v. 14), he is allowed to bring her before the priest (v. 15) who puts her under the law of jealousy to test whether she has been unfaithful (vv. 16-31). ${ }^{74}$

In the whole ritual process, the priest puts the woman under ארר (v. 18), so "he

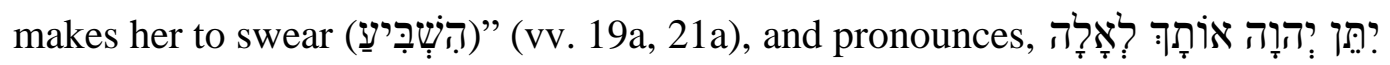

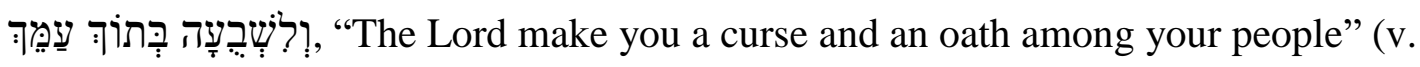
21b), to which "the woman shall say, amen, amen (אָמָן אָָָן)" (v. 22b). After this she drinks the water to test her faithfulness (vv. 24-31). As nobody is able to provide a witness, God takes part in this trial, acting as witness and judge. Therefore, the woman is

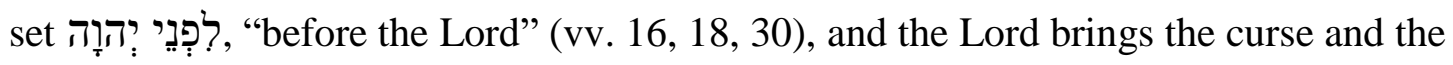

${ }^{74}$ See Noth, Numbers: A Commentary, OTL (Philadelphia, PA: Westminster, 1968), 49, who argues, "Divine judgments of this kind were known throughout the ancient Near East, especially in Mesopotamia. Nowhere, however, is there found an exact parallel to the present legislation." Accordingly, Timothy R. Ashley, The Book of Numbers, NICOT (Grand Rapids, MI: Eerdmans, 1993), 123, explains some practices in the ancient world that scholars call "trial by ordeal." And then, adds that "the ordeal was related to divination as a method for discovering the divine will for a course of action. The most common ordeals in the ancient world seem to be by water (e.g., plunging into rivers), by heat (e.g., carrying a redhot object or plunging the hand into boiling liquid), and by the action of some potion." However, Ashley explains that "differences between institutions, texts, etc., are likely to be at least as significant as similarities." On the same page he clarifies those differences.

For an analysis of ANE cultures which use curse in a trial cf. Julian Morgenstern, "Trial by Ordeal among the Semites in Ancient Israel," HUCA Special Issue (1925): 113-43; Jack M. Sasson, "Numbers 5 and the Waters of Judgment," BZ 16 (1972): 249-51; Michael Fishbane, "Malediction and Benedictions in the Ancient Near Eastern Vassal-Treaties and the Old Testament," ZAW 74 (1962): 1-19; ibid., "Accusations of Adultery: A Study of Law and Scribal Practice in Number 5:11-31," HUCA 45 (1974): 2545; T. Frymer-Kensky, “The Strange Case of the Suspected Sotah," VT 34 (1984): 11-26; Malu, "More on pachad vitschāq: 192-200; Philip J. Budd, Numbers, WBC 5 (Waco: TX: Word Books, 1984), 60-67. 
oath into a reality when it is proved that the accusation is true (v. 21b). On his part, Noth explains that "such as divine judgment was envisaged for those cases in which the question of guilt or innocence could not be clarified by human means."

It cannot be proven that the water in itself has a magical power, but through it God inflicts curse or blessing to the woman who has been put under oath (vv. 19-22, 27, 28). So, whatever happens to her has nothing to do with magic in the water but with God performing his divine judgment. Davidson calls this a "miraculous divine intervention.""76 This is the reason why he also says that this is "a striking legal case."77 Concerning this practice the Code of Hammurabi stipulates in Laws 131 and 132 as follows,

If a seignior's wife was accused by her husband, but she was not caught while lying with another man, she shall make affirmation by god and return to her house.

If the finger was pointed at the wife of a seignior because of another man, but she has not been caught while lying with the other man, she shall throw herself into the river for the sake of her husband. ${ }^{78}$

In the Code of Hammurabi the river has divine power, which means that even innocent women could be drawn into it. Thus, justice depends on the ability of the accused woman to swim. But in Israelite's court, the whole process is made before God who answers with blessings or curses depending on the faithfulness or unfaithfulness of the defendant.

\footnotetext{
${ }^{75}$ Noth, Numbers, 48, 49. Cf. Walter Riggans, Numbers (Philadelphia, PA: Westminster, 1983), 47-51.

${ }^{76}$ Davidson, Flame of Yahweh: Sexuality in the Old Testament (Peabody, MA: Hendrickson, 2007), 352.

${ }^{77}$ Ibid., 349. Cf. also ibid., 245.

${ }^{78}$ Code of Hammurabi $(A N E T, 171)$.
} 
More than One Witness (Num 35:30;

Deut 17:2-7; 19:15)

The requirement of more than one witness for a trial is established in Num 35:30, and repeated in Deut 17:6, 7 and 19:15 but with different details. ${ }^{79}$ The context of Num 35:30 suggests that a person who kills another accidentally could flee to a city of refuge (v. 15). In this accident nobody can prove a previous hate or jealousy from the manslayer, and it could be said also that the requirement of at least two people to testify is not accomplished (Num 35:22, 23; cf. Deut 19:15). Once the manslayer is in the city of refuge he is taken to have a trial with the avenger of blood (Num 35:24). Because of the lack of witnesses, the congregation is ordered to deliver the manslayer from the hand of the avenger of blood (v. 25). On the other hand, if that would not be the case, then the manslayer could die on the testimony of two or more witnesses when "he stands before

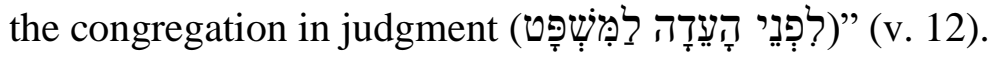

This practice is explained again in Deut 17:6, 7, but with different details. While Num 35:30 is specifically about a הרצצָ (“murderer”), the context of Deut 17:6, 7 specifies that the capital punishment is for those who sacrifice an imperfect animal (v. 1), transgress the covenant (v. 2), or worship idols (vv. 3-5); however, it is not God who brings sinners to judgment but other human beings (vv. 6, 7). Therefore, this is a mixed trial in which a person transgresses God's law but the accusation is brought to the court

${ }^{79}$ Cf. Tigay, Deuteronomy, 163; Ashley, The Book of Numbers, 655; Budd, Numbers, 384; Noth, Numbers, 256. In Num 5:13 there is not even one witness to accuse; nevertheless, a husband is allowed to bring his wife to the priest to put her fidelity to test. God has now the authority to vindicate or punish. 
by human witnesses, and after the verification of the allegation then a verdict is given by God, and executed by the people.

It is clear that Num 35:30 is a legislation based on a human-human relation, and

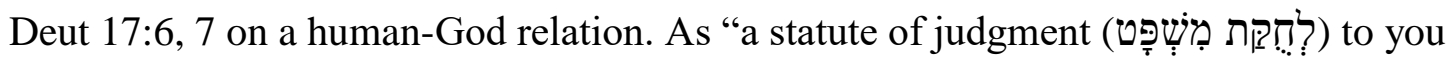
throughout your generations" (Num 35:29), God explains that "the hands of the witnesses shall be the first against" the wicked person, "and afterward the hands of all the people (Deut 17:7). ${ }^{180}$ On the other hand, Deut 19:15 which also requires the accusation of at least two witnesses to establish a case, is a general statement in a human-human trial. The rationale is to avoid a false witness that may rise in court (v. 16).

The Law on This Side of the Jordan (Deut 4:44, 45)

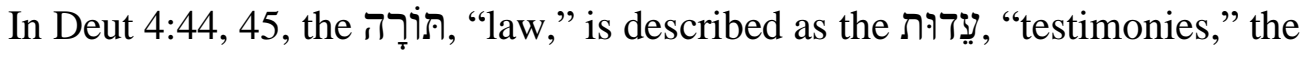

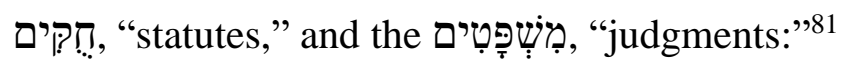

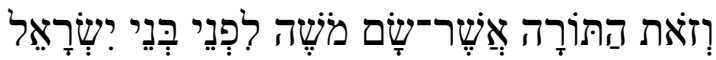

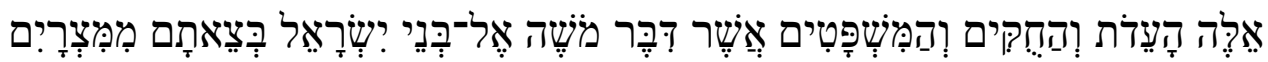

These two verses are translated this way: "And this is the law which Moses set before the children of Israel" (v. 44); and "These are the testimonies, and the statutes, and the judgments which Moses spoke to the children of Israel when they came out of Egypt"

${ }^{80}$ Cf. Von Rad, Deuteronomy, 117, who explains: "If the witnesses are to initiate the carrying out of the sentence, they expose themselves in the case of false evidence to the serious danger of blood revenge." See also ibid., 129; Craigie, The Book of Deuteronomy, 250-51. This matter is explained later in this dissertation under "If a False Witness Rises" (pp. 133-35).

${ }^{81}$ Weinfeld, Deuteronomy 1-11, AB 5 (NY: Doubleday, 1991), 234, translates תרֹ "teaching." Cf. John Barton, "Law and Narrative in the Pentateuch," CV 51 (2009): 126-40. 


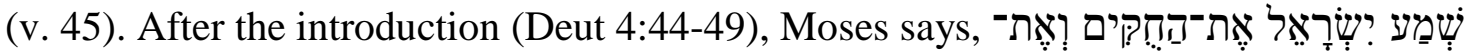

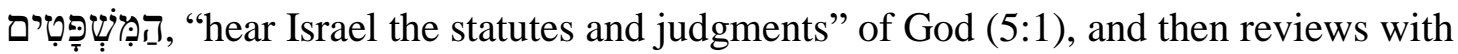

them the Ten Commandments (5:1-22) which he has referred to already as a "covenant"

(4:13). ${ }^{82}$ This elaborated way of thought could mean that throughout the book of

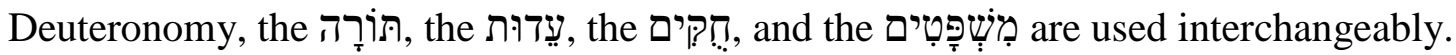

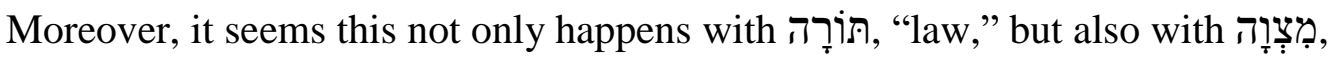

"commandment." 83

${ }^{82}$ Notice that the wording which Moses uses in Deut 5:2-5 is similar to Exod 19:9-25; 20:18-20.

${ }^{83}$ Craigie, The Book of Deuteronomy, 146, agrees with this interpretation of the text, saying that Deut 4:44 "refers to all the law that is about to be presented in chs. 5-26. The law about to be presented is then clearly identified as the same law (testimonies, statues, and judgments) that was proclaimed to the Israelites at Horeb/Sinai after the Exodus from Egypt (v. 45); it is not a new covenant in Deuteronomy, but the renewing of an old covenant."

Sailhamer, The Pentateuch, 423, affirms that Deut 1:5 is a key passage to understand the book of Deuteronomy. In this passage is clear that Deuteronomy is not merely a repetition of the law but an explanation of it or "a commentary on the earlier passages of the Pentateuch." Further on ibid., 435 Sailhamer adds that the purpose of Deut 4:44-49 "is to distinguish between the introductory material of the first three chapters [of Deuteronomy] and the exposition of the Law itself in the subsequent chapters."

Fretheim, The Pentateuch, IBT (Nashville, TN: Abingdon, 1996), 157-60, suggests that one of the structures of Deuteronomy "relates to the ordering of commandments and statues," and argues that "in Deuteronomy the arrangement of the statues in chaps. 12-26 appears to follow the ordering of the Decalogue." Thus in Deut 1:5 and 4:44 the word torah "means more than law or statue, or even instruction in its basic sense. . . The statutes are considered more as witnesses to the will of God than prescriptions with statutory force."

Daniel I. Block, "The Grace of Torah: The Mosaic Prescription for Life (Deut 4:1-8; 6:20-25),"

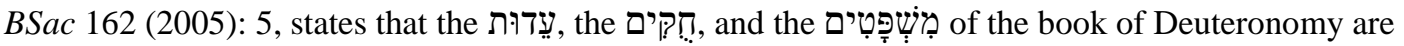
expressions which "represent the will of God as it had been revealed primarily at Horeb and to a lesser degree en route to the Promised Land. They point to all the moral, ceremonial, and civil regulations God prescribed as the appropriate response to His salvation and the privilege of covenant relationship." Cf. Ibid., Deuteronomy, 58, 152, 153.

Gerald Eddie Gerbrandt, Deuteronomy, BCBC, ed. Douglas B. Miller and Loren L. Johns (Harrisonburg, VA: Herald, 2015), 125, indicates that the teaching in Deut 4:44-49 is labeled torah as in ch. 1:5, and then says: "Three further terms supplement the general designation of torah: the decrees [RSV, testimonies] and the statutes and ordinances (4:45). These terms are largely synonyms within Deuteronomy even though originally they may have had distinct connotations."

Ajith Fernando, Deuteronomy: Loving Obedience to a Loving God, Preaching the Word; ed. R. Kent Hughes (Wheaton, IL: Crossway, 2012), 156, 157, says, “' 'Law' here [in Deut 4:44, 45] is Torah, which is 'a general term for the whole law.' 'Testimonies,' 'statutes,' and 'rules' refer to the different 'specific stipulations' of that law. These two verses introduce what is going to follow."

Stephen L. Cook, Reading Deuteronomy: A Literary and Theological Commentary (Macon, GA: Smith \& Helwys, 2015), 59, calls these words a "rich legal vocabulary." On their part, Waltke and Yu, $A n$ 
Taking that reasoning into account, in table 7, the list of verses shows the intention of the book of Deuteronomy in the parallelism of these words: ${ }^{84}$

Table 7. "Commandments," "testimonies," "statutes," "judgments"

\begin{tabular}{|c|c|c|c|c|}
\hline Deuteronomy & "Commandments" & "Testimonies" & "Statutes" & "Judgments" \\
\hline $4: 45$ & & עֵדוּּת & חדֶקִים & מִֹשָָּּטִים \\
\hline $5: 1$ & & & חָחְקים & 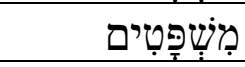 \\
\hline $5: 31 ; 6: 1$ & מִצְצְוָה & & חִקְּים & 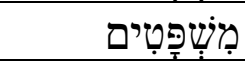 \\
\hline $6: 17$ & מִצְוֹת & עיכדוּת & חְִִּים & \\
\hline $6: 20$ & & עֵדוּת & חְִּּים & 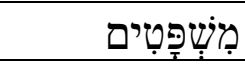 \\
\hline $6: 24$ & & & חָחְקִים & \\
\hline $6: 25$ & מִצִצְוָה & & & \\
\hline $7: 12$ & & & & 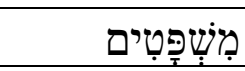 \\
\hline $8: 1$ & מִצְצְוָה & & & \\
\hline $8: 6$ & מִצִּוֹת & & & \\
\hline $8: 11$ & מִצְוֹת & & חִחקָת & 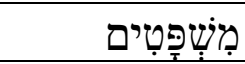 \\
\hline $10: 13$ & מִצְצְוָה & & חִחקְקת & \\
\hline 11:8 & מִצְָּוה & & & \\
\hline $11: 13$ & מִצְוֹוֹת & & & \\
\hline $11: 22$ & מִצְְָָּה & & & \\
\hline
\end{tabular}

Old Testament Theology, 500 say that torah includes statutes, judgments, apodictic laws, and commands; but later they say that only "the last two terms are interchangeable." It is difficult to know the rationale of this conclusion because they do not explain it.

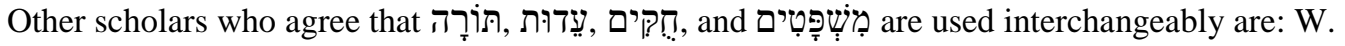
Gunther Plaut, "Deuteronomy," in The Torah: A Modern Commentary, ed. W. Gunther Plaut (NY: UAHC, 1981), 1354; Bruce C. Birch et al., A Theological Introduction to the Old Testament (Nashville, TN: Abingdon, 1999), 148-49; Martin J. Selman, "Law," in Dictionary of the Old Testament: Pentateuch, ed. T. Desmond Alexander and David W. Baker (Downers Grove, IL: InterVarsity, 2003), 499, 500; Eugene H. Merrill, "Deuteronomy," in Tyndale Cornerstone Biblical Commentary, ed. Philip W. Comfort (Carol Stream, IL: Tyndale, 2008), 456, 497, 507.

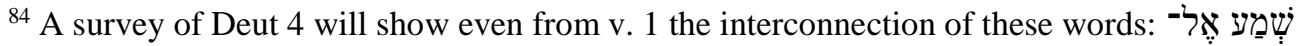

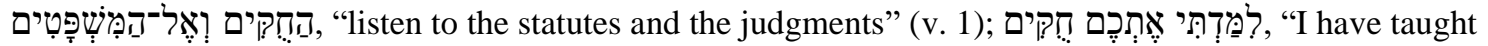

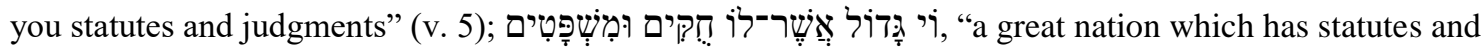

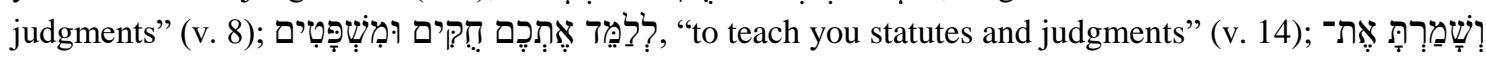

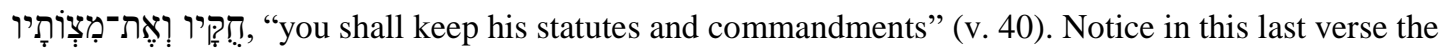

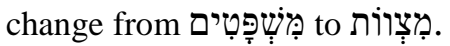




\section{Table 7-Continued}

\begin{tabular}{|c|c|c|c|c|}
\hline Deuteronomy & "Commandments" & "Testimonies" & "Statutes" & "Judgments" \\
\hline $11: 27,28$ & תמִִ & & & \\
\hline $12: 1$ & & & חִקְים & מִּשְׁפָּטִים \\
\hline $16: 12 ; 17: 19$ & & & חִקים & \\
\hline $26: 16$ & & & חִִּקים & 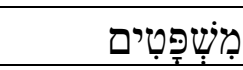 \\
\hline $27: 10$ & מִצ̦וֹת & & חִקים & \\
\hline $28: 1,9,13$ & מִצִưוֹת & & & \\
\hline $28: 15,45$ & מִצְוֹת & & חיחקת & \\
\hline $30: 8$ & 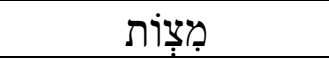 & & & \\
\hline $30: 10$ & מִִּּוֹת & & ח חקקת & \\
\hline $30: 16$ & מִưוֹת & & ח חקקת & 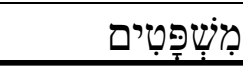 \\
\hline
\end{tabular}

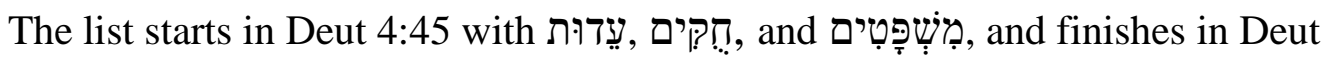

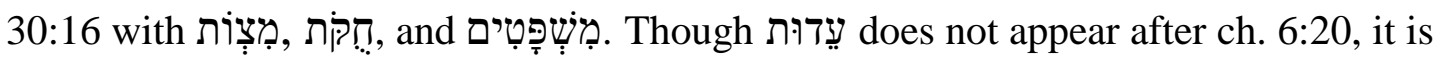
also true that in Deuteronomy there is no intention to use every word in one verse. ${ }^{85}$ The way in which these terms are used may suggest that they are rendered as synonyms or used interchangeably and constitute an expansion of what it is called הַּּוֹרָה, "the law," in ch. 4:44 and הָדברִרית, "the covenant," in ch. 29:1.

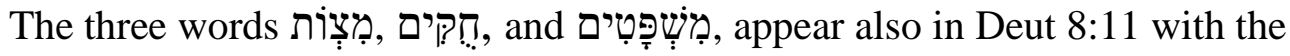
difference that is in feminine and differs "in shade of meaning" from ${ }_{\text {n }}{ }^{87}$ As table

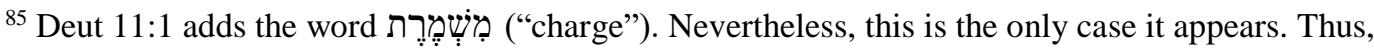
it is an exception to the rule. This word is used extensively in the book of Numbers, generally in relation to the Levites and their charge of the tabernacle (i.e. Num 1:53; 3:7, 8; 3:28, 32, 36, 38; 4:31, 32; 8:26; 9:19, $23 ; 18: 4,5,8 ; 31: 30,47)$.

${ }^{86}$ Cf. Tyler F. Williams, “צוה," NIDOTTE 3:779; Craigie, The Book of Deuteronomy, 146.

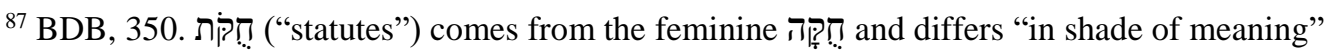

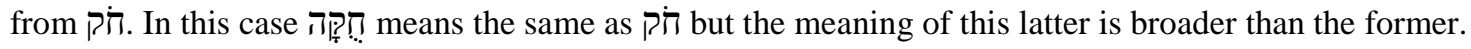




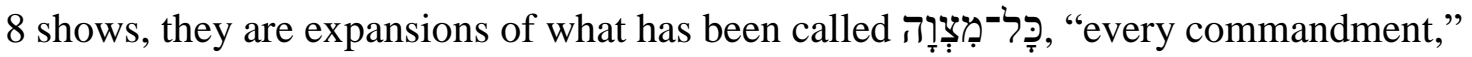
in Deut 8:1, and מְְִִוֹ, “commandments," in ch. 8:6:

Table 8. Deut 8:1, 6, 11

\begin{tabular}{|l|l|}
\hline Deut $8: 1$ & $\begin{array}{l}\text { "Every commandment which I command you today you must be careful } \\
\text { to observe" }\end{array}$ \\
\hline Deut 8:6 & "Therefore you shall keep the commandments" \\
\hline Deut 8:11 & $\begin{array}{l}\text { "Beware that you do not forget the Lord your God by not keeping his } \\
\text { commandments, his judgments, and his statutes" }\end{array}$ \\
\hline
\end{tabular}

This composition of words throughout Deuteronomy shows at the end of the book the blessings and curses for keeping or not keeping God's commandments as described in chs. 27-28, where curses and blessings are pronounced with the אָרוּר formulae.

On the one hand, the אָ formula appears 25 times in the Pentateuch, with 18 (72 percent) occurrences in Deut 27-28. Although Lev 26 has similar curses, the אָּרוּ formula only occurs in Deut 27-28. ${ }^{88}$

${ }^{88}$ Key words of Lev 26 are also "covenant" (vv. 9, 15, 25, 42, 44, 45; eight times); "statutes" (vv. 3, 15, 43, 46; four times); "commandments," (vv. 3, 14, 15; three times); and "judgments" (vv. 15, 43, 46; three times). The confirmation or breaking of the covenant depends upon the keeping of God's statues, commandments and judgments. In Lev 26 God requires Israel five things: (1) The children of Israel are forbidden to make idols and worship them (v. 1); (2) they shall keep God's Sabbaths (v. 2a); (3) reverence God's sanctuary (v. 2b); (4) walk in God's statutes (v. 3a); and (5) keep God's commandments (v. 3b). If the people of Israel do those things, God's covenant would be confirmed (v. 9); therefore, blessings would be the result of it (vv. 4-13). But the contrary would be true also: If they disobey, then curses are at hand because the covenant has been broken (vv. 14-39). As Cornelis Van Dam, "נכה,," NIDOTTE 3:102, says: God warns "that he would afflict (נכה) his people for their sins seven times over (Lev 26:24)." Cf. Noth, Leviticus: A Commentary, OTL, rev. ed. (Philadelphia, PA: Westminster, 1965), 196; Hartley, Leviticus, 461, 462; Gerstenberger, Leviticus: A Commentary, OTL (Louisville, KY: Westminster John Knox, 1996), 406, 409; Jacob Milgrom, Leviticus 23-27: A New Translation with Introduction and Commentary, AB 3B (Doubleday: NY: Doubleday, 2001), 2286-287. 
Von Rad explains that the twelve curses or אָרוּ formulas in Deut 27:14-26 were considered "to be a real destructive power" ratified by twelve "amens" affirming that "the cultic community accepts the situation produced by the curses which have been proclaimed." 89 On his part, Scharbert mentions that these twelve curses are "used as a ratification of the Yahweh-covenant regulations governing the whole life of Israel, which were proclaimed in the cult." 90 Table 9 tests these arguments:

Table 9. Subject-object-punishment of the Pentateuchal אָרוּר formula

\begin{tabular}{|l|l|l|}
\hline \multicolumn{1}{|c|}{ Passages } & \multicolumn{1}{|c|}{ Subject-Object } & \multicolumn{1}{c|}{ Punishment } \\
\hline \hline Gen 3:14 & God to the Serpent & $\begin{array}{l}\text { The serpent is condemned to go } \\
\text { on its belly and eat dust }\end{array}$ \\
\hline Gen 3:17 & God to the ground & $\begin{array}{l}\text { It will produce thistles, and it will } \\
\text { be hard for man to get produce } \\
\text { from it }\end{array}$ \\
\hline Gen 4:11 & God to Cain & Cain shall be a fugitive \\
\hline Gen 9:25 & Noah to Canaan & $\begin{array}{l}\text { Canaan shall be a servant of } \\
\text { servants }\end{array}$ \\
\hline Gen 27:29 & Isaac to those who curse Jacob & $\begin{array}{l}\text { Those who curse Jacob will be } \\
\text { cursed }\end{array}$ \\
\hline Gen 49:7 & Jacob to Simeon and Levi & $\begin{array}{l}\text { Jacob curses the anger of Simeon } \\
\text { and Levi }\end{array}$ \\
\hline Num 24:9 & $\begin{array}{l}\text { Balaam to those who curse } \\
\text { Israel }\end{array}$ & $\begin{array}{l}\text { Those who curse Israel shall be } \\
\text { cursed }\end{array}$ \\
\hline Deut 27:15-26 & $\begin{array}{l}\text { Israel's community to the } \\
\text { transgressors of the covenant }\end{array}$ & $\begin{array}{l}\text { Those who act wickedly toward } \\
\text { God, neighbors and animals shall } \\
\text { be cursed }\end{array}$ \\
\hline Deut 28:15-19 & $\begin{array}{l}\text { Israel's community to the } \\
\text { transgressors of the covenant }\end{array}$ & $\begin{array}{l}\text { Those who do not observe God's } \\
\text { commandments and statutes will } \\
\text { be cursed in their civil life, } \\
\text { fertility, and business }\end{array}$ \\
\hline \hline
\end{tabular}

${ }^{89}$ Von Rad, Deuteronomy, 167. Cf. Craigie, The Book of Deuteronomy, 331; Tigay, Deuteronomy, 253, 254; Wright, Deuteronomy, UBSC, 277.

${ }^{90}$ Scharbert, "ארר," TDOT 1:410, limits his commentary to vv. 16-25 where there are ten curse formulas. He believes that this ten curse formulas are "analogous to the decalogue in Dt. 5." Cf. Noth, Leviticus, 196. 
In Deut 28:15-19 Moses have registered six formulae intended to punish those who have broken the covenant by not observing God's commandments and statutes. These curses affect the "whole realm of life" and their ultimate consequence is "the exclusion of a person from the community" because he has broken "a commandment, a commonly accepted responsibility, or a far-reaching legal or ethical demand."91 Gordon explains that Deut 27-28 are "pronouncement of curses of both the deterrent and judicial types ... where long series of curses, in a manner redolent of the Near Eastern vassal treaties, warn against Israel's defection from the God who has conferred his benefits on her and has brought her into a covenant relationship with himself.",92

In the Pentateuch not only God pronounces the אָרוּר formula, but also those who articulate it believe that he is the one who puts it to work. Thus, Hamilton adds,

It will be observed that the majority of 'curse' sayings with 'arar fall into one of three general categories: (1) the declaration of punishments (Gen 3:14, 17); (2) the utterance of threats (Jer 11:3; 17:5; Mal 1:14); (3) the proclamation of laws (Deut 27:15-26; 28:16-19). It is interesting that all these curse-sayings are reflex of one violating his relationship to God..$^{93}$

Josef Scharbert accepts that the religious significance of the אָר formula is based on "that the will of God, divine judgment, and divine acts of vengeance proclaimed in the judicial system, in ethics, and in religion are executed. ${ }^{94}$ Meanwhile, Robert P.

${ }^{91}$ Scharbert, TDOT 1:409. Cf. Wenham, Genesis 1-15, 78.

92 Gordon, “ארר," NIDOTTE 1:525.

${ }^{93}$ Hamilton, "ארר," TWOT 1:75. Wenham, Genesis 1-15, WBC (Waco, TX.: Word Books, 1987), 78 , says that "in the Bible, to curse means to invoke God's judgment on someone, usually for some particular offense. Thus various grave but secret sins, for which it would be difficult to secure conviction in court, are cursed in Deut 27:15-26."

${ }^{94}$ Scharbert, TDOT 1:417. 
Gordon accepts that in the ארר root "the curse operates as deterrent and as judgment."95

On the other hand, the אָר formula has its antithesis in the formula which is also in the qal passive participle. As the curse-formula is expressed to exclude anyone from the community, table 10 shows that the solidarity with the one who is blessed, and it is also "suited to express acknowledgement of Israel's covenant God."96

Table 10. Subject-object-reward of the Pentateuchal จฺּ formula

\begin{tabular}{|c|c|c|}
\hline Passages & Subject-Object & Reward \\
\hline Gen 9:26 & Noah-God & Solidarity upon Shem \\
\hline Gen 14:19 & $\begin{array}{l}\text { Melchizedek- } \\
\text { Abraham }\end{array}$ & $\begin{array}{l}\text { Salutation and recognition of God as possessor of } \\
\text { his creation }\end{array}$ \\
\hline Gen 14:20 & Melchizedek-God & Salutation and recognition of God's blessing \\
\hline Gen 24:27 & Eliezer-God & Recognition of God's blessing upon Abraham \\
\hline Gen 24:31 & Laban-Eliezer & Salutation and solidarity \\
\hline Gen 26:29 & Abimelech-Isaac & Recognition of God's blessing \\
\hline Gen 27:29 & Isaac-Jacob & $\begin{array}{l}\text { The far-reaching limit of God's blessing: } \\
\text { "Blessed be those who bless you!" }\end{array}$ \\
\hline Gen 27:33 & Isaac-Jacob & Recognition of God's blessing \\
\hline Exod 18:10 & Jethro-God & Recognition of God's blessing upon Israel \\
\hline Num 22:12 & God-Israel & $\begin{array}{l}\text { Recognition and affirmation of God's blessing } \\
\text { upon Israel }\end{array}$ \\
\hline Num 24:9 & Balaam-Israel & $\begin{array}{l}\text { The far-reaching limit of God's blessing: } \\
\text { "Blessed is he who blesses you" }\end{array}$ \\
\hline Deut 7:14 & God-Israel & Increased cattle, healthy people \\
\hline $\begin{array}{l}\text { Deut 28:3-6 } \\
\text { (six times) }\end{array}$ & God-Israel & $\begin{array}{l}\text { Blessings in the city, in the country, more } \\
\text { children, in the produce of their ground, } \\
\text { increasing of herds and cattle and their offspring, } \\
\text { the basket and kneading bowl, and their coming } \\
\text { in and going out }\end{array}$ \\
\hline Deut 33:20 & Moses-Gad & $\begin{array}{l}\text { The far-reaching limit of God's blessing: } \\
\text { Blessing to he who enlarges Gad }\end{array}$ \\
\hline Deut 33:24 & Moses-Asher & He is most blessed of sons \\
\hline
\end{tabular}


The formula in Deut 28:3-6 works “on the condition of fidelity to Yahweh's covenant law."97 God's blessings include "human prosperity and well-being; long life, wealth, peace, good harvests, and children." 98 Wenham concludes, "What modern secular man calls 'luck' or 'success' the OT calls 'blessing,' for it insists that God alone is the source of all good fortune." 99

Martin Noth recognizes the "close parallels" between Deut 28 and the Code of Hammurabi. He states that the ending with "blessing and curse had its pattern in the Code of Hammurabi." ${ }^{100}$ He stretches this comparison even with the Hittite treaties affirming that "in international treaties, divinities who stood above the parties to the treaty and

${ }^{97}$ Ibid., 287.

98 Wenham, Genesis 1-15, 275.

99 Ibid.

${ }^{100}$ Noth, The Laws in the Pentateuch, 122. McCarthy, Treaty and Covenant, 179, 180, outlines Deut 28 as follows:

I. Blessings (1-14)

A. Condition governing blessings (1-2)

B. Results: the blessings (3-13a)

1. Impersonal formulations (3-6)

2. Personal: Yahwe acts (7-13a)

A'. Condition repeated (13b-14)

II. Curses (15-68)

A. Condition governing curses (15)

B. Results: the curses (16-44)

1. Impersonal formulations (16-19)

2. Personal: Yahweh acts (20-29)

a. $\quad$ Development (different agent) of topic sentence in 29 (30-34)

2'. Personal: Yahweh acts (35-37)

a'. $\quad$ Development (different agent) of topic sentence in 37 (38-44)

A'. Condition becomes fact: conclusion (45-46)

$\mathrm{A}^{2}$. Condition becomes fact: introduction (47)

B'. Results: Punishment (48-57)

1. Personal: Yahweh acts $(48 \mathrm{aB}-49 \mathrm{aA})$

a. Development: enemy and his acts (49aB-57) 
outlasted the treaty-making rulers were involved as guarantors, so that they could avert breaches of the treaty by implementing the curses included in the treaty document."101

“If a False Witness Rises" (Deut 19:16-21)

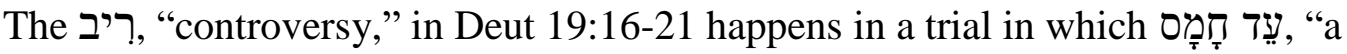
false witness," testifies against someone. This controversy starts outside the court; then, it is taken inside. Both men in the controversy "stand before the Lord, before the priests, and the judges who serve in those days" (v. 17), and then the priests and the judges make a decision based on what God has commanded. Therefore, this is a secular trial with religious implications, and the trial is based on a human-human controversy.

Moreover, Deut 19:16-21 takes portions of the wording of Exod 20:16 and 23:1. In Deut 19:16 the construction עָּד דָדָסט, "witness of violence," is employed as in Exod

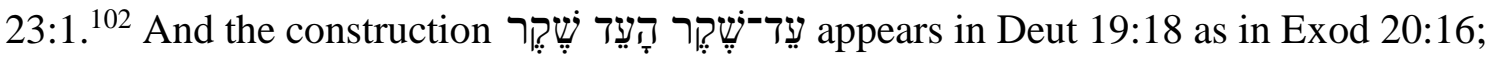
and again שֶֶׁ? is translated in English versions as a qualifier.

Though Exod 23:1 does not say what would happen to the "witness of violence," Deut 19:18, 19 indicates that he will be paid in the same way as he wanted the accused to

$\mathrm{A}^{3}$. Condition governing punishment (58)

$\mathrm{B}^{2}$. Results: Personal acts of Yahweh (59-68)

${ }^{101}$ Noth, The Laws in the Pentateuch, 123. Noth also compares the treaties of Mattinaza of Mittani, Suppiluluima with Tette of Nuhašše, Supiluliuma with Aziru of Amurru; Muršiliš with DuppiTešup of Amurru, Muršiliš with Targašnalliš of Happalla, Muršiliš with Manapa-Dattaš, Muwattalliš with Alakšanduš of Wilusa and Hattušil with Ramses II (ibid., 124).

102 This Hebrew phrase has been translated as "malicious witness" (ESV; NAS; NIV; NRS; RSV); "false witness" (KJV; NKV); "unjust witness" (NAB); "false evidence" (NJB); "to testify maliciously" (TNK). 
be punished. This practice has its equivalent in the Code of Hammurabi. ${ }^{103}$ However, they are also different:

While the biblical law is based ultimately upon decisions of either God or human beings (priests and judges), the Code of Hammurabi allows the opportunity for magical forces to intervene in the trial. Taking into account the danger of being a false witness, Durham explains:

The false witness was inimical to the relationship with Yahweh, upon which everything, including the very being of the Israelite, was dependent. The reputation of the neighbor was important, just as the Israelites' own reputation was important, of course. But however important these reputations were within the community, they were important to Yahweh most of all, for these people, as his people, were to be his witness to the world. ${ }^{104}$

In order to establish the falsehood or veracity of a testimony, further investigation was required and despite the fact that both men (the plaintiff and the defendant) appeared "before the Lord, before the priests and the judges who serve in those days" (v. 17), it seems that God allowed the judges to do their job making a "careful inquiry;" though part of their decision would be to look for God's answer.

${ }^{103}$ Meek in his translation of the "The Code of Hammurabi," 166, shows that Laws 1 to 4 say:

"I: If a seignior accused a(nother) seignior and brought a charge of murder against him, but has not proved it, his accuser shall be put to death.

"2: If a seignior brought a charge of sorcery against a(nother) seignior, but has not proved it, the one against whom the charge of sorcery was brought, upon going to the river, shall throw himself into the river, and if the river has then overpowered him, his accuser shall take over his estate; if the river has shown that seignior to be innocent and he has accordingly come forth safe, the one who brought the charge of sorcery against him shall be put to death, while the one who threw himself into the river shall take over the estate of his accuser.

"3: If a seignior came forward with false testimony in a case, and has not proved the word which he spoke, if that case was a case involving life, that seignior shall be put to death. of that case."

"4: If he came forward with (false) testimony concerning grain or money, he shall bear the penalty

${ }^{104}$ Durham, Exodus, 297. Cf. William H. C. Propp, Exodus 19-40, AB 2A (NY: Doubleday, 2006), 180 . 
Durham also repeats Klopfenstein's suggestion regarding the rationale of the difference between the Exodus and Deuteronomy versions. Durham says, "The Exodus version of his [God's] commandment refers more to the relationship of the witness toward a neighbor against whom he has given a perfidious report, while the version in Deuteronomy tends more to describe the malicious character of the witness himself." 105

However, Durham believes that Klopfenstein's suggestion “is more precise than the evidence in the OT will allow." $h \bar{a} m \bar{a} s$... refers to judicial violence, verbal action intended to harm another person. In (Deut 19) verse 18 this same person is characterized as a 'liar.' As in 17:6, the problem involves deflecting the legal process from the truth through 'false [empty] testimony." "107

The Song of Moses (Deut 31:19-21; 32)

The Song of Moses is called a witness "against the children of Israel" (Deut $31: 19,21)$. In this passage, God predicts to Moses the future rebellion of the people of Israel who will break the covenant after they enter Canaan (vv. 16, 20). Thus he

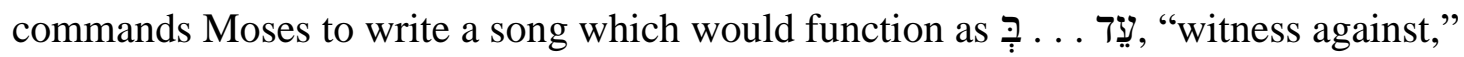
and לִפָנָָיו, "in the face of him (Israel)" (vv. 19, 21). Moses is called to teach Israel this

${ }^{105}$ Durham, Exodus, 296. Cf. Von Rad, Deuteronomy, 59.

${ }^{106}$ Durham, Exodus, 296. For a study of the Decalogue as a form of a Suzerain treaty see Mendenhall, "Ancient Oriental and Biblical Law," 26-46 and "Covenant Forms in Israelite Tradition," 5076; Eugene H. Merril, "ירד,," NIDOTTE 2:534. Contra Fretheim, Exodus, 208; John Van Seters, The Life of Moses: The Yahwist as Historian in Exodus-Numbers (Louisville, KY: John Knox, 1994), $253,254$. Weinfeld, TDOT 2:266, recognizes the analogy of Exod 19-24 with Hittite treaties but says that they are "not completely identical."

${ }^{107}$ Daniel I. Block, Deuteronomy, NIVAC (Grand Rapids, MI: Zondervan, 2012), 460, 461. 
song (v. 19), so, it would be a witness in their mouths (v. 21). ${ }^{108}$ This song is spoken in Deut 32, in which Moses starts calling heavens and earth to pay attention to him (v. 1).

While "Moses spoke in the hearing of all the assembly of Israel the words of this song until they were ended" (ch. 31:30), the people of Israel were spectators of a dialogue between Moses and the whole creation. The reason is that Moses summons heaven and earth to act as witnesses against Israel who has nothing more to do than listen to Moses's song. In this hearing, Israel is the accused while Moses is the plaintiff and God, the judge. ${ }^{109}$

Wright indicated that the Song of Moses (Deut 32), which is given in the form of a covenant lawsuit, is divided in five sections: (1) A summons to witness (v. 1); (2) An accusation framed as a question (v. 6); (3) A description of God's benefits to the accused (vv. 7-14); (4) A breach of covenant asserted (vv. 15-18); and (5) Sentencing and judgment (vv. 19-42). ${ }^{110}$

But a close look at Deut 32 will determine that Wright neglected v. 43 in which God calls the Gentiles to rejoice because: a) "He will avenge the blood of his servants," b) "render vengeance to his adversaries," and c) "provide atonement for his land and his people." Thus, v. 43 concludes that the Song of Moses is not only a covenant lawsuit with the people of Israel but also with the whole earth. Therefore, it is not a surprise that in v. 1 the song starts calling "heavens" and "earth" as witnesses, stating from the

${ }^{108}$ Cf. Craigie, The Book of Deuteronomy, 373, 374; Tigay, Deuteronomy, 295.

${ }^{109}$ Cf. Wright, "The Lawsuit of God," 26-67.

${ }^{110}$ Ibid., 26, 27. Examples of scholarly documents about Deut 32 are E. Baumann, "Das Lied Moses (Dt. XXXII 1-43) auf seine gedancliche Geschlossenheit untersucht," VT 6 (1956): 414-24; William Foxwell Albright, "Some Remarks," 339-46; Boston, "The Wisdom Influence," 198-202. 
beginning of the chapter the fullness of this declaration. Consequently, v. 43 is at the same time a promise of grace and final judgment in which God would cleanse his people and his land, punishing his adversaries, in order to give them rest on the earth.

The Book of the Law (Deut 31:24-26)

Also Moses asks the Levites to put the Book of the Law "beside the ark of the

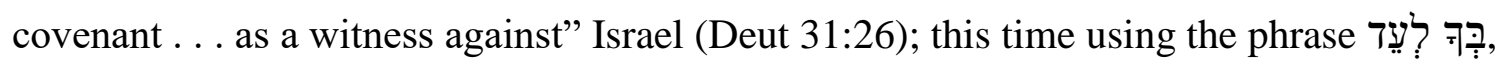
"for a witness against you." This function of the Book of the Law is based on the same rationale for which the song of Moses is written and taught (vv. 19-22). ${ }^{111}$

The fate of this trial has been pronounced beforehand: God's anger shall be aroused against the children of Israel, he will forsake them and "hide his face from them, and they will be devoured. And many evils and troubles shall befall them” (v. 17). Furthermore, Moses clarifies that "all the words of this law" are "all the words which I testify (מֵֵצידיד) against you today" (Deut 32:46). ${ }^{112}$

Though probably, in the reading of Deut 31 and 32, similar features are expressed for the "song" and for the "Book of the law," table 11 shows that some differences are displayed in those chapters that could clarify whether the "law" points out to the "song" of Moses or to the Book of the law:

${ }^{111}$ Craigie, The Book of Deuteronomy, 373, believes that the law of v. 24 is the song of v. 19.

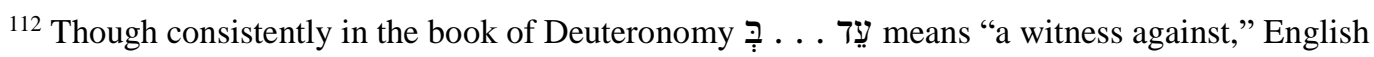

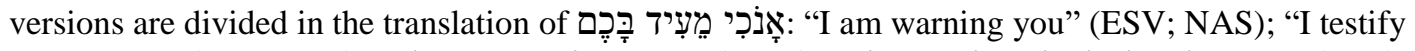
among you" (KJV; NKJ); "I have now given you" (NAB); "I have solemnly declared to you" (NIV); "I intend them ... to be evidence against you" (NJB); "I am giving in witness against you" (NRS); "I enjoin upon you" (RSV); "I have warned you" (TNK). The main disagreement is whether to translate the preposition $\underset{?}{?}$ as "among" or as "against" or even to establish whether it is positive, negative or neutral. 
Table 11. Song of Moses and the Book of the law

\begin{tabular}{|c|c|}
\hline Song of Moses (Deut 31:19, 21) & The Book of the Law (Deut 31:26) \\
\hline 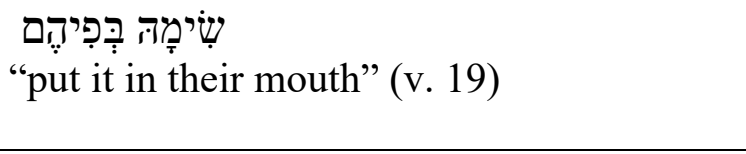 & 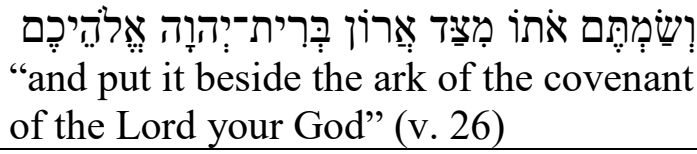 \\
\hline 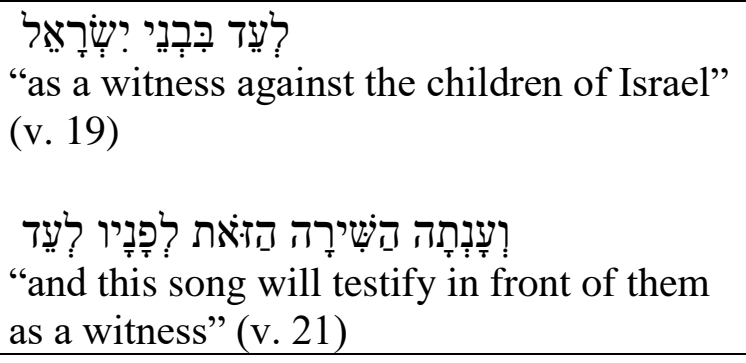 & 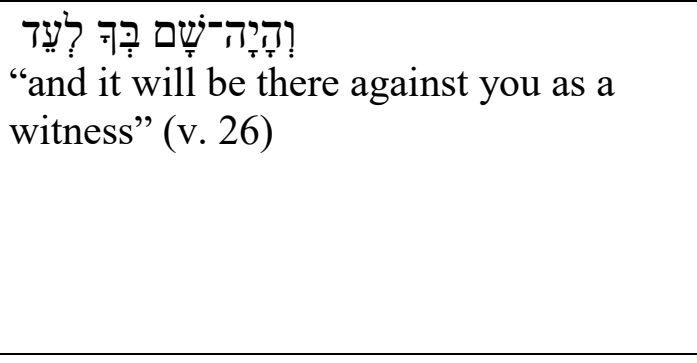 \\
\hline 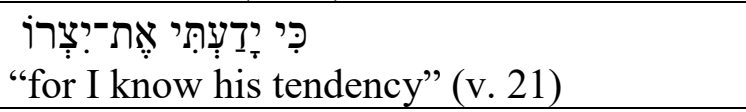 & 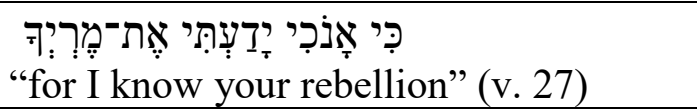 \\
\hline
\end{tabular}

About the equal and different functions between the law and the song of Moses,

Chisholm maintains,

In Deut 31 both the law scroll (v. 26) and Moses' song (vv. 19, 21; see Deut 32:143) serve as witnesses against Israel. If Israel breaks Yahweh's covenant, the law scroll can be brought forward as evidence supporting Yahweh's accusation, establishing Israel's guilt, and justifying divine judgment. Likewise Moses' song, which anticipates Israel's apostasy and God's judgment, would serve as an incriminating witness to Israel's ingratitude and as a verbal testimony vindicating Yahweh's implementation of the covenant curses. ${ }^{113}$

Therefore, the song of Moses, and the Book of the law have the same functions:

to be "witness against" the children of Israel because of their tendency and rebellion.

Nevertheless, the song is put in the "mouths of the children of Israel" while the Book of

the law is placed "beside the ark of the covenant."114

${ }^{113}$ Chisholm, NIDOTTE 3:338. Cf. Von Rad, Deuteronomy, 190; Tigay, Deuteronomy, 297, states, "Since the teaching is not personified in this paragraph, as the poem is in verse 21 , it is possible that 'ed, 'witness,' is used here in the related sense of 'evidence' (of the covenant)."

114 The deposition of the Book of the Law in the temple has its parallel feature in the Code of Hammurabi, 178: "In Esagila, which I love, may my name be spoken in reverence forever! Let any oppressed man who has a cause come into the presence of the statute of me, the king of justice, and then 


\section{Summary}

In the Pentateuch, the Hebrew word עֵ is introduced for the first time in feminine form (עָדָה) in Gen 21:30 in a rudimentary process of judgment in which Abraham gives sheep and oxen to Abimelech, a Philistine king, as a "witness" or "evidence" 115 that he has dug a well which Abimelech's servants have seized (Gen 21:25-32a). Accordingly, Abraham makes a covenant with Abimelech in order to stop the dispute. ${ }^{116}$ Though this covenant is similar in its structure to the parity treaty between Ramses of Egypt and Hattusilis of Hatti, Hittite treaties are free of judgment in their arrangement. Judgment could be mentioned during the making of the covenant, but in reality it is performed later if the covenant is broken.

Also, in the covenant between Jacob and Laban (Gen 31:44-52) the word

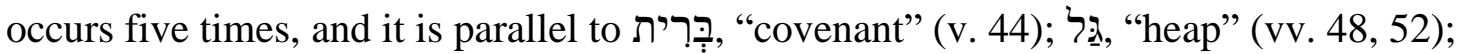

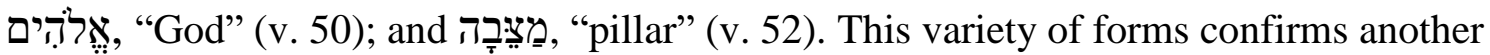
difference between treaties in the Pentateuch during Patriarchal times, and treaties in the ANE region. Though God is called to be a "witness" in this covenant, the list of pagan gods is excluded contrary to Laban's intention (v. 53).

On the other hand, the "covenant" is an agreement, and the "heap" and "pillar" are monuments rather than gods. At the same time, this covenant is also a parity treaty in

read carefully my inscribed stela." See also Niehaus, Ancient Near Eastern Themes, 60. For the similarities with Hittite treaties see Chapter I above.

${ }^{115}$ Durham, Exodus, 296.

${ }^{116}$ See Sarna, Genesis, 148; Von Rad, Genesis, 236-37; Hamilton, The Book of Genesis: Chapters 18-50, 87-93; and Speiser, Genesis, 160. 
which a judgment has been done before. Laban is persecuting Jacob with the purpose of harming him, not with the intention of making a covenant with him; however, God intervenes and Laban fails to do as he wishes. The story shows that Laban, who plans to bring judgment upon Jacob, is judged by Jacob, and forced to make a covenant that was not his original intention.

The Pentateuch also indicates that עֵָד is used to declare a warning against those who bring false testimony against their neighbor (Exod 20:16; 23:1; Deut 5:20; 19:1619); ${ }^{117}$ and the consequence that could happen to those who know or see something and do not testify about it (Lev 5:1). Also it is established that in order to pronounce a verdict there must be at least two witnesses in the trial (Numbers 35:30; Deut 17:6; 19:15).

The repetition of the ninth commandment in Exod 20:16 and Deut 5:20 uses the Word עִ עִ in a context of a secular trial. This commandment is concerned with testimonies in court against an accused person. Therefore, God emphasizes the purity of the process in order to avoid condemning the innocent and clearing the guilty. Although a covenant is not stated, the commandment itself belongs to the two tablets of the covenant, as God calls it (Exod 35:28, 29; Deut 9:9, 11, 15). On the whole, the ninth commandment cannot be taken as a covenant itself, but as part of a greater covenant.

A similar legislation is given in Exod 23:1, 2, but shows the consequence of being a witness who circulates a "false report." This passage describes the עִָד testifying in a judgment in which the ריב takes place in it; but without considering a covenant between the parties.

${ }^{117}$ See Propp, Exodus 19-40, 180. 
Further, in Exod 22:13 (Heb. v. 12) עֵָד appears also in a secular trial in which judges are called to do their job based on God's commandment. In addition, Lev 5:1 speaks about the wֵָד who hears "the utterance of an oath" to testify about any wrondoing that witness knows; however, instead of taking this matter to court, the witness prefers to be silent, making himself part of the wrongdoing.

Also, Num 5:11-31 has to do with an event in which witnesses are lacking in a suspicious event of infidelity. Thus the plaintiff has nothing to do but wait for God's decision because the Pentateuch prohibits making a trial when the accuser cannot provide at least two witnesses (Num 35:30; Deut 17:6; 19:15). The witness in each one of these passages is described in a secular trial without making a covenant.

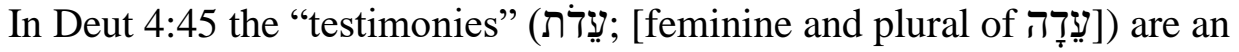
instrument "set (by Moses) before the children of Israel" equivalent to תחוֹרָה, "law,"

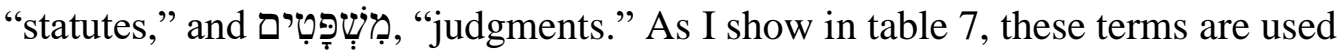
interchangeably throughout the book of Deuteronomy.

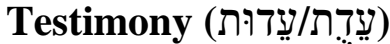

The word עִ עַדוּת appears for first time in the Pentateuch in Exod 16:34, in a context in which the children of Israel complain against Moses and Aaron (v. 2), ${ }^{118}$ but Moses

${ }^{118}$ The key word of Exod 16 is תְִּ? ("complaints") in vv. 7, 8 [two times], 9, 12 and its cognate verb לוּן ("complain") in vv. 2, 7. According to the BDB, 534, their respective translations are "murmuring" and "murmur." In the Pentateuch, these words only appear in Exodus and in Numbers: As a verb in Exod 15:24; 16:2, 7b; 17:3; Num 14:2, 27a, 29, 36; 16:11, 41 (Heb. ch. 17:6); as noun in Exod 16:7a, 8 (two times), 9, 12; Num 14:27b; 17:5 (Heb. v. 20). 


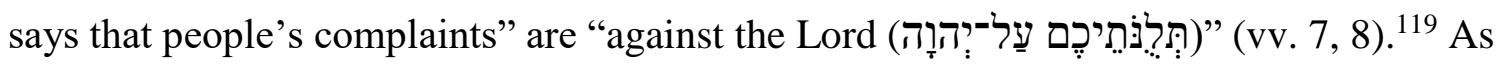
such, the Lord has already spoken with Moses about it and answers providing for the need of the people (vv. 4, 5). Then Moses, by God's instruction, asks Aaron to keep a portion of manna in a pot (vv. 33, 34): ${ }^{120}$

"And lay it up before the Lord to be kept." “And Aaron laid it up before the testimony to be kept.” In this chapter God functions as judge between Moses and Aaron and the congregation of Israel. Though God supports Moses and Aaron, at the same time, he decides to supply people's need. With this decision, God settles peacefully people's complaints. ${ }^{121}$

The importance of Aaron's action is highlighted by the fact that placing manna "before the Lord" it is the same as "before the testimony." However, at first sight it is not possible to know what the עִ עִ Exod 16:34 is; but according to Exod 31:18 the "two

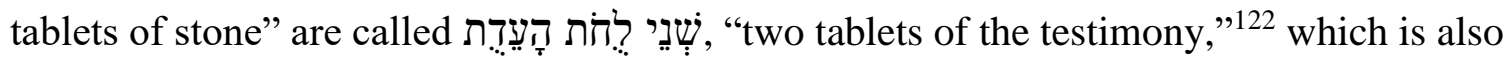

${ }^{119}$ Cf. Durham, Exodus, 220.

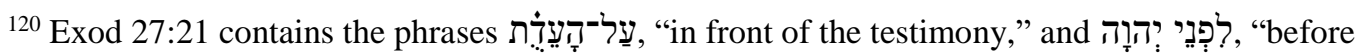
the Lord" with reference to the lampstand "outside the veil." See also Num 17:4 (Heb. v. 19), 7 (Heb. v. 22), 10 (Heb. v. 25). Also the portion of manna is not called a "testimony" but something "to be kept ...

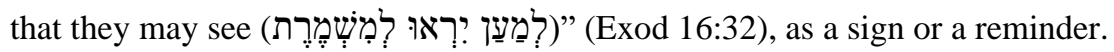

121 The structure of Exod 16 is: (1) Introduction: Israel's journey (v. 1); (2) People's complaints against Moses and Aaron (vv. 2, 3); (3) God's interventions to give answer to people's complaints (vv. 4, $5)$; (4) Moses and Aaron explain God's plan to the people, assuring that their complaints are against God (vv. 6-8); (5) God's glory appears (vv. 9, 10); (6) God repeats what he is going to do because he has heard people's complaints (vv. 11, 12); God gives meat and bread as the people ask (vv. 13-32); (7) Moses asks Aaron to place a portion of manna before the Testimony (vv. 33, 34); (8): Conclusion: Israel's journey (v. $35)$.

${ }^{122}$ This is also mentioned in Exod 32:15; 34:29. 
translated as "the words of the covenant, the Ten Commandments" (Exod 34:28b; cf. Deut $4: 13 ; 10: 4) .{ }^{123}$ Later, God commands Moses to build an ark for the sanctuary in order to put into it "the testimony (עִּרתת)" (Exod 25:16, 21; 40:20).

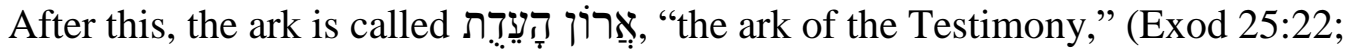
26:33, 34; 30:6, 26; 31:7; 39:35; 40:3, 5; Num 4:5; 7:89). ${ }^{124}$ Over this ark, covered with the commandments to the children of Israel about everything. Then, "the testimony" is used interchangeably with the "ark of the testimony" (Lev 24:3).

The significance of the "testimony" in the ark is emphasized in the ritual of the Day of Atonement in which God says that the high priest "shall put the incense on the fire before the Lord, that the cloud of incense may cover the mercy seat that is on the Testimony, lest he die" (Lev 16:13). Of course, the main purpose was to prevent that the high priest could see the mercy seat; but the mention of the Testimony instead of the ark could not pass unnoticed.

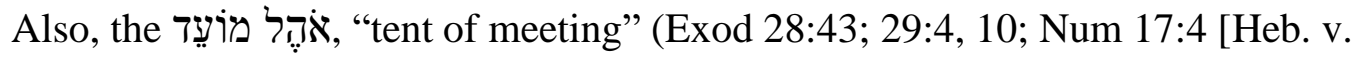

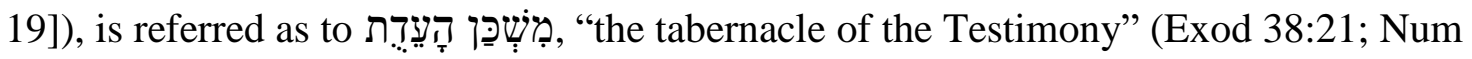

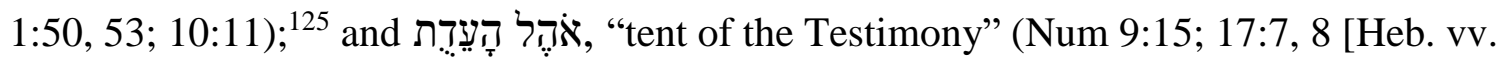

\footnotetext{
${ }^{123}$ As these two passages refer to the Ten Commandments as aִּ?ִִּ previous agreement is superseded by this. See Durham, Exodus, 280.

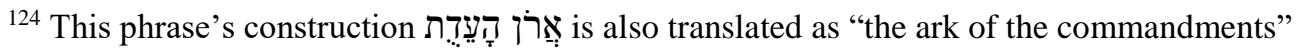
(NAB); "the ark of the covenant" (NRS); and "the Ark of the Pact" (TNK).

${ }^{125}$ English versions also translate this as: "the Dwelling of the commandments" (NAB), "the tabernacle of the covenant" (NRS), "the Tabernacle of the Pact" (TNK), "the tabernacle of the Testimony" $(\mathrm{NKJ})$.
} 
22, 23]; 18:2) because the "ark of the testimony" is placed in it (Exod 40:2, 3). ${ }^{126}$

In Num 17:1-12 (Heb. vv. 16-28), God commands Moses to place twelve rods, from each leader of the tribes of Israel, meeting before the Testimony" (v. 4 [Heb. v. 19]), in order to show who he has chosen to be high priest in Israel and, at a same time, to get rid of Israel's complaints once for all (vv. 5, 10 [Heb. vv. 20, 25]). Consequently, Aaron's rod is chosen by God and, as a

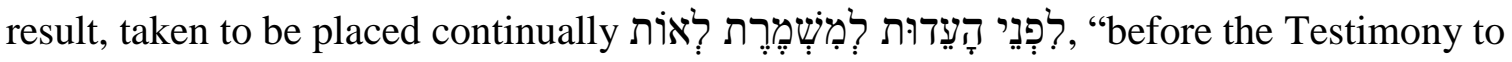
be kept as a sign (against the rebels)" (v. 10 [Heb. v. 25]). ${ }^{127}$ This clarifies that the Exod 16:34 is the two tables of the law or the Ten Commandments which later are kept inside the ark. Consequently, God executes his judgment from the sanctuary to the people of Israel, thus the Ten Commandments are placed in his presence to testify in favor of or against them.

${ }^{126}$ Other translations of this phrase are: "the tent of the commandments" (NAB), "the tent of the covenant" (NRS), "the Tent of the Pact" (TNK), and "the tabernacle of witness" (NKJ).

${ }^{127}$ Milgrom, Numbers: במדבר, JPSTC (Philadelphia, PA: JPS, 1989), 144, translates the word אוֹת as "lesson." He also adds on p. 145 that "since divine staffs were kept in the sanctuaries of Egypt and Phoenicia, it is possible that the purpose of assigning a mnemonic role to Aaron's staff . . was to deprive it of any magical or mythical significance." However, Aaron's staff was an ordinary object without divine property. Cf. R. K. Harrison, Numbers: An Exegetical Commentary (Grand Rapids, MI: Baker Book House, 1992), 245; Ashley, The Book of Numbers, 254.

R. Dennis Cole, Numbers: An Exegetical and Theological Exposition of Holy Scripture, NAC 3B (Nashville, TN: Broadman \& Holman, 2000), 276 suggests that this generations of this significant encounter with the Almighty" would have two purposes: (1) "A testimony to God's provision for his people in the Aaronic priesthood;" and (2) "The son of rebellion . . would no longer murmur and complain against God" and avoid punishment as before. 


\section{"To Bear Witness" or "To Testify" (עוּד)}

\section{Joseph and His Brothers in Egypt (Gen 43:3)}

In Gen 43:3 the verb עוּד, "to testify," is used emphatically two times in hiphil,

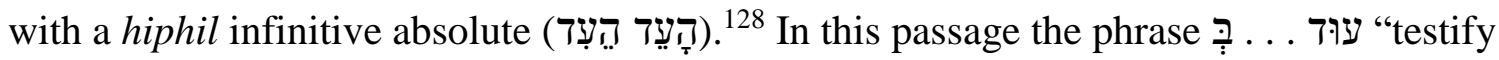
against" is translated by most English versions as "solemnly warn." Although it is not apparent at first glance, the context reveals that the composition of this story is a trial scene of two parties in which one party is the judge and the accuser at the same time: Joseph accuses his brothers of being spies $(42: 9,14)$, but they deny the allegation (vv. 10, 13). However, they are put in prison (v. 17). Later they are released, but one of them (Simeon) is kept in prison until the others return with the evidence (Benjamin), which would testify about the truthfulness of Joseph's brothers (vv. 10-15). Of course, this is a strategy that Joseph puts in action to test his brothers (vv. 14, 16), and have some knowledge about the interiority of their heart. Accordingly, Joseph repeats: "you shall be

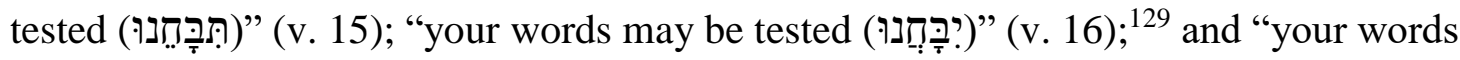

${ }^{128} \mathrm{Cf}$. Mathews, Genesis 11:27-50:26, 787. This infinitive absolute is used to intensify the main verb. For a discussion about the functions of the infinitive absolute, see Waltke and M. O'Connor, An Introduction to Biblical Hebrew Syntax (Winona Lake, IN: Eisenbrauns, 1990), 580-97. This intensification also occurs in 1 Sam 8:9 when the children of Israel ask to have a king as the surrounding nations do, and also in Jer 11:7 when God sent Jeremiah to remind the people how he had warned Israel to obey his voice or covenant.

129 The verb בּּז is: an "examination" of words by the ear (Job 12:11), to be under more pressure or punishment (Job 34:36), reminder of the trial and complaining of Israel in the wilderness (Ps 95:9), Jeremiah's heart has been tested by God (Jer 12:3), God will test Jerusalem by the sword (Ezek 21:13 [Heb. v. 18]), God asks Israel to examine him bringing the tithe to the temple (Mal 3:10). 


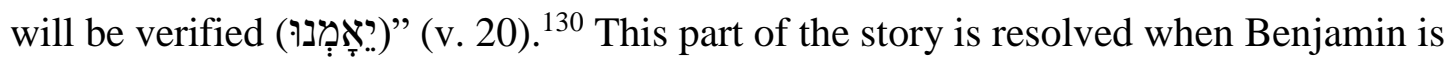
brought to Egypt. The evidence is presented, and the prisoner is released (43:15-23).

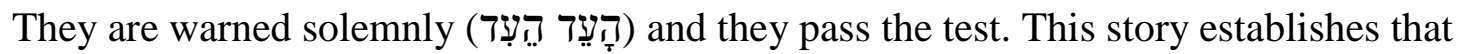
this is a secular trial in which Joseph, because of his position, is at the same time plaintiff and judge. He has the power to put them into prison and release them from prison.

Because of his position, he does not go to a third party to validate his accusation; he does by himself what he thinks it is right.

\section{God and Israel at Mount Sinai (Exod 19:21-23)}

The second time the verb עוּ is used in the Pentateuch is also in hiphil, in which

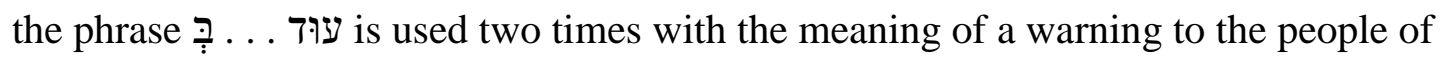
Israel (Exod 19:21-23). God is ready to descend upon Mount Sinai to give the Ten Commandments. Thus he asks Moses to warn (הָעָד) the people "lest they break through to gaze at the Lord, and many of them perish" (v. 22). This is again a solemn warning which has in itself a call to avoid a punishment as consequence if the children of Israel do not pay attention to God's warning which already has been introduced in vv. 12, 13:

"Whoever touches the mountain will surely be put to death (מוֹת יוְָּת). He shall surely be stoned or shot with arrows."131 These ways of punishment underline divine judgments

\footnotetext{
130 The verb אמן is used as a faithful priest that God will raise up (1 Sam 2:35); Salomon asking God to confirm his words to David (1 Kgs 8:26); the established word of God (1 Chr 17:23); faithfulness against lies (Hos 11:12 [Heb. 12:1]).

${ }^{131}$ Cf. Noel D. Osborn and Howard A. Hatton, A Handbook of Exodus (NY: UBS Handbook Series, 1999), 466-68; Waldemar Janzen, Exodus, BCBC (Waterloo, Ontario: Herald, 2000), 244-46; Douglas K. Stuart, Exodus, NAC 2: An Exegetical and Theological Exposition of Holy Scripture (Nashville, TN: Broadman \& Holman, 2006), 426-33.
} 
and show that God is the judge to whom all the earth belongs (Exod 19:5). ${ }^{132}$

\section{Warning to an Owner of an Ox (Exod 21:29)}

In Exod 21:29 an owner has an ox which "thrust with its horn in time past," and its owner "has been warned" (הוּעַד; hophal) about it. But he does not pay attention to the warning; and the ox, in the meantime, kills somebody. The verdict is to put both the ox and its owner to death. This warning, which is portrayed with the phrase $\underset{\text { עִ }}{\text {, }}$, is the consequence of what has been explained in v. 28, which mentions an ox which gores someone to death. But it is implied that the owner either has not been notified of his ox's inclination to thrust people or it is the first time this happens. Thus the owner's life is spared; nevertheless the ox is killed. The death sentence pronounced in v. 29 is executed not only because of a testimony of people who have seen the ox goring somebody, but also because of the repetition of the same event by the same ox. This law is explained in vv. 30-32, 35, 36 where other provisions are mentioned to spare the life of the owner of the goring ox.

\footnotetext{
${ }^{132} \mathrm{Cf}$. Archer, A Survey of Old Testament, 252; Wolf, An Introduction to the Old Testament, 128; Walter Beyerlin, Origins and History of the Oldest Sinaitic Traditions, trans. S. Rudman (Oxford: Blackwell, 1966); Heinz Kruse, "Exodus 19:5 and the Mission of Israel," NEAJT 24-25 (1980): 129-35; Anthony C. J. Phillips, “A Fresh Look at the Sinai Pericope,” VT 34 (1984): 39-52, 282-300; Thomas B. Dozeman, "Spatial Form in Exodus 19:1-8a and in the Larger Sinai Narrative," Semeia 46 (1989): 87-101; Elliot B. Gertel, "Sinai and what Makes Us Jewish," Judaism 42 (1993): 29-42; Brueggemann, Book of Exodus, NIB 1 (Nashville, TN: Abingdon, 1994), 833-34; Fretheim, "Because the Whole Earth is Mine: Theme and Narrative in Exodus," Int 50 (1996): 229-39; Alexander, "The Composition of the Sinai Narrative in Exodus XIX 1-XXV 11," VT 49 (1999): 282-94; William D. Barrick, "The Mosaic Covenant," MSJ 10 (1999): 213-32; John Arthur Davies, “A Royal Priesthood: Literary and Intertextual Perspectives on an Image of Israel in Exodus 19:6," TynBul 53 (2002): 157-59.
} 
Heavens and Earth (Deut 4:26; 30:19; 31:28)

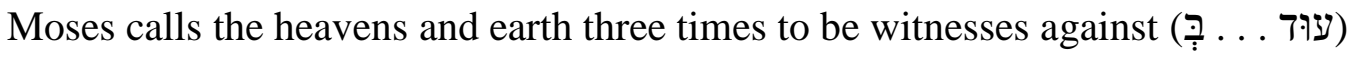

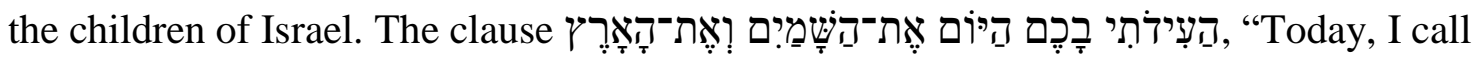
to witness against you the heavens and the earth," occurs two times (Deut 4:26; 30:19);

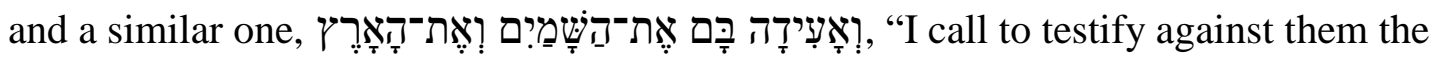
heavens and the earth" (ch. 31:28). Table 12 shows that the final result of Deut 30:19 is described in the same way as in 4:26:

Table 12. Context of Deut 4:26 and 30:19

\begin{tabular}{|l|l|}
\hline Context of Deut 4:26 & Context of Deut 30:19 \\
\hline $\begin{array}{l}\text { If the children of Israel "turn to the } \\
\text { Lord ... and obey his voice ... he will not } \\
\text { forsake" them (vv. 29-31) }\end{array}$ & $\begin{array}{l}\text { If the children of Israel "return to the } \\
\text { Lord ... and obey his voice ... the Lord } \\
\text { will bring" them "back from captivity" } \\
\text { (vv. 2, 3; see also vv. 4-6) }\end{array}$ \\
\hline $\begin{array}{l}\text { Keep his statutes and his commandments } \\
\text { (v. 40) }\end{array}$ & $\begin{array}{l}\text { Keep his statutes, commandments and } \\
\text { judgments (vv. 10, 16) }\end{array}$ \\
\hline $\begin{array}{l}\text { "That it may go well with you and with } \\
\text { your children after you, and that you may } \\
\text { prolong your days (v. 40) }\end{array}$ & "That you may live and multiply" (v. 16) \\
\hline $\begin{array}{l}\text { Idolatry is forbidden (vv. 15-19, 23) } \\
\text { "You will soon utterly perish from the land } \\
\text { which you cross over the Jordan to } \\
\text { possess; you will not prolong your days in } \\
\text { it, but will be utterly destroyed" (v. 26) }\end{array}$ & $\begin{array}{l}\text { "You shall surely perish; you shall not } \\
\text { prolong your days in the land which you } \\
\text { cross over the Jordan to go in and } \\
\text { possess" (v. 18) }\end{array}$ \\
\hline
\end{tabular}

The context of Deut 4:26 is a prohibition to the people of Israel to be involved in idolatry (vv. 15-19) because this practice breaks the covenant (v. 23) and as a result, God's judgment would come upon the idolaters (vv. 24-27) with destruction (v. 26), and scattering among the nations (v. 27). 
The second text (Deut 30:19) establishes that "heavens and earth" are witnesses against Israel and, at a same time, a support to what Moses has set before Israel: "life and death, blessing and cursing." However, heavens and earth are not call to give life and death, or to provide blessings or to inflict curses, because these elements-life and death, blessings and curses - would come depending on the actions of the children of Israel, and based on God's commandments, statutes and judgments (vv. 16-18).

The third text (Deut 31:28) predicts a bad future for the children of Israel after Moses's death. While the contexts of Deut 4:26 and 30:19 show the people of Israel with the probability to take one action or another, the context of Deut 31:28 predicts that the future rebellion of the children of Israel will be real. They will become idolaters and break God's covenant (vv. 16, 20), and for such disobedience God will forsake them and hide his face and many evils will come against them (vv. 17, 18, 21). In order to take the people of Israel into judgment, God commands Moses to write a song which will function

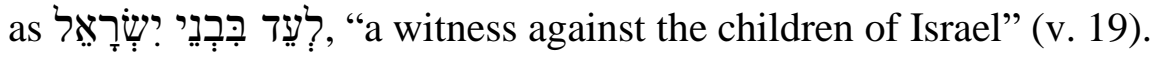

Whereas in Deut 4:26 and 30:19 Moses calls heavens and earth to witness "today" against the children of Israel, in ch. 31:28 the testimony of heavens and earth comes after Moses teaches his song to them in ch. 32. Afterward, Moses warns them to set their "hearts on all the words which" he testifies (מֵֵיד; [v. 46]). These "words" are parallel to "all the words of this law" which means that the book of Deuteronomy is not only a law

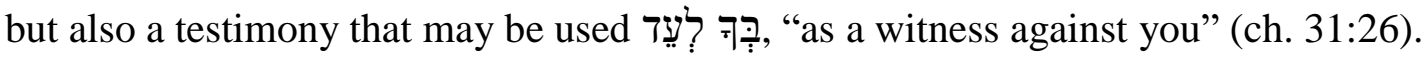
Accordingly, Chisholm says, "Moses adjured the heavens and earth as witnesses ... that 
the people had agreed to keep Yahweh's covenant and to subject themselves to its curses (judgments) in case of disobedience."133

Moses uses the verb עוּ in the same way as Suzerain treaties where "heaven and earth" along with the pantheon of gods are called to be witnesses of the treaty and to punish the vassal if he breaks the treaty. Notwithstanding, in the Bible "heaven and earth" are subordinate to God and serve his will. ${ }^{134}$ Moses calls "heaven and earth" just to be witnesses against Israel and nothing more. These natural elements have no power in Israel's religion; but Moses calls them as par pros toto, in a way of calling the whole "creation to join the Lord as witness to the covenant" as a fulfillment of the requirement of a need of at least two witnesses in order to validate a case (Deut 19:15) and bring it to judgment (Num 35:29). ${ }^{135}$

Moses's Testimony (Deut 8:18, 19; 32:46)

Moses also testifies in two instances against Israel: הַעִדּתִי רָכֶם , "I testify against

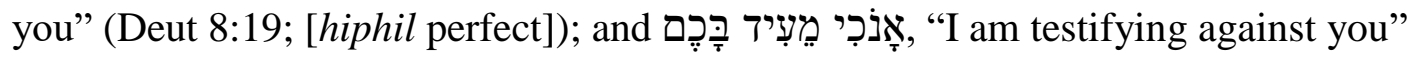
(32:46; [hiphil participle]). ${ }^{136}$ These two testimonies are causative which means that God

${ }^{133}$ Chisholm, NIDOTTE 3:338.

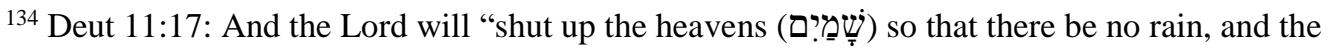
land yield no produce, and you perish quickly from the good land (אֶֶר which the Lord is giving you." Cf. Tigay, Deuteronomy, 52.

${ }^{135} \mathrm{Cf}$. Craigie, 366, who maintains that "the heavens and the earth, permanent and unchanging features of God's creation, would bear silent witness in the future to the faithfulness of the people in living out the implications of their choice."

Block, Deuteronomy, 132 n. 27, explains that Moses, who is a strict monotheist, is using "a merismic expression for 'all creation' (Gen 1:1; Deut 32:1; Isa 1:2; cf. Jer 6:19; Mic 1:2) substituting for the gods."

136 Thus, Block, Deuteronomy, 234, emphasizes that "Moses opens his announcement of judgment with a call for witnesses." 
motivates Moses to pronounce them. Also these testimonies are linked to Moses's call to Israel to keep God's covenant (8:18). While his first testimony displays the negative side of disobedience, which is death (8:19); his second testimony expresses the positive side of obedience, which is life (32:46). Furthermore, his first testimony is a warning against idolatry, and the second one is a call to the people of Israel to teach their children the law of God. These two testimonies encompass what the whole book of Deuteronomy is about. That is, the people of Israel have to choose God or idols, life or death, in order to maintain God's covenant.

Furthermore, table 13 shows that the last testimony of Moses to the children of Israel (Deut 32:46, 47) is a reminder of the fifth commandment which asks to honor father and mother with the following promise as result: "you shall prolong your days in the land" (Exod 20:12; Deut 5:16):

\section{Table 13. Last testimony of Moses in connection to the fifth commandment}

\begin{tabular}{|l|l|}
\hline "Your days will be prolonged in the land." (Exod \\
20:12)
\end{tabular}

If the children of Israel choose to break the covenant (Deut 8:18), then they will be condemned to destruction as the Canaanites (v. 20); but if they are careful to observe all the words of the law then they will have a long life $(32: 46,47)$. With these words, God is asserting two things: (1) Life does not only depend upon good human relations but also upon a good relationship with him; and (2) He is ultimately the father of all the 
children of Israel. Thus, they depend on him to live on the earth. In this last testimony Moses expresses before Israel what he has been saying from the beginning: Keep the law and live! (Deut 5:7; 6:14; 7:4; 8:19; 11:16, 28; 13; 17:2-5; 18:20; 28:14, 36, 64; 29:26

[Heb. v. 25]; 30:17, 18; 31:18, 20).

\section{Summary}

Each passage of this section uses the phrase עִ עִ . ע, "testify ... against," in which עוּד has been generally translated as "warn" by English versions as its main meaning. Table 14 shows a summary of the verb עוּד in the Pentateuch.

Table 14. Verb עוּ in the Pentateuch

\begin{tabular}{|c|c|c|}
\hline Passages & Case Involved & Judgment \\
\hline 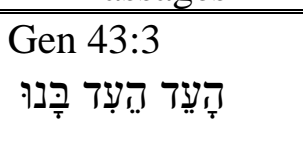 & $\begin{array}{l}\text { Joseph's brothers are accused as } \\
\text { spies }\end{array}$ & $\begin{array}{l}\text { They defend themselves } \\
\text { showing Benjamin as true } \\
\text { evidence of their testimony }\end{array}$ \\
\hline 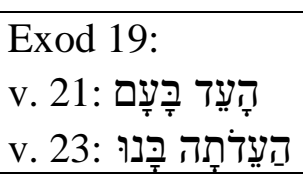 & $\begin{array}{l}\text { The children of Israel cannot break } \\
\text { Mount Sinai's limits }\end{array}$ & They will perish \\
\hline $\begin{array}{l}\text { Exod 21:29 } \\
\text { הוּעַד בִבְעָלָיו }\end{array}$ & $\begin{array}{l}\text { An owner is warned about his ox } \\
\text { which tended to thrust with its horn; } \\
\text { the ox kills somebody }\end{array}$ & $\begin{array}{l}\text { Either the owner and the ox } \\
\text { are killed, or the owner shall } \\
\text { pay a ransom to save his life }\end{array}$ \\
\hline הַעִידתחִי בָכֶם Deut 4:26 & $\begin{array}{l}\text { Moses calls heaven and earth, as the } \\
\text { representation of the whole } \\
\text { creation, to testify against the } \\
\text { people of Israel }\end{array}$ & $\begin{array}{l}\text { The people of Israel shall } \\
\text { obey or they will be } \\
\text { destroyed }\end{array}$ \\
\hline 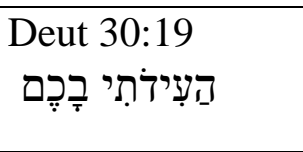 & $\begin{array}{l}\text { For the second time, Moses calls } \\
\text { heaven and earth against the } \\
\text { children of Israel }\end{array}$ & $\begin{array}{l}\text { Moses sets before the } \\
\text { children of Israel life and } \\
\text { death, blessing and cursing }\end{array}$ \\
\hline $\begin{array}{c}\text { Deut 31:28 } \\
\text { אָעִידָה דָּם }\end{array}$ & $\begin{array}{l}\text { This is the third time Moses calls } \\
\text { heaven and earth to testify against } \\
\text { the children of Israel }\end{array}$ & $\begin{array}{l}\text { Because of their } \\
\text { disobedience, God's anger } \\
\text { will fall upon the children of } \\
\text { Israel }\end{array}$ \\
\hline
\end{tabular}


Table 14-Continued

\begin{tabular}{|c|c|c|}
\hline Passages & Case Involved & Judgment \\
\hline 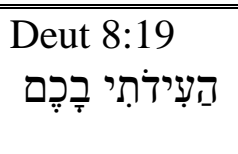 & $\begin{array}{l}\text { Moses testifies against the children } \\
\text { of Israel to not follow other gods }\end{array}$ & $\begin{array}{l}\text { The children of Israel will } \\
\text { perish for their worship of } \\
\text { other gods }\end{array}$ \\
\hline 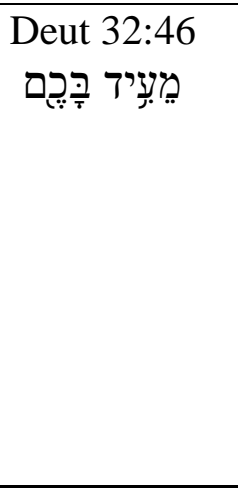 & $\begin{array}{l}\text { Moses commands the people of } \\
\text { Israel to pay attention to "all the } \\
\text { words which" he testifies against } \\
\text { them }\end{array}$ & $\begin{array}{l}\text { As part of the Song of } \\
\text { Moses, the people of Israel } \\
\text { are called to set their "hearts } \\
\text { on all these words" that } \\
\text { Moses testifies because by } \\
\text { keeping these words they } \\
\text { will have life and prolonged } \\
\text { days (Deut 32:47) or they } \\
\text { will be punished with curses } \\
\text { (vv. 19-35) }\end{array}$ \\
\hline
\end{tabular}

In the book of Deuteronomy, Moses uses a figure of speech when he calls heavens and earth to be witnesses against the children of Israel while he commands obedience from them (Deut 4:26; 30:19; 31:28). ${ }^{137}$ These entities, heaven and earth, have no life in Israel's environment, but are called to represent the whole creation which will be hostile to the people of Israel because of their disobedience.

Moses himself testifies against the children of Israel two times (Deut 8:19; 32:46): In the first testimony he has a binding authority, not only to expose the rebellion of the people of Israel but also to explain the punishment which will come as the consequence of their disobedience by worshiping other gods $(8: 19)$. And in the second testimony, he testifies, with heavens and earth acting as witnesses of the word of his mouth, proclaiming curses (Deut 32:19-35) and blessings (vv. 36-43).

\footnotetext{
${ }^{137}$ This figure of speech is called merism.
} 


\section{Conclusion}

The analysis of the word עִ and its cognates indicates that this word points out toward the following:

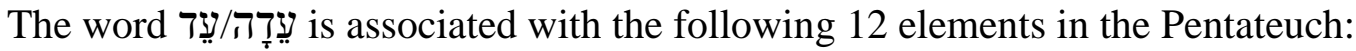
(1) Abimelech (Gen 21:30), (2) a covenant (Gen 31:44), (3) stones (Gen 31:48, 52), (4) God (Gen 31:50), (5) a false witness (Exod 20:16; 23:1; Deut 5:20; 19:16-18), (6) a torn animal (Exod 22:13 [Heb. v. 12]), (7) a person who fails to testify (Lev 5:1), (8) when there is no witness (Num 5:13), (9) when there is more than one witness (Num 35:30; Deut 17:6, 7; 19:15), (10) God's testimonies (Deut 4:45; 6:17, 20), (11) Moses's song (Deut 31:19,21), and (12) the book of the law (Deut 31:26).

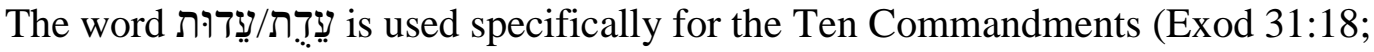
32:15) which are called "the testimony" (Exod 16:34; 27:21; 30:36; Lev 24:3; Num 17:4, 10 [Heb. vv. 19, 25]), and the "two tablets of the Testimony" (Exod 34:28, 29). As a result, when the Ten Commandments are placed inside the ark (Exod 25:16; 40:20), the ark is then called the ark of the testimony (Exod 25:21, 22, 33, 34; 30:6, 26; 31:7; 39:35; $40: 5,21$; Lev 16:13; Num 4:5; 7:89). In like manner, when the ark of the testimony is located in the sanctuary (Exod 40:2, 3), it is called the tabernacle of the testimony (Exod 38:21; Num 1:50, 53; 10:11; 17:7, 8 [Heb. vv. 22, 23]; 18:2) or the tent of the testimony (Num 9:15). From this place, God manifests his presence to the children of Israel and exercises his judgment for them.

The verb עוּ is used as a warning by Joseph ([which is reported by Judah]; Gen 43:3), God (Exod 19:21-23), and in a general stipulation (Exod 21:29). In these three instances the warnings convey the threat of capital punishment in a trial, or at least a 
definitive exclusion as in the case of Joseph and his brothers. Also this verb is used to call heavens and earth to be witnesses against the children of Israel for their unfaithfulness toward God's covenant (Deut 4:26; 30:19; 31:28); and as a final testimony from Moses to the children of Israel (Deut $8: 19 ; 32: 46$ ) in order to warn them about the positive results of obeying God's covenant or the impending consequences of disobedience. Thus, it exposes a threat that could befall those who are disobedient because of a warning that has been given in the past.

Two findings have emerged from this study: First, every element of עִ and its cognates can be arranged in four general categories that have been taken as witnesses independent of the specific Hebrew word that is used: (1) People, (2) Objects, (3) God, and (4) warnings. And second, the "witness" motif in the Pentateuch is related to judgment unless it appears in a narrative of stipulations to build and take care of the sanctuary or in the giving of the law to Moses. These findings are summarized in table 15:

Table 15. "Witness" and "bearing witness" in relation to judgment in the Pentateuch

\begin{tabular}{|l|c||c||c|}
\hline \multicolumn{1}{|c|}{ Passages } & Judgment & $\begin{array}{c}\text { Narrative to } \\
\text { build and to } \\
\text { take care of the } \\
\text { Sanctuary }\end{array}$ & $\begin{array}{c}\text { Narrative about God } \\
\text { giving the law to } \\
\text { Moses }\end{array}$ \\
\hline Gen 21:30 & $\mathrm{X}$ & & \\
\hline Gen 31:44-52 & $\mathrm{X}$ & & \\
\hline Gen 43:3 & $\mathrm{X}$ & & \\
\hline Exod 19:21-23 & $\mathrm{X}$ & & \\
\hline Exod 22:13 (Heb. v. 12) & $\mathrm{X}$ & & \\
\hline $\begin{array}{l}\text { Exod 20:16; 23:1; Deut } \\
\text { 5:20; 19:16-21 }\end{array}$ & $\mathrm{X}$ & & \\
\hline Exod 21:29 & $\mathrm{X}$ & & \\
\hline Exod 34:29 & & & \\
\hline
\end{tabular}


Table 15-Continued

\begin{tabular}{|c|c|c|c|}
\hline Passages & Judgment & $\begin{array}{c}\text { Narrative to } \\
\text { build and to } \\
\text { take care of the } \\
\text { Sanctuary }\end{array}$ & $\begin{array}{l}\text { Narrative about God } \\
\text { giving the law to } \\
\text { Moses }\end{array}$ \\
\hline Lev 5:1 & $X$ & & \\
\hline Lev 16:13 & $\mathrm{X}$ & & \\
\hline Num 1:50, 53 & $\mathrm{X}$ & & \\
\hline Num 5:11-31 & $\mathrm{X}$ & & \\
\hline $\begin{array}{l}\text { Num 17:4, } 10 \text { (Heb. vv. } \\
19,25)\end{array}$ & $\mathrm{X}$ & & \\
\hline $\begin{array}{l}\text { Num 17:7, } 8 \text { (Heb. vv. } \\
22,23)\end{array}$ & $\mathrm{X}$ & & \\
\hline Num 35:30 & $\mathrm{X}$ & & \\
\hline Deut 4:26 & $X$ & & \\
\hline Deut 4:45 & $\mathrm{X}$ & & \\
\hline Deut 8:19 & $\mathrm{X}$ & & \\
\hline Deut $17: 6 ; 19: 15$ & $X$ & & \\
\hline Deut 31:19-21 & $\mathrm{X}$ & & \\
\hline Deut 31:24-26 & $X$ & & \\
\hline Deut 32:46 & $\mathrm{X}$ & & \\
\hline $\begin{array}{l}\text { Exod } 16: 34 ; 25: 16-22 ; \\
36: 33,34 ; 27: 21 ; 30: 6, \\
26,36 ; 31: 7 ; 38: 21 ; \\
39: 35 ; 40: 3,5,20,21 ; \\
\text { Lev } 24: 3 ; \text { Num } 4: 5 ; \\
7: 89 ; 9: 15 ; 10: 11 ; 18: 2\end{array}$ & & $\mathrm{X}$ & \\
\hline Exod 31:18; 32:15; & & & $\mathrm{X}$ \\
\hline
\end{tabular}

The study of the "witness" language in the Pentateuch has demonstrated that, in the administration of justice, true witnesses are the key part to administer a just judgment. This results in punishing the wicked and acquitting the righteous. Since this dissertation is testing a connection of the Gospel of John with the Pentateuch in their legal language, it is appropriate to exeget each passage in which the "witness" language is used in the Gospel of John. 


\section{CHAPTER 4}

\section{ANALYSIS OF THE THEME OF WITNESS}

\section{IN THE GOSPEL OF JOHN}

Scholars agree that the Pentateuch and the Gospel of John are linked in many

topics. However, this connection has been taken for granted with the result of bypassing their common theme of witness and to bear witness and the practice of a just judgment. ${ }^{1}$ In order to remedy this omission, this chapter explores that link, and try to identify the purpose of the Evangelist in relationship to the Pentateuch.

I have referred before to the legal meaning of the Greek words $\mu \alpha \rho \tau \nu \rho i ́ \alpha$ and $\mu \alpha \rho \tau v \rho \varepsilon ́ \omega$ in the Gospel of John, and its relation to the Hebrew word עִּד and its cognates in the Pentateuch. ${ }^{2}$ In order to test this proposition, I examine the word "witness" and its

${ }^{1}$ See pp. 6, 7 and 45-96.

${ }^{2}$ Though scholars recognize the influence of the Pentateuch upon the Gospel of John, in the judicial aspect they indicate that the trial motif of the Gospel of John is based on Isa 40-55: Trites, The New Testament Concept of Witness, 23, 35-47, 78-127; Lincoln, Truth on Trial, 43-51. As a matter of example Barnabas Lindars, The Gospel of John, NCB (Greenwood, SC: Attic, 1977), 318, points out that Isa 40-55 "suits the eschatological emphasis of all John's thinking;" G. R. Beasley-Murray, Gospel of Life: Theology in the Fourth Gospel (Peabody, MA: Hendrickson, 1991), 61, claims that the ministry of the Paraclete is linked with the trial of Jesus's ministry based on Isa 43:8-13, 25-28, and 44:6-11; Westermann, The Gospel of John in the Light of the Old Testament, 6, 63, recognizes the influence of the Old Testament upon the Gospel of John, especially the prophet Jeremiah, and the so-called Deutero-Isaiah. Though he is aware of the use of the Pentateuch in the Gospel of John (p. 5), he prefers not to emphasize that evidence.

A different view is maintained by R. E. Brown, An Introduction to the New Testament (NY: Doubleday, 1997), 337, 338, who says that John's prologue is influenced by a personified wisdom from the Apocrypha, such as Sirach 24 and Wisdom 9. The same understanding is uphold by Peter Stuhlmacher, "My Experience with Biblical Theology," in Biblical Theology: Retrospect and Prospect, ed. Scott J. Hafemann (Downers Grove, IL: InterVarsity, 2002), 186, who believes in the influence of Jewish wisdom on the Gospel of John. 
cognate verb within their context, taking into account the many contrasts that the

Evangelist uses as a mean to infuse his Gospel with judicial language.

\section{Witnesses}

In court cases the rationale of the Pentateuch is to execute judgment with at least two witnesses (Num 35:30; Deut 17:6; 19:15) who are summoned to provide faithful testimony in court (Exod 20:16; Deut 5:20). ${ }^{3}$ Furthermore, in their justice, any witness from among the people of Israel shall stand with the righteous and punish the wicked (Exod 23:1). These requirements are in harmony with the Gospel of John in which Nicodemus asks his fellow religious leaders to judge according to the law (7:51), and Jesus maintains "that the testimony of two men is true" (8:17). Also more than a dozen witnesses testify in favor of Jesus to settle a dispute concerning him as the Son of God. ${ }^{4}$ In order to reach this goal, the Evangelist places three questions five different times which are answered throughout the Gospel: "Who are you?" $(1: 19 ; 8: 25 \mathrm{a} ; 21: 12$; [3 times]); "could this be the Christ?" (4:29b) and "do the rulers know indeed that this is truly the Christ?" $(7: 25,26) .^{5}$

\footnotetext{
${ }^{3}$ According to Trites, The New Testament Concept of Witness, 8, in Greek courts "there was no special adherence to the formal principle of establishing everything at the mouth of two or three witnesses." Also Trites cites Plato who in his Giorgias "differs . . . in his attitude to a minimal number of witnesses. Instead of the formal principle of a number of witnesses, Plato would place the testimony of one man whose truthfulness and integrity can stand the test of rational cross-examination" (ibid., 12). For more about witnesses in the Gospel of John, cf. Murray R. Wilton, "Witness as a Theme in the Fourth Gospel" (Ph.D. diss., New Orleans Baptist Theological Seminary, 1992), who studied this topic to demonstrate that this is a key theme in the Fourth Gospel but without taking into account any Old Testament influence; and Sanghee Michael Ahn, "Old Testament Characters as Christological Witnesses in the Fourth Gospel" (Ph.D. diss., Southern Baptist Theological Seminary, 2006), who limited his study to the witness of Old Testament characters in the Gospel of John, such as Jacob, Abraham, Elijah, David, and Moses.

${ }^{4}$ Cf. John Henry Bernard, A Critical and Exegetical Commentary on the Gospel According to St. John, ICC (Edinburgh: T\&T Clark, 1929), xc-xciii.

${ }^{5}$ See ch. V in which I propose a legal structure of the Gospel of John based on these three
} 
These three questions are answered by ten direct witnesses: ${ }^{6}$ (1) John the Baptist $(1: 6-8,15,19,32,34 ; 3: 26 ; 5: 33){ }^{7}$ (2) the Samaritan woman $(4: 39) ;$ (3) Jesus's works $(5: 36 ; 10: 25) ;(4)$ the Father $(5: 37,32 ; 8: 18) ;(5)$ the Scriptures $(5: 39) ;$ (6) Jesus himself $(8: 14,15 ; 18: 37) ;(7)$ the people who saw Lazarus raised from the dead $(12: 17) ;(8)$ the Holy Spirit (15:26); (9) Jesus's disciples (15:27); and (10) the Evangelist himself $(19: 35) .^{8}$

questions.

${ }^{6}$ I refer as "direct witnesses" those individuals and things that the Evangelist calls as such. John Painter, John: Witness \& Theologian (London: SPCK, 1975), 91, writes: "John records the tenfold witness to Jesus, and the Gospel is itself a book of witness."

${ }^{7}$ In order to avoid repetition and confusion, where it is necessary, from now on I will refer to John the Baptist as the Baptist, and the writer of the Gospel of John as the Evangelist. This latter choice has nothing to do with agreement or disagreement related to matters of authorship.

${ }^{8}$ Also, in two other times, Jesus's testimony is given along with the Father (8:13-18) and in an obscure plural form (3:11). Boice, Witness and Revelation, 25-27, following Westcott's suggestion, says that the Gospel of John mentions seven types of witnesses. These are: (1) John the Baptist; (2) other human witnesses (among whom he includes the Samaritan woman, the multitude who witnessed the raising of Lazarus, Jesus's disciples, the beloved disciple, and the blind man); (3) the Father; (4) Jesus Christ; (5) Christ's works; (6) the Scriptures; and (7) the Holy Spirit. This classification is also listed by Leon Morris, The Gospel According to John: The English Text with Introduction, Exposition and Notes, NICNT (Grand Rapids, MI: Eerdmans, 1971), 90.

Pfitzner, "The Coronation of the King," 11, 12, organizes his list with nine witnesses: (1) John the Baptist, (2) Jesus, (3) the Father, (4) Jesus's works, (5) the Scriptures, (6) the Samaritan woman and the crowd, (7) Pilate, (8) the Paraclete, and (9) Jesus's disciples and the apostolic authority.

Barrett, The Gospel According to St. John: An Introduction with Commentary and Notes on the Greek Text, 2nd ed. (Philadelphia, PA: Westminster, 1978), 159, enumerates 10 witnesses: (1) The Baptist, (2) the Samaritan woman, (3) the works of Jesus, (4) the Old Testament, (5) the multitude, (6) the Holy Spirit and the apostles, (7) God the Father, (8) Jesus himself (rejecting man's witness in his favor), (9) Jesus with the Father, and (10) the Gospel of John. A variation of this list appears in Brant, John, 31, who separates the testimony of the Holy Spirit and the apostles as two, and eliminates the testimony of Jesus along with the Father.

In my list, I depart slightly from these scholars in three ways: (1) I prefer to enumerate human witnesses individually since each testimony is important in its own term (contrary to Westcott, Boice and Pfitzner); (2) In the story of the man born blind the word "witness" does not appear, therefore I place it out of the main list of the 10 witnesses (contrary to Westcott and Boice. Pfitzner, on the other hand, does not mention this story); and (3) Not only the Evangelist narrates the testimony of the man born blind without using the word "witness" in the text, but also the Evangelist includes 11 more witnesses who testify in Jesus's favor within the same circumstance (contrary to Westcott, Boice and Barrett). Also I disagree that Pilate is a witness in favor of Jesus Christ (contrary to Pfitzner). Pilate is giving a verdict, not a testimony.

In a recent research, Beutler, Judaism and the Jews in the Gospel of John, SubBi 30 (Rome: Editrice Pontificio Instituto Biblico, 2006), 126-32, has divided the "testimony" of the Fourth Gospel in

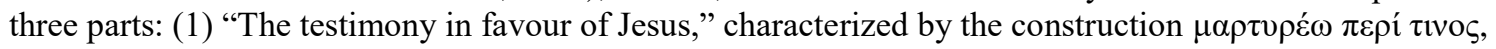


Also, the Evangelist reports about other people who give their testimonies in favor of Jesus though the word "witness" does not appear in the text, such as Andrew, Philip, Nathanael, Nicodemus, the Samaritans, the multitude on the mountain, Peter, many from the crowd, the officers of the Jews, the man born blind, many people beyond the Jordan, and Martha.

In order to present his dispute, the Evangelist highlights the Greek words

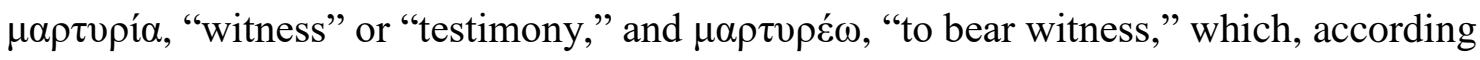
to the NIDNTTE, are emphasized "to express the event of the divine communication of revelation in all its aspects ... so as to be able to concentrate attention to the event." He also points out that the Evangelist uses $\mu \alpha \rho \tau v \rho i ́ \alpha$ and $\mu \alpha \rho \tau v \rho \varepsilon ́ \omega$, but not $\mu \alpha \rho^{\prime} \tau \tau \vartheta \varsigma$ and

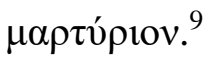

which is given by the Baptist; the Scriptures; the Father; Jesus's works; Jesus himself; the Paraclete and the

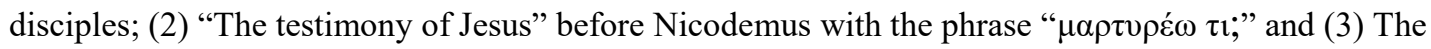
testimony of the Evangelist about Jesus with the verb $\mu \alpha \rho \tau \nu \rho \varepsilon ́ \omega$ with the objective accusative.

About the amount of witnesses in the Gospel of John, Ceslas Spicq, "Martus," TLNT 2:450, says that "when there are a great many witnesses ... their credibility is heightened, their persuasion is stronger, and the validity of their testimony is strengthened."

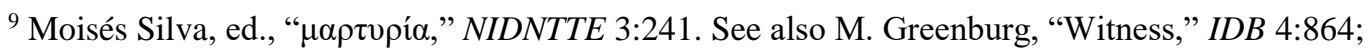
Boice, Witness and Revelation, 9, 16, 25.The word $\mu \alpha \rho_{\rho} \tau \varsigma_{\varsigma}$ does not appear in the Gospel of John; however, Minear, John: The Martyr's Gospel, xii, xiii, reduces the verb "to testify" and the noun "testimony" to the

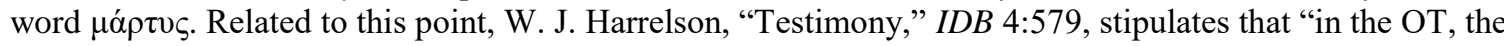
term refers particularly to the written law, while in the NT the testimony to God's action is provided in the proclamation of the gospel in word, deed, and suffering."

In a commentary about Antipas who was put to death according to the book of Revelation, Stephen S. Smalley, The Revelation to John: A Commentary on the Greek Text of the Apocalypse, (Downers Grove, IL: InterVarsity, 2005), 69, says that “the term 'witness' ( $\mu \alpha \rho^{\rho} \tau \nu \varsigma$, martys) came to be applied to those whose testimony to Christ resulted in their death (martyrdom); but the technical sense of that word had not been established by the end of the first century A.D."

Robert H. Mounce, "John," in Luke-Acts, EBC 10, rev. ed., ed. Tremper Longman and David E. Garland (Grand Rapids, MI: Zondervan, 2007), 370, suggests that the use of "the Greek martyria," in the Gospel of John, "with its English cognate 'martyrdom,' is a reminder of how quickly witnessing can lead to rejection and death."

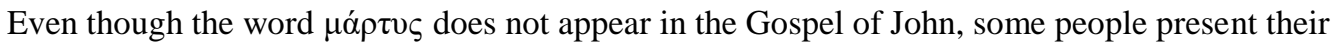
testimony as if they are in a court of law. Accordingly, Trites, The New Testament Concept of Witness, 9 , considers that in legal contexts, in secular Greek, "in order to qualify and be called as a witness, a special kind of knowledge is presupposed on the part of the witness. On the basis of this first-hand knowledge he can testify concerning disputed circumstances and events. So men present at the time of an occurrence and 
Jo-Ann Brant points out that in the Gospel of John, the verb $\mu \alpha \rho \tau v \rho \varepsilon ́ \omega$ is used "to signify that the character gives testimony in defense of Jesus," and also "identifies Jesus for others by virtue of what" he "has seen and heard."10 Likewise, Keener argues, "Witness" was especially a legal term, but the term's figurative extension naturally led to a more general usage. In the LXX the term indicates an appeal to objective evidence, and frequently appears in lawcourt or controversy imagery. Personal testimony implied firsthand knowledge. ... Against some commentators, John's usage may retain some legal associations. ${ }^{11}$

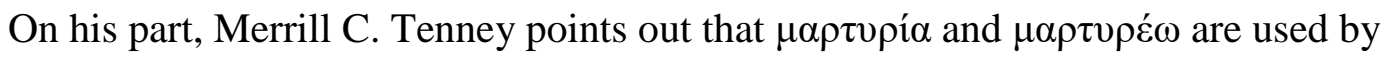
John as "the summary of the apologetic teaching that the Gospel advanced in defense of Jesus' life and work." ${ }^{12}$ And William Hendriksen says that the primary sense of testimony and testify is "(to give) competent testimony concerning that which one has himself seen, heard, or experienced."13 Or, as Morris explains, "when a man gets into a

able to give an eye- or ear-witness account of what happened are frequently called upon to state what they have seen or heard. In other words, $\mu \alpha \rho_{\rho} \tau \nu \varsigma$ is used of one who has direct knowledge or experience of certain persons, events or circumstances and is therefore in a position to speak out and does so. He may appear as a witness in a law-suit, in which case he bears witness for or against someone, or as a witness in a number of different circumstances connected with the business of law."

${ }^{10}$ Jo-Ann A. Brant, John (ПAI $\Delta$ EIA: Paideia Commentaries on the New Testament; Grand Rapids, MI: Baker, 2011), 31. Cf. Lincoln, “The Beloved Disciple as Eyewitness and the Fourth Gospel as Witness," JSNT 85 (2002): 3-26.

${ }^{11}$ Craig S. Keener, The Gospel of John: A Commentary (Peabody, MA: Hendrickson, 2010), 1:392. Suzanne de Diétrich, "You are my Witnesses," Int 8 (1954): 273-79, says plainly that the verb "to witness" is "the act of witnessing." She recognizes both its law-court meaning and its meaning based on the testimony to a truth without first-hand evidence. However, she is more concerned of the latter meaning than the former. According to Trites, The New Testament Concept of Witness, 8, $\mu \alpha \rho \tau v \rho i$ í is "the act or content of witnessing" and, as its cognates, it is "used in the New Testament, sometimes in a legal context, sometimes in a legal metaphor." Further, on p. 10, Trites adds that " $\mu \alpha \rho \tau v \rho i \alpha$ has first of all an abstract meaning - 'the bearing of a witness' and then it also comes to designate the witness itself."

${ }^{12}$ Merrill C. Tenney, “Topics from the Gospel of John, Part III: The Meaning of 'Witness' in John," BSac 132 (1975): 229.

${ }^{13}$ William Hendriksen, Exposition of the Gospel According to John: Two Volumes in One, NTC (Grand Rapids, MI: Baker Academic, 1983), 1:76. Also Rudolf Bultmann, The Gospel of John, 50 n. 5 , asserts that the concept of "testimony is based on knowledge, particularly on the account of an eyewitness." 
witness box and bears his witness he commits himself. He no longer has freedom to come down on either side of the question at issue. He has burned his bridges. He has destroyed his freedom."14

On his part, Paul Ricoeur establishes that while a "testimony" is "the action of testifying" about "what one has seen or heard," a "witness is the author of this action;" he is the one who "makes a report of the event." 15 Further, he adds that the trial is the circumstance in which "we give and listen to testimony."16

Taking these arguments into account, this chapter studies the Evangelist's intention in his use of the words $\mu \alpha \rho \tau v \rho i \alpha$ and $\mu \alpha \rho \tau v \rho \varepsilon ́ \omega$ in four groups: people's testimonies (John the Baptist, the Samaritan woman, the people who saw Lazarus raised from the dead, Jesus's disciples, and the Evangelist), objects' testimonies (Jesus's works and the Scriptures), Deity's testimonies (the Father and the Son either alone or together, and the Holy Spirit), and other testimonies (Andrew, Philip, Nathanael, Nicodemus, the Samaritans, the multitude on the mountain, Peter, the officers of the Pharisees and the chief priests, many from the crows, the man born blind, many beyond the Jordan, and Martha). ${ }^{17}$ This classification helps to (1) offer a parallel organization in agreement with

${ }^{14}$ Morris, The Gospel According to John, 323.

15 Ricoeur, Essays, 123.

${ }^{16}$ Ibid., 124.

${ }^{17}$ I say "peoples' testimonies" and "other testimonies" in order to make a distinction between the former where the word "testimony" and the verb "to bear witness" appear in the text, and the latter where these expressions are not in the text but the context implies a testimony in Jesus's favor. Cf. Bruce, The Gospel of John (Grand Rapids, MI: Eerdmans, 1983), 35; Gundry, Commentary on the New Testament: Verse-by-Verse Explanations with a Literal Translation (Peabody, MA: Hendrickson, 2010), 348, 369. 
the findings on pp. 152-56 of ch. III, and (2) avoid mixing the testimonies of the different groups and have clarity in the point of views about Jesus's origin and identity.

\section{People's Testimonies}

As I mentioned above, the Evangelist names at least 10 direct witnesses in favor of Jesus's origin and identity, apart from 12 more implicit witnesses. ${ }^{18}$ Of those 10 direct witnesses, in this subsection, I examine the testimony of the five witnesses who gave their testimonies in a direct way in Jesus's favor: the Baptist, the Samaritan woman, the people who saw Jesus's miracles, Jesus's disciples, and the Evangelist himself.

Thus, as Köstenberger explains, "From John (the Baptist . . .) to John (the apostle ...) witness has been borne, and continues to be borne, as long as the gospel is read, having as its purpose" which is stated in John 20:31. ${ }^{19}$

\section{John the Baptist}

The Evangelist is eager to highlight the differences between Jesus and the Baptist: The Baptist is "sent by God" (John 1:6), but Jesus is "God" (1:1); the Baptist came iv $\alpha$

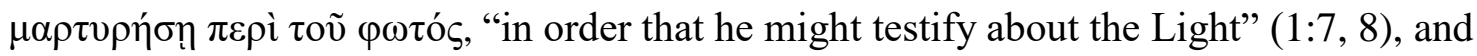
that he "was not that Light" (1:8), ${ }^{20}$ because Jesus "was the true Light" (1:9); the Baptist

${ }^{18}$ See pp. 158-62.

${ }^{19}$ Köstenberger, A Theology of John's Gospel and Letters, 244.

${ }^{20}$ Hendriksen, Exposition of the Gospel According to John, 1:76, explains that "it is probable that the words testimony and testify are here used in their primary sense; namely, (to give) competent testimony concerning that which one has himself seen, heard, or experienced. This follows from what is stated in $1: 29,32,34$. The clause (verse 7) that he might testify repeated for the sake of emphasis in verse 8 explains the preceding, 'for testimony.' " Cf. Brant, John, 31, 41, 42, 45-50, who portraits the possible polemic that existed between the followers of the Baptist and Christ, which resulted in diminishing the Baptist's role to a witness who defends Jesus's messiahship. 
himself $\mu \alpha \rho \tau \nu \rho \varepsilon \tilde{\imath}$ ("testifies") that Jesus is preferred before him $(1: 15,27,30)$; as a result, the Baptist's disciples leave him to follow Jesus (1:35-37). ${ }^{21}$

Jesus is portrayed as baptizing at the same time as the Baptist, "For John had not yet been thrown into prison" (3:22), and as baptizing "more disciples than John" (4:1). In this context, the Baptist repeats the same answer he gave to the religious leaders: "I am not the Christ" (3:28). And further, he admits to his disciples that Jesus is the "bridegroom" and the Baptist is "the friend of the bridegroom" (3:29). While Jesus "must increase," he "must decrease" (3:30); Jesus "comes from above" but the Baptist "is of the earth" $(3: 31) .^{22}$

In the prologue (1:1-18), the Evangelist introduces the Baptist as a man sent by

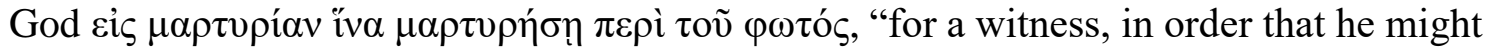

${ }^{21}$ Cf. Silva, ed., NIDNTTE 3:242. Greek texts are taken from the Novum Testamentum Graece, Nestle-Aland, 28th ed.

${ }^{22}$ Cf. J. Ramsey Michaels, The Gospel of John, NICNT (Grand Rapids, MI: Eerdmans, 2010), 32. Painter, The Quest for the Messiah: The History, Literature and Theology of the Johannine Community, 2nd ed. (Nashville, TN: Abingdon, 1993), 153, 154, goes further stating that despite of the contrasts between the two, "the Baptist emerges as the foundational and ideal witness through whom all will believe.” See also Köstenberger, A Theology of John's Gospel and Letters, 45; Menken, Old Testament Quotations in the Fourth Gospel: Studies in Textual Form, 22-25; Hoskyns, The Fourth Gospel, 2nd ed. (London: Faber, 1947), 151; T. Francis Glasson, "John the Baptist in the Fourth Gospel," ExpTim 67 (1956): 245-46; Morna D. Hooker, “John the Baptist and the Johannine Prologue," NTS 16 (1969-1970): 354-58; Marinus de Jonge, "John the Baptist and Elijah in the Fourth Gospel," in The Conversation Continues: Studies in Paul \& John in Honor of J. Louis Martyn, ed. R. T. Fortna and B. R. Gaventa (Nashville, TN: Abingdon, 1990), 299-309; Margaret Davies, Rhetoric and Reference in the Fourth Gospel, JSNTSup 69 (Sheffield, England: JSOT, 1992), 316; Thomas L. Brodie, The Gospel According to John: A Literary and Theological Commentary (NY: Oxford University Press, 1993), 143; Craig L. Blomberg, The Historical Reliability of John's Gospel: Issues and Commentary (Downers Grove, IL: InterVarsity, 2001), 76.

Concerning the question to whom the words of John 3:31 belong scholars are divided: Meyer, The Gospel of John, 140, explains that the Baptist is speaking in 3:31 but the Evangelist elaborates in his own style; Michaels, The Gospel of John, 211-12, states that this is not an important matter; however he believes that John the Baptist is speaking; Köstenberger, A Theology of John's Gospel, 287-88; and Osborne, The Gospel of John, 62, suggest that the Baptist is speaking in this verse. Burge, John, 122, believes this is a theological epilogue written by the Evangelist; for Beasley-Murray, John, 53, this is a reflection of the Evangelist and his community; Brant, John, 81; and Keener, The Gospel of John, 581 do not disqualify any choice. 
bear witness of the Light" (vv. 6, 7); and afterward (1:19-23), he presents a dialogue

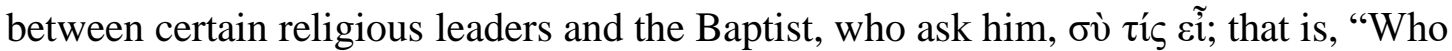
are you?" (v. 19). ${ }^{23}$ The expected answer would be, "I am John the Baptist," or at least to respond as in v. 23: "I am a voice." Nevertheless, he answers what nobody is asking but

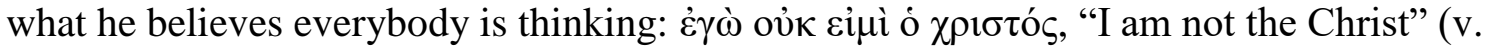
20). ${ }^{24}$

Why does the Evangelist introduce the Baptist in this way? What does he want to show to his audience? Is it really important for his audience to know, not only that the Baptist is not the Christ, but also that he himself says, "I am not the Christ," but "a voice"? Why does the Evangelist introduce the Baptist "as a witness to testify to the

${ }^{23}$ In the Gospel of John, the Jews are related to the Pharisees $(3: 1 ; 9: 13-19 ; 11: 45,46 ; 7: 45,46$; $18: 12,14)$ and also depicted as the leaders of Israel $(1: 19 ; 18: 14,24,28,31)$. Though both groups agree in the essential part of their argumentations, the proper understanding for the qualifying name "the Jews" has been a problem in the interpretation of the Gospel of John. Scholars disagree how to understand this word. With respect to this dissertation, whenever this name appears, I will use the context in order to do the best justice to the meaning the Evangelist intended to give it. For now, it is sound to say that "the Jews" of John 1:19 are religious leaders who sent "priests and Levites" to question the Baptist.

For a survey of different interpretations, see Francis A. Evelyn, "The Supra-Racial Gospel," ExpTim 49 (1938): 419-21; G. Baum, The Jews and the Gospel: A Re-examination of the New Testament (Westminster, MD: Newman, 1961), 101-2; A. T. Davies, ed., Anti-Semitism and the Foundations of Christianity (NY: Paulist, 1979); Von Wahlde, “The Johannine 'Jews': A Critical Survey,” NTS 28 (1982): 33-60; ibid., " “The Jews' in the Gospel of John: Fifteen Years of Research (1983-1998)," ETL 76 (2000): 30-55; P. Richardson and D. Granskou, eds., Anti-Judaism in Early Christianity (Waterloo: Wilfrid Laurier University Press, 1986); John Ashton, Understanding the Fourth Gospel (NY: Oxford, 1993), 158; R. Bieringer, D. Pollefeyt, and F. Vandecasteele-Vanneuville, eds., Anti-Judaism and the Fourth Gospel (Louisville, KY: Westminster John Knox, 2001); Lars Kierspel, The Jews and the World in the Fourth Gospel: Parallelism, Function, and Context, WUNT 220 (Tubingen: Mohr Siebeck, 2006), 67-69.

${ }^{24}$ Cf. Morris, The Gospel According to John, 117. For arguments about the messianic expectation in first-century Palestine, see C. H. H. Scobie, John the Baptist (London: Student Christian Movement, 1964); Roger L. Fredrickson, John, The Communicator's Commentary 4, ed. Lloyd J. Ogilvie (Waco, TX: Word Books, 1985), 52; Beasley-Murray, John, WBC 36 (Waco, TX: Word Books, 1987), 24; Collins, John and His Witness, 10-12; Craig A. Evans, "Messianism," in Dictionary of New Testament Background: A Compendium of Contemporary Biblical Scholarship, ed. Craig A. Evans and Stanley E. Porter (Downers Grove, IL: IVP, 2000), 698-703; Gary M. Burge, John, NIVAC (Grand Rapids, MI: Zondervan, 2000), 71, 72; Herbert W. Bateman, Darrell L. Bock, and Gordon H. Johnston, Jesus the Messiah: Tracing the Promises, Expectations, and Coming of Israel's King (Grand Rapids, MI: Kregel, 2012). 
Light"? (1:7). ${ }^{25}$ Why is the testimony of the Baptist so important for the Evangelist? The proper answer to these questions could give a better understanding of the court motif in the Gospel of John and provide clues for the Evangelist's theology of witness. ${ }^{26}$ That intention is made known by the two iv $\alpha$ clauses that he uses in ch. 1:7; the first one

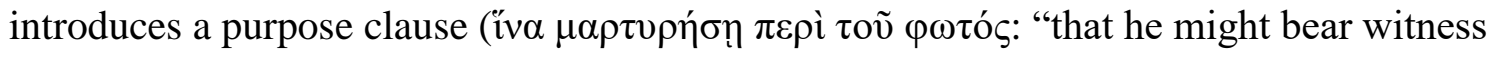

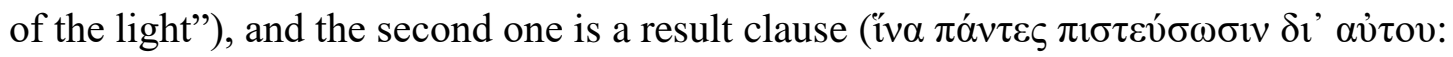
"that all might believe through him") which arises from the testimony of the Baptist. Also

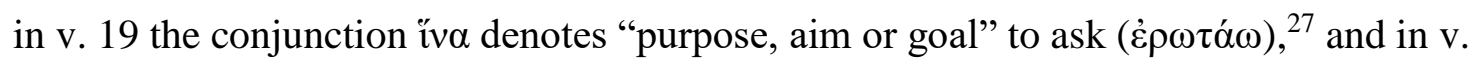

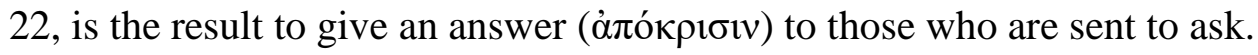

In order to start giving answer to the questions formulated above, R. V. G. Tasker says that the Evangelist wants to state that the Baptist does not "claim to be either the Messiah, or one of the great Old Testament figures who would, it was believed, be reincarnated before the Messiah came."28

\footnotetext{
${ }^{25}$ Brown, The Gospel According to John I-XII, 9, says that "the Fourth Gospel stresses more the role of John the Baptist as a witness than as a baptizer." Ricoeur, Essays, 137, claims that the Baptist is a witness in a "more theological sense" because he is a "witness of the light." See also Köstenberger, $A$ Theology of John's Gospel and Letters, 181, 201; Walter Wink, John the Baptist in the Gospel Tradition, SNTSMS 7 (Eugene, OR: Wipf \& Stock, 2000), 105.

${ }^{26}$ This has led Pancaro, The Law in the Fourth Gospel, 212, to say that the Baptist's testimony is "in order to induce belief, not in view of condemnation."

${ }^{27}$ Frederick William Danker, A Greek-English Lexicon of the New Testament and Other Early Christian Literature, 3rd ed. (Chicago, IL: University of Chicago Press, 2000), 475. Hendriksen, Exposition of the Gospel According to John, 77, argues that "the Baptist's intention was that all those who heard his testimony might embrace Christ by a living faith." Christ is the light while "the Baptist is a reflector. The latter is light in a derived sense. Thus only can he be called a burning shining lamp (5:35). John testifies concerning the Christ like the moon testifies concerning the sun." Cf. also Daniel B. Wallace, A Greek Grammar beyond the Basics: An Exegetical Syntax of the New Testament (Grand Rapids, MI: Zondervan, 1996), 471-75.

${ }^{28}$ R. V. G. Tasker, John, TNTC 4 (Grand Rapids, MI: Eerdmans, 1995), 49.
} 
Accordingly, Beasley-Murray explains that Jewish people traditionally believed

"that Elijah would anoint the Messiah, and thereby reveal his identity to him and to

Israel." 29 They were waiting for Elijah ${ }^{30}$ or "the return of Jeremiah or some other great

prophet who would be a forerunner of the Messiah." 31

Moses prophesied that the Lord "will raise up for you a Prophet like me" (Deut

18:15, 18). ${ }^{32}$ During Second Temple Judaism, the idea of a "type of the Exodus prophet,

${ }^{29}$ Beasley-Murray, John, 24. Cf. J. Louis Martyn, History and Theology in the Fourth Gospel, 2nd ed. (Nashville, TN: Parthenon), 102-28; Paul Trudinger, “A Prophet Like Me (Deut 18:5): Jesus and Moses in St John's Gospel, Once Again,” DRev 113 (1995): 193-95.

${ }^{30}$ See Fredrickson, John, 52.

${ }^{31}$ Ibid. For a survey of Jewish expectation about the coming of Elijah, see J. Jeremias "H $\lambda(\boldsymbol{\varepsilon}) 1 \alpha \varsigma, "$ TDNT 2:928-34; Julio T. Barrera, "Elijah," EDSS 1:246; Oscar Cullmann, The Christology of the New Testament, trans. Shirley C. Guthrie and Charles A. M. Hall (Philadelphia, PA: Westminster, 1963), 37; Robert Hayward, "Phinehas — the Same is Elijah: The Origins of Rabbinic Tradition," JJS 29 (1978): 2234; Morris M. Faierstein, "Why Do the Scribes Say That Elijah Must Come First?," JBL 100 (1981): 75-86; Michel E. Stone, ed., Jewish Writings of the Second Temple Period: Apocrypha, Pseudepigrapha, Qumran, Sectarian Writings, Philo, Josephus, CRINT 2 (Assen: Van Gorcum, 1984); Dale C. Allison, "Elijah Must Come First," JBL 103 (1984): 254-58; J. D. Martin, "Ben Sira's Hymn to the Fathers: A Messianic Perspective," in Crises and Perspectives: Studies in Ancient Near Eastern Polytheism, Biblical Theology, Palestinian Archaeology, and Intertestamental Literature, Papers Read at the Joint British-Dutch Old Testament Conference, Held at Cambridge, U.K., 1985, OtSt 24, ed. Johannes Cornelis de Moor (Leiden: Brill, 1986), 107-33; Richard A. Horsley, "Like One of the Prophets of Old: Two Types of Popular Prophets at the Time of Jesus," $C B Q 47$ (1985): 435-63; Joseph A. Fitzmyer, "More About Elijah Coming First," JBL 104 (1985): 295-96; Devorah Dimant and Lawrence H. Schiffman, eds., Time to Prepare the Way in the Wilderness, STDJ 16 (Leiden: Brill, 1995); John J. Collins, The Scepter and the Star: The Messiah of the Dead Sea Scrolls and Other Ancient Literature, ABRL 10 (NY: Doubleday, 1995); Thomas W. Overholt, "Elijah and Elisha in the Context of the Israelite Religion," in Prophets and Paradigms: Essays in Honor of Gene M. Tucker, ed. Stephen Breck Reid (Sheffield, England: Sheffield Academic, 1996), 94-111; Taylor, The Immerser: John the Baptist within Second Temple Judaism, SHJ (Grand Rapids, MI: Eerdmans, 1997); Donald W. Parry and Eugene C. Ulrich, eds., Prove International Conference on the Dead Sea Scrolls: Technological Innovations, New Texts, and Reformulated Issues, STDJ 30 (Leiden: Brill, 1999); Sukmin Cho, Jesus as Prophet in the Fourth Gospel (Sheffield, England: Sheffield Phoenix, 2003).

${ }^{32}$ Cf. Mounce, "John," 377. In The book of Sir 48:1, 10 the author says about Elijah that he "wast ordained for reproofs in their times, to pacify the wrath of the Lord's judgment, before it brake forth into fury, and to turn the heart of the father unto the son, and to restore the tribes of Jacob," thus giving a reference to Mal 4:5, 6 in which Malachi prophesies that Elijah would come "before the coming of the great and dreadful day of the Lord." In addition, in 4 Esdr 2 the author gives the promise to the Israelites that the Lord "will give them the kingdom of Jerusalem" (v. 10) sending his servants "Esau and Jeremy" (v. 18). And 1 Macc 14:46 the narrator says that Jewish people agreed "that Simon should be their governor and high priest for ever, until there should arise a faithful prophet." 
who repeats the miracles of the Exodus and conquest of the land" was developed. ${ }^{33}$ Thus, people thought that somebody, filled with God's Spirit would guide them to a political victory over their oppressors as Moses did over Egypt. With more than 300 years of oppression under Greek and Roman Empires it is not a surprise that they believed in a Messiah that would free them from their oppressors so that they could worship God faithfully, following the pattern of the Maccabees. ${ }^{34}$

Although some religious leaders thought that the Messiah and the prophet would be the same person, others made a distinction between them, knowing that the prophet would come as forerunner. ${ }^{35}$ This is the reason the delegation from the religious leaders asked the Baptist different questions regarding these personages $(1: 20,21,25)$. Therefore, the interrogation of the Baptist, concerning his identity with Elijah, was probably because there was a sense of doubt concerning the reason he preached the way he did. ${ }^{36}$

33 Beasley-Murray, John, 24.

${ }^{34}$ Burge. John, 71; Cf. Howard M. Teeple, The Mosaic Eschatological Prophet, JBLMS 10 (Philadelphia, PA: SBL, 1957); Wayne A. Meeks, The Prophet-King: Moses Traditions and the Johannine Christology, NovTSup 14 (Leiden: Brill, 1967); de Jonge, "Jesus as Prophet and King in the Fourth Gospel," ETL 47 (1993): 160-77; Peder Borgen, “John 6: Tradition, Interpretation and Composition," in From Jesus to John: Essays on Jesus and New Testament Christology in Honor of Marinus de Jonge, JSNTSup 84, ed. Martinus C. de Boer (Sheffield: JSOT, 1993), 269-71; John Lierman, The New Testament Moses: Christian Perceptions of Moses and Israel in the Setting of Jewish Religion, WUNT 173 (Tübingen: Mohr Siebeck, 2004).

35 Burge, John, 72.

${ }^{36}$ Morris, The Gospel According to John, 118, 119. Cf. John Marsh. Saint John, WPC (Philadelphia, PA: Westminster, 1977), 122; and Tenney, "Topics from the Gospel of John,” 230, 231. F. Collins, John and His Witness, 30-32, claims that the Evangelist characterizes the Baptist as a prophet though he does not call him as such. However, this status as a prophet is subordinate "to his role as a witness." Thus, in the Fourth Gospel "John is not really John the Baptist, he is John the witness." See also, Erns Heanchen, John 1: Commentary on the Gospel of John 1-6, Hermeneia, ed. and trans. Robert W. Funk (Philadelphia, PA: Fortress, 1984), 143; Beasley-Murray, John, 22. 
In his declaration, the Baptist provides five different words to affirm what he says

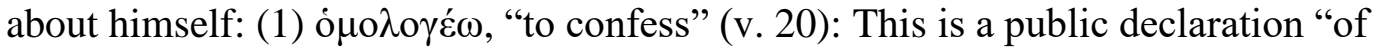
profession of allegiance;"' 37 and it is used specially to profess faith in Jesus $(9: 22 ; 12: 42)$;

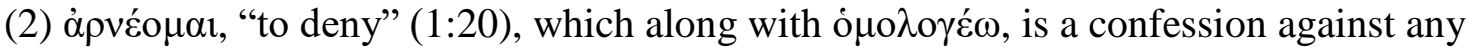
Messianic speculation about the person of the Baptist who, as a witness of the Messiah,

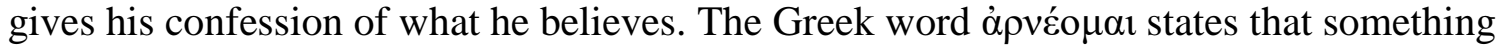
is not true, ${ }^{38}$ and suggests that the Baptist is denying any implications that the question of the religious leaders has in itself; ${ }^{39}$ (3) $\lambda \varepsilon^{\prime} \gamma \omega$ is an oral expression which anyone gives

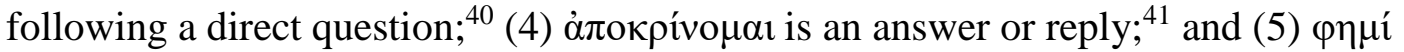
means "to affirm" or "to say;" "to state something orally . . . with direct discourse."

Another feature in this part of the Gospel of John is the use of the emphatic personal pronoun $\dot{\gamma} \gamma \omega ́$ ("I") which is used 132 times in the whole Gospel; more than

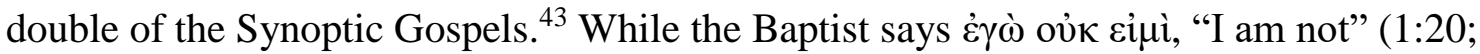

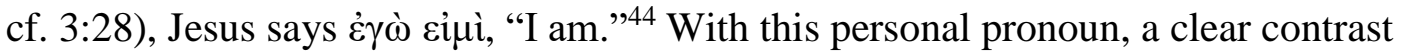

\footnotetext{
${ }^{37}$ Danker, A Greek-English Lexicon, 708. Mounce, “John," 377, explains that "to 'confess' is to 'admit or concede something to be true." "Thus, "John 'admitted' that he was not the Messiah." Cf. O.

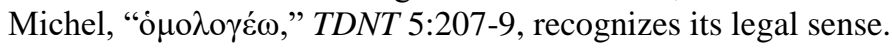

${ }^{38}$ Danker, A Greek-English Lexicon, 132. See also, H. Schrier, “ảpvéo $\mu \alpha 1, ” T D N T$ 1:469-71.

${ }^{39}$ Mounce, "John," 377.

${ }^{40}$ Danker, A Greek-English Lexicon, 588.

${ }^{41}$ Ibid, 113.

${ }^{42}$ Ibid, 1053.

${ }^{43}$ Matthew, 28 times; Mark, 16 times; and Luke, 21 times.

${ }^{44}$ See John 4:26; 6:20, 35, [41], 48, 51; 7:34, [36]; 8:12, 18, 21, [22], 23, 24, 28, 58; 10:7, 9, 11,

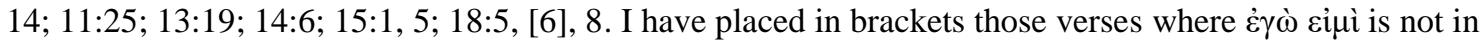

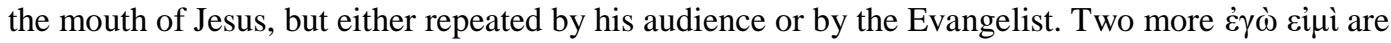
mentioned by Jesus in 12:26 and 14:3, but they have a locative sense with a neutral meaning.
} 
between the Baptist and Jesus is highlighted. The attributes that the religious leaders are

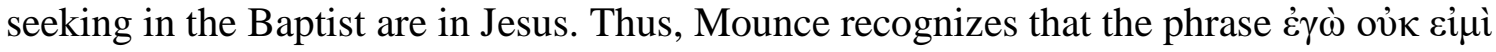
is "an implied contrast with egō eimi ('I am') of Jesus that so often falls from his lips."45

Also, the author of the Gospel of John shows the Baptist giving more than one testimony in favor of Jesus. Lincoln asserts that since the Baptist "is the first witness called in the trial proceedings, it is not surprising that so much attention is given to his functioning in this role." 46 Thus John 1:6-8 is an introduction to his testimony reported by the Evangelist; then v. 15 is the Baptist's first oral testimony, and as I display in table 16,

\footnotetext{
${ }^{45}$ Mounce, "John," 377. Also in John 8:58, Jesus reveals his identity to the Pharisees (v. 13) when

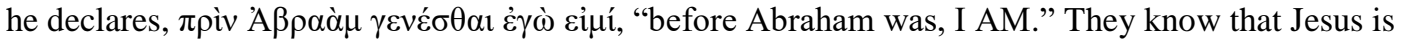

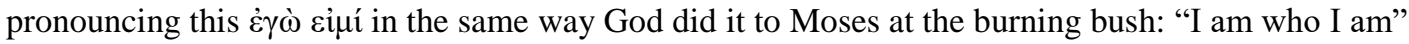

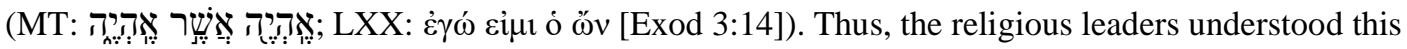
revelation as a claim of divinity on Jesus's part. Hence, "they took up stones to throw at Him" (8:59) because for them this pronouncement was a blasphemy (Lev 24:16).

Cf. R. E. Brown, The Gospel According to John, 29 A (NY: Doubleday, 1970): 533-37, who concludes that the Old Testament is the background of the Johannine "I am" sayings, especially from Genesis, Exodus, Leviticus, and the so called Deutero-Isaiah. See also, ibid., The Community of the Beloved Disciple: The Life, Loves, and Hates of an Individual Church in New Testament Times (Mahwah, NJ: Paulist, 1979), 45; Enz, "The Book of Exodus," 213; Glenn W. Barker, William L. Lane, and J. Ramsey Michaels, The New Testament Speaks (NY: Harper \& Row, 1969), 412; Ashton, Understanding the Fourth Gospel, 142; Blomberg, "The Globalization of Biblical Interpretation: A Test Case -John 3-4," BBR 9 (1995): 1-15; Ethelbert Stauffer, Jesus and His Story, trans. Richard Winston and Clara Winston (NY: Knopf, 1960), 176-78; Hugo Odeberg, The Fourth Gospel: Interpreted in Its Relation to Contemporaneous Religious Currents in Palestine and the Hellenistic-Oriental World (Amsterdam: B. R. Grüner, 1968), 308-10; Robert Kysar, John: The Maverick Gospel (Atlanta, GA: John Knox, 1976), 40-44; Philip B. Harner, The "I Am" of the Fourth Gospel: A Study in Johannine Usage and Thought, FBBS 26 (Philadelphia, PA: Fortress, 1970), 15-17; Culpepper Anatomy of the Fourth Gospel: A Study in Literary Design (Philadelphia, PA: Fortress, 1983), 108; Verlyn Verbrugge, "Exegetical Insight: Present Active Indicative," in Basics of Biblical Greek: Grammar, ed., William D. Mounce (Grand Rapids, MI: Zondervan, 2003), 129.

Contrary to this position are Barrett, The Gospel According to St John, 352; Beasley-Murray, Gospel of Life, 27; Keener, The Gospel of John, 1:770-72; Menken, Numerical Literary Techniques in John: The Fourth Evangelist's Use of Numbers of Words and Syllables (Leiden: Brill, 1985), 143, 144; David M. Ball, "I Am" in John's Gospel: Literary Function, Background, and Theological Implications, JSNTSup 124 (Sheffield, England: Sheffield, 1996), 195-98; Richard Bauckman, God Crucified: Monotheism and Christology in the New Testament (Grand Rapids, MI: Eerdmans, 1998), 55.

${ }^{46}$ Lincoln, Truth on Trial, 58.
} 
v. 27 is a repetition of the testimony with a variant in the second part. ${ }^{47}$ Hence, in the first testimony (v. 15), along with his confession that he is not the Christ (vv. 19-27), the Baptist declares Jesus's superiority:

Table 16. The Baptist's testimony in John 1:15, 27

\begin{tabular}{|c|c|}
\hline v. 15 & v. 27 \\
\hline 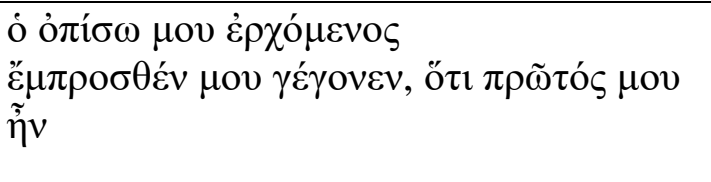 & 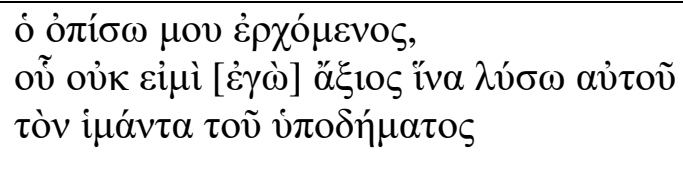 \\
\hline $\begin{array}{l}\text { "He who comes after me has been before } \\
\text { me; because he was before me" }\end{array}$ & $\begin{array}{l}\text { "He who comes after me, whose sandal } \\
\text { strap I am not worthy to loose" }\end{array}$ \\
\hline
\end{tabular}

The Baptist's second testimony (1:29-34) is an affirmation of what he has said the day before (v. 15), and also a double declaration of Jesus's identity and origin: ${ }^{48}$ (1) The Spirit identifies Jesus as the one who baptizes with the Holy Spirit (vv. 32, 33), and as a result of the verification of this sign, he confirms that (2) Jesus is the Son of God: oũ 0 '́ $\dot{\varepsilon} \sigma \tau \imath v$ ó viòs $\tau$ oṽ $\theta \varepsilon \circ \tilde{v}\left(\right.$ v. 34). ${ }^{49}$

${ }^{47}$ Bultmann, The Gospel of John, 84, believes that John 1:19-34 "is not an original unit." Collins, John and His Witness, 12, argues that this is "a literary doublet of the preceding interrogation." Collins arrives at this conclusion because he believes that the Gospel of John is "an edited version of an earlier text, which in turn may well have been an edited version of a still earlier text" (ibid., 16). This point of view is also true of Bultmann's reasoning. Contrary to this position, Lincoln, Truth on Trial, 58, supports that the "treatment twice in the prologue" of John the Baptist's witness "indicates just how significant" this topic "is for this Gospel."

${ }^{48}$ Cf. Michaels, The Gospel of John, 94, 95, who comments that of these two testimonies the first is negative and the second is positive. Thus "the issues raised by the delegation on one day are resolved on the next."

${ }^{49}$ Cf. Ricoeur, Essays, 137, who explains that the Baptist's testimony "is not other than the essential and total Christic confession." 
His last testimony (3:26-36) is given in response to his disciples concerning a negative report about Jesus. They complain that Jesus is baptizing and making followers of those who were before following the Baptist (v. 26). However, the Baptist confronts

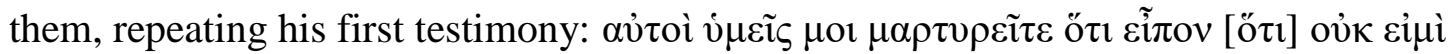

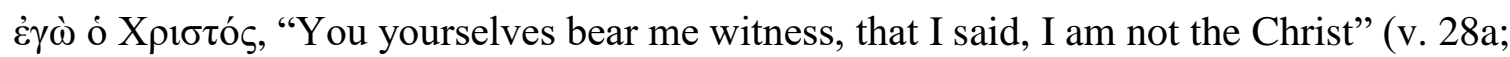
cf. 1:20). He refers to a statement that, according to him, he has said before but the

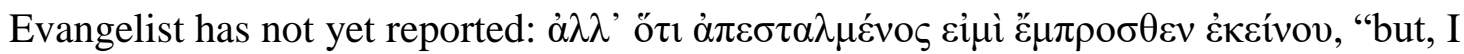
have been sent before him" (v. 28b).$^{50}$ Then, the Baptist concludes his testimony attesting that Jesus is the bridegroom, and he is the bridegroom's friend (v. 29); Jesus must increase but he must decrease (v. 30); Jesus comes from heaven, but he comes from the earth (v. 31); Jesus testifies what he has seen and heard, though no one receives his testimony (v. 32), but whoever receives Jesus's testimony certifies that God is true (v. 33); Jesus speaks God's words (v. 34); Jesus is so loved by the Father that he has given all things into Jesus's hand (v. 35); in order to have eternal life one must believe in Jesus, otherwise God's wrath “abides on him" (v. 36). ${ }^{51}$

Keener says that the Evangelist portrays the Baptist as an introduction to "his theme of witness" which goes "far beyond whatever significance" he wants to attach to it. ${ }^{52}$ Thus, in the Gospel of John, the Baptist is not so important as a baptizer or as the

${ }^{50}$ This second part of v. 28 seems to be an echo of Mal 3:1.

${ }^{51}$ Lincoln, Truth on Trial, 65, considers John 3:31-36 "very much like the narrator's further reflections on the earlier discourse, picking up most of its themes." Knowing the difficulties that most commentators and translations have to know, "where the words of the characters in the discourses cease and the reflections of the narrator begin" he stipulates that "a decision on this matter is not particularly significant for the exposition of the lawsuit motif" (ibid., 66).

${ }^{52}$ Keener, The Gospel of John, 1:391. Bultmann, The Gospel of John, 88, answers these questions stating, "The cumbrous introduction to the Baptist's answer (v. 20) corresponds to its preparation in v. 19; 
forerunner of the Messiah, but as a witness among many others.

\section{The Samaritan Woman}

Jesus's revelation of the secret life of the Samaritan woman (John 4:16-26)

compels her to share with others her impression about this unknown man (vv. 28-30).

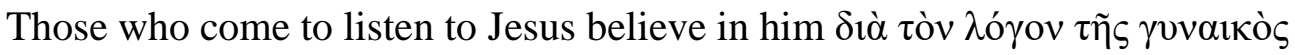

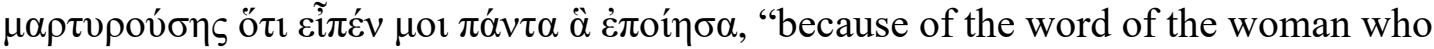

testifies, He told me all that I did" (v. 39). ${ }^{53}$ Thus, this woman is reported by the

Evangelist as a witness who testifies in Jesus's favor. ${ }^{54}$ In addition, in her testimony, she

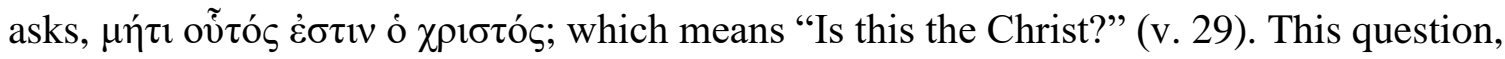

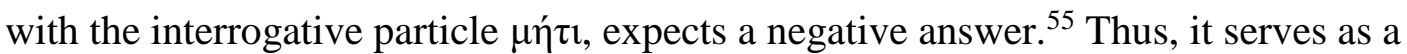

it has the full weight of the solemn testimony of a witness in a trial." Cf. R. H. Gundry, Commentary on the New Testament, 348.

53 This last declaration: "He told me all that I did" is repeated two times (vv. 29, 39) with a slight

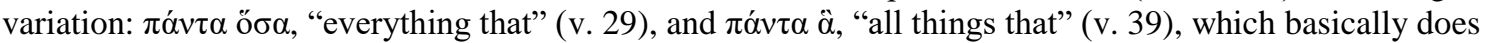
not imply any difference.

${ }^{54}$ Though the exclusion of women as witnesses in Israel is not supported by any text in the Hebrew Bible, the inclusion of the Samaritan woman as a witness in the Gospel of John is a turning point in Jewish law. In Ant. IV, 219, Josephus defends that women shall not be allowed to testify in court "on account of the levity and boldness of their sex." This turning point in the Gospel of John is also important because this person is not only a woman, but also a Gentile Samaritan (John 4:9).

Trites, The New Testament Concept of Witness, 6, talking about secular Greek ancient literature, argues that in Greek courts "women were not allowed as witnesses." This practice varies with that of Jewish culture in which the prohibition was not stated legally but traditionally. In his comment on the Samaritan woman, Hendriksen, Exposition of the Gospel, 175, indicates that "the talk ( $\left.\dot{\eta} \lambda \alpha \lambda \lambda^{\prime} \alpha\right)$ of the woman," in John 4:42, is contrasted "with the word (ó $\lambda$ ó ${ }^{\circ}$; ; 4:41) of Christ." However, in John 4:39 the woman's testimony ... is called her word ( $\lambda$ ó $\gamma \circ \varsigma)$.

The origin of the Samaritans is explained in 2 Kgs 17:23-29. For more information about the enmity of Samaritans against Jews see Ezra 4:1-3, 17-23; Neh 2:10; 4:1, 2; and Josephus, Ant. XX, 118137. Köstenberger, A Theology of John's Gospel and Letters, 499, admits that the Samaritan woman serves as a witness "somewhat ambivalently." On his part, Blomberg, "The Globalization of Biblical Interpretation," 10, portrays her as an "apostle" or a female witness who is "a missionary to her own people."

55 The NRS translates: "He cannot be the Messiah, can he?" (v. 29). Cf. B. F. Westcott, Gospel According to St. John: Greek Text with Introduction and Notes, Thornapple Commentaries 1, rep. ed. (Grand Rapids, MI: Baker Book House, 1980), 163. Contrary to this conclusion Blomberg, "The 
motivation for the people to know him and get their own information.

Accordingly, Michaels says that the Evangelist calls the Samaritan woman's invitation a testimony, "identifying her as a woman of faith" and "placing her alongside John [the Baptist] and Jesus, and all who 'speak what we know, and . . . testify to what we have seen' $(3: 11) .{ }^{, 56}$

The Pentateuch does not prohibit women from testifying in court; however, Flavius Josephus is against this practice, while rabbinic writings are divided. ${ }^{57}$ In the

Globalization of Biblical Interpretation," 11, thinks that "this adverb needs not imply a negative answer." However, he recognizes that John could have used the Greek ov "to avoid any sense of hesitancy." Also Blomberg quotes Morris saying, "It is as though a negative answer might be expected, but a positive one is hoped for." Thus, according to Blomberg this quotation is "the most balanced" attempt "to capture the significance of $\mu$ í $\tau$ " (Morris, The Gospel According to John, 275 n. 29, in Blomberg, "The Globalization of Biblical Interpretation," 11 n. 49). Therefore, Blomberg tries to agree with Morris that the significance of $\mu$ ท́ $\iota$ is negative but its implication is positive.

${ }^{56}$ Michaels, The Gospel of John, 268. Brant, John, 184, discusses some scholars' views about the place that the Gospel of John gives to women, saying that "the Gospel writer gives equal value to the testimony of either men or women as individuals" and further she concludes that John's purpose is christological rather than about women.

${ }^{57}$ See this dissertation's discussion under Flavius Josephus (c. 37-c. 100), pp. 40-41. For further analysis of the role of women in Israel, see Charlotte Hannah Adams, Women of Ancient Israel, 2nd ed. (NY: National Board of the Young Women's Christian Associations of the United States of America, 1913); Clovis Gillham Chappell, Christ and the New Woman (Nashville, TN: Cokesbury, 1928); David

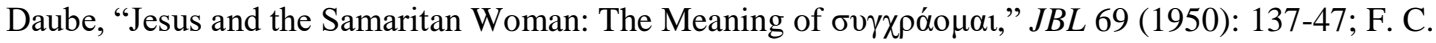
Hyman, "Women of the Bible," Judaism 5 (1956): 338-47; Argye M. Briggs, Christ and Modern Woman (Grand Rapids, MI: Eerdmans, 1958); Webb B. Garrison, Women in the Life of Jesus (Indianapolis, IN: Bobbs-Merrill, 1962); Harold John Ockenga, Women Who Made Bible History (Grand Rapids, MI: Zondervan, 1962); Eugenia Price, The Unique World of Women, in Bible Times and Now (Grand Rapids, MI: Zondervan, 1969); William Pierson Barker, Women and the Liberator (NJ: F. H. Revell, 1972); Alicia Craig Faxon, Women and Jesus (Philadelphia, PA: United Church, 1973); Phyllis Bird, "Images of Women in the Old Testament," in Religion and Sexism: Images of Women in the Jewish and Christian Traditions, ed. Rosemary Radford Ruether (NY: Simon \& Schuster, 1974), 41-88; Frederick Drimmer, Daughters of Eve: Women in the Bible (Norwolk, CT: C. R. Gibson, 1975); Anne Goldfeld, "Women as Sources of Torah in the Rabbinic Tradition," Judaism 24 (1975): 245-56; Joachim Jeremias, Jerusalem in the Time of Jesus: An Investigation into Economic and Social Conditions During the New Testament Period, trans. C. H. Cave and F. H. Cave (Philadelphia, PA: Fortress, 1975), 352-73; R. E. Brown, "Roles of Women in the Fourth Gospel," TS 36 (1975): 588-99; R. Scroggs, "Woman in the NT," IDBSup 966-68; Elizabeth Clark and Richardson Herbert, eds., Women and Religion (NY: Harper \& Row, 1977); Evelyn Stagg and Frank Stagg, Women in the World of Jesus (Philadelphia, PA: Westminster, 1978); Leonard Swidler, Biblical Affirmation of Women (Philadelphia, PA: Westminster, 1979); Jerome H. Neyrey, "Jacob Traditions and the Interpretation of John 4:10-26," CBQ 41 (1979): 419-37; Carroll D. Osburn, Essays on Women in Earliest Christianity, 2 vols., (Joplin, MO: College, 1995); Aubrey Malphurs, Biblical Manhood and Womanhood: Understanding Masculinity and Feminity from God's Perspective (Grand Rapids, MI: 
Gospel of John, women's testimony is supported and placed together, along with men's testimony, implying that the Evangelist is free of prejudice and decides to report every testimony without hesitation, no matter what its source. ${ }^{58}$

\section{The People Who Saw Lazarus Raised From the Dead}

After Lazarus is raised from the dead by Jesus (11:38-44), the people, who were

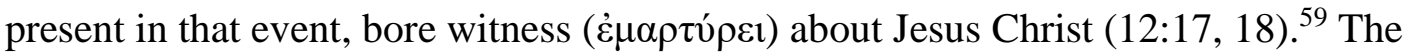

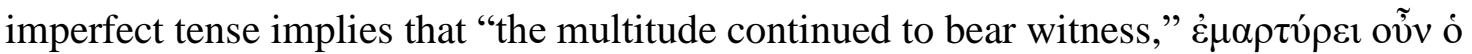
ő $\chi \lambda$ os, talking about Lazarus' resurrection for a certain time. ${ }^{60}$

They shared this miracle in such a way that many people came to Bethany to see Lazarus (12:9). ${ }^{61}$ As a result, many more people came to see Jesus in Jerusalem because they had heard that he would come for the Passover $(12: 12,18)$. When he came, they

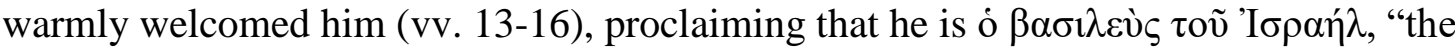
King of Israel" (v.13). Consequently, John 11:4 is fulfilled: God and the Son are glorified through Lazarus' sickness. However, while o ö $\chi \lambda \mathrm{o}$, , "the people" came to meet Jesus

Kregel, 1996); Klaus Scholtissek, "The Johannine Gospel in Recent Research,” in The Face of New Testament Studies: A Survey of Recent Research, ed. Scot McKnight and Grant R. Osborne (Grand Rapids, MI: Baker Academic, 2004), 468.

${ }^{58}$ Men's testimony is that Jesus is the Christ. This is the same argument of the Samaritan woman. Cf. Jerry M. Self, Men and Women in John's Gospel (Nashville, TN: Broadman, 1974).

59 Accordingly, Bultmann, The Gospel of John, 419, emphasizes the significance of Lazarus'

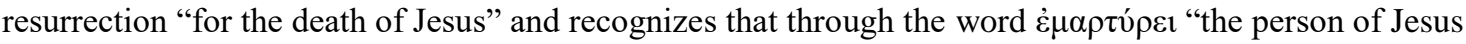
forms the subject of the trial between God and the world."

${ }^{60}$ Mounce, "John," 533, calls this "a continuous imperfect." Main English versions translate this phrase as follows: "continued to bear witness" (ESV); "continued to testify" (NAB; NAU; NRS); "were bearing Him witness" (NAS); "continued to spread the word" (NIV); "kept bearing witness to it" (NJB); "bore witness" (RSV; NKJV).

${ }^{61}$ The Evangelist wants to make the point that Jesus has power over his creation. He can bring Lazarus to life again because he is the Creator, who works in the world bringing a new creation. 


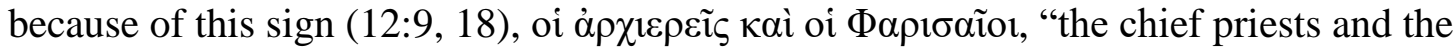
Pharisees," were complaining and plotting to put Jesus and Lazarus to death (11:47-57; $12: 10,19){ }^{62}$

\section{Jesus's Disciples}

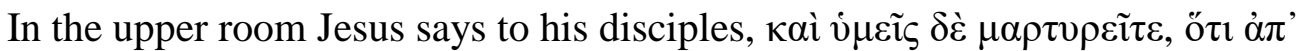
$\dot{\alpha} \rho \chi \tilde{\eta} \varsigma \mu \varepsilon \tau$ ’ $\dot{\varepsilon} \mu o \tilde{v} \dot{\varepsilon} \sigma \tau \varepsilon$, “And you also testify, because you are with me from the beginning" (15:27). The verb $\mu \alpha \rho \tau v \rho \varepsilon i \tau \varepsilon$ is in the present tense and could be either indicative or imperative. ${ }^{63}$ Despite this ambiguity, it could be better translated in the present indicative with a future sense because Jesus is talking to his disciples regarding the work of the Spirit in the future. In this case the $\dot{\varepsilon} \sigma \tau \varepsilon$ in the second clause is a present tense verb that extends from the past. Thus the second clause means: "because you have been with me from the beginning." This would make more likely that $\mu \alpha \rho \tau v \rho \varepsilon i \tau \varepsilon$, in the first part of the verse, is a futuristic present, meaning "you will certainly testify." This translation stresses the way the Holy Spirit will support the witness of the disciples

${ }^{62}$ In the Gospel of John the people (o ö $\chi \lambda \circ \varsigma_{\text {) }}$ are divided concerning Jesus's identity and origin (7:43). Notice that the Evangelist speaks of "the people" who are with Jesus "when he calls Lazarus out of his tomb and raises him from the dead, bear witness;" but also he mentions that "the people" hear that Jesus "had done this sign" $(12: 17,18)$. Therefore, in the Gospel of John the people (o ó $\chi \lambda \mathrm{o} \varsigma)$ are fragmented by groups that could be either in favor of Jesus $(7: 12 b, 31,40,41 a)$ or against him $(7: 12 c, 20,41 b, 42)$. A group of o ö $\chi \lambda \circ \varsigma$ "wanted to take Jesus" (7:44); but also the people (o ö $\chi \lambda \circ \varsigma)$ are rejected by the religious leaders (7:49). However, this division should not be a surprise in the Gospel of John because Jesus's disciples and the religious leaders are divided also regarding the same issue.

${ }^{63}$ This ambiguity is reflected in different biblical translation, such as the ESV; KJV; NAS; NJB; NKJ; NRS: "and you will bear witness/testify" (which is a future indicative); the NIV: "you . . must testify" (an imperative); the NAB and the RSV: "you ... testify" and "you . . . are witnesses" respectively (both in the present indicative). On his part, Wallace, A Greek Grammar, 487-88, states that "the imperative is commonly used to forbid an action. It is simply a negative command." And when it is used in a positive way, "to express a request," it "is normally seen when the speaker is addressing a superior." Thus here, Jesus is not commanding, but stating what has been happening already. 
because they have been with Jesus from the beginning. ${ }^{64}$ That is, the disciples have started their witnessing with Jesus, and with the Spirit they will continue witnessing for Jesus. $^{65}$

\section{The Evangelist}

On two occasions, the Evangelist narrates his experience with Jesus as a

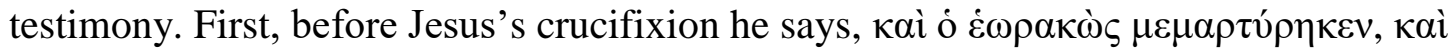

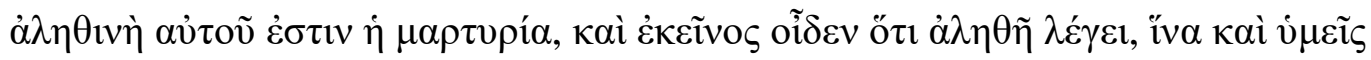
$\pi \imath \sigma \tau \varepsilon \tilde{[}[\sigma] \eta \tau \varepsilon$, “And he who has seen has testified, and his testimony is true; and he knows that he is telling the truth, so that you may believe" (19:35). ${ }^{66}$ And second, in spite of his

${ }^{64}$ Cf. Lindars, The Gospel of John, 496, 497; Gundry, Commentary on the New Testament, 436, 437. Michaels, The Gospel of John, 826, asserts, "This they must do, and this they are qualified to do because they have been with Jesus 'from the beginning' (v. 27), that is, from the beginning of - and throughout - his ministry. . . 'From the beginning' signals Jesus' ministry in its entirety, right up to his

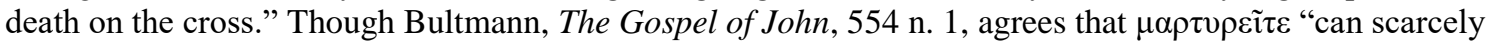
be an imperative," on the other hand he believes that "the present tense tells the disciples the role they will take, 'You are (ordained to be) witnesses.'"

${ }^{65}$ Cf. Köstenberger, Theology of John's Gospel and Letters, 244; Bultmann, The Gospel of John, 553,554 , expresses that "the word $\mu \alpha \rho \tau \nu \rho \eta ́ \sigma \varepsilon 1$ indicates that the Spirit is the power of the proclamation in the community, and this is made fully clear by the juxtaposition of the disciples' witness and that of the

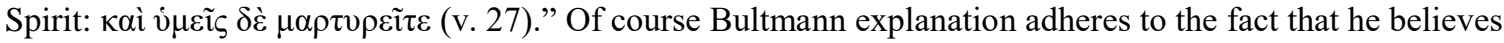
John, who was Jesus' disciple and Jacob's brother, did not write the Gospel.

${ }^{66}$ Scholars disagree on the interpretation of this verse. They are not sure about the person's identity who gives his testimony here. For example Lindars, The Gospel of John, 589, believes that "the soldier who pierced Jesus' side" is the one who bears witness; Michaels, The Gospel of John, 970-75, compares this testimony's content with the testimonies found in Mark 15:39 and Matt 27:54, and the prophecy of Zech 12:10, and concludes that the person who is giving the testimony in the Gospel of John is "a Roman centurion present at the crucifixion."

Mounce, "John," 639, discusses the use of third person in the Gospel and gives four possibilities: (1) If John is the writer of the Gospel he is talking about somebody else; (2) If John 19:35 is an interpolation, then those responsible for the interpolation are talking about "the beloved disciple;" (3) John

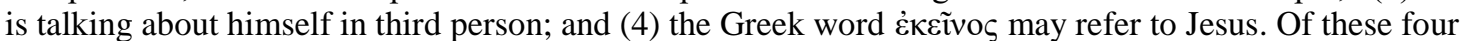
possibilities he maintains that the last two are unlikely, but the first two are possible.

On the one hand, Bultmann, The Gospel of John, 678, recognizes the difficult task of knowing to

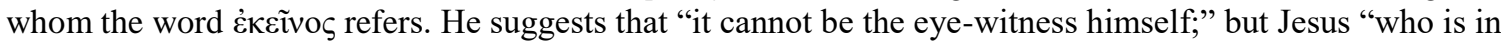
the position to guarantee the truth of the testimony." On the other hand, R. H. Gundry, Commentary on the New Testament, 454, 455, 462, 463, without specifying who "the beloved disciple" is, believes that this person is the same as the Gospel's author. Though I agree with Gundry, I am convinced that to believe otherwise is not going to change the outcome of this dissertation, which would be altered by adding one 
readers calling his writing a Gospel, at the end of his book, he calls it a $\mu \alpha \rho \tau v \rho i ́ \alpha$, “testimony" (21:24). ${ }^{67}$

Accordingly, Michaels agrees that the phrase " 'these things' cannot be limited to the immediately preceding scene" in ch. 21 "nor to chapter 21 alone. Rather, the notice pertains to the entire Gospel, the 'testimony' on which it rests, its authorship, and consequently its authority." 68 Therefore, he does not report only the testimonies of others but also his own which reflects his main purpose in his Gospel. In like manner, Barrett believes that the beloved disciple is "responsible for the $\mu \alpha \rho \tau$ pí $\alpha$ contained in the Gospel itself;" and "the claim made in v. 24 therefore refers to the Gospel as a whole."69

more witness to the group already cited. Furthermore, this dissertation is not concerned with matters of authorship.

${ }^{67}$ John Lightfoot, A Commentary on the New Testament from the Talmud and Hebraica, Matthew - 1 Corinthians: Luke - John (Grand Rapids, MI: Baker Book House, 1979), 3: 455, accepts that the Evangelist is an eyewitness who shows his testimony: "For in all judicial causes the ocular testimony prevailed."

${ }^{68}$ Michaels, The Gospel of John, 1054. So also Mounce, "John,” 661; Bultmann, The Gospel of John, 717; Ellis, The World of St. John, 83; Culpepper, Anatomy of the Fourth Gospel, 215; Collins, These Things Have Been Written: Studies on the Fourth Gospel (Grand Rapids, MI: Eerdmans, 1990), 10.

${ }^{69}$ Barrett, The Gospel According to St John, 583, 588. This is also the conviction of John A. T. Robinson, The Priority of John (Oak Park, IL: Meyer-Stone, 1987), 104, 105, who says that to believe that the beloved disciple is "the author of the last stage of the Gospel only . . . raises more difficulties than it solves - particularly for those who would say that he may originally have underlain the tradition but is now dead." Kevin Quast, Peter and the Beloved Disciple: Figures for a Community in Crisis (London, Great Britain: Sheffield, 1987), 7, claims for the interrelation of the whole Gospel of John.

Vernard Eller, The Beloved Disciple: His Name, His Story, His Thought (Grand Rapids, MI: Eerdmans, 1987), 43-73, defends his position saying that the source and the writer of the Gospel of John are different persons based on the use of the third person in chs. 19:35; 20:31; 21:24. Brant, John, 5, 6, 282, 286, 288-90, agrees with Eller's position. D. Moody Smith, Proclamation Commentaries: The New Testament Witnesses for Preaching, ed. Gerhard Krodel (Philadelphia, PA: Fortress, 1976), 42, explains that the Beloved Disciple is not John, the son of Zebedee, because "there is no firm basis in the Gospel for the traditional identification of this disciple with John."

For more exposition about the identity of the Beloved Disciple see John J. Huckle and Paul Visokay, The Gospel According to St. John, 3 vols. (NY: Crossroad, 1981); Smalley, John: Evangelist and Interpreter (Nashville, TN: Thomas Nelson, 1984); James H. Charlesworth, The Beloved Disciple: Whose Witness Validates the Gospel of John (Valley Forge, PA: Trinity Press International, 1995); Lincoln, "The Beloved Disciple as Eyewitness," 3-26; ibid., " 'We Know that His Testimony is True:' Johannine Truth, Claims, and Historicity," in John, Jesus, and History, Volume 1: Critical Appraisals of Critical Views, SBLSymS 44, eds. Paul N. Anderson, Felix Just, and Tom Thatcher (Atlanta, GA: SBL, 2007), 179-97; 


\section{Summary}

The Evangelist opens his Gospel by reporting the testimony of the Baptist in favor of Jesus. Though the people suspect that the Baptist is the Christ, he is eager to let everybody know that he has come to testify of the light, though he is not that light. The Baptist is not alone in his testimony, because the Evangelist also mentions the people who were present when Jesus raised Lazarus from the dead. At this point, the religious leaders are not willing to believe any of these testimonies; on the contrary, they want to put Jesus to death. Either they listen and believe what the people are saying about Jesus, or they become false witnesses and judge against him, thus transgressing the Pentateuchal legislation which requires that one must practice a just judgment (Deut 1:16, 17; cf. John 7:24). Later, at the end of Jesus's ministry, the Evangelist mentions a promise that Jesus gives to his disciples: They have been with him from the beginning of his ministry, and now the Paraclete will come to help them continue testifying in the future.

The Evangelist not only wants to report about others giving their testimonies for Jesus, he also takes a stand and gives his own testimony for Jesus's cause, saying that his Gospel is a true testimony about Jesus Christ. Along with these witnesses, he adds the Samaritan woman, with whom the Evangelist wants to accomplish at least two objectives: (1) It is not an easy task to include a woman as a witness, since Jewish people have been negatively influenced against paying attention to a testimony of a woman. ${ }^{70}$ However, the Evangelist knows that the Pentateuch has no provision for this prohibition;

Coling G. Kruse, The Gospel According to John: An Introduction and Commentary, TNTC 4 (Grand Rapids, MI: Eerdmans, 2003); Bauckman, The Testimony of the Beloved Disciple: Narrative, History, and Theology in the Gospel of John (Grand Rapids, MI: Baker Academic, 2007).

${ }^{70}$ See this dissertation under Flavius Josephus, pp. 40-41. 
consequently he goes ahead and includes her testimony. And (2) If the first objective is difficult, the second one pushes the line even further because the Evangelist gives importance to the testimony of a woman who is a Samaritan. Notwithstanding, the Evangelist accomplishes his goal: Not only testimonies of Hebrew men are important in favor of Jesus, but also the testimony of a Samaritan woman.

\section{Objects' Testimonies}

In the Gospel of John, the Evangelist refers to two elements placed as witnesses in favor of Jesus; that is, Jesus's works and the Scriptures. The placement of these elements agrees with the Pentateuch, in which diverse objects are placed also as witnesses and testimonies in order to make judgment and bring justice throughout the land. Above, in ch. III, these witnesses are: a covenant (Gen 31:44); stones (Gen 31:45-52); a torn animal (Exod 22:13 [Heb. v. 12]); the Ten Commandments (Exod 16:34; 27:21; 30:36; 31:18; 32:15; 34:28, 29); "heaven and earth" (Deut 4:26; 30:19; 31:28); Moses's song (Deut 31:19, 21); and the book of the law (Deut 31:26). Accordingly, in this section I examine the Evangelist's account regarding the testimonies of Jesus's works and the Scriptures, and test their connection with the Pentateuch.

\section{Jesus's Works}

In a conversation with the religious leaders Jesus enlists several witnesses in his favor (John 5:31-39), and one of them is his own work of which he says, $\mu \alpha \rho \tau v \rho \varepsilon \tilde{i} \pi \varepsilon \rho i$

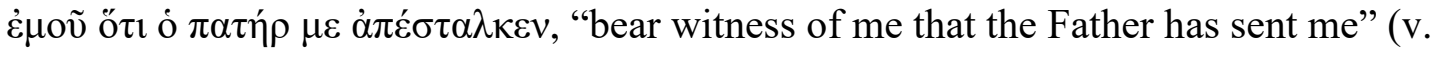
36). Mounce affirms that Jesus does not perform "miracles in order to prove his deity." However, "the miracles were not without evidential value. They not only strengthened 
faith but also witnessed to the fact that the Father had sent him on his redemptive mission." ${ }^{71}$ Also, Jesus asserts that the Baptist "has borne witness to the truth" (v. 33),

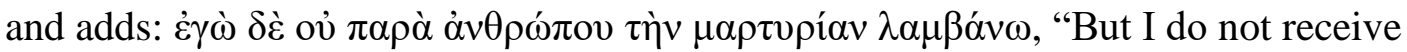
testimony from man" (v. 34). With this statement Jesus affirms that the Baptist is "the burning and shining lamp" (v. 35), and confirms what the Evangelist has been saying

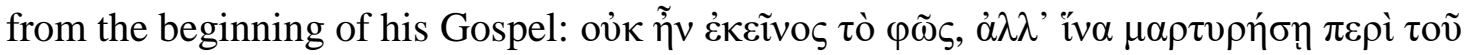
$\varphi \tau$ ós, "He [the Baptist] was not that light, but [he came] in order that he might bear witness of the Light [Jesus]" (1:8).

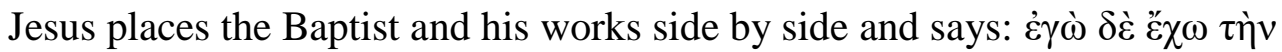

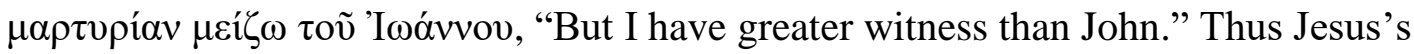

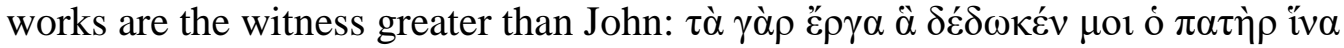

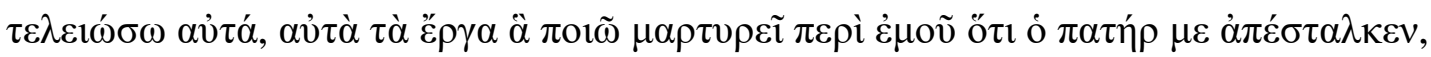
"For the works that the Father has given me to fulfill, the very works bear witness about me that the Father has sent me" (5:36) ${ }^{72}$ Concerning this point, during the Feast of Dedication, Jesus is confronted by the religious leaders who ask him to tell them once

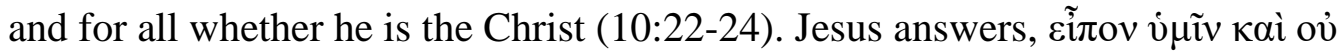

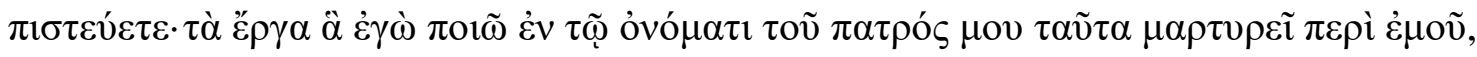
"I told you but you do not believe; the works that I do in my Father's name, they bear witness of me" (v. 25).

\footnotetext{
${ }^{71}$ Mounce, "John," 432. Cf. Von Wahlde, "The Witnesses to Jesus in John 5:31-40 and Belief in the Fourth Gospel," CBQ 43 (1981): 385-404; Barrett, The Gospel According to St John, 266. Painter, The Quest for the Messiah, 239, asserts that "indirectly it is the witness of the Father because the works done are those commissioned and authorized by the Father. It is the works done by the Son which he sees the Father doing, 5.19-20. Because the works of the Son are the works of the Father they bear witness 'that the Father has sent me.'"

${ }^{72}$ Cf. Lindars, The Gospel of John, 229; Gundry, Commentary on the New Testament, 378.
} 
Mounce explains that "although Jesus had never openly declared his messiahship, there can be no question that the miraculous deeds he had done by his Father's authority (i.e. 'in my Father's name') proved him to be the Christ." ${ }^{\text {"73 }}$ Thus, the religious leaders are supposed to know Jesus's answer by paying attention to the "many good works" ( $\pi \mathrm{o} \lambda \lambda \grave{\alpha}$

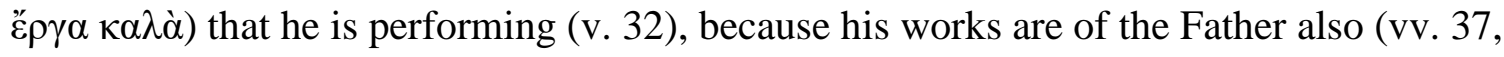

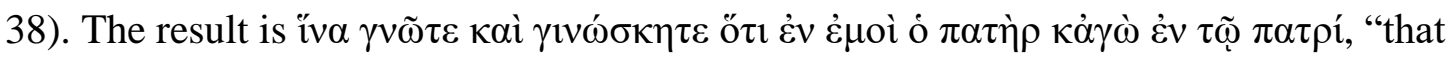
you might know and may learn that the Father is in me and I in the Father" (v. 38) ${ }^{74}$

Loren L. Johns and Douglas B. Miller explain that in the Gospel of John, हैprov refers to four things: (1) "a particular service or commission $(4: 34 ; 5: 36 ; 10: 25 ; 17: 4)$, , (2) "actions for which persons are morally accountable (3:19-21; 6:28-29; 7:7; 8:39, 41)," (3) "the activity of God through Jesus (10:32, 37-38; 14:10-12)," and (4) "Jesus' miracles in particular (5:20-21; 7:3, 21; 9:3-4; 15:24)." 75

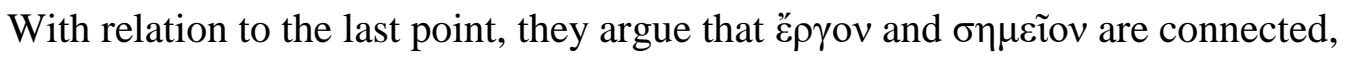
saying that though "Jesus does not say, 'My signs testify of me;" " the miracles that he performs, designated as $\ddot{\varepsilon} \rho \gamma o v$, are later, in the narrative, referred as $\sigma \eta \mu \varepsilon \tilde{o}{ }^{76}$

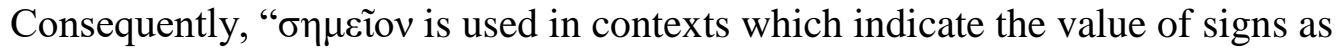

73 Mounce, “John,” 507.

${ }^{74}$ Cf. Bultmann, The Gospel of John, 265.

${ }^{75}$ Loren L. Johns and Douglas B. Miller, "The Signs as Witnesses in the Fourth Gospel: Reexamining the Evidence," CBQ 56 (1994): 525.

${ }^{76}$ Ibid., 525, 526. For example, before the healing of the man born blind, Jesus says, "We must work the works ( $\tau \grave{\alpha}$ है $\rho \gamma \alpha$ ) of Him who sent Me" (John 9:4); but later some of the Pharisees call it $\sigma \eta \mu \varepsilon i \tilde{\alpha}$ "signs" (9:16). Pancaro, The Law in the Fourth Gospel, 215, points out that Jesus's है $p \gamma \alpha$ refers to his miracles and words. 


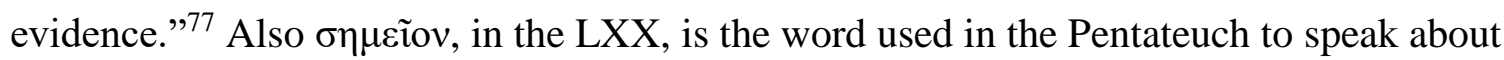
the miraculous signs that God made through Moses in the land of Egypt. ${ }^{78}$ In the Gospel of John, Jesus is the new Moses who performs miracles before his people. This evidence confirms the veracity of the Evangelist's testimony that Jesus is the Christ. Thus, in the book of Exodus the signs function as evidence or testimony in a trial; in like manner in the Gospel of John, Jesus's signs testify in his favor.

77 Johns and Miller, “The Signs as Witnesses," 526. As examples of this argument, Johns and Miller show John 7:31: "Yet many in the crowd believed in him and were saying, "When the Christ comes,

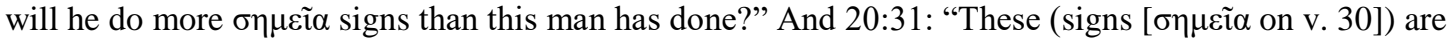
written that you might believe that Jesus is the Christ." More examples are John 10:41 and 12:37. Cf. also ibid., 519-35.

${ }^{78}$ Exod 4:17, 28, 30; 7:3; 10:1, 2; 11:9, 10; Num 14:22; Deut 6:22; 7:19; 11:3; 28:46; 29:2. For more explanation about Jesus's signs in the Gospel of John and their link to the Pentateuch see E. F. Scott, The Historical and Religious Value of the Fourth Gospel (London: Constable \& Company, 1910): 21-22; Alan Richardson, The Miracle-Stories of the Gospels (London: SCM, 1941), 114-22; C. H. Dodd, The Interpretation of the Fourth Gospel (Cambridge, England: Cambridge University Press, 1953), 142-43; Vernon McCasland, "Signs and Wonders," JBL 76 (1957): 149-52; L. Johnston, "The Making of the Fourth Gospel," Scr 12 (1960): 1-13; Smith, "Exodus Typology," 329-42; Rudolf Schnakenburg, God's Rule and

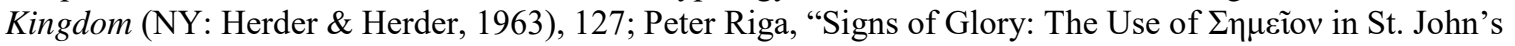
Gospel," Int 17 (1963): 402-24; Reginald H. Fuller, Interpreting the Miracles (London: SCM, 1963):88109; Vernon Ruland, "Sign and Sacrament: John's Bread of Life Discourse," Int 18 (1964): 450-62; T. C. Smith, "The Book of Signs: John 2-11," RevExp 62 (1965): 441-57; W. Nicol, The Semeia in the Fourth Gospel, NovTSup 32, ed. W. C. van Unnik (Leiden: Brill, 1972); R. E. Brown, The Gospel According to John, 29: 525-32; F. S. Parnham, “The Miracle of Cana," EvQ 42 (1970): 107-9; Robert T. Fortna, The Gospel of Signs (Cambridge: Cambridge University Press, 1970); Eduard Lohse, "Miracles in the Fourth Gospel," in What About the New Testament?: Essays in Honour of Christopher Evans, ed. Morna Hooker and Colin Hickling (London: SCM 1975), 64-75; Tenney, "Topics from the Gospel of John, Part II," $145-$ 60; Stanley D. Toussaint, "The Significance of the First Sign," BSac 139 (1977): 45-51; David Ronald Foubister, "The Nature and Purpose of Jesus' Miracles in the Gospels" (Ph.D. diss., Fuller Theological Seminary, 1981); Beasley-Murray, Jesus and the Kingdom of God (Grand Rapids, MI: Eerdmans, 1986), 80-83; D. A. Carson, The Gospel According to John (Grand Rapids, MI: Eerdmans, 1991), 103; Craig R. Koester, Symbolism in the Fourth Gospel: Meaning, Mystery, Community (Minneapolis, MN: Fortress, 1995); Mark R. Saucy, "Miracles and Jesus' Proclamation of the Kingdom of God," BSac 153 (1996): 281307; Köstenberger, Encountering John: The Gospel in Historical, Literary, and Theological Perspective, Encountering Biblical Studies, ed. Walter A. Elwell (Grand Rapids, MI: Baker Academic, 1999), 74-79;

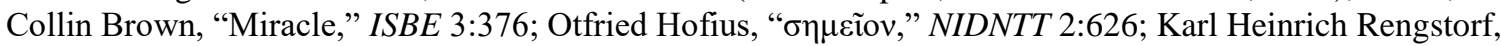

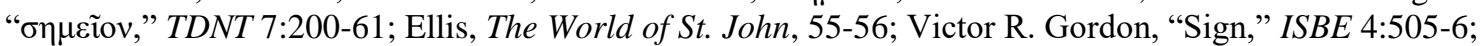
Barrett, The Gospel According to St. John, 75-78; Morris, The Gospel According to John, 684-91. 


\section{The Scriptures}

The Scriptures are the last of four witnesses that Jesus presents to the religious leaders in John 5, by which he affirms what they have been reading on a daily basis:

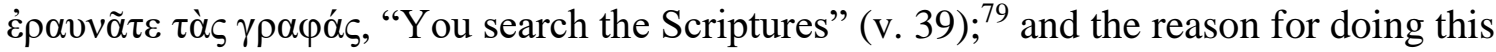

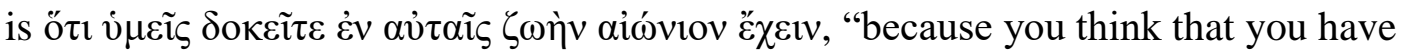

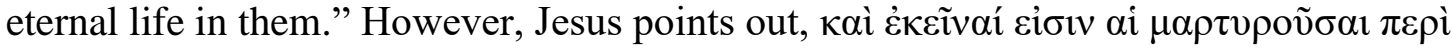
$\dot{\varepsilon} \mu \mathrm{ov}$, "And they are those that testify about me."

Though the religious leaders are searching the Scriptures, they are missing the main point, which is to see Jesus in the Scriptures. Thus, Jesus asserts that they do not believe what Moses has written; therefore, Moses will accuse them for their incredulity (v. 45) ${ }^{80}$ So, Jesus expresses a bitter irony: The religious leaders search the Scriptures in order to have eternal life (v. 39), but they do not want to come to Jesus who offers them life (v. 40). ${ }^{81}$ On the contrary, they prefer to have glory from people (vv. 41-44). Furthermore, some scholars have attested that Moses was regarded as a "spokesman" or

\footnotetext{
${ }^{79}$ Barrett, The Gospel According to St John, 267; Lightfoot, A Commentary on the New Testament, 3:301; Painter, The Quest for the Messiah, 241, believe this is an indicative mood.

${ }^{80}$ Tenney, "Topics from the Gospel of John," 234, asserts that "in referring to the testimony of the Scriptures" Jesus "meant the Old Testament, especially the Pentateuch." Painter, The Quest for the Messiah, 243, 244, explains that "although Deut 18.15, 18 may be in view, as is his custom, the evangelist alludes to the Old Testament generally rather than quoting texts." Also, Pancaro, The Law in the Fourth Gospel, 193, 226-30, suggests that the $\mu \alpha \rho \tau$ pía in John 5:39 is either the Torah or the $\mu \alpha \rho \tau$ cía "guaranteed as valid by the Law" and extended to the whole Scriptures through the prophets.

On the one hand, Köstenberger, Theology of John's Gospel and Letters, 209, is more specific saying that John 5:39 "may pertain particularly to the messianic passages in the five books of Moses." Ellis, The Word of St. John, 66, 67, adds: "In the final judgment Moses, 'on whom you set your hope', will be the key witness against the Jewish rejectors (5:45)." Cf. Lindars, The Gospel of John, 233; Keener, The Gospel of John, 662; Maronde, "Moses in the Gospel of John," 30-34; Brant, John, 109; and Raimo Hakola, Identity Matters: John, the Jews and Jewishness, NovTSup 118 (Leiden: Brill, 2005), 194.

${ }^{81}$ Cf. Painter, The Quest for the Messiah, 241.
} 
paraclete by the religious leaders. ${ }^{82}$ If this is true, the irony is increased because they place their hope in Moses, but they do not believe in him; therefore, Moses has become their accuser (vv. 45-47). Jesus makes the point that eternal life (v. 39) and hope (v. 45) are not based on people searching the Scriptures, which is not enough, but on their belief in $\operatorname{him}(\mathrm{v} .40) .^{83}$

\section{Summary}

In the Gospel of John, Jesus's works and the Scriptures are used as witnesses against the religious leaders. Jesus's works are evidence that the Father has sent him as God sent Moses to perform miraculous signs in Egypt. Jesus does the works of his Father as Moses did it; and, he who believes in the Scripture will have eternal life and escape Moses's condemnation. And the contrary would be true also: He who does not believe will perish (John 10:25-32). The Scriptures testify of Jesus, but the religious leaders, who search the Scriptures, do not find him in them; so as a result they will be condemned by Moses, who accuses them because they do not believe the Scriptures or Jesus.

This concept of witness is deeply rooted in the Pentateuch in which evidence is a particularly important piece in a judgment in order to arrive to a fair conclusion about facts. Accordingly, the Pentateuch is concerned that the people of Israel pay attention to every detail in their duty of the practice of justice. These details include a covenant which is made by Jacob and Laban, and called a "witness" between them (Gen 31:44). They

\footnotetext{
${ }^{82}$ Cf. Cf. Lindars, The Gospel of John, 233; Keener, The Gospel of John, 661; Bultmann, The Gospel of John, 272.

${ }^{83}$ Gundry, Commentary on the New Testament, 378, 379. A recent study about this topic is Paul Miller, “" 'They Saw His Glory and Spoke of Him': The Gospel of John and the Old Testament," in Hearing the Old Testament in the New Testament, MNTS, ed. Stanley E. Porter (Grand Rapids, MI: Eerdmans, 2006), 127-51.
} 
also place stones as witnesses between them to have agreements in matters of mutual faithfulness: Jacob should not afflict Laban's daughters nor take other wives besides them; and Laban should not pass certain geographical limits to persecute Jacob (Gen 31:45-52). The same is true for other objects such as heaven and earth, the song of Moses, and the book of the law which are regarded as legal beings with the capability to testify against those who are disobedient to God (Deut 4:26; 30:19; 31:19, 21, 26, 28). For that matter, a piece of a dead animal can be used as evidence that it has been torn by a beast; thus, this evidence would be enough to dismiss an accused person (Exod 22:13 [Heb. v. 12]). In addition, the Ten Commandments are called "the Testimony" before which "an omer of manna" (Exod 16:33), the sanctuary lamp (27:21), and a portion of incense (30:36) were put as a witness against the children of Israel (16:32-35).

\section{Deity's Testimonies}

In the Gospel of John, the Father and the Holy Spirit testify in favor of the Son in order to support his divine mission. On his part, the Son delivers his own testimony, either individually or along with the Father. Thus, the Evangelist shows divine testimonies that support Jesus's statement. These testimonies are pronounced in order to give eternal life to those who believe, and judge those who do not believe (John 3:17-21, 32-36; 5:39, 40; 8:13-18). Also in the Pentateuch, God is a witness of the covenant between Laban and Jacob (Gen 31:50), and gives his testimonies through Moses in the book of Deuteronomy $(6: 17,20)$. God is witness in the Pentateuch to bring justice to a trial, and in the Gospel of John to give eternal life to those who believe in Jesus. 


\section{The Father and the Son}

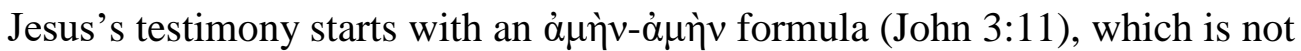

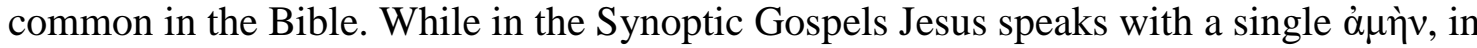

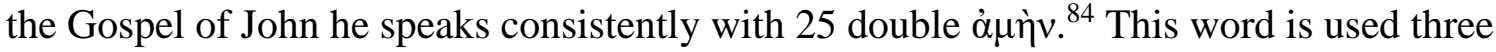
times in the canonical books of the LXX. ${ }^{85}$ Conversely, for this kind of expression the LXX uses the word $\gamma \varepsilon$ vor them in Deuteronomy, especially in chs. 27 and $28 .{ }^{86}$ The word $\gamma \varepsilon \dot{\varepsilon} v o 1 \tau o$ is an optative

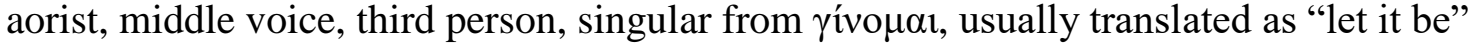

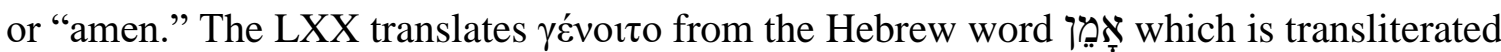
into Greek in the Gospel of John.

In his conversation with Nicodemus (John 3:11), after appealing to him in

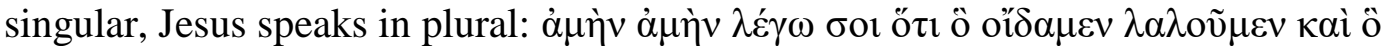

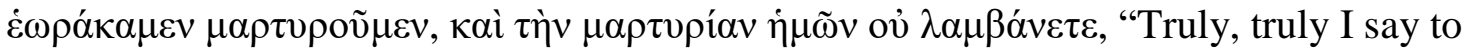
you [singular], we speak what we know, and we testify what we have seen, but you

${ }^{84}$ John $1: 51 ; 3: 3,5,11 ; 5: 19,24,25 ; 6: 26,32,47,53 ; 8: 34,51,58 ; 10: 1,7 ; 12: 24 ; 13: 16,20,21$, $38 ; 14: 12 ; 16: 20,23 ; 21: 18$.

${ }^{85} 1$ Chr 16:36; Neh 5:13; 8:6.

${ }^{86}$ Gen 44:7, 17; Num 5:22 (two times); 23:10; Deut 27:15, 16, 17, 18, 19, 20, 21, 22, 23 (two times); 24, 25, 26; 28:67 (two times); 29:18; Jos 22:29; 24:16; Ruth 2:12; 4:12; 1 Sam 24:16; 1 Kgs 1:36; $2: 33 ; 8: 57 ; 10: 9 ; 20: 3$; Pss 40:14 (two times); 71:19 (two times); 88:53 (two times); 105:48 (two times); Isa 25:1; Jer 3:19; 11:5; 15:11; Ezek 15:2.

Painter, The Quest for the Messiah, 226 n. 52, fails to recognize this connection, attesting that many of these sayings "are clearly Johannine constructions." Also he declares that this formula is

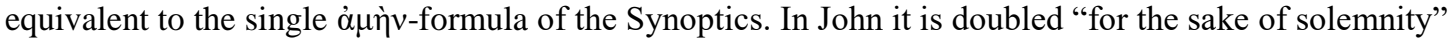
(ibid., 346).

Lindars, The Gospel of John, 155, in his comment, is closer to the Pentateuchal origin of this formula when he states that "the vocabulary of the saying is Johannine, but the synonymous parallelism of the first two clauses suggests a Semitic original." 
[plural] do not receive our testimony."

Though it could be suggested that $\lambda \alpha \mu \beta a ́ v \varepsilon \tau \varepsilon$, "you (plural) receive," could refer to the religious leaders or the people in general; it is not apparent what Jesus means with the five plurals surrounding $\lambda \alpha \mu \beta \alpha ́ v \varepsilon \tau \varepsilon:$ These are oí $\delta \alpha \mu \varepsilon v$, "we know," $\lambda \alpha \lambda \circ \tilde{\nu} \mu \varepsilon v$, "we

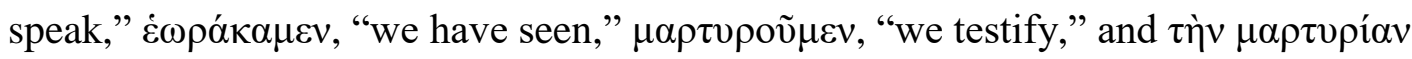
$\dot{\eta} \mu \tilde{\omega} v$, "our witness." Thus, who does "we" refer to? Bultmann suggests with uncertainty that "the unexpected plural 'we' ... probably goes back to the source, where the speaker was speaking as one of the group of messengers from God." 88

Hendriksen explains that "we know" corresponds to " "we have seen,' which is stronger," and refers to Jesus's knowledge "resulting from close communion with the Father," 89 and " 'we speak' . . . is explained by 'we testify,' which also is the more definite and forceful expression," and refers "to Jesus himself and John the Baptist."90 Michaels tries to explain these plurals with five possibilities, but after this effort he concludes that Jesus speaks with plurals because "it is still too early in the Gospel for Jesus to speak authoritatively in the first person as the Revealer of God."91 H. A. W.

${ }^{87}$ Cf. Tenney, "Topics from the Gospel of John," 231. Bultmann, The Gospel of John, 145, agrees that the "testimony" here has "its normal forensic meaning."

${ }^{88}$ Bultmann, The Gospel of John, 146. His answer fits with his claim that the authorship of the Gospel of John is uncertain. Thus, "we" could be one of the redactors of the writing (pp. 11, 12), or "one of the Christian preachers" (p. 146 n. 4). Brant, John, 76, says "that Jesus is quoting conventional wisdom."

${ }^{89}$ Hendriksen, Exposition of the Gospel According to John, 1:136. A variant answer to this problem is given by R. H. Gundry, Commentary on the New Testament, 361, who states that the "we" means Jesus and the Spirit.

${ }^{90}$ Hendriksen, Exposition of the Gospel According to John, 1:136.

${ }^{91}$ Michaels, The Gospel of John, 190, 191. Those five possible explanations are: (1) Jesus and his disciples, (2) Jesus and the Prophets, including the Baptist, (3) Jesus and the Father, (4) Jesus, the disciple, and the Johannine community, (5) Jesus is mocking Nicodemus. (The emphasis belongs to the author). 
Meyer believes that Jesus is using simply rhetorical "plurals of category" which "refer only to Jesus Himself." ${ }^{92}$ This is demonstrated by the singulars used in v. 12 . He also supports that any other conclusion "is arbitrary" to the text. ${ }^{93}$

So far, Jesus does not clarify this matter; but at the least he is establishing his accomplishment of the biblical requirement of a testimony with more than one witness. Though the text is not clear, and it is not wise to go further than what the text allows, it is safe to suggest that in this plural Jesus is including himself and his Father. The reason for this suggestion is that Jesus is starting his ministry and he does not have many followers at this time. In addition to this, his followers do not understand his mission.

Many scholars' interpretations on this matter are based on a supposed Johannine community portrayed, in some way, in the Gospel of John. This interpretation imposes a later historical reconstruction that implies some spiritual needs of this community. ${ }^{94}$

This kind of testimony is also reflected in John 8:13-18, in which the Pharisees

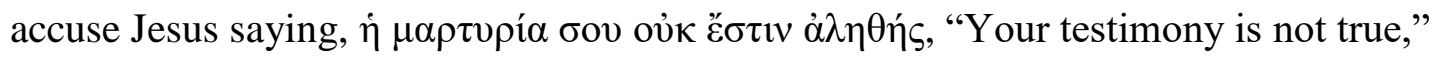
because, according to them, Jesus is bearing witness to himself (v. 13). But Jesus insists

\footnotetext{
${ }^{92}$ Heinrich August Wilhelm Meyer, Critical and Exegetical Handbook to the Gospel of John, MCNT 3 (Peabody, MA: Hendrickson, 1983), 173.

${ }^{93}$ Ibid.

${ }^{94}$ According to George Johnston, "The Spirit-Paraclete in the Gospel of John," Per 9 (1968): 35, "we" means Jesus and his church; Burge, John, 67, says, "The 'we' in 3:11 likely refers to Jesus and his followers, who are witnesses to the signs of the kingdom. They have all seen this new kingdom and can bear witness to it." Similarly, Morris, The Gospel According to John, 221, agrees that "we" means Jesus and his disciples, who could have been present at this meeting; Godfrey C. Nicholson, Death as Departure: The Johannine Descent-Ascent Schema, SBLDS 63 (Chico, CA: Scholars, 1983), 31, 87, says that "we" refers to Johannine Christians or the Evangelist's community; and Lincoln, Truth on Trial, 66, believes that the phrase " 'our testimony' . . indicates that Jesus here represents the perspective of a wider group in their witness, that of Johannine Christians."
} 
that even on that circumstance his witness is true (v. 14). ${ }^{95}$ Accordingly, Mounce adds, "His testimony is valid because he knows two things about himself of which they haven't the slightest idea: he knows (1) his origin ('where I came from') and (2) his destiny ('where I am going'). He is 'from the Father' $(1: 14 ; 16: 28)$ and will return 'to the Father' $(13: 1 ; 14: 12) . " 96$

Aware of the law that a valid testimony has to be supported by at least two witnesses (Num 35:30; Deut 17:6; 19:15), Jesus affirms that he bears testimony along with the Father (John 8:17, 18), for the Father corroborates Jesus's words and deeds. ${ }^{97}$ So, Barrett explains that "the conditions of the Law (Deut 17.6; 19.15) are thus fulfilled." 98

${ }^{95}$ The religious leaders reject Jesus's testimony because it comes from himself (John 8:13). This is a well-known tradition that later was registered in $m$. Ketub 2:9, which says, "No man can give evidence for himself." So, that kind of witness was not accepted that time; but Jesus responds that he can stand by himself, and moreover his Father gives testimony along with him. John wants to illustrate the importance of more than one person bearing witness $(5: 31)$ in any declaration. Therefore Jesus himself recognizes this necessity, claiming that the Father is the other one who testifies for him (8:17).

The accomplishment of this law gives Jesus the reliability that he needs, in order to show that he is who he says. But the Evangelist does not stop showing divine witnesses, as the Father and the Holy Spirit. Even though, for Jesus the claim of the testimony by him and his Father is enough, the Evangelist also wants to show other witnesses who could be reached by the people, and could be acceptable to accomplish the principle of the law. Furthermore, this could be the reason that Jesus was questioned by the high priest. He told the high priest to ask the people about him because they have heard him teaching, and seen his miracles, so they know him (18:19-21).

Tenney, "Topics from the Gospel of John, Part III," 237, explains the apparent contradiction between John 5:31 and 8:14 saying that "on legal grounds, self-testimony is not valid because it is presumably biased; but on personal grounds, who would know more about Him than Himself?" On the other hand, Von Wahlde, "The Witness to Jesus in John 5:31-40 and Belief in the Fourth Gospel," 395, says that John 5:31, 32 and 8:14-18 "are complementary." Thus, while in "the first statement (5:31-32)" Jesus emphasizes his "dependency and subordination . . . in relation to the Father," in the second one (8:1418), he "emphasizes the reverse of this." Cf. Lindars, The Gospel of John, 316; Ashton, Understanding the Fourth Gospel, 178; Brant, John, 143-46.

${ }^{96}$ Mounce, “John,” 474.

${ }^{97}$ Cf. Crossan, The Gospel of Eternal Life, 91.

${ }^{98}$ Barrett, The Gospel According to St John, 339. Cf. Painter, The Quest for the Messiah, 236. 
Jesus has several characteristics that his enemies do not have: (1) He knows where he comes from and where he is going, but they do not have that information (John 8:14); (2) While Jesus judges no one, his enemies judge according to the flesh (v. 15); and, for the sake of argument, (3) If Jesus judges, he affirms that his judgment is true because he judges along with the Father (v. 16).

For Jesus, his testimony with his Father is his judgment on the world: $\dot{\alpha} \lambda \eta \theta \eta \dot{s}$

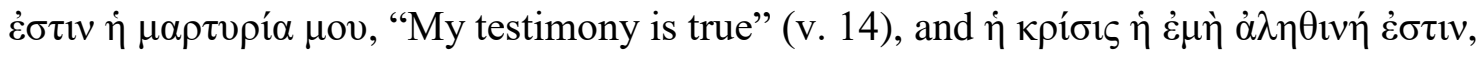
"My judgment is true" (v. 16). Thus, Jesus as a true witness is ready to take a stand against those who reject him (cf. Deut 17:7). This approach satisfies the requirement of at least two witnesses for a court case in Israel (Num 35:30; Deut 17:6; 19:15).

\section{Jesus}

The Gospel of John mentions four testimonies about Jesus; the first two are reported by the Baptist (3:32), ${ }^{99}$ and the Evangelist (4:44), and the last two by Jesus himself $(7: 7 ; 18: 37)$.

In the first testimony, the Baptist explains his disciples Jesus's testimony,

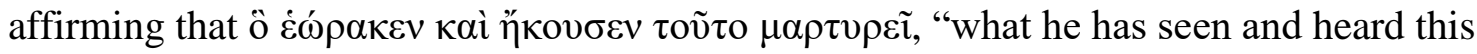
thing he testifies" (3:32). In this testimony the Baptist certifies that Jesus's testimony is according to the stipulation of Lev 5:1 which establishes that people who see or know about a matter are under obligation to testify in court. With this statement, the Baptist upholds the veracity of Jesus's testimony: He "comes from above" (John 3:31), thus Jesus has been in God's presence. This is firsthand testimony and demonstrates that God

${ }^{99}$ Lincoln, Truth on Trial, 65, argues that Jesus is "the protagonist" and "the chief witness in the lawsuit" in the Gospel of John. 
is true (v. 33). Accordingly, Michaels asserts that "Jesus' testimony is unique and final. All other Christian testimony ... is secondary to his, and depends on his." 100

In the second testimony, the Evangelist narrates Jesus's journey from Samaria to Galilee (4:43), and testifies that "a prophet has no honor in his own country" (v. 44). In the third, Jesus himself testifies to his brothers about the evil works of the world (7:7). As a result the world hates Jesus, but cannot hate his brothers because they reject Jesus, as the world does (7:5-8). And in the fourth testimony, Jesus makes clear before Pilate, $\dot{\varepsilon} \gamma \grave{\omega}$

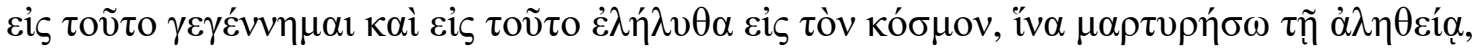
"For this reason I have been born and for this reason I have come into the world, that I should bear witness to the truth" (18:37). With this statement Jesus affirms the reason for his mission in the Gospel of John. ${ }^{101}$

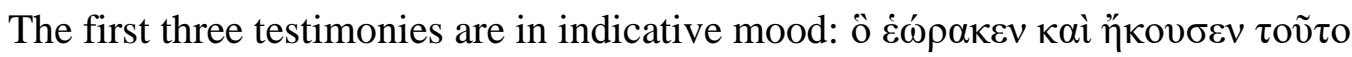

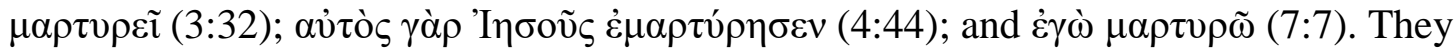
indicate the factual meaning of Jesus's testimony. The last one is in a subjunctive clause:

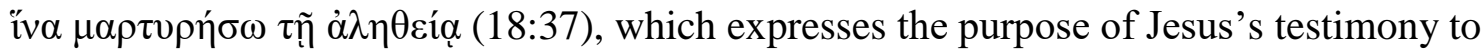
the truth. Thus far, Jesus is not testifying about himself but against the world, and concerning the truth, which means that with his testimony he takes a stand with the

${ }^{100}$ Ibid., 223; Hendriksen, Exposition of the Gospel According to John, 1:149 explains that "those who accept Christ's testimony concerning himself (namely, that he is the Son of God) thereby set the seal of their approval upon God's own testimony regarding Jesus: 'Thou art my beloved Son' (Luke 3:22; cf. John 1:34)."

${ }^{101}$ Buchanan, Introduction to Intertextuality, 62, says, "The Gospel of John, like other early Christian witnesses, thought of Jesus as a legal agent, and apostle of God, who was physically a human being ('low'), but legally he was equal to God ('high'). . . John 10, consistent with other parts of John, interpreted Jesus' role as that of an agent, so that, on the one hand, anyone who saw Jesus saw the Father (legally) (John 14:9), and Jesus held a status that was legally equal to God (John 10:33); but on the other hand, the Father (as the principal) was greater (John 14:28) than the Son, who was the agent." 
Father and the Paraclete in order to condemn the world.

\section{The Father}

In John 5, Jesus works along with the Father, thus he does what the Father does (vv. 17, 19, 21, 22) because he does not seek his own will but his Father's will (v. 30). And as Jesus works in unity with the Father, he has the advantage of showing the

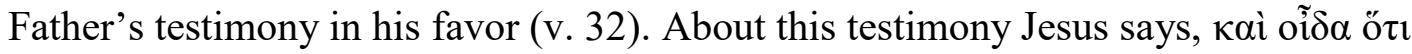

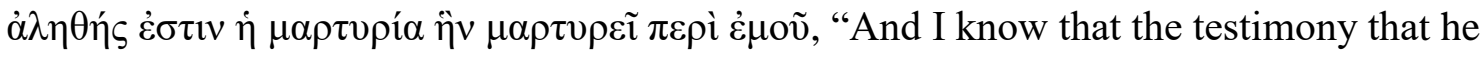
testifies about me is true." 102 In this testimony Jesus describes that in his judgment in which he is the judge (v. 30) he has witnesses greater than the Baptist and one of them is

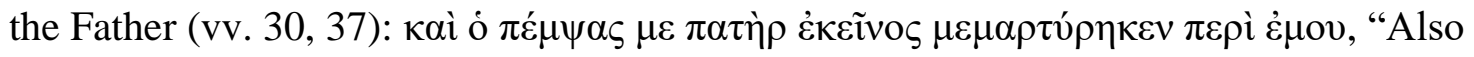
the Father who sent me has testified about me."103

\section{The Holy Spirit}

Jesus also has the Holy Spirit as one of his witnesses, whom he calls ó

102 Von Wahlde, "The Witnesses to Jesus," 390, suggests that the witness of the Father is his word "which he has given to Jesus and which Jesus gives to the world. The Jews fail to have the word of God abiding in them because they fail to believe Jesus." Cf. Mounce, "John," 431; Morris, The Gospel According to John, 323, 324, 437; Brant, John, 108.

103 This testimony could be confused with the Baptist's testimony which Jesus mentions in vv. 3335. Cf. Lindars, The Gospel of John, 228, 229; Barrett, The Gospel According to St. John, 258, 264. In like manner, Hendriksen, Exposition of the Gospel According to John, 208, says that Jesus is talking about "the Father's own testimony by means of the works of Christ." Similarly, Brown, The Gospel According to John, 29:224, confirms that someone could say that Jesus is talking about John the Baptist in John 5:32, but the sequence of ideas from vv. 33-38 clarifies that Jesus is talking about the Father. Ricoeur, Essays, 138, also agrees with this conclusion.

For more about how Jesus portraits the Father in the Gospel of John, cf. Marianne Meye Thompson, The Promise of the Father (Louisville, KY: Westminster, 2000); ibid., The God of the Gospel of John (Grand Rapids, MI: Eerdmans, 2001); ibid., "Jesus and His God," in The Cambridge Companion to Jesus, ed. Markus Bockmuehl (Cambridge: Cambridge University Press, 2001), 41-55. 
$\pi \alpha \rho \alpha ́ \kappa \lambda \eta \tau$ ๆo four times: ${ }^{104}$ Accordingly, (1) He is "the Spirit of truth" who will come to

abide with Jesus's disciples as a result of Jesus's prayer to the Father, and to avoid that

\begin{abstract}
${ }^{104}$ This word has been translated in many different ways: the Helper (ESV; NAS; NKJ; NAU; Lindars, The Gospel of John, 478, 479; Bruce Vawter, "John's Doctrine of the Spirit; A Summary of his Eschatology," in A Companion to John: Readings in Johannine Theology [John's Gospel and Epistles], ed. Michael J. Taylor [Staten Island, N.Y.: Alba House, 1977], 179); interpreter, intercessor or mediator (Johnston, "The Spirit-Paraclete," 32); the Advocate (NAB; NRS; Vawter, "John's Doctrine of the Spirit, 179; Lincoln, Truth on Trial, 113, 114; William H. P. Hatch, "The Meaning of John XVI, 8-11," HTR 14 [1921]: 105; Ben Witherington, John's Wisdom: A Commentary on the Fourth Gospel [Louisville, KY: Westminster, 1995], 264; Max Turner, The Holy Spirit and Spiritual Gifts, rev. ed. [Peabody, MA: Hendrickson, 1998], 85-87); Comforter (KJV); the Counselor (NIV; RSV); Legal assistant (Painter, John: Witness \& Theologian, 67. Painter also states that although the Spirit is given to all believers, what Jesus says "applies primarily to the eye-witness believers." However, he adds: "For those who are not eyewitnesses of the Word, the witness of the Spirit is inseparably linked with the inspired eye-witness testimony [15:26-27]. The Gospel of John is itself such inspired eye-witness testimony" [ibid., 67-68]).

Lawrence J. Lutkemeyer, “The Role of the Paraclete," CBQ 8 (1946): 220-29, translates ó $\pi \alpha \rho \alpha ́ \kappa \lambda \eta \tau o \zeta$ as called upon. Lutkemeyer favors this translation in his conclusion that the Holy Spirit is like a mother who does not wish to condemn her child, but to help him/her. Therefore, he concludes that to translate $\pi \alpha \rho \alpha ́ k \lambda \eta \tau o \zeta$ as advocate, comforter, exhorter, and the like is a mistake. He also emphasizes that the Holy Spirit came to continue to do for the whole world what Jesus was doing for Israel: call sinners and make them perfect through a progressive work. However, he fails to explain what would happen to those who reject this call.

More translations are: The intercessor and helper (Bultmann, The Gospel of John, 568. He explains, to advance this meaning, that "even if $\pi \alpha \rho \alpha \dot{\kappa} \kappa \lambda[\eta \tau o \varsigma]$ did not become a technical term for the counsel in a court of law, . . the concept is hall-marked by the juridical sphere: $\pi \alpha \rho \alpha ́ \kappa \lambda[\eta \tau ం \varsigma]$ means the one who speaks before the judges in favour of the accused." However, he denies that the Paraclete's meaning comes from John's literature or Christian circle, but from Gnosticism [ibid., 569-72]. And also, he translates this word as "mediator." Thus "where man's situation before God is conceived as responsibility before the judge, $\pi \alpha \rho \alpha ́ k \lambda[\eta \tau o \varsigma]$ is named the intercessor before God" [ibid., 568]); the representative (R. H. Gundry, Commentary on the New Testament, 437; thus, the Holy Spirit would come to replace Jesus); one called alongside (R. E. Brown, An Introduction to the New Testament, 353; V. George Shillington, "The Spirit-Paraclete as Jesus' alter ego in the Fourth Gospel," Vision 13 [2012]: 31. Shillington applies this concept to the so called Johannine community which is under the instruction of the Holy Spirit. So "members of the community do not speak out of their own human spirit-mind but only as the Spirit of truth instructs" [ibid., 38]).

For more discussion about this term, see Dodd, The Interpretation of the Fourth Gospel, 430;

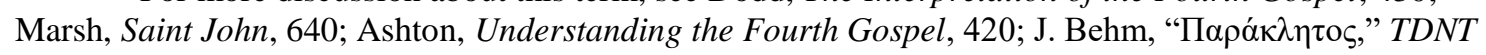
5:801; W. Bartlett, "The Coming of the Holy Ghost According to the Fourth Gospel," ExpTim 37 (1925): 72-75; Richardson, An Introduction to the Theology of the New Testament, 116-18; John Amedee Bailey, The Traditions Common to the Gospels of Luke and John, NovTSup 7 (Leiden: Brill, 1963), 94; Stephen Neill, The Interpretation of the New Testament 1861-1961 (London: Oxford University Press, 1964), 15790; Barrett, The Holy Spirit and the Gospel of Tradition (London: SPCK, 1966); Hans Windisch, The Spirit-Paraclete in the Fourth Gospel, FBBS 20 (Philadelphia, PA: Fortress, 1968); Edward Malatesta, "The Spirit/Paraclete in the Fourth Gospel," Bib 54 (1973): 539-50; Robert Kysar, The Fourth Evangelist and His Gospel: An Examination of Contemporary Scholarship (Minneapolis, MN: Augsburg, 1975), 127 31; J. D. G. Dunn, Jesus and the Spirit: A Study of the Religious and Charismatic Experience of Jesus and the First Christians as Reflected in the New Testament (Philadelphia, PA: Fortress, 1975); R. E. McKeown, "A Prolegomena to a Doctrine of the Holy Spirit: Studies in Biblical Sources and Epistemological Considerations" (Ph.D. diss., Duke University, 1976); M. Eugene Boring, "The Influence of Christian Prophecy on the Johannine Portrayal of the Paraclete and Jesus," NTS 25 (1978): 113-23; Schnackenburg, The Gospel According to St. John (NY: Crossroad, 1987), 3:84-88; W. S. Kurz, Farewell Addresses in the
\end{abstract}


they could be left orphans (14:16-18); (2) He will be sent by the Father in Jesus's name to teach and remind them of Jesus's words (14:26); (3) He "is the Spirit of truth," sent by Jesus “from the Father" to testify in Jesus's favor (15:26); and (4) He will come in Jesus's place "to convict the world of sin, and of righteousness and of judgment" $(16: 8) \cdot{ }^{105}$

In John 16:8, the verb "to convict" is translated from the Greek غ̇ $\lambda \dot{\varepsilon} \gamma \chi \varepsilon \imath v$ which in John is used also in ch. 3:20 in which Jesus affirms to Nicodemus that an evildoer does not come to the light in order to avoid being exposed ( $\dot{\varepsilon} \lambda \varepsilon \gamma \chi \theta \tilde{\eta})$; and in ch. 8:46, Jesus challenges his accusers to convict ( $\dot{\varepsilon} \lambda \dot{\varepsilon} \gamma \chi \varepsilon \imath)$ him of sin. The truth is that the world is sinful, not Jesus. Thus Burge agrees that the work of the world needs to be exposed. ${ }^{106}$

New Testament, Zacchaeus Studies: New Testament (MN: Michael Glazier, 1990); Tricia Gates Brown, Spirit in the Writings of John: Johannine Pneumatology in Social-Scientific Perspective, JSNTSup 253 (London: T\&T Clark, 2003).

${ }^{105}$ Ricoeur, Essays, 141, also mentions that "the Paraclete is the figure who is the counterpart of the accuser. The same Paraclete who 'will convince the world of sin and of righteousness and of judgment' (John 16:8) will be the counselor to the believers when Satan will have become the accuser."

On his part, Painter, John: Witness \& Theologian, 66, says that "the witness of the Paraclete vindicates Jesus and convicts the world." Furthermore, he adds that "Jesus is the original Paraclete (1 John 2.1) and the Spirit is referred to as 'another Paraclete' (14.16). Thus the Paraclete has functions which parallel those of Jesus.

"The parallelism is impressive but one difference is clear. The Paraclete is subordinate to Jesus. Jesus' witness to himself is paralleled by the Paraclete's witness request. If the Paraclete is sent by the Father, it is at Jesus' request (14.16) and he is sent in Jesus' name (14.26), or even sent from the Father by Jesus $(15.26 ; 16.7)$. The Paraclete is known only by those who believe in Jesus (14.17) and his activity is completely Christ-centered (14.26; 15.26; 16:13-15)" (ibid., 66, 67).

${ }^{106}$ Burge, John, 209, 210. Pancaro, The Law in the Fourth Gospel, 195, accepts that the verb $\dot{\varepsilon} \lambda \dot{\varepsilon} \gamma \chi \varepsilon i v$ is a judicial term. Hatch, "The Meaning of John XVI, 8-11," 105, gives a more complete meaning of this verb, concluding that it is used in a forensic context in a threefold way: (1) The world has sinned "because it has not believed in Christ;" (2) "Believers are justified . . because Christ has gone to the Father to act as their advocate;" and (3) "Evil has been condemned, because ... the devil has been condemned." See also Gundry, Commentary on the New Testament, 437, 438.

However, Lutkemeyer, "The Role of the Paraclete," 220-29 rejects that conclusion saying that this word implies a friend or a mother who tries to make someone see his mistake in order to help him, not to condemn him. Thus this term in the Hebrew mind is employed in a socio-religious sense, pedagogically, "not in the forensic sense," which is "according to the Greek or Roman mind."

On his part, Lindars, The Gospel of John, 501, argues that the meaning of غ̇ $\lambda \dot{\gamma} \gamma \chi \varepsilon 1 v$ is "to scorn," but by NT times this original meaning was weakened to mean "to expose." Carson, "The Function of the Paraclete in John 16:7-11," JBL 98 (1979): 558, maintains that its meaning is "to convict of" or "to 
Accordingly, Barrett explains that the meaning of $\dot{\varepsilon} \lambda \varepsilon \dot{\gamma} \chi \varepsilon \omega v$ is "to expose" sin or error, and it is "somewhat similar" to rebuke. ${ }^{107}$ It is also " "to bring to the light of day', 'to show a thing in its true colours.' It is the activity of a judge and prosecuting counsel in one."108 Therefore, the ministry of the $\pi \alpha \rho \alpha ́ \kappa \lambda \eta \tau o \zeta$ has the effect of judgment. ${ }^{109}$ In like manner, Silva says, "In the Gospel of John $\dot{\varepsilon} \lambda \dot{\varepsilon} \gamma \chi \omega$ is used, as in the prophetic warnings of judgment, with ref. to the conviction of $\sin . "{ }^{110}$ Bruce Vawter demonstrates that it is not the purpose of the Paraclete to judge the world; however, man rejects "the truth, and the life that have been revealed to him in the Son by the Spirit. In making his decision, man judges himself."111 Furthermore, Brant concludes that one of the meanings of this Greek word includes to put "to shame or to confound" those who are false witnesses. ${ }^{112}$

Lincoln states that the primary meaning of $\pi \alpha \rho \alpha ́ \kappa \lambda \eta \tau o \varsigma$ is "a person of influence, a patron or sponsor" that "could be called into a court to speak in favor of a person or a person's cause, thereby providing advocacy."113 Accordingly Brant adds that the

convince of." He opts for both meanings, arguing that the former is ambiguous and the latter inadequate; but both "are linguistically possible." Bultmann, The Theology of John, 561-62, agrees that the Paraclete "will uncover the world's guilt. The image that comes before the eyes is that of a lawsuit of cosmic dimensions, taking place before the court of God. The world is accused, and the Paraclete is the prosecutor."

${ }^{107}$ Barrett, The Gospel According to St John, 90, 486. See also ibid., 462.

${ }^{108}$ Ibid., 90.

${ }^{109}$ Ibid., 216, 217.

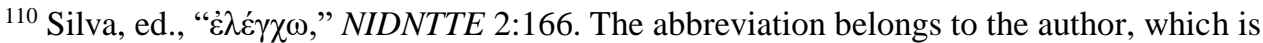
"reference."

${ }^{111}$ Bruce Vawter, The Four Gospels: An Introduction (NY: Image Books, 1969), 1: 185.

${ }^{112}$ Brant, John, 221. Cf. also ibid., 229-30.

${ }^{113}$ Lincoln, Truth on Trial, 113. 
$\pi \alpha \rho \alpha ́ \kappa \lambda \eta \tau \sigma \zeta$ is "a friend of the accused person, called to speak to his character, or

otherwise enlist the sympathy of the judges." 114

Burge repeats what Felix Porsch and I. de la Potterie say that "both the Paraclete and Christ must be first understood within John's literary technique of a 'trial motif.' "115 And further, he refers "that the Sitz im Leben of" the "Paraclete passages is that of the great theological trial between Jesus and the world." 116 Therefore, "the world is on trial before God because (ironically) Jesus is on trial before the Jews." ${ }^{117}$ Furthermore, "the Spirit will convince the world concerning its judgment because through Christ's death and resurrection the world's ruler has been judged." 118

\section{Summary}

The Gospel of John continues supporting Jesus's case supplying more witnesses to his cause. Therefore the Father and the Paraclete take part in this process of witness for and along with Jesus. Thus, Painter says correctly,

${ }^{114}$ Brant, John, 221; cf. Philo, Spec I, 237, who reports that a $\pi \alpha \rho \alpha ́ \kappa \lambda \eta \tau o \zeta$ is the "conviction of the

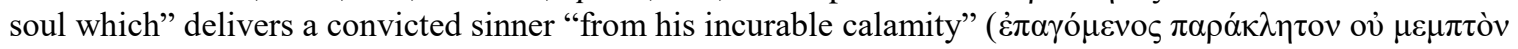

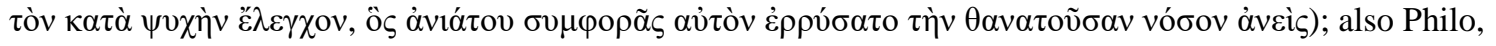
Flacc. I, 22, 23, says that the $\pi \alpha \rho \alpha ́ \kappa \lambda \eta \tau o \varsigma$ is "an advocate" that Flaccus needs in order that "Gaius may be

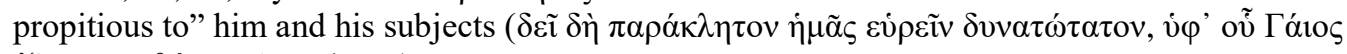

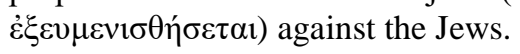

115 Ignace de la Potterie, La Verité dans Saint Jean, AB 73-74 (Rome: Biblical Institute, 1977), in Burge, The Anointed Community, 37.

${ }^{116}$ Ibid. I have pointed out above on p. 156 n. 2 that Beasley-Murray, Gospel of Life, 61, claims that the ministry of the Paraclete is linked with the trial of Jesus's ministry based on Isa 43:8-13, 25-28, and 44:6-11.

${ }^{117}$ Burge, The Anointed Community, 37.

118 Ibid., 210. On ibid., 209-10 Burge also surveys major researches about John's use of غ̇ $\lambda \dot{\gamma} \gamma \chi \varepsilon 1$ $\pi \varepsilon \rho i$ and concludes that "far more important than the syntactical explanation of these elements is the general promise that one major role of the Spirit Paraclete will be the confrontation of the world-indeed, the persuasion of the world." 
In the context of Jesus' ministry, the most important witnesses were the witness borne by the Father in Jesus' works and Jesus' self-testimony. The function of the other witnesses was to challenge men to take these two witnesses seriously. Ultimately, even the witness of Jesus' works is understood as a challenge to those who were skeptical of Jesus' claims $(10.38 ; 14: 11)$. All of the witnesses have the function of concentrating attention on Jesus' self-testimony. There is no way of avoiding the scandal of his claims by paying attention to other witnesses. ${ }^{119}$

Jesus's testimony along with the Father, and the individual testimonies of the Father and the Paraclete in Jesus's favor, satisfy the requirement of the Pentateuchal law, which asks for at least two witnesses for a fair and just judgment (Num 35:30; Deut 17:6; 19:15); ${ }^{120}$ but also, these testimonies take judgment from earth to heaven, and the judicial process from human beings to God. Meanwhile, Jesus asserts that those who believe the testimonies of the Father and of the Paraclete will have eternal life because they will not come into judgment. Though Jesus's enemies think they have power to judge him, they are judged by the Father, the Son, and the Paraclete; and, consequently, they are condemned, not only because they reject Jesus, but also because they become false witnesses. Thus, judgment comes from heaven to earth.

In his own word, Michaels asserts that Jesus does not need the testimony of two or three witnesses because this is a requirement "for the conviction of an offender, not for his acquittal." ${ }^{121}$ Therefore, the Pharisees, not Jesus, need witnesses in order to defend themselves. This shows the illegality of the Pharisees' requirement.

\footnotetext{
${ }^{119}$ Painter, John: Witness and Theologian, 91.

${ }^{120}$ See discussion of this matter on pp. 158-62; and 280-83.

${ }^{121}$ Michaels, The Gospel of John, 479-80.
} 


\section{Other Testimonies}

Though the word "testimony" is not stated in their respective narratives, the Gospel of John shows some people testifying in Jesus's favor. As this Gospel is shaped by this kind of argument, it is not surprising to read that someone is giving a statement about Jesus's identity and origin that resembles a testimony in court.

These statements are expressed by Andrew, Philip, and Nathanael (John 1:37-46), Nicodemus $(3: 1,2 ; 7: 50,51)$, the Samaritans $(4: 42)$, the multitude on the mountain (6:14), Peter $(6: 68,69)$, many from the crowd $(7: 40,41 a)$, the officers sent by the Pharisees and the chief priests $(7: 32,45,46)$, the man born blind who receives his sight (9:1-41), many beyond the Jordan (10:41), and Martha (John 11:27). Taking into account these witnesses, in this section, I am going to analyze their testimonies which are given in a similar way as those who are called to testify using the word $\mu \alpha \rho \tau v \rho i ́ \alpha$ and the verb $\mu \alpha \rho \tau v \rho \varepsilon ́ \omega$ in their respective contexts.

\section{Andrew}

Two disciples of the Baptist hear him give his testimony in favor of Jesus, in which he proclaims: "Behold! The Lamb of God" (1:29, 35-37). One of those disciples is

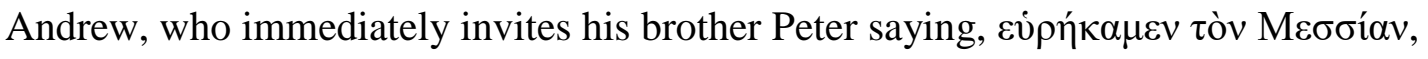
"We have found the Messiah" (v. 41).

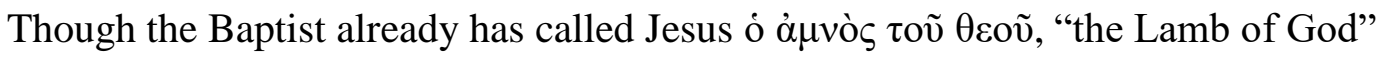

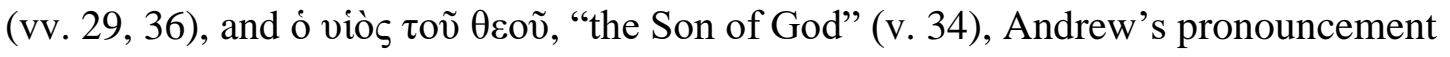
sets the stage to support Jesus's Messiahship from the beginning of the Gospel. Accordingly, Gundry stipulates, “Andrew joins the Baptist as a witness in Jesus' 
behalf." 122 For the moment, the Baptist has testified that he is not the Messiah (v. 20), thus, Andrew's testimony accomplishes two objectives: (1) a support that Jesus is the Messiah (v. 41); and (2) an affirmation of the Baptist's testimony to the Jewish delegation concerning his own identity. So, from the beginning of the Gospel of John, Jesus's identity is established promptly: He is the Messiah.

\section{Philip}

As soon as Philip becomes one of Jesus's disciples, he decides to share his experience with Nathanael (John 1:43, 44). In his own words Philip declares, "We have found Him of whom Moses in the law, and also the prophets, wrote-Jesus of Nazareth, the son of Joseph" (v. 45). ${ }^{123}$

Philip's declaration is a mix of certainty and doubt: While he has found the one of whom Moses and the prophets have written, this person, at the same time, is also "Jesus of Nazareth, the son of Joseph." This statement casts doubt on Nathanael who entertains the notion that something good could not come from Nazareth (v. 46a). ${ }^{124}$ However, in order to support his argument, Philip invites him, "Come and see” (v. 46b).

122 Gundry, Commentary on the New Testament, 354. Cf. Collins, John and His Witness, 46-50.

${ }^{123}$ Cf. Tenney, “Topics from the Gospel of John, Part III,” 231; Collins, John and His Witness, 79-81.

124 The Gospel of John shows two sources from which Jesus's origin and identity are put in doubt:

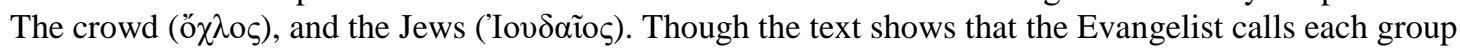
with different names, sometimes they use the same argument, and other times they use rhetorical questions, under the same line of thought. For example, when Jesus declares that he came down from heaven, the

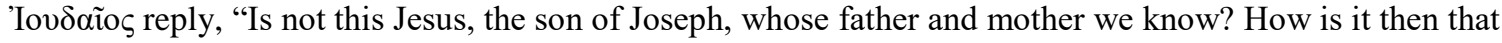
he says, I have come down from heaven?" (6:42). With this rhetorical question, they place Jesus's origin in a lower level, contradicting not only Jesus's argument, but also the Evangelist's introduction concerning

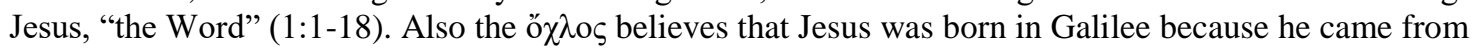
there, as a result they ask: "Will the Christ come out of Galilee? Has not the Scripture said that the Christ comes from the seed of David and from the town of Bethlehem, where David was?" (7:41b, 42). Further, in the dialogue with the man born blind "some of the Pharisees said" that Jesus "is not from God" (9:16). 


\section{Nathanael}

In John 1:46-51 the verb ópá $\omega$ is used six times as Jesus leads Nathanael to give a declaration of faith (vv. 46, 47, 48, 50 [two times], 51). Philip has said to Nathanael:

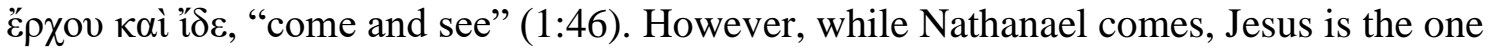

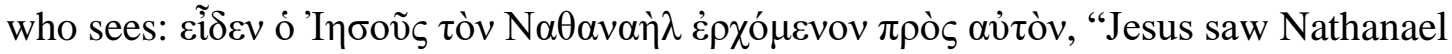

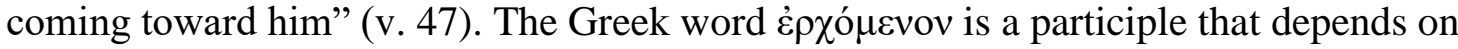
the main verb $\varepsilon \tilde{i} \delta \varepsilon v$ in a subsidiary clause in which a shift in perspective and an ellipsis occur. Before this point the story is told from Nathanael's perspective, but at v. 47 it shifts to Jesus's perspective. The ellipsis is Nathanael's decision to come- the key in his becoming a disciple. Even though he doubts, he comes; and the smallest revelation from Jesus convinces him. Furthermore, the one who sees also knows the one who comes (v.

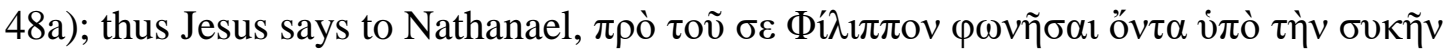

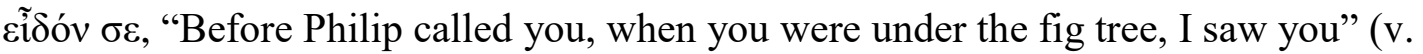
$48 b) .{ }^{125}$

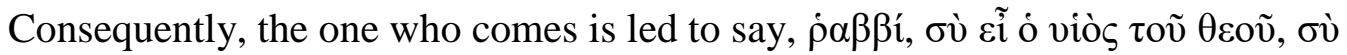

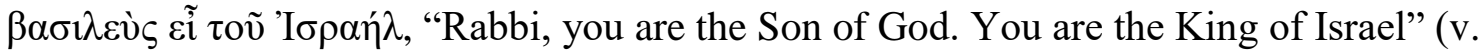

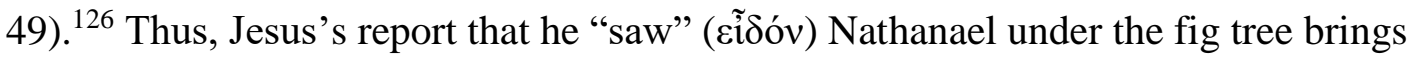

During the Feast of Tabernacle, the ö $\chi \lambda$ o argues with Jesus about his identity, saying, "You have

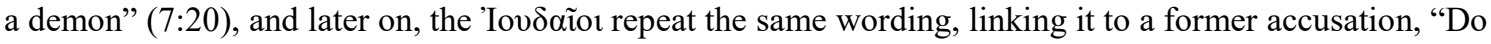
we not say rightly that you are a Samaritan and have a demon?" (8:48). They say the same two more times

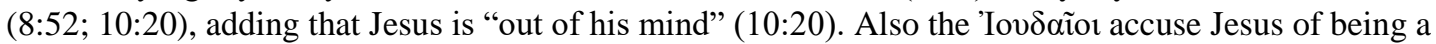
$\dot{\alpha} \mu \alpha \rho \tau \omega \lambda$ ó $\varsigma$ "sinner" (9:24), a person who says "blasphemy" (10:33), and at the end, before Pilate, they say Jesus is "an evildoer" (18:30).

${ }^{125}$ For further information about the importance of fig trees in Israel, see J. Duncan M. Derrett, "Fig Trees in the New Testament," HeyJ 14 (1973): 249-65.

${ }^{126}$ Cf. Tenney, "Topics from the Gospel of John, Part III," 231; Collins, John and His Witness, 90-92. Gundry, Commentary on the New Testament, 354, points out that Nathanael's recognition . . . echoes the Baptist's testimony." 
Nathanael to belief (v. 50a). Nathanael has started to see, but Jesus prophesizes: "you will see" (őษๆ) greater things than this (v. 50b). So, Jesus assures Nathanael and Philip: “Truly, truly I say to you, you will see (ő $\psi \varepsilon \sigma \theta \varepsilon)$ heaven opened" (v. 51). ${ }^{127}$

\section{Nicodemus}

Nicodemus comes to Jesus by night and commends him saying, $\dot{\rho} \alpha \beta \beta i ́$, oí $\alpha \mu \mu v$

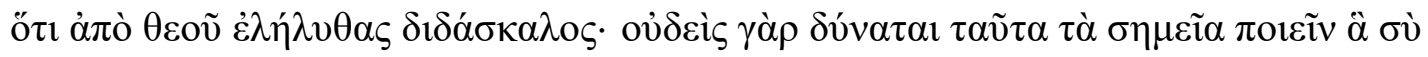

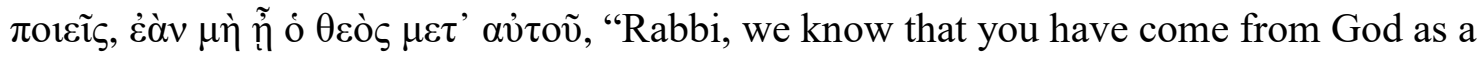
teacher; for no one can do these signs that you do, unless God is with him" (3:2).

Nicodemus' declaration is in plural: "we know" (oǐ $\delta \alpha \mu \varepsilon v)$, which could be taken as a plural of respect. Nevertheless, it is probable that he is speaking not only for himself but also for others of his own class, probably Pharisees. However, Nicodemus does not speak with Jesus of what he expects: that Jesus is the Christ, Elijah, or a prophet (cf. 1:20, 21).

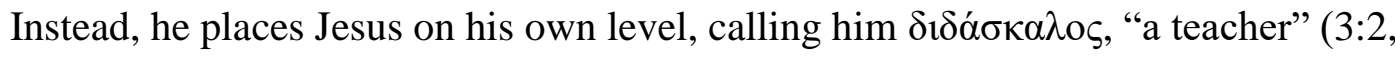
10). ${ }^{128}$ Notwithstanding, when the Pharisees and the chief priests plot to take Jesus by force (7:32), Nicodemus reminds them with a question that it is illegal to judge somebody without a trial (John 7:50, 51; cf. Exod 23:6-8). And, at the time of Jesus's death he comes by day to bury him (John 19:39).

\footnotetext{
${ }^{127}$ In the Gospel of John, people's testimony is linked many times with some kind of verb of sight or perception: The Baptist sees ( $\beta \lambda \varepsilon \dot{\pi} \omega)$ Jesus coming toward him, and says, "Behold! The Lamb of God" (1:29); "And John bore witness, saying, I saw ( $\theta \varepsilon \alpha \dot{o} \mu_{\alpha \iota)}$ the Spirit" (v. 32); Jesus declares to Nicodemus: "We testify what we have seen (óó $\omega$ ), and you do not receive our witness" (3:11); the Baptist makes clear

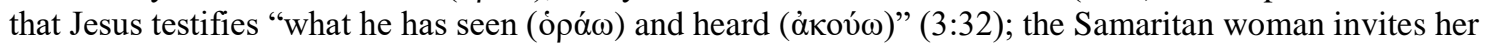
countrymen saying: "come, see (ópó $\omega)$ a Man . . . Could this be the Christ?" (4:29); those who saw (ópó $\omega)$ Jesus's miracle (11:45) when he called "Lazarus out of his tomb and raised him from the dead, bore witness" (12:17); and the one "who has seen (óó $\omega)$ has testified" (19:35). With these verbs the Evangelist emphasizes the reliability of Jesus's witnesses.

${ }^{128}$ Cf. J. M. Bassler, "Mixed Signals: Nicodemus in the Fourth Gospel,” JBL 108 (1989): 635-46.
} 


\section{The Samaritans}

The Samaritan woman has invited her countrymen to come and see Jesus, asking

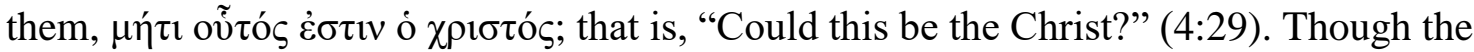
interrogative particle $\mu \eta ́ \tau \imath$ is left untranslated in English, in Greek language it expects a negative answer such as in 8:22 and 18:35. Nevertheless, the Samaritans' answer is contrary to everyday custom. They verify the information of this woman, and many of them believe because of her testimony (4:39).

Also, after an invitation, he stays in Samaria two days (v. 40), and others believe because of Jesus's own word (v. 41). As a result, they say to the Samaritan woman,

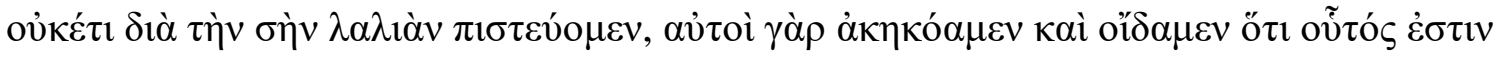
$\dot{\alpha} \lambda \eta \theta \tilde{\omega} \varsigma$ ó $\sigma \omega \tau \eta ̀ \rho ~ \tau o \tilde{~ \kappa o ́ \sigma \mu o v, ~ " W e ~ n o ~ l o n g e r ~ b e l i e v e ~ b e c a u s e ~ o f ~ w h a t ~ y o u ~ s a i d, ~ f o r ~ w e ~}$ have heard and known that this is truly the Savior of the world" (v. 42). While the Samaritan woman asks a question, mixed with uncertainty and hope, her countrymen are convinced that Jesus is "the Savior of the world." 129

\section{The Multitude on the Mountain}

The miraculous signs "Jesus performed on those who were diseased" attract a great multitude to him $(6: 1,2)$. Jesus takes advantage of this opportunity in order to teach

\footnotetext{
${ }^{129}$ For a discussion about the differences between Jewish and Samaritan expectations of the Messiah see Dodd, The Interpretation of the Fourth Gospel, 88-92; T. G. Gaster, "Samaritans," IDB 4:19097; De Jonge, "Jewish Expectation About the 'Messiah' According to the Fourth Gospel," NTS 19 (1973): 246-70; Charlesworth, ed., The Messiah: Developments in Earliest Judaism and Christianity: The First Princeton Symposium on Judaism and Christian Origins (Minneapolis, MN, Fortress, 1992); Gerbern S. Oegema, The Anointed and His People: Messianic Expectations from Maccabees to Bar Kochba, JSPSup 27 (Sheffield, England: Sheffield, 1998); Marie-Émile Boismard, Moses or Jesus: An Essay in Johannine Christology (Minneapolis, MN: Fortress, 1993); James H. Charlesworth, Hermann Lichtenberger, and Gerbern S. Oegema, eds., Qumran-Messianism: Studies on the Messianic Expectations in the Dead Sea Scrolls (Tübingen: Mohr Siebeck, 1998); Robert T. Anderson and Terry Giles, The Keepers: An Introduction to the History and Culture of the Samaritans (Peabody, MA: Hendrickson, 2002); ibid., Tradition Kept: The Literature of the Samaritans (Peabody, MA: Hendrickson, 2005).
} 
the people (v. 3); and after this, he performs another miracle, multiplying "five barley loaves and two small fish" (vv. 4-8), feeding them all and gathering up "twelve baskets with the fragments ... which were left over" (vv. 9-13). When the men see this sign, they

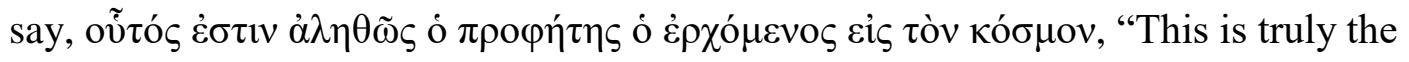
prophet who is to come into the world" (v. 14). With this pronouncement, these men answer the question of the priests and Levites sent from Jerusalem to ask the Baptist, o

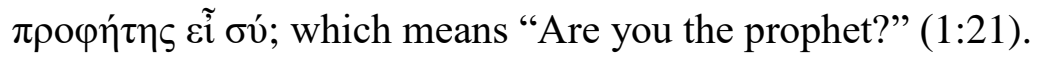

Before this event the Samaritan woman had already said about Jesus, кúpı,

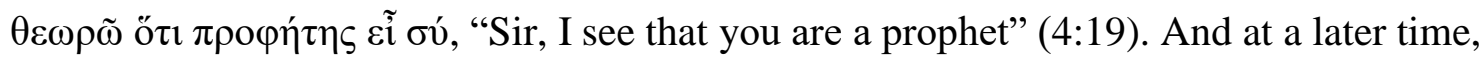
the man born blind, under the question of the Pharisees about Jesus, reacts in the same

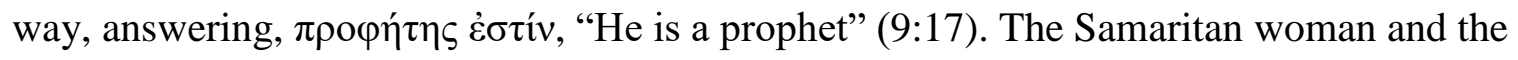
man born blind are in a process of growing in their understanding of Jesus's identity. But on the mountain, the men are clear about this matter, which is repeated by many when the crowd is divided, not only concerning this matter but also about his origin (7:40-44).

\section{Peter}

When Jesus sees that many of his disciples are leaving him under the allegation

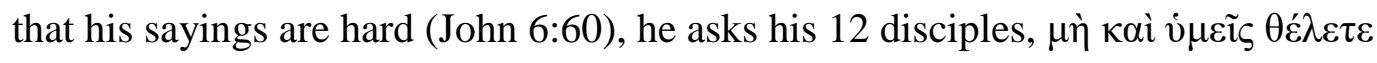

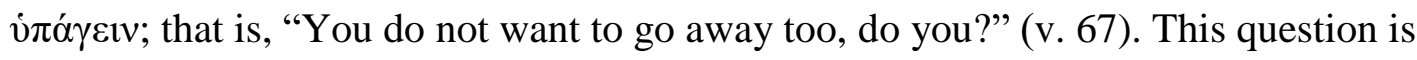

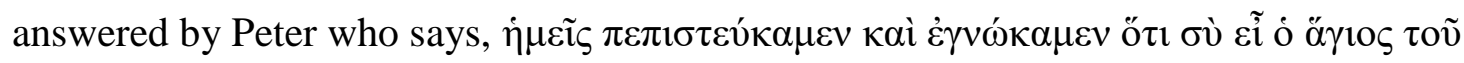
$\theta \varepsilon \circ \tilde{v}$, "We have believed and known that you are the Holy One of God" (6:69). ${ }^{130}$ This

\footnotetext{
${ }^{130}$ This Greek text is supported by $\mathrm{P}^{75}, \mathrm{~N}, \mathrm{~B}, \mathrm{C}^{*}, \mathrm{D}, \mathrm{L}$, from the early third to the ninth centuries. The NKJV translates: "You are the Christ, the Son of the living God," following $\Theta^{c}, \Psi, 0250, f 13,28,157$, $180,579,597,700,892,1006,1071,1241,1243,1292,1342,1424,1505$, from the sixth to the thirteenth
} 
declaration is a testimony of his commitment to Jesus and, at a same time, a confrontation

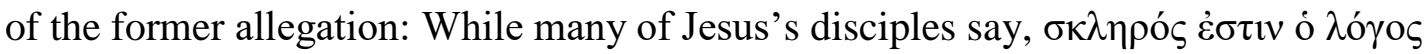

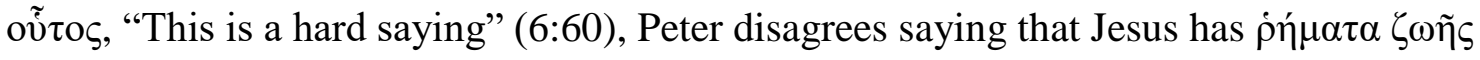

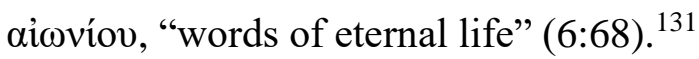

This account comes as a development of what the Evangelist has already said in his introduction in ch. 1:11, 12: "He came to his own, and his own did not receive him. But as many as received him, to them he gave the right to become children of God, to those who believe in his name."

\section{The Officers of the Pharisees and the Chief Priests}

The Pharisees and the chief priests look for occasion to seize Jesus, but they do

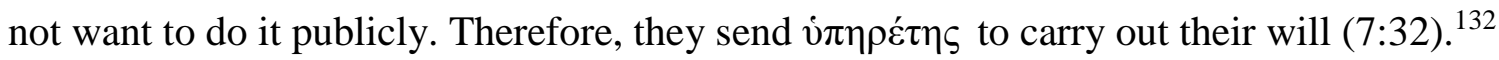
Nevertheless, after listening to Jesus's words, these men come with their hands empty; and under the question of their masters: "Why have you not brought him?" (7:45), they

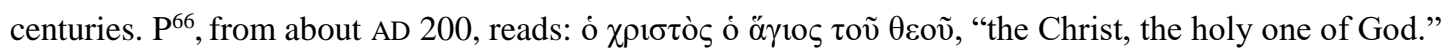
This text has several more variants that do not interfere with the outcome of this dissertation.

${ }^{131}$ For discussion of an identical confession in the Gospel of John see also Paul N. Anderson, The Christology of the Fourth Gospel: Its Unity and Disunity in the Light of John 6, WUNT 2/78 (Tübingen: Mohr, 1996), 17-32; Fuller, The Foundations of New Testament Christology (NY: Scribner, 1965); F. D. Trotter, ed., Jesus and the Historian (Philadelphia, PA: Fortress, 1968); Ferdinand Hahn, The Titles of Jesus in Christology: Their History in Early Christianity, trans. H. Knight and George Ogg (London: Lutterworth, 1969); Wilhelm Bousset, Kyrios Christos: A History of the Belief in Christ from the Beginning of Christianity to Irenaeus, trans. J. E. Steely (Nashville: Abingdon, 1970); Culpepper, "The Christology of the Johannine Writings," in Who Do You Say That I Am: Essays on Christology, ed. M. A. Powell and D. R. Bauer (Louisville, KY: Westminster John Knox, 1999), 66-87.

${ }^{132}$ In the text, the Evangelist uses $\dot{\pi} \eta \rho \varepsilon ́ \tau \alpha \varsigma$ which is the accusative plural. In John 7:32 it has been translated as "Officers" (ESV; KJV; NAS; NAU; NKJ; RSV); "guards" (NAB; NJB); "temple guards" (NIV); "temple police" (NRS). Also, with this word, Luke speaks about John (Mark) as an "assistant" of Barnabas and Saul (Acts 13:5). When Paul recounts his conversion he says that Jesus calls him as a "minister" (Acts 26:16), and he calls himself a "servant" of Christ (1 Cor 4:1). This means that vं $\eta \rho \varepsilon ́ \tau \eta \varsigma$ refers to people under the command of others. 


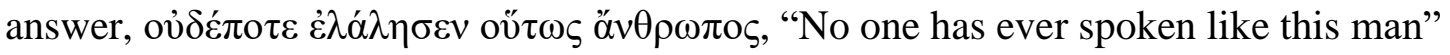
(7:46). This statement comes as an indication to the Pharisees and the chief priests that their plot to kill Jesus is unjustifiable. However, they react rebuking the officers, comparing them with the crowd that does not know the law (7:47-49). In this way they refuse to change their mind. This is an ironic statement for which the Pharisees disqualify themselves to be religious leaders: They are convinced that the people do not know the law; therefore, the people's mistake is understandable. However, the Pharisees know the law, as a result, they are supposed to make a righteous judgment (Deut 16:18-20), and accept Jesus as the Messiah (John 1:45; 5:45-47). Notwithstanding, though from their viewpoint they are not breaking the law, from the standpoint of the Evangelist they are ready to break the law and jeopardize their right to "inherit the land which the Lord" is giving them (Deut 16:20).

\section{Many from the Crowd}

At the time Jesus is teaching the multitude, his identity causes division among the people (John 7:43). A group believes that he is the Prophet (v. 40), and another that he is the Christ (v. 41a); yet a third group is confused with more questions than answers and with doubt about Jesus's origin (vv. 41b, 42). For this third group it is important to verify the origin of the Christ: He has to come "from the seed of David and from the town of Bethlehem" (v. 42) ${ }^{133}$ however, according to them, Jesus has come out of Galilee (v. 41). The Evangelist, in this way, points out the lack of knowledge of this group, taking into account that if it is true that the Messiah should come from Bethlehem and from the seed

${ }^{133}$ They are making reference to Mic 5:2; Isa 9:6, 7; 16:5. 
of David, it is also true that the Messiah comes from above, from heaven $(1: 18 ; 3: 31$;

$6: 46,51,62 ; 8: 23)$. While this group is concerned about the earthly origin of the Messiah, the Evangelist emphasizes his heavenly origin.

\section{The Man Born Blind}

In John 9, Jesus heals a blind man, who answers his inquisitors in three stages how he has been healed: First, he says that he was healed by "a Man called Jesus" (v. 11); second, he declares that his healer "is a prophet" (v. 17); and third, he concludes that his healer "comes from God" (v. 33). ${ }^{134}$

Although the word "testimony" is not mentioned in this chapter, the declarations of the restored man are given in a trial setting in which he testifies in favor of Jesus before the Pharisees (v. 13). While some of them accuse Jesus of being a lawbreaker and a sinner (vv. 16, 24), the healed man takes a stand affirming that Jesus has been able to do this sign because he comes from God (v. 33). However, in the same way, as with Nicodemus, it is not enough to testify that Jesus is "a teacher" who "has come from God" (3:2). Thus, by the end of the story, the man born blind concludes that Jesus is Lord, and worships him (9:38).

\footnotetext{
${ }^{134}$ Jesus heals the blind man on the Sabbath (John 9:14). On this occasion the Pharisees are divided about the rationale under which he heals during the Sabbath hours (v. 16). In a former story, Jesus cures a sick man at the pool of Bethesda (5:9), for which the religious leaders give a reprimand to the cured man for carrying his bed during the Sabbath (v. 10). For this reason, they want to kill Jesus because, according to them, he breaks the Sabbath $(5: 16,18 ; 7: 22,23)$. Throughout the book of John, the Sabbath is a day of controversy in which Jesus breaks Jewish traditions performing miracles during this day. Because of this, he is accused by the religious leaders as not coming from God (9:16). In the Pentateuch, the Sabbath is a commemoration of creation (Exod 20:8-11), and liberation (Deut 5:12-15), and in John, it is a day of a new creation when Jesus liberates people from their illness (John 7:23).

About the Sabbath conflicts in the Gospel of John, see Harold Weiss, "The Sabbath in the Fourth Gospel," JBL 110 (1991): 311-21; Tom Thatcher, "The Sabbath Trick: Unstable Irony in the Fourth Gospel," JSNT 76 (1999): 53-77; and Asiedu-Prepah, Johannine Sabbath Conflicts, 1-293.
} 
In the heat of this conflict the man born blind and the Pharisees are divided on the question of discipleship; while the man born blind professes to be a disciple of Jesus, the Pharisees claim themselves Moses's disciples and try to diminish Jesus's origin (vv. 2729). In the end the Pharisees cast out the man born blind (v. 34), but Jesus's judgment is against the Pharisees (v. 39). Although God's purpose is not "to condemn the world" (3:17), the world condemns itself because its deeds are evil $(3: 19,20 ; 5: 24-30 ; 7: 7){ }^{135}$

\section{Many Beyond the Jordan}

During the Feast of Dedication in Jerusalem, the religious leaders demand of Jesus a final answer about his identity (10:24). Thus, Jesus exposes that he is doing his Father's works and only his sheep believe in him, hear his voice, and follow him (vv. 2529). After this they try to stone him (vv. 30-39), but Jesus departs "beyond the Jordan where John was baptizing at first" (v. 40). Over there, many testify that "all the signs that John spoke about this man were true" (v. 41). With this argument, they support the Baptist's testimony about Jesus, who said, “This is the Son of God" (1:34). ${ }^{136}$

\section{Martha}

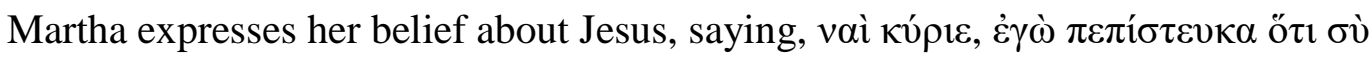

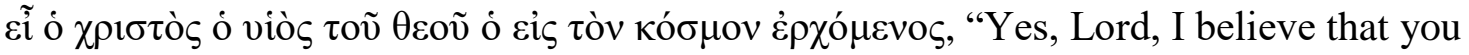
are the Christ, the Son of God the one coming into the world" (John 11:27). This

${ }^{135}$ Cf. R. H. Gundry, Commentary on the New Testament, 403, 404; Brown, An Introduction to the New Testament, 339; Culpepper, Anatomy of the Fourth Gospel, 3-11; Keener, The Gospel of John, 1:39293. As a result, John Painter, John: Witness \& Theologian, 90, stresses that "the World has Jesus on trial, but was unable to produce a valid witness. Jesus's witnesses not only cleared him of all charges; their evidence brought the world under judgement."

${ }^{136}$ Cf. Gundry, Commentary on the New Testament, 410; Lindars, The Gospel of John, 377, 378. 
statement of faith establishes that Martha is aware of Jesus's Messiahship. She does not

need to see beforehand the resurrection of Lazarus in order to believe that Jesus is the

Christ. Her previous experience with Jesus is enough to support what she is now

testifying. ${ }^{137}$

\section{Summary}

Although the narratives, in which each person of this section gives their

declaration, do not mention the Greek word $\mu \alpha \rho \tau v \rho i ́ \alpha$ or its cognate verb $\mu \alpha \rho \tau v \rho \varepsilon ́ \omega$, their

contexts demonstrate the legal nature of each one. From the mild but shocking

recognition of the officers that "never a man spoke in this manner" (John 7:46) to the

\footnotetext{
${ }^{137}$ Köstenberger, A Theology of John's Gospel and Letters, 500, notices the parallel of Martha's confession with "the witness of "the disciple whom Jesus loved" " John 20:31). Martha has been seen as a woman of faith by many commentators: Cf. Brown, The Community of the Beloved Disciple, 183, $185 \mathrm{n}$. 328; 191, 192; Schnackenburg, The Gospel According to St John, 2:329; A. T. Robertson, Some Minor Characters in the New Testament (Nashville, TN: Sunday School Board of the Southern Baptist Convention, 1928), 163; Richard C. H. Lenski, Interpretation of St. John's Gospel (Columbus, OH: Lutheran Book Concern, 1942), 804; Helga Rusche, They Lived by Faith: Women in the Bible, trans. Elizabeth Williams (Baltimore, MD: Helicon, 1963); Herber Lockyer, The Women of the Bible (Grand Rapids, MI: Zondervan, 1967); Sandra Schneiders, "Women in the Fourth Gospel and the Role of Women in the Contemporary Church," BTB 12 (1982): 35-45; ibid., Written That You May Believe: Encountering Jesus in the Fourth Gospel (NY: Crossroad, 1999), 104-5; Philip Siddons, Speaking Out for Women: A Biblical View (Valley Forge, PA: Judson, 1980); Witherington, Women in the Ministry of Jesus: A Study of Jesus' Attitudes to Women and Their Roles as Reflected in His Earthly Life, SNTSMS 51 (Cambridge: Cambridge University Press, 1984), 109; Turid Karlsen Seim, "Roles of Women in the Gospel of John," in Aspects on the Johannine Literature: Papers Presented at a Conference of Scandinavian New Testament Exegetes at Uppsala, June 16-19, 1986, ConBNT 18, ed. Lars Hartman and Birger Olsson (Uppsala: Uppsala Universitet, 1987), 56-73; Elisabeth Moltmann-Wendel, The Women Around Jesus (NY: Crossroad, 1987); Elisabeth Schüssler Fiorenza, In Memory of Her: A Feminist Theological Reconstruction of Christian Origins (NY: Crossroad, 1989); Carlo M. Martini, Women in the Gospels (NY: Crossroad, 1990); Brendan Byrne, Lazarus: A Contemporary Reading of John 11:1-46, Zacchaeus Studies: New Testament, ed. Mary Ann Getty (Collegeville, PA: Liturgical, 1990); Francis J. Moloney, "The Faith of Martha and Mary: A Narrative Approach to John 11, 17-40," Bib 75 (1994): 471-93; Bonnie Thruston, Women in the New Testament: Questions and Commentary (NY: Crossroad, 1998); Gail R. O'Day, "John," in Women's Bible Commentary, ed. Carol A. Newsom and Sharon H. Ringe (Louisville, KY: Westminster John Knox, 1998), 381-93; Adeline Fehribach, The Women in the Life of the Bridegroom: A Feminist Historical-Literary Analysis of the Female Characters in the Fourth Gospel (Collegeville, PA: The Liturgical, 1998); Robert Ellsberg, All Saints: Daily Reflections on Saints, Prophets, and Witnesses for our Time (NY: Crossroad, 1999), 311-13; Mary Ann Getty-Sullivan, Women in the New Testament (Collegeville, PA: Liturgical, 2001); Richard Bauckman, Gospel Women: Studies of the Named Women in the Gospels (Grand Rapids, MI: Eerdmans, 2002).
} 
bold testimony that Jesus is the Messiah, the Son of God $(1: 41,49 ; 4: 42 ; 6: 69 ; 7: 41 \mathrm{a}$;

9:38), the Evangelist establishes the Pentateuchal requirement of more than one witness to make a case (Num 35:30; Deut 19:15). The great majority of witnesses have testified in Jesus's favor; but again, as Jesus does "not receive testimony from man" (John 5:34), the Evangelist reports Jesus's saying that the testimony of the Father is enough, and decisive (v. 37).

\section{Conclusion}

In the Gospel of John the words $\mu \alpha \rho \tau v \rho i ́ \alpha$ and $\mu \alpha \rho \tau v \rho \varepsilon \dot{\varepsilon} \omega$ are used in three ways: (1) general statements on how testimonies and witnesses work; (2) testimonies concerning Jesus's identity, and (3) testimony concerning Jesus's origin.

The general statements on how testimonies and witnesses work are as follows: (1) Statements of truth to impart or develop faith $(1: 7 ; 19: 35)$. (2) Confession denying who one is not and who one is $(1: 19-23 ; 3: 28)$. (3) Confession of those who have known, seen or heard something such as Jesus and the Father (3:11), the Baptist $(1: 32,33 ; 3: 32)$, Jesus alone $(4: 39 ; 5: 32)$, those who saw Lazarus' resurrection (12:17), the disciples (15:27), and the Evangelist (19:35). (4) An affirmation: the Baptist says that the one who receives Jesus's testimony certifies that God is true (3:33), Jesus affirms that a prophet has no honor in his own country $(4: 44)$, Jesus makes the point that self-witness is not true $(5: 31$; cf. 8:13) but as he knows where he comes from and where he goes his self-witness is true (8:14), Jesus establishes that the works of the world are evil (7:7), and only a testimony of two persons is valid (8:17). (5) Jesus does not receive testimony from man (5:34). (6) Jesus and the Father testify together (8:18). (7) A declaration to reveal an evil deed 
(13:21). (8) An accusation of an evil deed (18:23). And (9) an affirmation of a truth by the Father (5:32), the Baptist (5:33), Jesus (18:37), and the Evangelist (19:35b; 21:24). ${ }^{138}$

Testimonies about Jesus's identity are these: (1) Jesus is the "true Light of the world" $(1: 7,8)$. (2) Jesus is preferred before the Baptist $(1: 15,27 ; 3: 28)$. (3) Jesus is the new Moses (1:16). And (4) Jesus is the "Son of God" (1:34).

Testimonies about Jesus's origin: (1) Jesus's works testify that the Father has sent $\operatorname{him}(5: 36,37 ; 10: 25)$. (2) The Scripture testifies about Jesus (5:39). (3) Jesus's own witness is acceptable because he knows from where he comes and goes (8:14). And (4) The Spirit who Jesus sends from the Father testifies about Jesus (15:26).

Also, the passages in which $\mu \alpha \rho \tau v \rho i ́ \alpha$ and $\mu \alpha \rho \tau v \rho \varepsilon ́ \omega$ are not used, but portray people giving a declaration about Jesus's identity, say that he is: the "Son of God" (1:34, 49a; 11:27), the "Lamb of God" (1:29, 36), "the Messiah/Christ" (1:41; 4:42c; 7:41a; 11:27), the one "of whom Moses in the law, and also the prophets wrote" (1:45), "the King of Israel" (1:49b), "the Savior of the world" (4:42c), "the Prophet" (6:14; 7:40), "the Holy One of the living God" (6:69), and "Lord" (9:38). These declarations or indirect testimonies, along with the other testimonies, support Jesus's origin and identity at least 22 times as table 17 shows. This table illustrates that the testimony of Jesus's Messiahship is overwhelming in the Gospel of John. Thus, the case against Jesus is without merit. On the contrary, his Messiahship is affirmed beyond a shadow of a doubt by numerous witnesses from a variety of backgrounds and situations in life.

\footnotetext{
138 The difference between points (1) and (9) is that while (1) has a purpose with the given testimony, (9) only establishes the truth without stating its purpose.
} 
Table 17. Testimonies in favor of Jesus

\begin{tabular}{|c|c|}
\hline Witnesses & Testimonies \\
\hline John the Baptist & $\begin{array}{l}\text { "Behold, the Lamb of God" }(1: 29,36) \\
\text { "This is the Son of God" }(1: 34)\end{array}$ \\
\hline Andrew & "We have found the Messiah" (1:41) \\
\hline Philip & $\begin{array}{l}\text { "We have found him of whom Moses in the law, and also } \\
\text { the prophets, wrote - Jesus of Nazareth, the son of Joseph" } \\
(1: 45)\end{array}$ \\
\hline Nathanael & $\begin{array}{l}\text { "You are the Son of God! You are the King of Israel!" } \\
(1: 49)\end{array}$ \\
\hline Nicodemus & "You are a teacher come from God" (3:2) \\
\hline The Samaritan Woman & $\begin{array}{l}\text { "Come and see a Man. ... Could this be the Christ?" (4:29) } \\
\text { "He told me all that I did" }(4: 39)\end{array}$ \\
\hline The Samaritans & "This is indeed the Christ" $(4: 29-42)$ \\
\hline $\begin{array}{l}\text { The Multitude on the } \\
\text { Mountain }\end{array}$ & $\begin{array}{l}\text { "This is truly the prophet who is to come to the world" } \\
(6: 14)\end{array}$ \\
\hline Jesus's Works & They testify that "The Father has sent me" (5:36; cf. 10:25) \\
\hline The Father & The testimony of the Father about Jesus is true $(5: 32)$ \\
\hline The Scriptures & "These are they which testify of Me" (5:39) \\
\hline Peter & "You are the Holy One of the living God" (6:69) \\
\hline The People & $\begin{array}{l}\text { "This is the Prophet" }(7: 40) \\
\text { "This is the Christ" }(7: 41 \mathrm{a})\end{array}$ \\
\hline $\begin{array}{l}\text { Jesus along with the } \\
\text { Father }\end{array}$ & $\begin{array}{l}\text { "I am one who bears witness of myself, and the Father who } \\
\text { sent me bears witness of me" }(8: 18)\end{array}$ \\
\hline The man born blind & $\begin{array}{l}\text { He is "a man" }(9: 11) \\
\text { "He is a prophet" }(9: 17) \\
\text { "Lord, I believe!" (9:38) }\end{array}$ \\
\hline $\begin{array}{l}\text { Many beyond the } \\
\text { Jordan }\end{array}$ & $\begin{array}{l}\text { "All things that John spoke about this man were true" } \\
(10: 41)\end{array}$ \\
\hline Martha & $\begin{array}{l}\text { "I believe that you are the Christ, the Son of God, who is to } \\
\text { come into the world" }(11: 27)\end{array}$ \\
\hline $\begin{array}{l}\text { The people who saw } \\
\text { Lazarus raised from the } \\
\text { dead }\end{array}$ & (Not stated $[12: 17])$ \\
\hline The Holy Spirit & $\begin{array}{l}\text { The Holy Spirit will teach all things, and bring to } \\
\text { remembrance all things that Jesus said to his disciples } \\
(15: 26 ; 14: 16-18,25 ; 16: 7)\end{array}$ \\
\hline Jesus's disciples & (Not stated [15:27]) \\
\hline Jesus himself & $\begin{array}{l}\text { "I am a king. ... I should bear witness to the truth" (18:37; } \\
\text { cf. } 8: 14,15)\end{array}$ \\
\hline The Evangelist & $\begin{array}{l}\text { "He who has seen has testified, and he knows that he is } \\
\text { telling the truth, that you may believe" (19:35; cf. } 21: 24)\end{array}$ \\
\hline
\end{tabular}


The Evangelist has placed many human witnesses in favor of Jesus. They have seen his deeds and listened his words. They have believed that he is the Messiah, the Son of God; but above all, the Evangelist writes that Jesus is also supported by the testimony of the Father, the Paraclete, and the Pentateuch. With these witnesses in his favor, Jesus is declared, not only the Messiah and the Son of God but also Witness and Judge. While this present chapter shows Jesus testifying along with the Father, the following chapter presents him judging along with the Father. Because of that, their testimony and judgment gives an assurance that the administration of justice of the heavenly trial is based on justice and truth: The Father and the Son accomplish the Pentateuchal legal requirement (Num 35:30; Deut 17:6, 7; 19:15-21) in the Gospel of John. 


\section{CHAPTER 5}

\section{INTERTEXTUAL ANALYSIS: PENTATEUCH}

\section{AND GOSPEL OF JOHN}

In this chapter, I demonstrate the close correspondence in the judicial content of the Gospel of John with the Pentateuch. I first propose that throughout the Gospel of John runs a legal structure, and after that I study the many passages that the Evangelist pervades with Pentateuchal language to demonstrate the illegality of Jesus's crucifixion. Though Jesus, among other characteristics, has brought a new creation, is the new sanctuary, and the new Moses, and greater than Abraham and Jacob, he is rejected under an illegal judgment based on false testimonies.

\section{Legal Structure of the Gospel of John}

C. H. Dodd and R. E. Brown, in their structure of the Gospel of John, agree on the first part of the Gospel (chs. 1-12) which they arrange as Introduction (ch. 1), and the "Book of Signs" (chs. 2-12). But, in the second part (chs. 13-20), they depart from each other: While Dodd calls it the "Book of Passion," R. E. Brown, the "Book of Glory."1 With these proposed structures they have greatly influenced scholars' opinions regarding

\footnotetext{
${ }^{1}$ Dodd, The Interpretation of the Fourth Gospel, x; Brown, The Gospel According to John, AB 29: cxxxviii. For more structural analysis of the Gospel of John cf. Schnackenburg, The Gospel According to St. John, 3:1-5; Collins, These Things Have Been Written (Grand Rapids, MI: Eerdmans, 1990), 185; Barrett, The Gospel according to John, 11-15.
} 
the Fourth Gospel. ${ }^{2}$ However, since I have studied the Gospel of John taking into account the author's judicial language, I prefer to propose a structure based on a legal trial.

In addition to the many references to the Pentateuch, the Gospel of John has a legal structure built around three questions, asked five times, which are answered by witnesses, testimonies, and evidences: ${ }^{3}$

(I) Introduction: Jesus, not John the Baptist, is the light (1:1-18).

(II) First question: Who are you? (1:19-4:26). ${ }^{4}$

(1) Testimonies of the Baptist (1:19-36).

(2) Testimonies of Jesus's first disciples (1:37-51).

(3) Evidence: Beginning of signs: Jesus turns water to wine (2:1-12).

(4) Evidence: "Destroy this temple" (2:13-25).

(5) Testimony: Nicodemus to Jesus: "You are a teacher come from God" (3:121).

(6) Testimony: John the Baptist repeats to his disciples: "I am not the Christ" (3:22-36).

(7) Testimony and revelation: The Samaritan woman and Jesus (4:1-26).

\footnotetext{
${ }^{2}$ See D. A. Carson and Douglas J. Moo, An Introduction to the New Testament (Grand Rapids, MI: Zondervan, 2005), 225, 226.

${ }^{3}$ The Gospel of John has more questions such as in 4:12; 8:53, and 18:33; but these are answered in the same chapter where they are asked, so they are put at rest and no asked anymore. However, the question "who are you" goes from the beginning to the end of the Gospel which establishes that any confusion about Jesus's identity and origin needs to be clearly settled in order to confirm that Jesus is the Messiah, the Son of God. Also related questions are highlighted in this structure taking into account that they are not only asked as consequence of the events which have previously taken place but also they are the base of the subsequent events which will happen to answer them.

${ }^{4}$ Moloney, The Gospel of John, SP, ed. Daniel J. Harrington (Collegeville, MN: Liturgical, 1998), 58, emphasizes as follows: "Although asked of John the Baptist, the question su tis ei? 'who are you?' could be taken as the leitmotif of the Fourth Gospel. Response to that question will determine the success or failure of all who encounter the Johannine Jesus."
} 
(III) Second question: “Could this be the Christ?” (4:27-7:24).

(1) The fields are ready for harvest (4:31-38).

(2) Testimony: The Samaritans to the Samaritan woman: "This is indeed the Christ” (4:39-42).

(3) Evidence: Second sign: Jesus heals a nobleman's son (4:43-54).

(4) Evidence: Jesus heals a man at the Pool of Bethesda (5:1-15).

(5) Judgment: God gave it to his Son (5:16-30).

(6) Testimonies: The Father, Jesus's works, and the Scriptures (5:31-47).

(7) Evidence and Testimony: Third sign: Jesus feeds the multitude (6:1-13). The multitude says, "This is truly the prophet who is to come to the world" (6:14).

(8) Evidence: Jesus walks on the sea (6:15-21).

(9) Evidence: Jesus is the bread of life (6:22-59).

(10) Rejection: Jesus is rejected by many of his disciples (6:60-67).

(11) Testimony: "You are the Holy One of the living God" (6:68-70).

(12) Testimony: Jesus testifies about the evil works of the world (7:1-9).

(13) Judgment: Jesus's judgment is righteous; the religious leaders judge according to appearance (7:10-24).

(IV) Third question: "Do the rulers know indeed that this is truly the Christ?" (7:258:24).

(1) Disagreements of the people and the religious leaders about Jesus's identity and origin (7:25-44).

(2) Defense and Rejection: The officer, the Pharisees, and Nicodemus argue about Jesus (7:45-53).

(3) Testimony: Jesus and the Father testify together (8:13-24). 
(V) Fourth question: Who are you? (8:25-20:31).

(1) Defense and rejection: The religious leaders and Jesus continue arguing about his identity (8:25-59).

(2) Evidence and testimony: Jesus heals a man born blind and declares himself to be "the Son of Man" (9:1-41).

(3) Defense: Jesus is the Good Shepherd (10:1-30).

(4) Accusation: The religious leaders reject Jesus and try again to kill him for blasphemy (10:31-39).

(5) Testimony: Jesus takes John the Baptist's place (beyond the Jordan), and many believe in him because what John the Baptist said about him was true $(10: 40-42)$.

(6) Testimony and evidence: Martha: "I believe that you are the Christ." Lazarus's resurrection (11:1-44).

(7) Judgment against Jesus: The Pharisees pass judgment to kill Jesus against the law (11:45-57).

(8) Preparation and testimony: Jesus is ready to die. Testimony of the people who saw Lazarus raised from the dead (12:1-50).

(9) Preparation to die: The Last Supper (13-17).

(10) Betrayal, Verdict, and Testimony: Jesus is betrayed, arrested and falsely accused. Jesus testifies and found innocent (18:1-19:16).

(11) Penalty, Witness and Testimony: Jesus is crucified and the Evangelist testifies (19:17-42).

(12) Evidence: Jesus, raised from the dead (20:1-29). 
(13) Conclusion: The Evangelist's purpose $(20: 30,31)$.

(VI) Fifth question no one dared to ask: (21:1-24).

(1) Evidence: One last miracle (21:1-11)

(2) Fifth question: No one "dared ask Him, "Who are you?" (21:12-14).

(3) Jesus restores Peter (21:15-19).

(4) The Evangelist's last days and his true testimony (21:16-24).

The opening dialogue of the religious leaders about the identification of the Baptist (1:19-23), introduces a question that runs through the Gospel of John until 21:12. Although more questions could be found $(4: 2,11,12$; and 19:33), the question "who are you?" addresses the main purpose of the Gospel of John which is to point out that the one who is going to be unlawfully crucified is the Messiah.

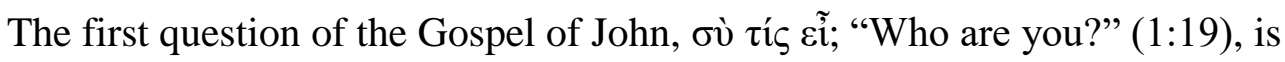
addressed to the Baptist — the wrong person — that same question later is addressed to Jesus (8:25a), the right person. The first one is answered by the Baptist who affirms without hesitation that he is not the Christ (1:9-36), and at the same time he persuades the religious leaders and his own disciples to look for that answer in Jesus.

As the attention is no longer on the Baptist, then it is centered on Jesus: Could this be the Christ? $(4: 29 b, 30)$. With this question on the table the Gospel focuses on giving answer to it with testimonies and evidences that Jesus "is indeed the Christ" (4:39-42), and "the Holy One of the living God" (6:68-70).

The third question is asked by some people who come from Jerusalem and their question has a sense of uncertainty and expectation $(7: 25,26)$. The people would like to 
know the opinion of the religious leaders about Jesus. These leaders do not accept Jesus as the Messiah; instead they send officers to take him (v. 32).

However the question has to be asked to Jesus by the religious leaders. They had the opportunity to ask the Baptist (1:19), now they ask the same question to Jesus: "Who are you" (8:25a). The answer is that Jesus is "the Son of Man" (9:1-41), the Good Shepherd (10:1-30), greater than the Baptist (10:40-42), and the Christ (11:1-44). In an unlawful judgment he is found innocent; notwithstanding he is crucified (18:1-19:42).

In order to answer these questions, the first twelve chapters have 22 testimonies in Jesus's favor; but these chapters report that some religious leaders, and part of the people, are against Jesus. The rest of the book indicates five more testimonies (chs. 13-21): The first one is a promise $(15: 26)$, the second is an assurance $(15: 27)$, the third is an explanation (18:37); and the fourth and fifth are supporting statements in order to persuade the readers about the truth of the Gospel's account. But these last five testimonies will not change the trial's outcome.

In the end of the structure the fifth question appears when the Evangelist reports that nobody dares to ask Jesus again "who are you?" because it was no longer necessary. This means that for the disciples, Jesus's identity and origin have been made clear at this point. Jesus has been glorified; he is now the powerful risen Lord. Therefore, the Evangelist, who introduces and develops Jesus's ministry based on these questions, finds answer in Jesus, showing that he is the Christ, the Son of the living God. ${ }^{5}$

\footnotetext{
${ }^{5}$ Cf. Michaels, The Gospel of John, 32, 35, 36, in his outline of the structure of the Gospel of John contends that the "first three chapters shall be designated 'the testimony of John." "And "in a general way" chapters 2-12 "can be regarded as a book of judgment. In one sense, Jesus is on trial, but in another 'the world' represented by the Jewish religious authorities, is being tried - and condemned." Thus, he comes up with the following outline: "Preamble (1:1-5). The testimony of John (1:6-3:30), with a transition on the lips of John (3:31-36) corresponding to the preamble. Jesus' self-revelation to the world (4:1-12:43), with a
} 


\section{The Pentateuch in the Gospel of John}

The main purpose of the study of this dissertation is to analyze the legal setting in which the word "witness" and its cognates appear. In order to accomplish this purpose I consider briefly in this section some of the passages that are either direct quotations or allusions in which the Gospel of John has used the Pentateuch for its legal language. Those passages are an affirmation of the argument that the legal language of the Gospel of John is pervaded with many narratives and situations which occurred in the Pentateuch. With this I demonstrate that the Pentateuch is the main source of the Gospel of John and its "witness" motif is not placed in a vacuum. ${ }^{6}$

As an example of these quotations and allusions, Menken says that John uses his own free phrasing in ch. 8:17 while citing Deut 19:15. He adds that "the legal content of Deut 19:15 has evidently been rephrased in Johannine language." ${ }^{77}$ In addition he points out that in the way John renders Old Testament quotations, shows that he is "more interested in the theological or juridical proposition based on the OT than in the precise wording of the OT text." content was relevant." $\mathrm{I}$ defend this content in the rest of the chapter. Table 18 gives an indication of the Evangelist's intention for his witness motif and his purpose to clarify

transition . . . on the lips of Jesus (12:44-50). Jesus' self-revelation to the disciples (13:1-16:33), with a ... transition ... of Jesus' prayer to the Father (17:1-26). Verification of Jesus' self-revelation in his arrest, crucifixion, and resurrection (18:1-21:25)." The detailed structure that I present above is based on the legal purpose of this dissertation.

${ }^{6}$ See below table 18 , p. 221.

${ }^{7}$ Menken, Old Testament Quotations, 16.

${ }^{8}$ Ibid., 18.

${ }^{9}$ Ibid. 
Jesus's identity and origin based on the Pentateuch:

Table 18. The Pentateuch in the Gospel of John

\begin{tabular}{|c|c|c|}
\hline John & The Pentateuch & Theme \\
\hline $1: 1-13$ & Gen $1: 1-10$ & Creation \\
\hline $1: 11-13$ & Exod 19:5, 6 & God's covenant people \\
\hline $1: 14$ & Exod $25-31 ; 35-40$ & The Sanctuary \\
\hline $1: 16-18$ & Exod 20-24; 33:20 & $\begin{array}{l}\text { "The Law given through Moses" } \\
\text { "Grace and truth came through Jesus" } \\
\text { Jesus is the new Moses }\end{array}$ \\
\hline $1: 21,45$ & Deut $18: 18$ & "Moses in the law" (a prophet like him) \\
\hline $1: 29,36$ & $\begin{array}{l}\text { Gen 22:7, 8; Exod 29:38- } \\
\text { 46; Num 28:1-8; Lev 16; } 23\end{array}$ & $\begin{array}{l}\text { Jesus is "The Lamb of God" } \\
\text { He takes away the sin (Expiation) }\end{array}$ \\
\hline $1: 51$ & Gen 28:10-22 & $\begin{array}{l}\text { Jacob's experience } \\
\text { Jesus is greater than Jacob }\end{array}$ \\
\hline $\begin{array}{l}2: 11,23 \\
4: 54\end{array}$ & Exod 10:2 & $\begin{array}{l}\text { Jesus performs signs, as God in Egypt; } \\
\text { thus, Jesus is the new Moses }\end{array}$ \\
\hline $2: 13,23$ & Exod 12:1-28, 43-51 & The Passover \\
\hline $3: 1-10$ & Gen 1:27 & New birth and new creation \\
\hline $3: 14-18$ & Num 21:4-9 & Jesus as the bronze serpent \\
\hline $3: 19-21$ & Gen $1: 3,4$ & $\begin{array}{l}\text { Jesus is the light of the world } \\
\text { Feast of Tabernacle }\end{array}$ \\
\hline $4: 1-23$ & $\begin{array}{l}\text { Gen } 33: 19 ; 48: 22 ; \text { Deut } \\
11: 26-29 ; 27: 11-13\end{array}$ & $\begin{array}{l}\text { Jesus is greater than Jacob } \\
\text { True worship of the Father is in spirit } \\
\text { and truth }\end{array}$ \\
\hline $5: 1-18$ & Exod 20:8-11 & Jesus brings rest to sick people \\
\hline $5: 37,38$ & Exod 19:9; 20:18, 19 & $\begin{array}{l}\text { The religious leaders have never heard } \\
\text { God's voice }\end{array}$ \\
\hline $5: 45-47$ & Gen $3: 15 ; 22: 1-14$ & $\begin{array}{l}\text { Moses wrote about Jesus; thus, he stands } \\
\text { with Jesus to accuse the religious leaders }\end{array}$ \\
\hline $6: 1-59$ & Exod 16:1-36 & $\begin{array}{l}\text { Jesus is the bread which came down } \\
\text { from heaven (The New Manna that } \\
\text { gives eternal life) }\end{array}$ \\
\hline $\begin{array}{l}6: 41,43,52, \\
61\end{array}$ & Exod 16:2, 7-12 & $\begin{array}{l}\text { People complain and murmur against } \\
\text { Jesus because of "his New Manna" }\end{array}$ \\
\hline $7: 1-51$ & $\begin{array}{l}\text { Lev 23:33-36, 39-43; Num } \\
\text { 29:12-40; Deut 16:13-17 }\end{array}$ & The Feast of Tabernacles \\
\hline $7: 19$ & Exod 20:13; Deut 5:17 & "You shall not murder" \\
\hline $7: 22,23$ & Gen 17:10-27; Lev 12:3 & The law of circumcision \\
\hline $7: 24,51$ & Deut $4: 8 ; 16: 18-20$ & Righteous judgment \\
\hline
\end{tabular}


Table 18-Continued

\begin{tabular}{|c|c|c|}
\hline $7: 40$ & Deut 18:15-18 & The Prophet \\
\hline [8:5] & Lev 20:10; Deut 22:22 & Punishment for adultery \\
\hline [8:7] & Deut 17:7; 19:16-19 & False witness \\
\hline $8: 12$ & Gen $1: 3-5$ & Light and darkness \\
\hline 8:13-18 & $\begin{array}{l}\text { Num 35:30; Deut 17:6, 7; } \\
\text { 19:15 }\end{array}$ & $\begin{array}{l}\text { The law of more than one witness for a } \\
\text { just judgment }\end{array}$ \\
\hline $8: 28$ & Num 21:4-9 & Jesus as the bronze serpent \\
\hline 8:33-40 & $\begin{array}{l}\text { Gen } 12: 1-3 ; 15: 1-6 ; 17: 1-4 ; \\
22: 17,18\end{array}$ & Abraham's seed \\
\hline $8: 48-58$ & Gen 12:1-25:11; Exod 3:14 & Jesus is greater than Abraham \\
\hline $8: 56$ & Gen 22:1-19 & Abraham saw Jesus's days \\
\hline $9: 1-41$ & Gen 1:1-2:25 & Two Stage Creation \\
\hline $10: 33$ & Lev 24:16 & Punishment for blasphemy \\
\hline 11:1-44 & Gen 1:1-2:25 & New Creation \\
\hline $11: 55,56$ & Exod 12:1-28, 43-51 & The Passover \\
\hline $12: 1-8,27$ & Exod 12:1-14 & The Passover Lamb is taken \\
\hline $12: 20-26$ & Gen $22: 18 ; 26: 4 ; 28: 14$ & In Jesus, all the earth is blessed \\
\hline $12: 32$ & Num 21:4-9 & Jesus as the bronze serpent \\
\hline $12: 35,36,46$ & Gen 1:3-5 & Light and Darkness: Jesus is the Light \\
\hline 13:1 & Exod 12:1-14 & The Passover Lamb is ready \\
\hline $13: 34-15: 17$ & Exod 20:1-17; Deut 5:1-21 & Jesus is the New Moses \\
\hline $17: 24$ & Exod 33:18-34:10 & To see Jesus's glory \\
\hline 18:1-19:31 & Exod 12:1-14 & The Passover Lamb is Crucified \\
\hline 19:33-36 & Exod 12:46; Num 9:12 & $\begin{array}{l}\text { Not one of the Passover Lamb's bones is } \\
\text { broken }\end{array}$ \\
\hline $20: 22$ & Gen 2:7 & Jesus is the Creator \\
\hline
\end{tabular}

I have shown before that scholarly studies in the Gospel of John have been inclined to maintain that the witness motif of the Gospel of John is based on Isa 40-55 rather than on the Pentateuch; however, the reckoning of passages with direct quotations, echoes, or allusions from the Pentateuch surpass the amount of passages used from any other OT book. Accordingly, Köstenberger enlists a survey chart of OT allusions and verbal parallels in the Gospel of John, and concludes: "The range of allusions spans 
virtually the entire OT. Particularly frequent are allusions to the Pentateuch, the Psalms, and OT prophetic literature, particularly Isaiah. . .."10

\section{Creation (John 1:1 and Gen 1:1; John 20:22 and Gen 2:7)}

The book of Genesis and the Gospel of John start in the same way with the expression $\dot{\varepsilon} v \dot{\alpha} \rho \chi \tilde{\eta}$, "in the beginning” (Gen 1:1 [LXX]; John 1:1); with which Genesis expresses its account about the creation narrative through God's word. For this expression the MT uses Gospel of John is clearly alluding to Genesis 1:1 and commences with the same phrase that begins Genesis 1:1 in the LXX."

As the light $(\varphi \tilde{\omega} \varsigma)$ takes part of the creation from the first day (Gen 1:3), in John, the Logos "was life, and the life was the light ( $\varphi \tilde{\omega} \varsigma)$ of men" (John 1:4). Meanwhile, the Evangelist uses Gen 1 in order to show a second creation narrative based on the redemptive power of the Logos of which the Baptist comes to bear witness (1:7).

In Gen 1 the light has a physical meaning, and John uses it in a metaphorical form. ${ }^{12}$ Thus, in Gen 1:4 God divides the "light ( $\left.\varphi \tilde{\omega} \varsigma\right)$ from the darkness" ( $\left.\sigma \kappa o ́ \tau o \varsigma\right)$; and

${ }^{10}$ Cf. Köstenberger, A Theology of John's Gospel, 307-9.

${ }^{11}$ Davidson, "The Genesis Account of Origins," in The Genesis Creation Account and Its Reverberations in the Old Testament," ed. Gerald A. Klingbeil (Berrien Springs, MI: Andrews University Press, 2015), 68.

Cf. Barker, Lane, and Michaels, The New Testament Speaks, 386, 387; Bruce, The Message of the New Testament (Grand Rapids, MI: Eerdmans, 1973), 103; Bruce K. Waltke, "The Creation Account in Genesis 1:1-3; Part IV: The Theology of Genesis 1," BSac 133 (1976): 28-41; Painter, "The Johannine Literature," in Handbook to Exegesis of the New Testament, ed. Stanley E. Porter (Leiden: Brill, 1993), 579; Minear, Christians and the New Creation: Genesis Motifs in the New Testament (Louisville, KY: Westminster, 1994), 87, 88; Lightfoot, A Commentary on the New Testament, 3: 237; Köstenberger, A Theology of John's Gospel and Letters, 405-6; Morris, The Gospel According to John, 72, 73, 117-18, 130; Westermann, The Gospel of John, 5, 61; Brant, John, 24, 28; Bultmann, The Gospel of John, 20.

12 The Greek word $\varphi \tilde{\omega} \zeta$ is used 23 times in the Gospel of John $(1: 4,5,7,8$ [two times], 9; 3:19 


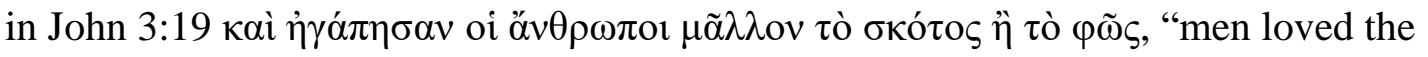
darkness more than the light." Also in John 1:5 "the light ( $\varphi \tilde{\omega} \varsigma)$ shines in the darkness

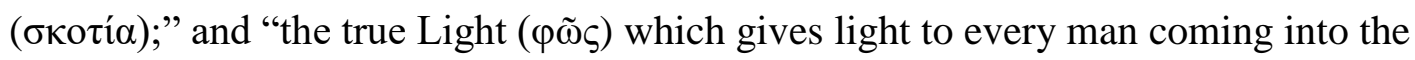

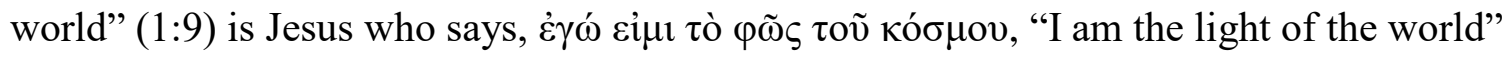
$(8: 12)$.

The Gospel of John, which begins within a creation context, finishes in the same tone, when Jesus breathes ( $\dot{\varepsilon} \mu \varphi v \sigma \alpha \dot{\alpha} \omega)$ the Holy Spirit on the disciple (20:22). The verb $\dot{\varepsilon} \mu \varphi v \sigma \alpha ́ \omega$ is the same one used in Gen 2:7 (LXX) at the time God formed man, breathing on him. While in Genesis, God breathes ( $\dot{\varepsilon} \mu \varphi v \sigma \alpha ́ \omega)$ and the man becomes "a living being," in the Gospel of John, Jesus breathes ( $\dot{\varepsilon} \mu \varphi v \sigma \alpha ́ \omega)$, and the disciples receives the Holy Spirit through whom they have not only life for themselves but also for others (20:23). So, it is noteworthy the Evangelist's purpose in narrating this story (21:25) is to show that Jesus is the Creator, the Son of God. ${ }^{13}$

\section{Sanctuary (John 1:4; Exod 25:8)}

The Evangelist advances his witness motif by connecting it with the Sanctuary, saying that "the Word became flesh and dwelt ( $\sigma \kappa \eta v o ́ \omega)$ among us" (1:14). This phrase is an echo of what God says to Moses in Exod 25:8: "And let them make me a sanctuary,

[two times], 20 [two times], 21; 8:12 [two times]; 9:5; 12:35 [two times]; 12:36 [three times]; 12:46). A possible difference to the metaphorical meaning is ch. 11:9, 10 in which Jesus compares the

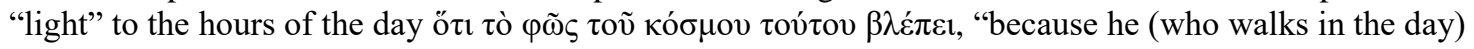

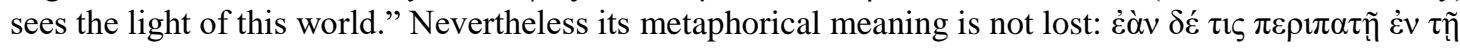

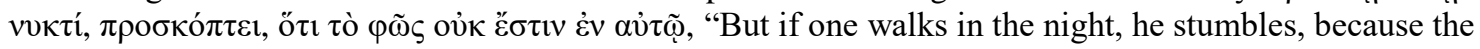
light is not in him." Also in John 5:35 Jesus calls the Baptist a light ( $\varphi \tilde{\omega} \varsigma)$ which comes from a burning and

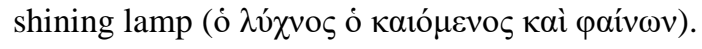

${ }^{13}$ For further analysis of John 20:22, see Kysar, John's Story of Jesus, 87, 88. 


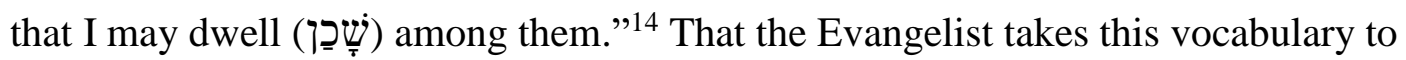
portray Jesus's presence on earth means that Jesus has provided his disciples with the privilege of seen God's glory as Moses and the people of Israel had through the earthly Sanctuary (Exod 40:34, 35). And the fact that "Moses was not able to enter into the tent of meeting because the cloud abode thereon, and the glory of the Lord filled the tabernacle" (Exod 40:34), led Morris to say that "John saw Jesus as a new and greater Moses."15

With these allusions and echoes from the creation narrative, the Evangelist establishes that the Baptist is the person who bears witness of Jesus proclaiming that even though Jesus comes after him, Jesus is before him, thus preexistent (John 1:15).

Moses and Jesus (John 1:17, 18; Exod 33:17-20)

The book of John traces a parallel between Moses and Jesus with law and grace, which have been given by them (1:17). In the Gospel of John, Jesus is the new Moses who brings “grace and truth." In order to show Jesus's level above Moses, the Evangelist gives an echo of the event at Mount Sinai when Moses asks God to see his glory (Exod 33:18). God affirms clearly that Moses only would be able to see his glory because no man can see God and live (vv. 19, 20). However, in the Gospel of John, Jesus is portrayed as the one "who is in the bosom of the Father" (1:18), who can explain the Father because he has lived with him. Moses has seen God's glory (Exod 33:18), but

${ }^{14}$ Cf. Bruce, The Message of the New Testament, 105, 106; Barrett, The Gospel According to St. John, 159, 160; Köstenberger, A Theology of John's Gospel and Letter, 406; McCaffrey, The House with Many Rooms, 222, 224.

${ }^{15}$ Morris, The Gospel According to John, 103. Cf. Käsemann, New Testament Questions of Today (London: SCMP, 1969), 159. 
Jesus has his own glory because Jesus is "the only begotten of the Father, full of grace and truth" (John 1:14). ${ }^{16}$

Jesus and Jacob

\section{Heaven Open (John 1:51; Gen 28:12-22)}

Jacob's dream of the staircase on which angels ascend and descend (Gen 28:12-

22) is mentioned by Jesus to Nathanael (John 1:51), connecting both events, in which the latter is an explanation of the former. ${ }^{17}$ In Jacob's dream the angels ascend and descend on "a staircase" (MT: סִלָּ; LXX: $\kappa \lambda \tilde{i} \mu \alpha \xi)$, but in the Gospel of John, the angels ascend

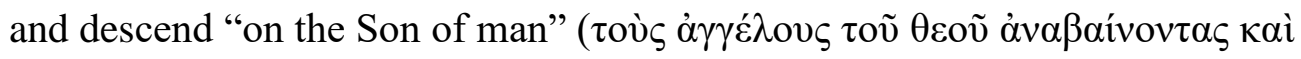

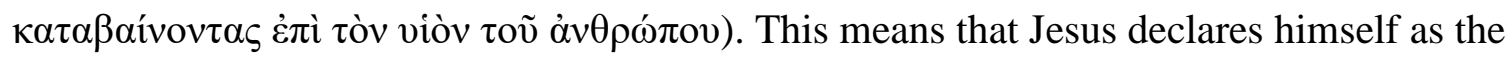
"staircase" of Jacob's dream which binds heaven and earth together. With this declaration, Nathanael's testimony concerning Jesus's Messiahship is confirmed: Jesus is

${ }^{16}$ Cf. Smith, Proclamation Commentaries, 29, 30; Maronde, "Moses in the Gospel of John," 2529; Pancaro, The Law in the Fourth Gospel, 216-31; Köstenberger, A Theology of John's Gospel and Letters, 409, 439. Köstenberger also sustains hat the expression "full of grace and truth" recalls "the phrase 'love and faithfulness' in Exod 34:6” (ibid., 409). See also T. Francis Glasson, Moses in the Fourth Gospel, SBT 40 (London: SMC, 1963); Martyn, History and Theology, 109, 110; Cherian Thomas, "Jesus the New Moses: A Christological Understanding of the Fourth Gospel” (Th.D. diss., Lutheran School of Theology at Chicago, 1987); Thielman, "Grace in Place of Grace: Jesus Christ and the Mosaic Law in John's Gospel," in The Law and the New Testament: The Question of Continuity, CNT, ed. Frank Thielmann (NY: Crossroad, 1992), 92-110; Dietmar Neufeld, “And When That One Comes?: Aspects of Johannine Messianism," in Eschatology, Messianism, and the Dead Sea Scrolls, SDSSRL 1, ed. Craig A. Evans and Peter W. Flint (Grand Rapids, MI: Eerdmans, 1997), 120-40; Culpepper, The Gospel and Letters of John (Nashville, TN: Abingdon, 1998), 72-86; Florence M. Gilman, “Moses: New Testament,” ABD 909-20.

${ }^{17}$ McCaffrey, The House with Many Rooms, 225-27. Cf. Dodd, The Interpretation of the Fourth Gospel, 245-49; Neyrey, "The Jacob Allusions in John 1:51," CBQ 44 (1982): 586-605; David H. Johnson, "Our Father Jacob: The Role of the Jacob Narrative in the Fourth Gospel Compared to Its Role in the Jewish Bible and in the Writings of Early Judaism" (Ph.D. diss., Trinity Evangelical Divinity School, 1992), 202, 203; John H. C. Neeb, “Jacob/Jesus Typology in John 1, 51,” PEGLMBS 12 (1992): 83-89. However, Gary T. Manning, Echoes of a Prophet: The Use of Ezekiel in the Gospel of John and in Literature of the Second Temple Period, JSNTSup 270 (London: T\&T Clark, 2004), 150-60, prefers to connect John 1:51 with Ezek 1:1. 
the Son of God who has come to bring salvation from heaven to earth. Thus, in the present spiritual condition of the people, Jesus wants them to see heaven open, for salvation has come to the earth in him.

\section{Jacob's Well (John 4)}

Another feature in the Gospel of John is the mention of the site where Jesus speaks to the Samaritan woman, which it is in "Sychar, near the plot of ground that Jacob gave to his son Joseph" (John 4:5); and it is also reported that "Jacob's well was there" (v. 6). ${ }^{18}$ This description connects the location between mounts Gerizim and Ebal, on which God commanded the people of Israel to utter "a blessing and a curse" respectively (Deut 11:26-29; 27:11-13).

Jesus makes clear to the Samaritan woman that whenever she drinks the water of this well she would thirst again (v. 13); therefore, what she needs is the living water that Jesus is offering her (v. 14). While the water of Jacob's well only helps for a while, Jesus's water gives eternal life. Jacob drank from this well and died; and whoever drinks from Jacob's well will have the same outcome. With these words, Jesus answers the

\footnotetext{
${ }^{18}$ Lightfoot, A Commentary on the New Testament, 3:274, reports that according to Gen 33:19; and 48:22, "Jacob had bought a piece of land of the children of Hamor for a hundred lambs, Gen xxxiii. 19. But, after the slaughter of the Shechemites, he with his family being forced to retire to places more remote, viz., to Bethel, Bethlehem, and Hebron; the Amorites thrust themselves into possession, and he failed to regain it with his sword and bow." The amount of "a hundred lambs," as Lightfoot maintains, is uncertain.

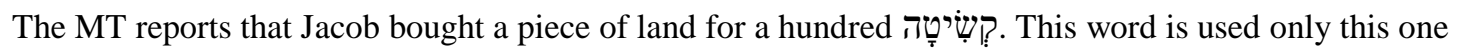
time in the Pentateuch, which could mean that the people of Israel did not use this weight and value in their business while they were in the wilderness.

Keener, The Gospel of John, 1:590, comments that Sychar is "about 1.5 kilometers northeast of Jacob's well. Though Shechem was closer to the well." For further discussion about Jacob's well, see D. C. Pellett, "Jacob's Well," IDB 2:787; Bultmann, The Gospel of John, 177 n. 2; Zdravko Stefanovic, "Jacob's Well," $A B D$ 3:608; Jürgen Zangenberg, "Between Jerusalem and Galilee: Samaria in the Time of Jesus," in Jesus and Archaeology, ed. James H. Charlesworth (Grand Rapids, MI: Eerdmans, 2006), 393-432; Urban C. von Wahlde, "Archaeology and John's Gospel," in Jesus and Archaeology, ed. James H. Charlesworth (Grand Rapids, MI: Eerdmans, 2006), 523-86.
} 
question of the Samaritan woman, "Are you greater than our father Jacob?" (v. 12). With this question, the Evangelist is implying his point that Jesus is superior to Jacob. ${ }^{19}$

Abraham and Jesus (John 8:31-59;

Gen $15: 5 ; 21: 12,13 ; 22: 18)$

For the people of Israel to be a descendant of Abraham has been historically an element of pride. Taking that topic into account, Jesus is confronted by them in the Gospel of John. For Jesus to know the truth brings freedom (John 8:32); but for the people of Israel, it is important to be descendants of Abraham because this privilege qualifies them to be free (v. 33). However, in the Gospel of John, Jesus establishes a

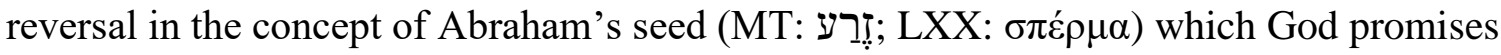
in the book of Genesis $(15: 5 ; 21: 12,13 ; 22: 18)$. Thus, Jesus assures the people of Israel that they are Abraham's descendants ( $\sigma \pi \varepsilon \dot{\rho} \rho \alpha$ [John 8:37]), but not Abraham's children ( $\tau \varepsilon ́ \kappa v o v$ [v. 39]). This reversal agrees with the introduction of the Gospel of John in which the Evangelist says that those who have received Jesus and believed in him have

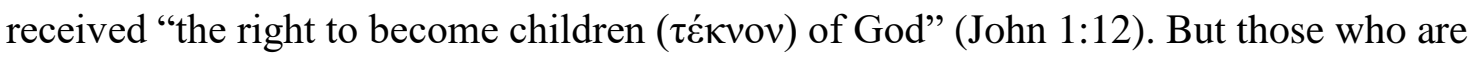
against Jesus are neither children of Abraham nor of God (John 8:39, 42), and because of this, they will be judged by the Father (v. 50). ${ }^{20}$ Furthermore, Abraham rejoiced and was

${ }^{19}$ Lightfoot, A Commentary on the New Testament, 3:274.

${ }^{20}$ Though Jesus has declared that the devil is the father of the Jews (John 8:44), later he concedes the statement: "Your father Abraham ..." (v. 56). This does not mean that he has changed his mind but that he is using this phrase just for the sake of argument. Cf. N. L. Calvert, "Abraham," DJG 3, 4; Urban C.von Wahlde, "You Are of Your Father the Devil' in Its Context: Stereotyped Apocalyptic Polemic in John 8:38-47," in Anti-Judaism and the Fourth Gospel: Papers of the Leuven Colloquium, 2000, Jewish and Christian Heritage Series 1, ed. R. Bieringer, D. Pollefeyt, and F. Vandecasteele-Vanneuville (Assen: Royal Van Gorcum, 2001), 418-44; Craig A. Evans, "Abraham in the Dead Sea Scrolls: A Man of Faith and Failure," in The Bible at Qumran: Text, Shape, and Interpretation, SDSSRL 1, ed. Peter W. Flint (Grand Rapids, MI: Eerdmans, 2001), 149-58. 
glad to see Jesus's day (v. 56), which means that the latter is greater than the former (v.

58).

Jewish Festivals

The Gospel of John is the only book in the NT that mentions the Feast of

Tabernacles along with the Sabbath, and the Passover. This feature implies also a

connection with the Pentateuch.

First, throughout the book of John the Sabbath is a day of controversy in which

Jesus performs miracles, breaking Jewish traditions; and because of this, he is accused by

the religious leaders as not coming from God. Thus, in the Pentateuch, the Sabbath is a

commemoration of creation (Exod 20:8-11) and liberation (Deut 5:12-15); and in the

Gospel of John it is a day of a new creation when Jesus liberates people from their illness

and religious traditions (John 7:23; 9:14, 16).

Second, in the Pentateuch the Passover commemorates Israel's liberation from

Egypt (Exod 12:27). ${ }^{21}$ Meanwhile, John asserts that Jesus is the true Passover lamb when

${ }^{21}$ John $2: 13,23 ; 6: 4 ; 11: 55 ; 12: 1 ; 13: 1$. Some scholars have seen these feasts in the Gospel of John as a structure that marks Jesus's ministry from the beginning to the end. Thus Hendriksen, Exposition of the Gospel According to John, 1:36, indicates, "On the basis of the great feasts that are mentioned in this Gospel the length of Christ's ministry can be determined." This same interpretation is shared by George E. Rice, "Interpretation of the Gospels and the Epistles," in Understanding Scripture, ed. George W. Reid (Silver Spring, MD: Biblical Research Institute, 2006), 211. Morgan, "Fulfillment in the Fourth Gospel," 155-65, advocates that John's message is within the framework of Jewish feasts; Culpepper, Anatomy of the Fourth Gospel, 220, believes that "Jesus' discourses at the Jewish festivals" are used "in the organization and thematic development of the gospel."

Contrary to this position, Ellis, The World of St. John, 64, argues that "these festivals probably are not intended to give a time-chart of the Lord's ministry. They may represent a summation of the festival acts and preaching of Jesus over several years." However, Ellis recognizes that "in any case the evangelist calls attention to the festival cycle primarily to present Jesus as the fulfillment of the religious meaning of these feasts" (ibid., 65). Richard Longenecker, Biblical Exegesis in the Apostolic Period (Grand Rapids, MI: Eerdmans, 1975), 152, 153, believes that "inherent to certain units of the Evangelist's festal structure is the representation of Jesus as the fulfillment of that which was symbolized by the feast" and that the "Fourth Evangelist had a great interest in the relation of Jesus to the Jewish festivals." But, he adds that this relation should not be exaggerated. Köstenberger, A Theology of John's Gospel and Letter, 194, agrees that "Jewish festivals in" the Gospel of John "has a cumulative effect of presenting Jesus as the comprehensive 
he confirms that Jesus's bones are not broken (19:36) as a fulfilment of Exod 12:46 and Num 9:12. ${ }^{22}$ Thus, Ellis asserts, "But this Passover is different. Now is the hour: Jesus, the Son of Man, will be 'glorified' by death and resurrection ([John] 12:23). No longer is he just 'the teacher' at the feast. Now he is to be the sacrificed Lamb of the feast." 23

And third, the Feast of Tabernacles with its celebration of the wandering of Israel in the wilderness (Lev 23:42, 43) is also mentioned in the Gospel of John (7:2) as a time when Jesus invites the people to know God's doctrine, which is given through him (vv. 16-18). ${ }^{24}$ Water and light are the two main features during the commemoration of this feast because, as Crossan asserts, the people of Israel remember the time in the wilderness when water was miraculously provided (Exod 17:1-7; Num 20:8), and the pillar of fire "led the Israelites through the desert toward the promised land (Exod 13:21)." 25 Thus, Jesus highlights these features and applies them to himself (John 7:37,

fulfillment of the symbolism inherent in" them "and other institutions (such as the tabernacle or the temple) throughout the gospel."

${ }^{22}$ Cf. Morgan, "Fulfillment in the Fourth Gospel, 156, contends that "Jesus was crucified at the Feast of the Passover. At the very hour when the Jewish people were bringing their paschal lambs into the temple as a sacrifice to Yahweh, Jesus offers his life upon the cross as the lamb of God, the sacrifice for sin." See also, R. Summers, Behold the Lamb: An Exposition of the Theological Themes in the Gospel of John (Nashville, TN: Broadman, 1979). Thus Jesus dies as the Passover lamb which has to be killed during the feast (Exod 12:6; Lev 23:5; cf. John 19:14)

Hendriksen, Exposition of the Gospel According to John, 2:430, is against this conclusion saying that the phrase "Preparation of the Passover ... does not mean, 'it was the Preparation for the Passover,' as if John wanted to indicate that Jesus was sentenced before the day of the Passover. Such a day of preparation (cooking the food to be used on that day, etc.) preceded sabbaths, not feasts." Further, he explains that "this particular sabbath was 'very great,' for it was the sabbath of the Passover-feast, a feast of seven days" (ibid., 436). However, it is more probable that this Sabbath was called "very great" (John 19:31) because the Passover fell in the same day.

${ }^{23}$ Ellis, The World of St. John, 71. Crossan, The Gospel of Eternal Life, 91, believes that "the unnamed feast of 5:1 might well be the same as the Feast of Tabernacles in 7:2."

${ }^{24}$ Ellis, The World of St. John, 69.

${ }^{25}$ Crossan, The Gospel of Eternal Life, 88, 91. Cf. Ellis, The World of St. John, 68, 69. 
$38 ; 8: 12)$.

\section{Jesus's “I Am” Saying (John 8:58; Exod 3:14)}

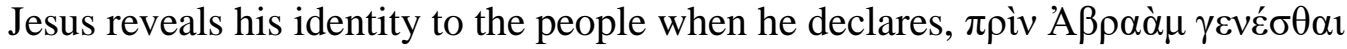

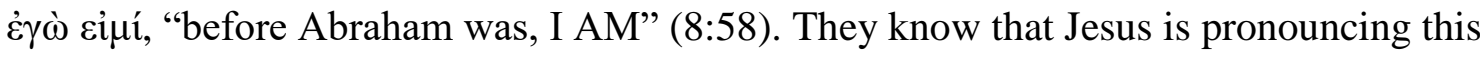

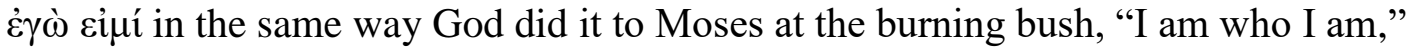

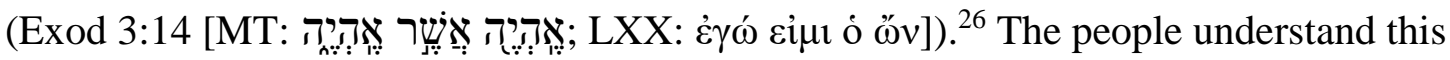
revelation as a claim of divinity on Jesus's part. Hence, they take up stones to throw at him (John 8:59) because they consider this pronouncement a blasphemy (Lev 24:16).

\section{Judgment and Truth}

For his judgment motif the Evangelist uses the Greek words кpiveıv "to judge"

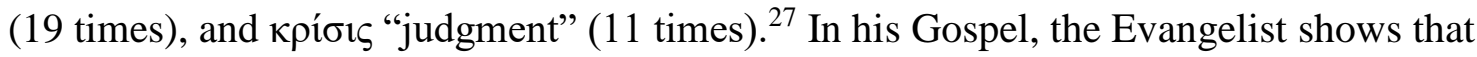
the Son of God is going to be lifted up as the serpent in the wilderness (John 3:14-16; cf. Num 21:4-9) in order to save, not to condemn, those who believe in him: "For God did not send the son into the world to judge (iv $\alpha$ кpív) the world; but that the world might be saved (ỉv $\sigma \omega \theta \tilde{n})$ through him" (John 3:17).

${ }^{26}$ Jerry L. Sumney, The Bible: An Introduction (MN: Fortress, 2010), 271, 272. Burge, John, 263, defends that the "I am" saying in John 8:58 "is an absolute claim to preexistence anchored in the absolute 'I am' (Gk. ego eimi) language we have already seen in this Gospel (cf. 4:26). 'I am' possesses no predicate (as in 'I am the bread of life,' 6:35) and so stands alone, no doubt echoing the Greek translation of God's divine name given in Exodus 3:14." Cf. Verbrugge, "Exegetical Insight," in Basics of Biblical Greek, 130.

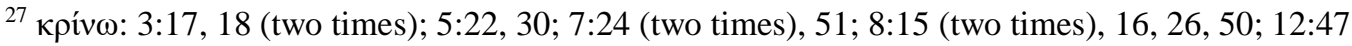

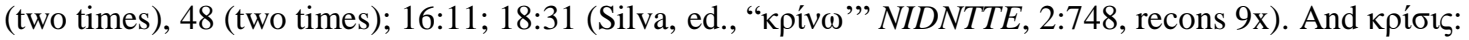
$3: 19 ; 5: 22,24,27,29,30 ; 7: 24 ; 8: 16 ; 12: 31 ; 16: 8,11$. For this judgment motif throughout the Gospel of John, see Köstenberger, Theology of John's Gospel and Letters, 468-70. Again, Lutkemeyer, "The Role of

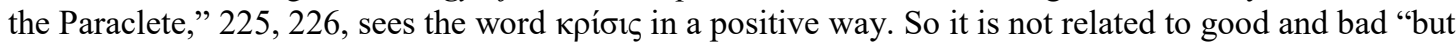
between what is good and what is better." 


\section{The Bronze Serpent}

As the bronze serpent was lifted up in the wilderness and the covenant people may look at it and be saved from the punishment of the judgment (Num 21:4-9), likewise, Jesus is lifted up to give eternal life to whomever believes in him (John 3:14, 15).

When Jesus links his testimony to the event of the bronze serpent, he is identifying himself, as Savior and Judge, because in the wilderness, the bronze serpent became a symbol of salvation, and judgment. The people were called to look at the bronze serpent in order to live or, if they refuse to look, to die (Num 21:4-9) ${ }^{28}$

\section{Manna}

In the same event in the wilderness, the people of Israel detested the bread from heaven, saying: "our soul loathes this worthless bread" (Num 21:5b); Jesus takes up this story and shows himself as the true bread from heaven (John 6:32), and affirms that he is the bread of life who came "down from heaven and gives life to the world" (John 6:3358). But as the people in the wilderness rejected "this worthless bread" (Num 21:5b), so also many of Jesus's disciples rejected him and "went back and walked with him no more" (John 6:66).

\footnotetext{
${ }^{28}$ The people in the wilderness complain "against God and against Moses," accusing Moses of bringing them up out of Egypt to die in the wilderness. Their argument is based on the reasoning that they have no food nor water, and the bread from heaven or manna has become detestable (Num 21:5). As a result, "God sent fiery serpents among the people, and they bit the people; and many of the people of Israel died" (v. 6). In the wake of the biting, the people repent, confess their sin and ask Moses "to take away the serpents" (v. 7). Thus, Moses prays and God answers, telling Moses to make a bronze serpent "and set it on a pole; and it shall be that everyone who is bitten, when he looks at it, shall live" (v. 8).

Cf. Rick R. Marrs, "John 3:14-15: The Raised Serpent in the Wilderness, the Johannine Use of an Old Testament Account," in Johannine Studies: Essays in Honor of Frank Pack, ed. James Eugene Priest (Malibu, CA: Pepperdine University Press, 1989), 141-47; Beasley-Murray, Gospel of Life, 50-52; Derrett, "The Bronze Serpent," EstBíb 49 (1991): 311-29; John T. Carroll and Joel B. Green, The Death of Jesus in Early Christianity (Peabody, MA: Hendrickson, 1995).
} 
Although the religious leaders are proud that their fathers ate bread from heaven (John 6:31), Jesus takes advantage of this opportunity in order to clarify two things: (1) Moses did not give them manna, God did (v. 32b). Although the people do not say that Moses gave manna to their fathers Jesus explains a misconception that Moses had already clarified in the wilderness story (Exod 16:4, 8, 15). God gave the manna to the children of Israel as a test whether they will walk in his law or not (Exod 16:4; Deut 8:16), but they failed to keep God's law, trying to gather manna on the seventh day; thus breaking the Sabbath (Exod 16:27-29). And (2) Jesus transports his audience from the wilderness in the past to their need in the present.

While the people use the verb $\delta i ́ \delta \omega \mu$ in aorist, $\check{\varepsilon} \delta \omega \kappa \varepsilon v$, which means "he gave"

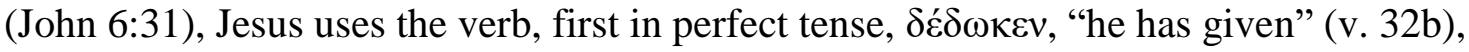
and then in present tense, $\delta$ í $\omega \sigma \mathrm{\imath}$, "he gives" (v. 32c). Jesus wants to make his case saying to the multitude that God gave manna to their fathers, but this is not the true bread from heaven, because they ate manna and died (vv. 49, 58). In addition, the people speak

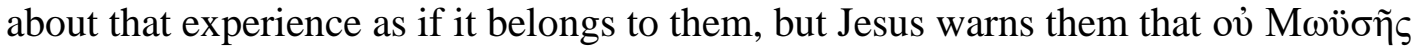

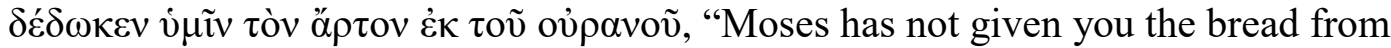
heaven" (v. 32); but now God $\delta i \delta \omega \sigma v$ ("gives") the true bread that descended from heaven "that gives ( $\delta 1 \delta$ ov̀ $\varsigma)$ life to the world" (v. 33), and this bread is present among you

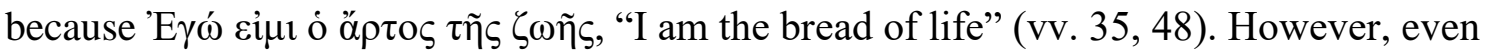
though they are proud of the manna's event, they misunderstand Jesus's revelation (vv. 41-71).

This story in John 6:31-59 shows a reverse within the similarities of both accounts in the reception that the people gave to the manna and to Jesus: In the wilderness, the 


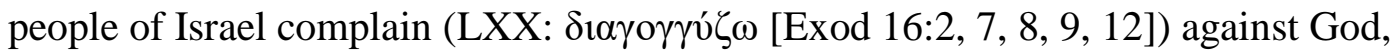

Moses, and Aaron because they are hungry, thus God gives them manna (Exod 16:2-12), and they accept the bread (vv. 13-36); in the Gospel of John, on the contrary, Jesus

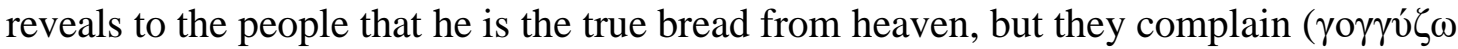
[John 6:41, 43, 61]) and as a result they reject him.

The people from the time of Jesus, with this attitude of complaining, act similarly to the people of Israel in the wilderness. However, both stories reveal that God is always willing to supply their need. In Exod 16, God functions as judge between Moses and Aaron, and the congregation of Israel. And though God supports Moses and Aaron, at the same time, he decides to supply the people's need and settle peacefully their complaints. $^{29}$

${ }^{29}$ Cf. Piper, "Unchanging Promises," 20; Brant, John, 122, 123; Brown, An Introduction to the New Testament, 345, 346; Menken, Old Testament Quotations in the Fourth Gospel, 47-65; Borgen, Bread from Heaven: An Exegetical Study of the Concept of Manna in the Gospel of John and the Writings of Philo, NovTSup 10 (Leiden: Brill, 1965); ibid., "John 6: Tradition, Interpretation and Composition," 26891; Bruce J. Malina, The Palestinian Manna Tradition: The Manna Tradition in the Palestinian Targums and Its Relationship to the New Testament Writings, AGSJU 7 (Leiden: Brill, 1968); Culppeper, ed., Critical Reading of John 6, BIS 22 (Leiden: Brill, 1997); Michael Labahn, "Controversial Revelation in Deed and Word: The Feeding of the Five Thousand and Jesus' Crossing of the Sea as a 'Prelude' to the Johannine Bread of Life Discourse," IBS 22 (2000): 146-81; Jan G. van der Watt, Family of the King: Dynamics of Metaphor in the Gospel According to John, BIS 47, ed. R. Alan Culppeper and Rolf Rendtorff (Boston, MA: Brill, 2000), 26; Andrew C. Brunson, Psalm 118 in the Gospel of John: An Intertextual Study on the New Exodus Pattern in the Theology of John, WUNT 2/158 (Tübingen: Siebeck, 2003); Susan Hylen, Allusion and Meaning in John 6, BZNW 137 (Berlin: Walter de Gruyter, 2005).

For a different point of view on this passage, cf. Diana M. Swancutt, "Hungers Assuaged by the Bread from Heaven: 'Eating Jesus' as Isaian Call to Belief, the Confluence of Isaiah 55 and Psalm 78 (77) in John 6:22-71," in Early Christian Interpretation of the Scriptures of Israel: Investigations and Proposals, JSNTSup 48, ed. Craig A. Evans and James A. Sanders (Sheffield, England: Sheffield, 1997), 218-51. 


\section{The Father and the Son Judge and Save Together}

In the Gospel of John, the Evangelist shows that the Father has given the Son all the power to judge because the Father does not judge $(5: 22)$. Notwithstanding, the Father and the Son work together in order to impart judgment and salvation. Therefore, if the people want to escape judgment they have to honor the Son in order to honor the Father (5:23), and hear not only Jesus's word but also believe in the Father $(5: 24,27) .{ }^{30}$ In the judgment the people are not going to be judged by Jesus but by Jesus's words, which have been given by the Father, which they rejected (12:44-50). Accordingly, Jesus's judgment looks to the Father's will (5:30). Furthermore, Moses wrote about Jesus (v. 46), which means that Moses (the Pentateuch) would accuse the religious leaders (v. 45) for not believing in Jesus (v. 46). The rationale is that if the religious leaders believe Moses's writings they will believe Jesus's words, but the contrary will be also true (v. 47).

Also Jesus affirms that the gift of salvation is linked to the expectation of

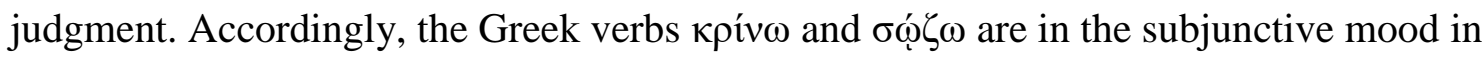
a purpose-result clause with the conjunction îva (John 3:17). ${ }^{31}$ Thus, God's purpose, through Jesus, was not to condemn but to save. Nevertheless, the condition is to believe

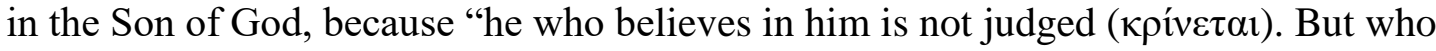

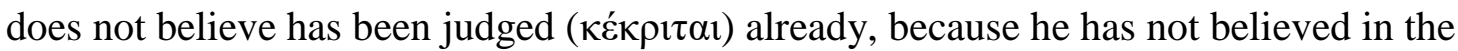
name of the only Son of God" (John 3:18).

\footnotetext{
${ }^{30}$ Painter, The Quest for the Messiah, 234, elaborates that John is talking here about judgment by work.

${ }^{31}$ Wallace, A Greek Grammar, 472, mentions that the iv $\alpha$ purpose clause focus "on the intention of the action of the main verb, whether accomplished or not."
} 
God does not want to judge or condemn, but to save. So the people who reject Jesus bring themselves under God's judgment. The crucial tipping point is human decision (John 3:32, 36).

\section{The Father and the Son Testify and Judge Together}

While the Pentateuch shows the veracity of a testimony based on more than one witness (Num 35:30; Deut 17:6; 19:15), in John 8:16-18, Jesus shows the veracity of his judgment based on more than one judge. Furthermore, this passage shows a parallelism in its structure as follows,

V. 16

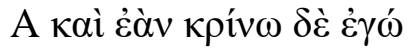

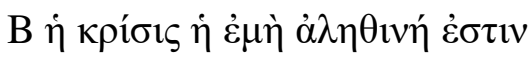

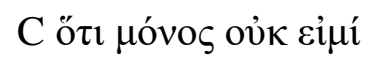

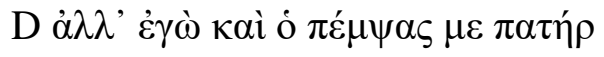

Vv. 17,18

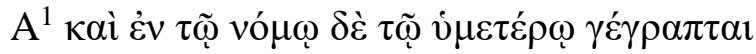

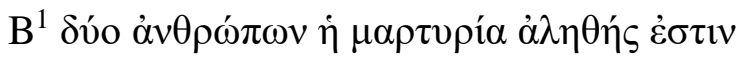

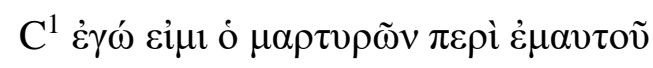

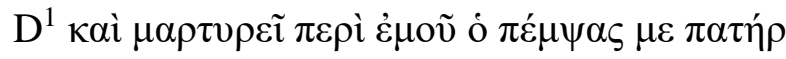

After an introduction in each section (A: “And if I judge," and $\mathrm{A}^{1}$ : “And in your law it is also written"), B and $\mathrm{B}^{1}$ place judgment and testimony side by side with Jesus and the Father judging and testifying together, which make true their judgment and testimony (B: "My judgment is true," and $\mathrm{B}^{1}$ : "The testimony of two men is true"). Then 
Jesus emphasizes that he is not alone (C: "For I am not alone," $\mathrm{C}^{1}$ : "I am one who bears witness of myself"), because he and the Father, who sent him, are judging and witnessing together (D: "But I am [with] the Father who sent me," and D": "And the Father who sent me bears witness of me").

Barrett summarizes this harmony in judgment saying, “Judgement, by the Father's will, belongs equally to the Father and the Son (and to the Holy Spirit, 16.8, 11)," because their functions are equivalent. ${ }^{32}$

\section{Righteous Judgment}

During the Feast of Tabernacle (John 7:14-24) Jesus rebukes the religious leaders, evoking the righteous judgment that Moses asks Israel's judges to perform (John 7:19; cf. Deut 1:16, and 16:18). In Deut 1:16, Moses repeats Jethro's advice to establish a legal system in the context of Exod 18:13-27. In the context of Deut 1:16, Moses reminds Israel's leaders to bring to him "the case (굮) that is too hard for" them (v. 17). This same verse "warns Israel's judges not to show partiality in judgment, for in executing

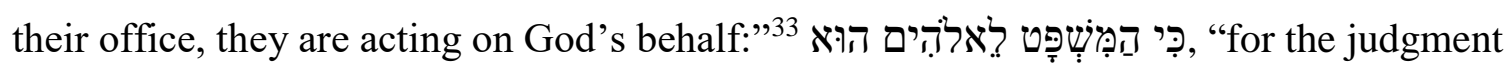
is God's." This legal system is at work in Num 27:1-11: Those who have a petition shall go to Israel's leaders (judges), who are at the "door of the tabernacle of meeting" (v. 2), and make their claim to them (vv. 3, 4). But when the judges, including Moses, do not

\footnotetext{
${ }^{32}$ Barrett, The Gospel According to St. John, 339.

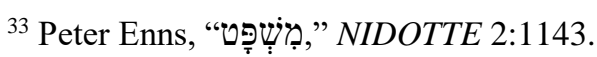


know any legislation for that claim, Moses shall bring the matter to God to give his

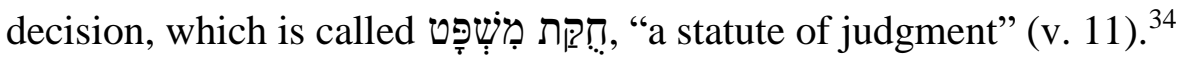

That practice agrees with the administration of justice in Deut 17:8-13. Thus the people of Israel have to continue doing what is a custom within their religious environment: The lesser cases are judged by the judges of each tribe, but any particularly difficult matter is to be taken before Moses, who shall inquire the Lord about it (Exod 18:13-26; Deut 1:9-18). In the future, in the land of Canaan, they would have to do the same (Deut 17: 8, 9). So, in a nomadic period, such as the one in the book of Deuteronomy, Hamp affirms that "a lawsuit was carried out . . . by the tribal chief, later by the elders at the gate of the city, and then by the king as the highest court and by his official judges." 35

Moses writes in Deut 17:8 about a difficult case that demands the intervention of the priests in order to come to a decision. ${ }^{36}$ The judges, especially those who were in the Sanctuary's city, and the priests were infused with such power in their judgment that every man in Israel had to follow their decision or would be sentenced to death (Deut $17: 10-12)$.

In agreement with this ancient practice, Jesus argues with the religious leaders: "Do not judge according to appearance, but judge with righteous judgment" (John 7:24). ${ }^{37}$ While Jesus judges with righteous judgment, the religious leaders "pervert

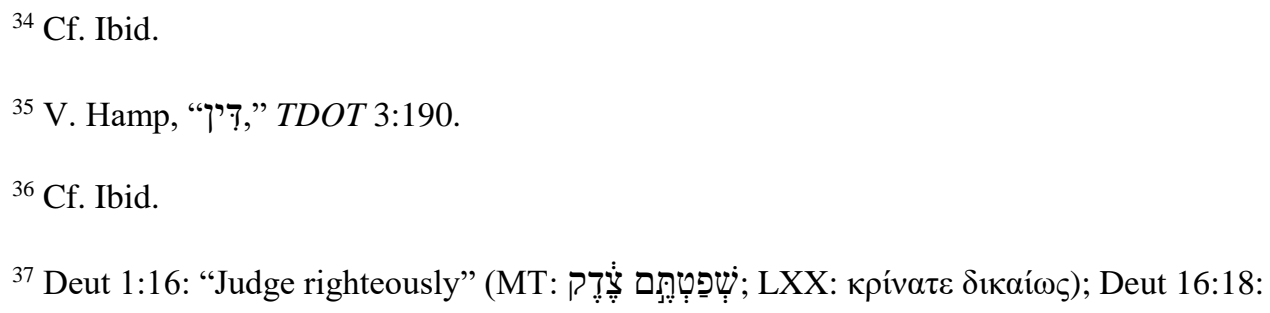


justice," judging Jesus before hearing and knowing his case (John 7:51; cf. Deut 16:19), and according to the flesh (John 8:15). Hence, Painter sees here an irony in which "the one who has been revealed as the judge $(5.22,27,29)$, who carries out the judgement of God, should himself have to face trial before men." 38 As an addition to this assertion, Köstenberger argues,

The world and the Jews think they can put Jesus on trial and condemn him, but in truth, it is Jesus and God the Father - as well as the Spirit ...- - who put an impressive list of witnesses on the witness stand. And turning the tables in a stunning reversal, it is the world that is condemned for its rejection of the Messiah despite overwhelming evidence that he is who he claimed to be. This is the cosmic trial motif in John's gospel (of which the "witness motif" is an important and integral part) that shows the universal and eternal legal repercussions of the world's rejection of Jesus. ${ }^{39}$

Accordingly, Jesus asserts that the religious leaders do not know him, because they do not know the Father (John 8:19). Therefore, Jesus shows himself as the true judge who does not pervert justice or show partiality (v. 16). Thus, the Evangelist establishes that the religious leaders can only condemn Jesus based on a corrupted trial.

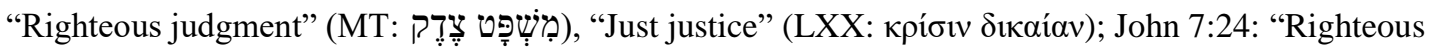
judgment" (

${ }^{38}$ Painter, The Quest for the Messiah, 235, 236. Examples of others who have studied Jesus's trial are: Ernst Bammel, The Trial of Jesus (Naperville, IL: Alec R. Allenson, 1970); Lincoln, "Trials, Plots and the Narrative of the Fourth Gospel," JSNT 56 (1994): 3-30.

${ }^{39}$ Köstenberger, A Theology of John's Gospel and Letters, 244. This same idea is voiced by Ashton, Understanding the Fourth Gospel, 226: "John shows how Jesus successfully refutes his accusers: in bringing him to trial and eventually sentencing him to death, they are actually passing judgement on themselves." Also Smalley, The Revelation to John, 30, agrees saying, "The fourth evangelist presents Jesus as a defendant to whom testimony is given by a series of witnesses, including the Paraclete. In the end the true identity of Jesus is revealed, as one with God and one with humanity, and the defendant ironically becomes the judge. John wishes his readers to make their own decision about Christ's person and to 'see' who he really is (John 20.31)." Also Bultmann, The Gospel of John, 655, states it in this way: "He indeed has come into the world for judgment $(9.39 ; 3.19)$, and his witness is at the same time an accusation against the world (7.7). It is in this 'witness' that he lays his claim to sovereignty; he himself is the $\dot{\alpha} \lambda \dot{\eta} \theta \varepsilon 1 \alpha$ to which he bears testimony $(14.6)$, and he testifies on behalf of himself $(8.14,18)$. He is the judge, who decides over life and death (5.19ff)."
} 


\section{Truth}

Lincoln expresses that in the Gospel of John truth is on trial: "For the author of the Gospel of John and the Christian community of which he was a part, belief in Jesus had resulted in a crisis of truth with profound religious, personal, and social consequences." $" 40$ Thus, the Evangelist shows a controversy about the word "truth" and the person of "Jesus" concerning the element of bearing witness.

God is true (3:33) and his witness is true (5:32), and according to Jesus, the Baptist gives witness to the truth $(5: 33 ; 10: 41)$. And although the Pharisees accuse Jesus that his witness is not true $(8: 13)$, Jesus testifies about himself that he is the truth $(14: 6)$. And later he adds that the only form to come to the truth is by the guidance of the Holy Spirit, who is "the Spirit of truth" $(15: 26 ; 16: 13)$. In the Fourth Gospel, Jesus is "the truth;" thus the Evangelist is ready to bear witness saying that his written testimony "is true" $(19: 35 ; 21: 24)$.

H. Douglass Buckwalter expresses that the validity of a testimony is related to its truth, which when tested could stand and be established. ${ }^{41}$ He also adds that in the Torah, when a witness proved his statement to be true, it was also possible for him to take the role of judge "in reaching the verdict and assist in executing the death sentence" (Deut 17:7). ${ }^{42}$ So the Evangelist has a written testimony, which is important for him to prove that it is true, and as such, he is ready to give his verdict, which is not against the

${ }^{40}$ Lincoln, Truth on Trial, 1.

${ }^{41}$ See Buckwalter, BTDB 766. For more about this controversy in the Gospel of John, see John $1: 14,17 ; 3: 21 ; 4: 23,24 ; 5: 33 ; 8: 32,40,44,45,46 ; 14: 6,17 ; 15: 26 ; 16: 7,13 ; 17: 17,19 ; 18: 23,37,38$; $19: 35$.

$$
42 \text { Ibid. }
$$


defendant, but in his favor. ${ }^{43}$ Furthermore, Jesus "bears witness to the truth" $(18: 37)$

which he himself embodies (14:6). As a result the world falls under his judgment because it is ready to reject him. ${ }^{44}$

In his introduction, the Evangelist identifies the Word ( $\lambda$ ó $о \varsigma)$ as "the true Light which gives light to every man coming into the world" (1:9); and Jesus proclaims himself

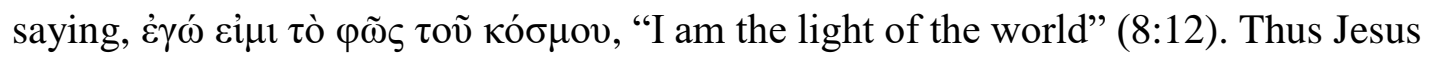

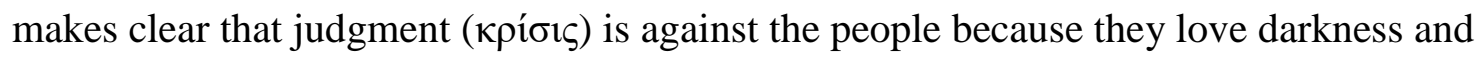
hate light $(3: 19,20) .{ }^{45}$ The ultimate goal of the judgment in the Gospel of John is emphasized by the two "now" (vข̃v) in ch. 12:31: "Now is the judgment of this world, now the ruler of this world will be cast out."

John Paulien writes about the importance of this judgment which has the following results: Satan is dethroned, Christ is enthroned, all sins of the world are "condemned and punished in the flesh of Christ," the ways of Satan is "forever stripped of their power to deceive," and "the way of God's self-sacrificing love would be forever exalted in their place." The ruler of this world will be dethroned by Jesus's death when he

\footnotetext{
${ }^{43}$ In this respect Brown, The Gospel According to John, 223, cites Jean Pierre Charlier, "L'exégèse johannique d'un précepte legal: Jean viii 17," $R B \quad 67$ (1960): 503-15, saying, "John is not dealing with witnesses necessary to condemn a man, but with witnesses to confirm someone's testimony."

The ninth commandment (Exod 20:16) is a warning to the people to avoid false testimony in court in order to judge with justice and truth (cf. Exod 23:1,2). Therefore, with his writing, the Evangelist stands at the side of justice and truth which are so important in his Gospel. See also Deut 19:15-19.

${ }^{44}$ Michaels, The Gospel of John, 34, argues, that “in John's Gospel the whole public ministry of Jesus (at least from chapter 5 and onward) is his trial at the hands of the Jewish religious authorities, one in which he is both accused and accuser, and one peppered with such terms" such as testify and testimony, judge and judgment, true and truth. Cf. Ricoeur, Essays, 119-53.
}

${ }^{45} \mathrm{Cf}$. Ashton, Understanding the Fourth Gospel, 226, who believes that the trial motif in the Fourth Gospel is more than a theological theme, it is judgment put into action. 
is "lifted up from the earth" $(12: 32,33) .{ }^{46}$ Moreover, the judgment of the ruler of this world is a conviction that the $\pi \alpha \rho \alpha \dot{\kappa} \lambda \eta \tau ం \varsigma$ brings to the world along with the conviction of $\sin$ and righteousness (16:8-11).

\section{False Witness}

The matter of bringing false accusation in ancient Israel meant to do the same punishment to the false witness as the law required to do to the accused if found guilty (Deut 19:15-19). ${ }^{47}$ The commandment "You shall not bring false testimony against your neighbor" (Exod 20:16; cf. Deut 5:20) shows the theological importance of being a true "witness" in civil matters and in criminal procedures. Accordingly Ricoeur indicates,

Thus false testimony cannot at all be reduced to an error in the account of things seen: false testimony is a lie in the heart of the witness. This perverse intention is so fatal to the exercise of justice and to the entire order of discourse that all codes of morality place it very high in the scale of vices. The extreme sanctions which in certain codes strike the false witness well marks the degree of indignation that false testimony evokes in the common conscience. ${ }^{48}$

The commandment of not giving false testimony against a neighbor in court (Deut

19:16) is an indication to the possible dishonesty of a witness who only could be discovered in a confrontation in the presence of the judges, in court, and "after a careful

\footnotetext{
${ }^{46}$ John Paulien, A Practical Guide to Abundant Christian Living in the Book of John, The Abundant Life Bible Amplifier, ed. Marvin Moore (Boice, ID: Pacific Press Publishing Association, 1995), 201. Cf. Michaels, The Gospel of John, 695-96; Beasley-Murray, John, 213-24; Mounce, "John," 537; Köstenberger, A Theology of John's Gospel, 469-70; Osborne, "The Gospel of John," in Cornerstone Biblical Commentary, ed. Phillip W. Comfort (Carol Stream, IL: Tyndale, 2015), 187-88. Carter, John, 8990 , suggests that the devil and human agents are linked in the Gospel of John. Though the phrase "ruler of this world" is understood to be the devil, also the Jerusalem authorities along with Roman's rulers are allies of the devil. Brant, John, 193-94, believes that this is "a battle cry for the overthrow of Roman occupation."

${ }^{47}$ Cf. Josephus, Ant IV, 219.

${ }^{48}$ Ricoeur, Essays, 128, 129. The emphasis belongs to the author.
} 
investigation." 49

In connection with this point, the Evangelist reports eight different accusations against Jesus's origin and identity that are given by two groups: Some people of the crowd and the religious leaders. As I point out in table 19, the crowd has two accusations against Jesus: (1) They accuse him of having a demon (John 7:20); and (2) they cast his origin in doubt, stating that while Jesus comes from Galilee, as they believe, the Scripture says that the Christ must come from Bethlehem (vv. 41b, 42). ${ }^{50}$

\section{Table 19. Accusations against Jesus}

\begin{tabular}{|c|c|}
\hline False Witnesses & Accusations \\
\hline Some of the People & $\begin{array}{l}\text { "You have a demon" }(7: 20) \\
\text { "Will the Christ come out of Galilee?" }(7: 41 \mathrm{~b}, 42)\end{array}$ \\
\hline The religious leaders & $\begin{array}{l}\text { We know his father and mother }(6: 41,42) \\
\text { "You are a Samaritan" }(8: 48) \\
\text { "You have/he has a demon" }(8: 48,52 ; 10: 20) \\
\text { "This man is not from God" }(9: 16) \\
\text { "This man is a sinner" }(9: 24) \\
\text { He is "mad" (10:20) } \\
\text { Blasphemy: "You, being a man, make yourself God" (10:33) } \\
\text { He is "an evildoer" (18:30) }\end{array}$ \\
\hline
\end{tabular}

Also, the religious leaders expose eight accusations against Jesus with two of them similar to the accusations of the crowd: (1) They reject Jesus's claim that he has come down from heaven, saying that they know his father and mother, which is an

${ }^{49}$ H. Ringgren, TDOT 10:501.

${ }^{50}$ Matthew $(2: 1,5,6,8,16)$ and Luke $(2: 4,15)$ confirm that Jesus was born in Bethlehem; however, Jesus's origin is not an issue in those Gospels; thus, it is remarkable that the Evangelist in the Gospel of John does not spill any ink to defend Jesus against this accusation, which could suggest that the Evangelist is unconcerned about the matter or wants to describe how ignorant the people are concerning Jesus's birth. 
evidence contrary to Jesus's argument (6:41, 42 [this argument is similar to the accusation of the crowd in 7:41b, 42]). (2) According to them, Jesus is a Samaritan (8:48). (3) Three times they say that Jesus has a demon $(8: 48,52 ; 10: 20$ [the same accusation of the crowd in 7:20]). (4) Jesus is not from God because he breaks the Sabbath (9:16). (5) "This man is a sinner" (9:24). (6) "He is mad" (10:20). (7) Jesus blasphemes making himself God (10:33). (8) Jesus is "an evildoer" (18:30).

The issue at stake in the Gospel of John is that false witnesses accuse Jesus of being a false Messiah; but the Evangelist brings witnesses in favor of Jesus in order to defend him. As a result, those who are against Jesus are accused by Moses (the Pentateuch) for being false witnesses (5:45-47; cf. Deut 19:18, 19).

Although Deut 19:16-19 provides for further investigation in order to establish the veracity or falsehood of a given witness, in the Gospel of John that provision is rejected by the religious leaders (7:50-52). While Nicodemus reminds them that the Law has regulations to give a person a fair hearing, they are ready to manipulate justice in such a way that the outcome will be against Jesus $(11: 49,50)$. The legal system in Israel stipulates that judges "shall not show partiality ... for the judgment is God's" (Deut $1: 17)$.

Through much of the Gospel of John, Jesus's enemies are divided concerning his Messiahship. ${ }^{51}$ However, in the end they bring him to Pilate, who asks them, $\tau$ ív $\alpha$

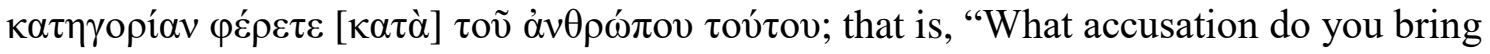
against this man?" (18:29). They divert their answer into a direct confrontation with

\footnotetext{
${ }^{51}$ John $6: 42,52,60,61,66 ; 7: 1-5,12,13,20,25-27,30-32,40-52 ; 8: 30,48-59 ; 9: 16 ; 10: 19-21$; $11: 45-52 ; 12: 10-19,34,37,42,43$.
} 


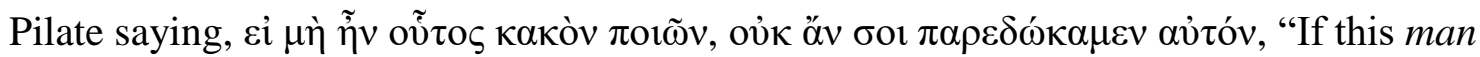
were not a troublemaker, we would not have delivered him up to you" (18:30). With this answer, they clarify Pilate that they do not want questions but actions: They want Jesus put to death (18:31b). But after his interrogation, Pilate is convinced that Jesus is

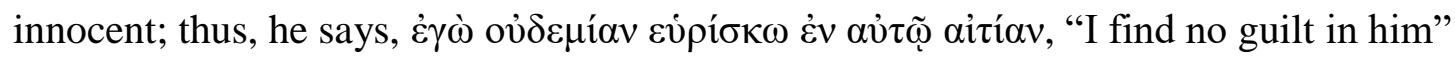
(18:38). With this answer, Pilate gives his judicial opinion about Jesus.

Though Pilate does not say that Jesus is the Christ, he establishes that the allegations of the religious leaders against Jesus are baseless. But as a politician he avoids confrontation, and immediately offers a solution which is contrary to the law but in agreement with a local custom: To release someone at the Passover (18:39).$^{52}$ A deep irony resides in this story. If Jesus is innocent (v. 38), why does Pilate ask the religious leaders if they want him to release Jesus? (v. 39). Pilate in effect suggests that Jesus is already guilty and only by a merciful release can he be saved.

A second time, Pilate indicates his verdict that Jesus is innocent, but this time

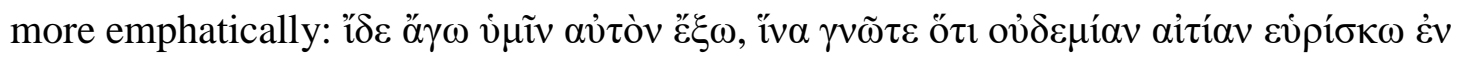

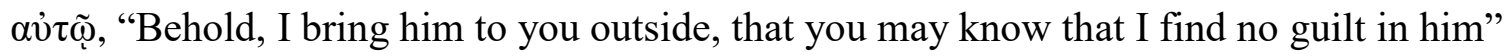

\footnotetext{
${ }^{52}$ Bultmann, The Gospel of John, 657 n. 2, explains that this custom has not been historically attested. So also, Barrett, The Gospel According to St. John, 538, dismisses some attempts to supply historical evidence for this custom. However, he thinks that "there is an allusion to it in Pesahim 8.6: They may slaughter the Passover ... for one whom they have promised to bring out of prison." Gerard S. Sloyan, John, IBC (Atlanta, GA: John Knox, 1988), 207, believes this is a legendary tradition. Brant, John, 245, points out that no source corroborates this tradition; however, according to Seneca, "Roman rulers did use the power of clemency as an indication of their supreme power." Keener, The Gospel of John, 1115-17, suggests that the audience of the Gospel of John was familiar with this practice in the gospel tradition. Also he argues that "we accept many ancient claims about customs that are attested in only one source, though more pleased when that source is corroborated in part or whole by other sources; the gospel tradition's account is plausible, and given the fact that it could be checked in the earliest period, appears more likely than not." Cf. Köstenberger, A Theology of John's Gospel, 280-81; Osborne, "The Gospel of John," 266.

Probably the Evangelist is mocking the religious leaders, stating in some way that they have become part of Rome's power against Jesus. This is confirmed when they later say: "We have no King but Caesar" (19:15).
} 
(19:4). But this decision is also rejected because the religious leaders want Jesus to be crucified (19:6a). So Pilate repeats his decision the third time but now anemically: $\lambda \alpha \dot{\beta} \varepsilon \tau \varepsilon$

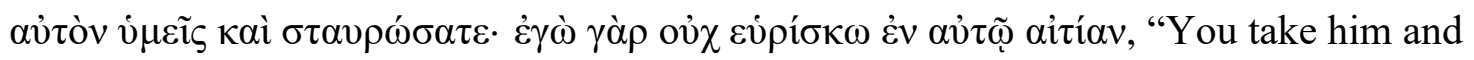
crucify him, for I find no guilt in him" (19:6). With this declaration Pilate makes clear that Jesus has been accused falsely and any human allegation to crucify him is unfounded. But Jesus's enemies want to finish this trial as soon as possible and place Pilate in a hard situation; therefore, they allege that Jesus has proclaimed himself a king who is against Caesar. As a result, Pilate has to kill Jesus or Pilate could be accused of being Caesar's enemy for allowing someone to proclaim himself a king (19:12).

Believing Jesus or mocking the religious leaders, Pilate proclaims in his judgment

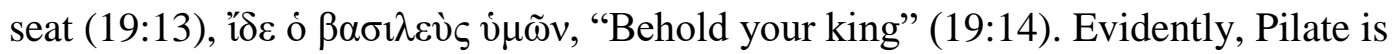
convinced about Jesus's character, but the religious leaders step over the line proclaiming that their king is Caesar (19:15). ${ }^{53}$ No one is able to prove Jesus's Messiahship wrong; nonetheless he is punished and crucified (19:1, 16-18). Although Pilate declares three times that Jesus is innocent, he delivers him up to them. Because of this, Köstenberger remarks that "John's account of Jesus' trial before Pilate . . . touches" the trial motif's theme "and the perspective of the cosmic spiritual conflict in which Jesus and the world

\footnotetext{
${ }^{53}$ In so doing the leaders illustrate that they are more concerned about crucifying Jesus than maintaining their national identity. Rensberger, "The Politics of John," 402-4, proposes that whenever Pilate calls Jesus the "King of the Jews" it is a calculated irony to put the Jews to shame for their nationalism. Also Rensberger accepts that Pilate is an unconscious witness, but no better than Caiaphas (ibid., 406). Cf. Barrett, The Gospel According to St. John, 539.

Pfitzner, "The Coronation of the King," 11, contends that Pilate "becomes a great witness to the truth, albeit unwittingly." He also adds that Pilate "becomes the last witness in the hour of glory" (ibid., 17).
} 
are engaged." $" 54$

However, Pilate has not finished his judgment. He places a title on Jesus's cross

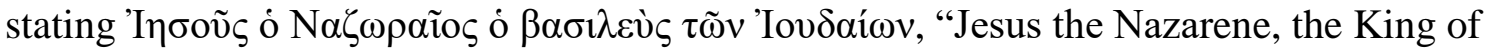
the Jews" (19:19). Pilates does this for two reasons: to mock the religious leaders who brought Jesus to the cross, and to indicate Rome's rejection of any person that stands against its power. ${ }^{55}$

But, in the Evangelist's perspective, the title is true; Jesus truly is the King of the Jews. So there is irony at work here: Pilate and the religious leaders believe that Jesus is an imposter being crucified, but the Evangelist believes that Jesus is the King of the Jews.

To sum up, the accusations that the religious leaders place against Jesus are clear violations of the Pentateuchal law that warns against false testimony (Exod 20:16; 23:1, 2; Deut 5:20; 19:16-21) and its concern for a just judgment (Deut 16:18-20).

\section{Covenant}

The word "covenant" does not appear in the Gospel of John; however, scholars recognize that the Gospel is permeated with this kind of language. ${ }^{56}$ In the wilderness,

\footnotetext{
${ }^{54}$ Köstenberger $A$ Theology of John's Gospel and Letters, 252, 253. See also ibid., 438-39; and Pfitzner, "The Coronation of the King," 17.

${ }^{55}$ Cf. Ibid., 18, in which Pfitzner says that even though this superscription is Pilate's last mocking, he is still stating the truth.

${ }^{56}$ Köstenberger A Theology of John's Gospel and Letters, 408, 409; Barker, Lane, and Michaels, The New Testament Speaks, 412; John W. Pryor, John: Evangelist of the Covenant People: The Narrative and Themes of the Fourth Gospel (Downers Grove, IL: InterVarsity, 1992); Sherri Brown, "Gift upon Gift: Covenant through Word in the Gospel of John" (Ph.D. diss., The Catholic University of America, 2008).

Wilson Paroschi, "Incarnation and Covenant in the Prologue to the Fourth Gospel (John 1:1-18)" (Ph.D. diss., Andrews University, 2003), 125, 128, defends his view that $\tau \grave{\alpha}$ ' í $\delta 1 \alpha$ and oi 'í $\delta 101$ in John 1:11 is

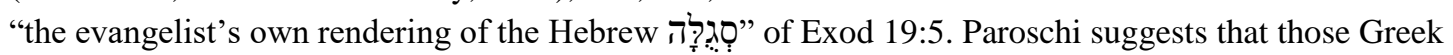

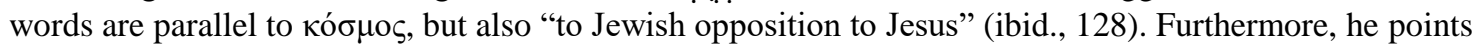
out that "by not accepting Jesus, oi ' $\delta 101$ missed a decisive opportunity within salvation history to enter into a higher level of relationship with God as his spiritual children, born of him and no longer relying on
} 
Moses calls heaven and earth as witnesses to certify that he has placed before the children of Israel "life and death, blessing and cursing" (Deut 30:19); and with this invitation he makes clear what kind of blessings and curses they will have (Deut 27-32).

In the Gospel of John, though people are living in the darkness, they also have the opportunity to choose the light $(1: 4,5)$; however, they reject it (1:11). People are invited to become children of God $(1: 12,13)$, but they prefer to be children of the devil $(8: 41$, 44). They are called to listen to Jesus's word and have everlasting life $(5: 39 ; 8: 51 ; 11: 25)$. Notwithstanding, they choose not to listen; so they reject eternal life $(5: 40 ; 8: 52,53,59)$. In listening to Jesus's truth they will be freed and become Jesus's disciples $(8: 31,32)$; but if they reject the truth, they will be enslaved to sin (8:33).

The Baptist is clear in Jesus's purpose in coming to the earth and thus people are confronted to make a decision: Believe and have everlasting life, or do not believe and receive the wrath of God (3:36). Though these examples have been seen just as "dualistic symbols," I suggest that the final response of human beings to the Evangelist's witnesses would be either life or death. Taking these dualistic symbols into account Jesus is challenging his audience, as Moses did, to take a stand for him or face destruction. ${ }^{57}$

human descent or bloodline. . . Therewith, the promise of the new covenant found its fulfillment in the life of a faithful remnant, the öбot. To them who did receive Jesus and believe in his name, 'he gave the right to

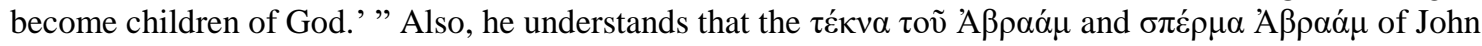
8:31-47 are equivalents to $\tau \varepsilon ́ \kappa v \alpha \theta \varepsilon$ oṽ of John 1:12 "in the sense of God's covenant people" (ibid., 135). Therefore, he proposes that as the Jews do not respond positively to Jesus, then "they are no longer the true

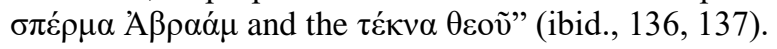

${ }^{57}$ Cf. Neill, The Interpretation of the New Testament, 308-13; Günther Bornkamm, The New Testament: A Guide to Its Writings (Philadelphia, PA: Fortress, 1973), 137, 138; Mark Allan Powell, Introducing the New Testament: A Historical, Literary, and Theological Survey (Grand Rapids, MI: Baker Academic, 2009), 188-89; Russell Pregeant, Encounter with the New Testament: An Interdisciplinary Approach (Minneapolis, MN: Fortress, 2009), 174-75.

Kysar, John: The Maverick Gospel, 47-64, shows these dualistic symbols as positive and negative poles: Light and darkness (1:5), above and below (8:23), spirit and flesh (3:26), life and death (3:36), truth and falsehood (8:44f.), heaven and earth (3:31), God and Satan (13:27), Israel and Jews/the world (1:19, 


\section{Summary}

In the Gospel of John, Jesus is: (1) the light of the new creation (1:1-13; Gen 1:15) that God brings into the world in order to offer salvation for those who believe, and in this new creation he introduces (breathes) the Holy Spirit to his disciples in order to forgive sins.

(2) The new sanctuary (John 1:14; Exod 25:8, 40; 40:34-38) in which God manifests his glory with fullness and truth.

(3) Greater than Moses (John 1:17, 19-21; 6:31-59; Exod 16:1-35; 33:17-20; Deut 18:15-18). Although Jesus is predicted by Moses as a prophet like him, Moses asked God to see his glory, while Jesus lived in the glory of the Father. Another feature is the mention of the Sabbath, the Passover, and the Feast of Tabernacles by which the Evangelist indicates that Jesus is the new Moses that has come to bring a new creation (Sabbath [Exod 20:8-11]), a new liberation (Sabbath [Deut 5:12-15], and Passover [Exod 12:6, 27, 46; Lev 23:5; Num 9:12]), and light and water for eternal life (the Feast of Tabernacle).

47; 17:14). Also, Smith, Proclamation Commentaries, 23, recognizes the connection between John and Genesis; however, he also believes that John in his dualism shows his actual environment which is permeated by Zoroastrianism, Gnosticism, a late Platonism, and a first-century Palestinian Judaism as revealed in the Qumran scrolls. On his part, Bultmann, The Gospel of John, 157 n. 5, interprets that the division of light and darkness which brings judgment to men in general has been found in the Gnostic tradition.

However, I believe that John is using these dualisms in agreement to OT prophets, showing the people the whole equation by contrasts in order to call them to choose between good and evil, and warn them about the respective consequences (cf. Deut 27; 28). A good start for this interpretation is Théo Preiss, La Vie en Christ, 9-11. He is clearly against those who see the Gospel of John based on mystical trends, and at the same time he is in favor to interpret it on its judicial language. Köstenberger, A Theology of John's Gospel, 280, says that this language in the Gospel of John "is not an absolute dualism" because "John's gospel is pervaded by a strong missionary thrust" by which God wants to redeem humanity through Jesus. Then, when Köstenberger interprets about the polarity of "life and death" he strongly says that with this language John is striking "an important salvation-historical note, as life and death are presented in God's dealings with OT Israel as the consequences of obedience or disobedience to the covenant (e.g., Deut 30:19)" (ibid., 284). 
(4) Greater than Jacob (John 1:51; Gen 28:12-22). Jesus proclaims himself to be the staircase that Jacob saw in his dream when he was running from Esau (Gen 28:1222), and Jesus gives the water of eternal life that Jacob's well cannot provide (John 4:13, 14).

(5) Greater than Abraham (John 8:31-59; Gen 15:5; 21:12, 13; 22:18). Jesus certifies that he is greater than Abraham when he clarifies that it is not enough for salvation to be Abraham's descendant. The people of Israel have to believe in Jesus as the Messiah in order to obtain salvation. In addition, Jesus's declaration that he was before Abraham confirms his superiority over Abraham (8:58).

(6) The true bread that descended from heaven. Although the manna was sent by God, and the people of Israel ate of it (Exod 16:4-35), they died in the wilderness (Num 26:63-65); but whoever eats Jesus's flesh will have eternal life (John 6:22-59).

Taking these features into account, I have shown in table 18 that the Evangelist registers at least 48 references which are allusions, echoes, or direct quotations from the Pentateuch. ${ }^{58}$ Thus, this is a strong support that the Evangelist has in view a Pentateuchal language for his witness motif. As a result, he wants to show that Jesus is greater than Moses, Abraham and Isaac; and that Jesus is the Creator who has visited his covenant people and revealed them his glory as in a new sanctuary.

${ }^{58}$ See pp. 221-22. The Evangelist also quotes from the Prophets and the Writings in 21 occasions, of which 11 belong to the book of Psalms. These are: John 2:17 (Ps 69:9); 6:31 (Ps 78:24); 10:34 (Ps 82:6); 12:13 (Ps 118:26); 12:34 (Ps 110:4); 13:18 (Ps 41:9); 15:25 (Ps 35:19; 69:4); 17:12 (Ps 41:9); 19:24 (Ps 22:18); 19:28 (Ps 69:21); 19:36 (Ps 34:20). This last one is originally from Exod 12:46 and Num 9:12 as I have noted in table 18. The rest of the other quotations and allusions from the Old Testament are: John 1:21 (Mal 4:5); 1:23 (Isa 40:3); 5:29 (Dan 12:2); 6:45 (Isa 54:13); 7:38 (Ezek 47:1; Zech 14:8); 10:11-13 (Ezek 34:11, 12); 12:15 (Zech 9:9); 12:34 (Isa 9:7; Ezek 37:25); 12:38 (Isa 53:1); 12:40 (Isa 6:10); $19: 37$ (Zech $12: 10)$. 
Jesus is also the new manna who has come down from heaven to give life to those who eat his flesh, and in order to save them he is going to be lifted up as the serpent in the wilderness. He is the Passover Lamb who has been crucified, giving his life voluntarily (John 10:17, 18; 19:11). But his people have been unfaithful to him (1:10, 11); therefore, he has the authority to judge them in a judgment according to the law (5:30), which is supported by more than a dozen witnesses that include the Father, the Holy Spirit, Moses (the Pentateuch or the Scripture), Jesus's works, and some human beings. While Jesus's enemies pretend to have authority to judge him (11:49; 18:1219:16); the truth is that they are judged by Jesus (9:39), his word (12:47), and Moses, who wrote about him (5:45-47).

In the Gospel of John, Jesus is not only greater than the Baptist, Abraham, Jacob, and Moses; but he is the "I am" who spoke with Moses at the burning bush (Exod 3:14) and made "a covenant with his people." 59

In their relation to the witness motif, the Pentateuch and the Gospel of John focus on the topics of truth and judgment which are associated in a legal language, calling for the acquittal of the innocent and the punishment of the wicked.

Truth in a judgment is the minimum prerequisite for an impartial trial; however, in the Gospel of John, most of the religious leaders do not care about truth. Thus, the irony is increased because they have been taught to judge based on truth, but they judge the truth instead. ${ }^{60}$ They accuse Jesus as an evildoer (18:30) who makes himself the Son

\footnotetext{
${ }^{59}$ Barker, Lane, and Michaels, The New Testament Speaks, 412.

${ }^{60}$ Exod 18:21, 22; 23:6-8; Lev 19:15; Deut 1:17; 4:8; 16:18, 19; 25:1. Cf. Painter, Reading John's Gospel Today (Atlanta, GA: John Knox, 1975), 90.
} 
of God (19:7) and a king (19:12); so, it is evident that they become false witnesses in this judgment. Furthermore, they arrest Jesus and deliver him to Pilate, accusing him of blasphemy for claiming to be other than what they expected the Messiah to be (John $2: 14-21 ; 5: 16-18 ; 6: 41-60 ; 7: 20,47-52 ; 8: 13,48,59 ; 9: 16,24,28,29 ; 10: 31-39 ; 11: 45-$ $53 ; 18: 12-14)$.

Jesus, who lives according to his own teachings, performing a righteous and a true judgment $(5: 30 ; 8: 16)$, calls the religious leaders to "judge with righteous judgment" $(7: 24)$ that is far from them because they are more concerned with their "place and nation" (11:45-48), than with the truth (8:44-46; cf. 18:37).

\section{Conclusions}

The Evangelist uses $\mu \alpha \rho \tau v \rho \varepsilon ́ \omega$ and $\mu \alpha \rho \tau u \rho i ́ \alpha$ in a judicial context establishing two trials: (1) A secular trial, plagued with false testimony against Jesus; and (2) a divine judgment, applied with justice and truth.

(1) A secular judgment: Although based on the procedure of bringing at least two witnesses to a trial (Num 35:30; Deut 17:6; 19:15), the judgment against Jesus has been manipulated by the religious leaders who accept false testimonies and judge him according to the flesh (John 8:15), in a violation of the law demanding accusers bring true witnesses for a just judgment (Exod 20:16; Deut 19:16-21). Therefore, Jesus is condemned in a faulty judgment led by wicked people (John 7:19-24, 46-52; 11:47-53; 18:1-19:16) who disagree about his origin and identity $(7: 43,44 ; 9: 16 ; 10: 19-21)$. In this way the religious leaders become disqualified and, as a result, fall under condemnation $(5: 45-47)$. 
(2) A divine judgment: Divine witnesses stand in Jesus's favor, but also against those who reject him (John 1:11; 3:19). The Evangelist establishes that Jesus's testimony, along with the Father, makes his judgment true $(5: 32 ; 8: 14-18)$. Though Jesus wants to give them life $(5: 40)$ through his flesh $(6: 27-40)$, they prefer to complain in like manner as the people of Israel stood against God, Moses, and Aaron in the wilderness (John 6:4161; Exod 16; Num 16). In their rejection of Jesus, they demonstrate that they do not believe in Moses (John 5:39, 45-47); thus they are neither children of God (1:12; 8:42, 47) nor children of Abraham (8:39). In doing so they become the devil's children (8:44), doing the devil's desires. Ultimately, they break God's covenant (1:11), and prefer Caesar as their king (19:15). At the end, they are not judged by Jesus, but by Jesus's words $(12: 47,48)$.

Jesus's origin and identity have been questioned by his opponents with eight different arguments: Two against his heavenly origin, and six against his messianic identity. Concerning his heavenly origin, Jesus affirms that he has come down from heaven (6:41), but (1) part of the crowd and some religious leaders reject him three times using the same argument: They know he is from the earth, not from God (John 6:42; $7: 41,42 ; 9: 16$ ); and also (2) some religious leaders reject him with the claim that he is a Samaritan (8:48). Concerning his identity, Jesus has said that he is the Christ (4:26), but (1) both groups (the crowd and the religious leaders) agree that Jesus is demon possessed $(7: 20 ; 8: 48,52 ; 10: 20)$; and (2) on the part of the religious leaders the claim is that Jesus is not from God (9:16), but (3) a "sinner" (9:24), (4) a "mad" man (10:20), (5) a person who blasphemes (10:33), and (6) an “evildoer" (18:30). 
However, Pilate's arguments are different. He says three times that Jesus is innocent $(18: 38 ; 19: 4,6 b)$; notwithstanding, his verdict is rejected by the religious leaders $(18: 40 ; 19: 6 a, 7,15)$. Though Pilate declares that Jesus should not die, Jesus is crucified (19:16). Therefore, this event establishes that the Pentateuchal law of justice in a fair judgment has been broken by Jesus's enemies (Num 35:30; Deut 17:6, 7; 19:15-21). ${ }^{61}$

${ }^{61}$ Allen, Numbers, 2:1005. 


\section{SUMMARY, CONCLUSIONS, AND IMPLICATIONS}

\section{Summary and Conclusions}

In the present investigation I have studied the substantive "witness" and the verb "to bear witness" in the Pentateuch and in the Gospel of John in order to evaluate the link that these literatures share. Accordingly, the summary of the data is as follows,

Chapters 1 is divided in two sections: The first section deals with the review of the literature of ANE cultures from 18th to 7th centuries BC, such as the Code of Hammurabi, Mesopotamian Legal Documents, the Treaty between Niqmepa of Alalakh and Ir- ${ }^{\mathrm{d}}$ im of Tunip, four Hittite treaties (Suppiluliumas and Kurtiwaza, Suppiluliumas and Aziras, Mursilis and Duppi-Tessub, and Ramses Meri-Amon of Egypt and Hattusilis of Hatti), and two Akkadian treaties from Assyria (Ashurninari V of Assyria and Mati'ilu of Arpad, and the Vassal-Treaties of Esarhaddon). The second section discusses ancient Jewish interpretation of the lawsuit trial in the Pentateuch from 2 nd century BC to AD 5th century, such as the Qumran documents, Philo of Alexandria, Flavius Josephus, and the Talmud.

The ANE literature reveals that treaties among nations had consistently two fashions: (1) A vassal treaty, in which the great king imposed his will upon another king who had been defeated in a war, such as the one between Suppiluliumas and Kurtiwaza; and (2) The parity treaty, in which two kings agreed to finish their quarrels based on common grounds, such as the treaty between Ramses Meri-Amon of Egypt and Hattusilis 
of Hatti. Thus, these treaties were a particular genre internationally known in the ANE culture.

These treaties show in their composition a list of gods called to be witnesses in order to impart blessings on those who kept the treaty and curses on those who violated it. Therefore these gods were not only witnesses of the treaty, but also judges of it. In the treaty between Suppiluliumas and Kurtiwaza, the gods, called to be witnesses, were the same ones which were called to bring curses and blessings upon Kurtiwaza and his people. This same pattern is present in the treaty between Ramses Meri-Amon of Egypt and Hattusilis of Hatti, with the difference that this is a parity treaty in which the gods are called to be witnesses and judges by each party involved. In the former treaty, only the Suzerain invokes gods as witnesses and judges, and the vassal accepts the treaty.

The tablet on which the treaty of Suppiluliumas and Aziras was written is mutilated in the part where the invocation of gods as witnesses is supposed to be located. The translator of this tablet agrees that a list of gods was present in the integral writing of the tablet. Another feature is the addition of natural elements to the list of gods in the formulation of the treaty between Mursilis and Duppi-Tessub.

On the other hand, the two Akkadian treaties studied in this dissertation (the treaty between Asurnirari V of Assyria and Mati'ilu of Arpad, and the Vassal-Treaties of Esarhaddon, which are from the first century BC), show the pattern of a list of gods; but with the difference that they are only invoked to curse the vassal, his family and his country, not to bless them.

Taking into account the list of gods called as witnesses and judges, the Code of Hammurabi, which antedates suzerain-vassal treaties, has the same feature as Hatti's 
treaties, in which Hammurabi calls the gods to judge, giving blessings to the man who accepts his law, or curses to the one who rejects it. Furthermore, the wording of this law code shows the regulations to accept secular witnesses and establish law and justice through court.

On the part of Jewish writings, the language of "witness" and "bearing witness" was used more by the Qumran community than by Philo, Josephus, or the Talmud. On the one hand, the members of the Qumran community believed they were God's remnant, for whom the blessings of Deut 28 had come because they were living under a covenant with God. On the other hand, Philo, because of his Jewish background, was well acquainted with Deut 17:6 and 19:15 regarding the regulation of more than one witness to bring a binding case to court. And the importance of Josephus on this topic is based on his discussion of the reliability of women as witnesses in a judgment. He believed that women were not suitable to give secure information in court.

The Talmud uses "witness" and its cognate language in a context of a trial, based on Exod 23:1 in which it is prohibited to bear false witness. The penalty of a false witness is to be cast to the dogs.

Chapter 2 also is divided in two sections dealing with the review of the literature of modern research. The first part of the study is based on the Old Testament as described by scholars from Hermann Gunkel to Paul J. N. Lawrence, and the second part on the Gospel of John as described by scholars from Théo Preiss to Andrew T. Lincoln.

In the first section, the witness motif is studied in relation to the covenant lawsuit genre which has been linked by scholars with Hittite treaties from the second millennium BC. Most scholars believe that these treaties better resemble the covenant relation 
between Yahweh and Israel than treaties from before and after the Hittite empire from the third or the first millennium BC. Scholars say that God's covenant with Israel was used in a religious sphere as an adaptation of the Hittite treaties used in political matters, especially during time of war. And that adaptation was based on the fact that while Hittite treaties were made among human beings, the Hebrew covenant treaty was made between God and the people of Israel.

On the part of the witness language, G. Ernest Wright $(1950,1962)$ studied Deut 32, concluding that this is a covenant lawsuit in which the call to the witnesses to give ear to the proceedings of the covenant lawsuit is one of its major elements.

George Mendenhall (1954) concluded that the Decalogue has connection with the Hittite treaties; but it lacks three important elements, one of them being the list of witnesses that is always present in Hittite treaties; however, the inclusion of the ninth commandment places the Decalogue's language in agreement with the Code of Hammurabi.

Herbert Huffmon (1959) outlined in two ways some lawsuit oracles, and said that the most striking part of them is the appeal to the natural elements to hear the controversy between Yahweh and his people. Thus, he showed that Deut 4:26; 30:19, and 31:28 are passages in agreement with the background of the Hittite treaties. Likewise, James Muilenburg (1959) maintained that Exod 19-24 and the book of Deuteronomy have the same structure based on the fixed forms of ANE utterance.

Meredith G. Kline (1960) arrived at the same conclusion as Mendenhall, regarding the Decalogue, but he explained that the invocation of gods as witnesses is implicit in the third commandment, where God says to the people of Israel that their oath 
must be sworn by the name of Yahweh. Furthermore, Kline maintained that the deposit of the Decalogue in the tabernacle of the testimony (Exod 25:16, 21; 40:20; Deut 10:2) is a clear indication that God is both witness and judge. He also added to Muilenburg's conclusion with respect to the structure of the book of Deuteronomy, challenging current scholarship and arguing for the unity of Deuteronomy. In his five-part structure, he pointed out that the invocation of witnesses is in the last part which he called "succession arrangements or covenant continuity."

In his survey of ancient treaties from 2500 to 700 BC, Dennis J. McCarthy (1963) concluded that these documents had two elements that appear constantly: the gods called to be witnesses, and the curse and blessing.

Ray F. Chester (1966) examined the covenants that God made with Abraham, Noah, Moses, Joshua, and David; and concluded that the structure of the Mosaic covenant is in agreement with the six traditional parts of the Hittite-treaty framework. ${ }^{1}$ In this Mosaic covenant only the people of Israel were bound to it based on the parallels of the treaties in which vassals were bound to the Great King.

James Limburg (1969) was more concerned with the covenant lawsuit in the Prophets, and concluded that the legal forms of speech, in which the root ריב appears, are connected with international treaties.

Klaus Baltzer (1971) examined the structure of the Hittite treaty formula in

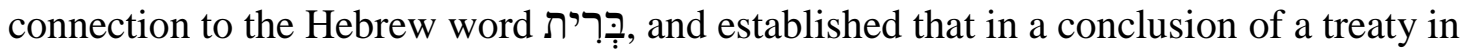
ANE culture, witnesses were necessary, and for this function, lists of gods were

\footnotetext{
${ }^{1}$ These are: (1) Prologue or Preamble, (2) Stipulations, (3) Historical background, (4) Deposit of the Law, (5) List of gods and witnesses, and (6) Blessings and curses.
} 
mentioned including natural elements. These gods acted as witnesses to guarantee the stipulations of the treaty, and as judges to bring blessings if the treaty was kept, or curses if the treaty was broken.

Kenneth Anderson Kitchen (1978) agreed with Mendenhall that the Sinai covenant and the international covenant treaties of the second millennium BC are strikingly parallel in form. In this parallelism he considered that in the Sinai covenant the list of gods invoked to witness the covenant are excluded, and replaced by memorial stones (Exod 24:4) or law-book (Deut 31:26).

Michael de Roche (1983) was against those scholars who believed that ריב meant a "lawsuit" in which only two parties were involved. He said that in a lawsuit proper, a third party must take part of the process, hearing all the arguments, in order to hand down a verdict that is binding on all parties. Therefore, he added that ריב has nothing to do with a judicial process but only with the grievance or a contention of a party against another; and concluded that the root ריב is more in agreement with the marriage metaphor in which Yahweh is Israel's God, and Israel is God's people.

Dwight R. Daniels (1987) agreed with de Roche's conclusions, and added that the invocation of natural elements as witnesses to the covenant is a late development in Israel covenantal formulation. He contended that this invocation was not used in Israel before 701 BC during Hezekiah’s kingdom.

As a response to de Roche's and Daniel's conclusions, Richard M. Davidson (2007) surveyed more than 320 passages from the OT and the NT, and affirmed that the divine covenant lawsuit is pervasive in Scripture. Thus, he concurred with Mendenhall that the "covenant lawsuit" structure of Israel is parallel to the Hittite suzerain treaties, 
but with the difference that in the Israelite covenant lawsuit pattern for breach of covenant, the witnesses are often placed at the beginning of the list. In this case, natural elements, which are Yahweh's creation, are featured witnessing the people of Israel's breach of covenant, and Yahweh's just actions toward Israel.

Paul J. N. Lawrence (2011) demonstrated the late-second-millennium BC writing of the Pentateuch. He compared 34 Hittite treaties with the covenant in Exodus/Leviticus and Deuteronomy, and recognized that its content and layout have involved adaptation in the Hebrew tradition. That is, though Pentateuchal covenants resemble the format of late Second Millennium Hittite treaties which have a witness section and clauses for the deposit and reading of the terms of the covenant, they are different in the sequence of curses and blessings. In the late Second Millennium Hittite treaties, the sequence is curses and blessings; but in the Pentateuchal covenants it is blessings and curses, following the Code of Hammurabi form which is a law collection. However, he concluded that Treaties and Law Collections are related genres.

The second section of the review of the literature in ch. II shows that most scholars who accept the presence of judicial language in the Gospel of John are familiar with the presence of Pentateuchal language in it:

Théo Preiss (1952) warned scholars of his days to study the Gospel of John, paying attention to its judicial terms and arguments. He believed that the terms "witness" and "to witness" are religious and judicial at the same time.

Following Preiss' suggestion, J. M. Boice (1970) studied the word "witness" in the Gospel of John, and proposed that this term has nothing to do with the meaning given to the word martys in the second century to denote one who dies for Jesus; instead he 
suggested that "witness" is related to the book of Isaiah and to the testimony of the law of God. Moreover, according to him, John is moving forward with this term, giving it the distinctive character of Christian revelation. Thus the Gospel of John is the Gospel in which Jesus reveals the Father. In agreement with Boice's first conclusion, A. A. Trites (1977) concurred that in the Gospel of John "witness" and its cognate verb are connected to Isaiah 40-55. Likewise, after integrating each former study about the trial motif in the Gospel of John, Andrew T. Lincoln (2000) arrived to Trites' conclusion.

Johannes Beutler (1972), for his part, disagreed that the Gospel of John is connected to the Old Testament lawsuit through the word "witness." Beutler believes that John is giving to this word a new meaning based on the history of Jewish people from the time of Qumran to his days.

A. E. Harvey (1976) argued that the Gospel of John is an extended trial, in which the Evangelist confronts Jesus's righteousness against his enemies before an imaginary court composed by his readers. This court is challenged to decide whether Jesus is the Messiah, the Son of God. In this case, the readers function as witnesses and as judges, according to Jewish legal procedure.

Robert Gordon Maccini (1996) agreed with Harvey that John seeks to persuade the reader that Jesus is the Messiah. And also for his main argument, the Evangelist shows the testimonies of women in court in order to support the claim that Jesus is the Messiah. For Maccini, women are individuals, not a class, who testify in favor of Jesus.

Chapter 3 is an exegetical analysis of the Pentateuchal passages in which עֵ its cognates appear. This chapter is organized in three parts, taking into account the categories of meanings of those words. 
In the first category, I analyze the masculine substantive עִִּ and its feminine

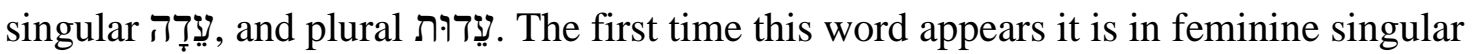
(Gen 21:30), and applied either to the sheep that Abraham gave to Abimelech as "witness" or "evidence" that he had dug a well (LXX), or to Abimelech himself (MT) as "testimony" that he had taken seven ewe lambs from Abraham's hands.

Thus, עָדָדה is used in the context of an accusation and a defense which was settled with a gift and concluded with a covenant between human beings. This covenant has similarities with the parity treaty between Ramses Meri-Amon of Egypt and Hattusilis of Hatti (1280 BC).

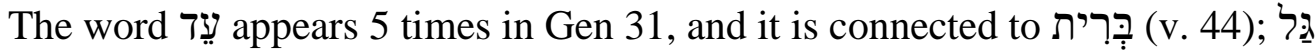

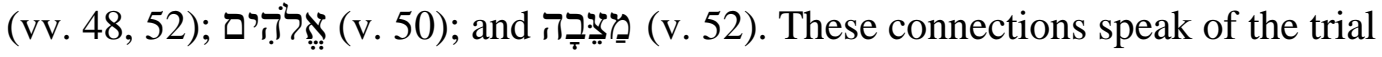

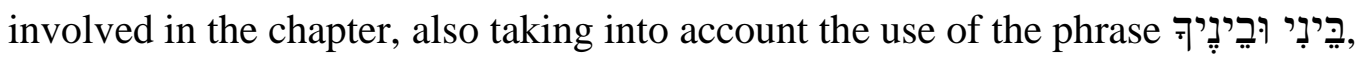
"between you and me" (v. 44), which has the notion of divine judgment; and the verb

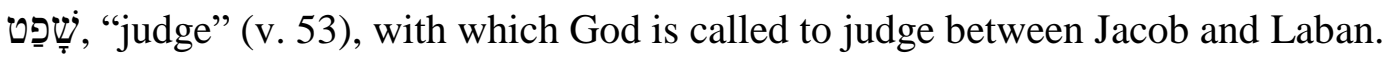

In the ninth commandment of Exod 20:16, the word עִּד means "testimony," and it is related to שֶׁק, which is a negative word. In Deut 5:20, שֶׁק is replaced by its equivalent שְִֶׁ. In the ninth commandment, God warns witnesses giving false testimonies in court. The nature of a witness who gives false testimony in a dispute (ריב) is exposed in Exod 23:1, 2. This false witness stands with the guilty, not only defending him, but also promoting violence and wrong. The punishment of a false witness is legislated in Deut 19:16-21, in which this person is punished with the same punishment he wanted to deliver to the accused. The Code of Hammurabi, in Laws 1 to 4, has 
legislation on this matter with the difference that Law 2 introduces the decision of the judgment resting on magical power. Also the trial of Deut 19:16-21 is a secular judgment with religious implications.

On the other hand, while a person could go to court as a false witness, it was also possible that a witness could prefer not to go to court and testify (Lev 5:1). In ancient Israel, anyone with knowledge of a wrongdoing was under obligation to step forward and speak about it; otherwise, this person would be under God's punishment.

Pieces of a torn animal are shown as עֶֶ, "evidence" (Exod 22:13 [Heb. v. 12]) in court in order to demonstrate that an animal that has been given to be kept has not been stolen by the keeper (Exod 22:10 [Heb. v. 9]). This is a secular judgment with a divine procedure in its development. This OT law has similarities and differences with the Code of Hammurabi, laws 122 to 125 . While both have the purpose to avoid loss of property, the Code of Hammurabi requires the presence of witnesses and a contract in order to take the case to court; otherwise it is not subject to claim. However, this requirement is not necessary in the Old Testament law.

Also in Num 5:11-31, a man could suspect that his wife has been unfaithful to him, but he has no "witness" (עָד) to prove it. Thus, he takes his wife to court before the priest, who puts her under oath and makes her to drink water through which God acts miraculously. This practice is also legislated in the Code of Hammurabi, in laws 131 and 132. But in these stipulations, the woman is thrown into a river. Therefore, the outcome of the matter depends on the woman's ability to swim. However, in the Pentateuchal law, God is directly involved in the judgment, acting in favor or against the woman. So, a secular judgment becomes a divine one. 
The requirement of more than one "witness" (עָָד) for a trial is established in Num 35:30; Deut 17:6, 7 and 19:15. The legislation of Num 35:30 and Deut 19:15 is based on a human-human trial, while the one of Deut 17:6, 7 is on a human-God relation.

In Deut 4:44, 45, the "law" (תָֹרָה) is used as synonym of "testimonies" (עָדוּת)),

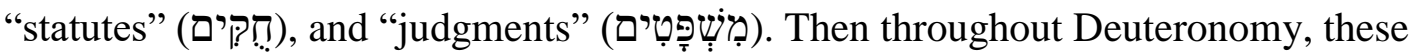
words, as well as "commandment" (מִצְְָוָה), are used interchangeably. This pattern appears

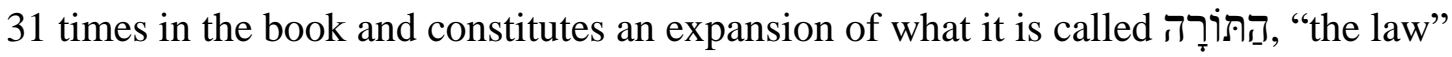
(4:44) and הַדְּרִית, "the covenant” (29:1).

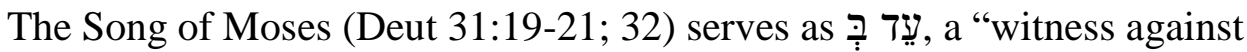
[Israel]” (31:19), and עָָנָָה לְפָננָיו, “[to] speak in the face of” the people of Israel (v. 21), because they will worship idols in Canaan. Thus, they are the defendants; Moses is the plaintiff, and God, the judge.

Also the book of the law (Deut 31:24-26) is placed by Moses "beside the ark of

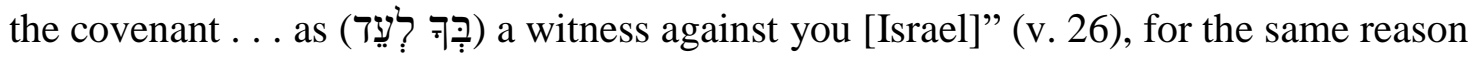
that the Song of Moses will be against the people of Israel. God knows that they will turn their back on him because of their evil tendency and rebellion.

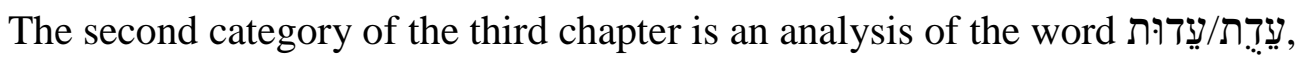
which is used for first time in Exod 16:34 and translated as "testimony." Throughout the Pentateuch, this word points to the Ten Commandments. That is the reason the

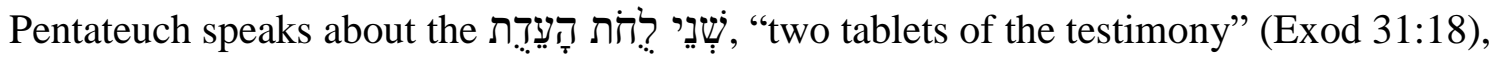

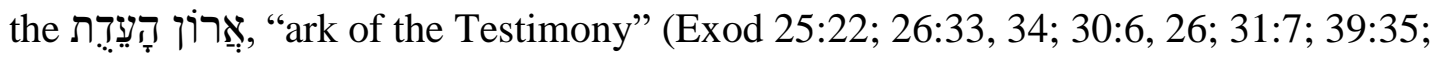




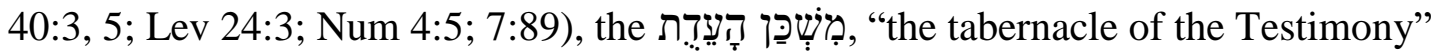

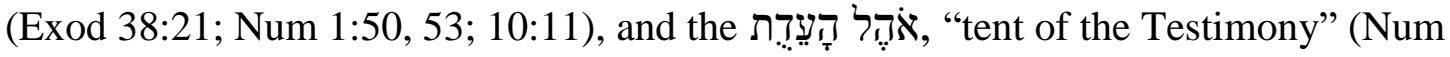
9:15; 17:7, 8 [Heb. vv. 22, 23]; 18:2).

The last category of chapter 3 is based on the verb עוּר ,to testify" or "to bear witness." This verb is used as a solemn warning to pay attention to a requirement and avoid any wrongdoing which would bring an immediate punishment as consequence.

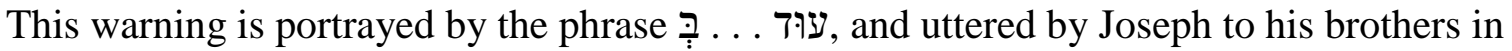
Egypt (Gen 43:3), God to Israel at Mount Sinai (Exod 19:21-23), to an owner of an ox (Exod 21:29), by Moses, summoning heavens and earth against the children of Israel (Deut 4:26; 30:19; 31:28), and by Moses himself to the children of Israel (Deut 8:18, 19; 32:46). This phrase has been translated as "solemnly warn" in most English versions; but the translation "testify against" should not be discarded because the composition of these stories portray trial scenes in their context, and those who pronounce the warning also have the authority to inflict the punishment as soon as the wrongdoing happens.

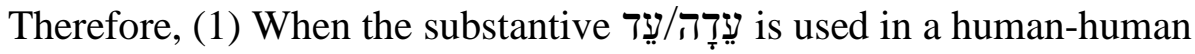
relationship, the context is a secular judgment in which a judgment is made without a covenant. This is parallel to the Code of Hammurabi, Laws 1 to 13, and to the lawsuit among Shukriya, Kula-hupi and Tarmiya in the Nuzi Akkadian from the 15th century BC. These trials are legislations to be performed in court. The only exceptions to this conclusion are the covenant between Abraham and Abimelech which has similarities and differences with the parity treaty between Ramses and Hattusilis in $1280 \mathrm{BC}$, and the covenant of no harm between Jacob and Laban in which God is summoned to be a judge 
between them. In this latter narrative, covenant is an incidental part, but judgment is the central event.

(2) The word עִ עָדוּת is reserved for the Ten Commandments, which is called "the testimony" (Exod 16:34; 27:21; 30:36; Lev 24:3; Num 17:4, 10 [Heb. vv. 19, 25]). As a result, when the Ten Commandments are placed inside the ark (Exod 25:16; 40:20) this latter is called the "ark of the testimony" (Exod 25:21, 22, 33, 34; 30:6, 26; 31:7; 39:35; 40:5, 21; Lev 16:13; Num 4:5; 7:89). In like manner, as the ark of the testimony is located in the sanctuary (Exod 40:2,3) then this is called "the tabernacle of the testimony" (Exod 38:21; Num 1:50, 53; 10:11; 17:7, 8 [Heb. vv. 22, 23]; 18:2), or the "tent of the testimony" (Num 9:15).

(3) The word is used for people in power when they give a warning of a capital punishment against their vassals if something happens contrary to their will (Gen 43:3; Exod 19:21, 23; 21:29; Deut 4:26; 8:19; 30:19; 31:28; 32:46). Related to this point, whenever the construction עִ עוּד appears in the Pentateuch, it has been translated generally as "warn ... against," by English Bible versions, but the translation "testify ... against" should be used.

Chapter 4 is a study of the Greek words $\mu \alpha \rho \tau v \rho i ́ \alpha$ and $\mu \alpha \rho \tau v \rho \varepsilon ́ \omega$ in the Gospel of John, along with "truth" and "judgment." This chapter starts with the proposition that the Gospel of John, with its legal language is linked to the Pentateuch with the Hebrew substantive עִ and its cognates.

The Evangelist is aware of the Pentateuchal legal requirements to execute judgment with at least two witnesses (John 8:17; cf. Num 35:30; Deut 17:6; 19:15); therefore, he gathers 10 direct witnesses in favor of Jesus's origin; and apart from that, 
even though the words $\mu \alpha \rho \tau v \rho i ́ \alpha$ and $\mu \alpha \rho \tau v \rho \varepsilon \dot{\varepsilon} \omega$ are absent in the story, he shows other witnesses giving their testimonies in favor of Jesus. In order to reach this conclusion chapter 4 is divided in four groups: people's testimonies, objects' testimonies, Deity's testimonies, and other testimonies.

In the first group, people's testimonies, the Evangelist introduces John the Baptist, not necessarily as Jesus's forerunner but as one of his witnesses who answers questions from religious leaders and complaints from his disciples. For the Baptist, Jesus is the Son of God (John 1:34).

Another person that the Evangelist shows in his Gospel is the Samaritan woman $(4: 29,39)$. This is a challenge taking into account Jewish debates about the acceptance of women's testimonies in court. However, the Evangelist, free of prejudice, presents this woman along with men testifying in Jesus's favor.

The people who saw Jesus Christ raise Lazarus from the dead (11:38-44) bore witness for Jesus, in such a way that many more people came to see him and proclaimed that he is the King of Israel (12:13).

Jesus assures his disciples that by the work of the Holy Spirit, they will testify for Jesus as they have being testifying for him during Jesus's ministry (15:27). This promise certifies that they will be assisted to do something that will require courage and valor in the midst of accusations against Jesus.

Twice the Evangelist reports his own testimony about Jesus. In the first one, he testifies that what he has seen is true (19:35), and in the second, certifies that the entire Gospel is a "testimony" about Jesus (21:24). 
In the second group I study objects or elements that the Evangelist portrays giving testimonies in favor of Jesus. These elements are Jesus's works (5:36; 10:25), and the Scriptures (5:39). These witnesses resemble the diverse objects that the Pentateuch depicts as witnesses or testimonies in a trial, which I refer in ch. III of this dissertation. These are: a covenant (Gen 31:44), stones (Gen 31:45-52), a torn animal (Exod 22:13 [Heb. v. 12]), the ten commandments (Exod 16:34; 27:21; 30:36; 31:18; 32:15; 34:28, 29), “heaven and earth" (Deut 4:26; 30:19; 31:28), Moses's song (Deut 31:19, 21), and the book of the law (Deut 31:26).

Jesus points out that his works or miracles are greater than the Baptist, and they prove that he has been sent by the Father (John 5:36; 10:25). With these affirmations, Jesus makes clear that the truthfulness of his identity does not depend on the testimony of a human being $(5: 33,34)$, but on what he does (his miracles). Therefore, as in the Pentateuch an object may function as evidence or testimony in a trial, in the Gospel of John Jesus shows his miracles as evidence that he is the Messiah.

In agreement with the last paragraph, Jesus also asserts that the Scriptures testify about him (5:39). He warns the religious leaders that they will be accused by Mosesthat is the Pentateuch—because Moses wrote about him (vv. 45-47). Their condemnation is based on that they do not believe that Jesus is the Son of God (3:18).

The third group shows the testimonies of the Father and Jesus, Jesus alone, and the Holy Spirit. They testify in order to support Jesus's origin and identity, give eternal life to those who believe, and condemn those who do not believe (3:17-21, 32-36; 5:39, 40; 8:13-18). Also in the Pentateuch, God is a witness between Laban and Jacob (Gen 31:50) and delivers his testimonies throughout the book of Deuteronomy. 
In the first testimony (John 3:11) Jesus employs a plural (we) that has been interpreted in various ways: This "we" means the speaker in the Gospel of John and the group of messengers from God (Bultmann); Jesus and the Father, and Jesus and the Baptist (Hendriksen); it is too early in the Gospel for Jesus to speak authoritatively in the first person as the Revealer of God (Michaels); or Jesus is using a plural of category, speaking about himself (Meyer). However, I believe that Jesus is speaking about himself and the Father. Thus, Jesus agrees with the Pentateuchal requirement that a valid testimony has to be supported by at least two witnesses (John 3:11; 8:17, 18; cf. Num 35:30; Deut 17:6; 19:15).

Jesus alone gives four testimonies: He testifies: (1) about what he has seen and heard (John 3:32; cf. Lev 5:1); (2) that a prophet has no honor in his own country (John $4: 44)$; (3) that the works of the world are evil (7:7); and (4) that he was born and came into the world to bear witness to the truth (18:37). These testimonies show that Jesus takes a stand with the truth, in order to condemn the world.

Jesus makes clear that the Father testifies of him (5:37), and this testimony in his favor is true (v. 32). This testimony is also greater than the one of the Baptist (vv. 33-36), and gives veracity to Jesus's judgment, which relies on the Father's will (v. 30).

The role of being a witness in a judgment in the Gospel of John is enhanced by Jesus's promise that the Father will send the Holy Spirit or the Paraclete, "the Spirit of truth" who will support the disciples' testimony (14:16-18), reminding them Jesus's words (v. 26). He is also sent by the Father to testify in court and speak in Jesus's favor (15:26), and will convict ( $\dot{\varepsilon} \lambda \dot{\varepsilon} \gamma \chi \varepsilon ı v)$ the world of sin, of righteousness and of judgment (16:8). Jesus and the world are on trial. The Paraclete acts as witness, judge, and 
prosecutor at the same time; thus, he comes not only to testify in Jesus's favor but also to expose the world's sin, and to rebuke it. The world rejects the truth, and the life of Jesus, so the world judges itself.

The last section of this chapter surveys some groups and individuals who testify

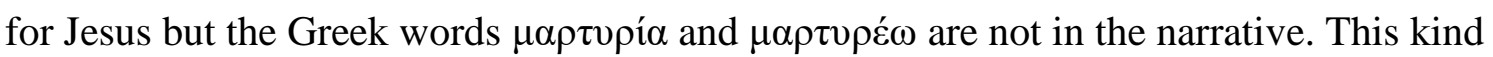
of statement proves that the Gospel of John is a trial that permeates the book from beginning to end.

From the beginning of the Gospel of John, Andrew testifies about Jesus's identity saying that he is the Messiah (1:41). The Baptist is not the Messiah; Jesus is. This testimony gives support to what the Baptist has affirmed in his own testimony (1:20). Andrew's faithful argument is followed by Philip's declaration: Moses and the prophets have written about Jesus; but he is from Nazareth, and the son of a man called Joseph (1:45). This declaration raises doubts on Nathanael's mind (v. 46a); however, Philip invites him to come and see for himself (v. 46b). Though Nathanael doubts, he comes and sees; and after a short conversation with Jesus, he is convinced that Jesus is "the Son of God" and "the King of Israel" (vv. 47-49).

Another person who had to grow in his experience with Jesus was Nicodemus. He was convinced that the person in front of him was extraordinary, but he calls him a "teacher" (3:2). Later, Nicodemus defends Jesus when the Pharisees and the chief priests plot to take Jesus $(7: 32)$, indicating that a trial is only legal when it is done based on the Pentateuchal law (7:50, 51; cf. Exod 23:6-8). 
The testimony of the Samaritan woman about Jesus (John 4:29) encourages her people to test the information (v. 39) and later believe and declare that Jesus "is truly the Savior of the world" (v. 42).

The reaction of the multitude on the Mountain is somewhat similar to the Samaritan people. They have seen that Jesus is able to heal their diseases $(6: 1,2)$ and feed them with only "five barley loaves and two small fish" (vv. 4-8). So, these events lead them to confess that Jesus "is truly the prophet who is to come into the world" (v. 14).

Many disciples abandon Jesus because of his "hard saying" $(6: 60,66)$; thus Jesus asks his twelve disciples if they also want to go away (v. 67), to which Peter answers, as speaking for the twelve, that they believe that Jesus is "the Holy One of God" (v. 69), and that his sayings are "words of eternal life" (v. 68), thus affirming that the former allegation is wrong.

The Pharisees and the chief priests send officers or temple guards to seize Jesus; however, after listening to Jesus speaking, they conclude that "no one has ever spoken like this man" (7:46). This proclamation indicates that the Pharisees and the chief priests' plot to kill Jesus is illegal, contrary to the Pentateuchal requirement of a righteous judgment (Deut 16:18-20). Nevertheless, they prefer to go ahead and put their inheritance of the land in danger (Deut 16:20).

Jesus's words cause division among the people. Some of them believe that he is a prophet (John 7:40), others that he is the Christ (v. 41a), and some of them are confused (vv. 41b, 42). This variety of arguments and beliefs establishes that people are not ready to judge Jesus based on a righteous judgment (Deut 16:20). 
The testimony of the man born blind in favor of Jesus establishes that Jesus is "a Man" (John 9:11), "a prophet" (v. 17), that he "comes from God" (v. 33), and the "Lord," whom he worships (v. 38). In this story the Pharisees have judged the man born blind, casting him out of the synagogue (v. 34; cf. v. 22); but Jesus judges them because they are not willing to believe in him (vv. 39-41).

Jesus is not welcome in Jerusalem (10:22-39) where the religious leaders try to stone him. So Jesus moves beyond the Jordan, where people see his signs and many believe in him referring back to the Baptist's testimony about Jesus: "All things that John spoke about this Man were true" (v. 41). And one of the things that the Baptist said about Jesus was, "This is the Son of God" (1:34).

Martha does not hesitate to proclaim that Jesus is the Christ, the Son of God (11:27). Her belief in Jesus has nothing to do with miracles, because she already believed before Lazarus's resurrection (vv. 43, 44). Her faith has been supported by her previous experience with Jesus.

In chapter 5 , I analyzed intertextually the pattern of continuity between the Gospel of John and the Pentateuch. For this I suggest a legal structure for the Gospel of John that is built on five questions asked throughout the Gospel: "Who are you" (1:19; 8:25a; 21:12; [three times]), "Could this be the Christ?" (4:29b, 30), and "Do the rulers know indeed that this is truly the Christ?" $(7: 25,26)$. These questions are answered by 27 testimonies that support that Jesus is the Christ.

In order to maintain the legal structure in which the word "witness" and its cognate verb appear, I show in table 18 that in the Gospel of John 48 references come from the Pentateuch, used either as direct quotations, allusions or free phrasings. While I 
study many of these references along with the Greek word "testimony" and its cognate verb in chapter 4 , I consider briefly the rest of the references in chapter 5 .

The Gospel of John starts with the phrase "in the beginning" as the book of Genesis does, which indicates the intention of the Evangelist in his quest (John 1:1; Gen 1:1). Also, at the end of the Gospel, Jesus breathes the Holy Spirit upon his disciples (John 20:22) as God breathed breath of life into man's nostrils (Gen 2:7). This shows Jesus as the new Creator in the Gospel of John.

Jesus becomes flesh in the Gospel of John, and as a result he dwells among us (John 1:14). This is an echo of Exod 25:8 where God commands Moses to build a sanctuary and dwell among his people. With this connection, Jesus becomes the new sanctuary.

The Evangelist speaks in several occasions about Moses and Jesus, and one of them is that while Moses has given the law in the Pentateuch, Jesus has given grace and truth in the Gospel of John (John 1:17, 18; Exod 33:17-20).

The Evangelist shows two stories related to Jacob. The first one is connected to the dream that Jacob had in which he saw a "staircase" on which angels ascended and descended (Gen 28:12-22). In the Gospel of John, Jesus says to Nathanael that he "shall see heaven open, and the angels of God ascending and descending upon the Son of Man" (John 1:51). Thus, Jesus declares himself to be the "staircase" that Jacob saw in his dream. The second story is related to Jacob's well (John 4) to which the Samaritan woman had to go every day to drink. Jesus tells her that she needs to drink the water that he would give her to have thirst no more (vv. 13, 14). With this declaration, Jesus is 
answering the Samaritan woman's question, “Are you greater than our father Jacob?" (v. 12). Thus in these two narratives, Jesus is greater than Jacob.

With the manna story, Jesus clarifies the people that he is the true bread which descended from heaven (John 6:32, 33, 35, 48). While their forefathers ate the manna in the wilderness (Exod 16:35) and died (Num 26:63-65), Jesus teaches the people that the only way they could have eternal life is eating from him. This story shows once again that Jesus is the new Moses.

In the Gospel of John, the people are Abraham's descendants (John 8:37), but neither Abraham's children (v. 39) nor God's children (v. 42). Listening to Jesus's word is what matters (vv. 37, 43, 47, 51). Abraham rejoiced to see Jesus's day and was glad (v. 56); Jesus's expectation is not less with Jewish people (v. 39). As the Samaritan woman asked Jesus, "Are you greater than our father Jacob?" (4:12a), the people ask now, “Are you greater than our father Abraham?" (8:53). Jesus answers this question saying that he was before Abraham (v. 58). While Abraham is dead from long ago, Jesus is still alive. Therefore, the Evangelist shows that Jesus is greater than Abraham.

Jewish festivals in the Gospel of John mark a framework for Jesus's ministry in the Gospel of John. The Sabbath is a day of controversy when Jesus breaks Jewish traditions performing miracles, and for that it becomes a day of a new creation and liberation (John 7:23; cf. Exod 20:8-11; Deut 5:12-15). The Passover, which commemorates Israel's liberation from Egypt (Exod 12:27), marks the time when Jesus, the true Passover Lamb, dies (John 19:14; cf. Exod 12:6, 46; Lev 23:5; Num 9:12). And the Feast of Tabernacles, commemorated with water and light (Lev 23:42, 43; Exod 
13:21; 17:1-7; Num 20:8), is applied by Jesus to his own ministry and life (John 7:37, 38; 8:12).

The "I Am" statement of Jesus in John 8:58 is mentioned in a way that the people remember when God proclaimed to Moses from the burning bush, "I am who I am" (Exod 3:14). With this proclamation, Jesus is claiming his divinity.

Other Greek words frequently used by the Evangelist are $\kappa p i ́ v \omega$, "to pass judgment" (19 times), and кpíøı, "judgment" (11 times). These words demonstrate the judicial setting in the Gospel of John; but also establish that Jesus has no plan to condemn the world, but to save it. That is why Jesus shows himself as the bronze serpent $(3: 14,15)$ which was lifted up in the wilderness in a time of rebellion of the people of Israel (Num 21:4-9). Whoever wanted to live was called to see the bronze serpent. With this pronouncement Jesus proclaims that he is Judge and Savior at the same time.

Also when Jesus says that he is the true bread from heaven (John 6:33-58), he is testing the people as God tested the children of Israel with the manna (Exod 16:4; Deut 8:16). Many did not pass this test because they rejected Jesus (John 6:66).

The Father and the Son not only testify together (8:18), they also judge (v. 16) and save together $(5: 22,23,30)$. However the goal is not to condemn, but to save $(3: 17)$. At the end, people will condemn themselves because they rejected the word of God (5:45, $46 ; 12: 48)$.

Righteous judgment is fundamental in Pentateuchal legislation (Gen 18:25; Deut $1: 16-19 ; 17: 0,11)$; the same is true in the Gospel of John. Jesus and Nicodemus ask the religious leader to practice what is right (John 7:24, 50, 51), and to not judge according to the flesh (8:15). Jesus, for his part, judges with truth, because he judges along with the 
Father (v. 16). Truth is a significant word in the Gospel of John because Jesus is the truth (14:6), and the Father bears witness of it (5:32). The Baptist bears witness to the truth (5:33), the Paraclete is the Spirit of truth who testifies of Jesus $(15: 26 ; 16: 13)$, and the Son himself bears witness to the truth (18:37). Furthermore, the Evangelist makes the point that his Gospel is a true testimony (19:35). Although Jesus is on trial in the Gospel of John, he is the truth; to reject him is to reject the truth $(1: 9 ; 3: 19-21)$.

In the Gospel of John many people, including the religious leaders, have eight different accusations against Jesus's origin $(6: 42 ; 7: 41 \mathrm{~b}, 42 ; 8: 48 ; 9: 16)$ and identity $(7: 20 ; 8: 48,52 ; 9: 24 ; 10: 20,33 ; 18: 30)$. Despite these accusations, the religious leaders are not able to prove them. Therefore when they stand before Pilate, they hear three times that Jesus is innocent $(18: 38 ; 19: 4,6)$. However, Pilate ultimately delivers Jesus to the religious leaders, and Jesus is crucified (19:16-18). In this way the religious leaders become false witnesses, breaking the Pentateuchal law which prohibits bearing false witness (Exod 20:6; Deut 5:20). At the same time, they fall under the penalty of being false witnesses (Deut 19:16-20).

At the end of chapter 5, I survey the dual language that appears in the Gospel of John which has been taken by scholars as "dualistic symbols" connected with Zoroastrianism, Gnosticism, a late Platonism, or a first-century Palestinian Judaism as revealed in the Qumran scrolls covenant language. However, I suggest that these "dualistic symbols" constitute a covenant language in the form that a prophet would call the people of Israel to choose between good and evil as Moses did with the people of Israel (Deut 30:19; cf. also Deut 27-32). Therefore, with this language, the Evangelist is challenging his readers to accept Jesus or face judgment. 
To finalize, I maintain that the language of "witness" in the Gospel of John is utilized in a context of judgment (divine or secular) in order to show many witnesses in favor of Jesus, certifying that he is the Messiah, the Son of God. Also, he may be judged by human beings, but as these are false witnesses, this judgment is faulty and against the law. On the contrary, Jesus's judgment is righteous and true because he testifies along with the Father, and the Father and the Paraclete testify for him, which is sufficient to establish Jesus's identity and origin.

\section{Implications for Biblical Studies and Further Research}

Theodicy: A key biblical implication in this topic of witness is Theodicy. Many

theologians have challenged God's moral character saying that the God of the Old

Testament is an angry being who punishes without mercy those who rebel against him, while the God of the New Testament is loving and merciful. So the God of the Old Testament has been misinterpreted as being different from the God of the New Testament. ${ }^{2}$ However, it has been noted throughout the topic of witness that God works

\footnotetext{
${ }^{2}$ Studies about this topic are in T. W. Manson The Teaching of Jesus (Cambridge: Cambridge University Press, 1931); Burrows, An Outline of Biblical Theology (Philadelphia, PA: Westminster, 1946); Robert C. Dentan, The Design of the Scriptures: A First Reader in Biblical Theology (NY: Seabury, 1961); ibid., The Knowledge of God in Ancient Israel (NY: Seabury, 1968); William L. Moran, "The Ancient Near Eastern Background of the Love of God in Deuteronomy," CBQ 25 (1963): 77-87; James S. Chesnut, The Old Testament Understanding of God (Philadelphia, PA: Westminster, 1968); James L. Crenshaw, ed., Theodicy in the Old Testament (Philadelphia, PA: Fortress, 1983); Fretheim, The Suffering of God: An Old Testament Perspective (Philadelphia PA: Fortress, 1984); James Barr, Biblical Faith and Natural Theology (Oxford: Clarendon, 1993); Gregory A. Boyd, God At War: The Bible and Spiritual Conflict (Downers Grove, IL: InterVarsity, 1997); ibid., Satan and the Problem of Evil: Constructing a Trinitarian Warfare Theodicy (Downers Grove, IL: InterVarsity, 2001); ibid., Is God to Blame?: Beyond Pat Answers to the Problem of Suffering (Downers Grove, IL: InterVarsity, 2003); John G. Stackhouse, Can God Be Trusted?: Faith and the Challenge of Evil (Oxford: Oxford University Press, 1998); C. S. Cowles et al., Show Them No Mercy: 4 Views on God and Canaanite Genocide, ed. Stanley N. Gundry (Grand Rapids, MI: Zondervan, 2003); D. Z. Phillips, The Problem of Evil and the Problem of God (Minneapolis, MN: Fortress, 2005); John G. Swinton, Raging with Compassion: Pastoral Responses to the Problem of Evil (Grand Rapids, MI: Eerdmans, 2006); Eric A. Seibert, Disturbing Divine Behavior: Troubling Old Testament Images of God (Minneapolis, MN: Fortress, 2009); Norman L. Geisler, If God, Why Evil?: A
} 
in a similar way in the Pentateuch and in the Gospel of John. There is only one God who demands obedience and justice, and at the same time is willing to provide forgiveness to those who have violated his commandments.

In this matter, God's grace and righteousness have been revealed in many biblical passages (Exod 23:1, 2; Lev 5:1; Num 5:13-31; 35:30; Deut 4:26-28; 16:19, 20; 17:6; $19: 15-21 ; 24: 17 ; 27: 19 ; 32: 4 ;$ John $5: 22-30,39,40,45-47 ; 7: 21-24) .{ }^{3}$ God is not only willing to provide forgiveness to his people but also to empower them to be loving and kind to their neighbors. That is the reason he asks them to avoid being false witnesses in a judgment because this practice is a perversion of justice. God's plan is to administer justice throughout the land. Therefore, his grace and righteousness demand that his people may live righteously in order to be faithful to the covenant. Taking this point into account, when God's grace and righteousness are violated his judgment is ready for those who pervert justice against him or their neighbors.

Great Controversy: The controversy between good and evil is tackled in the Gospel of John when Jesus proclaims Satan's condemnation (12:31), and assures that as the bronze serpent became a symbol of salvation and judgment in the wilderness when it was lifted up by Moses (Num 21:4-9), in the same way Jesus would be "lifted up from the earth" to draw everyone to himself (John 12:32) and give eternal life to "whoever

New Way to Think about the Question (Bloomington, MN: Bethany House, 2011); N. T. Wright, Evil and the Justice of God (Downers Grove, IL: InterVarsity, 2013); R. W. L. Moberly, Old Testament Theology: Reading the Hebrew Bible as Christian Scripture (Grand Rapids, MI: Baker Academic, 2013),107-43.

${ }^{3}$ On this topic of grace in the Old Testament, especially in the Pentateuch, see Kline, "Law Covenant," WTJ 27 (1964): 1-20; McCarthy, "Covenant in the Old Testament," 217, 233; Craigie, The Book of Deuteronomy, 201, 2013; Walter Brueggemann, Genesis, IBC (Atlanta, GA: John Knox, 1982), 49, 50, 60; Dumbrell, Covenant and Creation, 13; Rolf Rendtorff, “ 'Covenant' as a Structuring Concept in Genesis and Exodus," 390; Hamilton, The Book of Genesis: Chapters 1-17, 43, 47; Fretheim, Exodus, 28889. 
believes in him" (John 3:14, 15); but at the same time, he would be lifted up to dethrone Satan, bringing Satan's kingdom to its end $(12: 31,32){ }^{4}$

Women's right to testify: The exclusion of women as witnesses in Israel is not supported by any text in the Pentateuch. However, this right became a heated debate among the people of Israel with the result that women's testimony was traditionally prohibited in court. ${ }^{5}$ On the part of the Gospel of John, it is evident that the Evangelist's concern is to demonstrate that Jesus is the Christ, the Son of God; and both men and women, Jews and Gentiles have equal rights to give their testimony for Jesus. ${ }^{6}$ Therefore, the Evangelist is free of prejudice and shows the Samaritan woman and Martha in the group of people who give testimony in favor of Jesus.

John's purpose and the witness theme: The witness motif is an important theme to answer the dilemma of the particular purpose of the Gospel of John stated in 20:31. Does the Gospel of John have a pastoral or an apologetic purpose? Although the different Greek manuscripts report an ambiguous result, the witness motif points out to a pastoral purpose. $^{7}$

${ }^{4}$ Cf. Marrs, "John 3:14-15," in The Raised Serpent, 141-47; Beasley-Murray, Gospel of Life, 5052; Derett, "The Bronze Serpent," 311-29; Carroll and Green, The Death of Jesus; Paulien, A Practical Guide, 201; Michaels, The Gospel of John, 695-96; Beasley-Murray, John, 213-24; Köstenberger, A Theology of John's Gospel, 469-70; Osborne, "The Gospel of John," in Cornerstone Biblical Commentary, 187-88; and Carter, John, 89-90. 75, 208-9.

${ }^{5}$ For the debate and supporting sources of this topic, see this dissertation, pp. 40-41, 91-92, 173-

${ }^{6}$ Here I am echoing Brant's views on this matter who says that John's purpose is christological rather than about women (cf. Brant, John, 184). Thus the main concern of the Evangelist is to show that Jesus is the Christ, the Messiah, and in order to do that the Evangelist does not hesitate to report the testimony of any person without paying attention to issue of gender.

${ }^{7}$ In this passage the verb $\pi \iota \tau \tau \varepsilon v ́ \varepsilon ı v$ ("to believe") is rendered as an aorist subjunctive ( $\pi 1 \sigma \tau \varepsilon v ́ \sigma \eta \tau \varepsilon:$ "that you may come to believe") by $\aleph^{2}, \mathrm{~A}, \mathrm{C}, \mathrm{D}, \mathrm{L}, \mathrm{N}, \mathrm{W}, \Delta, \Psi, 0141, f^{1}, f^{13}, 33,180,205,565,597,700$, 1006, 1010, 1071, 1241, 1243, 1292, 1342, 1424, 1505, Byz [E, G', H, N], Lect, $l^{70 \mathrm{~m}}$, syr $\mathrm{s}^{\mathrm{s}}$, h, pal , and Cyril 
The Gospel of John and Isa 40-55: It is not new that scholars have recognized that

\author{
the Evangelist infused his book with legal language, similar to that used in the Old
}

Testament, especially in Isa 40-55. ${ }^{8}$ Trites and Lincoln, in their studies, referred to many

passages from the Pentateuch in relation to the Gospel of John but as subsidiaries of Isa

(from IV to XV century); and as a present subjunctive ( $\pi \iota \tau \varepsilon \varepsilon v ́ \eta \tau \varepsilon$ : “that you may continue believing”) by $\mathrm{P}^{66 \mathrm{vid}}, \boldsymbol{K}^{*}, \mathrm{~B}, \Theta, 0250,157$, and $892^{\text {supp }}$ (from about AD 200 to 1122). Scholars interpret the purpose of the Gospel of John depending on which tense is more faithful to the original manuscript.

Scholars who believe that the best reading is a present tense are as follows: Keener, The Gospel of John, 1215-16, recognizes that the aorist subjunctive is supported by more manuscripts, but he prefers the present tense arguing that the material registered in the Gospel of John has the purpose to reaffirm believers in their faith in Jesus. So also Brant John, 273-74; Michaels, The Gospel of John, 1022; Blomberg, The Historical Reliability of John's Gospel, 62, 63; David A. deSilva, An Introduction to the New Testament: Contexts, Methods, and Ministry Formation (Downers Grove, IL: InterVarsity, 2004), 159, 402-3; Dean Flemming, Contextualization in the New Testament: Patterns for Theology and Mission (Downers Grove, IL: InterVarsity, 2005), 257-59; Steven A. Hunt, "Nicodemus, Lazarus, and the Fear of 'the Jews' in the Fourth Gospel," in Repetitions and Variations in the Fourth Gospel: Style, Text, Interpretation, BETL 223, ed. G. Van Belle, M. Labahn, and P. Maritz (Leuven, Belgium: Peeters, 2009), 199, 206, 212; Luke Timothy Johnson, The Writings of the New Testament, 3rd ed. (Minneapolis, MN: Fortress, 2010), 467-68; John Drane, Introducing the New Testament, 3rd ed. (Minneapolis, MN: Fortress, 2011), 204-5.

Scholars who believe that the original tense is an aorist: Harrelson, IDB 4:579; Jon Paulien, $A$ Practical Guide to Abundant Christian Living, 271; Paul J. Achtemeier, Joel B. Green, and Marianne Meye Thompson, Introducing the New Testament: Its Literature and Theology (Grand Rapids, MI: Eerdmans, 2001), 200; Bart D. Ehrman, A Brief Introduction to the New Testament (New York, NY: Oxford University Press, 2004), 144-45; ibid., The New Testament: A Historical Introduction to the Early Christian Writings, 3rd ed. (New York, NY: Oxford University Press, 2004), 162; Warren Carter, John: Storyteller, Interpreter, Evangelist (Peabody, MA: Hendrickson, 2006), 79, 80; Jocelyn McWhirter, The Bridegroom Messiah and the People of God: Marriage in the Fourth Gospel (Cambridge, United Kingdom: Cambridge University Press, 2006), 17, 29, 38, 106; Carson and Moo, Introducing the New Testament: A Short Guide to Its History and Message, ed. Andrew David Naselli (Grand Rapids, MI: Zondervan, 2010), 47.

Scholars who believe that John 20:31 has room for both tenses: Mounce, "John," 652; BeasleyMurray, John, 387-88; C. K. Barrett, The Gospel According to St. John, 26; René Kiefer, "John," in The Oxford Bible Commentary, ed. John Barton and John Muddiman (Oxford, NY: Oxford University Press, 2001), 998; Gundry, Commentary on the New Testament, 459. To support this view Anderson, The Riddles of the Fourth Gospel: An Introduction to John (Minneapolis, MN: Fortress, 2011), 85-87, discusses this matter saying that this verb means "coming to faith for the first time" (apologetic) or "abiding and remaining in Jesus as a matter of faithfulness" (pastoral), and then concludes that the Gospel of John is a composition of more than one edition which includes both materials: apologetic and pastoral. For him, the witness motif is in the apologetic material which is the first edition. See also ibid, 23, 24.

${ }^{8}$ A leading scholar with this interpretation is Andrew T. Lincoln who has given an important contribution to NT studies with his book Truth on Trial, which he has based on the narrative and readerresponse criticisms. In his book he refers to other scholars who have answered, according to him, "the strangely neglected juridical aspect of Johannine thought” (ibid., 4-6). They are Josef Blank, James Montgomery Boice, Johannes Beutler, Severino Pancaro, Anthony Ernest Harvey, Allison A. Trites, Paul Minear, and Robert Gordon Maccini. See more on this argument on ch. II of this dissertation. 
40-55. Furthermore, Lincoln states that Isa 40-55 "points back to exodus motifs," especially to "the supply of the water from the rock." ${ }^{9}$ Thus, since Isaiah has done so for his argumentation, it is also possible that the Evangelist has done the same to write his book..$^{10}$

It can be true that the Evangelist, with his broad Old Testament understanding has not forgotten Isa 40-55 in his writing; however, it is difficult to ignore the many allusions and motifs, already mentioned in chapter V, which the Evangelist took from the Pentateuch. Taking this into account, it is pertinent to show some arguments which make preferable to propose that the Evangelist has based his witness motif on the legal language of the Pentateuch:

(1) Interestingly, on the one hand, for the word "witness" the LXX of Isa 40-55

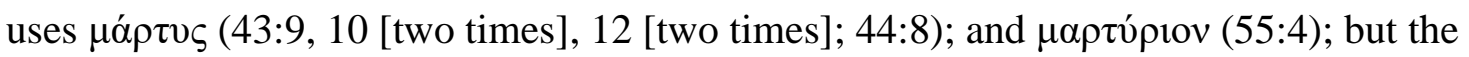

${ }^{9}$ Lincoln, Truth on Trial, 51.

${ }^{10}$ Edwin C. Hoskyns, "Genesis I-III and St John's Gospel," JTS 21 (1920): 210-18, shows the influence of Genesis in John; Richard Morgan, "Fulfillment in the Fourth Gospel: The Old Testament Foundations," Int. 11 (1957): 155-65, defends that the content of John's message is "within the framework of Jewish feasts;" Otto A. Piper, "Unchanging Promises: Exodus in the New Testament," Int. 11 (1957): 12, 13, 15, indicates the provisional character of Christocentric typology in the book of Exodus which, in the Gospel of John, came to its full realization in Jesus; Jacob J. Enz, "The Book of Exodus as a Literary Type for the Gospel of John," JBL 76 (1957): 208-15, believes that the Gospel of John is organized on the pattern of Exodus; Robert Houston Smith, "Exodus Typology in the Fourth Gospel," JBL 81 (1962): 329-42, suggests that the ten plagues on Egypt have influenced the "signs" of John; Pancaro, 216-31, states the links between John 5:37, 38 with the figure of Moses and the events of Sinai; James McCaffrey, The House with Many Rooms: The Temple Theme of Jn. 14, 2-3, AnBib 114 (Roma: Editrice Pontifio Istituto Biblico, 1988), 112-14, 120, 121, 222-25, explains the similarities between John's temple theme in ch. 14:1, 2, and the temple of the book of Exodus; Eric Matthew Edouard Wallace, "The Testimony of Moses: Pentateuchal Traditions and Their Function in the Gospel of John" (Ph. D. diss., Union Theological Seminary, 2004), maintains the influence of Pentateuchal tradition through Moses's testimony; Robert H. Gundry, "New Wine in Old Wineskins: Bursting Traditional Interpretations in John's Gospel (Part 1)," BBR 17 (2007): 115-30, connects John with Gen 1-3, the Feast of Tabernacles, the Sanctuary's menorah, and Jacob's dream; Christopher A. Maronde, "Moses in the Gospel of John," CTQ 77 (2013): 23-44, explains the connections between Moses and Jesus in the Gospel of John: They are instruments to give God's gift to his people. See also Brown, The Gospel According to John, AB 29: lix, lx; Brant, John, 107, 108, 140. 
Gospel of John never use those words. ${ }^{11}$ On the other hand, the Evangelist prefers to use

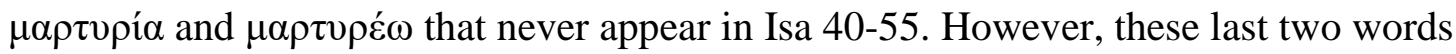
are used in the Pentateuch in the story of Jacob and Laban, and in the ninth commandment ( $\mu \alpha \rho \tau v \rho \varepsilon ́ \omega:$ Gen 31:48, 52 [three times]; Num 35:30; Deut 19:15, 18;

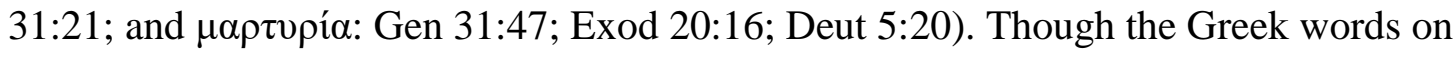
this paragraph are cognate, the selection of the Evangelist seems intentional.

(2) Key words of Isa 40-55 are $\pi$ aĩ $(41: 8,9 ; 42: 1,19 \mathrm{a} ; 43: 10 ; 44: 1,2,21$ [two

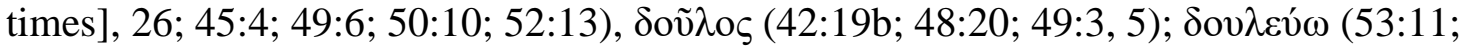
[participle]); and $\theta \varepsilon \rho \alpha \pi \varepsilon v ́ \omega ~(54: 17$; [participle]). These words have been translated into English as "servant." 12 This figure ("servant") is prominent in the legal trial of Isa 40-55; however in the Gospel of John $(4: 51 ; 6: 9 ; 8: 34,35 ; 13: 16 ; 15: 15,20)$, specifically $\pi \alpha$ ĩ and $\delta o v \tilde{\lambda} \mathrm{o}_{\text {, }}$ are used with different tone, and without relation to Isa $40-55 .^{13}$

(3) The Sabbath day is an important feature in the Gospel of John (5:9, 10, 16, 18; 7:22; 23 [two times]; 9:14, 16; 19:31 [two times]) while in Isa 40-55 this day is never mentioned. ${ }^{14}$ Thus in the Gospel of John the controversy has other aspects in view that have not relation to Isa 40-55.

Valid questions would be as follows: Why has the Evangelist left so important words of Isa 40-55 for his witness motif and instead has used others? My answer to this question is that in the legal setting of the Gospel of John the Evangelist has two points in

${ }^{11}$ Cf. Silva, ed., NIDNTTE 3:241, who mentions this point. See also this dissertation, p. 160 n. 9.

12 The MT consistently uses the word עֶבְבד

${ }^{13}$ In Isa 40-55 the "servant" of the Lord is either corporate Israel or an individual. (This is not part of my topic. I include this observation here for the sake of clarity).

${ }^{14}$ See above on p. 207 n. 134, and pp. 229-31. 
view related to the legal setting of the Pentateuch: (1) a fair and just judgment, and (2) the ninth commandment which calls to avoid false witness.

(1) As the people of Israel were summoned to testify in court with two or more witnesses for a fair and just judgment (Num 35:30; Deut 19:15, 18), the Evangelist has shown many witnesses who testify in Jesus's favor in order to get the appropriate result; and

(2) Jesus would have had a fair and just judgment only if the ninth commandment would have been properly practiced (Exod 20:16; Deut 5:20) in a careful inquiry by the judges (Deut 19:18). The outcome unfolds in the Gospel of John indicates that the trial against Jesus has been flawed in every step of the Pentateuchal court.

The Gospel of John and the rest of the Scripture: Another point that deserves attention is what Carson and Moo have said about the use of the Old Testament in the Gospel of John. They recognize the following:

Although John does not cite the Old Testament as frequently as does Matthew, for example, his use of the Old Testament is characterized by an extraordinary number of allusions, and above all by his insistence that Jesus in certain respects replaces revered figures and institutions from the old covenant (e.g., temple, vine, tabernacle, serpent, Passover). The underlying hermeneutic assumed deserves close study. ${ }^{15}$

\footnotetext{
${ }^{15}$ Carson and Moo, An Introduction to the New Testament, 278. Another scholar who recognizes this feature is Menken, Old Testament Quotations in the Fourth Gospel, 206-7. The question on the continuity and discontinuity between the Testaments has been largely studied by scholars. For example, Cf. John S. Feinberg, Continuity and Discontinuity: Perspective on the Relationship Between the Old and New Testaments (Wheaton, IL: Crossway, 1988); David L. Baker, Two Testaments, One Bible: A Study of the Theological Relations Between the Old \& New Testaments (Downers Grove, IL: InterVarsity, 1991); James H. Charlesworth and Walter P. Weaver, eds., The Old and the New Testaments: Their Relationship and the "Intertestamental” Literature (Valley Forge, PA: Trinity Press International, 1993); Davidson, "New Testament Use of the Old Testament," JATS 5 (1994): 14-39; Moyise, The Old Testament in the New: An Introduction, Cont (London: Continuum, 2001); Craig A. Evans, ed., From Prophecy to Testament: The Function of the Old Testament in the New (Peabody, MA: Hendrickson, 2004); Walter C. Kaiser, Darrell L. Block, and Peter Enns, Three Views on the New Testament Use of the Old Testament, ed. Kenneth Berding, Jonathan Lunde, and Stanley N. Gundry (Grand Rapids, MI: Zondervan, 2008); Gregory K. Beale, Handbook on the New Testament Use of the Old Testament: Exegesis and Interpretation (Grand Rapids, MI: Baker Academic, 2013).
} 
This need has been supplied in this present dissertation, in which it has been evident that most of these features, taken from the Pentateuch, have a new meaning in Jesus Christ. Thus Jesus's figure surpasses Abraham, Jacob, and Moses; and at the same time he is the Creator, the new temple, the new manna, the Passover Lamb, and the bronze serpent. 


\section{BIBLIOGRAPHY}

Abbott, Edwin A. Johannine Vocabulary: A Comparison of the Words of the Fourth Gospel with Those of the Three. London: A. \& C. Black, 1905.

Achtemeier, Paul J., Joel B. Green, and Marianne Meye Thompson. Introducing the New Testament: Its Literature and Theology. Grand Rapids, MI: Eerdmans, 2001.

Adams, Charlotte Hannah. Women of Ancient Israel. 2nd ed. NY: National Board of the Young Women's Christian Associations of the United States of America, 1913.

Ahn, Sanghee Michael. "Old Testament Characters as Christological Witnesses in the Fourth Gospel.” Ph.D. diss., Southern Baptist Theological Seminary, 2006.

Albright, William Foxwell. "Some Remarks on the Song of Moses in Deuteronomy XXXII." VT 9 (1959): 339-46.

. "The Hebrew Expression for 'Making a Covenant' in Pre-Israelite Documents." BASOR 121 (1951): 21-22.

Alexander, T. D. “Gen 22 and the Covenant of Circumcision.” JSOT 25 (1983): 17-22.

. "The Composition of the Sinai Narrative in Exodus XIX 1-XXV 11." VT 49 (1999): 282-94.

Alibaigi, Sajjad, Abdol-Malek Shanbehzadeh, and Hossain Alibaigi. "The Discovery of a Neo-Assyrian Rock-Relief at Mishkhas, Ilam Province (Iran).” IA 47 (2012): 2940 .

Allen, Ronald B. Numbers. EBC 2. Grand Rapids, MI.: Zondervan, 1990.

Allison, Dale C. "Elijah Must Come First.” JBL 103 (1984): 254-58.

Alonso-Schökel, L. "Sapiential and Covenant Themes in Gen 2-3." TD 13 (1965): 3-10.

Amador, J. David Hester. Academic Constraints in Rhetorical Criticism of the New Testament: An Introduction to a Rhetoric of Power. JSNTSup. Sheffield, England: Sheffield Academic, 1999. 
Anderson, Paul N. The Christology of the Fourth Gospel: Its Unity and Disunity in the Light of John 6. WUNT 2/78. Tübingen: Mohr, 1996.

The Riddles of the Fourth Gospel: An Introduction to John. Minneapolis, MN: Fortress, 2011.

Anderson, Paul N., Felix Justo, and Tom Thatcher, eds. John, Jesus, and History: Critical Appraisals of Critical Views. Vol. I. Atlanta, GA: Society of Biblical Literature, 2007.

Anderson, Robert T., and Terry Giles. The Keepers: An Introduction to the History and Culture of the Samaritans. Peabody, MA: Hendrickson, 2002.

. Tradition Kept: The Literature of the Samaritans. Peabody, MA: Hendrickson, 2005.

Andrew, M. E. "Falsehood and Truth: An Amplified Sermon on Exodus 20:16." Int 17 (1963): 425-38.

Archer, Gleason. A Survey of Old Testament Introduction. Rev. and exp. ed. Chicago, IL: Moody, 1994.

Ashley, Timothy R. The Book of Numbers. NICOT. Grand Rapids, MI: Eerdmans, 1993.

Ashton, John. Understanding the Fourth Gospel. NY: Oxford, 1993.

Asiedu-Prepah, Martin. Johannine Sabbath Conflicts as Juridical Controversy. WUNT 132. Tübingen: Mohr Siebeck, 2001.

Aune, D. E. Early New Testament in its Literary Environment. Philadelphia, PA: Westminster, 1987.

Bailey, John Amedee. The Traditions Common to the Gospels of Luke and John. NovTSup 7. Leiden: Brill, 1963.

Baker, David L. Two Testaments, One Bible: A Study of the Theological Relations Between the Old \& New Testaments. Downers Grove, IL: InterVarsity, 1991.

Ball, David M. “I Am” in John's Gospel: Literary Function, Background, and Theological Implications. JSNTSup 124. Sheffield, England: Sheffield Academic, 1996.

Baltzer, Klaus. The Covenant Formulary in Old Testament, Jewish and Early Christian Writings. Translated by D. Green. Philadelphia, PA: Fortress, 1971.

Bammel, Ernst. The Trial of Jesus. Naperville, IL: Alec R. Allenson, 1970. 
Bandy, Alan S. "Word and Witness: An Analysis of the Lawsuit Motif in Revelation Based on the Witness Terminology." 13-16. Accessed 29 May 2013. Available from http://www.phc.edu/journalfiles/bandy.

Barker, Glenn W., William L. Lane, and J. Ramsey Michaels. The New Testament Speaks. NY: Harper \& Row, 1969.

Barker, William Pierson. Women and the Liberator. NJ: F. H. Revell, 1972.

Barr, James. Biblical Faith and Natural Theology. Oxford: Clarendon, 1993.

Barrett, C. K. “John and Judaism.” Pages 231-46 in Anti-Judaism and the Fourth Gospel. Edited by R. Bieringer, D. Pollefeyt and F. Vandecasteele-Vanneville. Louisville: Westminster, 2001.

. The Gospel according to St. John: An Introduction with Commentary and Notes on the Greek Text. 2nd ed. Philadelphia, PA: Westminster, 1978.

. The Holy Spirit and the Gospel Tradition. London: Society for Promoting Christian Knowledge, 1966.

Barrick, William D. “The Mosaic Covenant.” MSJ 10 (1999): 213-32.

Bartlett, W. "The Coming of the Holy Ghost According to the Fourth Gospel." ExpTim 37 (1925): 72-75.

Barton, John. 'Intertextuality and the 'Final Form' of the Text." Pages 33-37 in Congres Volume. VTSup 80. Edited by A. Lemaire and M. Saebo (Boston, MA: Brill, 2000 .

. "Law and Narrative in the Pentateuch." CV 51 (2009): 126-40.

Bassler, J. M. "Mixed Signals: Nicodemus in the Fourth Gospel.” JBL 108 (1989): 63546.

Bateman, Herbert W., Darrell L. Bock, and Gordon H. Johnston. Jesus the Messiah:

Tracing the Promises, Expectations, and Coming of Israel's King. Grand Rapids, MI: Kregel, 2012.

Bauckman, Richard. God Crucified: Monotheism and Christology in the New Testament. Grand Rapids, MI: Eerdmans, 1998.

. Gospel Women: Studies of the Named Women in the Gospels. Grand Rapids, MI: Eerdmans, 2002. 
The Testimony of the Beloved Disciple: Narrative, History, and Theology in the Gospel of John. Grand Rapids, MI: Baker Academic, 2007.

Bauer, David R., and Robert A. Traina. Inductive Bible Study: A Comprehensive Guide to the Practice of Hermeneutics. Grand Rapids, MI: Baker Academic, 2001.

Baum, G. The Jews and the Gospel: A Re-examination of the New Testament. Westminster, MD: Newman, 1961.

Baumann, E. "Das Lied Moses (Dt. XXXII 1-43) auf seine gedancliche Geschlossenheit untersucht." VT 6 (1956): 414-24.

Beal, Timothy K. "Intertextuality." Pages 128-30 in Handbook of Postmodern Biblical Interpretation. Edited by A. K. M. Adam. St. Louis, MI: Chalice, 2000.

Beale, Gregory K. Handbook on the New Testament Use of the Old Testament: Exegesis and Interpretation. Grand Rapids, MI: Baker Academic, 2013.

Beasley-Murray, George R. Gospel of Life: Theology in the Fourth Gospel. Peabody, MA: Hendrickson, 1991. . Jesus and the Kingdom of God. Grand Rapids, MI: Eerdmans, 1986. . John. WBC 36. Waco, TX: Word Books, 1987.

Becker, Jürgen. Das Evangelium nach Johannes. KNT 4. 2 vols. 3rd ed. Würzbur: Echter, 1979.

Benjamin, Don C. Old Testament Parallels. Law and Stories from the Ancient Near East. NY: Paulist, 2006.

Berman, Joshua. "CTH 133 and the Hittite Provenance of Deuteronomy 13.” JBL 130 (2011): 25-44.

. "History Twice Told: Deuteronomy 1-3 and the Hittite Treaty Prologue Tradition." JBL 132 (2013): 229-50.

Bernard, John Henry. A Critical and Exegetical Commentary on the Gospel According to St. John. ICC. Edinburgh: T\&T Clark, 1929.

Beutler, Johannes. "In Search of a New Synthesis." Pages 23-34 in What We Have Heard from the Beginning: The Past, Present, and Future of Johannine Studies. Edited by Tom Thatcher. Waco, TX: Baylor University Press, 2007.

. Judaism and the Jews in the Gospel of John. SubBi 30. Rome: Editrice Pontificio Instituto Biblico, 2006. 
. Martyria: Traditionsgeschichtliche Untersuchungen zum Zeugnisthema bei Johannes. Frankfurt: Josef Knecht, 1972.

Beyerlin, Walter. Origins and History of the Oldest Sinaitic Traditions. Translated by S. Rudman. Oxford: Blackwell, 1966.

Bieringer, R., D. Pollefeyt, and F. Vandecasteele-Venneuville, eds. Anti-Judaism and the Fourth Gospel. Louisville, KY: Westminster John Knox, 2001.

Birch, Bruce C., Walter Brueggemann, Terence E. Fretheim, and David L. Petersen. A Theological Introduction to the Old Testament. Nashville, TN: Abingdon, 1999.

Bird, Phyllis. "Images of Women in the Old Testament." Pages 41-88 in Religion and Sexism: Images of Women in the Jewish and Christian Traditions. Edited by Rosemary Radford Ruether. NY: Simon \& Schuster, 1974.

Blank, Josef. Krisis: Untersuchungen zur Johanneischen Christologie und Eschatologie. Freiburg im Breisgau: Lambertus-Verlag, 1964.

Blank, Sheldon H. "The Curse, the Blasphemy, the Spell and the Oath." HUCA 23 (1950/51): 73-95.

Block, Daniel I. Deuteronomy. NIVAC. Grand Rapids, MI: Zondervan, 2012.

. "The Grace of Torah: The Mosaic Prescription for Life (Deut 4:1-8; 6:20-25)." BSac 162 (2005): 3-22.

Blomberg, Craig L. "The Globalization of Biblical Interpretation: A Test Case John 3-4." BBR 5 (1995): 1-15.

. The Historical Reliability of John's Gospel: Issues and Commentary. Downers Grove, IL: InterVarsity, 2001.

Bock, Darrell L. "Opening Questions: Definition and Philosophy of Exegesis." Pages 2332 in Interpreting the New Testament Text: Introduction to the Art and Science of Exegesis. Edited by Darrell L. Bock and Buist M. Fanning. Wheaton, IL: Crossway Books, 2006.

Boecker, Hans Jochen. Law and the Administration of Justice in the Old Testament and Ancient East. MN: Augsburg, 1980.

. Redeformen des Rechtslebens im Alten Testament. Wissenschaftliche Monographien zum Alten und Neuen Testament 14. 2nd ed. Neukerchen-Vluyn: Neukirchener, 1970. 
Boice, James Montgomery. Witness and Revelation in the Gospel of John. Grand Rapids, MI: Zondervan, 1970.

Boice, James Montgomery, and Philip Graham Ryken. Jesus on Trial. Wheaton: Crossway, 2002.

Boismard, Marie-Émile. Moses or Jesus: An Essay in Johannine Christology. Minneapolis, MN: Fortress, 1993.

Bokovoy, David E. "שמעו בבית והעידו יעקב: Invoking the Council as Witnesses in Amos 3:13." JBL 127 (2008): 37-51.

Borgen, Peder. Bread from Heaven: An Exegetical Study of the Concept of Manna in the Gospel of John and the Writings of Philo. NovTSup 10. Leiden: Brill, 1965.

"John 6: Tradition, Interpretation and Composition." Pages 268-91 in From Jesus to John: Essays on Jesus and New Testament Christology in Honour of Marinus de Jonge. JSNTSup 84. Edited by Martinus C. de Boer. Sheffield, England: JSOT, 1993.

. Philo, John, and Paul: New Perspectives on Judaism and Early Christianity. Atlanta, GA: Scholars, 1987.

Boring, M. Eugene. "The Influence of Christian Prophecy on the Johannine Portrayal of the Paraclete and Jesus." NTS 25 (1978): 113-23.

Bornkamm, Günther. The New Testament: A Guide to Its Writings. Philadelphia, PA: Fortress, 1973.

Boston, James R. “The Wisdom Influence upon the Song of Moses.” JBL 87 (1968): 198202.

Botterweck, G. Johannes, Helmer Ringgren, and Heinz-Josef Fabry, eds. Theological Dictionary of the Old Testament. 15 vols. Translated by J. T. Willis, G. W. Bromiley, and D. E. Green. Grand Rapids, MI: Eerdmans, 2004.

Bousset, Wilhelm. Kyrios Christos: A History of the Belief in Christ from the Beginning of Christianity to Irenaeus. Translated by J. E. Steely. Nashville: Abingdon, 1970.

Boyd, Gregory A. God at War: The Bible and Spiritual Conflict. Downers Grove, IL: InterVarsity, 1997.

Is God to Blame?: Beyond Pat Answers to the Problem of Suffering. Downers Grove, IL: InterVarsity, 2003. 
. Satan and the Problem of Evil: Constructing a Trinitarian Warfare Theodicy. Downers Grove, IL: InterVarsity, 2001.

Boyle, Marjorie O'Rourke. "The Covenant Lawsuit of the Prophet Amos III 1 - IV 13." VT 21 (1971): 338-62.

Brant, Jo-Ann A. John. ПAI $\Delta$ EIA: Paideia Commentaries on the New Testament. Grand Rapids, MI: Baker Academic, 2011.

Briggs, Argye M. Christ and Modern Woman. Grand Rapids, MI: Eerdmans, 1958.

Brodie, Thomas L. The Gospel According to John: A Literary and Theological Commentary. NY: Oxford University Press, 1993.

Brown, F., S. Driver, and C. Briggs. The Brown-Driver-Briggs Hebrew and English Lexicon. MA: Hendrickson, 2003.

Brown, Raymond E. An Introduction to the New Testament. NJ: Doubleday, 1997. . The Community of the Beloved Disciple: The Life, Loves, and Hates of an Individual Church in New Testament Times. Mahwah, NY: Paulist, 1979. . The Gospel According to John. AB 29-29A. NY: Doubleday, 1966-1970.

. The Gospel and Epistles of John: A Concise Commentary. Collegeville, MN: Liturgical, 1988.

. "The Qumran Scrolls and the Johannine Gospel and Epistles.” Pages 183-207 in The Scrolls and the New Testament. Edited by Krister Stendahl. NY: Harper, 1957.

. "Roles of Women in the Fourth Gospel." TS 36 (1975): 588-99.

Brown, Sherri. “Gift upon Gift: Covenant through Word in the Gospel of John.” Ph.D. diss., The Catholic University of America, 2008.

Brown, Tricia Gates. Spirit in the Writings of John: Johannine Pneumatology in SocialScientific Perspective. JSNTSup 253. London: T\&T Clark, 2003.

Bruce, F. F. The Gospel of John. Grand Rapids, MI: Eerdmans, 1983.

. The Hittites and the Old Testament. London: Tyndale, 1947.

. The Message of the New Testament. Grand Rapids, MI: Eerdmans, 1973.

Brueggemann, Walter. Book of Exodus. NIB 1. Nashville, TN: Abingdon, 1994. 
. Genesis. IBC. Atlanta, GA: John Knox, 1982.

Theology of the Old Testament: Testimony, Dispute, Advocacy. Minneapolis, MN: Fortress, 1997.

Brunson, Andrew C. Psalm 118 in the Gospel of John: An Intertextual Study on the New Exodus Pattern in the Theology of John. WUNT 2/158. Tübingen: Siebeck, 2003.

Bryant, Tamera. The Life and Times of Hammurabi. Hockessin, DE: Mitchell Lane, 2005.

Bryce, Trevor. Life and Society in the Hittite World. Oxford, England: Oxford University Press, 2002.

The Kingdom of the Hittites. New ed. Oxford, England: Oxford University Press, 2005.

Buchanan, George Wesley. Introduction to Intertextuality. Mellen Biblical Press Series 26. Lewiston, NY: Edwin Mellen, 1994.

Buck, David W. “Exodus 20:1-17.” LTJ 16 (1982): 65-75.

Budd, Philip J. Numbers. WBC 5. Waco: TX: Word Books, 1984.

Bultmann, Rudolph. "Die Bedeutung der neuerscholssenen mandäischen un manichäischen Quellen für das Verständnis des Johannesevangeliums." ZNW 24 (1925): 100-46.

. The Gospel of John: A Commentary. Edited by R. W. N. Hoare and J. K. Riches. Translated by G. R. Beasley-Murray. Oxford: Basil Blackwell, 1971.

. Theology of the New Testament. 2 vols. NY: Charles Scribner's, 1951-1955.

Burge, Gary M. The Anointed Community: The Holy Spirit in the Johannine Tradition. Grand Rapids, MI: Eerdmans, 1987.

. John. NIVAC. Grand Rapids, MI: Zondervan, 2000.

Burrows, Millar. An Outline of Biblical Theology. Philadelphia, PA: Westminster, 1946. . More Light on the Dead Sea Scrolls. NY: Viking, 1958.

Buttrick, George Arthur, ed. The Interpreter's Dictionary of the Bible. 4 vols. Nashville, TN: Abingdon, 1962. 
Byrne, Brendan. Lazarus: A Contemporary Reading of John 11:1-46. Zacchaeus Studies: New Testament. Edited by Mary Ann Getty. Collegeville, PA: Liturgical, 1990.

Cahill, Michael. "Reader-Response Criticism and the Allegorizing Reader." TS 57 (1996): 89-96.

Cairns, Ian. Word and Presence: A Commentary on the Book of Deuteronomy. ITC. Grand Rapids, MI: Eerdmans, 1992.

Calderone, Philip J. Dynastic Oracle and Suzerainty Treaty. Manila, Philippines: Loyola House of Studies, 1966.

Callahan, Allen Dwight. A Love Supreme: A History of Johannine Tradition. MN: Fortress, 2005.

Campbell, Antony F., and Mark A. O'Brien. Rethinking the Pentateuch: Prolegomena to the Theology of Ancient Israel. Louisville, KY: Westminster John Knox, 2005.

Carmichael, Calum. "Law and Narrative in the Pentateuch." Pages 332-33 in The Blackwell Companion to the Bible. Edited by Leo G. Perdue. Oxford: Blackwell, 2001. . The Laws of Deuteronomy. Ithaca, NY: Cornell University Press, 1974.

Carpenter, Joseph Estlin. The Johannine Writing: A Study of the Apocalypse and the Fourth Gospel. Boston, MA: Houghton Mifflin, 1927.

Carroll, John T., and Joel B. Green. The Death of Jesus in Early Christianity. Peabody, MA: Hendrickson, 1995.

Carson, D. A. "The Function of the Paraclete in John 16:7-11.” JBL 98 (1979): 547-66. . The Gospel According to John. Grand Rapids, MI: Eerdmans, 1991.

Carson, D. A., and Douglas J. Moo. An Introduction to the New Testament. Grand Rapids, MI: Zondervan, 2005.

. Introducing the New Testament: A Short Guide to Its History and Message. Edited by Andrew David Naselli. Grand Rapids, MI: Zondervan, 2010.

Carson, Robert M. "Human Rights and Dignity under the Laws of the Pentateuch." Pittsburgh Perspective 2 (1961): 27-41.

Carter, Warren. John: Storyteller, Interpreter, Evangelist. Peabody, MA: Hendrickson, 2006. 
. The Documentary Hypothesis and the Composition of the Pentateuch. Jerusalem: Shalem, 2006.

Ceram, C. W. The Secret of the Hittites. Translated by Richard Winston and Clara Winston. NY: Schocken Books, 1973.

Chappell, Clovis Gillham. Christ and the New Woman. Nashville, TN: Cokesbury, 1928.

Charlesworth, James H., ed. The Messiah: Developments in Earliest Judaism and Christianity: The First Princeton Symposium on Judaism and Christian Origins. Minneapolis, MN, Fortress, 1992.

. The Beloved Disciple: Whose Witness Validates the Gospel of John. Valley Forge, PA: Trinity Press International, 1995.

Charlesworth, James H., Hermann Lichtenberger, and Gerbern S. Oegema, eds. QumranMessianism: Studies on the Messianic Expectations in the Dead Sea Scrolls. Tübingen: Mohr Siebeck, 1998.

Charlesworth, James H., and Walter P. Weaver, eds. The Old and the New Testaments: Their Relationship and the "Intertestamental" Literature. Valley Forge, PA: Trinity Press International, 1993.

Chavalas, Mark W., and Lawson Younger, eds. Mesopotamia and the Bible: Comparative Explorations. Grand Rapids, MI: Baker, 2002.

Chesnut, James S. The Old Testament Understanding of God. Philadelphia, PA: Westminster, 1968.

Chester, Ray F. “Covenant Types.” ResQ 9 (1966): 285-89.

Childs, Brevard S. Biblical Theology in Crisis. Philadelphia, PA: Westminster, 1970. . Biblical Theology of the Old and New Testaments: Theological Reflection on the Christian Bible. Minneapolis, MN: Fortress, 1993.

Cho, Sukmin. Jesus as Prophet in the Fourth Gospel. Sheffield, England: Sheffield Phoenix, 2003.

Clark, Elizabeth, and Richardson Herbert, eds. Women and Religion. NY: Harper \& Row, 1977.

Clark-Soles, Jamie. Scripture Cannot Be Broken: The Social Function of the Use of Scripture in the Fourth Gospel. Leiden: Brill, 2003. 
Clements, R. E. "Prophecy and Covenant." Pages 27-34 in SBT. Edited by C. F. D. Moule. London: Student Christian Movement, 1965.

Clines, D. J. A. "Noah's Flood: The Theology of the Flood Narrative." Faith and Thought 100 (1972-73): 128-42.

Coats, G. W. "The Curse in God's Blessing." Pages 31-41 in Die Botschaft un die Boten: FS für H. W. Wolff. Edited by Joachim Jeremias and L. Perlitt. Neukirchen: Neukirchener Verlag, 1981.

Cole, R. Alan. Exodus: An Introduction \& Commentary. TOTC. Leicester, England: InterVarsity, 1973.

Cole, R. Dennis. Numbers: An Exegetical and Theological Exposition of Holy Scripture. NAC 3B. Nashville, TN: Broadman \& Holman, 2000.

Collins, Billie Jean. The Hittite and Their World. SBL 7. Atlanta, GA: SBL, 2007.

Collins, John J. The Scepter and the Star: The Messiah of the Dead Sea Scrolls and Other Ancient Literature. ABRL 10. NY: Doubleday, 1995.

Collins, Raymond F. John and His Witness. Collegeville, MN: Liturgical, 1991.

. These Things Have Been Written: Studies on the Fourth Gospel. Grand Rapids, MI: Eerdmans, 1990.

Cook, Stephen L. Reading Deuteronomy: A Literary and Theological Commentary. Macon, GA: Smith \& Helwys, 2015.

Cook, W. Robert. The Theology of John. Chicago, IL: Moody, 1979.

Cornelius, Izak. "Gen 26 and Mari: The Dispute over Water and the Socio-Economic Way of Life of the Patriarchs." JNSL 12 (1984): 53-61.

Cowles, C. S., Eugene H. Merrill, Daniel L. Gard, and Tremper Longman. Show Them No Mercy: 4 Views on God and Canaanite Genocide. Edited by Stanley N. Gundry. Grand Rapids, MI: Zondervan, 2003.

Cowley, A. E. The Hittites. London: Oxford University Press, 1920.

Craigie, Peter C. The Book of Deuteronomy. NICOT. Grand Rapids, MI: Eerdmans, 1976.

Crenshaw, James L., ed. Theodicy in the Old Testament. Philadelphia, PA: Fortress, 1983. 
Crim, K., ed. Interpreter's Dictionary of the Bible: Supplementary Volume. Nashville, TN, 1976.

Cross, Frank M. “The Council of Yahweh in Second Isaiah.” JNES 12 (1953): 274-77.

Crossan, John Dominic. The Gospel of Eternal Life: Reflections on the Theology of St. John. Milwaukee, WI: Bruce, 1967.

Cullman, Oscar. The Christology of the New Testament. Translated by Shirley C. Guthrie and Charles A. M. Hall. Philadelphia, PA: Westminster, 1963.

Culpepper, R. Alan. Anatomy of the Fourth Gospel: A Study in Literary Design. Philadelphia, PA: Fortress, 1983.

. "An Introduction to the Johannine Writings." Pages 9-27 in The Johannine Literature. Edited by Barnabas Lindars, Ruth B. Edwards, and John M. Court. Sheffield, England: Sheffield Academic, 2000.

, ed. Critical Reading of John 6. BIS 22. Leiden: Brill, 1997.

. Review of A. E. Harvey, Jesus on Trial: A Study in the Fourth Gospel. RevExp 76 (1979): 114-16.

. "The Christology of the Johannine Writings." Pages 66-87 in Who Do You Say That I Am: Essays on Christology. Edited by M. A. Powell and D. R. Bauer. Louisville, KY: Westminster John Knox, 1999.

. The Gospel and Letters of John. Nashville, TN: Abingdon, 1998.

Czander, Giovanna Raengo. "You Are My Witnesses: A Theological Approach to the Laws of Testimony." Ph.D. diss., Fordham University, 2009.

Dalley, Stephanie. Esther's Revenge at Susa: From Sennacherib to Ahasuerus. Oxford: Oxford University Press, 2007.

Daniels, Dwight R. “Is There a 'Prophetic Lawsuit' Genre?” ZAW 99 (1987): 339-60.

Danker, Frederick William. A Greek-English Lexicon of the New Testament and Other Early Christian Literature. 3rd ed. Chicago, IL: University of Chicago Press, 2000.

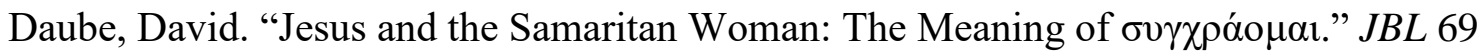
(1950): 137-47.

Davidson, Richard M. Flame of Yahweh: Sexuality in the Old Testament. Peabody, MA: Hendrickson, 2007. 
. "The Divine Covenant Lawsuit Motif in Canonical Perspective." JATS 21 (2010): 45-84.

. "New Testament Use of the Old Testament." JATS 5 (1994): 14-39.

. "The Genesis Account of Origins." Pages 59-129 in The Genesis Creation Account and Its Reverberations in the Old Testament." Edited by Gerald A. Klingbeil. Berrien Springs, MI: Andrews University Press, 2015.

Davies, A. T., ed. Anti-Semitism and the Foundations of Christianity. NY: Paulist, 1979.

Davies, John Arthur. "A Royal Priesthood: Literary and Intertextual Perspectives on an Image of Israel in Exodus 19:6.” TynBul (2002): 157-59.

Davies, Margaret. Rhetoric and Reference in the Fourth Gospel. JSNTSup 69. Sheffield, England: JSOT, 1992.

Davies, Philip R. The Damascus Document. Sheffield, England: JSOT, 1982.

Davis, John D. The WDB. Philadelphia, Westminster, 1944.

De Diétrich, Suzanne. "You Are My Witnesses.” Int 8 (1954): 273-79.

De Jonge, Marinus. "Jesus as Prophet and King in the Fourth Gospel.” ETL 47 (1993): 160-77.

. "Jewish Expectation about the 'Messiah' According to the Fourth Gospel." NTS 19 (1973): 246-70.

. "John the Baptist and Elijah in the Fourth Gospel." Pages 299-309 in The Conversation Continues: Studies in Paul \& John in Honor of J. Louis Martyn. Edited by R. T. Fortna and B. R. Gaventa. Nashville, TN: Abingdon, 1990.

De la Fuente, García. "Los Contratos en el AT Comparados con los de Egipto, Asiria y Babilonia.” EstBíb 14 (1955): 223-54.

De la Potterie, L. "The Truth in Saint John.” Pages 67-82 in The Interpretation of John. 2nd ed. Edited by J. Ashton. Edinburgh: T\&T Clark, 1997.

Dentan, Robert C. The Design of the Scriptures: A First Reader in Biblical Theology. NY: Seabury, 1961. . The Knowledge of God in Ancient Israel. NY: Seabury, 1968. 
De Roche, Michael. "Yahweh rîb Against Israel: A Reassessment of the So-Called 'Prophetic Lawsuit' in the Preexilic Prophets." JBL 102 (1983): 563-74.

Derrett, J. Duncan M. “The Bronze Serpent.” EstBíb 49 (1991): 311-29.

. "Fig Trees in the New Testament." HeyJ 14 (1973): 249-65.

DeSilva, David A. An Introduction to the New Testament: Contexts, Methods, and Ministry Formation. Downers Grove, IL: InterVarsity, 2004.

Dimant, Devorah, and Lawrence H. Schiffman, eds. Time to Prepare the Way in the Wilderness. STDJ 16. Leiden: Brill, 1995.

Dodd, C. H. The Interpretation of the Fourth Gospel. Cambridge, England: Cambridge University Press, 1953.

. "Spatial Form in Exodus 19:1-8a and in the Larger Sinai Narrative." Semeia 46 (1989): 87-101.

Draisma, Spike, ed. Intertextuality in Biblical Writings: Essays in Honour of Bas van Iersel. Kampen, Netherlands: J. H. Kok, 1989.

Drane, John. Introducing the New Testament. 3rd ed. Minneapolis, MN: Fortress, 2011.

Drimmer, Frederick. Daughters of Eve: Women in the Bible. Norwolk, CT: C. R. Gibson, 1975.

Driver, Godfrey R., and John C. Miles. The Assyrian Laws. Oxford: Clarendon, 1935. . The Babylonian Laws. 2 vols. Oxford: Clarendon, 1952-55.

Driver, S. R. Deuteronomy. ICC. NY: Scribner, 1895.

Dumbrell, William J. Covenant and Creation: A Theology of Old Testament Covenants. Nashville, TN: Thomas Nelson, 1984.

Dunn, J. D. G. Jesus and the Spirit: A Study of the Religious and Charismatic Experience of Jesus and the First Christians as Reflected in the New Testament. Philadelphia, PA: Fortress, 1975.

Du Rand, Jan Abraham. Johannine Perspectives: Introduction to the Johannine Writings. NY: Orion, 1991.

Durham, John I. Exodus. WBC 3. Nashville: Thomas Nelson, 1987. 
Ehrman, Bart D. A Brief Introduction to the New Testament. New York, NY: Oxford University Press, 2004.

. The New Testament: A Historical Introduction to the Early Christian Writings. 3rd ed. New York, NY: Oxford University Press, 2004.

Eischrodt, W. "Covenant and Law." Int 20 (1966): 302-21.

Eller, Vernard. The Beloved Disciple: His Name, His Story, His Thought. Grand Rapids, MI: Eerdmans, 1987.

Ellis, E. Earle. Christ and the Future in New Testament History. NovTSup 97. Leiden: Brill, 2000.

. The World of St. John: The Gospel and the Epistles. Grand Rapids, MI: Eerdmans, 1984.

Ellsberg, Robert. All Saints: Daily Reflections on Saints, Prophets, and Witnesses for our Time. NY: Crossroad, 1999.

Elwell, Walter A., ed. BTDB. Grand Rapids, MI: Baker Books, 1996.

Elwell, Walter A., and Philip W. Comfort, eds. TBD. Wheaton, IL: Tyndale House, 2001.

Enz, Jacob J. "The Book of Exodus as a Literary Type for the Gospel of John.” JBL 76 (1957): 208-15.

Eph'al, Israel. "Esarhaddon, Egypt, and Shubria: Politics and Propaganda.” JCS 57 (2005): 99-111.

Erdman, Charles R. The Gospel of John: An Exposition. Philadelphia, PA: Westminster, 1944.

Evans, Craig A. "Abraham in the Dead Sea Scrolls: A Man of Faith and Failure." Pages 149-58 in The Bible at Qumran: Text, Shape, and Interpretation. SDSSRL 1. Edited by Peter W. Flint. Grand Rapids, MI: Eerdmans, 2001.

, ed. From Prophecy to Testament: The Function of the Old Testament in the New. Peabody, MA: Hendrickson, 2004.

. "Messianism." Pages 698-703 in Dictionary of New Testament Background: A Compendium of Contemporary Biblical Scholarship. Edited by Craig A. Evans and Stanley E. Porter. Downers Grove, IL: IVP, 2000. 
Evans, Craig A., and Shemaryahu Talmon, eds. The Quest for Context and Meaning: Studies in Biblical Intertextuality in Honor of James A. Sanders. Leiden, Netherlands: Brill, 1997.

Evelyn, Francis A. “The Supra-Racial Gospel.” ExpTim 49 (1938): 419-21.

Faierstein, Morris M. "Why Do the Scribes Say That Elijah Must Come First?” JBL 100 (1981): 75-86.

Falk, Z. W. "Forms of Testimony.” VT 11 (1961): 88-91.

Farkas, David S. "In Search of the Biblical Hammurabi.” JBQ 39 (2011): 159-64.

Faxon, Alicia Craig. Women and Jesus. Philadelphia, PA: United Church, 1973.

Fehribach, Adeline. The Women in the Life of the Bridegroom: A Feminist HistoricalLiterary Analysis of the Female Characters in the Fourth Gospel. Collegeville, PA: The Liturgical, 1998.

Feinberg, John S., ed. Continuity and Discontinuity: Perspective on the Relationship between the Old and the New Testaments. Wheaton, IL: Crossway, 1988.

Fensham, F. Charles. "Clauses of Protection in Hittite Vassal-Treaties and the Old Testament." VT 13 (1963): 133-43.

. "Common Trends in Curses of the Near Eastern and Kudurru-Inscriptions Compared with Maledictions of Amos and Isaiah.” ZAW 75 (1963): 155-75.

. "Maledictions and Benedictions in the Ancient Near Eastern Vassal-Treaties and the Old Testament." ZAW 74 (1962): 1-19.

. "The Possibility of the Presence of Casuistic Legal Material at the Making of the Covenant at Sinai." PEQ 93 (1961): 143-46.

Fernando, Ajith. Deuteronomy: Loving Obedience to a Loving God. Preaching the Word. Edited by R. Kent Hughes. Wheaton, IL: Crossway, 2012.

Feuillet, André. Johannine Studies. Staten Island, NY: Alba House, 1965.

Fewell, Danna Nolan, ed. Reading Between Texts: Intertextuality and the Hebrew Bible. Louisville, KY: Westminster John Knox, 1992.

Fiorenza, Elisabeth Schüssler. In Memory of Her: A Feminist Theological Reconstruction of Christian Origins. NY: Crossroad, 1989. 
Fishbane, Michael. "Accusations of Adultery: A Study of Law and Scribal Practice in Number 5:11-31." HUCA 45 (1974): 25-45.

. Biblical Interpretation in Ancient Israel. Oxford: Clarendon, 1985.

. “Types of Biblical Intertextuality.” Pages 39-44 in Congres Volume. VTSup 80. Edited by A. Lemaire and M. Saebo (Boston, MA: Brill, 2000.

Fitzmyer, Joseph A. “More About Elijah Coming First.” JBL 104 (1985): 295-96.

Flemming, Dean. Contextualization in the New Testament: Patterns for Theology and Mission. Downers Grove, IL: InterVarsity, 2005.

Fortna, Robert T. The Gospel of Signs. Cambridge: Cambridge University Press, 1970.

Foubister, David Ronald. "The Nature and Purpose of Jesus' Miracles in the Gospels." Ph.D. diss., Fuller Theological Seminary, 1981.

Fowler, Robert M. "Who is 'the Reader' in Reader Response Criticism." Semeia 31 (1985): 5-23.

Frankena, R. "The Vassal Treaties of Esarhaddon and the Dating of Deuteronomy." OtSt 14 (1965): 122-54.

Fredrickson, Roger L. John. The Communicator's Commentary 4. Edited by Lloyd J. Ogilvie. Waco, TX: Word Books, 1985.

Freed, Edwin D. Old Testament Quotations in the Gospel of John. Netherlands: Brill, 1965.

Freedman, David N., ed. ABD. 6 vols. NY: Doubleday, 1992.

Fretheim, Terence E. "Because the Whole Earth is Mine: Theme and Narrative in Exodus.” Int 50 (1996): 229-39.

. Exodus. IBC. Louisville, KY: John Knox, 1991.

. The Pentateuch. IBT. Nashville: Abingdon, 1996.

. The Suffering of God: An Old Testament Perspective. Philadelphia, PA: Fortress, 1984.

Frey, Jörg, Jan G. Van der Watt, and Ruben Zimmermann. Imagery in the Gospel of John Tübingen, Germany: Mohr Siebeck, 2006.

Frymer-Kensky, T. “The Strange Case of the Suspected Sotah.” VT 34 (1984): 11-26. 
Fulco, William J. Maranatha: Reflections on the Mystical Theology of John the Evangelist. NY: Paulist, 1973.

Fuller, Reginald H. Interpreting the Miracles. London: Student Christian Movement, 1963. . The Foundations of New Testament Christology. NY: Scribner, 1965.

Gaebelein, Frank E., ed. John-Acts. EBC 9. Grand Rapids, MI: Zondervan, 1990.

Gane, Roy. Genesis, Exodus, Leviticus, Numbers, Deuteronomy. Zondervan Illustrated Bible Backgrounds Commentary: Old Testament. Volume 1. Edited by John H. Walton. Grand Rapids, MI: Zondervan, 2009. . Leviticus, Numbers. NIVAC. Grand Rapids, MI: Zondervan, 2004.

García Martínez, Florentino. The Dead Sea Scrolls Translated: The Qumran Texts in English. 2nd ed. Grand Rapids, MI: Eerdmans, 1996.

Garrison, Webb B. Women in the Life of Jesus. Indianapolis, IN: Bobbs-Merrill, 1962.

Garstang, John. The Hittite Empire: Being a Survey of the History, Geography and Monuments of Hittite Asia Minor and Syria. NY: Richard R. Smith, 1930.

Garvie, Alfred Ernest. The Beloved Disciple: Studies of the Fourth Gospel. London: Hodder \& Stoughton, 1922.

Geisler, Norman L. If God, Why Evil?: A New Way to Think about the Question. Bloomington, MN: Bethany House, 2011.

Gelb, Ignace J. Review of D. J. Wiseman, The Vassal Treaties of Esarhaddon. BO 19 (1962): 159-62.

Gemser, B. "The Rîb- or Controversy-pattern in Hebrew Mentality." Pages 120-37 in Wisdom in Israel and in the Ancient Near East. VTSup 3. Edited by Martin North and D. Winton Thomas. Leiden: Brill, 1955.

Gentry, Peter John. "The Covenant at Sinai.” SBJT 12 (2008): 38-63.

Gerbrandt, Gerald Eddie. Deuteronomy. BCBC. Edited by Douglas B. Miller and Loren L. Johns. Harrisonburg, VA: Herald, 2015.

Gerstenberger, Erhard S. “Covenant and Commandment.” JBL 84 (1965): 38-51. . Leviticus: A Commentary. OTL. Louisville, KY: Westminster John Knox, 1996. 
Gertel, Elliot B. "Sinai and What Makes Us Jewish.” Judaism 42 (1993): 29-42.

Getty-Sullivan, Mary Ann. Women in the New Testament. Collegeville: Liturgical, 2001.

Gevirtz, Stanley. "West-Semitic Curses and the Problem of the Origins of Hebrew Law." VT 11 (1961): 137-58.

Giere, S. D. A New Glimpse of Day One: Intertextuality, History of Interpretation, and Genesis 1.1-5. Berlin: Walter de Gruyter, 2009.

Glasson, T. Francis. "John the Baptist in the Fourth Gospel.” ExpTim 67 (1956): 245-46. . Moses in the Fourth Gospel. SBT 40. London: Student Christian Movement, 1963.

Godet, Frederick Louis. Commentary on the Gospel of John. Translated from the 3rd French ed. with Preface, Introductory Suggestion and Additional Notes by Timothy Dwight. Grand Rapids, MI: Zondervan, 1955.

Goldfeld, Anne. "Women as Sources of Torah in the Rabbinic Tradition." Judaism 24 (1975): 245-56.

Gressmann, Hugo. "Die literarische Analyse Deuterojesajas.” ZAW 34 (1914): 254-97.

Gundry, Robert H. Commentary on the New Testament: Verse-by-Verse Explanations with a Literal Translation. Peabody, MA: Hendrickson, 2010.

. "New Wine in Old Wineskins: Bursting Traditional Interpretations in John's Gospel (Part 1).” BBR 17 (2007): 115-30.

Gunkel, Hermann. Die Psalmen. Göttingen: Vandenhoeck and Ruprecht, 1926.

. "Propheten Israels seit Amos." in Religion in Geschichte und Gegenwart. 2nd ed. Tübingen: Mohr, 1909-1913.

Gunkel, Hermann, and Joachim Begrich. An Introduction to the Psalms: The Genres of the Religions Lyric of Israel. Translated by James D. Nogalski. Macon, GA: Mercer University Press, 1998.

Gurney, Oliver R. "Hittite Prayers of Mursili II.” AAA 27 (1940): 3-163.

. Some Aspects of Hittite Religion. Oxford, England: Oxford University Press, 1977.

. The Hittites. Baltimore: Penguin, 1961. 
Güterbok, Hans G. Authority and Law in the Hittite Kingdom. JAOSSup 17. New Haven: American Oriental Society. 1954.

Hahn, Ferdinand. The Titles of Jesus in Christology: Their History in Early Christianity. Translated by H. Knight and George Ogg. London: Lutterworth, 1969.

Hakola, Raimo. Identity Matters: John, the Jews and Jewishness. NovTSup 118. Leiden: Brill, 2005.

Hallo, William W., and K. Lawson Younger, eds. Early Mesopotamian Royal Titles. AOS 43. New Haven: AOS, 1957.

Hamilton, Victor P. The Book of Genesis. 2 vols. NICOT. Grand Rapids, MI: Eerdmans, 1990-1995.

Hammer, Robert Alan. “The New Covenant of Moses.” Judaism 27 (1978): 345-50.

Hara, Minoru. “Divine Witness.” Journal of Indian Philosophy 37 (2009): 253-72.

Harner, Philip B. The "I Am" of the Fourth Gospel: A Study in Johannine Usage and Thought. FBBS 26. Philadelphia, PA: Fortress, 1970.

Harper, Robert Francis. The Code of Hammurabi, King of Babylon. London: University of Chicago Press, 1904.

Harrison, E. F., ed. BDT. Grand Rapids, MI: Baker Book House, 1968.

Harris, Elizabeth. Prologue and Gospel: The Theology of the Fourth Evangelist. Sheffield, England: Sheffield Academic, 1994.

Harris, R. Laird, Gleason Archer, and Bruce Waltke. TWOT. 2 vols. Chicago: Moody, 1981.

Harrison, R. K. Numbers: An Exegetical Commentary. Grand Rapids, MI: Baker Book House, 1992.

Hartley, John. Leviticus. WBC 4. Nashville: Thomas Nelson, 1992.

Harvey, Anthony Ernest. Jesus on Trial: A Study in the Fourth Gospel. London: SPCK, 1976.

Harvey, Julien. 'Le 'Rîb Pattern,' requisitoire prophétique contre Israël, après la rupture de l'alliance." Bib 43 (1962): 172-96.

Hasel, Gerhard. “The Meaning of the Animal Rite in Gen 15.” JSOT 19 (1981): 61-78. 
Hatch, William H. P. “The Meaning of John XVI, 8-11.” HTR 14 (1921): 103-5.

Hayes, John H., and Carl R. Holladay. Biblical Exegesis: A Beginner's Handbook. 3rd ed. Louisville, KY: Westminster John Knox, 2007.

Hayward, Robert. "Phinehas-the Same is Elijah: The Origins of Rabbinic Tradition." JJS 29 (1978): 22-34.

Heanchen, Erns. John 1: Commentary on the Gospel of John 1-6. Hermeneia. Translated and Edited by Robert W. Funk. Philadelphia, PA: Fortress, 1984.

Helyer, Larry R. "The Separation of Abram and Lot: Its Significance in the Patriarchal Narratives." JSOT 26 (1983): 77-88.

Hendriksen, William. Exposition of the Gospel According to John: Two Volumes in One. NTC. Grand Rapids, MI: Baker Academic, 1983.

Hengel, Martin. The Johannine Question. Philadelphia, PA: Trinity, 1989.

Hepner, Gershon. Legal Friction. Law, Narrative, and Identity Politics in Biblical Israel. NY: Peter Lang, 2010.

Hernando, James D. Dictionary of Hermeneutics: A Concise Guide to Terms, Names, Methods, and Expressions. Springfield, MI: Gospel Publishing House, 2005.

Hillers, Delbert R. “Covenant.” Pages 133-37 in vol. 4 of ER. Edited by Mircea Eliade. 16 vols. NY: Macmillan, 1987.

. Covenant: The History of a Biblical Idea. Baltimore, MD: Johns Hopkins University Press, 1969.

. Treaty-Curses and the Old Testament Prophets. BibOr 16. Rome: Pontifical Biblical Institute, 1964.

Holladay, William L. The Root Sûbh in the OT with Particular Reference to its Usage in Covenant Contexts. Leiden: Brill, 1958.

Holtz, Shalom E. "Inventing God's Law: How the Covenant Code of the Bible Used and Revised the Laws of Hammurabi." $C B Q 72$ (2010): 820-22.

. "The Prophet as Summoner." No pages. Cited 10/10/2012. Online: www. academia.edu/1153662/The_Prophet_as_Summoner.

Hooker, Morna D. "John the Baptist and the Johannine Prologue.” NTS 16 (1969-1970): 354-58. 
Horong, Michael. Introducing Covenant Theology. Grand Rapids, MI: Baker Book House, 2006.

Horsley, Richard A. "Like One of the Prophets of Old: Two Types of Popular Prophets at the Time of Jesus." CBQ 47 (1985): 435-63.

Horton, Michael. Introducing Covenant Theology. Grand Rapids, MI: Baker Book House, 2006.

Hoskyns, Edwin C. “Genesis I-III and St John’s Gospel.” JTS 21 (1920): 210-18. . The Fourth Gospel. 2nd ed. London: Faber, 1947.

House, Paul R. Old Testament Theology. Downers Grove, IL: InterVarsity, 1998.

Howard, Wilbert F. Christianity According to St. John. London: Duckworth, 1943. . The Fourth Gospel in Recent Criticism and Interpretation. London: Epworth, 1931.

Huckle, John J., and Paul Visokay. The Gospel According to St. John. 3 Vols. NY: Crossroad, 1981.

Huffmon, Herbert B. "The Covenant Lawsuit in the Prophets.” JBL 78 (1959): 285-95.

Hunt, Steven A. "Nicodemus, Lazarus, and the Fear of 'the Jews' in the Fourth Gospel." Pages 199-212 in Repetitions and Variations in the Fourth Gospel: Style, Text, Interpretation. BETL 223. Edited by G. Van Belle, M. Labahn, and P. Maritz. Leuven, Belgium: Peeters, 2009.

Hurtado, Larry W. "New Testament Christology: Retrospect and Prospect." Semeia 30 (1984): 15-27.

Hylen, Susan. Allusion and Meaning in John 6. BZNW 137. Berlin: Walter de Gruyter, 2005.

Hyman, F. C. “Women of the Bible.” Judaism 5 (1956): 338-47.

Jacobsen, Thorkild. "Primitive Democracy in Ancient Mesopotamia." JNES 2 (1943): 159-72.

Jackson, Henry Latimer. The Problem of the Fourth Gospel. Cambridge, England: Cambridge University Press, 1918.

Janzen, Waldemar. Exodus. BCBC. Waterloo, Ontario: Herald, 2000. 
Jenni, Erns, and Claus Westermann, ed. TLOT. 3 vols. Peabody, MA: Hendrickson, 1997.

Jeremias, Joachim. Jerusalem in the Time of Jesus: An Investigation into Economic and Social Conditions During the New Testament Period. Translated by C. H. Cave and F. H. Cave. Philadelphia, PA: Fortress, 1975.

Johns, Loren L., and Douglas B. Miller. "The Signs as Witnesses in the Fourth Gospel: Reexamining the Evidence." CBQ 56 (1994): 519-35.

Johnson, David H. "Our Father Jacob: The Role of the Jacob Narrative in the Fourth Gospel Compared to Its Role in the Jewish Bible and in the Writings of Early Judaism." Ph.D. diss., Trinity Evangelical Divinity School, 1992.

Johnson, Luke Timothy. The Writings of the New Testament. 3rd ed. Minneapolis, MN: Fortress, 2010.

Johnston, George. “The Spirit-Paraclete in the Gospel of John.” Per 9 (1968): 29-37.

Johnston, L. "The Making of the Fourth Gospel." Scr 12 (1960): 1-13.

Jong, Maltthijs J. Isaiah Among the Ancient Near Eastern Prophets: A comparative Study of the Earliest Stages of the Isaiah Tradition and the Neo-Assyrian Prophecies. VTSup. Leiden: Brill, 2007.

Kaiser, Walter C., Darrell L. Block, and Peter Enns. Three Views on the New Testament use of the Old Testament. Edited by Kenneth Berding, Jonathan Lunde, and Stanley N. Gundry. Grand Rapids, MI: Zondervan, 2008.

Kalluveettil, Paul. Declaration and Covenant. AnBib 88. Rome: Biblical Institute, 1982.

Kapelrud, Arvid S. “The Covenant as Agreement." SJOT 1 (1988): 30-38.

Käsemann, Ernest. New Testament Questions of Today. London: SCMP, 1969.

. The Testament of Jesus: A Study of the Gospel of John in Light of Chapter 17. Philadelphia: Fortress, 1968.

Keener, Craig S. The Gospel of John: A Commentary. 2 vols. Peabody, MA: Hendrickson, 2010.

Keil, C. F., and F. Delitzch. Biblical Commentary on the Old Testament. Translated by J. Martin et al. 25 vols. Edinburgh, 1857-1878. Reprint, 10 vols., Grand Rapids, MI: Eerdmans, 1983.

Kelley, Shawn. "Let the Reader Understand: A Response." Proc 13 (1993): 241-53. 
Kennedy, George Alexander. Classical Rhetoric \& Its Christian and Secular Tradition from Ancient to Modern Times. Rev. and enl. 2d ed. Chapel Hill: University of North Carolina Press, 1999.

. New Testament Interpretation through Rhetorical Criticism. Chapel Hill: University of North Carolina Press, 1984.

Kiefer, René. “John.” Pages 960-1000 in The Oxford Bible Commentary. Edited by John Barton and John Muddiman. Oxford, NY: Oxford University Press, 2001.

Kierspel, Lars. The Jews and the World in the Fourth Gospel: Parallelism, Function, and Context. WUNT 220. Tubingen: Mohr Siebeck, 2006.

Kitchen, Kenneth A. Ancient Orient and Old Testament. Chicago, IL: InterVarsity, 1966. . "The Fall and Rise of Covenant: Torah and Treaty." TynBul 40 (1989): 118-35.

Kitchen, Kenneth A., and Paul J. N. Lawrence, Treaty, Law and Covenant in the Ancient Near East. 3 vols. Wiebaden: Harrassowitz Verlag, 2012.

Kittel, Gerhard, ed. TDNT. Grand Rapids, MI: Eerdmans, 1967.

Kline, Meredith G. Deuteronomy. WBC. Edited by C. F. Pfeiffer and E. F. Harrison. Chicago, IL: Moody, 1962.

. “Dynastic Covenant." WTJ 23 (1960): 1-15.

. "Law Covenant." WTJ 27 (1964): 1-20.

. "The Two Tables of the Covenant.” WTJ 22 (1960): 133-46.

. Treaty of the Great King: The Covenant Structure of Deuteronomy. Grand Rapids, MI: Eerdmans, 1963.

Klingbeil, Gerald A. "The Text and the Canon of Scripture." Pages 91-110 in Understanding Scripture: An Adventist Approach. Edited by George W. Reid. Hagerstown, MD: Review and Herald Publishing Association, 2006.

Klingler, David Ryan. "Validity in the Identification and Interpretation of a Literary Allusion in the Hebrew Bible." Ph.D. diss., Dallas Theological Seminary, 2010.

Knierim, Rolf P. The Task of Old Testament Theology: Substance, Method, and Cases. Grand Rapids, MI: Eerdmans, 1995. 
Koester, Craig R. Symbolism in the Fourth Gospel: Meaning, Mystery, Community. Minneapolis, MN: Fortress, 1995.

Koester, Helmut. "The History-of-Religions School, Gnosis, and Gospel of John.” ST 40 (1986): 115-36.

Köhler, Ludwig. Deuterojesaja stilkritisch untersucht. BZAW 37. Giessen: Alfred Töpelmann, 1923.

Köhler, Ludwig, and Walter Baumgartner. HALOT. 2 vols. Leiden: Brill, 2001.

Korosec, Viktor. "The Warfare of the Hittites-From the Legal Point of View." Iraq 25 (1963): 159-66.

Köstenberger, Andreas J. A Theology of John's Gospel and Letters: The Word, the Christ, the Son of God. BTNTS. Grand Rapids, MI: Zondervan, 2009.

. Encountering John: The Gospel in Historical, Literary, and Theological Perspective. Encountering Biblical Studies. Edited by Walter A. Elwell. Grand Rapids, MI: Baker Academic, 1999.

. Studies on John and Gender: A Decade of Scholarship. SBL 38. NY: Peter Lang, 2001.

Kruse, Coling G. The Gospel According to John: An Introduction and Commentary. TNTC 4. Grand Rapids, MI: Eerdmans, 2003.

Kruse, Heinz. "Exodus 19:5 and the Mission of Israel.” NAJT 24-25 (1980): 129-35.

Kuhn, Karl Allen. The Heart of Biblical Narrative: Rediscovering Biblical Appeal to the Emotions. MN: Fortress, 2009.

Kurz, W. S. Farewell Addresses in the New Testament. Zacchaeus Studies: New Testament. MN: Michael Glazier, 1990.

Kysar, Robert. John's Story of Jesus. Philadelphia, PA: Fortress, 1984. . John: The Maverick Gospel. Atlanta, GA: John Knox, 1976.

. The Fourth Evangelist and His Gospel: An Examination of Contemporary Scholarship. Minneapolis, MN: Augsburg, 1975.

Labahn, Michael. "Controversial Revelation in Deed and Word: The Feeding of the Five Thousand and Jesus' Crossing of the Sea as a 'Prelude' to the Johannine Bread of Life Discourse." IBS 22 (2000): 146-81. 
Lamb, David T. "The Non-Eternal Dynastic Promises of Jehu of Israel and Esarhaddon of Assyria." VT 60 (2010): 337-44.

Laney, J. Carl. “The Role of the Prophets in God's Case against Israel.” BSac 138 (1981): $313-25$.

Lauinger, Jacob. "Esarhaddon's Succession Treaty at Tell Tayinat: Text and Commentary." JCS 64 (2012): 87-123.

Lawrence, Paul J. The Books of Moses Revisited. Eugene, OR: Wipf \& Stock, 2011.

Leaney, A. R. C. "The Johannine Paraclete and the Qumran Scrolls." Pages 38-61 in John and the Dead Sea Scrolls. Edited by James H. Charlesworth. NY: Crossroad, 1990.

Leene, Henk. Newness in Old Testament Prophecy: An Intertextual Study. OTS 64. Edited by B. Becking. Boston, MA: Brill, 2014.

Lehmann, Manfred R. “Abraham's Purchase of Machpelah and Hittite Law.” BASOR 129 (1953): 15-17.

Leichty, Erle. The Royal Inscriptions of Neo-Assyrian Period. Winona Lake, IN: Eisenbraus, 2011.

Leithart, Peter J. Deep Exegesis: The Mystery of Reading Scripture. Waco, TX: Baylor University Press, 2009.

Lenski, Richard C. H. Interpretation of St. John's Gospel. Columbus, OH: Lutheran Book Concern, 1942.

Levenson, Jon D. “Covenant and Commandment.” Tradition 21 (1983): 42-51. . "The Theologies of Commandment in Biblical Israel." HTR 73 (1980): 17-33.

Levine, Baruch A. Numbers. AB 4-4A. NY: Doubleday, 1993-2000.

Levinson, Bernard M. "Esarhaddon's Succession Treaty as Source for the Canon Formula in Deuteronomy 13:1." JAOS 130 (2010): 337-47.

Levison, J. R. "Did the Spirit Inspire Rhetoric?: An Exploration of George Kennedy's Definition of Early Christian Rhetoric." Pages 25-40 in Persuasive Artistry: Studies in New Testament Rhetoric in Honor of George A. Kennedy. Edited by Duane F. Watson. JSOTSup 50. Sheffield, England; JSOT, 1991.

Lewis, J. P. A Study of the Interpretation of Noah and the Flood in Jewish and Christian Literature. Leiden: Brill, 1968. 
Lewy, Immanuel. "The Puzzle of Dt. XXVII. Blessings Announced but Curses Noted." VT 12 (1962): 207-11.

Lierman, John. The New Testament Moses: Christian Perceptions of Moses and Israel in the Setting of Jewish Religion. WUNT 173. Tübingen: Mohr Siebeck, 2004.

Lightfoot, John. A Commentary on the New Testament from the Talmud and Hebraica, Matthew - I Corinthians: Luke - John. Grand Rapids, MI: Baker Book House, 1979.

Limburg, James. "The Lawsuit of God in the Eight-Century Prophets.” Th.D. diss., Union Theological Seminary, 1969.

. ריב ריב and the Prophetic Lawsuit Speeches." JBL 88 (1969): 291-304.

Lincoln, Andrew T. "The Beloved Disciple as Eyewitness and the Fourth Gospel as Witness." JSNT 85 (2002): 3-26.

. "Trials, Plots and the Narrative of the Fourth Gospel." JSNT 56 (1994): 3-30.

. Truth on Trial: The Lawsuit Motif in the Fourth Gospel. Peabody, MA: Hendrickson, 2000.

. " 'We Know that His Testimony is True:' Johannine Truth, Claims, and Historicity." Pages 179-97 in John, Jesus, and History: Critical Appraisals of Critical Views. Volume 1. SBLSymS 44. Edited by Paul N. Anderson, Felix Just, and Tom Thatcher. Atlanta, GA: SBL, 2007.

Lindars, Barnabas. The Gospel of John. NCB. Greenwood, SC: The Attic, 1977.

Lockyer, Herber. The Women of the Bible. Grand Rapids, MI: Zondervan, 1967.

Loewenstamm, S. E. Comparative Studies in Biblical and Ancient Literatures. AOAT 204. Kevelaer: Butzon \& Bercker, 1980.

Logan, Alastair H. B. "John and the Gnostics: The Significance of John for the Debate about the Origin of the Johannine Literature." Pages 109-37 in The Johannine Writings. Edited by Stanley E. Porter and Craig A. Evans. Sheffield, England: Sheffield Academic, 1995.

Lohse, Eduard. "Miracles in the Fourth Gospel." Pages 64-75 in What About the New Testament?: Essays in Honour of Christopher Evans. Edited by Morna Hooker and Colin Hickling. London: Student Christian Movement, 1975. 
Longenecker, Richard. Biblical Exegesis in the Apostolic Period. Grand Rapids, MI: Eerdmans, 1975.

Longman, Tremper, and David E. Garland, eds. EBC 1. Grand Rapids, MI: Zondervan, 2006-2008.

Longman, Tremper, and Peter Enns. Dictionary of the Old Testament: Wisdom, Poetry and Writings. Downers Grove, IL: InterVarsity, 2008.

Longman, Tremper, and Raymond B. Dillard. An Introduction to the Old Testament. 2nd ed. Grand Rapids, MI: Zondervan, 2006.

Lopez, René. "Israelite Covenant in the Light of Ancient Near Eastern Covenants (Part 2 of 2)." CTSJ 10 (2004): 72-106.

Lucas, Ernest C. “Covenant, Treaty and Prophecy.” Themelios 8 (1982): 19-23.

Luthardt, Christoph Ernst. St. John's Gospel Described and Explained According to its Peculiar Character. 3 vols. Edinburgh: T\&T Clark, 1876-1878.

Lutkemeyer, Lawrence, J. "The Role of the Paraclete.” $C B Q 8$ (1946): 220-29.

Maarsingh, B. Numbers: A Practical Commentary. Translated by John Vriend. Grand Rapids, MI: Eerdmans, 1987.

Mabee, Charles. "Jacob and Laban: The Structure of Judicial Proceedings (Genesis XXXI 25-42)." VT 30 (1980): 192-207.

Maccini, Robert Gordon. Her Testimony Is True: Women as Witnesses According to John. Sheffield, England: Sheffield Academic, 1996.

MacIntosh, Jane. Ancient Mesopotamia: New Perspective. Santa Barbara, CA: ABCCLIO, 2005.

Macqueen, J. G. The Hittites and Their Contemporaries in Asia Minor. Rev. and enl. ed. London: Thames \& Hudson, 1975.

Mafico, T. J. "The Crucial Question Concerning the Justice of God (Gen. 18:23-26)." JTSA 42 (1983): 11-16.

Malamat, Abraham. "Doctrines of Causality in Hittite and Biblical Historiography: A Parallel." VT 5 (1955): 1-12.

Malatesta, Edward. "The Spirit/Paraclete in the Fourth Gospel." Bib 54 (1973): 539-50. 
Malina, Bruce J. The Palestinian Manna Tradition: The Manna Tradition in the Palestinian Targums and Its Relationship to the New Testament Writings. AGSJU 7. Leiden: Brill, 1968.

Malphurs, Aubrey. Biblical Manhood and Womanhood: Understanding Masculinity and Femininity from God's Perspective. Grand Rapids, MI: Kregel, 1996.

Malul, Meir. "More on pachad vitschāq (Genesis 31:42, 53) and the Oath by the Thigh." VT 35 (1985): 192-200.

Manning, Gary T. Echoes of a Prophet: The Use of Ezekiel in the Gospel of John and in Literature of the Second Temple Period. JSNTSup 270. London: T\&T Clark, 2004.

Manson, T. W. The Teaching of Jesus. Cambridge: Cambridge University Press, 1931.

Maronde, Christopher A. "Moses in the Gospel of John.” CTQ 77 (2013): 23-44.

Marrs, Rick R. "John 3:14-15: The Raised Serpent in the Wilderness, the Johannine Use of an Old Testament Account." Pages 141-47 in Johannine Studies: Essays in Honor of Frank Pack. Edited by James Eugene Priest. Malibu, CA: Pepperdine University Press, 1989.

Marsh, John. Saint John. WPC. Philadelphia, PA: Westminster, 1977.

Marshal, I. Howard. New Testament Theology: Many Witnesses, One Gospel. Downers Grove, IL: InterVarsity, 2004.

Martin, J. D. "Ben Sira's Hymn to the Fathers: A Messianic Perspective.” Pages 107-33 in Crises and Perspectives: Studies in Ancient Near Eastern Polytheism, Biblical Theology, Palestinian Archaeology, and Intertestamental Literature, Papers Read at the Joint British-Dutch Old Testament Conference, Held at Cambridge, U.K., 1985. OtSt 24. Edited by Johannes Cornelis de Moor. Leiden: Brill, 1986.

Martini, Carlo M. Women in the Gospels. NY: Crossroad, 1990.

Martyn, J. Louis. History and Theology in the Fourth Gospel. 2nd ed. Nashville, TN: Parthenon, 1979.

Mathews, Kenneth A. Genesis. NAC 1A-B: An Exegetical and Theological Exposition of Holy Scripture. Nashville, TN: Broadman \& Holman, 1996-2005.

Mayes, A. D. H. Deuteronomy. NCB. Greenwood, SC: Attic, 1979.

McCaffrey, James. The House with Many Rooms: The Temple Theme of Jn. 14, 2-3. AnBib 114. Roma: Editrice Pontificio Istituto Biblico, 1988. 
McCarthy, Dennis J. " $b^{e} r i ̂ t$ in Old Testament History and Theology.” Bib 53 (1972): 10121.

. "Covenant in the Old Testament: The Present State of the Inquiry." $C B Q 27$ (1965): 217-40.

. Old Testament Covenant: A Survey of Current Opinions. Oxford: Blackwell, 1972.

. "Three Covenants in Genesis." CBQ 26 (1964): 179-89.

. Treaty and Covenant: A Study in Form in the Ancient Oriental Documents and in the Old Testament. Rome: Pontifical Biblical Institute, 1981.

McCasland, Vernon. "Signs and Wonders." JBL 76 (1957): 149-52.

McConville, J. G. Law and Theology in Deuteronomy. JSOTSup 33. Sheffield, England: JSOT, 1984.

McGrath, Alister E. The Making of Modern German Christology: 1750-1990. 2d ed. Grand Rapids, MI: Zondervan, 1994.

McKenzie, John L. "The Divine Sonship of Israel and the Covenant.” CBQ 8 (1946): 320-31.

McKeown, R. E. "A Prolegomena to a Doctrine of the Holy Spirit: Studies in Biblical Sources and Epistemological Considerations." Ph.D. diss., Duke University, 1976.

McKnight, Edgar V. Postmodern Use of the Bible: The Emergence of Reader-Oriented Criticism. Nashville: Abingdon, 1988.

McWhirter, Jocelyn. The Bridegroom Messiah and the People of God: Marriage in the Fourth Gospel. Cambridge, United Kingdom: Cambridge University Press, 2006.

Meeks, Wayne A. The Prophet-King: Moses Traditions and the Johannine Christology. NovTSup 14. Leiden: Brill, 1967.

Mendenhall, George E. “Ancient Oriental and Biblical Law.” BA 17 (1954): 26-46.

. "Covenant Forms in Israelite Tradition." BA 17 (1954): 50-76.

. Law and Covenant in Israel and the Ancient Near East. Pittsburgh, PA: Biblical Colloquium, 1955. 
. "Puppy and Lettuce in Northwest-Semitic Covenant Making." BASOR 133 (1954): 26-30.

Menken, Maarten J. J. Numerical Literary Techniques in John: The Fourth Evangelist's Use of Numbers of Words and Syllables. Leiden: E. J. Brill, 1985.

. Old Testament Quotations in the Fourth Gospel: Studies in Textual Form. Kampen, Netherlands: Kok Pharos, 1996.

Merrill, Eugene H. "Deuteronomy." Pages 445-679 in Tyndale Cornerstone Biblical Commentary. Edited by Philip W. Comfort. Carol Stream, IL: Tyndale, 2008.

Messerschmidt, L. The Hittites. Translated by J. Hutchison. London: David Nutt, 1903.

Meyer, Heinrich August Wilhelm. Critical and Exegetical Hand-Book to the Gospel of John. MCNT 3. Peabody, MA: Hendrikson, 1983.

Michaels, J. Ramsey. The Gospel of John. NICNT. Grand Rapids, MI: Eerdmans, 2010.

Milgrom, Jacob. Leviticus 23-27: A New Translation with Introduction and Commentary. AB 3B. Doubleday, NY: Doubleday, 2001.

. במדבר Numbers. JPSTC. Philadelphia, PA: JPS, 1989.

Miller, Patrick D. Deuteronomy. Int. Louisville: John Knox, 1990.

Miller, Paul. “ 'They Saw His Glory and Spoke of Him': The Gospel of John and the Old Testament." Pages 127-151 in Hearing the Old Testament in the New Testament. MNTS. Edited by Stanley E. Porter. Grand Rapids, MI: Eerdmans, 2006.

Milton, John P. God's Covenant of Blessing. Rock Island, IL: Augustana, 1961.

Minchin, Basil. Covenant and Sacrifice. London: Longmans, 1958.

Minear, Paul Sevier. Christians and the New Creation: Genesis Motifs in the New Testament. Louisville, KY: Westminster, 1994. . John, The Martyr's Gospel. NY: Pilgrim, 1984.

Moberly, R. W. L. Old Testament Theology: Reading the Hebrew Bible as Christian Scripture. Grand Rapids, MI: Baker Academic, 2013.

Moloney, Francis J. "The Faith of Martha and Mary: A Narrative Approach to John 11, 17-40." Bib 75 (1994): 471-93. 
. The Gospel of John. SP. Edited by Daniel J. Harrington. Collegeville, MN: Liturgical, 1998.

Moltmann-Wendel, Elisabeth. The Women around Jesus. NY: Crossroad, 1987.

Moran, William L. "The Ancient Near Eastern Background of the Love of God in Deuteronomy." CBQ 25 (1963): 77-87.

Morgan, Richard. "Fulfillment in the Fourth Gospel: The Old Testament Foundations." Int 11 (1957): 155-65.

Morgenstern, Julian. "Trial by Ordeal among the Semites in Ancient Israel." HUCA Special Issue (1925): 113-43.

Morris, Leon. The Gospel According to John: The English Text with Introduction, Exposition and Notes. NICNT. Grand Rapids, MI: Eerdmans, 1971.

Moskala, Jiří. “The Gospel According to God's Judgment,” JATS 22 (2011): 28-49.

. "Toward a Biblical Theology of God's Judgment: A Celebration of the Cross in Seven Phases of Divine Universal Judgment (An Overview of a TheocentricChristocentric Approach)." JATS 15 (2004): 138-65.

Mounce, Robert H. “John.” Pages 357-661 in Luke-Acts. EBC 10 revised ed. Edited by Tremper Longman and David E. Garland. Grand Rapids, MI: Zondervan, 2007.

Mounce, William D. Basics of Biblical Greek: Grammar. Grand Rapids, MI: Zondervan, 2003.

, ed. Mounces' Complete Expository Dictionary of Old and New Testament Words. Grand Rapids, MI: Zondervan, 2006.

Moyise, Steve. "Intertextuality." Pages 14-41 in The Old Testament in the New Testament: Essays in Honour of J. L. North. JSNTSup 189. Edited by Steve Moyise. Sheffield, England: Sheffield Academic, 2000.

. The Old Testament in the New: An Introduction. Cont. London: Continuum, 2001.

Muilenburg, James. "The Form and Structure of the Covenantal Formulations." VT 9 (1959): 347-65.

Munn-Rankin, J. M. "Diplomacy in Western Asia in the Early Second Millennium." Iraq 18 (1956): 68-110.

Murray, John. The Covenant of Grace: A Biblico-Theological Study. London: Tyndale, 1956. 
Mussner, Franz. The Historical Jesus in the Gospel of St. John. NY: Herder \& Herder, 1967.

Na'aman, Nadav. Ancient Israel and its Neighbors: Interaction and Counteraction: Collected Essays. Vol. 1. Winona Lake, IN: Eisenbrauns, 2005.

Neeb, John H. C. “Jacob/Jesus Typology in John 1, 51.” PEGLMBS 12 (1992): 83-89.

Neill, Stephen. The Interpretation of the New Testament 1861-1961. London: Oxford University Press, 1964.

Nelson, Richard D. Deuteronomy: A Commentary. OTL. Louisville, KY: Westminster John Knox, 2002.

Neufeld, Dietmar. "And When That One Comes?: Aspects of Johannine Messianism." Pages 120-40 in Eschatology, Messianism, and the Dead Sea Scrolls. SDSSRL 1. Edited by Craig A. Evans and Peter W. Flint. Grand Rapids, MI: Eerdmans, 1997.

Newell, Lloyd D. “John's Testimony and Teachings on Truth." Pages 186-200 in The Testimony of John the Beloved: the $27^{\text {th }}$ Annual Sidney B. Sperry Symposium. Edited by Sidney B. Sperry. Salt Lake City, UT: Deseret Books, 1998.

Newman, Murray L. The People of the Covenant. Nashville, TN: Abingdon, 1962.

Neyrey, Jerome H. "Jacob Traditions and the Interpretation of John 4:10-26." $C B Q 41$ (1979): 419-37.

. "The Jacob Allusions in John 1:51." CBQ 44 (1982): 586-605.

Nicholson, Godfrey C. Death as Departure: The Johannine Descent-Ascent Schema. SBLDS 63. Chico, CA: Scholars, 1983.

Nicol, G. G. "Studies in the Interpretation of Gen 26:1-33.” Ph. D. diss., Oxford, 1987.

Nicol, W. The Semeia in the Fourth Gospel. NovTSup 32. Edited by W. C. van Unnik. Leiden: E. J. Brill, 1972.

Niehaus, Jeffrey J. Ancient Near Eastern Themes in Biblical Theology. Grand Rapids, MI: Kregel, 2008.

Nielsen, Kirsten. "Intertextuality and Hebrew Bible." Pages 17-31 in Congress Volume. VTSup 80. Edited by A. Lemaire and M. Saebo. Boston, MA: Brill, 2000. 
. Yahweh as Prosecutor and Judge: An Investigation of the Prophetic Lawsuit (Rîbpattern). Sheffield, England: Department of Biblical Studies, University of Sheffield, 1978.

Noth, Martin. Leviticus: A Commentary. OTL. Rev. ed. Philadelphia, PA: Westminster, 1965.

. Numbers: A Commentary. OTL. Philadelphia, PA: Westminster, 1968.

. The Laws in the Pentateuch and other Studies. Translated by D. R. Ap-Thomas. Edinburgh: Oliver \& Boyd, 1966.

Ockenga, Harold John. Women Who Made Bible History. Grand Rapids, MI: Zondervan, 1962.

O’Day, Gail R. “John.” Pages 381-93 in Women's Bible Commentary. Edited by Carol A. Newsom and Sharon H. Ringe. Louisville, KY: Westminster John Knox, 1998.

. "Toward a Narrative-Critical Study of John.” Int 49 (1995): 341-46.

Odeberg, Hugo. The Fourth Gospel: Interpreted in Its Relation to Contemporaneous Religious Currents in Palestine and the Hellenistic-Oriental World. Amsterdam: B. R. Grüner, 1968.

Oegema, Gerbern S. The Anointed and His People: Messianic Expectations from Maccabees to Bar Kochba. JSPSup 27. Sheffield, England: Sheffield Academic, 1998.

Olbricht, Thomas H., Dennis L. Stamps, and Stanley E. Porter. Rhetorical Criticism and the Bible. JSNTSup. Sheffield, England: Sheffield Academic, 2002.

Ollenburger, Ben C. Old Testament Theology: Flowering and Future. Sources for Biblical and Theological Study 1. Winona Lake, IL: Eisenbrauns, 2004.

Olson, Dennis T. Numbers. IBC. Louisville, KY: John Knox, 1996.

Olyan, Saul M. "Honor, Shame, and Covenant Relations in Ancient Israel and its Environment." JBL 115 (1996): 201-18.

Orlin, Louis L. Life and Thought in the Ancient Near East. Ann Arbor, MI: University of Michigan Press, 2007.

Osborn, Noel D., and Howard A. Hatton. A Handbook of Exodus. NY: UBS Handbook Series, 1999. 
Osborne, Grant R. "The Gospel of John.” Pages 1-313 in Cornerstone Biblical Commentary. Edited by Philip W. Comfort. IL: Tyndale, 2015. . The Hermeneutical Spiral: A Comprehensive Introduction to Biblical Interpretation. Rev. and exp. ed. Downers Grove, IL: InterVarsity, 2006.

Osburn, Carroll D., ed. Essays on Women in Earliest Christianity. 2 vols. Joplin, MO: College Press, 1995.

Overholt, Thomas W. "Elijah and Elisha in the Context of the Israelite Religion." Pages 94-111 in Prophets and Paradigms: Essays in Honor of Gene M. Tucker. Edited by Stephen Breck Reid. Sheffield, England: Sheffield Academic, 1996.

Painter, John. John: Witness \& Theologian. London: SPCK, 1975. . Reading John's Gospel Today. Atlanta, GA, John Knox, 1975.

. "The Johannine Literature." Pages 555-90 in Handbook to Exegesis of the New Testament. Edited by Stanley E. Porter. Leiden: Brill, 1997.

. The Quest for the Messiah: The History, Literature, and Theology of the Johannine Community. 2nd ed. Nashville, TN: Abingdon, 1993.

Pancaro, Severino. The Law in the Fourth Gospel: The Torah and the Gospel, Moses and Jesus, Judaism and Christianity According to John. NovTSup 42. Leiden: Brill, 1975.

Parnham, F. S. “The Miracle at Cana." EvQ 42 (1970): 107-9.

Paroschi, Wilson. "Incarnation and Covenant in the Prologue to the Fourth Gospel (John 1:1-18).” Ph.D. diss., Andrews University, 2003.

Parry Donald W., and Eugene C. Ulrich, eds. Prove International Conference on the Dead Sea Scrolls: Technological Innovations, New Texts, and Reformulated Issues. STDJ 30. Leiden: E. J. Brill, 1999.

Paulien, Jon. A Practical Guide to Abundant Christian Living in the Book of John. The Abundant Life Bible Amplifier. Edited by George R. Knight. Boise, ID: Pacific Press Publishing Association, 1995.

Perkins, Pheme. "Crisis in Jerusalem: Narrative Criticism in New Testament Studies." TS 50 (1989): 296-313.

Peters, John P. “Excavation in Persia.” HTR 8 (1915): 82-93. 
Petersen, David L. “Covenant Ritual: A Traditio-Historical Perspective.” BR 22 (1977): 7-18.

Pfitzner, Victor C. "The Coronation of the King: The Passion Narrative and Passion Theology in the Gospel of John." LTJ 10 (1976): 1-12.

Phillips, Anthony C. J. "A Fresh Look at the Sinai Pericope: Part 1 and 2." VT 34 (1984): 39-52, 282-300.

Phillips, D. Z. The Problem of Evil and the Problem of God. Minneapolis, MN: Fortress, 2005.

Pike, Mark A. “The Bible and the Reader's Response.” JECB 7 (2003): 37-57.

Pilgaard, Aage. "The Qumran Scrolls and John's Gospel.” Pages 126-42 in New Readings in John: Literary and Theological Perspectives: Essays from the Scandinavian Conference on the Fourth Gospel in Arhus 1997. JSNTSup 182. Edited by J. Nissen and S. Pedersen. Sheffield, England: Sheffield Academic, 1999.

Piper, Otto A. "Unchanging Promises: Exodus in the New Testament." Int 11 (1957): 322.

Plaut, W. Gunther. "Deuteronomy." Pages 1287-588 in The Torah: A Modern Commentary. Edited by W. Gunther Plaut. NY: UAHC, 1981.

Poirier, John C. "Some Detracting Considerations for Reader-Response Theory." CBQ 62 (2000): 250-63.

Porter, Stanley E., and Kent D. Clarke. "What is Exegesis?: An Analysis of Various Definitions." Pages 3-21 in A Handbook to the Exegesis of the New Testament. Edited by Stanley E. Porter. Boston, MA: Brill, 2002.

Powell, Mark Allan. Introducing the New Testament: A Historical, Literary, and Theological Survey. Grand Rapids, MI: Baker Academic, 2009.

. What is Narrative Criticism? MN: Fortress, 1990.

Pregeant, Russell. Encounter with the New Testament: An Interdisciplinary Approach. Minneapolis, MN: Fortress, 2009.

Preiss, Théo. Life in Christ. IL: Alec R. Allenson, 1954.

Price, Eugenia. The Unique World of Women, in Bible Times and Now. Grand Rapids, MI: Zondervan, 1969. 
Priest, John F. “The Covenant of Brothers.” JBL 84 (1965): 400-6.

Pritchard, James B., ed. Ancient Near Eastern Texts Relating to the Old Testament. Princeton, NJ: Princeton University Press, 1950.

, ed. The Ancient Near East: An Anthology of Texts and Pictures. 2 vols. Princeton, NJ: Princeton University Press, 1958-1975.

Pröbstle, Martin. "Truth and Terror: A Text-Oriented Analysis of Daniel 8:9-14." Ph.D. diss., Andrews University, 2006.

Propp, William H. C. Exodus 19-40. AB 2A. NY: Doubleday, 2006.

Pryor, John W. John: Evangelist of the Covenant People: The Narrative and Themes of the Fourth Gospel. Downers Grove, IL: InterVarsity, 1992.

Quast, Kevin. Peter and the Beloved Disciple: Figures for a Community in Crisis. London, Great Britain: Sheffield, 1987.

. Studies in Deuteromony. SBT 9. Translated by D. Stalker. Chicago, IL: Regnery, 1953.

Ramsey, G. W. "Speech-Forms in Hebrew Law and Prophetic Oracles.” JBL 96 (1977): $45-58$.

Rendtorff, Rolf. “ 'Covenant' as a Structuring Concept in Genesis and Exodus.” JBL 108 (1989): 385-93.

. The Covenant Formula: An Exegetical and Theological Investigation. Edinburgh: T\&T Clark, 1998.

Rensberger, David. Johannine Faith and Liberating Community. Philadelphia, PA:

Westminster, 1988.

. "The Politics of John: The Trial of Jesus in the Fourth Gospel." JBL 103 (1984): 395-411.

Resseguie, James L. Narrative Criticism of the New Testament: An Introduction. Grand Rapids, MI: Baker Book House, 2005.

Rice, George E. "Interpretation of the Gospels and the Epistles." Pages 205-22 in Understanding Scripture. Edited by George W. Reid. Silver Spring, MD: Biblical Research Institute, 2006.

Richardson, Alan. An Introduction to the Theology of the New Testament. London: Student Christian Movement, 1958. 
Richardson, M. E. J. Hammurabi's Laws: Text, Translation, and Glossary. London: T\&T Clark, 2004.

Richardson, P., and D. Granskou, eds. Anti-Judaism in Early Christianity. Waterloo: Wilfrid Laurier University Press, 1986.

Ricoeur, Paul. Essays on Biblical Interpretation. Philadelphia, PA: Fortress, 1980.

Riga, Peter. "Signs of Glory: The Use of $\Sigma \eta \mu \varepsilon i ̃ v$ in St. John's Gospel.” Int 17 (1963): 402-24.

Riggans, Walter. Numbers. Philadelphia, PA: Westminster, 1983.

Roberts, Simon. Order and Dispute: An Introduction to Legal Anthropology. Middlesex, England: Penguin, 1979.

Robertson, A. T. Some Minor Characters in the New Testament. Nashville, TN: Sunday School Board of the Southern Baptist Convention, 1928.

Robinson, John A. T. The Priority of John. Oak Park, IL: Meyer-Stone, 1987.

Rofé, Alexander. Deuteronomy: Issues and Interpretation. OTS. London: T\&T Clark, 2002.

Rogers, C. L. "The Covenant with Abraham and Its Historical Setting." BSac 127 (1970): 241-56.

Ruland, Vernon. "Sign and Sacrament: John's Bread of Life Discourse." Int 18 (1964): 450-62.

Rusche, Helga. They Lived by Faith: Women in the Bible. Translated by Elizabeth Williams. Baltimore, MD: Helicon, 1963.

Sailhamer, John H. Introduction to Old Testament Theology: A Canonical Approach. Grand Rapids, MI: Zondervan, 1995.

. The Pentateuch as Narrative: A Biblical-Theological Commentary. Library of Biblical Interpretation. Grand Rapids, MI: Zondervan, 1992.

Sarna, Nahum M. Genesis. JPSTC. Philadelphia, PA: The Jewish Publication Society, 1989.

Sasson, Jack M. "Numbers 5 and the Waters of Judgment.” BZ 16 (1972): 249-51. 
Sassoon, John. Ancient Laws and Modern Problems: The Balance Between Justice and a Legal System. Bristol: Intellect, 2004.

Saucy, Mark R. "Miracles and Jesus' Proclamation of the Kingdom of God." BSac 153 (1996): 281-307.

Sayce, A. H. The Hittites: The Story of a Forgotten Empire. London: The Religious Tract Society, 1892.

Schmidt, Hans. Die großen Propheten. Göttingen: Vandenhoed and Ruprecht, 1915.

Schnackenburg, Rudolf. God's Rule and Kingdom. NY: Herder \& Herder, 1963. . The Gospel According to St. John. 3 vols. NY: Crossroad, 1966-1987.

Schneiders, Sandra. "Women in the Fourth Gospel and the Role of Women in the Contemporary Church." BTB 12 (1982): 35-45.

. Written That You May Believe: Encountering Jesus in the Fourth Gospel. NY: Crossroad, 1999.

Schnelle, Udo. Antidocetic Christology in the Gospel of John: An Investigation of the Place of the Fourth Gospel in the Johannine School. Minneapolis, MN: Fortress, 1992.

Scholtissek, Klaus. "The Johannine Gospel in Recent Research.” Pages 444-72 in The Face of New Testament Studies: A Survey of Recent Research. Edited by Scot McKnight and Grant R. Osborne. Grand Rapids, MI: Baker Academic, 2004.

Schulz, Siegfried. Das Evangelium nach Johannes. 5th ed. Das Neue Testament Deutsch 4. Göttingen: Vandenhoeck \& Ruprecht, 1987.

Scobie, C. H. H. John the Baptist. London: Student Christian Movement, 1964.

Scott, E. F. The Historical and Religious Value of the Fourth Gospel. London: Constable \& Company, 1910.

Segal, Alan F. “Covenant in Rabbinic Writings.” SR 14 (1985): 53-62.

Seibert, Eric A. Disturbing Divine Behavior: Troubling Old Testament Images of God. Minneapolis, MN: Fortress, 2009.

Seim, Turid Karlsen. "Roles of Women in the Gospel of John." Pages 56-73 in Aspects on the Johannine Literature: Papers Presented at a Conference of Scandinavian New Testament Exegetes at Uppsala, June 16-19, 1986. ConBNT 18. Edited by Lars Hartman and Birger Olsson. Uppsala: Uppsala Universitet, 1987. 
Self, Jerry M. Men and Women in John's Gospel. Nashville, TN: Broadman, 1974.

Selman, Martin J. "Law." Pages 497-515 in Dictionary of the Old Testament: Pentateuch. Edited by T. Desmond Alexander and David W. Baker. Downers Grove, IL: InterVarsity, 2003.

ShaDal (S. D. Luzzatto). The Book of Genesis: A Commentary. Northvale, NJ: Jason Aronson, 1998.

Shillington, V. George. "The Spirit-Paraclete as Jesus' alter ego in the Fourth Gospel (John 14-16).”Vision 13 (2012): 31-39.

Siddons, Philip. Speaking Out for Women: A Biblical View. Valley Forge, PA: Judson, 1980.

Silva, Moisés, ed. NIDNTTE. 5 vols. Grand Rapids, MI: Zondervan, 2014.

Sloyan, Gerard S. John. IBC. Atlanta, GA: John Knox, 1988.

Smalley, Stephen S. John: Evangelist and Interpreter. Nashville, TN: Thomas Nelson, 1984.

. The Revelation to John: A Commentary on the Greek Text of the Apocalypse. Downers Grove, IL: InterVarsity, 2005.

Smart, Wyatt Aiken. The Spiritual Gospel. NY: Abingdon-Cokesbury, 1946.

Smith, D. Moody. Proclamation Commentaries: The New Testament Witnesses for Preaching. Edited by Gerhard Krodel. Philadelphia, PA: Fortress, 1976.

Smith, Robert Houston. "Exodus Typology in the Fourth Gospel.” JBL 81 (1962): 32942.

Smith, T. C. “The Book of Signs: John 2-11.” RevExp 62 (1965): 441-57.

Snijders, L. A. “Gen 15: The Covenant with Abram.” OtSt 12 (1958): 261-79.

Speiser, E. A. Genesis. AB 1. Garden City, NY: Doubleday, 1987.

Sperling, S. David. "Rethinking Covenant in the Late Biblical Books.” Bib 70 (1989): 5073.

Spicq, Ceslas. Theological Lexicon of the New Testament. 3 vols. Edited and Translated by James D. Ernest. Peabody, MA: Hendrickson, 1994. 
Stackhouse, John G. Can God be Trusted?: Faith and the Challenge of Evil. Oxford: Oxford University Press, 1998.

Stagg, Evelyn, and Frank Stagg. Women in the World of Jesus. Philadelphia, PA: Westminster, 1978.

Stauffer, Ethelbert. Jesus and His Story. Translated by Richard Winston and Clara Winston. NY: Knopf, 1960.

Stone, Michel E., ed. Jewish Writings of the Second Temple Period: Apocrypha, Pseudepigrapha, Qumran, Sectarian Writings, Philo, Josephus. CRINT 2/2. Assen: Van Gorcum, 1984.

Strachan, Robert Harvey. The Fourth Gospel, its Significance and Environment. London: Student Christian Movement, 1941.

Stuart, Douglas K. Exodus. NAC 2: An Exegetical and Theological Exposition of Holy Scripture. Nashville, TN: Broadman \& Holman, 2006.

Stuhlmacher, Peter. "My Experience with Biblical Theology.” Pages 174-93 in Biblical Theology: Retrospect and Prospect. Edited by Scott J. Hafemann. Downers Grove, IL: InterVarsity, 2002.

Summers, R. Behold the Lamb: An Exposition of the Theological Themes in the Gospel of John. Nashville, TN: Broadman, 1979.

Sumney, Jerry L. The Bible: An Introduction. MN: Fortress, 2010.

Swancutt, Diana M. 'Hungers Assuaged by the Bread from Heaven: 'Eating Jesus' as Isaian Call to Belief, the Confluence of Isaiah 55 and Psalm 78 (77) in John 6:2271." Pages 218-251 in Early Christian Interpretation of the Scriptures of Israel: Investigations and Proposals. JSNTSup 48. Edited by Craig A. Evans and James A. Sanders. Sheffield, England: Sheffield, 1997.

Swezey, Charles M. “Thou Shalt Not Bear False Witness Against Thy Neighbor.” Int 34 (1980): 405-10.

Swidler, Leonard. Biblical Affirmations of Women. Philadelphia, PA: Westminster, 1979.

Swinton, John. Raging with Compassion: Pastoral Responses to the Problem of Evil. Grand Rapids, MI: Eerdmans, 2006.

Tasker, R. V. G. John. TNTC 4. Grand Rapids, MI: Eerdmans, 1995.

Taylor, Joan E., and Federico Adinolfi. "John the Baptist and Jesus the Baptist: A Narrative Critical Approach.” JSHJ 10 (2012): 247-84. 
. The Immerser: John the Baptist within Second Temple Judaism. SHJ. Grand Rapids, MI: Eerdmans, 1997.

Taylor, Michael J., ed. A Companion to John: Readings in Johannine Theology (John's Gospel and Epistles). NY: Alba House, 1977.

Teeple, Howard M. The Mosaic Eschatological Prophet. JBLMS 10. Philadelphia, PA: SBL, 1957.

Tenney, Merrill C. "Topics from the Gospel of John, Part II and III: The Meaning of the Signs.” BSac 132 (1975): 145-60, 229-41.

Thatcher, Tom. "The Sabbath Trick: Unstable Irony in the Fourth Gospel." JSNT 76 (1999): 53-77.

Thielmann, Frank. "Grace in Place of Grace: Jesus Christ and the Mosaic Law in John's Gospel." Pages 92-110 in The Law and the New Testament: The Question of Continuity. CNT. Edited by Frank Thielmann. NY: Crossroad, 1992.

. Theology of the New Testament: A Canonical and Synthetic Approach. Grand Rapids, MI: Zondervan, 2005.

Thiessen, Matthew. "The Form and Function of the Song of Moses (Deuteronomy 32:143).” JBL 123 (2004): 401-24.

Thomas, Cherian. "Jesus the New Moses: A Christological Understanding of the Fourth Gospel.” Th.D. diss., Lutheran School of Theology at Chicago, 1987.

Thompson, John A. "Covenant Patterns in the Ancient Near East and their Significance for Biblical Studies.” RTR 18 (1959): 64-75.

. Deuteronomy: An Introduction and Commentary. TOTC 5. Leicester: InterVarsity, 1974.

. The Ancient Near East Treaty and the Old Testament. London: Tyndale, 1963.

Thompson, Marianne Meye. "Jesus and His God." Pages 41-55 in The Cambridge Companion to Jesus. Edited by Markus Bockmuehl. Cambridge: Cambridge University Press, 2001.

. The God of the Gospel of John. Grand Rapids, MI: Eerdmans, 2001.

. The Promise of the Father. Louisville, KY: Westminster, 2000. 
Thruston, Bonnie. Women in the New Testament: Questions and Commentary. NY: Crossroad, 1998.

Tigay, Jeffrey H. Deuteronomy: דברים. The JPS Torah Commentary. Philadelphia, PA: The Jewish Publication Society, 1996.

Toussaint, Stanley D. “The Significance of the First Sign in John's Gospel.” BSac 134 (1977): 45-51.

Trites, Allison A. The New Testament Concept of Witness. Cambridge: Cambridge University Press, 1977.

Trotter, F. D., ed. Jesus and the Historian. Philadelphia, PA: Fortress, 1968.

Trudinger, Paul. “A Prophet Like Me (Deut 18:5): Jesus and Moses in St John's Gospel, Once Again." DRev 113 (1995): 193-95.

Tucker, Gene M. "Covenant Forms and Contract Forms.” VT 15 (1965): 487-503.

Turner, Max. The Holy Spirit and Spiritual Gifts. Rev. ed. Peabody, MA: Hendrickson, 1998.

. "New Testament Commentary and Systematic Theology: Strangers or Friends." Pages 54-55 in Between Two Horizons: Spanning New Testament Studies and Systematic Theology. Edited by J. B. Green and M. Turner. Grand Rapids, MI: Eerdmans, 2000.

Van de Mieroop, Marc. A History of the Ancient Near East, ca. 3000-323 B.C. Malden, MA: Blackwell, 2007.

___. "Hammurabi’s Self-Presentation." Or 80 (2011): 305-38.

Van der Deijl, Aarnoud. Protest or Propaganda: War in the Old Testament Book of Kings and Contemporaneous Ancient Near Eastern Texts. Leiden: Brill, 2008.

VanderKam, James C. The Dead Sea Scrolls Today. Grand Rapids, MI: Eerdmans, 1994.

Van der Watt, Jan G. Family of the King: Dynamics of Metaphor in the Gospel According to John. BIS 47. Edited by R. Alan Culppeper and Rolf Rendtorff. Boston, MA: Brill, 2000.

VanGemeren, Willem A., ed. NIDOTTE. 5 vols. Grand Rapids, MI: Zondervan, 1997.

Van Seters, John. The Life of Moses: The Yahwist as Historian in Exodus-Numbers. Louisville, KY: John Knox, 1994. 
Vawter, Bruce. The Four Gospels: An Introduction. NY: Image Books, 1969.

Venema, Cornelis P. "Theology and Narrative: A Critical Introduction.” MAJTh 9 (1993): 149-53.

Vermes, Geza. The Complete Dead Sea Scrolls in English. 4th ed. London, England: Penguin Books, 2004.

Vogels, Walter. "Lot in His Honor Restored: A Structural Analysis of Gen 13:2-18." EgT 10 (1979): 5-12.

Von Rad, Gerhard. Deuteronomy: A Commentary. OTL. Philadelphia, PA: Westminster, 1966. . Genesis: A Commentary. Philadelphia: Westminster, 1972.

Von Wahlde, Urban C. “Archaeology and John's Gospel.” Pages 523-86 in Jesus and Archaeology. Edited by James H. Charlesworth. Grand Rapids, MI: Eerdmans, 2006.

. The Gospel and Letters of John. Grand Rapids, MI: Eerdmans, 2010.

. " 'The Jews' in the Gospel of John: Fifteen Years of Research (1983-1998).” ETL 76 (2000): 30-55.

. "The Johannine 'Jews': A Critical Survey.” NTS 28 (1982): 33-60.

. "The Witnesses to Jesus in John 5:31-40 and Belief in the Fourth Gospel." $C B Q$ 43 (1981): 385-404.

. " 'You Are of Your Father the Devil' in Its Context: Stereotyped Apocalyptic Polemic in John 8:38-47." Pages 418-44 in Anti-Judaism and the Fourth Gospel: Papers of the Leuven Colloquium, 2000. Jewish and Christian Heritage Series 1. Edited by. R. Bieringer, D. Pollefeyt, and F. Vandecasteele-Vanneuville. Assen: Royal Van Gorcum, 2001.

Wallace, Daniel B. A Greek Grammar beyond the Basics: An Exegetical Syntax of the New Testament. Grand Rapids, MI: Zondervan, 1996.

Wallace, Eric Matthew Edouard. "The Testimony of Moses: Pentateuchal Traditions and Their Function in the Gospel of John." Ph. D. diss., Union Theological Seminary, 2004.

Waltke, Bruce K. "The Creation Account in Genesis 1:1-3; Part IV: The Theology of Genesis 1." BSac 133 (1976): 28-41. 
Waltke, Bruce K., and Charles Yu. An Old Testament Theology: An Exegetical, Canonical, and Thematic Approach. Grand Rapids, MI: Zondervan, 2007.

Waltke, Bruce K. and M. O'Connor. An Introduction to Biblical Hebrew Syntax. Winona Lake, IN: Eisenbrauns, 1990.

Weinfeld, Moshe. "Ancient Near Eastern Patterns in Prophetic Literature." VT 27 (1977):178-95. . Deuteronomy 1-11. AB 5. NY: Doubleday, 1991.

. Deuteronomy and the Deuteronomic School. Oxford: Oxford University Press, 1972.

. "Traces of Assyrian Treaty Formulae in Deuteronomy." Bib 46 (1965): 417-27.

Weiss, Harold. “The Sabbath in the Fourth Gospel.” JBL 110 (1991): 311-21.

Wellhausen, Julius. Prolegomena to the History of Israel. Translated by J. S. Blace and A. Menzies. Atlanta, GA: Scholar, 1994.

Wenham, Gordon J. Genesis 1-15. WBC. Waco, TX: Word Books, 1987. . Genesis 16-50. WBC. Nashville, TN: Thomas Nelson, 1994. . The Book of Leviticus. NICOT. Grand Rapids, MI: Eerdmans, 1979.

Westbrook, Raymond, F. Rachel Magdalene, and Bruce Wells. Law from the Tigris to the Tiber: The Writings of Raymond Westbrook. Winona Lake, IN: Eisenbrauns, 2009.

Westcott, B. F. Gospel According to St. John: Greek Text with Introduction and Notes. Thornapple Commentaries. Grand Rapids, MI: Baker Book House, 1980.

Westermann, Claus. Basic Forms of Prophetic Speech. Translated by Hugh C. White. Louisville: Westminster, 1991.

. The Gospel of John in the Light of the Old Testament. Translated by Siegfried S. Schatzmann. Peabody, MA: Hendrickson, 1998.

Whitley, Charles Francis. "Covenant and Commandment in Israel." JNES 22 (1963): 3748.

Whybray, R. Norman. Introduction to the Pentateuch. Grand Rapids, MI: Eerdmans, 1995. 
Widengren, Geo. "King and Covenant.” JSS 2 (1957): 1-32.

Wigram, George V. The Englishman's Hebrew and Chaldee Concordance of the Old Testament. 5th ed. Grand Rapids, MI: Zondervan, 1970.

Wilder, A. N. Early Christian Rhetoric. Cambridge, MA: Harvard University Press, 1971.

Wilson, E. "Rîb in Israel's Historical and Legal Traditions: A Study of the Israelite Setting of Rib-Form." Ph.D. diss., Drew University, 1970.

Wilson, John Albert, E. A. Speiser, and H. G. Guterbock. Authority and Law in the Ancient Orient. JAOSSup 17. Baltimore: American Oriental Society, 1954.

Wilton, Murray R. "Witness as a Theme in the Fourth Gospel." Ph.D. diss., New Orleans Baptist Theological Seminary, 1992.

Windisch, Hans. The Spirit-Paraclete in the Fourth Gospel. FBBS 20. Philadelphia, PA: Fortress, 1968.

Wink, Walter. John the Baptist in the Gospel Tradition. SNTSMS 7. Eugene, OR: Wipf \& Stock, 1968.

Wiseman, Donald John. “The Vassal-Treaties of Esarhaddon.” Iraq 20 (1958): 1-99.

Witherington, Ben. John's Wisdom: A Commentary on the Fourth Gospel. Louisville, KY: Westminster, 1995.

. Women in the Ministry of Jesus: A Study of Jesus' Attitudes to Women and Their Roles as Reflected in His Earthly Life. SNTSMS 51. Cambridge: Cambridge University Press, 1984.

Wolf, Herbert. An Introduction to the Old Testament: Pentateuch. Chicago, IL: Moody, 1991.

Wright, Christoher J. H. Deuteronomy. NIBC 4. Peabody, MA: Hendrickson, 1996.

. Deuteronomy. UBCS. Grand Rapids, MI: Baker Book House, 2012.

Wright, G. Ernest. Deuteronomy. IB 2. Nashville, TN: Abingdon, 1953.

. "The Lawsuit of God: A Form-Critical Study of Deuteronomy 32." Pages 26-67 in Israel's Prophetic Heritage: Essays in Honor of James Muilenburg. Edited by Bernhard W. Anderson and Walter Harrelson. NY: Harper \& Row, 1962.

Wright, N. T. Evil and the Justice of God. Downers Grove, IL: InterVarsity, 2013. 
Yamauchi, Edwin M. Gnostic Ethics and Mandaean Origins. HTS 24. Cambridge: Harvard University Press, 1970.

Zangenberg, Jürgen. "Between Jerusalem and Galilee: Samaria in the Time of Jesus." Pages 393-432 in Jesus and Archaeology. Edited by James H. Charlesworth. Grand Rapids, MI: Eerdmans, 2006.

Zehnder, Markus. "Building on Stone? Deuteronomy and Esarhaddon's Loyalty Oaths. (Part 1): Some Preliminary Observations.” BBR 19 (2009): 341-74.

. 'Building on Stone? Deuteronomy and Esarhaddon's Loyalty Oaths. (Part 2): Some Additional Observations." BBR 19 (2009): 511-35.

Zer-Kavod, Mordecai. "The Code of Hammurabi and the Laws of the Torah." JBQ 26 (1998): 107-10. 